DEPARTMENT OF THE INTERIOR

HUBERT Work, Secretary

United States Geological Survey

George Otis Smith, Director

Water-Supply Paper 499

\title{
THE PAPAGO COUNTRY, ARIZONA
}

A GBOGRAPIIC, GEOLOGIC, AND HYDROLOGIC RECONNAISSANCE

WITH A GUIDE TO DESERT WATERING PLACES

BY

KIRK BRYAN

inis copy is PURLIT PPOPERTY and is not to be removed frow $A, \ldots$ Fing. PRIVATE POSSESSION IS UNLAHFUL (R.: EIp. Vo', 2, po. 360, Sec 749.)

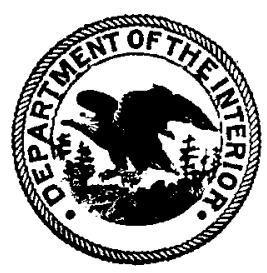

WASHINGTON

GOVERNMENT PRINTING OFFICE 


\section{CONTENTS}

Preface, by 0 . E. Meinzer

Introduction_........ 1

Location _-_-_-_-_-_-__- 1

Maps _-

Acknowledgments

Historical sketch, by F. L. Ransome

Introduction

Spanish exploration

American exploration

Early settlement and the Civil War 20

Later development

The Papago Indians _.

Climate _.

Flora - -

The arboreal desert

The trees _. 41

The cacti_..._-___._. 46

The yuccas and their relatives._._. 47

Fauna - -

Geology -..-_- 53

Stratigraphy _-_.

Pre-Cambrian basal complex

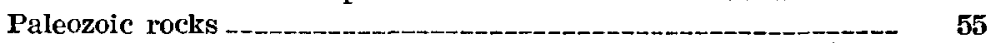

Mesozoic rocks _._. 57

Sedimentary rocks___n_. 59

Igneous rocks _-_ 68

Tertiary rocks________ 59

Sedimentary rocks______ $\mathbf{5 9}$

Volcanic rocks____________ 63

Quaternary deposits _..._. 65

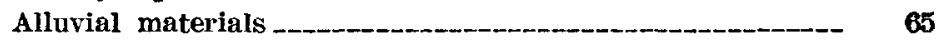

General character -

Older alluvium _-___- 66

Younger alluvium _._- 67

Recent deposits

Basalt _-_. 70

Structure

Salient features _._. 70

Faults _-_- 71

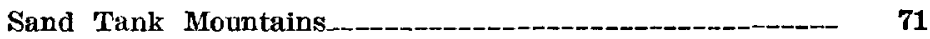

Tule Mountains___ 72

Growler Mountains _..._- 73

Geologic classification of the mountains___- 73

General character-______ $\quad 73$

Mountains composed largely of volcanic rocks_____ 74

Mountains composed largely of granite and schist, with patches of volcanic rocks___-__- 75

Mountains with no known patches of volcanic rocks________ $\quad 76$

Summary of classification_._- 77 
Physiography

Influence

Mountain slopes

Determining conditions

Grades of mountain slopes

Cliffy slopes

Boulder-controlled slopes_-_____-_-___- 82

Rain-washed slopes____-_-__- 86

Canyon cutting

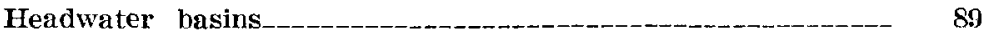

Minor erosional features_______._. 90

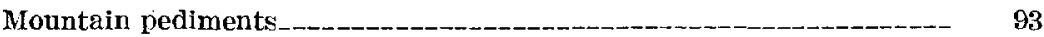

Character _...... 93

Concealed pediments_._._. 97

Coalescing pediments._._. 97

Dissected pediments____.._- 99

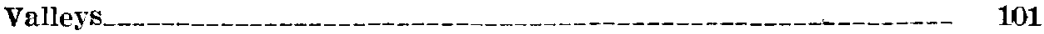

Structural origin of valleys_____._. 101

Processes operating in the valleys_________________________ 102

Features of the valley floors

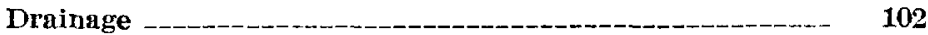

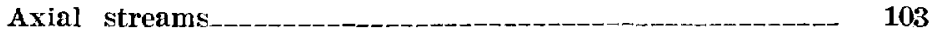

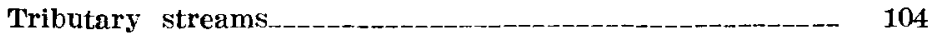

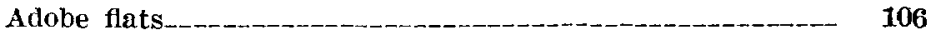

Playas _..-_-_-_-_-_-_-_-_-_ 106

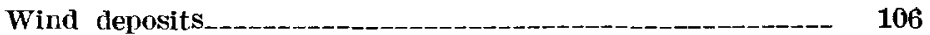

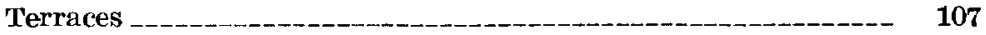

Terraces of Gila River-_._____- 108

Terraces of Altar and Santa Cruz valleys_________-_-_ $\quad 109$

Terraces in the interior valleys

Geologic and physiographic history

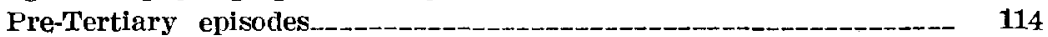

Tertiary landscape

Pleistocene and Recent time____________________________ 117

Surface water_________-_ 118

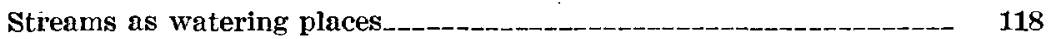

Streams in general__-_____- 118

Intermittent and interrupted streams______._. 119

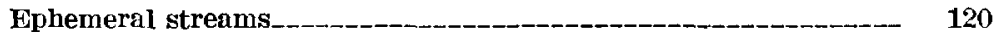

Lakes and ponds

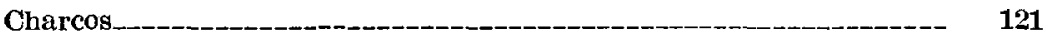

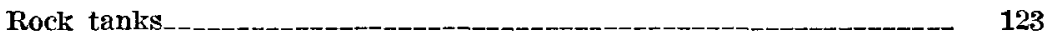

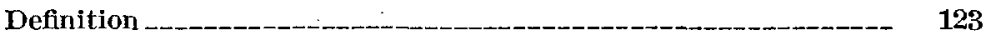

Rock tanks away from stream channels_________________- 124

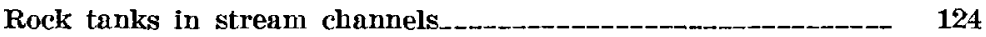

Physiographic relations of rock tanks_________________-_ 127

Falls due to differing resistance of rocks to erosion__________ 127

Falls due to changes in stream grade_-_____________-_ 120

Falls due to rénewed uplift_____ 131

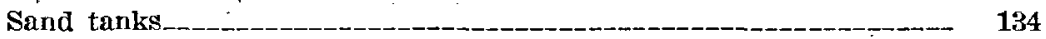

Characteristics of water in tanks ______________ 135 
Surface water-Continued.

Direct utilization of rain water._._._.__ 136

Rain water shed from roofs___- 136

Water catches________ 136

Use of water catches

Construction of water catches_____- 139

Area of water catch required_.___._. 139

Sanitary considerations____..._._. 140

Reservoirs

Purposes _._.

Reservoirs in the mountains and foothills._._._._._._._._._. 148

Reservoirs in the plains and valleys______________ 144

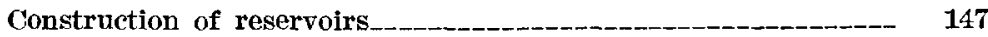

Protection of the embankment

Diversion dams and protection of spirlway channels_______-_ 149

Débris-filled reservoirs and artificinl springs______________-_-_ 151

Advantages._._. 151

Methods of construction_._. 151

Ground whter _-___._- 153

Source and amount of ground water-_________ 154

Vegetation as an indicator of ground water

Quality of ground water.___._ 157

Methods of analysis_...... 157

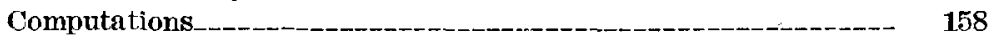

Classification

Potability of waters

Springs__.....-_-_-_- 161

Fracture springs_-_-__-_-_-_- 161

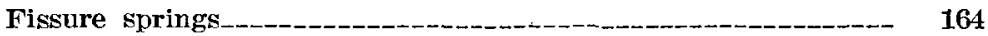

Water in the crystalline complex

Water in the sedimentary rocks_________________- 172

Water in the Tertiary volcanic rocks_______________- 173

Water in the alluvium______-_._- 176

Character of the alluvium.-_- 176

Depth of the alluvium____-_._. 179

Depth to water in the alluvium

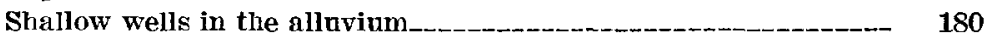

Deep wells in the alluvium________- 185

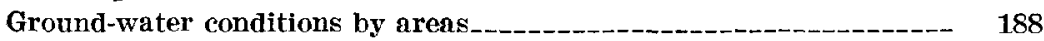

Western portion _._._._. 188

Location, topography, and geology

Mountainous areas _- 189

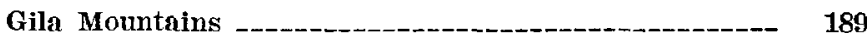

Tinajas Altas Mountains:-_-_-_-_- 189

Sierra de la Lechuguilla_______________- 190

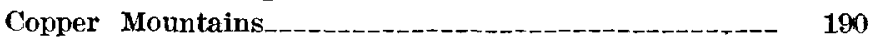

Cabeza Prieta Mountains._-_._._._._- 190

Tule Mountains _._-__-__- 191

Pinta Mountains _._. 192

Mohawk Mountains

Aguila Mountains___- 193

Granite Mountains__-_. 194 
Ground water-Continued.

Ground-water conditions by areas-Continued.

Western portion-Continued.

Mountainous areas-Continued.

Agua Dulce Mountains

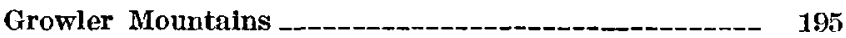

Wellton Hills___________-_ 196

Baker Peaks_-_-_-__-_-_-_-_-_-_-_-_-_-_-_-_ 197

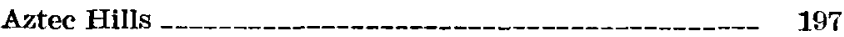

O'Neill Hills _._-_._._...

Hills near Papago Well__-______-_-_- 198

Quitobaquito Hills___________________________- 199

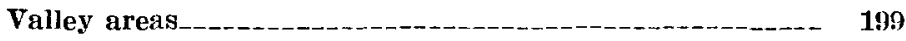

Yuma Desert______________._. 199

Lechuguilla Desert _.__-_-_- 200

Mohawk Valley -____-_-__- 201

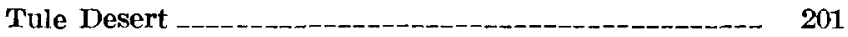

Growler Valley

San Cristobal Valley______._. 202

Sentinel Plain and adjacent plains_______-_-__-_ 203

Ground-water resources _._-___-_ 203

West-central portion

Location, topography, and geology

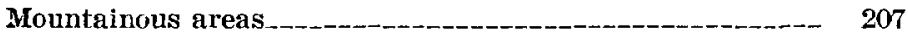

Painted Rock Mountains, by C. P. Ross_________ 207

Crater Mountains__...... 207

Childs Mountain _._._-_._- 207

Little Ajo Mountains and adjacent hills____________-_ 208

Dripping Spring Mountains___-_-_-_-_ 210

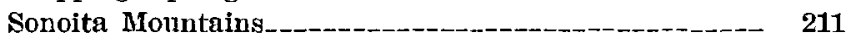

Sauceda Mountains and associated mountains_..._._-_- 211

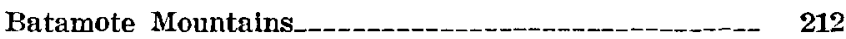

Pozo Redondo Mountains

Gunsight Hills___- 214

Ajo Mountains _- 215

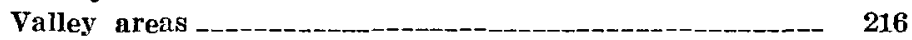

Gila Bend Plains__-_-_-_-_ 216

Valley between Crater and Sauceda mountains_-_-_-_ 216

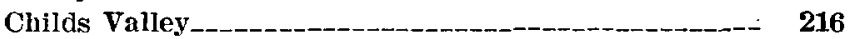

Valley of the Ajo

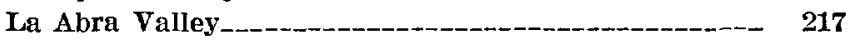

Sonoita Valley

Ground-water resources_____________- 218

Central portion_-_.

Location, topography, and geology

Mountainous areas

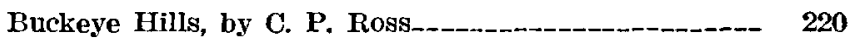

Maricopa Mountains _-_-_-_-_-___-_-_-_-_-_-_- 220

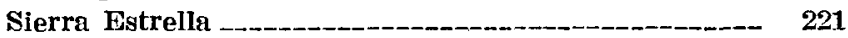

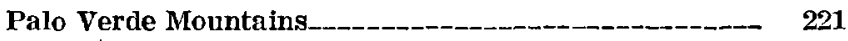

Table Top and associated mountains________-_-__-_- 222

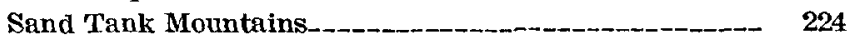

Vekol Mountains ______- 228 
Ground water-Continued.

Ground-water conditions by areas-Continued.

Central portion-Continued.

Mountainous areas-Continued. Page

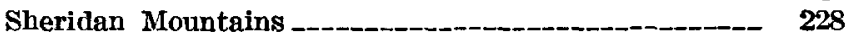

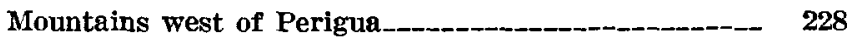

Mountains east of Perigua______________________-__-_ 229

Mountain southwest of Kaka___________________ $\quad 229$

Quijotoa Mountains___-_____________-_ $\quad 230$

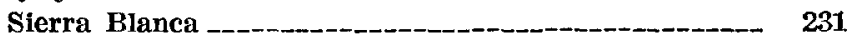

Brownell Mountains _-_-_-__________________-_ 231.

Nonmountainous upland

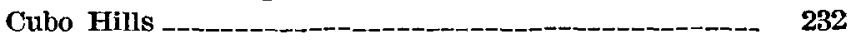

Mesquite Mountains _-____-_______________________ 233

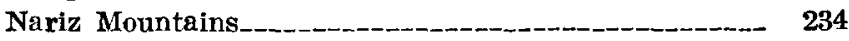

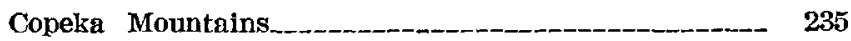

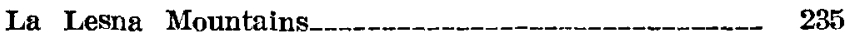

Hills southwest of Copeka Mountains____________ 235

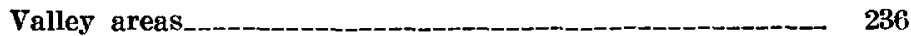

Jornada de las Estrellas_______._. 236

Vekol Valley

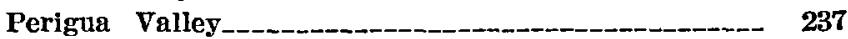

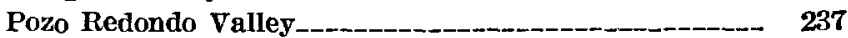

Quijotoa Valley

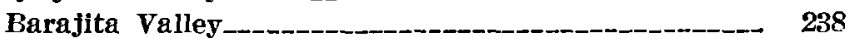

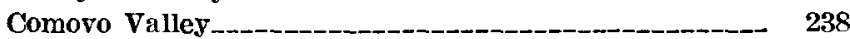

La Quituni Valley_-___-__-__-_ 239

The Great Plain

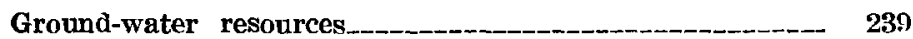

East-central portion___-__-_ 242

Location, topography, and geology_______________ 242

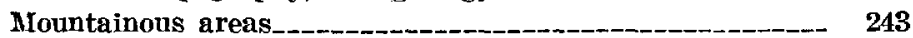

Casa Grande Mountain_._- 243

Silver Reef Mountains__-_._- 213

Mountains west of Cocklebur._.____________ 243

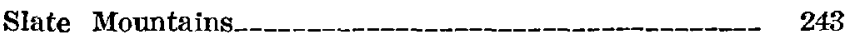

Sawtooth Mountains _- 243

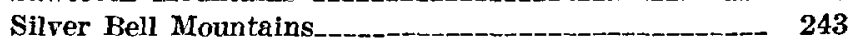

Waterman Mountains___________________________ 244

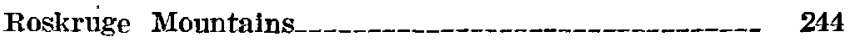

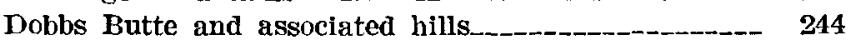

Santa Rosa Mountains_________________________-_ 244

Vaca Hills_____-__-__-_ 245

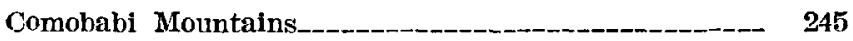

Cobabi Mountains_____________________-_ 245

Artesa Mountains

Alvarez Mountains

Las Animas Hills_.__________________________- 246

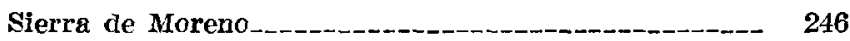

Coyote Mountains

Baboquivari Mountains____________________-_ 247

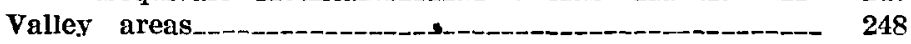

Santa Cruz Valley (Casa Grande section) _.___._._-_._. 248

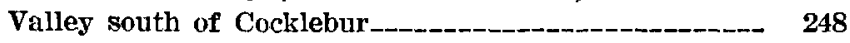


Ground water-Continued.

Ground-water conditions by areas-Continued.

East-central portion--Continued.

Valley areas--Continued. Page

Santa Rosa Valley_____-_-__-_ 249

Valley north of Baboquivari Mountains______________ 249

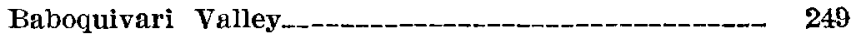

Plains west of Indian Oasis______________________-_ 249

Tecolote Valley

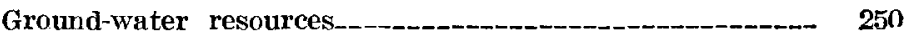

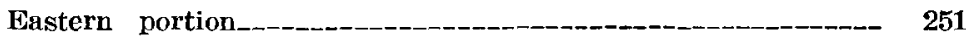

Location, topography, and geology

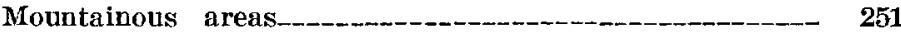

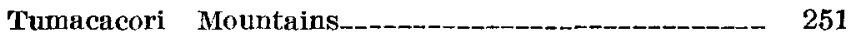

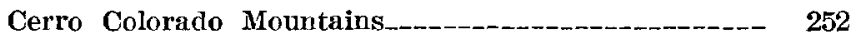

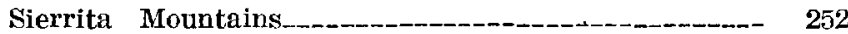

Tucson Mountains __-__-_._- 253

Valley areas___._._._._- 258

Altar Valley _.......... 253

Abra Valley _-_-_-_._- 254

Santa Cruz Valley_._._. 254

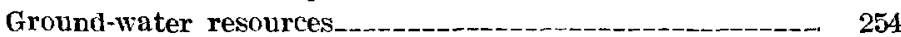

Guide to watering places________________ 255

Distribution and types of watering places_______________________ 255

Types of roads _._. 258

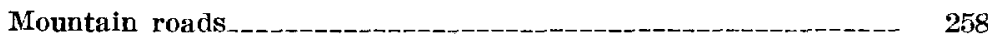

Malpais roads_...

Plains roads _._._- 259

River-bottom roads._-_._._-_._- 259

Good, fair, and bad roads____________ 260

Road signs _._._. 260

Road difficulties and suggestions for surmounting them

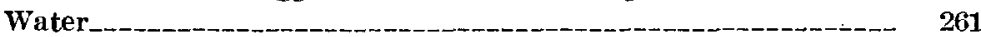

Gasoline and spare parts _________ 261

Equipment .......... 262

Choice and equipment of automobile________________ $\quad 262$

Crossing an arroyo or wash

Crossing other sandy areas

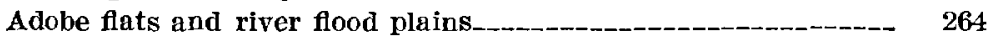

Mountain and hill areas_________-_._- 265

Plan of logs and descriptions_____- 265

Road $\operatorname{logs}$ _.

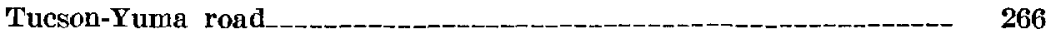

Old main route____._. 266

Tucson to Yuma___._. 266

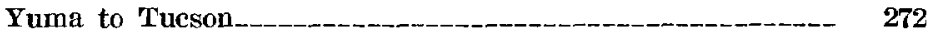

Northern road between Indian Oasis and Big Fields__________ 276

Indian Oasis to Geological Survey sign at Big Fields_______ $\quad 276$

Geological Survey sign at Big Fields to Indian Oasis_______ $\quad 277$

Pozo Blanco route-..._._._. 277

Tucson to Ajo____ 277

Ajo to Tucson 
Road logs-Continued.

Tucson-Yuma road-Continued. Page

Cubo route 280

Tueson to Ajo__._. 280

Ajo to Tucson____ 280

Comoro route - 281

Tucson to Ajo_______._. 281

Ajo to Tucson____ 282

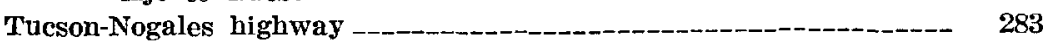

Tucson to Nogales_______ 283

Nogales to Tucson

Tueson-Nogales road by way of San Xavier and Twin Buttes_____- 285

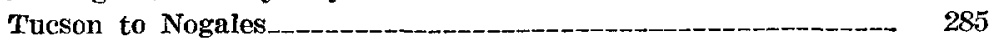

Nogales to Tueson_._. 286

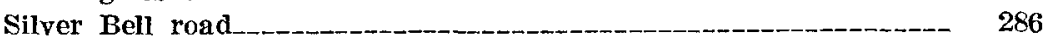

Routes in and to the Altar Valley______________- 287

Tucson-Sasabe road_______________- 287

Tucson to Sasabe__________ 287

Sasabe to Tucson

Arivaca road _-__-_-_-__- 289

Amado to Ronstadt gate________________________- 289

Ronstadt gate to Amado__________ 290

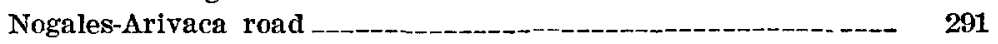

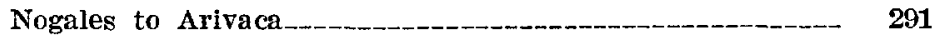

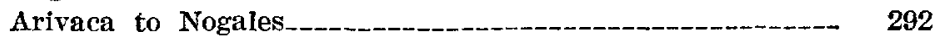

Figueroa ranch to Buenos Aires and points on the east side of

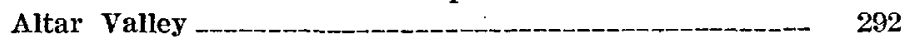

Tucson-Phoenix highway________-__-_ 293

Tueson to Phoenix

Phoenix to Tucson

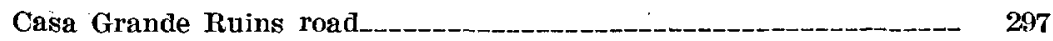

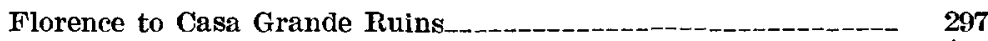

Casa Grande Ruins to Florence

Tucson-Casa Grande road

Tucson to Casa Grande

Casa Grande to Tucson

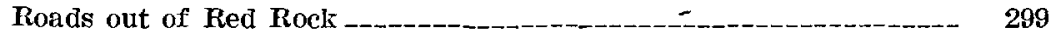

Roads out of Casa Grande

Casa Grande to Maricopa_____ 300

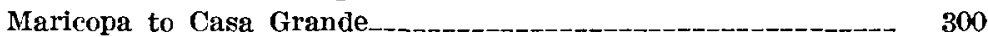

Phoenix to Casa Grande by way of Sacaton________________-_ $\quad 300$

Casa Grande to Phoenix by way of Sacaton____________._. 301

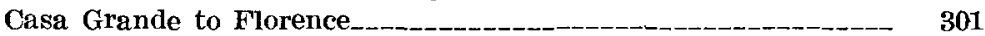

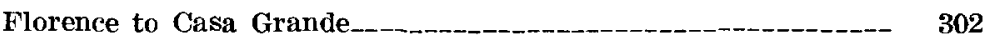

Casa Grande to Pozo De Luis, Sonora, by way of Jackrabbit and the Santa Rosa Valley

Pozo De Luis, Sonora, to Casa Grande by way of Santa Rosa

Valley and Jackrabbit

Casa Grande to Cocklebur and Quajote 307

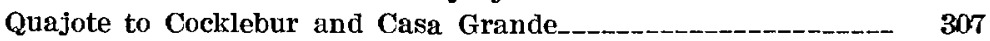

Roads out of Maricopa__- 307

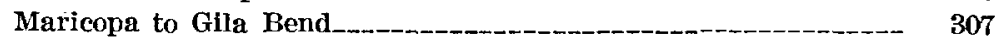

Gila Bend to Maricopa____ 308

$104211-25-2$ 
Road logs-Continued.

Roads out of Maricopa-Continued. Page

Phoenix to Maricopa by way of Gila Crossing

Maricopa to Phoenix by way of Gila Crossing

Maricopa to Vekol Valley, Kaka, and Covered Wells_-_-_-_-_-_-- 309

Covered Wells to Kaka, Vekol Valley, and Maricopa_______-_ 311

Maricopa to Cocklebur._._- 312

Roads out of Gila Bend._._. 313

Phoenix to Gila Bend by way of Gila Crossing _._-________. $\quad 313$

Gila Bend to Phoenix by way of Gila Crossing _..._._._._._. 314

Phoenix to Gila Bend by way of Buckeye

Gila Bend to Phoenix by way of Buckeye

Gila Bend to Sentinel_.__ 317

Sentinel to Gila Bend____ 317

Gila Bend to Vekol

Vekol to Gila Bend___-_-_-_-__-_ 319

Gila Bend to Pozo Blanco by way of Sauceda______________ $\quad 320$

Pozo Blanco to Gila Bend by way of Sauceda__________ 321

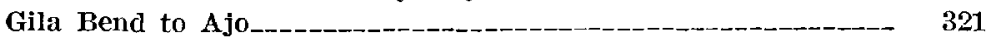

Ajo to Gila Bend_-_-_._- 323

Gila Bend to Mesquite Tank___- 323

Mesquite Tank to Gila Bend__________ 324

Routes in the Baboquivari and Tecolote valleys

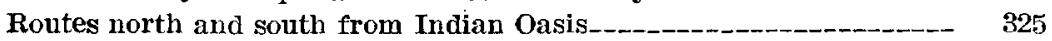

Miscellaneous routes between Quijotoa Mountains and Gunsight Pass_ $\quad 326$

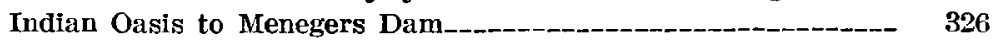

Menegers Dam to Indian Oasis______-__- 327

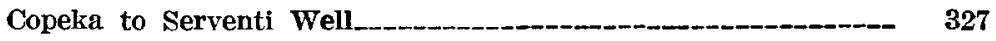

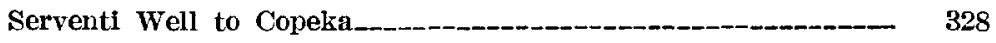

Copeka to Karolik by way of Tonukvo

Kavolik to Copeka by way of Tonukvo___________________ 328

Pozo Blanco to Pisinemo

Pisinemo to Pozo Blanco

Comovo to Camote-____- 329

Camote to Comovo

Charco en Medio to Cubo_-_- 330

Cubo to Charco en Medio

Walls Well to Menegers Dam and Mexico_________________________- 331

Walls Well to Menegers Dam by way of Cochibo___________- 331

Walls Well to Menegers Dam by way of Cubo and Charco Colorado

Menegers Dam to Walls Well by way of Cochibo

Menegers Dam to Walls Well by way of Charco Colorado and Cubo_

$\begin{array}{rr}\text { Routes from and near Ajo_- } & \mathbf{3 3 4} \\ \text { Ajo to Yuma by the Camino del Diablo } & \mathbf{3 3 4}\end{array}$

Yuma to Ajo by the Camino del Diablo_____________ 338

Ajo to Pozo Redondo and Perigua

Perigua to Pozo Redondo and Ajo___ 341

Ajo to Sonoita

Sonoita to Ajo

Walls Well to Bates Well_____ 344

Bates Well to Walls Well_____________ 344 
Road logs-Continued.

Routes from and near Ajo-Continued. Page

Bates Well to Quitobaquito

Quitobaquito to Bates Well____________ 345

Roads near the Little Ajo Mountains_______________ 346

Minor roads west of Ajo-_. 346

Roads in and adjacent to San Cristobal Valley

Wellton to Baker Tanks and points south_______ 348

Baker Tanks to Wellton________ 348

Blaisdell to Fortuna mine

Detailed descriptions ___ 349

Tueson to Yuma

Old main route.______ 349

Indian Oasis to Big Fields (northern road) _ 364

Pozo Blanco route._._._- 365

Cubo route......._- 367

Comovo route

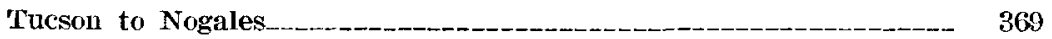

Main route_____n_...- 369

Route by way of San Xavier and Twin Buttes____-____- 372

Routes in and to the Altar Valley_____ 374

Tucson to Sasabe._._- 374

Amado to Ronstadt gate__o 378

Nogales to Arivaca______- 380

Tucson to Phoenix

Florence to Casa Grande Ruins_________ 385

Tucson to Casa Grande____ 388

Phoenix to Casa Grande-_. 389

Roads out of Casa Grande___n__ 390

Casa Grande to Florence-_. 390

Casa Grande to Pozo de Luis, Sonora

Phoehix to Maricopa by way of Gila Crossing-_-_-_- 393

Maricopa to Covered Wells_____ 393

Phoenix to Gila Bend by way of Gila Crossing__________ 397

Phoenix to Gila Bend by way of Buckeye-________ 400

Roads out of Gila Bend..._. 402

Gila Bend to Sentinel

Gila Bend to Vekol_______ 402

Gila Bend to Pozo Blanco

Gila Bend to Ajo__._. 405

Gila Bend to Mesquite Tank_________ 406

Routes in the Baboquivari Valley-_-__-_-_-_-___-_-_-_-_-_-_ 406

Miscellaneous routes between Quitojoa Mountains and Gunsight Pass_ 408

Indian Oasis to Menegers Dam____._... 408

Copeka to Kavolik by way of Tonukvo___________- 410

Pozo Blanco to Pisinemo. 410

Comovo to Camote.

Charco en Medio to Cubo

Walls Well to Menegers Dam____ 411

Routes from and near Ajo_. 413

Ajo to Yuma by the Camino del Diablo__ 413

Ajo to Perigua___ 423

Ajo to Sonoita___- 424

Bates Well to Quitohaquito 


\section{ILLUSTRATIONS}

Plate I. Map of the arid region of the United States showing areas covered by guides to watering places and other maps and watersupply papers of the United States Geological Survey ........ XvI

II. Relief map of the western part of the Papago country, Ariz _ In pocket.

III. Relief map of the central part of the Papago country, Ariz _ In pocket.

IV. Relief map of the eastern part of the Papago country, Ariz In pocket-

V. $A$, Church and Papago houses at Covered Wells; B, Mortar or "béchete" hole at Tule Tank

VI. $A$, Luxuriant vegetation near Big Fields; $B$, Desert willow in stream channel at Batamote Well

VII. $A$, Palo verde with mistletoe on west side of Growler Mountains; $B$, Crucifixion thorn southwest of Gila Bend.......

VIII. $A$, Forest of dead mesquite north of Crater Mountains; $B$, Tilted Tertiary conglomerate east of Comobabi.

IX Reconnaisance geologic map of the Papago country

X. $A$, Ajo Peaks, from the east; $B$, Cliffy slopes of massive lava flows on the west side of the Ajo Mountains................

XI. A, Growler Mountains, from Bates Well; B, Growler Mountains south of Bates Well, from the west

XII. $A$, Raven Butte, from the east; $B$, Lava-capped mountain in the
Cabeza Prieta Mountains.

XII. $A$, Raven Butte, from the east; $B$, Lava-capped mountain in the
Cabeza Prieta Mountains.

XIII. $A$, Granite slope exposed by removal of talus by ephemeral stream at Raven Butte; $B$, Mountain slope and dissected pediment at Sand Tanks

XIV. $A$, Pass west of Tule Tank; $B$, Niches in granite at Tinajas Altas.

XV. $A$, Headwater basin and dissected pediment in the Tumacacori Mountains; $B$, Sasabe Flat, at south end of Altar Valley; $C$, Dissected pediment between Sierra Blanca and Browriell Mountains.

XVI. $A$, Charco near Pozo Redondo; $B$, Miniature canyons near head of a charco, La Quituni Valley.

XVII. $A$, Black Tanks; $B$, Tule Tank about a week after a rain.....

XVIII. $A$, Tinajas Altas; $B$, Open mountain canyon above the falls at Tinajas Altas; $C$, The lower tank at Tinajas Altas about a week after a rain

XIX. $A$, Stand for selling water on main street of Clarkstown; $B$, House in Old Ajo

XX. $A$, Represo at Copeka; $B$, Water catch at Fortuna mine.....

XXI. $A$, Represo in hills south of Dobbs Butte; $B$, Represo at Pisinemo . . . . . . . .

XXII. $A$, Represo at Comovo; $B$, Compartidero, a represo used for watering cattle . . . . . .

XXIII. $A$, Mesquite tree of sprawling habit south of Casa Grande ruins: $B$, Mesquite trees of upright habit at Fresnal Well ......

XXIV. $A$, Dripping Spring; $B$, Quitobaquito, from the hills on the north

XXV. $A$, Cochibo; $B$, Papago Well

XXVI. $A$, Artesa Pond; $B$, Papago farming near Toapit...........

XXVII. Road across a sandy wash dug out and corduroyed with brush.- 
Figure 1. Map of the Papago country, Ariz., showing principal roads and watering places and areas covered by Plates II, III, and IV

Page

2. Geologic cross section in the western part of the Sand Tank Mountains

3. Geologic cross section in the Tule Mountains

4. Geologic cross section of the southern part of the Lechuguilla Desert

5. Diagram to show the range in grade of mountain slopes_---

6. Sketch map of the Papago country showing distribution so far as observed of gullied and ungullied mountains of approximately the same size

7. Diagram showing four stages in the erasion of a block of the earth's crust to form the sierra type of mountain

8. Cross section of niche in granite at Tinajas Altas
9. Diagram illustrating weathering of Tertiary arkose conglomerate in the Papago Saguaro National Monument

10. Cross section of a niche in coarse conglomerate, Papago Saguaro National Monument.

11. Map of part of the Sacaton Mountains

12. Map of the northern border of the Baboquivari Mountains

13. Map of the vicinity of Fresnal and Topahua, showing dissected pediment

14. Diagram showing the structural relations assumed for a typical valley in the Papago country

15. Cross sections on the north and west sides of the Baboquivari Mountains

16. Cross section of part of Santa Cruz Valley (Nogales Wash), from Mount Benedict to the Tumacacori Mountains

17. Cross section of Santa Cruz Valley from Sardina Peak to the Santa Rita Mountains near Tubac

18. Cross section of Santa Cruz Valley at Jaynes_

19. Cross section of Santa Cruz Valley near Toltec.

20. Cross section through the northern pond at Susuta, Sonora-

21. Diagram showing five types of depressions in channels

22. Cross section of the stream channel and water hole in the Vekol Valley

23. Sketch map of Baker Tanks

24. Section along stream channel at Tabaseca Tank, Riterside County, Calif

25. Diagram showing the production of falls and tanks by erosion of mountain pediment on a new grade

26. Sketch map of the Black Tanks, Crater Mountains.

27. Diagram showing production of falls and tanks by renewed uplift of eroded fault-block mountains

28. Sketch map of Tinajas Altas

29. Diagrammatic profile of falls of Tinajas Altas

30. Idealized diagram to show effect of joint system on course of stream and position of tanks at Tinajas Altas

31. Diagram showing water catch at old Ajo

32. Sketch map showing drainage area at water catch near Fortuna mine, south of Blaisdell 
Flgure 33. Reinforced-concrete cistern for water catch

34. Diagrammatic map showing location of represo at one side of main flood-water channel

35. Idealized map showing use of run-off from road ruts and relation of reservoirs to slopes

36. Profle throurh typical Papago represo

37. Cross section of earth dam

38. Diagram showing the use of $\operatorname{logs}$ and brush for diversion

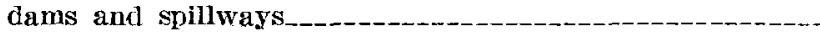

39. Diagram showing construction of a water drop to prevent. erosion of channels

40. Diagram showing rock-fill dam for an artificial spring

41. Diagram showing the relation of fracture systems to Irip-

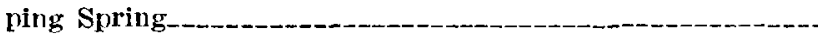




\title{
PREFACE
}

\author{
By O. E. Meinzer
}

The arid region of the United States, as outlined on Plate I, covers about 500,000 square miles, or one-sixth of the entire country. This vast region includes some large irrigation districts and well-watered mountains, but most of it is so arid that it can not safely be traversed by anyone who does not have adequate information regarding the location of watering places. The desert is not vanishing, although here and there relatively small tracts of it have been reclaimed by irrigation, and the aggregate number of watering places has been slowly increasing. It has, however, become much more accessible than formerly-first through the building of railroads and recently through the use of automobiles.

In 1917 the sum of $\$ 10,000$ was appropriated by Congress for a survey of desert watering places which had been authorized in an act approved August 21, 1916, as follows:

Be it enacted by the Senate and House of Representatives of the United States of America in Congress assembled, That the Secretary of Interior be, and he is hereby, authorized and empowered, in his discretion, in so far as the authorization made herein will permit, to discover, develop, protect, and render more accessible for the benefit of the general publid springs, streams, and water holes on arid public lands of the United States; and in connection therewith to erect and maintain suitable and durable monuments and signboards at proper places and intervals along and near the accustomed lines of travel and over the general area of said desert lands, containing information and directions as to the location and nature of said springs, streams, and water holes, to the end that the same may be more readily traced and found by persons in search or need thereof; also to provide convenient and ready means, apparatus, and appliances by which water may be brought to the earth's surface at said water holes for the use of such persons; also to prepare and distribute suitable maps, reports, and general information relating to said springs, streams, and water holes and their specific location with reference to lines of travel.

The work thus authorized was assigned to the United States Geological Survey. To the small appropriation made for this purpose was added a part of the Geological Survey's regular allotment for ground-water investigations in the United States, and the scope of the survey was enlarged so as to include a reconnaissance of the ground-water conditions in the area covered. 
The area selected for survey lies in southeastern California and southwestern Arizona (see Pl. I) and occupies about 60,000 square miles, or somewhat more than one-tenth of the entire arid region. It is larger than the State of Illinois and nearly as large as New England. This is, on the whole, the driest and hottest area in the United States, and until the watering-place survey was made it was also one of the least explored and most poorly mapped. In a large part of the area the average annual rainfall is less than 5 inches. This slight rainfall and the high temperature together produce a high degree of aridity. The high temperature adds greatly to the danger of perishing by thirst.

The area was divided into four parts, each of which was covered by a geologist who was assisted by a nontechnical helper and was provided with a Ford automobile, a light camping outfit, a plane table, and other equipment. The four parts of the area are for convenience called the Salton Sea region, the Mohave Desert region, the lower Gila region, and the Papago country. (See Pl. I.)

Maps were prepared of the entire area showing the relief and the location of watering places, roads, and other features. The watering places, with a few exceptions, were examined, about 160 samples of water were collected and shipped to the water-resources laboratory of the United States Geological Survey for analysis, and signs directing to water were erected at 305 localities. In order to give information as to the specific location of watering places with reference to lines of travel, logs were made of nearly all the roads, including those that lead into the remotest parts of the desert. Guide books containing the detailed maps, the road logs, and condensed information regarding watering places were published as Water-Supply Papers 490-A, 490-B, 490-C, and 490-D. Exploratory geologic maps of the area were made, and much information was obtained concerning its geography, geology, and ground-water conditions. Four comprehensive water-supply papers have been prepared, of which the present volume is the third to be published. The first two cover the Salton Sea region and the lower Gila region and were issued as Water-Supply Papers 497 and 498; the paper on the Mohave Desert region will be published later.

Among the most valuable of the products of this desert survey are the large maps, which show the mountains and other land forms by relief shading in brown, in a manner that can be understood by anyone. This relief shading will help travelers greatly in keeping their bearings and will at the same time enable physiographers to gain an adequate understanding of the surface features of the region. The relief shading was done by John $\mathrm{H}$. Renshawe, on the basis of copy furnished by the geologists who did the field work. Mr. Ren- 


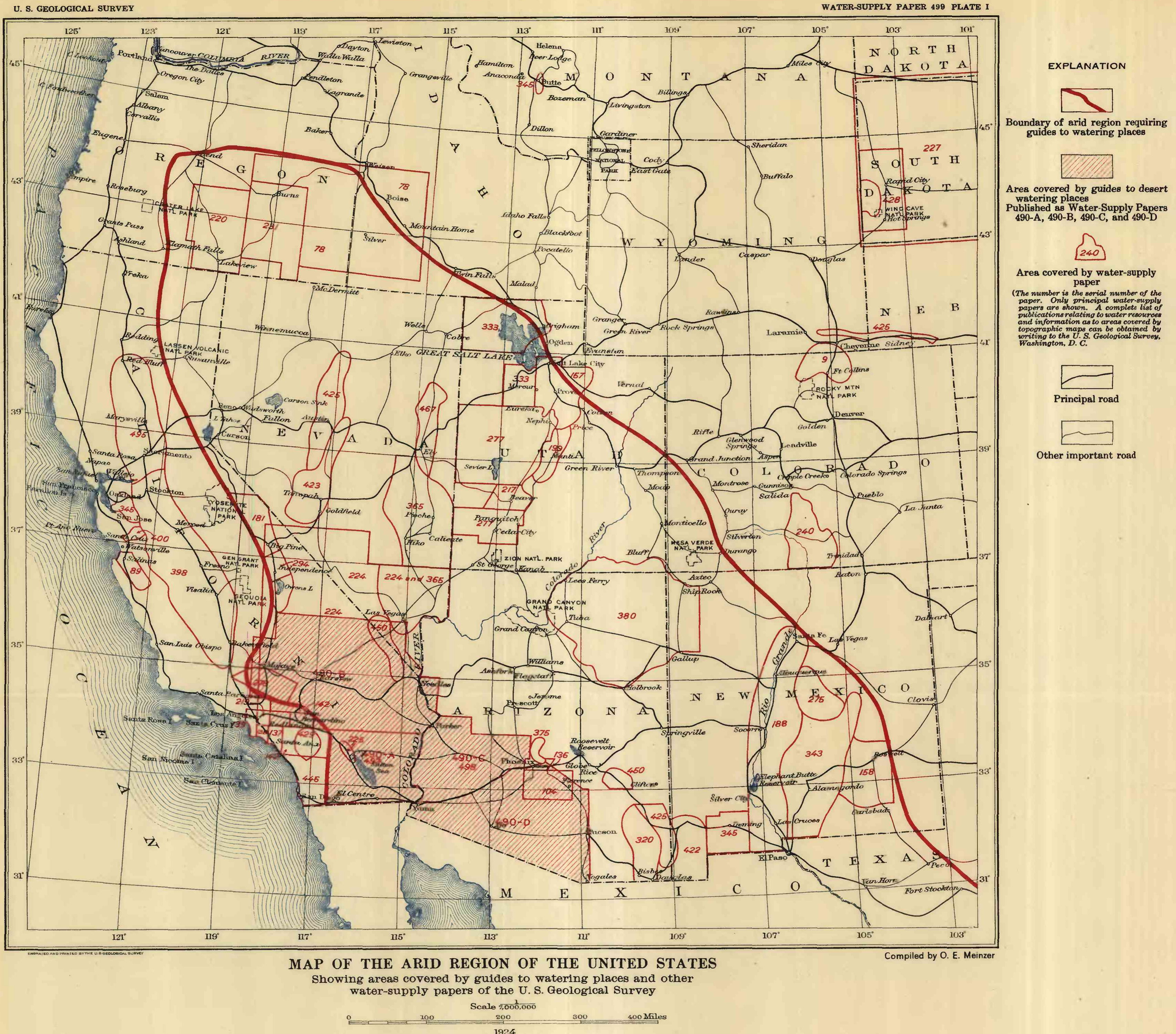


shawe brought to this task not only the skill and esthetic appreciation of an artist but also an intelligent understanding of desert forms resulting from long experience as a topographer in the West. The reproduction of the relief shading on the printed maps, which involved serious technical difficulties, was the work of S. J. Kubel and his able assistants in the division of engraving of the Geological Survey.

The so-called Papago country, lying south of Gila River, between Tucson and Yuma, has had until recently only a few white inhabitants and has seemed so waterless and formidable a region that it has been rarely visited by white men. It has been a sort of strange wonderland, isolated and different from the rest of the country-a desert that has perhaps taken a larger toll of human life than any other arid section of the United States, yet green and tree-covered and for unknown generations providing a home and livelihood for a simple-hearted, peace-loving tribe of Indians. At one time the entire region was sparsely inhabited by the Papago Indians, but at present they live only in the eastern and central parts, whereas the western part, shown in Plate V, includes an area (in the United States) nearly as large as Connecticut, whose only human inhabitant is a solitary white man, the caretaker of an abandoned mine. This western part has a rainfall amounting to less than 5 inches a year and contains so few permanent reliable watering places that they can almost be counted on the fingers of one hand. Near its southern margin runs the dreaded Camino del Diablo, along which, it is estimated, not less than 400 wayfarers have perished at one time or another.

In recent years the Papago country has become much more accessible because of the use of automobiles, the establishment of a large mining camp at Ajo, in the heart of the region, the building of a railroad to that point, and operations of the United States Office of Indian Affairs in mapping the region, drilling wells, and making other improvements.

The present volume is based largely on information obtained in the field and is by far the most detailed and accurate description of the region that has been published. Mr. Bryan's purpose has been to prosent the facts in regard to the region and their interpretation in the most concise and direct manner possible, without attempt at literary effect, but these facts and interpretations are so intensely interesting that the book has the fascination of a good work of fiction.

The question of water supplies has of course always been the vital problem of the Papago country, both for the Indians who have made their meager living from the products of the region and for the 
white men who have come into the region to develop mines, to build railroads, or to help the Indians. The developments by the Office of Indian Affairs, the railroad company, and the mining companies have yielded much valuable information in regard to ground-water conditions, which has been thoroughly utilized by Mr. Bryan in his study of the water resources of the region. The present volume is valuable both for its accurate description of existing water supplies and for its detailed discussion of the prospects of developing new supplies. The discussion of practicable methods of storing smal! supplies of surface water is a contribution of unique value, and still more important is the surprising conclusion, which is developed on the basis of sound data, that in most of the region good water supplies for ordinary purposes, not including irrigation, can be obtained by digging or drilling wells to moderate depths. 


\title{
THE PAPAGO COUNTRY, ARIZONA
}

\author{
By KIrK Bryan
}

\section{INTRODUCTION}

Location.-The Papago country derives its name from a group of seminomadic Indians belonging to the Pima stock, who were called by the early Spanish explorers the Pimos frijoleros, or bean-eating Pimas. Somewhat later the name Papago (pronounced pa'pago; both a's as in ah) became generally current. These Indians ranged over the desert country west and south of Santa Cruz and Gila valleys and north of Altar Valley in Sonora as far west as the Gulf of California. The Spanish named the whole region inhabited by Indians of the Piman stock the Pimería and later distinguished the portion west of Santa Cruz River as the Papaguería.

The Papago country as considered in this report includes the part of the original Papaguería that lies north of the international boundary in southwestern Arizona. (See fig. 1.) It is bounded by Santa Cruz, Gila, and Colorado rivers but includes also the routes from Tucson to Florence, Casa Grande to Florence, and Florence to Phoenix.

The Papago country is part of the desert region of Arizona and is included in the Basin and Range province of the United States. Broad alluvium-floored valleys bordered by relatively small steepsided mountains are characteristic of the region. A warm climate, almost constant sunshine, and very little rain set the area apart as a land of small population, both animal and human. The vegetation is, however, remarkable in the great number of trees, bushes, and large cacti, which give an appearance of verdant fertility to an almost waterless land. This strange vegetation, the picturesque, almost fantastic forms of the desolate mountains, the play of color on mountain and cloud, the shadows of morning and evening, and the lambent haze of midday combine to fascinate the traveler who has the hardihood to face the discomforts of desert travel.

Maps.-The map of the Papago country is published in three sheets as Plates II, III, and IV (in pocket). The area covered by these sheets in relation to one another and the whole area is shown in Figure 1.

The maps are the result of plane-table work done by me, combined with existing published and unpublished data. The most detailed recent work has been done by the United States Indian Service. The larger part of the detail of the Papago villages and 
roads in their vicinity has been compiled from this source. 'The topography and roads of the Tumacacori Mountains have been

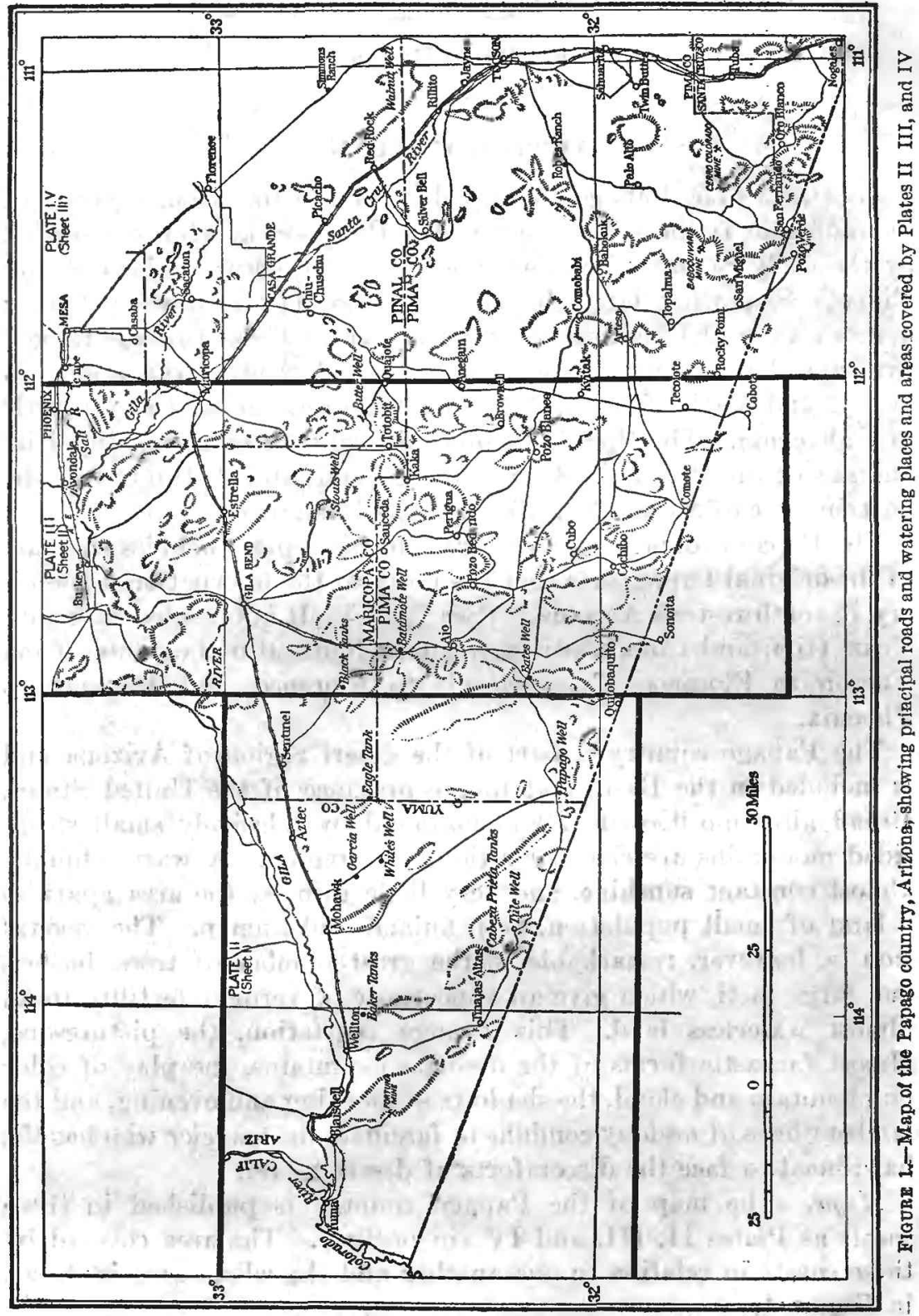

redrawn from maps of the United States Forest Service. Much material was derived also from topographic sheets of the United States Geological Survey, plats of the General Land Office, railroad alinements, and maps of the Mexican Boundary Survey. 
The topography has been drawn by Mr. John H. Renshawe from the best available data. In the flatter areas the darkest color represents the lowest elevation and lighter colors the higher elevations. The mountains are shown by shading, as if seen under a strong light coming at a low angle from the northwest. The general form, size, and location of the mountains and the general relation of the roads, towns, and watering places to one another and to the topography are correctly shown, but minute exactness can not be expected in work of this type. Many locations are marked as approximate, and perhaps more should be so marked. Much detail is missing, particularly in the parts of the map that were compiled from maps made several years ago. It is thought, however, that all the features shown on the map will be found on the ground.

Acknowledgments.-I am indebted to many people for kinduess and for information of great value furnished during the course of the field work. Mr. Clyde P. Ross, who was in charge of the work on desert watering places north of Gila River, cooperated heartily in contiguous territory, especially in making and compiling the map. He has furnished logs for about 60 miles of road, as is further noticed in the text. My field assistant, C. G. Puffer, made travel in the desert easy and contributed much local information. $\mathrm{He}$ is responsible for the mapping of the northern border of the Sauceda Mountains and for placing the signposts. I am particularly indebted for favors and information to Col. John C. Greenway and Messrs. August de Nave, W. B. Kibbey, Joseph Meneger, Thomas Childs, Manuel L. Corrillo, W. C. Gietz, Charles M. Findman, C. R. Oldberg, W. D. Tremaine, and Samuel Clark.

In the preparation of the manuscript $I$ have had the advice of Mr. O. E. Meinzer, under whose supervision the work was done. Dr. F. V. Coville and his assistants, of the Bureau of Plant Industry, have kindly read and criticized the section on flora. Mr. F. L. Ransome generously furnished the section on history. I take this opportunity of acknowledging the services of the editors and illustrators of the Geological Survey, whose skill and interest have made a finished book of the original manuscript.

\section{HISTORICAL SKETCH}

By Frederick Lestie Ransome ${ }^{2}$

\section{INTRODUCTION}

The history of Arizona is divisible into three major periods. The first is the era of Spanish exploration and mission planting, extending from 1539 to 1823 , a span of 284 years. The second is the

1 This sketch of the history of Arizona, written for another purpose, has, with Mr. Ransome's consent, been condensed and modifled by Kirk Bryan for use in this guide. 
interval of Mexican control, from 1823 to 1848 or 1853, according to locality. This was on the whole a time of social and economic decay, during which much that had been built up by the military and ecclesiastical forces of Spain crumbled to ruin. The third is the epoch of American occupation and development. The story of the earlier periods is interesting in its social and geographic aspects and supplies a picturesque background to the modern development of Arizona, in which the Papago country as yet plays a very minor part.

\section{SPANISH EXPLORATION}

It appears that as early as 1530 , only eight years after the conquest of Mexico, Nuño de Guzmán, president of the audiencia, or governing board of New Spain, and the rival and enemy of Cortés, was informed of the existence of seven cities, rich in gold and silver, that lay in the unknown country to the north. De Guzmán organized an expedition for the discovery and conquest of these cities, but, through fear of Cortés, he abandoned his enterprise after founding the frontier town San Miguel de Culiacan, from which most of the later expeditions to the north started.

Six years later four strange wanderers reached Culiacan. These were the stout-hearted Ảlvar Núñez Cabeza de Vaca and three companions, one of them a Moroccan negro known as Estevan or Stephen. These men had been members of Narváez's ill-fated Florida expedition, which had been wrecked off the coast of Texas in 1528, and after devious and perilous wanderings they at last reached the Spanish outposts in Mexico. They related their amazing adventures and, among other things, told of reports that had reached them at various times concerning powerful villages to the north, with many-storied houses, inhabited by a superior race of Indians. When, in 1538, Don Francisco Vásquez de Coronado was appointed Governor of Culiacan, the negro, Estevan, retold the story to the new governor. Coronado on March 7,1539 , sent out from Culiacan an expedition under Marcos de Niza, a Franciscan friar, with Estevan as guide, to find these cities. There has been much difference of opinion concerning the route followed by this expedition; the records are vague, and the actual itinerary may never be known with certainty.' Bancroft and others have supposed that it lay down the Santa Cruz, past the sites of Tucson and Florence, and then northeastward over the mountains. Some eminent modern authorities, however, believe that Estevan, followed by Marcos, entered what is now Arizona by way of the San Pedro and descended that stream to the vicinity of the modern Benson, and thence traveled northeastward through Dragoon and Railroad passes to the Gila near the point where Solomonsville now stands. The ruined red adobe structure that figures in the old 
narratives as Chichilticalli and marked the passage from the easily traversed country to the wilderness (el despoblado) is supposed by those who support this view to have stood near the site of Solomonsville and, as they point out, can scarcely have been the Casa Grande, near Florence, which is gray, not red. The latest contribution to this puzzling question is that of Potter, ${ }^{2}$ who believes that the route was down the Santa Cruz, past the site of 'Tueson, and over the Tortilla and Pinal ranges to Salt River near the mouth of Pinal Creek. Potter makes the ingenious but not altogether convincing suggestions that the name Chichilticalli was applied to one of the bold castellated promontories of red quartzite that projects from the south end of the Sierra Ancha, near the east end of the present Roosevelt Reservoir, and that this original designation was later applied to an aboriginal ruin which has been discovered by Potter in the neighborhood.

North of Chichilticalli, or Solomonsville, if the opinions of Hodge ${ }^{3}$ and Cones are accepted, the expedition entered the wilderness or rough mountainous country embraced within the present Fort Apache and White Mountain Indian reservations and the Apache National Forest. It crossed the Rio de las Balsas (Salt River), gained the platean of northeastern Arizona near the present eastern boundary of the State, and headed directly for the Zuñi pueblos-the "Seven Cities of Cibola." The unusual manner in which the services of Estevan were utilized now brought the expedition to disaster. With a considerable retinue of friendly Indians he kept in advance of the friar, who, with the main force, followed more leisurely on his trail. When Marcos de Niza had come within a few days journey of Hawikú, the most southwesterly of the Zuñi pueblos, the main body was met by a terrified fugitive who informed the friar that Estevan had not been permitted to enter the first city of Cibola and had been killed. It appears that the Indians, exasperated by the negro's insatiable demands for turquoises and beautiful women and skeptical as to a man of his complexion being the ambassador of white men such as he described, had concluded, after three days' deliberation, that his unreasonable demands merited death. Friar Marcos then advanced to a point whence he could view the fatal city and hurried back with, as he expressed it, "much more fear than victuals."

The friar's story with imaginative embellishment in regard to the use of gold and silver vessels in the cities aroused the interest and cupidity of the Spaniards, and on February 23, 1540, began the famous but futile march of Coronado's expedition. His force con-

\footnotetext{
2 Potter, S. O. L., Chichilticalli: Am. Geog. Soc. Bull., vol. 40, pp. 257-276, 1908.

s Hodge, F. W., Coronado's march to Quivira, in Brower, J. V., Memoirs of explorations in the basin of the Mississippi, vol. 2, pp. 29-73, St. Paul, Minn., 1899.

4 Coues, Elliot, On the trail of a Spanish pioneer, vol. 2, pp. 481-485, 517-518, New York, 1900.
} 
sisted of about 250 Spanish horsemen, 75 regular foot soldiers, 300 or more Indian allies, and over 1,000 Indian and negro servants. Coronado followed practically the same route as Marcos de Niza and on July 4 reached and captured the pueblo of Hawikú, which he named Granada. The much-advertised Seven Cities of Cibola he found, greatly to his disappointment, to be seven poor little villages. In his letter to Mendoza he stated, with the inconsistent piety of the time:

As far as I can judge, it does not appear to me that there is any hope of getting gold or silver, but I trust in God that, if there is any, we shall get our share of it, and it shall not escape us through any lack of diligence in the search.

From Hawikú Pedro de Tovar was sent to investigate the Hopi (Moqui) pueblos of Tusayan. He returned in 30 days with reports of a tremendous canyon west of the Hopi pueblos, and about August 25 García López de Cárdenas, Coronado's army master, started with 12 men to verify these reports. He discovered the Grand Canyon about September 15, 1540. With Coronado's march eastward across the Pecos and out on the Great Plains the present work is not particularly concerned. He returned to Mexico in the autumn of 1542 without making a permanent settlement.

In the meantime Hernando de Alarcón, who had been ordered, such was the knowledge of geography at that time, to keep in touch with Coronado's army by sea, entered the mouth of the Colorado on August 26, 1540, and ascended it for many miles in boats. He named the stream Río de Buena Guía (river of the good guide). Melchior Diaz, who had been dispatched overland from Sonora by Coronado to find Alarcón and his ships, reached the Colorado, which he named Río del Tisón (firebrand river), early in October, after Alarcón had given up hope of effecting a junction and had, returned to New Spain. Melchior Díaz was thus the first explorer to traverse the Papago country, but his route is unknown.

For many years the Spaniards made little attempt to follow up Coronado's explorations, and it was not until late in 1582 that Antonio de Espejo explored New Mexico and visited the Zuñi and Hopi pueblos. With four companions he traveled west from the Hopi pueblos for 45 leagues and in the neighborhood of two rivers "of a reasonable bigness" took out "with his own hands exceeding rich metals holding great quantities of silver." "Espejo is supposed to have obtained his silver ore somewhere in the headwater region of the Verde. His find in 1583 is the first record of prospecting in Arizona.

${ }^{5}$ Hakluyt, Richard, Voyages, vol. 2, p. 471, Irondon (reprinted), 1810. 
About 20 years later, on October 7, 1604, Juan de Oñate, conqueror and first governor of New Mexico, with two priests and about 30 men, started from his capital San Juan with the purpose of reaching the "South Sea." He passed through Hawiku and proceeded to the Hopi pueblos. Thence he crossed the Little Colorado, which from its red color he named Río Colorado, and descending from the plateau at the headwaters of the Verde discovered Santa María or Williams River, which he followed to its junction with the Colorado. 'This stream he called Río Grande de Buena Esperanza, although he knew it had previously been named Río del Tisón. The Gila he designated Río del Nombre de Jesús. Onate reached the mouth of the Colorado on January 25, 1605.

The year 1691 was marked by the first entry into Arizona of Father Eusebio Francisco Kino, ${ }^{b}$ of the Company of Jesus, one of the most remarkable men who contributed to the development of the Southwest. A native of the Austrian Tyrol, well educated, with a decided talent for mathematics, he arrived in Mexico on May 3, 1681, in his thirty-seventh year. He at first engaged in missionary work in Lower California, which, notwithstanding the earlier explorations of Alarcón, Díaz, and Oñate, was then supposed to be an island. When, however, in 1685, the conquest of California was suspended, he sought other fields of labor and early in 1687 was assigned to Pimería Alta, a region of which little was then known, as it lay outside of the Spanish frontier. As its boundaries were subsequently developed it extended from Altar River, in Sonora, to the Gila and from the San Pedro on the east to the Colorado and Gulf of California on the west. The Piman tribes occupied all the country, except that along the lower Gila and the Colorado there were a number of Yuman tribes, including the Yumas, Cocomaricopas, Cocopas, and Quiquimas. All these tribes, cultivators of the plains and riparian lowlands, were generally friendly to the Spaniards and hostile to the nomadic, murderous, and plundering Apaches', who from their fastnesses in the mountain region north and east of Pimeria Alta harried the more peaceful tribes of the lowlands and, in later years, levied bloody toll upon the missions and ranches of the Spaniards. Far in the northeast corner of what is now Arizona were the Hopis, or Moquis, as the Spaniards called them, who asked only to be let alone, and the more truculent Navajos, a branch of the Apache group of tribes, who waged frequent war upon the Spaniards in New Mexico.

Kino began his work by founding in 1687 the mission of Nuestra Señora de los Dolores on a beautiful site on San Miguel River, about 60 miles a little east of south of the present town of Nogales. Here

Bolton, H. F., Kino's Historical memoir of the Pimerfa Alta, Cleveland, 1919. 
he made his headquarters, and for 25 years with tireless energy he journeyed over his vast field, exploring its remotest corners, establishing missions and cattle ranches, and winning the affection and devotion of the Indians. He made the first map of Pimería Alta, based on his explorations, and established the fact, apparently forgotten soon after its original discovery in 1540, that it was possible to travel overland from Pimería Alta into California. Kino made at least 14 extensive journeys into what is now southwestern Arizona. Only a few of these can here be briefly recounted. His first entrance was made in company with Father Juan María de Salvatierra early in 1691, when, at the invitation of the Sobaipuris, the two padres reached the ranchería or village of Tumacacori, on Santa Cruz (Santa Maria) River. In the following year he visited the Sobaipuris on the San Pedro (Rio Quíburi) and at the large ranchería of San Xavier del Bac, 12 miles sauth of Tucson, where over 800 of the tribe were living.

In February, 1694, Domingo Petriz de Crusate was put in command of the military forces in Pimería to wage war on the Apaches. His nephew, Juan Mateo Mange, was commissioned a lieutenant and detailed to escort Kino and his associates in their missionary journeys. Mange, a very intelligent and observing man, kept excellent journals that have been among the most valuable records of the time. In June, 1694, Mange made an " entrada" from Tubutama, passing through Saric and thence on the west side of the Baboquivari Mountains to Gubo and Cups, which are probably the modern villages of Comobabi and Cobabi; thence he returned to Sonora by a more westerly route through Moicaqui to Caborca. Mange was thus the first white man except, perhaps, Melchior Díaz, previously mentioned, to penetrate the interior of the Papago country, and during this trip he first heard of the Casa Grande. In November, 1694, Kino visited and held mass in the Casa Grande, and he was probably the first white man to reach this part of the "Río de Hila," as he called it. Curiously enough, Kino supposed that the Casa Grande and its associated ruins were the remains of the Seven Cities of Cibola.

There were some Indian disturbances in 1695 , and at Tubutama, about 50 miles northwest of the Dolores mission, in what is now Sonora, Father Francisco Xavier Saeta was murdered. In Arizona, however, the depredations appear to have been committed by the Apaches, who were pursued by a military force to the Chiricahua Range (Serro de Chiguicagui), where considerable booty was recovered. In this year, ${ }^{7}$ as the result of a journey by Kino to the

7 As Bolton points out, in Illustration of Kino's tireless energy, he was 51 years old when he made, on horseback, this journey of 1,500 miles in 53 days, including stops, or an average of nearly 30 miles a day. 
City of Mexico, five missionaries were assigned to assist him in Pimería.

In January, 1697, Kino placed some cattle, sheep, goats, and mares with the Indians of San Xavier del Bac and also supplied livestock to the Indians on the San Pedro. Thus began the cattle industry of Arizona. On November 9 of the same year Kino, with Mange and servants, was joined at Quíburi (not far from the site of the present Hereford, on the San Pedro, west of Bisbee) by Lieut. Cristóbal Martín Bernal with a small body of soldiers. The party then proceeded down the San Pedro to its mouth, near the place where Winkelman now stands, and followed the Gila, ${ }^{8}$ through large cottonwood groves, past the site of Kelvin and through the gorge to Casa Grande, a few miles west of the point where Florence now stands. Thence they turned south through San Xavier del Bac and along the Santa Cruz. Most of this route, so far as known, had not previously been traveled by Europeans.

In September, 1698, Kino, with Capt. Diego Carrasco, who had taken Mange's place as head of the Compañía Volante, with express orders to hunt for a quicksilver mine reported among the Sobaipuris, left Dolores and proceeded to San Xavier, and thence down the Santa Cruz to Gila River west of Casa Grande. Thence they turned south from San Andrés, near the present town of Maricopa, and explored new territory. They passed through San Angelo del Botum (Akchin or possibly Cocklebur) and San Bonifacio del Coati y del Sibuoidag (Quajote, also called Kohakt) to San Francisco del Adid and Anagam (the modern Anegam). From this center of Papago life in the Santa Rosa Valley they went south and west through San Serafín del Actum, the modern Alchin, and three unnamed villages to Nuestra Señora de la Merced del Batqui. This locality, consisting of fields but having no permanent water, is probably Mesquite Charcos, called to-day El Mesquite by the Mexicans and Vatjeli by the Papagos. From Batqui they went southwestward around the point of Mesquite Mountain to the fields of San Rafael del Actum el Grande. The Papago name Akchin, which Kino corrupted, is still further changed to the modern La Quituni. From this place they went to San Marcel del Sonoidag (Sonoita), and thence, after a trip west to the Pinacate Mountains, returned to Dolores by way of Caborca. This journey was the first across the Papaguería, and on the knowledge thus gained Kino made his next journey over what is now called the Camino del Diablo.

\footnotetext{
Bino at this time refers to the Gila as "the Río Grande. or Río de Hila"; a little later it appears occasionally as "Rio Grande de Hila." His "Río Colorado" is consistently applied to the Colorado in the modern sense, athough, as has been seen, this name was first given by Oñate to what is now the Little Colorado.
} 
On February 7, 1699, Kino, Mange, and Father Adamo Gilg, with servants and pack animals, started for the lower Gila. According to Mange's itinerary, they went from Dolores to Tubatama and thence through Saric to El Guvo Verde, a tank of rain water 10 leagues west, and thence to the clear spring of Santa Eulalia, 5 leagues west. This locality seems to be the modern Pozo Verde, near the south end of the Baboquivari Mountains. Thence passing a small tank at 4 leagues, they came to a flowing stream near a high square peñasco (Baboquivari Peak), 9 leagues from Pozo Verde. This seems to be Fresnal. Thence they struck across to Sonoita, making the journey in two days, and as they did not go through Actum Grande (La Quituni) it seems likely that they went by way of the modern Vamori and Cobota and then followed Sonoita River to Sonoita and, traveling by way of Tinajas Altas and along the east side of the Gila Range, reached the Gila from 15 to 20 miles above its mouth. Here the Indians presented Kino with some beautiful blue sea shells. ${ }^{9}$ Later, Kino remembered that he had seen similar shells during his missionary work in California and reasoned, soundly enough, that these shells had come overland from California through the channels of Indian trade. The conviction thus formed that California was not an island, but could be reached by a land route, was the inspiration of much of his later exploration.

In October, 1699, Kino, with the Father Visitor Antonio Leal, Gonzolbo, Mange, and two soldiers, ascended to San Xavier del Bac and after visiting the neighboring rancherías on November 5, they struck westward to Fl Tups (Tupo), the modern Comobabi, and thence to El Cupo or El Humo (Cobabi), to San Serafín del Actum, the modern Akchin, in the Santa Rosa Valley. This was the first journey over the modern route from the Santa Cruz Valley into the Papago country. From Akchin they went to San Francisco del Adid, also in Santa Rosa Valley, and thence "turning somewhat to the south" to Nuestra Señora de la Merced del Batqui. ${ }^{10}$ Kino and Mange left the main party here and went to Sam Rafael del Actum (La Quituni) and thence north 9 leagues to Baguiburisac, which was probably at or near the modern Cubo, and thence they went to El Coat y Sibagoyda (Quajote) and returned to Sonoita, by traveling ail night. On November 11 they went probably by way of San Rafael del Actum to Busanic, near Saric, overtaking the main party, and thence all proceeded to Dolores.

\footnotetext{
It may reasonably be surmised that these were the abalone (Haliotis) of the California coast.

10 Mange gives 12 leagues. His distance is In error, or Batquit is not the modern Mesquite Charcos.
} 
On April 21, 1700, Kino left Dolores and proceeded to San Xavier del Bac, where on the 28th he began the foundations of a large church on the site of the existing mission. At the same time he gave orders to roof a little temporary mission church, for dedication to Nuestra Señora de Loreto, that may have been begun here in 1699 . On September 24 he started again from Dolores and, following nearly the same route as in February, 1699, he reached Batqui on the 29th. Going north from Batqui 20 leagues and passing four lesser rancherías, he arrived at San Gerónimo, where there were $280 \mathrm{In}$ dians. After a journey of 6 leagues he reached a watering place, and 12 leagues beyond, another watering place among inaccessible rocks. From this locality it was 10 leagues to the Gila. The route pursued is not clear, but San Gerónimo is either Sauceda or Kaka, probably the latter, as the people of Sauceda are usually harvesting their crops at Kaka in September. From Kaka to a charco in the Vekol Valley and thence by way of Sand Tanks to Gila Bend or from Kaka by way of Sauceda or Moivavi to a tank along the north front of the Sauceda Mountains and thence to the river would complete the journey.

On reaching Gila River he followed that stream toward its mouth, in his search for a land route to California. He did not quite reach the Colorado, but from a hill, apparently a few miles west of the present Dome, he was able to see the confluence of the two rivers and to satisfy himself that the Gulf of California did not extend thus far north. He set out on his return, reserving for a later trip actual exploration of the Colorado, but was persuaded by the importunities of the Yumas to resume his westward journey. He reached, but did not cross, the Colorado on the 8th and returned to the vicinity of Wellton on the 9th. Thence he returned to Sonoita by way of Tinajas Altas.

On March 1 of the following year, still occupied with his search for a land route to California, he started from Dolores to the Gulf, which he reached on the 21st, by way of Sonoita, but was prevented by extensive sand dunes from proceeding northward along the shore to the mouth of the Colorado. On November 3 he once more set out from Dolores to the Gulf, and on his way he laid the foundation for a large church at Guevavi, on the Santa Cruz, about 9 miles north of the site of modern Nogales, where a small one had apparently been. built during the previous year. Apparently at this time resident fathers were established at Guevavi and at San Xavier del Bac. On this journey, instead of going north to San Xavier del Bac, Kino turned southwest to Busanic, near Saric, and then followed approximately the route of September, 1699, by way of La Quituni to Sonoita 
and thence by Tinajas Altas to the Gila at Wellton. He reached the Gila on November 16 and the Colorado on the following day. On November 21 Kino crossed the Colorado on a raft. On the west bank he was given many of the blue shells that had so aroused his interest and was told that they came from a sea eight or ten days' journey toward the west. Satisfied that he had found the land route to California and conscious of administrative duties awaiting him at Dolores, Kino pushed his exploration no farther at this time but returned to his mission headquarters by the same route.

On February 5, 1702, the indefatigable Kino again set out from Dolores with Father Manuel Gonzales, 12 servants, and 80 horses and mules, traveling by approximately the same route as in the previous year. He mentions establishing ranches at various points along what he expected would become an important highway to the missions in California. On the 28th they reached San Dionisio, at the confluence of the Gila and Colorado. On March 7 Kino and Gonzales descended to the mouth of the Colorado, and again on the 10th. On March 12 they attempted to return to Dolores by going along the eastern shore of the Gulf to the bay west of Pinacate Mountain but were forced to abandon the attempt in consequence of lack of water and pasturage, and to retrace their steps to the Gila. Lumholtz, more than 200 years later, accomplished this difficult journey. ${ }^{11}$

Although Kino made a number of later journeys, he never again reached the Colorado nor penetrated the Papago country. His last recorded expedition was with Father Manuel de la Oyuela, Alférez Juan Mateo Ramires, and Juan Antonio Duran to Pinacate Mountain, which he called the Serro de Santa Clara, whence he pointed out to his companions the mouth of the Colorado. He died in 1711, and for 20 years thereafter no Spaniard is known to have entered Arizona. If resident missionaries were placed at Bac and Guevavi in 1701, they appear to have been withdrawn a year or two later, and in 1706 Kino was pleading with his superiors for three padres for Arizona, where he had prepared the way. Kino's efforts toward the material development of Arizona were confined mainly to the establishment of stock ranches on which the stock was cared for by Indians and to the encouragement of agriculture and the introduction of new food plants. Kino's practical pioneering spirit is well shown in a rather formal report to his superior Father Visitor Antonio Leal, dated April 2, 1702. 'The resemblance of this report ${ }^{12}$ to the advertising matter of modern enterprising towns makes its reproduction worth while.

11 Lumboltz, Carl, New trails in Mexico, New York, 1912.

12 Bolton, H. E., op cit., vol. 1, pp. 357-358. 
TEMPORAL MEANS FOR THESE NEW CONVERSIONS AND FOR THE TOTAL REDUCTION OF THIS NORTH AMERICA, WHICH HITHERTO HAS BELN UNKNOWN

I. First, there are already many cattle, sheep and goats, and horses; for, although in the past year $I$ have given more than 700 cattle to the four fathers who entered this Pimeria, I have for the other new conversions and missions, which by the favor of heaven it may be desired to establish, more than 3,500 more cattle; and some of them are already far inland, 90 leagues from here, ${ }^{12}$ and by the divine grace they can pass with ease to the Californias, Upper and Iower, as a certain important person is pleased to name them, the latter being in 26 and the former in 30 and more degrees of latitude.

II. There are in this very fertile and rich Pimería, which already has five missions with five fathers, many fields of wheat, maize, beans, etc.; and it produces all sorts of vegetables, garden products, and fruit trees, as in Europe. There are already vines for Castilian wine for the missions, a watermill, pack trains, fields, oxen, lands, level roads, beautiful rivers, abundant pasturage, good timbers for buildings, and mineral lands.

III. Of these new nations almost all are composed of industrious, docile, affable, and very friendly Indians; and only in some remote parts are there some Indians somewhat more barbarous and uncivilized, because of never having seen civilized people in all their lives.

IV. The temperature of these lands, which extend from 30 degrees of latitude to 31, 32, 33, 34, etc., is similar to that of Mexico and ihe better part of Europe, without excessive heat or excessive cold.

V. With these means and with these new conversions it will be possible to trade by sea and land with other near-by and remote provinces, nations, and kingdoms, with Sonora, Hyaqui, Cinaloa, Culiacan, with all New Galicia, with New Biscay, with Moqui, with New Mexico, which will be able to come to join hands with these provinces of Sonora, and even with New France.

There is no record of mining in Kino's time beyond a brief statement, in the part of his memoirs written in 1705, as follows: ${ }^{14}$

In these new nations and new lands there are many good veins and mineral lands bearing gold and silver; and in the neighborhood and even in sight of these new missions and new conversions some very good new mining camps of very rich silver ore are now being established.

Probably some of the silver deposits in the Santa Rita Mountains were discovered about this time, but many writers on Arizona have undoubtedly erred in stating that extensive mining operations were conducted by the Jesuits in what is now Arizona before the middle of the eighteenth century.

In 1731 there seems to have been a revival of interest in Pimería Alta and some reawakening of missionary zeal. In 1732 Father Felipe Segesser took up his residence at San Xavier del Bac and Juan Bautista Grashoffer at Guevavi. Shortly afterward, about 1736, was discovered the famous Bolas de Plata deposit at Arizonac. Bancroft ${ }^{16}$ states:

The site was between Guevavi and Saric, but apparently just south of the Arizona line. The unparalleled richness of the silver deposits brought a crowd

18 Those at Sonoits, for example.

16 Bolton, H. E., op. cit., vol. 2, p. 266.

15 Bancroft, H. H., History of Arizona and New Mexico, p. 362, San Francisco, 1889. 
of treasure seekers and caused the king to claim, it as his own, it being not a mine but a criadero de plata; but the supply of nuggets was soon exhausted and the place was in a few years well-nigh forgotten.

The bitter rivalry between the Franciscans in New Mexico and the Jesuits in Pimería Alta led, in 1743, to attempts by the Jesuits to reach the obdurate Hopis through Arizona. Padre Keller went up the Gila for this purpose, but his expedition was attacked by the Apaches and forced to return. In the same year Father Jacobo Sedelmair reached the Gila near the Casa Grande. In October he explored Salt and Verde rivers until he was driven out by the Apaches. He then went down the Gila, exploring the big bend for the first time. He left the river, supposedly at the spring known to-day as Agua Caliente, and struck boldly across country to the Colorado, which he reached somewhere near the site of the present Ehrenberg. He then went up the Colorado to Williams River and ascended that stream in an attempt to follow Onate's route to the Hopi pueblos, which, however, for reasons not clearly related, he did not reach. Sedelmair made additional journeys along the Gila in 1748 and 1750 , but they were geographically unimportant.

In 1750 the Pima Indians, hitherto generally friendly to the Spaniards and hostile to the Apaches, revolted, and in 1751 the church at San Xavier del Bac was plundered. Peace was restored in 1752, Tubac was made a presidio, with a garrison of $50 \mathrm{men}$, and the missions were reoccupied; but the genius of Father Kino was lacking in his successors, the old kindly relations between Indians and padres had been impaired, and the mission establishments were undergoing deterioration and being harried by the Apaches.

In 1765 the Franciscans triumphed over their rivals of the Company of Jesus, and through a royal decree issued at Madrid the expulsion of the Jesuits was effected in 1767. At that time there were only two missions in what is now Arizona, those of San Xavier del Bac and San Miguel de Guevavi.

Fray Francisco Garcés, of the Order of St. Francis and a native of Spain, arrived at San Xavier del Bac on June 30, 1768, and is said to have been joyfully received by the Indians. He was then 31 years of age. A man of far less ability and force than Kino, with narrower interests, he was a devoted and fearless soldier of the cross, who in his zeal for saving human souls performed some of the most remarkable and perilous journeys ever accomplished in a region calling especially for fortitude, endurance, and courage in those who ventured into its arid, stony wastes. Whereas Kino usually traveled with companions, servants, and numerous pack animals, Garcés in some of his longest journeys was accompanied only by two or three Indians and at times pursued his way quite alone. 
On August 8, 1768, Garcés set out on the first of several long journeys, a descent of the Gila and Colorado to the Gulf, his object being to prepare the Yuma Indians for the establishment of a mission. On January 8,1774 , he left Tubac on a more pretentious journey with a military expedition under Capt. Juan Bautista do Anza that was intended to open overland communication between Sonora and Monterey, in California. He went as far as San Gabriel mission, still standing near Los Angeles, and then returned to the Colorado and visited a number of tribes, making inquiries concerning a route to the Hopis.

About this time (1773-1776) Fray Sylvestre Vílez de Escalante crossed the Colorado above the Grand Canyon and reached the Uinta Mountains. His explorations belong rather to the history of Utah, however, than of Arizona.

On October 23, 1775, Garcés, with Fray Tomas Eisarc and Fray Pedro Font, left Tubac with a second expedition under Anza, now lieutenant colonel, bound for California by way of Santa Cruz and Gila rivers. Font, who kept a diary of the journey, is characterized by Coues as "a troublesome fellow and a model journalist." 16 On December 5 Garcés left the expedition at the mouth of the Gila and visited the tribes along the Colorado to its mouth. He left the Colorado on February 14 and, traveling northward through the mountains, reached the river again on the $28 \mathrm{th}$, near the point where the present town of Needles stands. He claims to have been the first Spaniard to reach the Mojave Indians, although it is possible that Alarcón may have come into contact with this tribe in 1540, and some of its members may have been seen by Oñate in 1604 or 1605, or by Sedelmair in 1743. On March 4 Garcés left the Colorado and struck out for San Gabriel mission, which he reached on the 24th. After a perilous exploration in California he was on May 30 back again among the Mojaves on the Colorado. On June 5 Garcés crossed the river into Arizona, and traveling across country never before seen by a Spaniard he gained the plateau and reached the Havasupai community that then, as now, inhabited the depths of Cataract Canyon. From Cataract Canyon Garcés skirted the south side of the Grand Canyon, of which, however, he says nothing, and reached the Hopi pueblo of Oraibi on July 2, 1776. He entered the pueblo but was refused admittance to the houses. For two lonely nights the intrepid padre slept at a street corner, without food and exposed to the unfriendly scrutiny of hundreds of eyes. On the 4th of July, on the very day when in another part of the continent the American Nation had its birth, this lonely hero, with

16 Coues, Elliot, on the trail of a Spanish pioneer, vol. 1, p. 58, footnote 4. New York, 1900.

$104211-25-3$ 
courage superior to hunger, disappointment, and defeat, mounted his mule and smilingly rode through the menacing crowd, descended to the plain, and started entirely alone on his long return journey. Later in the day he was overtaken by his original Yavapai guides, sent after him by the Hopis, who, if obdurate, proved neither bloodthirsty nor vindictive.

About this time, probably in 1776 , Tucson, hitherto merely an Indian village or ranchería, became a Spanish settlement, the garrison from Tubac being transferred thither as part of a plan for more effective warfare against the Apaches. Tumacacori, or San José, on the Santa Cruz south of Tubac, was at this date merely a visita or missionary outpost of Guevavi and, having been attacked by the Apaches in 1769, was partly dilapidated. It probably did not become an independent mission until about 1784. Arivaca, about 16 miles west of Tubac, is mentioned in 1777 as a mining locality.

The Yuma Indians, under their chief, Palma, had been pressing for the establishment of a mission among them, and in 1779 Garcés and Fray Juan Díaz were sent to prepare the Indians for the proposed mission. Garcés reached the Yumas late in August, and Díaz joined him on October 2 , with less than 15 soldiers. They found the Indians restless and discontented. In 1780 orders were received from - Mexico to found on the Colorado two settlements of a new type, each embodying a combination of mission, presidio, and colony. These novel communities, established in the autumn of that year, contained in addition to priests and soldiers agricultural settlers with their wives and children. In June, 1781, a third body of Spanish soldiers went into camp at the mouth of the Gila. This was more than the Indians bargained for, and outraged by the cool appropriation of their best lands by the newcomers, they rose in revolt on July 17, 1781. Four priests, including the brave and kindly Garcés, and most of the soldiers and male settlers were slain. This ended Spanish attempts at settlement on the Colorado.

During the 30 years from 1790 to 1820 the missions on the Santa Cruz appear to have been prosperous. Stock ranches were developed in connection with them, some mining was carried on, and the Apaches caused comparatively little trouble. At no time, however, during the Spanish or Mexican control does mining appear to have been extensively practiced in what is now Arizona. A few mines were worked near Tubac and probably at one of two other localities; but the great copper deposits that are now the mainstay of the mining industry of this region were unknown. With the exception of that at Ajo, they lay within the rough, wild country where the Apaches were supreme. There is no evidence that either Spaniards or Mexicans conducted smelting operations, and concentration was, 
of course, a much later development. Probably the only ores worked were such as were rich enough in silver or gold to be treated by primitive amalgamation processes.

In 1818 and 1819 the Navajos warred against the Spaniards, and in 1820 the mission at Tumacacori was partly destroyed by the Apaches. The period of decay and disaster had set in, and during the troublous times that immediately preceded the establishment of the Republic of Mexico, in 1823, the missions were abandoned and they, as well as the stock ranches, were raided and plundered by the Apaches.

\section{AMERICAN EXPLORATION}

The first American pioneers known to have entered Arizona were Sylvester Pattie and his son James. These men, in 1825 and 1826, trapped beavers, then abundant in the Gila and its tributaries. A certain Doctor Anderson made a trip to California by way of the Gila in 1825. In 1828 the Patties made their way to California, where they were thrown into prison by the Mexican commander at San Diego. The elder Pattie died in confinement. Kit Carson is known to have traversed Arizona nearly as early as the Patties, and Pauline Weaver, who subsequently discovered the gold placers near La Paz, was in the country as early as 1832. Little mining was done at this time, although in 1828 Calabasas is mentioned as a ranch near which some poor people worked a gold mine.

Up to 1836 the Apaches had been generally friendly to the American trappers and adventurers, but in that year one of their chiefs, Juan José, and many of his people were killed by some American miscreants for the sake of the Mexican scalp bounty. From that time on, until 1886, the Apaches when not actively hostile were an ever-present menace and a sinister deterrent to the industrial development of the region.

In the war with Mexico begun in 1846 the region now included within Arizona lay outside of the field of hostilities but was traversed by two military expeditions. Gen. S. W. Kearney, with Kit Carson as guide and a party of 200 dragoons, left the Rio Grande in October, 1846, and going by way of the copper mines at Santa Rita, N. Mex., he followed the Gila tr its mouth and crossed into California. He was accompanied by Lieut. W. H. Emory, whose notes ${ }^{17}$ constitute the first official American contribution to the geography of Arizona. On December 2 of the same year Lieutenant Colonel Cooke, ${ }^{18}$ commanding a Mormon battalion, for the purpose of open-

\footnotetext{
17 Emory, W. H., Notes of a military reconnaissance from Fort Leavenworth, in Missouri, to San Diego, Calif.: 30th Clong., 1st sess., S. Ex. Doc. 7 (H. Ex. Doc. 41), pp. 1-416, 1848.

18 Cooke, P. St. G., Report of his march from Santa Fe, N. Mex., to San Diego, Upper California : 30th Cong., 1st sess., H. Ex. Doc. 41, p. 551-563, 1848.
} 
ing a wagon route to California, reached San Bernardino, near what is now the southeast corner of Arizona, finding the ranch abandoned. He went west to the San Pedro and down that stream to the point where Benson now stands. Thence he laid out his road to Tucson and the Gila, and reached the Colorado on January 9, 1847.

By the treaty of Guadalupe-Hidalgo, which was ratified on May 30, 1848, all of Arizona north of the Gila, together with a small area extending down to the Chiricahua Mountains along what is now the eastern border of the State, and a vast region from which California, Nevada, Utah, and parts of Colorado and New Mexico were formed, came into the possession of the United States.

In 1849 the first American Boundary Commission began its work, and for its protection an Army post was established at Yuma. At this time also began the great rush to the gold placers in California, and the Gila became one of the principal emigrant routes followed by the pioneers. In 1850 a ferry was placed in operation at Yuma, and Capt. and Bvt. Maj. S. P. Heintzelman, with three companies of infantry, was established there. At this time Tubac, although largely in ruins, was occupied by a small Mexican garrison, and Tucson was a squalid settlement of about 400 Mexicans and halfbreeds.

In March, 1851, Heintzelman effected a final subjugation of the Yuma Indians, who, unlike the Pimas, had resented the coming of the Americans. The post was abandoned in December but was reestablished under the name Camp Yuma on February 29, 1852. On December 3, 1852, the first steamer reached Yuma from the Gulf of California. The first expedition across northern Arizona to Yuma under the auspices of the United States was that of Capt. Lorenzo Sitgreaves ${ }^{19}$ in 1851.

On December 30, 1853, negotiations were completed for the purchase by the United States of that part of the present area of Arizona and New Mexico that lies south of the Gila and was not included in the territorial transfer effected by the treaty of GuadalupeHidalgo. The United States thus acquired by this so-called Gadsden Purchase the northern part of Pimería Alta, including the area covered in this report. Surveys to provide a railway route through Arizona to California, the particular object of this purchase, were already in progress. One of these, under Lieut. A. W. Whipple, ${ }^{20}$ traversed northern Arizona only, but early in 1854 Lieut. J. G. Parke, with another party, ${ }^{21}$ went from Yuma to the Pima villages on the Gila and thence explored a route to the Rio Grande. By

19 Sitgreaves, Lorenzo, Report of an expedition down the Zuni and Colorado rivurs, Washington, 1854.

${ }^{20}$ U. S. Pacific R. R. Expl., vol. 3, $185 \overline{6}$.

21 Idem, vol. 2, 1855 . 
way of Tucson he went east to the San Pedro near the site of Benson, thence through what is now Dragoon Pass, and crossed into San Simon Valley through Apache Pass (El Puerto del Dado) between the Dos Cabezas and Chiricahua ranges.

Toward the end of this year the United States Boundary Commission, ander W. H. Emory, with the Mexican commission, began the work of surveying and marking the new boundary. Earlier in the year, however, American enterprise had availed itself of the mining opportunities offered by the Gadsden Purchase. Charles D. Poston and associates had begun a search for gold and silver deposits in the Tubac region, and a company was organized in San Francisco to work the Ajo copper deposits. An American townArizona City - was laid out on the site of Yuma.

In 1855 Lieutenant Parke, accompanied by Dr. Thomas Antisell as geologist, led a second expedition up the Gila and on to the Rio Grande. The party divided on the Gila, Parke and Antisell going up to the mouth of the San Pedro and ascending that stream to the present line of the Southern Pacific Railroad, where the remainder of the party, who had gone with the wagons by way of Tucson, joined them. The main party continued east through Apache Pass, but Parke, going around the north end of the Dos Cabezas Range, discovered the lower pass now used by the Southern Pacific. Antisell was the first to give any connected geologic description of southern Arizona.

In this year the boundary survey was completed and the Gadsden Purchase formally turned over to the United States. American troops replaced the Mexican garrisons at Tubac and Tucson.

In 1856 the Santa Rita silver mine was opened and prospecting was carried on in the Santa Rita, Cerro Colorado, and near-by mountains. The old town of Tubac became the center of this new activity, and here was begun, in 1858, the first newspaper in Arizona, the Weekly Arizonian. Fort Breckenridge, afterward Camp Grant, was established on the San Pedro, near its mouth, in 1856, and Fort Buchanan, on Sonoita Creek, east of Tubac, in 1857. Prospectors from California began to find their way across the Colorado into what later became Mohave County, and ore was found at a number of places, especially in the vicinity of Sacramento Valley. In the autumn of 1857 the semiweekly Butterfield stage line from San Antonio, Tex., to San Diego, Calif., was placed in operation, the stages running over the Cooke road.

Northern Arizona was traversed in 1857 and 1858 by the expeditions of Lieut. Joseph C. Ives ${ }^{22}$ and Edward F. Beale. ${ }^{23}$ In 1858

${ }^{22}$ Ives, J. C., Report upon the Colorado River of the West: 36th Cong., 1st sess., $\mathbf{s}$. Doc., 1861.

${ }^{28}$ Beake, E. F., Wagon road from Fort Defiance to the Colorado River: 35th Cong., 1st sess., H. Ex. Doc. 124, 1858 . 
also was completed another wagon road which was nearly coincident with Cooke's route, but which continued down the San Pedro to the mouth of Arivaipa Creek and thence went west to the Gila near the site of Florence. In August of the same year the Butterfield semiweekly stages began running over this road, and this service was maintained until the outbreak of the Civil War. In those days it took 22 days to travel by stage from St. Louis to San Francisco by way of southern Arizona. Pumpelly, ${ }^{24}$ who in 1860 made the journey from Missouri to Tucson by this line, which by that time had changed to the route through Railroad and Dragoon passes, has vividly recorded the hardships to which travelers were then subjected.

\section{EARLY SETTLEMENT AND THE CIVIL WAR}

From 1858 to the outbreak of the Civil War Arizona, in spite of the increasing Apache depredations, was making rapid strides in material prosperity. The Gila City placers, which were discovered in 1858, 20 miles east of Yuma, were quickly exhausted, but lode mining was well under way in the Tubac region at the Salero, Cerro Gordo, Mowry, Heintzelman, and other mines, and prospectors were active in the country north of Williams River.

On the beginning of the Civil War mining progress was arrested. "The regular mail stages were discontinued, troops were withdrawn, and the Apaches, no longer deterred by any fear of pursuit and punishment, indulged to the full their propensity for murder and plunder. The last stand by the Americans was made at Tubac by the Santa Rita Mining Co., three of whose technical staff were killed at different times by the savages, who, according to Pumpelly, ${ }^{25}$ had a short time previously received wholly uncalled-for provocation through an act of treachery committed under orders of one of the officers at Fort Buchanan. Cochise, the most noted of the Apache chiefs, barely escaped with his life on that occasion.

In February, 1862, Confederate irregulars from Texas occupied Tucson and were planning to move on Yuma. They fell back, however, to the Rio Grande on the advance of Gen. J. H. Carleton, who with a force of California Volunteers occupied Arizona for the Union. Camp Lincoln (afterward Camp Verde), Camp McDowell, and Fort Whipple were established by Carleton. Even the disturbances of that time did not drive all the prospectors from the hills, and in 1862 Pauline Weaver discovered the gold placers 7 miles east of La Paz, a few miles northeast of the present town of Ehrenberg.

24 Pumpelly, Raphael, Across America and Asia, New York, 1870.

so Idem, p. 16. 


\section{LATER DEVELOPMENT}

On February 24, 1863, Arizona became a separate Territory with four counties-Pima, Yavapai, Yuma, and Mohave. The Territorial government was set up on December 29 at Navajo Springs, but on May 30, 1864, it was established at the new capital of Prescott. John N. Goodwin, of Maine, was the first governor, and Charles D. Poston the first Delegate to Congress.

In October, 1863, Maj. David Ferguson, accompanied by Lieut. C. P. Nicholas, J. B. Mills, jr., and 17 men of $\mathbf{E}$ Company of the First Cavalry, California Volunteers, made a trip from Tucson to Lobos Bay on the Gulf of California. Ferguson's brief report is mostly concerned with the route in Sonora and the conditions of the port and contains very little about Arizona. ${ }^{23}$

From this time on mines were opened in rapid succession. Among the discoveries of 1863 may be mentioned the placer deposits in the Sierra Prieta; on Antelope Peak, in the Weaver Mountains; and on Big Bug, Hassayampa, and Lynx creeks-all in the Prescott region. The Lynx Creek gold placers were probably the richest ever found in Arizona. Lodes reported to have been discovered during the same year are those of the Moss mine, near Oatman, in the Black Mountains; the Vulture mine, in the Vulture Mountains, near Wickenburg; and the Planet mine, near Williams River, northeast of Parker. The Mowry mine, in the Patagonia Mountains, was being worked at this time. The ore was treated in twelve furnaces, operated six at a time, and yielded a silver-lead bullion that was shipped to England in 70-pound bars. Small silver bars were also made to serve as currency. Similarly, gold bars from the Vulture mine were a little later found circulating as money in many parts of Arizona. In addition to those mentioned, hundreds of lode claims were located at this time in the Cerbat, Black, and Hualpai ranges, in Mohave County, by prospectors who had crossed into Arizona from California. There were at this time two main currents of immigration-one from Texas and other Southern States into southeastern Arizona and one from California into northwestern Arizona.

In 1866, by act of Congress of February 24, 12,225 square miles in the northwestern part of the Territory was transferred to Nevada. In this year Tucson began to assume some importance as a center of trade, particularly for the cattle industry. In 1867 the capital was moved from Prescott to Tucson. About this time also settlers, largely Mormons, began to cultivate the Salt River valley under irrigation. Phoenix was laid out in 1868, the year that saw the establishment of a public-school system in the Territory.

* Letter of the Secretary of War communicating copy of report of Maj. D. Ferguson on the country, its resources, and the route between Tucson and Lobos Bay: 37 th Cong., spec. sess,, S. Ex. Doc. 1, pp. 1-22, 1863. 
In 1870 Tucson had a population of about 3,200, Yuma 1,150, and Prescott nearly 700. Notwithstanding the growth of the towns, the opening of many new mines, including those of Clifton, in 1871, and the settlement of agriculturists along the irrigable river bottoms, the Apaches were exceedingly troublesome and remained the chief obstacle to progress. In June, 1871, Gen. George Crook was placed in command at Fort Whipple, near Prescott, and in April, 1872, Gen. O. O. Howard was made special Indian commissioner. While General Crook prepared for military operations, General Howard visited Cochise and persuaded him not only to abandon hostilities himself but to use his influence with other chiefs to the same end. The Indians who submitted were placed on the newly established Chiricahua Reservation, and then from 1872 to 1874 General Crook waged relentless war upon those Apaches who remained hostile. The last band surrendered in 1874, and a large part of the mountain belt of central and southeastern Arizona became free from the lurking terror that had so long kept it the same wilderness that Coronado crossed on his way to Cibola.

The consequences were immediately apparent in the discovery of the silver deposits of Globe, McMillanville, Richmond Basin, Chromo Butte, and Silver King. In northwestern Arizona the Signal, Palmetto, and McCracken mines began to be productive at this time. The development of western Arizona was assisted by the establishment by the Colorado Steam Navigation Co., in 1872, of a regular line of steamers from San Francisco to Yuma.

With the subjugation of the Apaches and the death of Cochise in 1874 it was supposed that trouble with the Indians was over, and the control of the reservations was transferred from the War Department to the Interior Department. Occasional depredations were committed, however, and in June, 1876, an attempt was made to transfer the Apaches from the Chiricahua Reservation to the White Mountain Reservation. A number escaped at this time and went on the warpath. Others joined them in 1877, and numerous raids were made under Victorio and Gerónimo. Victorio was killed in 1880. Crook returned Gerónimo and his warriors to the reservation in 1885. Gerónimo was again forced to surrender to Gen. Nelson A. Miles in August, 1886, and, with all the Chiricahua and Hot Springs Apaches, was sent to Florida. Thus ended over three centuries of nearly constant hostility between the Apaches and the white men.

Certain later explorations are of particular interest for the $\mathrm{Pa}$ pago country, because the results of Kino's work were largely forgotten and this region has retained that air of mystery and the unknown that once characterized all of Arizona. The international boundary survey to relocate the boundary line between Mexica and the United States west of the Rio Grande was provided for under 
the convention of July 29, 1882. The surveying parties were in the field in February, 1892, and the last monuments were set by October, 1894. An excellent map giving topography in contours for a strip 6 miles wide was made, and permanent and conspicuous monuments were erected. ${ }^{27}$ A biologic survey by Maj. E. A. Mearns, surgeon of the American commission, resulted in an excellent report including material on both plants and animals. ${ }^{2 s}$

In 1907 an expedition from the Carnegie Desert Botanical Laboratory, of Tucson, under the leadership of Dr. D. T. MacDougal, made a trip through the Papago country on the way to the Pinacate Mountains of Sonora. ${ }^{29}$ Carl Lumholtz's two years of wandering in southern Arizona and Sonora resulted in a book full of interesting geographic and ethnologic material and an excellent map. ${ }^{30}$ A most unusual event in exploration was Pumpelly's trip in 1903 from Tucson to Yuma. Accompanied by members of his family, in four automobiles, he followed approximately the route which he took in 1863 to escape the Apaches and the problems of the Civil War. ${ }^{31}$

In the modern State of Arizona the Papago country has remained an unknown and forgotten land. The various attempts at settlement, the peculiar Indian inhabitants, and the startling changes brought about by the opening of the New Cornelia mine, Ajo, and the coming of automobile transportation are recorded in detail in the route descriptions that follow.

\section{THE PAPAgo INDIANS}

The region between the Baboquivari Mountains and Gunsight Pass is inhabited by the Papagos and the nearly related Kohakt Pimas. The Indians number about 6,000 . No Indians have more closely adapted their habits of life to the character of the region in which they live than the Papagos.

Physically, the Papagos are a large, well-formed people, having a dark skin and bold if somewhat heavy features. Delayed maturity is common, and there is often a great contrast between the large and heavy middle-aged man and the slight and slender youth. The women are not uncommonly brighter and more vivacious than the men. Many of them are very handsome. Tuberculosis and tra-

\footnotetext{
T Report of International Boundary Commission upon the survey and remarking of the boundary between the United States and Mexico west of the Rio Grande, 1891-1896:

Mearns, E. A., Mammals of the Mexican boundary of the United States, pt. 1: U. ธ. Nat. Mus. Bull. 56, 1907.

macDougal, D. T., Across Papaguerla : Am. Geog. Soc. Bull., vol. 40, pp. 705-725, maps 1 and 2, 1908. Hornaday, W. T., Camp fires on desert and lava, New York, 1908.

${ }^{80}$ Lumholtz, Carl, New trails in Mexico, New York, 1912.

Pumpelly, Raphael, Reminiscences, vols. 1 and 2, New York, 1918. In the first volume the material given in "Across America and Asia," 3d ed., New York, 1870, is repeated. The Journey of 1903 is described in the second volume,

65th Cong., 2d sess., S. Dac. 247, 1898.
} 
choma are prevalent diseases. Travelers should use caution in and about Papago camps, particularly on account of trachoma.

The tribe is nominally Christian, and the greater number, having been converted under Mexican infiuence, are Catholic. Many, however, are Presbyterians, having been influenced toward that faith by their relatives, the Pimas of the Gila Valley. The original moral spirit of the race appears to have been high. They were brave in their almost constant wars with the Apaches, though peaceable in their relations with the whites, both Mexican and American. Nor have they sunk into that moral degradation which is all too common as a result of the contact of American civilization with primitive tribes. The Papagos present the unique example of a so-called inferior race profiting by the mistakes and failures of a superior race. However, much of their apparent success is due to their low standard of living, lack of pride, and somewhat hazy notion of property rights.

Before the coming of the white man the Papago had no beasts of burden or domestic animals. During the winter the people gathered around the permanent water holes and springs in the mountains, principally along the western foot of the Baboquivari Mountains and at Comobabi. With the coming of the summer rains they moved down into the valleys and planted crops of corn and beans in the broad flats that are liable to overflow. (See Pls. IV and XXVI, B.) These localities were usually at or near charcos-natural water holes that filled with water during the floods. (See Pl. XVI.) As the crop was dependent on the floods also, there was always drinking water for planting and harvesting. During this period they gathered mesquite beans and the fruit of the sahuaro and pitahaya. Doubtless they hunted small game at all times, and certain members of the tribe were detailed to hunt deer, mountain sheep, and goats. The food not used immediately was carried back to permanent water holes in the mountains. This precarious method of farming and gathering of wild crops was not always successful; and if the season was a failure, the following winter was one of starvation. Whole rillages moved without hesitation toward better water supplies or to villages where the crop had been good. The rigors and hardships of this life can not be emphasized too much, especially as the Papago possessed no beasts of burden. The journeys from the winter home to the planting ground, distances of 10 to 30 miles, had to be made afoot, often with heavy burdens. Annually also a group made a trip to the Gulf of California for salt, which was an important article of aboriginal commerce. 
According to Lumholtz, ${ }^{82}$ the Papagos are divided into five groups, two of which are classed together as "red velvet ants" and the other three as "white velvet ants." The red velvet ant people are the original owners of the country, but after they had offended Elder Brother he brought the white velvet ant people from the underworld and after many fights the red people were almost exterminated and are to this day fewer in number than the white people. Descent in these clans goes by the male line, a custom quite distinct from the clan relationship of the Pueblo Indians of northern Arizona and New Mexico.

The rancherías are divided into four groups. (1) Anekam, the villages of the upper Santa Rosa Valley. (2) Hobóla, the villages of the northwestern part of the Papago country, including Moivavi, Sauceda, Pozo Blanco, Barajita, the villages at Gila Bend and Akchin, near Maricopa. These people are thought to have spread from the ranchería of Kaka. (3) Tótokvan ("those who wear loose breechcloths"); also called Kikima ("smart ones"). This district comprises most of the Santa Rosa Valley, the villages of the Comobabi Mountains, and San Xavier. (4) Kokeleroti ("the owl people," from the Spanish tecoloteros). This division extends from Indian Oasis southward and includes Fresnal, Tecolote, Pozo Verde, and other villages. These Indians are said to have spread from Tecolote.

In addition to these divisions there are the Sand Papagos, or Areneños. The Papagos of Sonora are in part absorbed in the Mexican population, and the Sobaipuris, who once lived in the Santa Cruz and San Pedro valleys, are now extinct or reabsorbed in the Papago and Pima tribes, from whom they douhtless differed little or not at all.

The Papagos originally had dancing festivals but otherwise no very elaborate ritual. Their government was also of like simplicity. They prayed to the sun, whom they called Father, but their principal deities were Elder Brother and Earth Magician.

Races were formerly a part of their social life. The most important was the foot race, which was accompanied by a great gathering of people and much betting. The race was run by two men, each of whom kicked along a ball made from mesquite wood. One or two men on horseback assisted the racers in finding the balls and gave them new ones in case of loss or breakage. One of the last races took place in 1904 in the Santa Rosa Valley. In the betting many Indians impoverished themselves, the village of Barajita losing more than 200 animals. These gatherings are now largely replaced by the annual fair, held at Indian Oasis under the auspices of the Indian Service in October or November of each year. Prizes are

Lumboltz, Carl, op. cit., pp. 354 et seq. 
awarded for livestock, agricultural products, and the handiwork of women. These fairs are interesting events and are liberally supported by the merchants of Tucson.

One of the principal occupations of the Papagos was the trade in salt. All the Piman tribes went to the coast for salt, but the Papagos seem to have specialized in these expeditions. The salt is found in saline deposits on the Gulf of California, west of Pinacate. Large amounts were brought to the vicinity of Tucson for smelter operations in the period 1850 to 1870 . The Papagos traded chiefly, however, with the Pimas of Gila Valley. Russell ${ }^{33}$ gives the following list of articles of trade which the Papagos brought to the Pimas at the time of the June harvest:

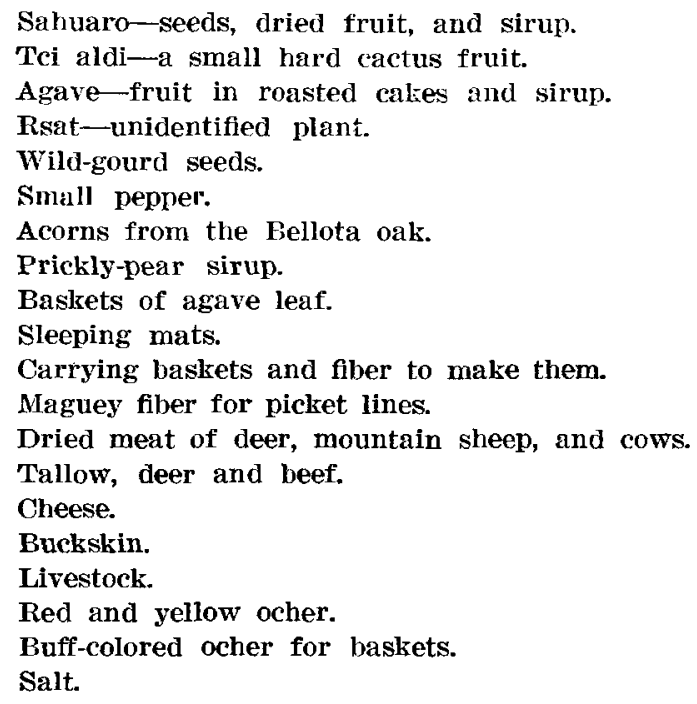

In exchange for products and labor in the harvest the Pimas gave Wheat.

Corn.

Beans.

Mesquite beans and meal.

Cotton blankets and fiber.

Dried squash, melon, and pumpkin.

Rings of willow splints and devil's claw for baskets.

The Areneños, or Sand Papagos, were a division of the Papagos who lived west of the Growler Mountains and spent a large part of their time in the sandy country of the Pinacate region of Sonora. Their native name was Hiatit Ootam ("sand people"). They probably numbered about 150 at the most, but about 1851, they were attacked by an epidemic in which all but four families perished. It

as Russell, Frank, The Pima Indians: Bur. Am. Ethnology Twenty-sixth Ann. Rept., p. $93,1908$. 
is said that they were also decimated by military expeditions of the Mexican Government. A few survivors of the Sand Papagos are to be found near Ajo, in Sonoita, and scattered in other Papago rancherías. The principal headquarters were at Hotúnikat ("sunset"), south of the Pinacate Mountains. The existence of these people depended on their knowledge of the few places in the mountains where there are tanks and of the localities on the seashore where water may be had by digging. In hot weather they caught jack rabbits by running them down in the sand. They killed mountain sheep, mule deer, and antelope with bow and arrows. They ate lizards and probably, as the Seris do to this day, nearly anything else found alive or dead. At certain seasons they went to the coast for fish. They probably had one small temporal or field, but their principal vegetable food was the camote (Amnobroma sonorae), an edible root found in the sand dunes, which they knew how to obtain at all seasons. They ate also the fruits of sahuaro and pitohaya and ground the beans of mesquite and the seeds of palo fierro for pinole. Mortars in solid rock, called "béchete" or "péchita" holes, are found near all watering places and testify to the activity of these people. (See Pl. V, B.) Except in being more intractable than the other Papagos, they differed from them very little in custom or speech.

Spanish missionary enterprise produced its first effect on the Papagos with the journeys of Father Eusebio Kino, an Austrian Jesuit, whose activities have been reviewed on pages 7-13. Yearly and sometimes oftener from 1691 to 1702 he journeyed through the country, preaching the gospel, introducing horses, cattle, and chickens, and encouraging house building. (See Pls. V, $A$, and XXII, A.)

Valuable as the introduction of domestic animals and the art of house building was to the Papagos, the gain was more than offset by the loss through Apache raids. In the late sixties and seventies American settlers came to find mines or establish stock ranches. They immediately improved the springs or seeps used by the Indians and in many places dug new wells. Each white man's camp had its near-by Papago camp dependent on the new or improved water supply. The Indians worked for wages when work was to be had-and the Papago is a good worker-or pilfered and begged when there was no work. As the prospects usually did not become mines, the white men moved away and the Indians inherited the watering places. Even successful mines like the Weldon, where at one time there was a town of 11,000 people, had a relatively short life. When the ore was exhausted the white men moved away. San Antone, a winter ranchería with a few Papago families, remains as the successor of Weldon. Covered Wells, Alamo, and several other villages are dependent on wells dug by white

\section{The coy is PUPLIC PROPERTY and is not to}

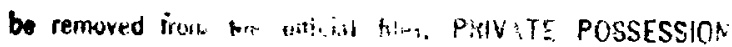

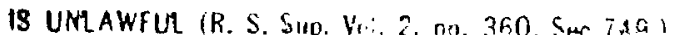


miners. The white stockmen were fewer in number than the miners, but they also generally failed and moved away, partly because of poor range and partly perhaps because of poor management. In addition they had to contend with the sullen opposition of Papago cattlemen and with the Papago belief that cows were made to eat. Pozo Redondo is a winter ranchería founded on the site of such an abandoned ranch and is dependent on the well dug by a member of the well-known Redondo family of Yuma. Kulkomalik has a similar history. The Fresnal and Ventana ranches were supplied by bored wells whose machinery the Indians could not operate or replace, else doubtless the same thing would have happened when these ranches were abandoned. The Indian Service has now installed a pumping plant at the well on the Fresnal ranch, and under white supervision it can be maintained. A winter ranchería will probably spring up, and the history of Pozo Redondo will be repeated.

The Papagos are much as they were when first found by the Spanish, except that they wear white men's clothes and use wagons, horses, and many iron tools. They no longer hunt, for the big game is too scarce to make hunting profitable, but they do raise cattle. This industry promises to grow, but the people still mainly depend on floodwater farming. Around the fields or temporals are villages composed of more or less permanent houses called summer rancherías. From the Mexicans or Americans the Indians learned to build small dams with basins behind them to store flood water for drinking. These represos are to be found at almost every temporal. They supplement the charcos and enable the people to remain long enough to harvest the crop. The water is, however, usually muddy and often foul. As the summer rains begin the people migrate from the winter rancherías, near permanent water, to the temporals, and they return in the autumn. The Indian Service has drilled a number of deep wells at summer rancherias, and these new sources of water may eventually break up the system of migration.

This brief description of the life of the Papago Indians shows that they are great travelers. It is practically impossible to find a place where diligent search will not reveal the former presence of the Papagos. Potsherds, broken stones, mortars, and remains of camps are common at every watering place. Formerly they went afoot, but now they go on horseback or by wagons. There are in consequence many roads, most of which follow the old foot trails and thus pass every available watering place, however infrequently it may hold water. Most of these watering places are small charcos. As many of these as were found are shown on the map, though many of them are of little value to the traveler.

The roads are a perfect maze in the vicinity of the villages or rancherias. From each of the scattered houses there is a road to 
every other house and to every near-by ranchería. Only at some distance from the village do these roads combine. At certain ran-

- cherías also cattle are watered either from wells or from ponds. The daily trampling of cattle often obliterates wagon tracks over the whole area of the village, and the stranger has much difficulty in getting out of a village and onto the right road. The road logs of these localities have been made as full as possible, but the traveler who has studied the map and knows the direction in which he is going may follow any track in that direction and be reasonably sure of coming into the right road.

Ordinarily the Indians drive around obstacles and do no work on roads. Some work is done, however, on the roads around their winter rancherias in the mountains. The other roads are simple wagon tracks or natural highways. A few Indians use broad-gage wagons, or the axle has been sprung so as to give the wagon an excessively broad gage. Unfortunate is the automobilist who follows a road made by such a wagon.

\section{CLIMATE}

The climate of the Papago country is marked by high temperature and low rainfall. The summer heat is intense; it often passes $100^{\circ}$ F. and at times reaches $120^{\circ} \mathrm{F}$, as measured by thermometers placed in the shade. The dryness of the air and the consequent cooting of the body by rapid evaporation, however, make these high temperatures bearable. The usual occupations can be carried on if an adequate amount of water is provided to replace the moisture lost so rapidly from the body by evaporation. The high temperatures favor a long growing season. At Yuma killing frosts rarely if ever occur except in the lower parts of the valley. Farther east each winter has a few killing frosts, and at Tucson there is a distinct though mild winter.

The range in temperature, both daily and seasonal, is very large. The absolute range for several stations is given in the following table, which, with other weather data given below, is derived from the published records of the United States Weather Bureau:

Highest and lowest temperatures, in degrees Fahrenheit, recorded at certain stations in the Papago country

\begin{tabular}{|c|c|c|c|}
\hline Station & Highest & Lowest & Range \\
\hline $\begin{array}{l}\text { Tucson } \\
\text { Nogales._. } \\
\text { Maricopa } \\
\text { Phoenix } \\
\text { Gila Bend. } \\
\text { Aztec } \\
\text { Mobawk } \\
\text { Yuma }\end{array}$ & $\begin{array}{l}112 \\
110 \\
126 \\
117 \\
120 \\
125 \\
126 \\
118\end{array}$ & $\begin{array}{r}6 \\
10 \\
8 \\
16 \\
11 \\
15 \\
22 \\
22\end{array}$ & $\begin{array}{r}106 \\
100 \\
118 \\
101 \\
109 \\
110 \\
104 \\
96\end{array}$ \\
\hline
\end{tabular}


The mean temperature for the same stations is given below : Mean temperature, in degrees Fahrenheit, at certain stations in the Papago country

\begin{tabular}{r|r|r|r|r|r|r|r|r|r|r|r|r|r|r}
\hline Station & $\begin{array}{c}\text { Length } \\
\text { of } \\
\text { record } \\
\text { (years) }\end{array}$ & Jan. & Feb. & Mar. & Apr. & May & June & July & Aug. & Sept. & Oct. & Nov. & Dec. & An- \\
nual
\end{tabular}

The daily range in temperature is very high and probably as high in winter as in summer. The effect of these changes is discussed on page 81 . In the following table the maximum range of temperature for each month of 1921 is given for three stations:

Maximum daily range in temperature, in degrees Fahrenheit, for 1921 at three stations in the Papago country

\begin{tabular}{|c|c|c|c|c|c|c|c|c|c|c|c|c|}
\hline Station & Jan. & Feb. & Mar. & Apr. & May & June & July & Aug. & Sept. & Oet. & Nov. & Dec: \\
\hline $\begin{array}{l}\text { Yuma } \\
\text { Ajo } \\
\text { Tueson_.4 }\end{array}$ & $\begin{array}{r}\times 34 \\
42 \\
-50\end{array}$ & $\begin{array}{l}38 \\
46 \\
47\end{array}$ & $\begin{array}{l}43 \\
53 \\
47\end{array}$ & $\begin{array}{l}43 \\
51 \\
47\end{array}$ & $\begin{array}{r}\quad 41 \\
55 \\
044\end{array}$ & $\begin{array}{r}42 \\
46 \\
\times 47\end{array}$ & $\begin{array}{l}42 \\
39 \\
36\end{array}$ & $\begin{array}{r}35 \\
41 \\
a 32\end{array}$ & $\begin{array}{l}41 \\
35 \\
42\end{array}$ & $\begin{array}{r}\times 38 \\
35 \\
53\end{array}$ & $\begin{array}{r}38 \\
\times 36 \\
57\end{array}$ & $\begin{array}{l}34 \\
31 \\
55\end{array}$ \\
\hline
\end{tabular}

- Twice in the month.

The winds of the region are not notably strong, though occasionally winds reach high velocities. The average wind movement and direction at three stations is shown in the following table:

Average hourly wind movement and direction at stations in the Papago country

Movement (miles per hour)

\begin{tabular}{r|r|r|r|r|r|r|r|r|r|r|r|r|r|r}
\hline Station & $\begin{array}{r}\text { Length } \\
\text { of } \\
\text { record } \\
\text { (years) }\end{array}$ & Jan. & Feb. & Mar. & Apr. & May & June & July & Aug. & Sept. & Oct. & Nov. & Dec. & An- \\
nual
\end{tabular}

Direction

\begin{tabular}{|c|c|c|c|c|c|c|c|c|c|c|c|c|c|}
\hline $\begin{array}{l}\text { Phoenix..... } \\
\text { Yuma }\end{array}$ & $\begin{array}{l}17 \\
33\end{array}$ & E. & $\begin{array}{l}\mathrm{E} . \\
\mathrm{N}\end{array}$ & $\begin{array}{l}\mathbf{E} . \\
\mathbf{W}\end{array}$ & $\begin{array}{l}\mathbf{E} . \\
\mathbf{W}\end{array}$ & $\begin{array}{l}\mathbf{E} \\
\mathbf{W}\end{array}$ & $\begin{array}{c}\mathbf{E} . \\
\mathbf{N} \mathbf{W}\end{array}$ & sw. & $\begin{array}{l}\text { E. } \\
\text { s. }\end{array}$ & $\begin{array}{l}\mathbf{E} . \\
\mathbf{N E} .\end{array}$ & E. & $\begin{array}{l}\mathbf{E} \text {. } \\
\text { N. }\end{array}$ & $\begin{array}{l}\mathbf{E} . \\
\mathbf{N}\end{array}$ \\
\hline
\end{tabular}

The very low rainfall is the chief characteristic of the climate of the Papago country. In a general way the purtions at the lowest altitudes have the least rain. Yuma, at an altitude of 141 feet, has a 
normal annual rainfall of 3.33 inches; Tucson, at 2,435 feet, has 11.85 inches; and Nogales, at 3,840 feet, has 14.15 inches. The belt of low rainfall, less than 5 inches annually, extends up Gila Valley to Gila Bend and in the interior of the Papago country to the Growler Mountains. Gila Bend, Phoenix, Maricopa, and Casa Grande have from 5 to $71 / 2$ inches of rain, and doubtless much of the Papago country to the south has about the same amount. The 8-year record at Ajo shows a normal of 11.12 inches. The station is in the hills and has been operated during eight relatively wet years, 1914 to 1921. At Yuma the normal for this period, calculated from records of the Yuma station, is 3.69 inches, or 0.36 inch above the normal for 51 years. At Tucson the calculated normal for the same period is 13.49 inches, or 1.64 inches above the normal for 54 years. It seems probable, therefore, that the mean annual rainfall at Ajo is less than the amount shown, and it may be below 10 inches. The same considerations apply to the records at Indian Oasis and Ronstadt ranch; but it is probable that these places, because of higher altitude, have a greater rainfall than Ajo. The greater amount of native vegetation and especially the presence of a good cover of grass at Ronstadt ranch indicate greater rainfall. The boundary between areas without perennial grass and with perennial grass lies between 'Tucson, where the mean annual rainfall is $\mathbf{1 1 . 8 5}$ inches, and Nogales, where it is 14.15 inches.

So far as erosion and sedimentation are concerned, the rate of rainfall and fluctuations in rainfall are perhaps more important than the average amount. Yuma has had as little as 0.6 inch in 1899 and as high as 11.41 inches in 1905 . The highest monthly rainfall in 51 years occurred in August, 1909, when 6.25 inches fell-nearly twice the normal annual rainfall. On September 30, 1921, 3.63 inches of rain fell in 24 hours, an amount exceeding the normal annual rainfall for the station by 0.3 inch. On August 16, 1909, 3.33 inches fell. The effect of such storms in erosion and in the transportation of débris by floods on ephemeral streams is obvious. (See pp. 83-84.) Somewhat similar storms occur at Ajo, where on July 7, 1914, 2.48 inches fell, and on December 12, 1915, 3 inches. At Tucson the rainfall is more uniform. The highest monthly rainfall here occurred in August, 1882, when 6.32 inches was recorded. The highest daily rainfall in recent years occurred on January 19, 1916, when 2.63 inches fell: Rainfalls of 1 to 2 inches in 24 hours are, however, fairly frequent.

Periods of drought and groups of dry years are of the most serious disadvantage to the stock grower. During these times little or no grass grows, the cattle consume the woody plants and the tender cacti and, according to the local expression, "eat out the range" 
If the dry years continue, the stockman must move out his cattle at great expense, and he may have to relinquish homesteads and other range rights. The tables that follow give the monthly and annual precipitation at the stations for which records are available. The period 1891 to 1898 was the most protracted drought that the country has suffered. The year 1905 was wet throughout southern Arizona and belonged in a group of wet years. The dry season of 1920 was unusually long and, combined with the low price of cattle, had serious consequences, but it does not show clearly in the weather records.

Records of precipitation at stations in the Papago country

Yuma, Yuma County

[Altitude, 141 feet]

\begin{tabular}{|c|c|c|c|c|c|c|c|c|c|c|c|c|c|}
\hline Year & an. & reb. & Mar. & Apr. & May & June & July & Aug. & Sept. & Oct. & Nov. & Dec. & $\begin{array}{l}\text { An: } \\
\text { nual }\end{array}$ \\
\hline 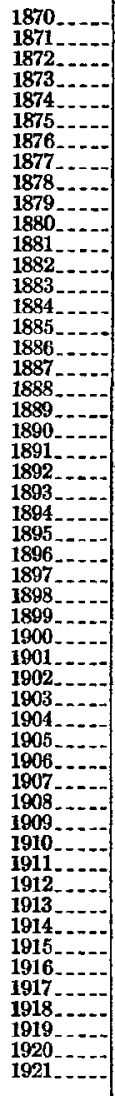 & $\begin{array}{c}0.00 \\
.00 \\
.00 \\
.00 \\
.55 \\
1.50 \\
.44 \\
.09 \\
.00 \\
.59 \\
\mathrm{Tr} . \\
.00 \\
1.35 \\
.96 \\
\mathrm{Tr} . \\
\mathrm{Tr} . \\
1.06 \\
.00 \\
.18 \\
1.12 \\
\mathrm{Tr} . \\
.00 \\
1.85 \\
\mathrm{Tr} . \\
.00 \\
.78 \\
.14 \\
2.83 \\
.42 \\
.01 \\
.08 \\
.12 \\
.26 \\
\mathrm{Tr} . \\
.00 \\
1.15 \\
.02 \\
.39 \\
.16 \\
.05 \\
.02 \\
.42 \\
.00 \\
.12 \\
.05 \\
2.56 \\
.52 \\
1.02 \\
.81 \\
.24 \\
1.47 \\
.70\end{array}$ & $\begin{array}{c}0.25 \\
.08 \\
.24 \\
.00 \\
.85 \\
.16 \\
.46 \\
1.72 \\
.06 \\
1.21 \\
\text { Tr. } \\
.00 \\
.01 \\
.68 \\
1.58 \\
02 \\
.08 \\
\text { Tr. } \\
.05 \\
.06 \\
.86 \\
2.53 \\
.87 \\
\text { Tr. } \\
\text { Tr. } \\
.02 \\
.00 \\
.06 \\
.00 \\
.01 \\
.11 \\
3.01 \\
\text { Tr. } \\
.23 \\
\text { Tr. } \\
3.43 \\
.50 \\
.10 \\
.84 \\
.08 \\
.00 \\
.64 \\
\text { Tr. } \\
.14 \\
.32 \\
.72 \\
\text { Tr. } \\
.06 \\
.12 \\
\text { Tr. } \\
.66 \\
.03\end{array}$ & $\begin{array}{c}0.50 \\
.00 \\
.00 \\
.90 \\
.20 \\
.00 \\
.04 \\
.00 \\
.13 \\
.48 \\
.00 \\
\mathrm{Tr} . \\
.00 \\
\mathrm{Tr} . \\
1.48 \\
\mathrm{Tr} . \\
.33 \\
.00 \\
.05 \\
.24 \\
\mathrm{Tr} . \\
\mathrm{Tr} . \\
.52 \\
1.29 \\
.74 \\
\mathrm{Tr} . \\
.43 \\
.48 \\
.39 \\
\mathrm{Tr} . \\
.06 \\
.30 \\
.21 \\
\mathrm{Tr} . \\
.28 \\
3.33 \\
.30 \\
.72 \\
.08 \\
.64 \\
.02 \\
.12 \\
.78 \\
\mathrm{Tr} . \\
.72 \\
\mathrm{Tr} . \\
.24 \\
\mathrm{Tr} . \\
.72 \\
.41 \\
.37 \\
.09\end{array}$ & 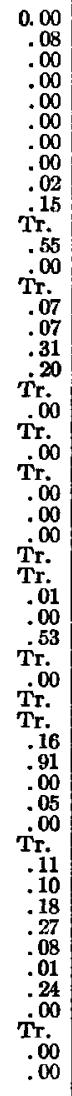 & $\begin{array}{c}0.00 \\
.00 \\
.00 \\
.00 \\
.00 \\
.00 \\
.00 \\
.06 \\
.00 \\
.00 \\
.00 \\
.00 \\
.00 \\
.00 \\
44 \\
\mathrm{Tr} . \\
00 \\
\mathrm{Tr} . \\
.00 \\
.00 \\
.00 \\
\mathrm{Tr} . \\
.05 \\
.29 \\
\mathrm{Tr} . \\
.00 \\
\mathrm{Tr} . \\
\mathrm{Tr} . \\
.00 \\
.00 \\
\mathrm{Tr} . \\
\mathrm{Tr} . \\
.00 \\
.00 \\
.00 \\
.00 \\
.08 \\
.00 \\
.00 \\
.00 \\
.00 \\
.00 \\
.90 \\
.00 \\
\mathrm{Tr} . \\
\mathrm{Tr} \\
.00 \\
\mathrm{Tr} . \\
\mathrm{Tr} . \\
\mathrm{Tr} . \\
.00 \\
.06 \\
\end{array}$ & $\begin{array}{c}0.00 \\
.00 \\
.05 \\
.00 \\
.00 \\
.00 \\
.00 \\
.00 \\
.00 \\
.00 \\
.00 \\
\text { Tr. } \\
.05 \\
.00 \\
\text { Tr. } \\
.00 \\
.00 \\
.01 \\
.00 \\
\text { Tr. } \\
.00 \\
.00 \\
.00 \\
\text { Tr. } \\
.00 \\
\text { Tr. } \\
.00 \\
.00 \\
\text { Tr. } \\
\text { Tr. } \\
.00 \\
.00 \\
\text { Tr. } \\
.00 \\
.00 \\
.00 \\
.00 \\
.00 \\
.00 \\
.00 \\
.00 \\
.00 \\
.62 \\
.00 \\
\text { Tr. } \\
.00 \\
.00 \\
.00 \\
.02 \\
.00 \\
\text { Tr. } \\
\text { Tr. }\end{array}$ & $\begin{array}{c}0.60 \\
.00 \\
.00 \\
.00 \\
1.40 \\
.00 \\
.00 \\
.50 \\
.55 \\
.00 \\
\mathrm{Tr} . \\
.20 \\
.20 \\
.31 \\
.01 \\
.05 \\
\mathrm{Tr} . \\
\mathrm{Tr} . \\
.04 \\
\mathrm{Tr} . \\
\mathrm{Tr} . \\
.04 \\
.00 \\
.50 \\
.36 \\
.01 \\
.41 \\
\mathrm{Tr} . \\
.00 \\
\mathrm{Tr} . \\
.02 \\
\mathrm{Tr} . \\
.11 \\
.04 \\
.05 \\
\mathrm{Tr} . \\
.30 \\
.02 \\
1.34 \\
.01 \\
.84 \\
.42 \\
.18 \\
.17 \\
\mathrm{Tr} . \\
.34 \\
.92 \\
.50 \\
.02 \\
.06 \\
\mathrm{Tr} . \\
.05\end{array}$ & $\begin{array}{c}1.15 \\
.25 \\
2.38 \\
1.60 \\
2.40 \\
.00 \\
.00 \\
.06 \\
1.59 \\
.00 \\
\text { Tr. } \\
.08 \\
.03 \\
.22 \\
.32 \\
.86 \\
2.23 \\
\text { Tr. } \\
\text { Tr. } \\
.25 \\
.83 \\
.05 \\
.02 \\
.38 \\
.10 \\
\text { Tr. } \\
.32 \\
.57 \\
.19 \\
.06 \\
\text { Tr. } \\
.22 \\
\text { Tr. } \\
\text { Tr. } \\
.69 \\
.02 \\
1.69 \\
T r . \\
.30 \\
6.25 \\
.18 \\
.01 \\
.14 \\
.28 \\
.00 \\
.41 \\
.02 \\
.23 \\
.53 \\
.88 \\
.62 \\
1.44 \\
\end{array}$ & 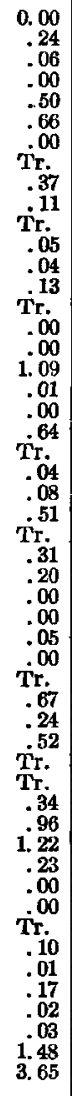 & 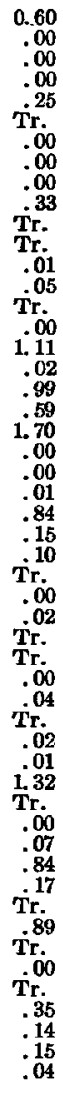 & $\begin{array}{c}0.00 \\
.00 \\
.00 \\
.00 \\
.00 \\
.00 \\
.00 \\
.00 \\
.02 \\
.15 \\
.00 \\
.00 \\
.09 \\
.00 \\
\text { Tr. } \\
1.71 \\
.23 \\
2.43 \\
.68 \\
\text { Tr. } \\
.12 \\
.00 \\
.00 \\
.19 \\
.00 \\
.37 \\
.06 \\
.00 \\
.21 \\
.50 \\
\text { Tr. } \\
.00 \\
.57 \\
.00 \\
\text { Tr. } \\
2.44 \\
.23 \\
.06 \\
.24 \\
.18 \\
1.58 \\
.00 \\
.00 \\
.15 \\
.47 \\
\text { Tr. } \\
.00 \\
.00 \\
.07 \\
.28 \\
.00 \\
00\end{array}$ & $\begin{array}{r}0.00 \\
.00 \\
.00 \\
.64 \\
.50 \\
.00 \\
.00 \\
1.23 \\
.14 \\
.27 \\
.74 \\
.10 \\
.00 \\
1.61 \\
1.96 \\
.01 \\
.00 \\
.15 \\
.95 \\
2.43 \\
.52 \\
.05 \\
\mathrm{Tr} . \\
.26 \\
.40 \\
.00 \\
.78 \\
.04 \\
1.16 \\
\mathrm{Tr} . \\
.00 \\
.00 \\
.78 \\
\mathrm{Tr} \\
.10 \\
.34 \\
.36 \\
.00 \\
2.58 \\
.46 \\
.00 \\
\mathrm{Tr} . \\
.22 \\
.00 \\
.98 \\
.12 \\
.73 \\
.00 \\
.24 \\
\mathrm{Tr} . \\
\mathrm{Tr} . \\
.92 \\
\end{array}$ & $\begin{array}{r}5.35 \\
3.90 \\
2.95 \\
4.69 \\
4.67 \\
2.67 \\
3.35 \\
3.00 \\
2.95 \\
1.33 \\
2.55 \\
4.18 \\
2.38 \\
.60 \\
.85 \\
3.65 \\
1.93 \\
.98 \\
1.43 \\
11.41 \\
5.40 \\
2.61 \\
5.93 \\
8.63 \\
3.93 \\
2.79 \\
3.11 \\
1.04 \\
3.70 \\
4.33 \\
2.45 \\
2.22 \\
2.90 \\
2.04 \\
4.75 \\
6.98 \\
\text {. } \\
\end{array}$ \\
\hline Iear & .46 & .44 & .34 & .08 & .03 & .01 & .20 & .57 & .28 & .21 & .29 & .42 & 3. 33 \\
\hline
\end{tabular}

Note.-Records from January, 1870, to September, 1875, obtained at Fort Yuma, Calif. (altitude, 267 feet), a few miles north of Yuma, Ariz 
Records of precipitation at stations in the Papago country-Continued

Artec, Yama County

[Altitude, 492 feet]

\begin{tabular}{|c|c|c|c|c|c|c|c|c|c|c|c|c|c|}
\hline Year & Jan. & Feb. & Mar. & Apr. & May & June & July & Aug. & Sept. & Oct. & Nov. & Dec. & $\begin{array}{l}\text { An- } \\
\text { nual }\end{array}$ \\
\hline 1899 & 0.03 & 0.00 & Tr. & 0.00 & $\mathbf{T r}$. & Tr. & & 0.00 & Tr. & o. 13 & 1.00 & 0. 13 & \\
\hline & .05 & .13 & 0.27 & 1. 31 & 0.07 & 0.00 & 0.40 & .00 & 0.27 & .24 & .26 & .00 & 3.00 \\
\hline & 21 & .86 & .05 & .00 & .00 & .00 & .00 & .00 & .00 & .00 & .00 & .00 & 1. 12 \\
\hline & .25 & .00 & .30 & .00 & .00 & .00 & Tr. & .15 & .00 & .00 & 2. 00 & i. 25 & 3.45 \\
\hline 190 & .10 & Tr. & Tr. & .00 & .00 & .00 & $\mathrm{Tr}$. & .85 & .35 & .00 & .00 & .00 & 1.30 \\
\hline & ir. & .00 & 01 & .00 & .00 & .15 & .00 & .95 & $\begin{array}{r}.75 \\
.75\end{array}$ & .00 & .00 & $\dot{\mathrm{T}} \mathbf{r}$. & 1.86 \\
\hline & 1.15 & 4.25 & 2.27 & Tr. & .00 & .00 & .00 & .30 & .10 & .00 & 5. 30 & .20 & 13.57 \\
\hline & .00 & 1.50 & .24 & Tr. & .00 & .00 & Tr. & .76 & Tr. & .00 & .70 & 1.02 & 4.22 \\
\hline & 1. 34 & .30 & .80 & .00 & .52 & .00 & .27 & .00 & .00 & .96 & .00 & .00 & 4.1 \\
\hline & $\begin{array}{r}1.07 \\
.28\end{array}$ & 1. 35 & .03 & 1. 35 & .00 &.$\infty$ & .60 & .79 & 5 & .00 & .03 & 3.55 & 7.55 \\
\hline & .00 & .00 & .75 & 00 & .00 & & & & & .00 & .79 & .93 & \\
\hline & .59 & .00 & 10 & g & .00 & .00 & .31 & .11 & .32 & .19 & 1.05 & .08 & 3.42 \\
\hline & 70 & .05 & .18 & .24 & .00 & .00 & .95 & .00 & .48 & .50 & .00 & .00 & 3. 10 \\
\hline & .00 & .00 & 1. 19 & .6 & 0 & .00 & Tr. & 1. 11 & .24 & 1. 31 & .00 & 200 & 6. 57 \\
\hline & .10 & 1. 07 & .00 & .00 & .00 & .00 & 1.60 & .58 & .2 & .00 & i. 10 & .00 & 4. 10 \\
\hline & .70 & .15 & 1.00 & .00 & .0 & .45 & .13 & .04 & .80 & 1.15 & 1.00 & & \\
\hline & 2.10 & 1. 18 & .48 & & 0 & .00 & 1.35 & .10 & .12 & Tr. & .27 & 1.90 & \\
\hline & $\begin{array}{l}1.28 \\
\text {. }\end{array}$ & .01 & .30 & Tr. & 0 & .00 & .56 & .65 & I. 85 & .45 & .00 & .62 & $\overline{5} .72$ \\
\hline & 1. 72 & .75 & .00 & .98 & .12 & .00 & .40 & .52 & $\begin{array}{l}.38 \\
.38\end{array}$ & .15 & .00 & .00 & 5. 03 \\
\hline & 1.18 & Tr. & 1.05 & .00 & .00 & .75 & 1.00 & 1.42 & .00 & .01 & .24 & .27 & 5.92 \\
\hline & .10 & .79 & .63 & -0 & .18 & .00 & .38 & & & .47 & 1.83 & .08 & \\
\hline & 237 & .85 & .22 & .00 & .00 & .00 & 1.00 & Tr. & 00 & .01 & .00 & .00 & 4.26 \\
\hline & .76 & & .73 & & & .00 & .09 & 1.70 & & & & & \\
\hline Mean... & .65 & .58 & .46 & .28 & .04 & .06 & .43 & .48 & .35 & .25 & .71 & .57 & 4.84 \\
\hline
\end{tabular}

Mohawk, Yama County

[Altitude, 538 feet]

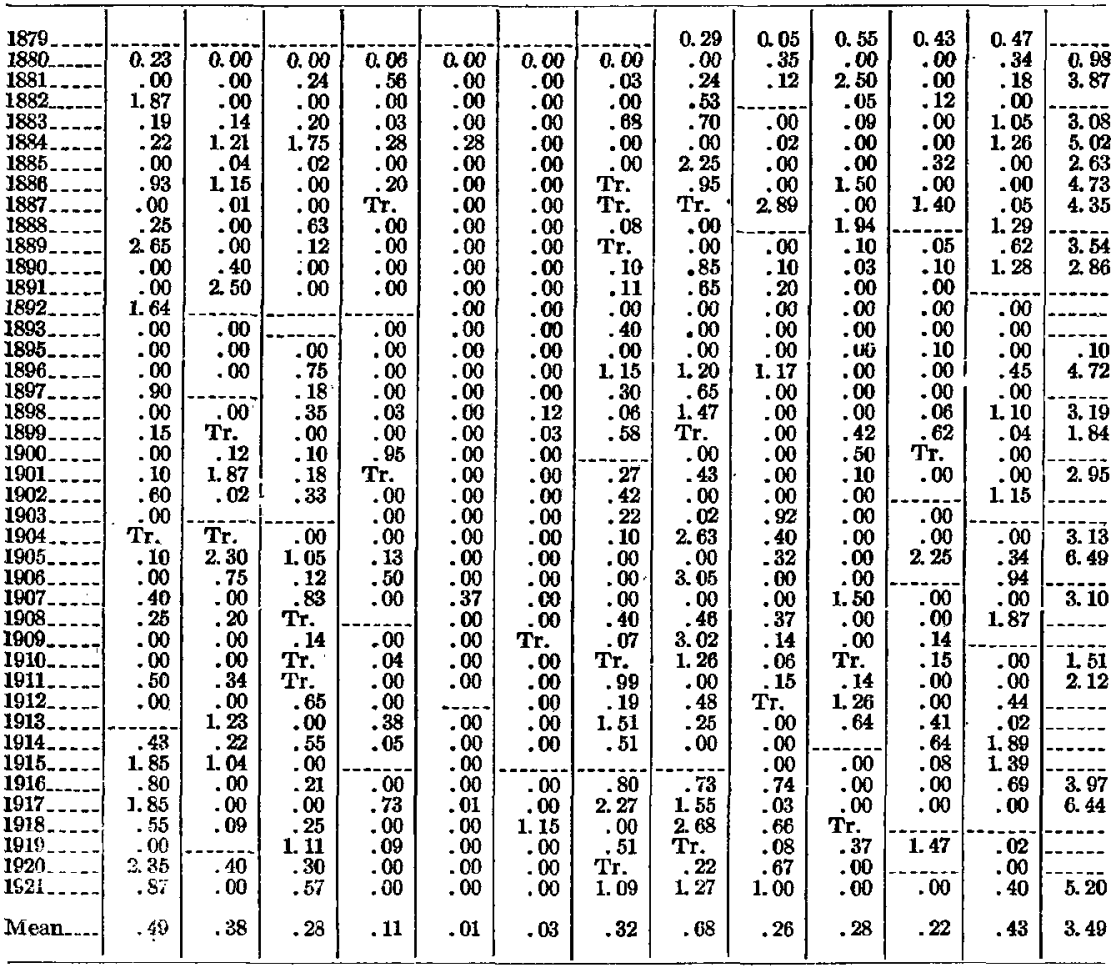

Notz.-Fecords from August, 1879, to June, 1000, obtained at Texas Hill (altitude, 353 feet), about 6 miles east of Mohawk. 
Reoords of precipitation at stations in the Papago country-Continued Sentinel, Maricopa County

[Altitude, 685 feet]

\begin{tabular}{|c|c|c|c|c|c|c|c|c|c|c|c|c|c|}
\hline Year & Jan. & Feb. & Mar. & Apr. & May & June & July & Aug. & Sept. & Oct. & Nov. & Dec. & $\begin{array}{l}\text { An- } \\
\text { nual }\end{array}$ \\
\hline 1899 & 0. 60 & 0.00 & 0.00 & & 0.00 & 0.00 & 0.75 & 0.00 & Tr. & 0.00 & 1. 11 & 0.12 & \\
\hline $\begin{array}{l}1900 \\
1901\end{array}$ & $\begin{array}{r}.00 \\
.33\end{array}$ & $\begin{array}{r}.00 \\
1.58\end{array}$ & .00 & $\begin{array}{l}0.92 \\
.00\end{array}$ & $\begin{array}{l}.00 \\
.00\end{array}$ & $\begin{array}{l}.00 \\
.00\end{array}$ & 1.03 & $\begin{array}{l}.00 \\
.00\end{array}$ & 0. 00 & $\dot{T r}^{00}$ & $\begin{array}{r}50 \\
.00\end{array}$ & .00 & 245 \\
\hline 1902 & .75 & Tr. & io & .00 & .00 & .00 & .00 & .50 & .00 & .00 & i. 60 & i.04 & $\begin{array}{l}1.81 \\
4449\end{array}$ \\
\hline & .00 & & & .00 & .00 & .00 & .50 & .25 & 1. 00 & .00 & .00 & .00 & \\
\hline 190 & .00 & .25 & .10 & .00 & Tr. & .00 & .00 & & .00 & .00 & .00 & .00 & \\
\hline 190 & & & & 0 & .00 & .00 & .00 & .00 & .45 & .00 & & .18 & \\
\hline 1906 & .00 & 1.47 & .04 & 12 & .00 & .00 & .06 & .53 & Tr. & .00 & .88 & .77 & 3.87 \\
\hline $190^{\circ}$ & 1.27 & & .45 & .00 & Tr. & .00 & 1.51 & .00 & Tr. & 1.08 & .00 & .00 & \\
\hline 190 & .50 & 1. 09 & .05 & .50 & Tr. & .00 & .02 & 1.55 & .26 & .32 & .05 & 1. 55 & 6.79 \\
\hline 190 & .02 & & .73 & .00 & .00 & Tr. & .05 & 1.82 & .10 & .00 & .25 & .51 & \\
\hline 191 & .06 & .00 & .00 & .20 & .00 & .00 & .52 & .05 & .25 & Tr. & .62 & .00 & 1.70 \\
\hline 1911 & 1. 04 & .32 & .26 & .12 & .00 & .04 & 3. 54 & 10 & 1.17 & .47 & .00 & .00 & 7.06 \\
\hline 1912 & .00 & .00 & 1.86 & .93 & .00 & .14 & .07 & 2. 53 & .13 & .33 & .00 & & \\
\hline 1913 & .30 & 1. 28 & .00 & .46 & 00 & .00 & .02 & 1.03 & .08 & .00 & & $\mathrm{Tr}$ & \\
\hline 1914 & .03 & .18 & .76 & .10 & Tr. & Tr. & .47 & .17 & .48 & 2.07 & .60 & 2.00 & 6.86 \\
\hline 1915 & 1. 28 & .86 & Tr. & .37 & Tr. & -41 & .40 & .64 & Tr. & .00 & .55 & 1. 94 & 6.45 \\
\hline 1916 & 1. 32 & Tr. & .33 & Tr. & .00 & .00 & .39 & .74 & $\operatorname{Tr}$ & 1.30 & .00 & .68 & 4.76 \\
\hline 1917 & 1. 52 & .85 & .00 & 1. 20 & .12 & .00 & 1. 16 & 1.70 & .05 & .08 & .00 & .00 & 6.68 \\
\hline 1918 & 1. 43 & .07 & .97 & .00 & .00 & 1.78 & .11 & 3.05 & .41 & .30 & .37 & .82 & 9.24 \\
\hline & (2) & 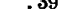 & 1.18 & 800 & -43 & & & & & & & & \\
\hline Mean & .53 & .49 & .36 & .26 & .03 & .12 & .57 & .77 & .24 & .30 & .36 & .51 & 4. 54 \\
\hline
\end{tabular}

Gila Bend, Maricopa County

[A.ltitude, 737 feet]

\begin{tabular}{|c|c|c|c|c|c|c|c|c|c|c|c|c|c|}
\hline 889 & & & & & & & 0.36 & 1. 03 & 0.00 & 1. 50 & 0.00 & 2. 80 & \\
\hline 390 & 0.00 & 0.40 & 0.00 & 0.00 & 0.00 & 0.00 & 1.40 & 1.05 & .23 & .05 & 64 & 1. 42 & 5. 1 \\
\hline 891 & .00 & 2.23 & .11 & .03 & .04 & .00 & .12 & .00 & 08 & .00 & .00 & .07 & \\
\hline 1892 & 2. 30 & 2. 46 & .63 & .31 & .23 & .00 & .05 & -27 & 36 & .00 & .00 & .34 & \\
\hline 1893. & Tr. & -00 & 1.94 & .00 & .40 & .00 & 1. 20 & 1.79 & .14 & .20 & 1.25 & .19 & \\
\hline $\begin{array}{l}894 \\
895\end{array}$ & .00 & .40 & .71 & .00 & .00 & .00 & .99 & .00 & 00 & .60 & .00 & 1. 55 & \\
\hline 6. & .81 & .00 & .00 & .00 & Tr. & .00 & .30 & 1. 40 & Tr. & .50 & .28 & .00 & 10 \\
\hline $6_{-}$ & 1. 20 & Tr. & 1. 10 & Tr. & .00 & .00 & 2.45 & 2.58 & 1. 06 & 1. 42 & $\mathbf{T r}$ & .40 & 10. \\
\hline 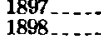 & 262 & $\begin{array}{r}.70 \\
-00\end{array}$ & -40 & $-\infty$ & .00 & .00 & .20 & 2. 57 & Tr. & .20 & .00 & .00 & \\
\hline$\ldots$ & $\begin{array}{r}1.65 \\
80\end{array}$ & .00 & .49 & -00 & .00 & $\dot{T}^{70}$ & .25 & .60 & .00 & & Tr. & 1. 10 & \\
\hline & .80 & $\dot{\mathrm{Tr}}$ & 100 & 100 & .00 & Tr. & 1.60 & .42 & .80 & $\mathbf{1 r}$ & 1. 10 & Tr. & \\
\hline $1801-$ & 15 & 90 & 1. 50 & Tr. & 00 & 00 & 60 & 00 & 00 & 40 & & & \\
\hline 1903. & -2. &. & & .14 & 03 & .00 & .57 & .40 & 1.01 & .00 & & & \\
\hline 1904 & .00 & & .00 & .00 & 09 & 00 & 80 & 1. 30 & .60 & 00 & 00 & .00 & \\
\hline 5 & 1.30 & & 2.74 & Tr. & 00 & 01 & 34 & .05 & 1. 03 & .00 & 3.84 & .30 & \\
\hline 906. & .00 & 10 & .03 & .10 & 00 & 00 & & & .00 & .00 & 1.10 & 2. 43 & \\
\hline 907 & 1.83 & .00 & .50 & .00 & 02 & .00 & 1. 02 & 1.00 & .00 & 1. 95 & .00 & .00 & 6. \\
\hline 1908 & .40 & 1. 47 & .47 & 1.25 & 00 & .00 & .42 & .21 & .40 & .45 & .08 & 2. 54 & \\
\hline 900 & .17 & .32 & 63 & .00 & .03 & $\mathbf{T r}$ & .37 & 2.87 & .12 & .00 & .42 & $-1-1$ & \\
\hline & - & -- & .20 & & & & & & & & & & \\
\hline & & & & & 0 & .00 & 2.27 & .00 & $-2-2$ & .05 & .00 & .00 & \\
\hline a) & .00 & 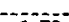 & 2. 00 & .00 & 56 &. $\mathbf{0 0}$ & 1. 06 & 2.68 & .00 & .53 & .00 & .97 & \\
\hline 1913 & .28 & 1.70 & .00 & 1.10 & 05 & 00 & .72 &. $\mathbf{3 0}$ & .00 & .00 & 1.24 & .25 & \\
\hline 1914 & .06 & .08 & .98 & Tr. & 66 & .00 & .17 & . 11 & .16 & 1. 99 & .73 & 2.92 & \\
\hline 1915 & 1. 53 & 1.15 & .18 & .34 & 21 & .20 & .21 & Tr. & .25 & .00 & .77 & 2.69 & \\
\hline 9 & 2.45 & .16 & .50 & $\mathbf{T r}$ & .00 & .00 & 1.18 & .22 & 2.32 & .95 & .00 & .69 & \\
\hline & 1.60 & .05 & .20 & .92 & Tr. & .00 & 1. 50 & .50 & .00 & .10 & .00 & .00 & 4.8 \\
\hline & .80 & .24 & 1.05 & .00 & .00 & 1.01 & .76 & & .60 & .50 & .88 & .85 & \\
\hline & .10 & .46 & 1.25 & .10 & .20 & .20 & 1.05 & 1.25 & 2.45 & .00 & 1.95 & .00 & 9.01 \\
\hline & 1. 45 & .80 & 1.30 & .00 & .00 & .00 & .80 & 1.00 & .00 & .50 & .00 & .00 & \\
\hline & .20 & .00 & .20 & & .10 & .00 & 1. 45 & 1.58 & .3 & .0 & .1 & 1. 20 & \\
\hline Mean. & .77 & .59 & .66 & .18 & .09 & .07 & .79 & .84 & .38 & .38 & .48 & .78 & 6.01 \\
\hline
\end{tabular}


Records of precipitation at stations in the Papago country-Continued

Phoenix, Maricopa County

[Altitude, 1,108 feet]

\begin{tabular}{|c|c|c|c|c|c|c|c|c|c|c|c|c|c|}
\hline Year & Jan. & Feb. & Mar. & Apr. & May & June & July & Aug. & Sept. & Oct. & Nov. & Dec. & $\begin{array}{c}\text { An- } \\
\text { nual }\end{array}$ \\
\hline 1876 & & 0.82 & 0.27 & 0.00 & 0.00 & & & & 0.90 & 0.72 & 0.00 & 0.00 & \\
\hline 1877. & 0.60 & 1. 63 & .31 & .00 & .00 & 0.00 & Tr. & 0.02 & 1.11 & & .03 & .43 & 4. 17 \\
\hline 1878 & .07 & 1. 07 & .86 & 1. 25 & 04 & .00 & 2.40 & 1. 63 & .19 & .00 & .27 & .64 & 8. 52 \\
\hline 1879 & .07 & .75 & $\begin{array}{r}.33 \\
.33\end{array}$ & .07 & 00 & .00 & .54 & .67 & 69 & & 1. 66 & 1.35 & 6.40 \\
\hline 1880 & 1. 16 & .38 & .26 & .15 & 00 & .49 & 1. 18 & .72 & .67 & & .00 & 1. 61 & 6. 82 \\
\hline 1881 & -00 & .20 & 1. 46 & 1.10 & 12 & .00 & 2.03 & 2. 19 & 1.04 & .25 & .36 & .16 & 8. 91 \\
\hline 1882 & 1. 62 & .17 & 00 & 00 & .00 & .37 & .32 & 1. 81 & 1. 25 & .10 & 1. 30 & .00 & 6. 94 \\
\hline 1883 & .83 & 1. 27 & 1. 6 & Tr. & .44 & .00 & .07 & $.0 \%$ & .00 & .20 & .00 & 3. 36 & 7.40 \\
\hline 1884 & .16 & 246 & 2. 14 & .40 & 01 & .15 & .07 & 1. 84 & 1. 50 & 1. 12 & .24 & 2.74 & 1283 \\
\hline 1885 & .00 & .47 & .33 & .00 & -65 & .04 & .18 & .71 & .07 & .09 & .91 & .32 & 3. 77 \\
\hline 1886 & I. 32 & 1. 25 & 86 & 29 & 00 & .00 & .05 & .59 & .45 & & .32 & .07 & 5. 78 \\
\hline $\begin{array}{l}1887 \\
1888\end{array}$ & .00 & .28 & Tr. & $\begin{array}{l}75 \\
01\end{array}$ & .06 & .00 & 13 & $\pi$ & 23 & & 110 & & \\
\hline 1889 . & 1.56 & $a .24$ & $\bullet 1.00$ & .01 & .00 & .00 & .136 & i. 77 & $\begin{array}{r}.20 \\
.39\end{array}$ & .99 & $\begin{array}{r}.77 \\
\end{array}$ & 3.38 & 10.89 \\
\hline 1890. & .05 & .52 & 1. 18 & .51 & .00 & .00 & 0.79 & 0.68 & จ. 19 & ๑. 46 & -1. 36 & -1.82 & 8.46 \\
\hline 1891 & 0.00 & a3. 90 & a. 29 & - $\mathrm{Tr}$ & Tr. & .00 & 0.45 & $a .07$ & a. 12 & a. 00 & .00 & .14 & 4. 97 \\
\hline 1892 & 1.98 & 2.34 & .73 & .68 & .15 & .00 & .06 & .00 & .00 & .00 & .00 & .00 & 5. 94 \\
\hline 1893 & .00 & .00 & .46 & 00 & 1. 00 & .00 & 3. 20 & -1. 42 & .00 & .00 & .60 & 1.00 & 7. 68 \\
\hline 1894 & .08 & .34 &. .62 & .00 & .07 & .00 & .97 & .79 & 15 & .77 & .00 & 1. 48 & 5. 22 \\
\hline 1895 . & -1. 72 & $\therefore .00$ & a. 00 & $=a .00$ & $\mathrm{Tr}$ & a. 00 & $\circ .00$ & .27 & -10 & .80 & .89 & .09 & 3.87 \\
\hline 1896 & .46 & .05 & .39 & .05 & Tr. & $\mathrm{Tr}$ & 4. 25 & 1. 77 & 1.18 & 1.02 & .64 & .67 & 10.48 \\
\hline 1897 & 3. 67 & 47 & .53 & Tr. & .01 & .00 & .59 & .61 & 3.67 & .15 & 00 & -17 & 0. 87 \\
\hline 1898 & 163 & Tr. & .03 & 18 & 01 & .08 & .24 & 1. 03 & .04 & .00 & 1. 01 & 1. 70 & 5. 95 \\
\hline 1899 & 1. 28 & .10 & Tr. & Tr. & 00 & .75 & .87 & .89 & 37 & .30 & .55 & .08 & 5. 19 \\
\hline 1800 & .11 & .04 & .22 & 1. 12 & 12 & .00 & 1. 70 & .01 & -12 & .22 & 1. 73 & .00 & 5. 39 \\
\hline 1901 & .43 & 1. 46 & .33 & Tr. & 10 & .00 & .35 & 1. 73 & $\mathbf{T r}$ & .46 & .01 & .00 & 4. 87 \\
\hline 1902 & .79 & .10 & 46 & Tr. & Tr. & .12 & .32 & .56 & 1. 46 & Tr. & 201 & 1.06 & 6.88 \\
\hline 1903 & Tr. & .64 & 42 & .45 & $\mathrm{Tr}$. & .18 & .70 & .70 & 3. 16 & $\therefore 22$ & .00 & .14 & 6. 61 \\
\hline 1904 & -11 & .26 & .12 & .00 & Tr. & Tr. & 1.89 & 1. 61 & 1.23 & Tr. & .00 & .35 & 5.57 \\
\hline 1905 & 3.31 & 4. 64 & 2. 38 & 2.59 & 04 & $\therefore 15$ & .28 & .92 & 1. 23 & 00 & 3. 61 & .58 & 19. 73 \\
\hline 1906 & .35 & .99 & .67 & .48 & Tr. & $\mathrm{Tr}$. & .20 & 2. 07 & Tr. & Tr. & 1. 20 & 2. 59 & 8. 55 \\
\hline 1907. & 1. 15 & .26 & .93 & .35 & .27 & $\mathrm{Tr}_{\mathrm{x}}$ & 2. 18 & .80 & .02 & 200 & -21 & $\mathbf{T r}$ & 8.17 \\
\hline 1908. & .35 & 1.87 & 41 & .90 & -03 & .00 & 2.98 & .81 & .51 & .52 & .36 & 1.94 & 10.68 \\
\hline 1909 & .00 & .68 & .67 & .07 & Tr. & Tr. & 1.00 & 1. 94 & .42 & .00 & .28 & 1.02 & 6. 17 \\
\hline 1910. & .50 & Tr. & 61 & .29 & Tr. & $\mathrm{Tr}$. & .65 & .14 & Tr. & .18 & 1. 61 & .34 & 4,32 \\
\hline 1811. & 1. 14 & .66 & .64 & .02 & .00 & $\mathrm{Tr}$ & 6.47 & 1. 68 & 1. 16 & 224 & Tr. & .11 & 14.12 \\
\hline 1912 & .00 & .00 & 1.96 & .52 & .58 & .01 & 1. 29 & .72 & .14 & .82 & .00 & .83 & 6.87 \\
\hline 1913 & .38 & 1. 93 & .07 & 51 & .00 & .00 & .94 & .32 & & .01 & .83 & .27 & 5.39 \\
\hline 1914 & .30 & .71 & .92 & 10 & Tr. & .05 & .21 & .30 & Tr. & 2. 30 & 1.00 & 3. 09 & 8.98 \\
\hline 1015 & 1.79 & 1. 21 & .33 & .88 & .17 & .48 & 1. 12 & .25 & .10 & Tr. & .54 & 2.54 & 9.41 \\
\hline 1916. & 2. 34 & .13 & .37 & .15 & Tr. & .00 & .77 & .30 & 1. 66 & .65 & .00 & .39 & 6. 76 \\
\hline 1917. & 2.20 & .95 & .15 & 1. 22 & .45 & .00 & 3.97 & .11 & .55 & Tr. & .00 & .00 & 9.60 \\
\hline 1918 & 1. 14 & 45 & 83 & .02 & Tr. & .08 & 1. 02 & 3.47 & .39 & .52 & 1.92 & 1. 16 & 11. 10 \\
\hline 1919 & .22 & .75 & .97 & .17 & .06 & Tr. & 1. 05 & 2.40 & 1. 93 & .25 & 2.38 & .13 & 10. 31 \\
\hline 1920 . & 1. 42 & 1. 46 & 1.35 & .00 & .42 & Tr. & .25 & .75 & .10 & .46 & Tr. & Tr. & 6. 21 \\
\hline 1921 . & .13 & .11 & .03 & .02 & .17 & .04 & .38 & 1. 62 & .33 & .1 & .04 & .87 & 3.85 \\
\hline Mean.-- & .85 & .84 & .63 & .33 & .11 & .07 & 1.11 & .97 & .64 & .43 & .66 & .87 & 7. 51 \\
\hline
\end{tabular}

a Data from Peoria, a few miles northwest of Phoenix. 
Records of precipitation at stations in the Papago country-Continued

Maricopa, Pinal Connty

[Altitude, 1,173 feet]

\begin{tabular}{|c|c|c|c|c|c|c|c|c|c|c|c|c|c|}
\hline Year & Jan. & Feb. & Mar. & Apr. & May & June & July & Aug. & Sept. & Oct. & Nov. & Dec. & $\begin{array}{l}\text { An- } \\
\text { nual }\end{array}$ \\
\hline \multicolumn{14}{|l|}{1875 . } \\
\hline & $\begin{array}{r}0.72 \\
.08 \\
.00\end{array}$ & $\begin{array}{l}0.27 \\
1.57 \\
1.01\end{array}$ & $\begin{array}{r}0.39 \\
.30\end{array}$ & $\begin{array}{r}0.00 \\
.03\end{array}$ & $\begin{array}{r}0.00 \\
.41\end{array}$ & $\begin{array}{r}0.45 \\
.00\end{array}$ & $\begin{array}{l}0.44 \\
1.26\end{array}$ & $\begin{array}{r}1.09 \\
.00\end{array}$ & $\begin{array}{l}0.00 \\
1.07\end{array}$ & $\begin{array}{r}0.10 \\
.00\end{array}$ & $\begin{array}{l}.41 \\
.01\end{array}$ & $\begin{array}{r}.00 \\
1.54\end{array}$ & $\begin{array}{l}3.87 \\
6.27\end{array}$ \\
\hline & & & & & & .00 & .10 & 1.81 & .38 & .04 & .85 & .80 & \\
\hline & 1. 45 & .16 & .00 & .75 & .00 & .00 & .00 & $\therefore 00$ & & .00 & .00 & & \\
\hline & Tr. & .00 & .88 & .00 & .00 & $\begin{array}{l}.00 \\
.00\end{array}$ & $\begin{array}{r}.00 \\
.00\end{array}$ & $\begin{array}{r}1.47 \\
.38\end{array}$ & $\begin{array}{r}50 \\
.00\end{array}$ & .00 & $\begin{array}{l}.00 \\
.00\end{array}$ & .00 & $\begin{array}{r}2.85 \\
.38\end{array}$ \\
\hline & 1.34 & .00 & .00 & .00 & .00 & .00 & & 3.57 & .30 & .00 & .00 & 1.06 & \\
\hline & .38 & .74 & 2.83 & .51 & .01 & .32 & .53 & .86 & 1.10 & 1.51 & .20 & 2.97 & 11. 96 \\
\hline & .00 & .45 & .15 & .00 & .18 & .04 & .48 & .92 & Tr. & .00 & .56 & .19 & 2.97 \\
\hline & 1.32 & 1.65 & 1.71 & .06 & .00 & .00 & .16 & .08 & .06 & .76 & .21 & .11 & 6.12 \\
\hline & .00 & .17 & Tr. & .51 & .31 & .03 & .43 & & & .28 & 1.13 & .00 & 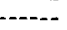 \\
\hline & .00 & .12 & .48 & .00 & .00 & .00 & .80 & .22 & .35 & .52 & & .70 & ..... \\
\hline & .85 & .15 & 1.19 & .00 & .00 & .00 & .55 & .90 & .90 & 1.20 & .83 & & 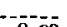 \\
\hline & 00 & .22 & 1.02 & .00 & .00 & 00 & .10 & 4.29 & .15 & .07 & .31 & 247 & 8.63 \\
\hline & .02 & 2. 33 & .00 & .01 & .00 & .0 & 13 & .39 & .13 & .0 & .0 & .00 & 3. 01 \\
\hline & 1.55 & 2.44 & .50 & .40 & .14 & .00 & .62 & .25 & .15 & 0 & 0 & .00 & 6. \\
\hline & 1. 26 & .00 & .14 & .00 & .64 & .0 & .68 & .50 & 2.08 & .00 & .30 & .00 & 6.60 \\
\hline & .32 & .12 & .50 & .00 & .00 & .00 & .3 & 1.96 & .35 & .5 & .00 & 244 & 6. \\
\hline & .61 & .00 & .00 & .00 & .00 & .00 & .93 & .85 & 1.10 & 1.10 & 1.48 & .00 & 6.0 \\
\hline & .68 & .00 & .22 & .00 & .00 & .0 & 1.18 & .27 & .30 & .41 & 3.60 & .00 & 6.69 \\
\hline & 2. 53 & .19 & .00 & .00 & .00 & .00 & & .28 & 1. 27 & .7 & .00 & Tr. & 6. \\
\hline & .98 & .00 & .14 & Tr. & .00 & Tr. & 1.30 & 1. 01 & .00 & .0 & .4 & 2.12 & 5. \\
\hline & .75 & .26 & .00 & .00 & .00 & 1.81 & .71 & .28 & .36 & -0 & .7 & Tr. & 4. \\
\hline & .00 & Tr. & .20 & .40 & Tr. & .00 & .24 & Tr. & Tr. & Tr. & 1. 25 & .00 & \\
\hline & .75 & 1.65 & Tr. & .00 & Tr. & Tr. & 1.50 & .39 & .00 & .40 & .00 & .00 & 4. \\
\hline & 1.00 & .00 & .20 & .00 & $\mathbf{T r}$ & Tr. & .34 & .00 & 1. 04 & .01 & 1.10 & 1. 20 & 4. \\
\hline & .00 & .47 & .30 & Tr. & .12 & .10 & .25 & .52 & 2.76 & .00 & .00 & .20 & 4. \\
\hline & Tr. & .30 & .10 & .00 & Tr. & .00 & 1.00 & 1.40 & Tr. & Tr. & Tr. & .35 & 3.15 \\
\hline & 1. 60 & 2.70 & 1. 72 & 1.71 & Tr. & Tr. & .33 & .72 & .41 & .00 & 3.47 & .85 & 13. 51 \\
\hline & .15 & .94 & .30 & .46 & .00 & .00 & & 3.10 & & .00 & 1.2 & 26 & \\
\hline & 1. 36 & .22 & .86 & .60 & .2 & .00 & 1.70 & .87 & .10 & 1.47 & .10 & .00 & 7.57 \\
\hline & .28 & $\begin{array}{r}1.85 \\
62\end{array}$ & .70 & & & .00 & 2.80 & 170 & & .35 & & & \\
\hline & & & & & & & $\cdots$ & & .43 & & & .32 & \\
\hline & & & & & & .01 & 4.59 & & 2.16 & 1.6 & .00 & .45 & \\
\hline & .00 & .00 & 1.00 & .51 & .53 & .25 & 1.80 & 1.41 & .0 & 2. 35 & & 1.04 & 8.8 \\
\hline & .60 & 1.08 & Tr. & . & Tr. & Tr. & .37 & .52 & .10 & .05 & 1.2 & .60 & 5.02 \\
\hline & .24 & & 1. 00 & .05 & .13 & .10 & .23 & .65 & .27 & 2. 30 & 1.59 & 4,42 & \\
\hline & 1.83 & .75 & .49 & .40 & .20 & Tr. & 1.2 & 1. 46 & .00 & .13 & .7 & 2. 17 & 8. 37 \\
\hline & 1. 88 & .35 & .50 & 16 & Tr. & .00 & 5. & .0 & 1.45 & .2 & .0 & .70 & 10 . \\
\hline & 2. 33 & 1.15 & .20 & .14 & .57 & .66 & 3.9 & & .2 & .3 & .0 & .00 & 10. 27 \\
\hline & .87 & .76 & .97 & Tr. & Tr. & .8 & 1.3 & 1.9 & .35 & .5 & .5 & 1.66 & 9.80 \\
\hline & .56 & 1.05 & .78 & .92 & Tr. & .12 & 2. 79 & 3. & 1. 39 & .3 & 1.95 & .40 & 13. 93. \\
\hline & 1.79 & .66 & 1.61 & .03 & .25 & .05 & .77 & 2. 1 & .11 & .1 & Tr. & 0 & 7.61 \\
\hline & .34 & & .07 & .07 & .12 & Tr. & 3.06 & 1. 42 & .45 & .10 & 1. 55 & 1.79 & 9.15 \\
\hline Mean & .72 & . 63 & .52 & $.20^{\circ}$ & .10 & .11 & 1.06 & 1.07 & .54 & .41 & .61 & .81 & 6.78 \\
\hline
\end{tabular}


Records of precipitation at stations in the Papago country-Continued

Casa Grande, Pinal County

[Altitude, 1,396 feet]

\begin{tabular}{|c|c|c|c|c|c|c|c|c|c|c|c|c|c|}
\hline Year & Jan. & Feb. & Mar. & Apr. & May & June & July & Aug. & Sept. & Oct. & Nov. & Dec. & $\begin{array}{l}\text { An- } \\
\text { nual }\end{array}$ \\
\hline \multicolumn{14}{|c|}{0.05} \\
\hline $\begin{array}{l}1881 \\
1882\end{array}$ & 0.00 & 0.00 & 0.00 & $\begin{array}{r}0.73 \\
.00\end{array}$ & $\begin{array}{r}0.00 \\
.00\end{array}$ & 0.00 & $\begin{array}{r}0.00 \\
.00\end{array}$ & $\begin{array}{l}\text { Tr. } \\
0.00\end{array}$ & $\begin{array}{r}0.00 \\
.00\end{array}$ & .00 & .00 & $\begin{array}{r}0.00 \\
.00\end{array}$ & \\
\hline & .00 & .00 & .00 & .00 & $\therefore 24$ & .00 & & .81 & .00 & 10 & .00 & .86 & \\
\hline 1884 & .75 & & 1. 08 & .00 & .00 & .00 & .00 & 2. 37 & .00 & 1. 31 & .00 & 3.20 & \\
\hline 188 & .00 & .30 & .10 & .00 & .00 & .00 & .75 & .64 & .00 & .00 & .23 & .00 & 2.02 \\
\hline 386 & .90 & & .17 & .09 & .00 & .00 & .33 & 1. 46 & .00 & .00 & .35 & .00 & \\
\hline 1887 & .00 & .40 & .00 & .30 & .20 & .40 & 1.07 & $\begin{array}{r}.97 \\
.97\end{array}$ & 1.99 & .95 & 1. 28 & .15 & 7.71 \\
\hline $\begin{array}{l}1888 \\
1899\end{array}$ & .61 & .00 & .45 & $\cdots$ & .00 & .00 & .28 & .00 & -41 & -10 & .70 & -75 & ....... \\
\hline $1890-$ & 30 & .00 & .50 & .10 & .00 & .00 & $\cdot \begin{array}{r}00 \\
38\end{array}$ & $\begin{array}{r}.00 \\
3.41\end{array}$ & $\begin{array}{r}.50 \\
96\end{array}$ & $\begin{array}{r}80 \\
38\end{array}$ & 200 & $\begin{array}{r}1.25 \\
.87\end{array}$ & 10.70 \\
\hline 1891. & .65 & 1.90 & .00 & .00 & .00 & .00 & $\begin{array}{r}.90 \\
.90\end{array}$ & .00 & .00 & .00 & .00 & 17 & 3.62 \\
\hline 1892 . & 3. 25 & 2. 35 & .65 & .00 & .34 & .00 & .23 & .64 & .00 & .15 & .00 & 1. 14 & 8.75 \\
\hline 1893. & .06 &.$\infty$ & 1.87 & .00 & .07 & .00 & 1. 72 & .95 & .00 & .00 & .00 & .25 & 4. 92 \\
\hline 1894 . & .00 & .10 & .62 & .00 & .07 & .00 & .67 & .81 & .89 & .13 & .00 & 2.53 & 5.82 \\
\hline 1895 & .45 & .00 & .00 & .00 & .00 & .00 & .35 & 1. 30 & 2.00 & 1.60 & .60 & .00 & 6.30 \\
\hline & .65 & .00 & .10 & .00 & .00 & .00 & & .88 & 1.15 & 1.85 & .00 & .70 & ........ \\
\hline 397 & 3. 03 & .00 & .00 & .00 & .00 & .00 & .00 & .00 & & .00 & .00 & .00 & . \\
\hline 98 & & .00 & & .10 & .00 & .60 & .30 & 1.25 & 1.00 & .00 & .05 & 1.42 & \\
\hline 98 & .90 & .20 & .00 & .00 & .00 & .75 & .61 & Tr. & .00 & Tr. & .74 & .00 & 3.20 \\
\hline 1900 & .20 & .00 & .19 & .55 & .00 & .00 & .00 & .50 & .30 & .22 & 1.25 & .00 & 3.21 \\
\hline 1901 & .84 & 1.30 & Tr. & .00 & .10 & .00 & .90 & 1.45 & .0 & .45 & .00 & .00 & 6.04 \\
\hline 402 & 1.56 & .00 & .46 & .00 & .00 & .00 & .00 & 1.53 & Tr. & .00 & 1. 15 & 1.70 & 6.40 \\
\hline 0 & .00 & .66 & & .00 & .29 & .65 & .60 & .00 & 1.40 & .00 & .00 & Tr. & \\
\hline 100 & .14 & .75 & .12 & .00 & .00 & Tr. & 1.96 & 2.83 & & .00 & .00 & .63 & \\
\hline$O$ & 2.76 & 4.99 & 1.98 & 1.27 & .00 & .42 & .36 & .02 & .60 & .00 & 6.32 & .80 & 1952 \\
\hline 1906 & .18 & .88 & .37 & .57 & .00 & .00 & 1.18 & 2.50 & .00 & .00 & .75 & 3.10 & 9.53 \\
\hline 0 & - & .00 & .50 & .00 & Tr. & .50 & 1.75 & .60 & .25 & .80 & .00 & .00 & $\ldots$ \\
\hline 1908 & .75 & 1.50 & $\mathrm{Tr}_{\mathrm{5}}$ & .50 & .00 & .00 & 3.00 & 1.62 & 1. 58 & & & 1.65 & $-\infty$ \\
\hline & & & .75 & Tr. & 00 & & & 1.05 & & 00 & & $60-1$ & -...... \\
\hline & & & & & & & 30 & & $\begin{array}{l}.00 \\
1.65\end{array}$ & $\begin{array}{l}.0 \\
1.15\end{array}$ & $\infty$ & $\mathrm{Tr}$ & \\
\hline & .00 & Tr. & 4.11 & 1.25 & .19 & 1.00 & 1. 30 & .66 & .00 & .35 & .00 & 70 & 9.56 \\
\hline & .70 & 1.75 & .07 & .03 & .00 & . & 1.15 & .5 & .0 & 01 & 2. & .71 & 7. \\
\hline 191 & .29 & .32 & .14 & .00 & .00 & .96 & .69 & .23 & .20 & .45 & 2.35 & 4. 24 & 9.87 \\
\hline & $\ldots$ & - & - & & & & & & & & & & \\
\hline & & - & .14 & .00 & $\mathrm{Tr}$. & .00 & 3. 42 & .10 & & .00 & .00 & .00 & - \\
\hline & & 113 & & & .00 & $\begin{array}{r}21 \\
+35\end{array}$ & 3.24 & 2.82 & Tr. & 1.02 & 1. 01 & 1.46 & $-\overrightarrow{60}$ \\
\hline & i. 62 & $\begin{array}{l}1.13 \\
1.01\end{array}$ & 2. 20 & . 38 & & & 3.33 & 3.10 & & .18 & 2.02 & $\begin{array}{r}.74 \\
.05\end{array}$ & 10.60 \\
\hline & .40 & .18 & .00 & .12 & .00 & $\mathrm{Tr}$. & & .90 & .42 & .18 & & .60 & 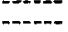 \\
\hline iegn & .70 & .63 & .53 & .18 & .04 & .16 & .96 & .99 & .57 & .34 & .67 & .80 & 6.57 \\
\hline
\end{tabular}


Records of precipitation at stations in the Papago country-Continued

Redrock, Pinal County

[Altitude, 1,864 feet]

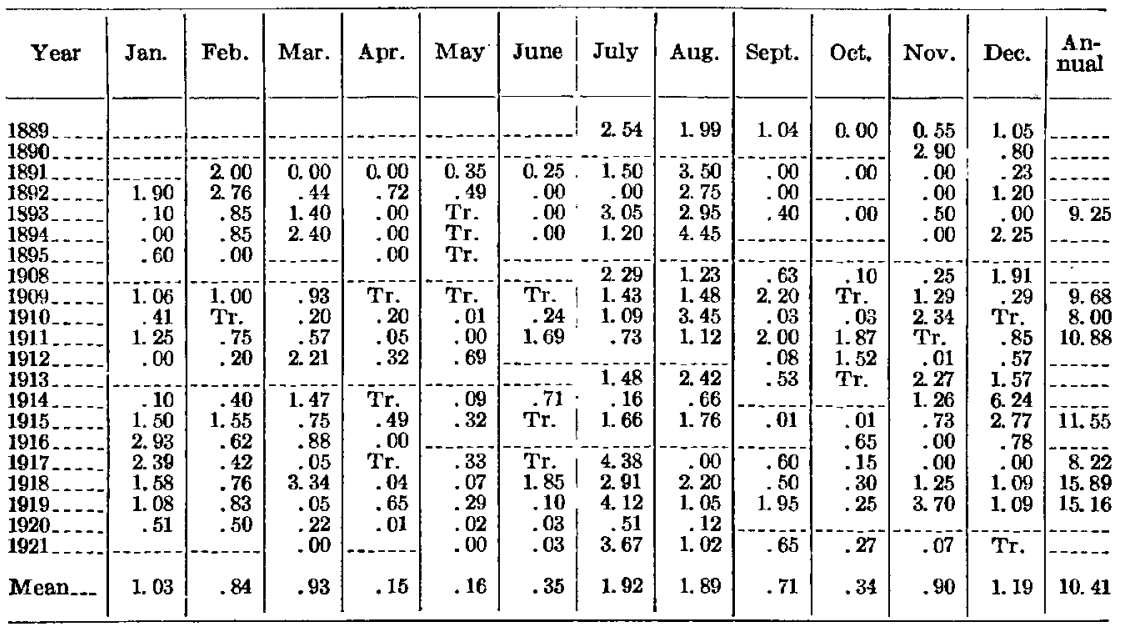

Ajo, Pima County

[Altitude, 1,805 feet]

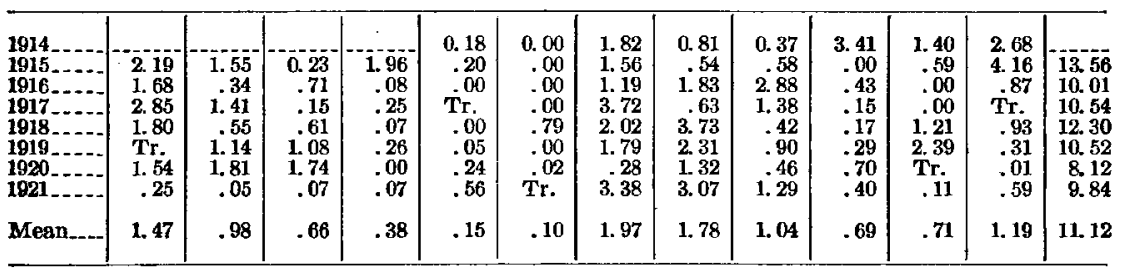

Indian Oasis, Pima County

[Altitude, 2,380 feet]

\begin{tabular}{|c|c|c|c|c|c|c|c|c|c|c|c|c|c|}
\hline 1911 & & 0.42 & & & & 2.00 & & & & & 0.00 & & \\
\hline 1912 & 0.00 & Tr. & & & & $\ldots$ & 2. 89 & & & & .05 & & \\
\hline 1913 & $\ldots$ & 2. 52 & & 0.41 & & & $-\ldots$ & & 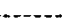 & - & - & & --..- \\
\hline 1914_ - & - & $-\ldots-1$ & - & 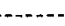 & & 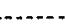 & - . - & & & 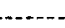 & . & - & $-\ldots$ \\
\hline 1915 & 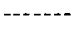 & & & & & & n. & & & & & & \\
\hline 1917. & & & -1 & & 1.03 & .00 & 8.81 & 0.19 & 1.88 & 0.00 & .00 & 0.00 & \\
\hline 1918 & 1.96 & .67 & 0.33 & $\mathrm{Tr}$. & .06 & 1. 32 & 1.98 & 2.93 & $\mathrm{Tr}$. & .47 & 1.09 & 1.72 & 12.53 \\
\hline 1919 & .37 & .48 & .46 & .95 & .45 & 1.20 & 8.17 & 1. 59 & 3. 40 & .15 & 2. 32 & .73 & 20.28 \\
\hline 1920 & 2. 46 & .53 & 1.45 & Tr. & .55 & .50 & 1.55 & 2. 35 & .20 & .60 & .00 & .00 & 10.19 \\
\hline 1921 & .00 & .10 & .09 & .55 & .00 & .00 & 4. 41 & 3. 43 & 1. 70 & .45 & .00 & .22 & 10.95 \\
\hline Mean ... & .96 & .67 & .58 & .38 & .42 & .84 & 4. 63 . & 2. 09 & 1. 43 & .33 & .49 & .53 & 13. 35 \\
\hline
\end{tabular}


Records of precipitation at stations in the Papago country-Continued

Ronstadt ranch (Santa Margarita), Pima County

[Altitude, about 4,000 feet]

\begin{tabular}{|c|c|c|c|c|c|c|c|c|c|c|c|c|c|}
\hline Year & Jan. & Feb. & Mar. & Apr. & May & June & July & Aug. & Sept. & Oct. & Nov. & Dec. & $\begin{array}{l}\text { An- } \\
\text { nual }\end{array}$ \\
\hline 1917 & & & & & & 0.52 & 8. 54 & 1. 40 & 2.02 & 0.00 & 0.00 & 0.00 & \\
\hline 1918 & 3.01 & 1.46 & 0.70 & 0.00 & 0.18 & 1.02 & 2. 24 & 3. 32 & 1.81 & & & & \\
\hline $\begin{array}{l}1919 \\
1920\end{array}$ & 38 & 1.88 & 298 & .85 & .73 & $\begin{array}{r}.72 \\
25\end{array}$ & 7.88 & 2.62 & 241 & .23 & 3. 40 & $\begin{array}{r}86 \\
.88\end{array}$ & 7565 \\
\hline 1921 & $\begin{array}{r}.00 \\
.20\end{array}$ & $\begin{array}{r}.10 \\
.42\end{array}$ & $\begin{array}{r}.22 \\
.22\end{array}$ & 110 & - Y1 & .26 & 5. 58 & 5.92 & 1. 93 & & & .70 & 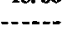 \\
\hline Mean & 1.85 & 1. 22 & 1.07 & .21 & .45 & .57 & 5. 15 & 3. 19 & 2. 04 & .36 & 1.13 & .41 & 17.65 \\
\hline
\end{tabular}

NoTE.-Records from June, 1917, to September, 1918, obtained at Las Moras, 1 mile to the southwest and in about the same relation to the Baboquivari Mountains and Altar Valley.

Silver Bell, Pima County

[Altitude, 2,664 feet]

\begin{tabular}{|c|c|c|c|c|c|c|c|c|c|c|c|c|c|}
\hline 1906 & & 0.77 & 0.40 & 0.21 & Tr. & 0.00 & & 2.15 & 0.00 & 0.07 & & 3. 48 & \\
\hline 907 & 1.56 & .24 & .53 & $\mathrm{Tr}$ & 1.11 & .06 & 1.52 & 3,33 & .84 & 1.05 & 1.25 & $\mathrm{Tr}$. & 11.43 \\
\hline 908 & .66 & 3.39 & .21 & .13 & $\begin{array}{l}1.12 \\
.06\end{array}$ & $\begin{array}{l}.00 \\
.14\end{array}$ & 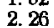 & $\begin{array}{l}\text { 2. } 20 \\
\text { 2. }\end{array}$ & 1. 40 & .08 & .30 & 2.93 & 13.83 \\
\hline & 71 & .90 & .18 & Tr. & .00 & .07 & $\begin{array}{l}1.83 \\
\end{array}$ & 4. 79 & 2.71 & .00 & 1. 33 & .23 & 12.75 \\
\hline & .76 & .00 & 34 & .13 & Fr. & I. 16 & 3.11 & 1.85 & 1. 21 & .08 & 2. 93 & .45 & 1202 \\
\hline & 1.09 & & .71 & .00 & .00 & .76 & 3. 5 & 1.5 & 3.67 & 1.65 & .00 & .85 & - \\
\hline 191 & .00 & .25 & 2.65 & .60 & .40 & .90 & 4. 86 & 1. 25 & .00 & & & 1.10 & \\
\hline & .80 & 293 & .02 & .25 & .30 & Tr. & .36 & 2.73 & & & 2.17 & 1. 53 & 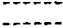 \\
\hline 191 & .56 & .15 & 1.29 & .00 & .10 & .06 & .95 & 1. 10 & .24 & 2.99 & 1. 64 & 4. 68 & 13.76 \\
\hline & 1.17 & 1. 53 & .74 & & .42 & Tr. & 1. 28 & .72 & & & .67 & & \\
\hline & 310 & & & & & & & & & $\begin{array}{r}-10 \\
-05\end{array}$ & -00 & .70 & \\
\hline 1918 & 3.19 & 75 & .12 & 15 & $\therefore 36$ & $\mathrm{Tr}$. & 4.72 & & $\begin{array}{r}.53 \\
85\end{array}$ & .05 & $\begin{array}{r}.00 \\
0.5\end{array}$ & & $15 \mathrm{~m}$ \\
\hline $\begin{array}{l}1918 \\
1919\end{array}$ & 2.23 & .75 & $\begin{array}{r}.57 \\
40\end{array}$ & Tr. & 1.04 & .92 & 2.27 & 3. 10 & .85 & .63 & $\begin{array}{r}-95 \\
247\end{array}$ & 1.70 & 15.01 \\
\hline 1920 & 2.04 & 1.08 & 3.21 & .00 & .00 & .10 & .12 & 3. 57 & 2.32 & 1.40 & .00 & .00 & 13.79 \\
\hline Mean & 1.23 & 1.09 & .81 & .19 & .30 & .30 & 2. 68 & 2.32 & 1. 33 & .67 & 1.05 & 1. 30 & 13. 27 \\
\hline
\end{tabular}

Nogales, Santa Cruz County

[Altitude, 3,840 feet]

\begin{tabular}{|c|c|c|c|c|c|c|c|c|c|c|c|c|c|}
\hline 389 & & & & & & 0.13 & 3. 40 & 2.48 & 2,51 & & 0.00 & 0.83 & \\
\hline $1890_{-}$ & 2. 62 & 0.38 & 0.00 & 0.21 & 0.00 & $\begin{array}{r}.00 \\
\end{array}$ & & & & 0.10 & .50 & 1.95 & $+\infty$ \\
\hline 1891 & -35 & 1. 58 & .30 & .00 & .54 & 2.55 & 1.68 & 2. 27 & .35 & .00 & $\therefore 00$ & .03 & 9.65 \\
\hline 1892 & 2.32 & 1. 73 & .82 & .33 & .04 & .40 & 2.67 & 1. 71 & .63 & .94 & Tr. & & 11. 83 \\
\hline 1893 & Tr. & .72 & 1. 53 & .00 & .00 & .00 & 3. 04 & 2.73 & 1. 76 & .00 & .35 & .15 & 10.28 \\
\hline 1894 & .60 & .75 & .79 & .08 & .00 & .00 & 2. 23 & 2.49 & .41 & 1.15 & .00 & 1.79 & 10.02 \\
\hline 1895 & .88 & .00 & .00 & .00 & .06 & .00 & 2. 66 & 6.77 & 1.88 & .12 & 2.67 & .10 & 15. 14 \\
\hline 1896 . & .60 & .37 & .00 & .00 & .00 & .85 & 5. 92 & 2.57 & 3.89 & 2.53 & .53 & & \\
\hline $1897-$ & 2.39 & .00 & -23 & .00 & .01 & .08 & 2.61 & 3. 28 & 2. 17 & .03 & .00 & .00 & 10.83 \\
\hline $\begin{array}{l}1898 \\
1899\end{array}$ & 1. 81 & $\begin{array}{r}.00 \\
38\end{array}$ & 1. 21 & .60 & & & & 8. 51 & -04 & .00 & .60 & $---\overline{0}$ & $-\cdots$ \\
\hline 1900 & .21 & i. 13 & .00 & $\therefore 80$ & & $T$ & & 215 & 1.71 & 1. 06 & -53 & .00 & $-x$ \\
\hline $\begin{array}{l}1900 \\
1901\end{array}$ & .21 & 3.10 & $\begin{array}{r}-84 \\
24\end{array}$ & 1. 28 & & 0 & 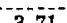 & 2.15 & 2,70 & +39 & 1. 33 & .00 & $\cdots$ \\
\hline 1902 & 1.00 & & .24 & 00 & & .00 & 3. 71 & 7.97 & 2.08 & 1.70 & $\therefore 21$ & .08 & - n \\
\hline 1903 & $\mathbf{T r}$ & .50 & 98 & .00 & & & $\begin{array}{r}.00 \\
1.90\end{array}$ & 3.01 & & & $\begin{array}{r}2.41 \\
00\end{array}$ & 68 & \\
\hline 1904 & .17 & 76 & .02 & . & & & & & & & & & \\
\hline 1909. & & & & & & .88 & 5.65 & 5. 54 & 2.14 & .00 & .88 & .91 & $\ldots$ \\
\hline 10 & 1.15 & & & & & & $\cdots$ & -1 & & & & $\cdots$ & $\ldots$ \\
\hline 912 _ & 西 & & & & & & & & & & & & \\
\hline 13 & & & & & & & & & & & & .26 & \\
\hline 1014 & .59 & .41 & .92 & .00 & .15 & .90 & 3.40 & 2.86 & 1.16 & 1.94 & 1.75 & 5. 60 & 19.68 \\
\hline 1915 & 2. 14 & 1.35 & 1. 25 & .23 & Tr. & $\mathrm{Tr}$ & 1. 91 & 1. 15 & .67 & .00 & .85 & 2. 37 & 11.92 \\
\hline 1916 & 4. 77 & .10 & .78 & .49 & .00 & $\mathrm{Tr}$ & 6.20 & 1.29 & .52 & .67 & .00 & .75 & 15.57 \\
\hline 1917. & 2. 28 & .75 & .03 & Tr. & .34 & .30 & 6.89 & 3. 88 & 290 & .00 & .00 & .00 & 17. 37 \\
\hline 1918 & 2.49 & .94 & .41 & .00 & .04 & 0.87 & 2. 78 & 3. 63 & .50 & .32 & .83 & 2. 44 & 15. 13 \\
\hline 191 & .48 & 1. 31 & .38 & .58 & .13 & .56 & 3. 93 & 2.86 & 4.47 & .44 & 2. 70 & .15 & 17. 99 \\
\hline 1920 & 2. 63 & .88 & .63 & .05 & .12 & .17 & 2.59 & 3. 17 & 1. 54 & .14 & .00 & .07 & 12.03 \\
\hline & .22 & .38 & .53 & .25 & Tr. & .46 & 4.45 & 4.75 & .73 & .21 & .24 & .58 & 12.80 \\
\hline Mean & 1. 35 & .78 & .54 & .23 & .05 & .41 & 3.42 & 3.69 & 1.62 & .52 & .68 & .86 & 14.15 \\
\hline
\end{tabular}

Note.-Records from June. 1889. t.o A pril. 1899, obtained at Calabasas (altitude 3.440 feet), about 10 miles northwest of Nogales. 
Records of precipitation at stations in the Papago country-Continued

Tueson, Pima County

[Altitude, 2,425 feet]

\begin{tabular}{|c|c|c|c|c|c|c|c|c|c|c|c|c|c|}
\hline Year & Jan. & Feb. & Mar. & Apr & May & June & July & Aug. & Sept. & Oct. & Nov. & Dec. & $\begin{array}{l}\text { An- } \\
\text { nual }\end{array}$ \\
\hline & & & & & 0.00 & 0.00 & 2. 90 & 1. 40 & D. 60 & & 0. 20 & 1. 70 & \\
\hline & 0.57 & 0.57 & 0.30 & 1.09 & .10 & .00 & 3. 34 & .67 & 3. 83 & 0.25 & .32 & .50 & 11. 54 \\
\hline 69 & 1.09 & 1. 58 & .70 & Tr. & .00 & .35 & 2.49 & 6. 31 & .30 & .03 & i. 01 & 1.83 & 14. 69 \\
\hline 1870 & .02 & .20 & .03 & .16 & .00 & & 2.82 & 2. 04 & Tr. & .00 & .00 & .94 & 6.21 \\
\hline 371. & .52 & .64 & .16 & .04 & Tr. & .40 & 1.02 & 3. 70 & 200 & Tr. & .21 & .35 & 9.04 \\
\hline 72 & .54 & .12 & .00 & .05 & .01 & .26 & 3. 94 & 3.81 & 3. 06 & .40 & .00 & 1.39 & I3. 58 \\
\hline 1873 & & .69 & 1.01 & .00 & & .00 & .08 & 2. 73 & .62 & .00 & d. 32 & .97 & 7.42 \\
\hline 74 & 1.76 & 1. 66 & 1.19 & .43 & .07 & .00 & 4.82 & 1.93 & .00 & 1. 08 & .92 & .37 & 14.23 \\
\hline 1875 & .37 & l. 22 & .00 & .09 & .00 & 20 & 4.22 & 2,09 & 2.39 & .00 & .18 & .82 & 11. 58 \\
\hline 1876 & .37 & .25 & 1. 22 & .00 & .00 & .29 & 3. 71 & 4. 19 & 2. 28 & .96 & .75 & .00 & 14.02 \\
\hline 1877. & .19 & 2. 53 & .20 & .57 & .41 & .00 & 3. 04 & .02 & 2.44 & .46 & .00 & 2. 91 & 12.77 \\
\hline 1878 & .22 & 1. 00 & 1. 77 & .52 & .00 & .65 & 5. 72 & 4. 71 & .08 & .00 & 1.31 & .68 & 16. 66 \\
\hline 79 & 2. 02 & .94 & .83 & .02 & .00 & .01 & .84 & 1. 76 & .74 & .94 & .60 & 3.31 & 12.01 \\
\hline 80 & .56 & .15 & .41 & .04 & .00 & Tr. & 1. 62 & 1. 28 & i. 89 & .00 & .00 & .57 & 6.61 \\
\hline 188 & .05 & .25 & i. 17 & .62 & .04 & .00 & 5. 69 & 3.92 & 2. 37 & .62 & .00 & .19 & 14.92 \\
\hline 18 & 1.75 & 1. 64 & .72 & .05 & .01 & .99 & 2. 63 & 6. 32 & .32 & .00 & 1. 12 & .04 & 15. 59 \\
\hline 98 & 1. 27 & .51 & 1. 14 & Tr. & .37 & .64 & 3. 46 & 4. 64 & 1.06 & .78 & .48 & 3. 18 & 17. 53 \\
\hline & 83 & 2. 59 & 1.91 & .17 & .23 & 23 & .32 & l. 15 & .30 & 2. 24 & .34 & 4. 72 & 15. 03 \\
\hline 85 & .00 & .42 & .40 & .00 & .00 & .13 & 1. 00 & 1.76 & .12 & .00 & .42 & 1.01 & 5.26 \\
\hline 1886 & i. 61 & .36 & .87 & .06 & .00 & .00 & 1. 06 & 2. 47 & 1. 04 & .31 & .45 & .40 & 8.63 \\
\hline 87 & .00 & .85 & .00 & .38 & .32 & 26 & 5. 08 & 1. 25 & 2.08 & 1.72 & .74 & .27 & 12.95 \\
\hline 88 & .73 & .57 & 1.03 & Tr. & .32 & .55 & 1. 58 & .92 & .10 & .78 & 206 & 1.96 & 10.60 \\
\hline 89 & 1. 74 & 1.06 & I. 98 & .18 & Tr. & .30 & 5. 66 & 206 & 3. 12 & .36 & .32 & 1. 59 & 18. 37 \\
\hline in & 1. 27 & .76 & .29 & .91 & .00 & Tr. & 2. 37 & 5.23 & 1. 44 & .62 & .83 & 1. 32 & 15. 04 \\
\hline 11 & .16 & 3. 28 & .16 & .00 & .22 & .27 & .38 & 2.07 & .48 & .00 & Tr. & .25 & 7. 22 \\
\hline 92 & 1. 52 & 2. 63 & .98 & .18 & .17 & .10 & 1. 00 & 2.14 & .37 & 27 & Tr. & .25 & 9.61 \\
\hline 02 & .27 & .82 & 1.16 & Tr. & .75 & .00 & 2. 78 & 5.40 & 1. 02 & .00 & .43 & .49 & 13.12 \\
\hline 94 & .11 & i. 04 & 1.17 & Tr. & .05 & Tr. & 1. 60 & 1.01 & .12 & .31 & .00 & i. 88 & 7.29 \\
\hline 8 & .63 & Tr. & $\mathrm{Tr}$ & Tr. & .10 & Tr. & .11 & 4.48 & .75 & .68 & 4. 30 & .08 & 11. 13 \\
\hline & .53 & .08 & .27 & 12 & Tr. & .19 & 3. 45 & 1.25 & 1. 13 & 3. 31 & .30 & .76 & 11. \\
\hline $9 d$ & i. 79 & .08 & .13 & Tr. & .00 & .00 & 1.98 & 3.43 & 2.71 & .54 & .00 & .11 & 10.77 \\
\hline I8 & 1. 10 & .00 & .63 & 1.05 & .00 & .20 & 3. 22 & 3.94 & .10 & .0 & .85 & 1.63 & 12.72 \\
\hline 49 & .78 & .39 & .37 & .62 & Tr. & 1. 27 & 1.87 & 1.82 & .03 & .67 & .56 & Tr. & 8. \\
\hline 00 & .16 & .49 & .54 & 1. 12 & Tr. & .17 & .65 & .95 & .85 & .41 & 2. 45 & Tr. & 7.79 \\
\hline 1 & 1. 15 & 1.38 & .64 & .04 & .41 & .00 & 2.57 & 1.99 & .28 & 1.18 & .08 & .00 & 9. \\
\hline 9 & .53 & Tr. & .44 & Tr. & $\mathrm{Tr}$. & .19 & .42 & 1.31 & .58 & 1. 64 & 1.34 & 2.15 & 8. \\
\hline & .00 & 1.11 & 1. 63 & .00 & .20 & .22 & i. 52 & 2. 67 & 1. 17 & .00 & .00 & .28 & 8.8 \\
\hline & .20 & .54 & .06 & .00 & .61 & .18 & 1. 75 & 2. 65 & .89 & .0 & Tr. & .98 & 7. \\
\hline & 2. 25 & 4. 15 & 3.88 & 3.53 & .02 & .24 & 1. 10 & .56 & 2.84 & .09 & 4.61 & .90 & 24. \\
\hline & .50 & .33 & .33 & .50 & Tr. & .00 & 1. 82 & 2.53 & .43 & Tr. & .74 & 4. 57 & 11. \\
\hline 7 & 1.76 & .75 & .56 & .15 & .43 & Tr. & 4. 27 & 3.46 & .80 & 1.13 & .78 & .00 & 14. \\
\hline & .76 & 2.08 & .39 & .10 & .16 & 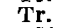 & 4. 77 & 2. 18 & .55 & .26 & .17 & 2. 62 & 14. 04 \\
\hline & .51 & .50 & .33 & .00 & .00 & .54 & 4.04 & 1.36 & i. 25 & .00 & .87 & .81 & 10. \\
\hline & 1.02 & Tr. & .10 & .08 & Tr. & .12 & 4. 21 & 2. 55 & .30 & .04 & 1.32 & .06 & 9.8 \\
\hline & 1.31 & .99 & .25 & .27 & .00 & .07 & 1.57 & 2. 06 & 2. 65 & 1.23 & Tr. & .85 & 11. 25 \\
\hline & .00 & .37 & 2.12 & .28 & .32 & .61 & 3. 0 & .96 & .01 & 1. 7 & .00 & .39 & 9. \\
\hline 0 & .80 & 1.86 & .12 & .70 & Tr. & .08 & 1. 32 & 1. 21 & .14 & .22 & 1,98 & .89 & 9. \\
\hline & .15 & .52 & 1.18 & .00 & .49 & 1. 31 & 2. 94 & 3.45 & .40 & 2.59 & 1.02 & 5.85 & 19.90 \\
\hline & 1. 33 & 1.68 & .76 & & .15 & .14 & 239 & 1. 51 & .92 & .00 & 1. 04 & 2. 35 & 12. 62 \\
\hline & 4. 00 & .58 & .50 & .51 & .00 & .07 & 2. 03 & 2. 26 & 1. 29 & 1.10 & .00 & .81 & 13. 15 \\
\hline & 1.92 & .44 & .15 & .28 & .82 & .00 & 3. 00 & 2.31 & .88 & Tr. & .00 & .00 & 10.70 \\
\hline 19 & 1.40 & 1. 26 & 32 & .04 & .18 & .34 & 1.54 & .78 & .13 & 68 & 1.04 & 1.41 & 9.12 \\
\hline & .26 & .87 & .63 & 1. 10 & .82 & .32 & 5. 53 & 1. 82 & 2.54 & .35 & 3.13 & .04 & 18.01 \\
\hline 19 & 229 & 1.00 & 1.96 & .16 & 21 & .56 & .25 & 2.84 & .74 & .55 & .01 & .15 & 10.72 \\
\hline & .34 & .47 & .13 & .62 & Tr. & .22 & 6.24 & 1. 79 & 3.01 & .25 & .59 & .12 & 13. 78 \\
\hline 5 & .87 & .93 & .73 & .32 & .14 & .23 & .26 & 2.46 & 1. 12 & .56 & .75 & 1.13 & 11.85 \\
\hline
\end{tabular}

Note.-Records from May, 1867, to October, 1875; from May, 1883, to December, 1883; and for September, 1886, obtained at Camp Lowell (altitude 2,530 feet), 7 thiles east of Tucson. Records from January, 1916. to December, 1921, obtained at University of Arizona.

\section{FLORA}

\section{THE ARBOREAI DESERT}

The vegetation of southern Arizona has striking characteristics, which impress even the casual traveler and lend to the region one of its most fascinating charms. This region is one of the most thinly settled parts of the United States, and only a small proportion of the white population subsist on products of the soil, yet in this true 


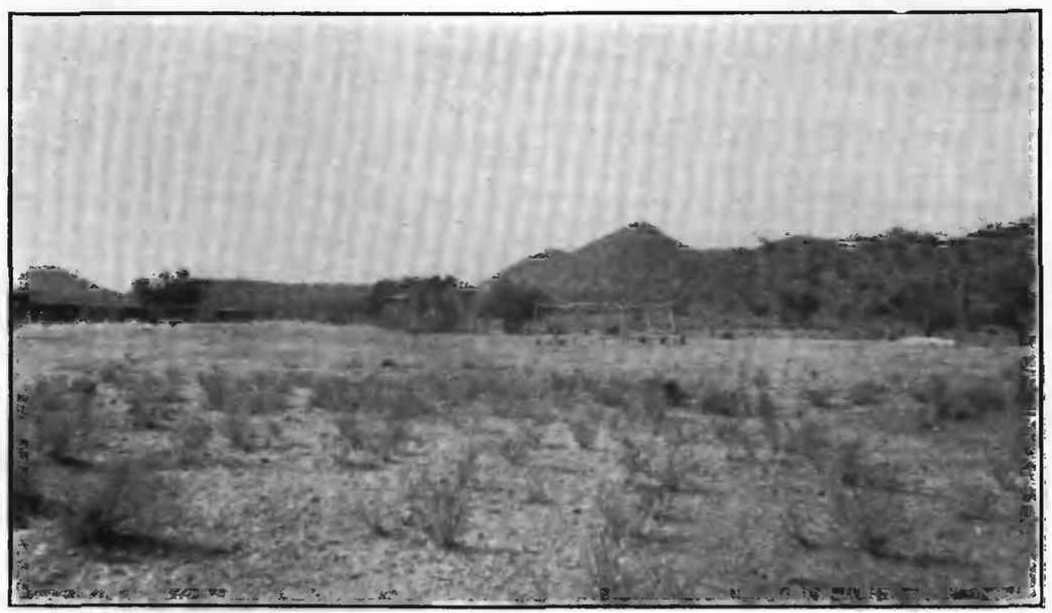

A. CHURCH AND PAPAGO HOUSES AT COVERED WELLS

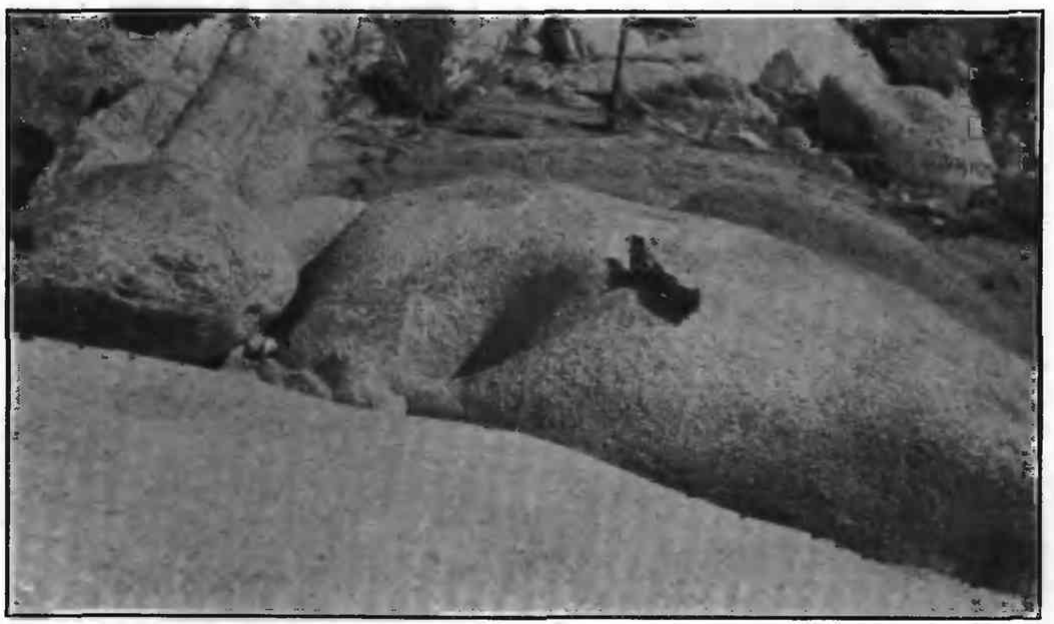

B. MORTAR OR "BECHETE" HOLE AT TULE TANK 


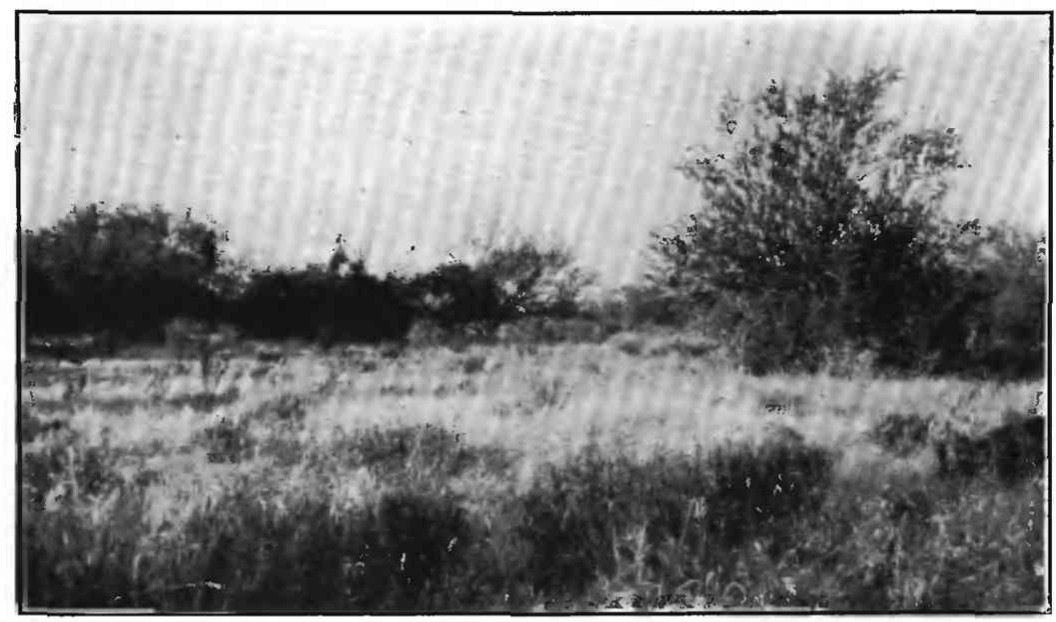

A. LUXURIANT VEGETATION NEAR BIG FIELDS

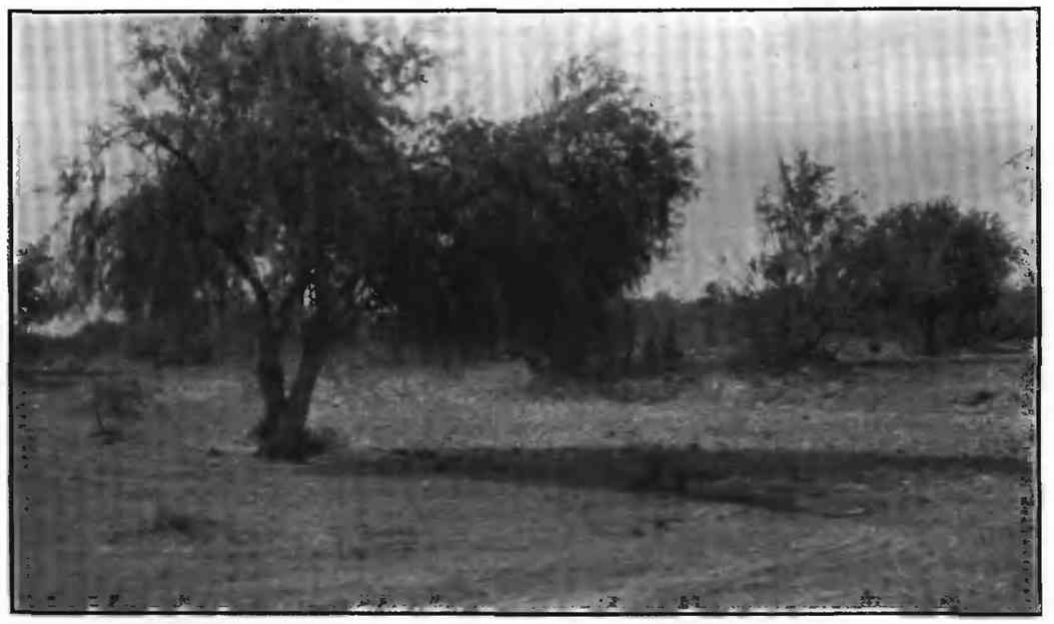

B. DESERT WILLOW IN STREAM CHANNEL AT BATAMOTE WELL

Note effect of browsing by cattle 


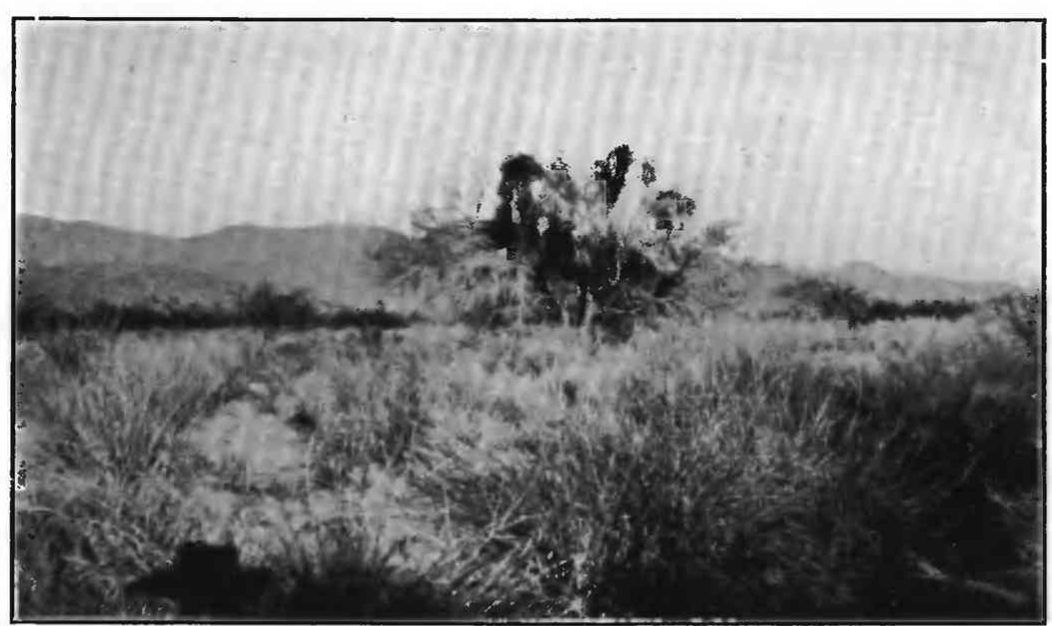

A. PAlO VERDE With Mistletoe ON WEST SIDE OF GROWLER MOUNTAINS

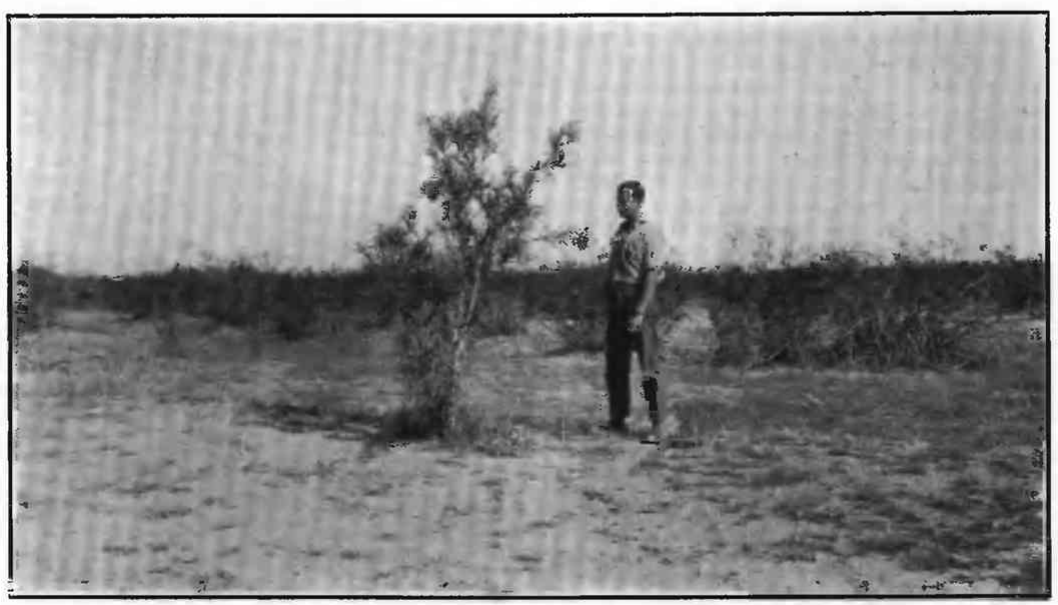

B. CRUCIFIXION THORN SOUTHWEST OF GILA BEND 


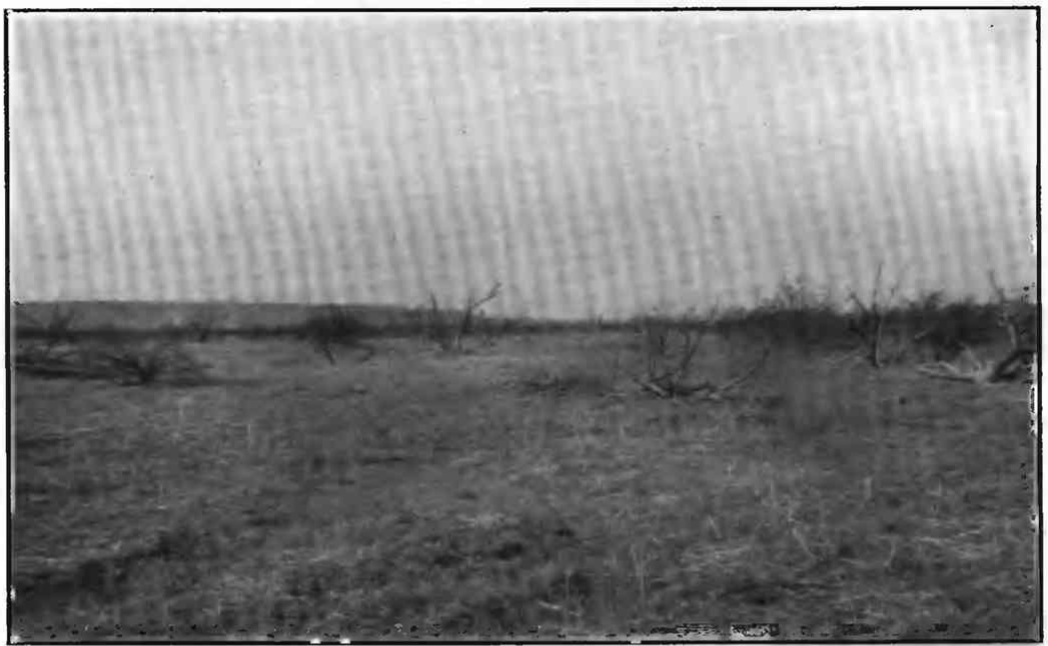

A. FOREST OF DEAD MESQUITE NORTH OF CRATER MOUNTAINS

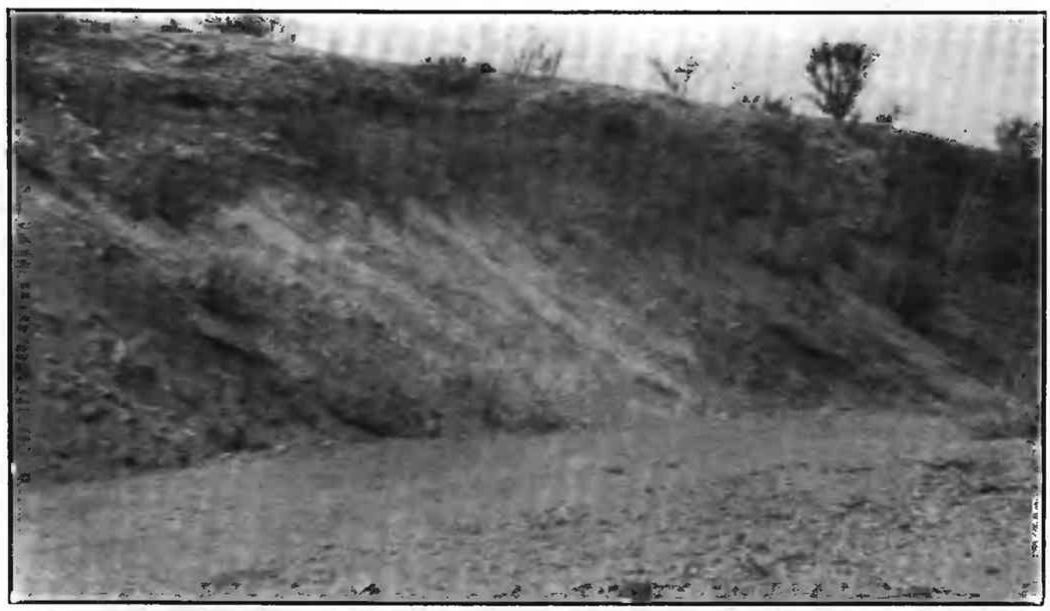

B. TILTED TERTIARY CONGLOMERATE EAST OF COMOBABI 
desert are found not only many plants but large numbers of trees, which are in many places so close together as to form thickets and miniature forests. (See Pls. VI, $A$, and XXI, A.) In contrast to the treeless plains of New Mexico and southeastern Arizona, this is an arboreal desert, where large shrubs and trees give the country a deceiving verdure that is in marked contrast to its ability to support animal and human life.

To the seasonal concentration of the rainfall with accompanying high temperature is due the exceptional character of this flora. The predominant plants--creosote bush, palo verde, and the great cactirange southward into Mexico, and hence this type of vegetation is called the Sonoran or Sonora-Arizona type.

\section{THE TREES}

The common desert trees (five in number) are mesquite, palo verde, palo fierro, catsclaw or acacia, and ocotillo. Mesquite is by far the most abundant and has a wide range outside of the area. The mesquite is a thorny legume, resembling the eastern honey locust. The flowers are greenish yellow, and the seeds are borne in pods 3 to 4 inches long. Near Tucson the common species is Prosopis velutina; on the drier alluvial slopes and the rocky slopes of the foothills this is a small and inconspicuous shrub, but on the flood plain of Santa Cruz River it grows into a tree 20 to 40 feet high and 6 to 14 inches in diameter. The large size of these trees seems to be associated with shallow ground water, to which the roots penetrate to obtain moisture. Along Gila River mesquite is found in great thickets or in more or less regularly spaced clumps of large trees. Many limbs and trunks are almost prone, and this sprawling habit is in marked contrast to the character of the mesquite in other localities. Near Casa Grande Ruins, where the depth to ground water is between 30 and 40 feet, the plain is covered with a forest of mesquite composed of clumps similar to the one shown in Plate XXIII, $A$. In sandy areas on the flood plain or the terraces south of Gila River mesquite is usually found capping and protecting the sand dunes. The most remarkable forests of mesquite, however, occur in the interior valleys of the Papago country, where floods spread out in thin sheets over the so-called adobe flats. The mesquite are found here as lines or strings of trees along the channels or spaced at intervals so as to look like orchards. The trees are from 4 to 12 inches in diameter and from 15 to 40 feet high and have an upright habit. Apparently they derive moisture largely from flood water, and lines of dying and dead mesquite are common features along abandoned flood-water channels. (See Pl. VIII, A.) The wood rots slowly, and dead mesquite is the common source of firewood for the camper. It is excellent fuel, though it has a disagreeable odor when burning-by no means, how- 
ever, comparable to that of palo verde. Mesquite timber is seldom used, though it makes a very good cabinet wood, much like walnut. In summer and sometimes in the fall also the mesquite bears a crop of beans, which are relished by all herbivorous animals. These beans were a staple food of the Papago Indians, and their mortars, called "béchete holes," can be found in many localities. (See Pl. V, B.) The screw bean (Prosopis pubescens) is a closely related species, although the tree is usually of smaller size. The pods are twisted and not flat, hence the common name. The screw bean is common near Yuma but is rarely found in the rest of the area.

The palo verde is the most widely distributed tree of the region. (See Pl. VII, A.) Its green branches and trunk are particularly striking in appearance and give rise to the name (Spanish for "green tree"). There are three species-Parkinsonia aculeata, Parkinsonia microphylla, and Parkinsonia torreyana. They are not easily distinguished and have in common the green trunk and branches, finely divided locust-like leaves, which are shed in the dry season, and yellow flowers, which make a great display in the spring. Palo verde grows on the rocky slopes of the mountains as a small shrub. On the plains it is larger, and particularly along stream channels it attains a diameter of 12 to 18 inches and a height of 30 to 40 feet. According to Mearns, the common form on rocky slopes is Parkinsonia microphylla, and the very large individuals along stream channels are Parkinsonia torreyana. Parkinsonia aculeata has been found in the wild state in Arizona only at La Osa, in the Altar Valley, and La Ventana, in Baboquivari Valley, and in Sonora only along Sonoita River. ${ }^{34}$

Some conception of the age of desert plants and the stability of any particular association of plants can be obtained from the investigations of Shreve. ${ }^{35}$ He found that of 146 trees of Parkinsonia microphylla growing in a tract on Tumamoc Hill, near Tucson, 16 were more than 300 years old, of which one was 420 years old. Only 10 were less than 25 years old. Of 542 seedlings that sprouted after the summer rains in 1910 , all but 62 were dead in 16 months, the deaths being distributed as follows:

\begin{tabular}{|c|c|c|}
\hline Season & $\begin{array}{c}\text { Number of } \\
\text { deaths }\end{array}$ & $\begin{array}{l}\text { Number of } \\
\text { survivors }\end{array}$ \\
\hline $\begin{array}{l}\text { Humid midsummer, } 1910 \\
\text { Arid period of the late summer, } 1910 \\
\text { Winter, } 1910-11 \\
\text { Arid period of the early summer, } 1911 \\
\text { Eumid midsummer, } 1911\end{array}$ & $\begin{array}{r}43 \\
157 \\
74 \\
146 \\
60\end{array}$ & $\begin{array}{r}499 \\
342 \\
268 \\
122 \\
62\end{array}$ \\
\hline
\end{tabular}

* Mearns, E. A., Mammals of the Mexican boundary of the United States: U. S. Nat. Mus. Bull. 56, pt 1, pp. 60, 61, 1907.

s5 Shreve, F., Establishment and behavior of the palo verde: Plant World, vol. 14, p. 293, 1911. 
The dead seedlings on the same ground in 1910 numbered 160 and represented the deaths of the preceding 12 or 18 months. Of these only three were more than 3 years old. It seems, then, that palo verde and probably most other desert trees have a very high mortality as seedlings but once past the third year are likely to reach maturity and often live to great age.

The leaves and branches of palo verde are eaten by stock, and in dry seasons the trees are sometimes cut down by cattlemen to furnish forage. The trunks are used by the Papagos in constructing shelters from the sun and as roof timbers for their houses. The wood is a poor fuel, burning without coals and having a very disagreeable odor.

Palo fierro (also written palo hierro), or Sonoran ironwood (Olneya tesota), is a handsome tree with an erect bushy crown and blue-green leaves. Like palo verde and mesquite it is a legume and has numerous thorns from a quarter to half an inch in length. Palo fierro is usually found along stream channels on the higher parts of the alluvial slopes and is especially noticeable around the base of the mountains, where it grows in open groves like an orchard. Here individual trees may have a trunk 1 to 2 feet in diameter and are about 30 feet high. Palo fierro is more common west of Ajo than in the region east of that place. The leaves are eagerly eaten by stock, and it is a common practice for prospectors to cut down the trees near their camp, so as to provide fodder for their burros and horses. The wood is very hard and durable, and although it has a somewhat more pronounced odor than mesquite it is better fuel. The seeds when roasted have a fine flavor and were a staple food of the Papagos.

Under the name catsclaw are included a number of species of Acacia, of which the common one in the neighborhood of Tucson is Acacia greggii. This is a shrubby tree rarely over 18 feet high, in habit somewhat like the locust. It has many curved thorns about half an inch long, from which the popular name, a translation of the Spanish uña de gato, is derived. The catsclaw grows along arroyos on the alluvial slopes and in the foothills, and in places forms impenetrable thickets.

The ocotillo (Fouquieria splendens) is one of the most striking of desert plants. It consists of several wandlike stems about 1 inch in diameter, which rise from a common base to a height of 5 to 10 feet. Each stem has a graceful curve away from the center, so that the whole plant has a vaselike shape. The stems are coated with wax and bear numerous thorns. At each thorn are leaves, which turn yellow and drop off in the dry season. The ocotillo bears masses of bright-red flowers in the spring. Its habitat is the upper 
and dryer parts of the alluvial fans and pediments, where it is commonly associated with the sahuaro and other cacti. Ocotillo branches are used by the Papagos to make temporary shelters. The butts of the branches are stuck in the ground along the two long sides of a rectangle 8 to 10 feet long and 4 to 5 feet wide. The ends are brought together and tied, and the ribs thus formed are fastened to longitudinal strips. The result is a framework in shape like the cover of a prairie schooner. Brush, skins, or blankets are used to keep out rain and sunlight. Ocotillo branches are also used for fences and for the sides and tops of arbors. The ends, when buried a few inches and given a little water, will grow and make an arbor which keeps green throughout the greater part of the year and is adorned with the beautiful red flowers in the spring.

The indigo thorn (Parosela spinosa) is a spiny tree between 20 and 30 feet in height and from 8 to 15 inches in diameter. It has violet-colored blossoms with a delicious fragrance. The tree grows in the sandy bottoms of arroyos rather than on their banks. It is found in the Sonoita Valley, around Tule Well, and more abundantly in southeastern California.

The wild china tree (Sapindus marginatus), called cherioni by the Mexicans, is found sparingly along arroyos in the Papago country. The specimens seen were about 4 inches in diameter and 20 feet high. Cherioni is popularly thought to be an unfailing indicator of water, a tradition derived from the Papagos. The Cherioni Well, in the valley of the Ajo, was dug on this assumption but failed to find any large amount (p. 181). The wood is tough and is occasionally used for handles of tools and the repair of wagons.

The desert willow (Chilopsis linearis) grows to a height of about 20 feet. (See Pl. VI, B.) It has willowlike leaves and on the ends of the branches bears bunches of purplish flowers and later seed pods 15 inches long. The flowers and pods resemble those of the catalpa, a nearly related tree. This tree grows along sandy arroyos and has a reputation as an indicator of underground water hardly borne out by the facts. Its wood, however, resists decay and it makes very durable fence posts.

The crucifixion thorn (Holocantha emoryi) is another impressive desert plant. (See PI. VIII, B.) It is usually little more than a shrub, but sometimes grows to a height of more than 20 feet. The main stalk and branches have a green bark, and there are no leaves. The smaller branches are fleshy, and each twig is a thorn, so that the plant appears to be a mass of thorns, most of which are about $11 / 2$ inches long and a quarter of an inch in diameter at the base. The seeds are reddish berries, which grow in dense clusters and remain on the plants for many months. The crucifixion thorn 
grows in the most rocky and barren soil; most of the specimens seen were in the region west of Ajo.

Trees of the high mountains of southeastern Arizona are found on Tumacacori Mountains, the westernmost wooded range in southern Arizona. The dominant trees are oaks of three species-Quercus oblongifolia, Quercus arizonica, and Quercus emoryi. These species have small evergreen leaves. The first is commonest on the lower slopes and drier situations of the mountains, where the individuals have trunks from 6 to 12 inches in diameter and 20 to 30 feet high. The second is similar in form and habit, and the rough whitish bark, dense foliage, and equal spacing give a stand of these trees an orchard-like appearance. The third species is usually called the bellota oak by the Mexicans. The largest and best specimens grow in valleys, where they attain 3 or 4 feet in diameter and nearly 100 feet in height. The acorns are sweet, and flour made from them was once a staple article of food with the Papagos and early Mexican settlers.

With these oaks are associated-although they form only a small part of the forest-the Mexican piñon (Pinus cembroides) and the alligator juniper (Juniperus pachyphloea). These trees, together with the oaks, occur in small numbers and very much reduced in size in the higher parts of the Baboquivari Mountains and perhaps other ranges.

Along the flood plains of Gila River and the upper Santa Cruz the common tree is the cottonwood (Populus fremontii). Wherever there is permanent water, as on Arivaca and Sonoita creeks and around many springs, the cottonwood is found, but it is often difficult to determine whether or not it has been introduced by man. With it is commonly associated the black willow (Salix nigra).

In Santa Cruz and Arivaca valleys the leatherleaf ash (Fraxinus velutina), the western walnut (Juglans rupestris), and the Mexican elder (Sambucus mexicana) are large trees common along permanent water. With them is usually found the Arizona sycamore (Platanus wrightii), which also occurs as a lone tree or small clump at the springs and wells along the base of the Baboquivari Mountains.

The hackberry is called cumaru by the Mexicans and kom by the Papagos. It plays a large part in the legends of the Papagos, as may be seen in many place names, such as Comobabi and Comovo. The principal species is Celtis occidentalis, a large tree that may reach 3 feet in diameter and 50 feet in height. It occurs in the upper Santa Cruz Valley and along Arivaca Creek, and there are many small groves and single trees along stream channels at the foot of the Tumacacori and Baboquivari mountains. The tree seems to require considerable water for full development and probably deserves its 
reputation as an indicator of underground water. A smaller species, Celtis reticulata, is included under the popular name hackberry or cumaru. It is more widely distributed and doubtless can grow on the moisture from flood waters alone.

\section{THE CACTI}

The cacti of southern Arizona are remarkable for their size and peculiarity of form. Of these the giant cactus, or sahuaro ( $C$ arnegiea gigantea), is the most conspicuous and in primitive times was the most important to man. It is shown in a number of photographs in this report. (See Pls. V, $A ; \mathrm{XV}, C$; and XXVII, B.) It has a straight trunk with vertical parallel ribs, from 12 to 18 inches in diameter, and may attain a height of 40 feet. One or more clublike branches are given off at irregular heights and grow up more or less parallel to the parent stem. They produce many fantastic shapes, which have a large part in the weird and unearthly appearance of the desert. The sahuaro occurs along the Mexican boundary from Nogales west to the Gila Mountains. Farther north it occupies suitable locations in the broad desert valleys adjacent to Gila River and its tributaries as far east as Graham County and as far north as the foot of the Bradshaw Mountains. Near the northern boundary of its range the trunk is commonly unbranched and often not more than 10 feet in height. In common with most of the other cacti, the sahuaro prefers a rocky soil and is usually found on the upper parts of alluvial fans, on pediments, and on the lower slopes of mountains. The white flowers are borne near the top of the column in May, and the fruit ripens in July. The fruit is prized by the Papagos, who use it for making sahuaro sirup and wine; the seed is used for making flour. The spines of sahuaro are dry and will burn, if lighted at the base, with startling rapidity and with a bright flare. This quality leads to the occasional use of the sahuaro for signaling at night. When the plant dies the flesh shrivels up, leaving the parallel woody ribs standing and bound together with only a network of fibers. Each rib is a pole about an inch in diameter, and such poles are frequently used by the Indians for forming the side walls of their rude huts and in constructing corrals.

The pitahaya dulce or organ-pipe cactus (Cereus thurberi) consists of a clump of columns, each 3 to 4 inches in diameter and 3 to 8 feet high. (See Pl. XXIV, B.) The pitahaya is much more rare than the sahuaro and is more closely confined to rocky slopes. The fruit also is larger and more prized than that of sahuaro.

The bisnaga or barrel cactus (Echinocactus wislizeni) is from 18 inches to 2 feet in diameter and rarely grows over 4 feet high. The ribs twist in a spiral from the base to the top and bear clumps of large 
recurved spines. 'The bright-red flowers are borne near the top. The pulp of bisnaga is not bitter like that of sahuaro and is used in making the cactus candy, a famous Arizona product.

Cholla is the name applied to several species of cactus, all of which are characterized by cylindrical branching stems, a bushy habit of growth, numerous spines, and prominent clusters of juicy fruit which form valuable stock food. (See Pl. XXVI, A.) Opuntia mammillata, Opuntia fuigida, and perhaps Opuntia bigelovii are the common chollas of the Papago region. These similar species grow from a single stalk 3 to 6 inches in diameter into a much branched brush 3 to 6 feet in height. In places the bushes grow so close together as to make almost impenetrable thickets. Not only are the spines numerous, but the terminal joints are easily detached, and any animal feeding on the cholla wears a fringe of these irritating joints around the muzzle. Travel through cholla thickets is most difficult and painful. At the slightest touch, the long yellow spines penetrate the flesh for an eighth to a quarter of an inch. The process of pulling off the joints and then the remaining spines is excruciating torture. The flesh is often ruptured so completely as to give the effect of a bruise. The pack rat (Neotoma albigula) drags the joints off to form a protecting barricade in front of his doorway. As the plant readily propagates from these joints, their ease of detachment and liability to transportation by animals accounts for the wide distribution of the chollas. The fruits occur in great drooping clusters of red and yellow pulpy berries, which remain attached to the plant for three or four years. After the rotting of the fruits the hard seeds drop to the ground and may lie there inactive for years. Lumholtz states that some of the cattle of western Sonora live almost exclusively on cholla in the winter, successfully ridding themselves of the spiny joints, enduring the pain of the spines, and going for periods of three months without water because of the juicy character of their food. ${ }^{36}$ Among American cattlemen such animals are known as "cholla fiends." Prickly pears (Opuntia), small ball cacti (Mammillaria), and many rarer and less conspicuous members of the cactus family are found in the region. The variety and beauty of these forms can be appreciated only by taking long rambles off the beaten tracks in the desert ranges during the spring, when the cacti are in bloom.

\section{THE YUCCAS AND THEIR RELATIVES}

The yuccas are members of the lily family adapted to dry environment. All have a cluster of narrow leaves around a center from which new leaves grow and whence rises the flowering stalk.

Iumboltz, Carl, New tralls in Mexico, pp. 151-154, New York, 1912. $104211-25-5$ 
The yucca, or Spanish bayonet, has narrow stiff leaves, triangular in cross section and tapering to a sharp, thorny point at the top. In some species the cluster of leaves rises directly from the ground; in others there is a woody trunk from 1 to 6 feet high. From the center of the cluster the flower stalk rises from 2 to 6 feet and on it are borne panicles of white waxy flowers. The yucca is not common on the plains of the Papago country except in the head of Altar Valley, where it is associated with a rather heavy grass cover.

The sotols and agaves are similar plants which are found on the rocky slopes of hills and mountains. The agaves, usually known as century plants, have broad leaves, often armed with spines along the edges. The bases of the leaves and the central stalk are fleshy, and in them is stored plant food for a period of several years. At the end of the period a flower stalk grows to a height of several feet in a few days. After flowering and fruiting, the whole plant dies. The central stalk just before flowering is considered a tender morsel by the Papagos. It is also used by the Mexicans in making the fiery liquor called mescal.

\section{FAUNA}

No study of the fauna of the Papago country was attempted in this investigation, and the following notes are intended simply to supply information to the traveler. An interesting account of the wild life of the region, and particularly of the big sheep, is Hornaday's "Camp fires on desert and lava."

The predatory animals, with the exception of the coyote, are not often seen. It seems likely that they have decreased in numbers in the last 50 years, with the decrease in game and the increase in the use of firearms by the inhabitants. In the mountains bordering Santa Cruz Valley the panther, jaguar, and Sonora grizzly were common in the early days, though now rarely reported. The wild cat or lynx has a wide distribution over the Papago country. It frequents the mountains, and, according to reports, the Papagos have within the last few years abandoned their ranchería at the spring near Squaw Tit Peak because wild cats killed all their colts.

The lobo, or timber wolf, is rare and is seen only at considerable intervals in the Tumacacori Mountains and along the Santa Cruz. His cousin, the coyote, or prairie wolf, is found over the whole region. Along the Camino del Diablo, west of Ajo, in 1917, when the region seemed deserted by every living thing and even the creosote bush was suffering from lack of water, the tracks of coyotes were present around water holes, though the animals were not seen. Between the Gunsight Hills and the Baboquivari Mountains coyotes are very numerous, and eight were shot in the course of a month's work. A specimen shot in the upper end of the Altar Valley in 
November was much larger and darker than usual. It is the local opinion that the coyotes of the Tumacacori Mountains are all somewhat larger and darker than the coyotes of the valleys and drier mountains of the western portion of the Papago country. In Robles Pass five coyotes were seen running in a pack. All the others seen, however, were alone. The common habit of the coyote to travel the road and then turn off into the brush as a traveler goes by leads to many daytime encounters.

The two species of foxes which are known in the region are shy and are usually seen only at dusk or in the early morning. Both white-tailed and black-tailed deer were once more plentiful than now, their decrease being due to hunting and the occupation of their grazing lands by horses and cattle. The early military expeditions and boundary surveys depended for a large part of their meat on deer killed by professional hunters. The Papagos once hunted deer for meat and hides, but the lack of market for buckskin has led to their abandoning the hunting of deer for more profitable pursuits. Deer should now increase in number, especially in and around the drier mountain ranges. Antelope were once very plentiful. The international boundary survey of 1892-1894 found antelope in every open valley along the boundary from Nogales to Yuma. The Valley of the Ajo was a favorite haunt, and antelope have been seen along the Camino del Diablo within the last three or four years. During the present investigation the tracks of only one lone antelope were seen on the Gila Bend-Ajo road. It is presumed that the abnormally dry season had driven the others southward into Sonora.

Mountain sheep were once found over the whole region. They are now largely confined to the desert ranges southwest of Ajo and to the Pinacate Mountains of Sonora. The sheep as a rule inhabit inaccessible and rocky places, though they are reported to come down on the plains at times to feed on mesquite beans. Within the last 15 years sheep have been seen by local hunters on the Sierra Estrella, ${ }^{37}$ Childs Mountain, Growler Mountains, and Ajo Mountains. About 5 years ago a dead sheep was found in Heart Tank, in the Pinta Mountains. Sheep now frequent the Tule Mountains south of the international boundary and the Sierra de Lechuguilla. At Tinajas Altas the Survey party saw a buck and three does. Signs of sheep are very plentiful at this locality, and there are many trails where the rock is worn smooth by their feet. Rubbing places and lairs, which the sheep use during the heat of the day, are common. The finding of the bodies of two sheep in the upper tanks is referred to on page 134 . Hornaday gives a very complete account of these animals. The mountain goat, however, is not

${ }^{87}$ Schrader, F. C., unpublished mannscript. 
now known in the region. In 1847 one was killed on the Mohawk Mountains. ${ }^{38}$

Jack rabbits and cottontails are common, except in the region west of the Growler Mountains. It is probable that these prolific animals populate this region rapidly in times of abundant rainfall. The jack rabbit is not highly esteemed for food, and, especially when in the dry season they feed largely on creosote bush, the flesh is not very palatable. Young jack rabbits killed in the spring, however, have as dainty flesh as the cottontail. The cottontail frequents the stream beds, and the traveler can usually add one or more to his larder if he hunts in the evening or in the early morning.

The antelope jack rabbit ${ }^{39}$ (Lepus alleni) is one of the most interesting of the desert animals. He is taller, more slender, and wilder than the ordinary jack rabbit. The body is gray, and the ears, very large and rounded at the top, have almost no hair, and consequently are bright shell pink with a fringe of white hairs. The running gait is a series of long high leaps at a rate compared to which that of the ordinary jack seems very slow. In running he shows a characteristic peculiar sinuous movement of the rump. The white parts of the belly and side are pulled up on the rump, first on one side and then on the other, and this habit produces the white patch to which he owes his name. The animals are usually seen in pairs, and occasionally several pairs may be seen together. The antelope rabbit is not so stupidly curious as the ordinary jack rabbit; and although interested in travelers, usually watches them from a distance of $\mathbf{5 0}$ to 100 yards. On the slightest alarm he takes flight, showing his white patches alternately first on one side and then on the other, often running some distance, nor will he stop for a whistle or cry, as the jack rabbit often does. The habitat of the antelope jack is the broad open spaces of the great valleys or the smaller valleys, such as the Pozo Redondo Valley. Specimens were seen as far north as the Vekol Valley and near Santa Cruz River north of Tucson. The principal range lies between the Baboquivari Mountains and Gunsight Pass. No specimens were seen west of Ajo. The antelope jack rabbit is not hunted for game by the whites. Of the several individuals killed during the investigation all had one or more large tumors under the skin and were much emaciated.

Numerous small rodents inhabit the region. Of these the pack rat or wood rat and the kangaroo rat are the most interesting to

Emory, W. H., Military reconnaissance from Fort Leavenworth, Mo., to San Diego, Calif., p. 92, 1848.

${ }^{20}$ W. T. Hornaday (op. cit., p. 312) doubts the existence of these jack rabbits, but several were killed by the writer's fleld assistants and examined by the writer. See also Nelson, E. W., Rabbits of North America: North Am. Fauna No. 29, pp. 25, 115-117, 1909, and Bryan, Kirk, The antelope Jack rabbit of Arizona : Forest and Stream, vol. 43, p. 561, 1923. 
travelers. The pack rat builds a nest of rubbish in loose rocks or driftwood, or in caves in rocky places, where it is often protected from prowling animals by masses of loose cholla joints. The pack rat is a bold marauder in camps and will carry off not only provisions but cartridges, buttons, tableware, and almost anything else that is loose. He often returns with rubbish of various kinds which he leaves in place of the pilfered articles, hence one of his names is "trade rat."

The kangaroo rat lives in areas of drifting sand and is a beautiful little animal with soft fur, buff on the back and white below. He has a tail about 6 inches long with a.tuft of white hair on the end. The tracks of the hind legs, with the trace of the tail between, are often seen in. sandy places, making a fantastic pattern between the bushes. The animals are nocturnal in habit and rather shy. East of Wellton one night several came into,camp, which was lighted by a large fire. In spite of being shot at several times they persisted in coming back, and one was finally caught in the hand. The fore limbs are much smaller than the hind limbs but are doubtless used more in walking than one would judge by the tracks. Certainly these individuals, when investigating the Survey camp, went on all fours.

The buzzard and the raven are the most common of the larger birds. The buzzard is more likely to be seen in the Santa Cruz and Gila valleys, but the raven was seen in the most desolate places. Several species of owls are known, but all are more common in the mountains than in the plains. Several species of hawks were seen but not identified. Hornaday reports the golden eagle. The picturesque "road runner" inhabits the region but is not common.

The commonest game bird of the region is Gambel's quail, by far the most beautiful of the quails. These birds roost in bunches of 10 to 50 in the trees along the arroyos, and their cheerful clucking, very like that of barnyard fowl, is often the first thing to wake the traveler in the morning. They are difficult to flush, usually preferring to run and hide. As they run faster than a man can walk, and as the creosote and other bushes are usually waist high, it is difficult to get large bags from single coveys. The. best hunting season is in the fall in the vicinity of Papago temporales, where the quail congregate to feed on the residue of the crop and seeds of the pigweed. ${ }^{40}$ The blue or valley quail and the white-top or mountain quail are occasionally found in the area.

The turtledove is found outside of the Santa Cruz and Gila valleys only in the neighborhood of permanent water. They come in to water at dusk, when they are easily killed. The traveler should

${ }^{4}$ Hornaday, W. T., op. cit., pp. 318-320. An interesting account of hunting these birds. 
refrain from killing more than he needs, for these birds are few in number near the desert water holes.

Each open body of water, such as the ponds at Quitobaquito, Comovo, Tonukvo, and Buenos Aires, has its share of water fowl. Geese, mallard, and teal duck and the inevitable mud hen were seen on such ponds. Doubtless all these were migrants breaking a long journey at these spots of water on the desert.

Of poisonous and venomous animals the desert has its full share. but the number of these animals as well as their deadliness is much exaggerated. ${ }^{41}$

The rattlesnake is one of the most widely distributed and well advertised poisonous animals of North America. The diamond-back, which includes several species, and the sidewinder, or horned rattlesnake, are found in the Papago country. The sidewinder is small, from 2 to $2 \frac{1}{2}$ feet in length, and somewhat more active and therefore more to be feared than the other rattlers. Ordinary travelers will, however, seldom see rattlesnakes unless they ramble around in the brush or in rocky places. The bite of a rattlesnake is serious but seldom fatal, except to children and persons in poor health. Proper treatment consists in placing a ligature between the wound and the heart, opening the wound so that the blood will flow freely and if necessary sucking out the blood, and then washing the wound with a strong solution of potassium permanganate.

The annulated snake (Libon septentrionalis), a slender snake $21 / 2$ feet long, is rarely found. It can not strike but if provoked will seize a finger and embed its poisonous fangs.

The Sonoran coral snake (Elaps euryxanthus) is a slender snake, less than 2 feet long, marked with yellow and black bands encircling the body, the black bands being bordered by the yellow, thus distinguishing it from the harmless king and milk snakes, which have black bands between either yellow or red bands. The coral snake has a poison much more deadly than that of the rattlesnake, but it can not strike and must chew in order to insert the fangs. It is said not to bite unless handled. This snake also is rarely found.

The Gila monster, a big clumsy lizard, and a similar species in Mexico are the only poisonous lizards known. All the others, however horrible in appearance, are nonpoisonous. The Gila monster is sluggish and difficult to annoy but has a brutish temper and a grip like a bulldog. From around the teeth in the lower jaw poison is excreted which will get in the wound. The bites are fatal to small animals, but there is no recorded case of a human fatality.

The "hydrophobia skunk" is more or less of a myth, but it seems true that skunks of all species are subject to rabies or hydrophobia.

41 Vorhies, C. T., Poisonous animals of the desert : Arizona Univ. Agr. Frper. Sta. Bull. 83. 1917. Much of the materlal here given is drawn from this useful paper. 
When suffering from the disease they will bite persons sleeping in exposed places and give them the disease. Persons bitten by skunks are advised by Vorhies ${ }^{42}$ to take the Pasteur treatment for rabies.

The tarantula, a large hairy spider, the scorpion, and the centipede are all poisonous, but their bites or stings are only painful, not deadly. The traveler should shake out his boots in the morning, inspect his blankets before lying on them, and use other reasonable measures to avoid the discomfort of being bitten. Fear is not justified, for no authenticated fatalities among healthy adults have been reported from the desert country.

The "niño de la tierra" (child of the earth), which has an evil reputation among the Mexicans, is a burrowing and wingless insect very like a grasshopper and as dangerous. The "velvet ants" or "cow killers" differ from the ants in being hairy and are actually wingless wasps. In the Papago country a red species three-eighths of an inch long is common. Their stings are doubtless no more dangerous than those of ordinary wasps, and they are not nearly so warlike.

The praying mantis, common also in the eastern United States, is called "campamocha" by the Mexicans and is thought, without foundation, to bring about the death of any horse or cow that may accidentally eat it.

The " mato venado," or killdeer, is also called vinegarroon-a name correctly used only for the scorpion. It is about 1 inch long and resembles a scorpion, though it has no sting but four pointed jaws. It can give a severe bite but is nonpoisonous, though suspected of being a disease carrier.

Similarly the Arizona bedbug, or cone-nose bloodsucker, is from half an inch to an inch long, and though apparently harmless, its bite should be avoided for the same reasons as the bite of the ordinary bedbug. Some of the South American relatives of the bedbug are known disease carriers, and the ordinary bedbug is not above suspicion.

\section{GEOLOGY}

\section{STRATIGRAPHY}

The rocks of the Papago country consist of pre-Cambrian schist, gneiss, and intrusive rooks, Paleozoic limestone and quartzite, Mesozoic clastic rocks and granitic intrusives, Tertiary conglomerate and volcanic rocks, and Quaternary alluvium.

The pre-Cambrian rocks are a basal complex whose history is as yet unraveled and which is separated by a great unconformity from the succeeding rocks. The Paleozoic rocks now exist as scattered

${ }^{12}$ Vorhies, C. T., op. cit., pp. 368-373. 
patches infaulted into the pre-Cambrian or embedded in later Mesozoic intrusive rocks. The Mesozoic clastic rocks are arkosic sandstone and shale, which are separated from the Paleozoic limestone and quartzite by an unconformity. The Mesozoic igneous rocks occupy large areas, but the granitic intrusives and more or less metamorphosed lava flows are not easily distinguished from the preCambrian, and the undifferentiated rocks of both ages are referred to as the crystalline complex. The Tertiary conglomerate and lava flows are separated from all the rocks previously formed by an unconformity that represents a desert surface in the old age of erosion. 'The pre-Tertiary and Tertiary rocks form the mountains and hills, but in the valleys lies a great mantle of alluvium, composed of débris derived from the destruction of the older formations. The general distribution of these rocks is shown on the geologic map ${ }^{42 a}$ (Pl. IX, in pocket) and is more particularly described below.

\section{PRE-CAMBRIAN BASAL COMPLEX}

The pre-Cambrian rocks of the region form a highly metamorphosed complex consisting largely of schist and gneiss. No sequence of pre-Cambrian sedimentary rocks such as have been found north of Gila River ${ }^{43}$ has yet been determined, but doubtless some of the schist and gneiss are metamorphosed sedimentary rocks. In the northern part of the Salt River Mountains the complex is mostly chloritic schist. In the Sand Tank Mountains chloritic schist has been feldspathized, and there are many transitions from schist to gneiss. Fine-grained biotite granite and phyllite occur also. The northern parts of the Gila Mountains are composed mostly of coarse biotite granite and micaceous and hornblende schist and gneiss. As noted by Blake, ${ }^{44}$ near the Fortuna mine the schistosity dips $45^{\circ}$ to the south and west and is very even and regular. There hornblende schist predominates, and parallel to the schistosity are quartzose beds in which gold occurs. Blake noted also feldspathic dikes that intersect the schistosity and seem to be connected with great intrusions of pinkish granite, which form the higher peaks.

The older gneisses, which are of pre-Cambrian age, in many localities have a very definite sheeting that divides them into layers

12a This geologic map was made in 1917 and first published in 1922 (U. S. Geol. Survey Bull. 730, pl. 9). Equipped with a manuscript copy of it, the authors of the recently published geologic map of Arizona (Darton, N. H., Lausen, C., and Wilson, E. D., Geologic map of Arizona : Arizona Bur. Mines and U. S. Geol. Survey, 1925) did fleld work in 1921 and the following years that resulted in a new base map on the scale. The geologic boundaries were adjusted to this map and the gaps flled in. Areas of Paleozoic and Mesozole stratlfed rocks were discovered and mapped, and the crystalline complex was divided into three parts-pre-Cambrian schist, pre-Cambrian granite, and Mesozoic granite The later, more basic lava flows of the faulted and dislocated volcanic series, here considered of Tertiary age, were mapped separately and placed with the Quaternary basalt.

4 Ross, C. P., Geology of the lower Gila River region, Ariz.: C. S. Geol. Survey Prot. Paper 129, pp. 184-185, 1922.

4 Blake, W. P., Geology of the Gila Range : Governor of Arizona Rept., 1898, p. 25. 
from 2 to 4 feet thick. Such gneisses, which are easily distinguished from the later intrusive rocks of supposed Mesozoic age, were observed near Tule Tank, in the Cabeza Prieta Range, and in the Baker Peaks, Sierra Blanca, and Coyote Mountains. In the Coyote Mountains the almost perfect sheeting controls the erosion of the mountain range, which has the topographic form of a monoclinal block of sedimentary rock.

\section{PALEOZOIC ROCKA}

The Paleozoic rocks occur in two situations-as plates or blocks resting on the eroded surface of the pre-Cambrian complex, or as blocks more or less engulfed and metamorphosed by later intrusions.

In the western part of the Tucson Mountains, beneath a blanket of lava, mostly Tertiary rhyolite, ${ }^{45}$ lie limestone and quartzite of Cambrian and Carboniferous age. ${ }^{46}$ At Snyders Hill, just west of Robles Pass, blue limestone has been quarried for burning lime, and also for road metal. Fossils collected at this locality have been identifed by G. H. Girty as follows :
Zaphrentis? sp.
Pustula aff. P. porrecta.
Productus aff. P. subhorridus.
Rhynchopora? n. sp.
Squamularia perplexa.
Composita mexicana.

Mr. Girty considers that this fauna is probably younger than that found at the Vekol mine and indicates later Pennsylvanian, perhaps even Permian time.

South of this locality, on the east side of the Sierrita Mountains, limestone and quartzite, in which Pennsylvanian fossils were found, occur at Mineral Hill and Twin Butte. ${ }^{47}$

The ore deposits of Silver Bell occur in blocks of limestone embedded in post-Paleozoic intrusive rocks. ${ }^{48}$ In the near-by Silver Bell Mountains Tolman ${ }^{19}$ found 3,700 feet of alternating quartzite, shaly quartzite, and limestone, of which the massive limestone contains Carboniferous fossils.

North of Pozo Blanco, at the east foot of the Sierra Blanca, the galena ore of the Black Prince mine is found in blocks of blue limestone which, with some red shale, are embedded in intrusive rocks. No fossils were found at this locality.

45 Tolman, C. F., The geology of the vicinity of the Tumamoc Hills: Carnegie Inst. Washington Pub. 113, p. 76, 1909.

46 Blake, W. P., Geologic sketch of the region of Tucson, Ariz. : Carnegie Inst. Washington Pub. 99, pp. 45-68, 1908. Jenkins, O. P., and Wilson, E. D., A geological reconnaissance of the Tucson and Amole mountatns: Arizona Univ. Bur. Mines Bull., Geol. ser. 2, p. 11, 1920.

17 Ransome, F. L., Ore deposits of the Sierrita Mountains, Pima County, Ariz.: U. S. Geol. Survey Bull. 725, p. 412, 1922.

4s Stewart, C. A., The geology and ore deposits of the Silver Bell mining district, Ariz. : Am. Inst. Min. Eng. Trans., vol. 43, pp. 240-290, 1913.

49 Tolman, C. F., Copper depasits of Sllverbell, Ariz.: Min. and Scl. Press, vol. 99, pp. 710-712, 1909. 
The northern part of the Vekol Mountains consists of a monocline of limestone, quartzite, and shale, extending from the Vekol mine to the Reward mine. These sedimentary rocks rest on a basal complex of schist, granite, and diorite and have been faulted and intruded by granitic masses and later siliceous porphyry dikes and plugs. ${ }^{50}$ On the south side of the monocline, near the Vekol mine, fossils were collected in three lots from a thickness of about 200 feet of thick-bedded gray limestone. The surface of this limestone is marked by brown siliceous concretions, and the lower beds are cherty. Near the mine the same limestone is red. The fossils were submitted to G. H. Girty, who reports the following combined list:

Cladochonus sp.

Campophyllum torquium.

Rhombopora lepidodendroides.

Schizophoria? sp.

Chonetes verneuilianus.
Productus semireticulatus.

Marginifera splendens.

Spirifer cameratus.

Spirifer rockymontanus.

Composita subtilita.

Mr. Girty states that the beds are "Pennsylvanian, apparently lower Pennsylvanian." They thus correspond in age to the lower part of the Naco limestone of the Bisbee district. ${ }^{51}$

About 14 miles northwest of the Vekol mine and 3 miles east of Stouts Well is a small hill composed of massive gray limestone, which dips gently to the southeast. About 100 feet of limestone is exposed. This mass appears to be an infaulted fragment of the great limestone series exposed in the Vekol Mountains. A few fossils were collected and submitted to Edwin Kirk, who reports as follows:

There are no determinable fossils in the lot that definitely fix the stratigraphic horizon. The crinoid fragments, however, are of such a nature that they could not be older than Devonian nor younger than Carboniferous. There is little doubt in my mind that the material is of Carboniferous age.

West of this hill only one other outcrop of limestone was found. At the east side of Growler Pass is a high, irregular hill composed of limestone and quartzite which appear to have been mashed and the limestone later silicified. Because of this alteration fossils seem to be rare; none were found by the writer in the short time available.

The remnants of Paleozoic rocks occurring at widely scattered places in the Papago country indicate that the Paleozoic seas were limited on the west by land. The Cambrian and Devonian rocks extend no farther west than the Santa Rita and Tucson mountains; the later Paleozoic (Pennsylvanian) has a wider extent. Earth movements following the Paleozoic era, with consequent erosion, con-

\footnotetext{
co Higgins, Edwin, Vekol copper deposits (Pinal County, Ariz.) : Eng. and Min. Jour., vol. 91, pp. 473-474, 1911.

51 Ransome, F. I., Some Paleozoic sections in Arizona and their correlation: U. S. Geol. Survey Prof. Paper 98, p. 148, 1916.
} 
tributed the clastic materials that now form the Mesozoic sedimentary rocks and destroyed a large part of the previously deposited Paleozoic rocks. Similarly uplift and subsequent erosion incident to the Mesozoic period of igneous activity further diminished the volume of Paleozoic rock, which now forms isolated blocks that are separated by great distances and are preserved largely because they are infaulted and protected by other formations.

\section{MESOZOIC ROCKS}

\section{SEDIMENTARY ROCKS}

In the Santa Rita and Patagonia mountains, small portions of which are shown on the geologic map (Pl. IX), Schrader and Hill found a great series of shale, sandstone, and conglomerate, with calcareous layers, aggregating about 6,000 feet in thickness. ${ }^{52}$ Fossils found in a thin-bedded arenaceous limestone near Mowry indicate, according to T. W. Stanton, that the beds are of Lower Cretaceous (Comanche) age. Because of faunal and lithologic similarities Schrader ${ }^{53}$ considers that the Mesozoic rocks of the Santa Rita and Patagonia mountains are equivalent to the Comanche series ("Bisbee group") of the Bisbee quadrangle. ${ }^{54}$ At Bisbee there are numerous beds of limestone with a well-developed marine fauna. In the Patagonia region, however, the calcareous layers are few, and the greater part of the beds are red sandstone and shale.

What seem to be the same rocks are found in the Tumacacori Mountains. Just east of the Montana mine is a great mass of red sandstone, conglomerate, and shale, dipping to the west at high angles and unconformably overlain by tuff. Both east and west of Arivaca. are red and green shales with incipient slaty cleavage, which may be part of the same formation. Red sandy shale and arkosic gray sandstone of a total thickness of 2,140 feet, attributed to Mesozoic time, have been found in the Tucson Mountains.55 Red and green shales with thin quartzitic sandstone are exposed on the east side of the Sierrita Mountains. They may be of Mesozoic age. ${ }^{56}$

West of the Tumacacori and Tucson mountains red shale and arkose sandstone were seen at Agua la Vara, faulted against the gneiss of the Coyote Mountains, and again at Pozo Blanco, associated with the limestone already mentioned. In these small outcrops no fossils

\footnotetext{
E2 Schrader, F. C., and Hill, J. M., Mineral deposits of the Santa Rita and Patagonia mountains, Ariz.: U. S. Geol. Survey Bull. 582, p. 53, 1915.

53 Idem, p. 53.

${ }^{54}$ Ransome, F. L., The geology and ore deposits of the Bisbee quadrangle, Ariz. : U. S. Geol. Survey Prof. Paper 21, pp. 51 et seq., 1904.

to Jenkins, O. P., and Wilson, E. D., op. cit., p. 11.

r Ransome, F. I., op. cit. (Bull. 725), p. 412.
} 
were seen, but it seems not unlikely, because of lithologic similarity, that they are westward remnants of the Mesozoic formations.

\section{IGNEOUS ROCKS}

The igneous rocks which are thought to be Mesozoic are difficult to distinguish from the pre-Cambrian rocks without detailed study. In general they are characterized by lack of sheeting and gneissoid structure and by the fact that many of the granitic types have both orthoclase and plagioclase feldspars.

In the Santa Rita and Patagonia mountains the Mesozoic igneous rocks, consisting of granite, granite porphyry, quartz monzonite, quartz diorite, aplitic and lamprophyric dike rocks, syenite, and gabbro, are intruded into the Paleozoic sedimentary rocks but nowhere cut the Mesozoic sedimentary rocks. The period of igneous intrusion is therefore thought to be pre-Cretaceous or at the latest very early Cretaceous. .7

At Silver Bell the Mesozoic intrusive rocks consist of alaskite, alaskite porphyry, biotite granite, andesite, and quartz porphyry. ${ }^{58}$

In the Sierra Estrella Schrader found biotite granite, granitic aplite, and pegmatite, which intrude older gneiss and schist. In the Sacaton Mountains he found mica diorite similarly intruded. These rocks he considers Mesozoic. ${ }^{59}$

The copper ores of Ajo occur as disseminated deposits in monzonite, or as vein deposits in rhyolite lava and tuff into which the monzonite is intruded. ${ }^{80}$ These two types of rock make up the eastern portion of the main part of the Little Ajo Mountains and are older than the conglomerate of the Ajo Peaks and the lava flows of Black Mountain. Older gneiss and schist which resemble the preCambrian complex form the western part of the mountains. The igneous rocks that contain the ores, both the monzonite and the rhyolite into which the monzonite is intruded, seem, because of their lack of intense dynamic metamorphism and their relation to the older crystalline rocks, to belong to the Mesozoic period of igneous activity.

In a number of localities in the Papago country were observed granitic and granitoid rocks containing both plagioclase and orthoclase feldspars, which probably belong to the same period of igneous activity. These localities are the Palo Verde Mountains, the mountains in the pass north of Table Top Mountains, the Maricopa Mountains near Estrella, the O'Neill Hills, the Tule Mountains, and the

67 Schrader, F. C., and Hill, J. M., op. cit., p. 57.

s Stewart, C. A., op. cit., p. 246.

so Schrader, F. C., unpublished report on the Gila River Indian Reservation, Ariz.

o Joralemon, I. B., The Ajo copper-mining district, Ariz. : Am. Inst. Min. Hng. Bull. 92, pp. $2011-2028,1914$. 
'Tinajas Altas Mountains. Fractured and altered porphyritic felsite of pre-Tertiary age was seen in the Papago Saguaro National Monument north of Tempe and in Growler Pass.

TERTIARY ROCKS

SEDIMENTARY ROCKS

The sandstone and conglomerate found at a number of localities in this region are thought to be of Tertiary age. The evidence for their age is not definite but consists in their stratigraphic position and their similarity to rocks in the lower Gila region that are associated with calcareous beds from which Tertiary fossils have been collected. ${ }^{61}$ The close association of the conglomerate with the great sequence of lavas is probably the best evidence of its Tertiary age.

The beds included in this group are probably not strictly synchronous. Wherever their lower members were observed they rest on the eroded surface of the older rocks and are made up of angular débris derived from those rocks. In general the Tertiary sedimentary rocks are composed of coarse, poorly sorted arkosic material, such as is deposited by ephemeral streams in the same region to-day. In some localities so much tuffacous material is included that it is evident that they were deposited during the volcanic period. Outcrops of the rocks were studied at nine localities, which are shown upon the geologic map (Pl. IX). The beds range in thickness from 50 feet to more than 1,000 feet and are, without exception, dislocated and extensively eroded.

Tertiary rocks near Tempe.-One of the largest exposures of the Tertiary rocks forms Tempe Butte and the picturesque hills north of it in the Papago Saguaro National Monument. The northerly hills are composed of arkosic conglomerate in beds 20 to 50 feet thick, consisting mostly of fragments of granite, many of which are 6 inches to 6 feet in diameter. In certain beds there is little or no matrix, the boulders being tightly packed together. In other beds the boulders are embedded in a matrix of coarse sand made up of feldspar and quartz fragments from one-eighth to one-half inch in diameter. Only the finer material shows any sorting, except that there are a few small lenses of sandy laminated clay, and in some beds the larger boulders are ranged along the bottom. The whole rock and many of the constituent pebbles are stained by hematite, and though calcite is the principal cement, hematite doubtless helps to bind the particles together. The peculiar erosion forms of the conglomerate are described on page 91. Just north of Hole in the Rock the conglomerate rests on granite gneiss, and most of the constituent fragments are of this rock. There are also many schist

${ }^{61}$ Ross, C. P., op. cit., p. 189. 
fragments similar to a schist that crops out to the east. South of Hole in the Rock the conglomerate rests on a porphyritic felsite, shattered by minute fracturing and recemented by silica. The conglomerate of this locality is composed largely of fragments of the felsite, and the near-by Quaternary gravel cemented by caliche consists of materials derived from both rocks. The shattered felsite and the Tertiary and Quaternary conglomerates, composed of materials derived from it, are very difficult to distinguish in the field. Near the bridge across Gila River and on the north flank of Tempe Butte is a mass of red arkosic sandstone showing mud cracks. The sandstone appears to be a higher member of the formation to which the conglomerate previously mentioned belongs. At the base of Tempe Butte the sandstone dips $55^{\circ}$ SE. and strikes N. $60^{\circ}$ E. It is more shaly at the top and is overlain by a thick bed of lava, which caps the butte.

Blake considered these rocks to be of Triassic age, because of their lithologic similarity to the Triassic elsewhere. ${ }^{62}$ Lee ${ }^{63}$ considers that they can hardly be Triassic, because the Triassic rests on the Paleozoic rocks in the plateau region to the east with apparent conformity, and assigns them to the Tertiary. In Tempe Butte the upper shaly beds are intruded by a thin basic sill and are interbedded with an amygdaloidal basalt flow and capped by a thick bed of lava. This close association and contemporaneity with lava, which resembles in every way the other Tertiary igneous rocks, seems in the absence of fossils to be good evidence that the beds are of Tertiary age.

Conglomerate near Comobabi.-In the pass between North and South Comobabi mountains there is a large area underlain by conglomerate. About half a mile east of the village of Comobabi the conglomerate is well exposed in a cliff (Pl. VIII, B), where it is overlain unconformably by 12 feet of cemented gravel containing fossil bone. (See p., 68.) The dip is $30^{\circ} \mathrm{NW}$., and the strike N. $87^{\circ}$ E. Boulders 3 and 4 feet in diameter are common; the ordinary size, however, is about 4 to 6 inches, and there is a sandy and pebbly matrix. In angularity of pebbles and lack of sorting this rock is similar to the other outcrops of conglomerate. The material is derived largely from the erosion of porphyritic rocks of andesitic type, but there are many granite boulders. The conglomerate is red but not so thoroughly cemented as in some other localities.

Conglomerate in the pass north of Table Top Mountains.-Gray arkosic conglomerate interbedded with lava occurs near the water

\footnotetext{
${ }^{62}$ Blake, W. P., Some salient features of the geology of Arizona with evidences of shallow seas in Paleozoic time: Am. Geologist, vol. 27, p. 166, 1901.

as Lee, W. T., Underground waters of the Salt River valley, Ariz.: U. S. Geol. Survey Water-Supply Paper 136, p. 97, figs. 15, 16, 1905.
} 
hole in the pass on the Maricopa-Covered Wells road, 18 miles from Maricopa. The beds dip $14^{\circ} \mathrm{SW}$. and strike N. $42^{\circ} \mathrm{W}$. The conglomerate is interbedded with basalt flows, the lowest of which rests on granite on the north side of the pass. The conglomerate, however, has very few basalt pebbles but is made up of granitic material. Some of the boulders are 6 to 8 feet in diameter.

Conglomerate at Totobit Tanks.-The Totobit Tanks lie along the main drain of Vekol Valley, 5 miles southwest of the Vekol mine. They consist of a series of plunge pools and potholes in conglomerate and lava. The conglomerate has a tuffaceous matrix, and the pebbles are rounded boulders from 1 inch to 2 feet in diameter, mostly of basalt. As the conglomerate is interbedded with basalt it probably represents stream action during the period of Tertiary volcanism.

Conglomerate at Sand Tanks.-At Sand Tanks, 23 miles southeast of Gila Bend, tuffaceous conglomerate crops out in a narrow canyon in the dissected pediment of the Sand Tank Mountains. The tanks consist of plunge pools eroded in the conglomerate, which dips $20^{\circ} \mathrm{N}$. and strikes N. $80^{\circ} \mathrm{W}$. The following is a section of the beds exposed:

\section{Section of Tertiary rocks at Sand Tanks}

Feet

Brown tuffaceous conglomerate with large granite pebbles and grains of pumice, 1 inch or more in diameter.

Brown tuff with only occasional granite pebbles

Brown tuffaceous conglomerate with fragments of pumice and scattered boulders, 4 to 8 inches in diameter, of granite, porphyry, felsite, aplite, vein quartz, and schist. It is mudcracked throughout in blocks 12 inches across

Purple tuff with no large fragments of pumice

Brown sandy tuff with 3 inches of yellow pumice at top

Speckled tuff composed of pebbles of pumice--
Brown sandy tuff with small pebbles of various rocks, lower part faulted and crumpled

Green sandy tuff

White tuff, laminated and with occasional pebbles; thickness concealed by faulting.

Brown pebbly tuff. Normal fault with 6 feet throw to west and reverse fault with small throw extend outcrops of this bed to the west

Granite gneiss, much fractured, on which the conglomerate rests unconformably.

It is evident from the section that these rocks were formed after volcanism had begun in the neighborhood. The pre-Tertiary rocks were exposed, and at this place streams deposited poorly assorted débris derived from the erosion of the pre-Tertiary volcanic rocks, mixed with the materials of ash showers. 
Conglomerate near Ajo.-Red conglomerate occupies a large area south of Ajo and forms the picturesque Ajo Peaks. This conglomerate rests on the Mesozoic igneous rocks of the Little Ajo Mountains and dips about $10^{\circ} \mathrm{S}$. The individual beds are from 20 to 50 feet thick. Boulders from 6 inches to 4 feet in diameter are embedded in a matrix of quartz and feldspar fragments. The cement appears to be hematite and calcite, and all the fantastic erosion forms of the conglomerate of the Papago Saguaro National Monument are repeated. Pebbles of fresh-looking siliceous lavas and of copper ores are found. The conglomerate was therefore deposited after the period of copper mineralization in the Ajo district. The contact with the main Tertiary lava flows, of which about 1,200 feet is exposed in the near-by Black Mountain, is concealed, but the conglomerate is presumably the older rock. The presence of lava pebbles, however, indicates that the Tertiary volcanism had begun before the deposition of the conglomerate.

Conglomerate near Tule Well.-Near Tule Well on the Camino del Diablo there are three exposures of conglomerate. About 4 miles southeast of the well the road goes over a little divide on conglomerate made up of pebbles of lava of many varieties. This bed of conglomerate is about 50 feet thick and is interbedded with lava flow. It seems to be due to stream action during the extrusion of the lava. At 2 miles east of Tule Well is a group of low hills with the picturesque topography typical of the arkosic conglomerate of the Papago Saguaro National Monument. The conglomerate, which is reddish yellow, is thick bedded and dips about $30^{\circ} \mathrm{E}$. Embedded in the matrix of quartz and feldspar débris are pebbles as much as 6 inches in diameter of granite and other rocks of pre-Tertiary age. Pebbles of lava are also present. Hills of similar color and topography lie 4 miles northwest of Tule Well and are probably formed of like material.

Conglomerate east of Wellton.-The Baker Tanks are a group of potholes and plunge pools in a stream channel along the southwestern flank of Baker Peaks. By headward erosion the stream is cutting a canyon about 30 feet deep and 100 feet wide in a plain developed on pinkish-red conglomerate. Near the tanks the conglomerate strikes $\mathrm{N}$. $77^{\circ} \mathrm{W}$. and dips $65^{\circ} \mathrm{SW}$. The rock is massive but much broken by joints, many of which show slickensides. Along the joints. dehydration has taken place, and there is much variation in color. The beds are mostly an aggregate of quartz and feldspar grains from one-eighth to one-half inch in diameter. Where the finer materiaI predominates the beds show lamination and cross-bedding. Boulders from 3 inches to 3 feet in diameter lie scattered in this matrix, either singly or in groups and clusters. Near the lower tanks are two beds made up almost wholly of boulders. The conglomerate at Baker 
Tanks is so similar to the gravel laid down by present streams that drain the granite gneiss of Baker Peaks as to force the conclusion that it was derived from the same rocks under similar conditions of climate.

About 4 miles northwest of Baker Tanks is a hill which rises above the Quaternary gravel on the north side of the Southern Pacific Railroad. In this hill is exposed about 400 feet of arkosic sandstone. The strike is $\mathrm{N} .35^{\circ} \mathrm{W}$. and the dip $15^{\circ} \mathrm{SW}$. The beds of sandstone range from 5 to 20 feet in thickness and, as exposed in an abandoned quarry on the east side of the hill, are fairly uniform for short distances. Coarse sandstone of quartz feldspar and biotite mica with lenses of small pebbles is the common rock, but pebbles over 3 inches in diameter were not found. The color is slightly darker than that of the rocks at Baker Tanks and more uniform. Concentration of iron oxide at the surface forms a dark-red crust. Weathering produces many small pits and miniature caves at the surface, but there is none of the picturesque topography of other conglomerate outcrops.

North of this hill is another which at a distance appears to be made up of the same material. Two miles to the northeast is Antelope Hill, which, according to Ross, ${ }^{64}$ is composed of gray arkosic sandstone that strikes nearly east and dips gently south. The grains of the sandstone range from one-sixteenth to one-fourth inch in diameter. The thickness exposed is over 500 feet.

In spite of differences in altitude, color, and size of grain, it is probable that the rocks of all these localities belong to the same formation. The northerly outcrops may be higher in the sequence and were certainly farther from the source of material.

Outcrops north of Blaisdell.-About 3 miles north of Blaisdell, in the cuts along the main Tucson-Yuma road, is an exposure of sandstone and clay shale. The rocks, which strike N. $80^{\circ}$ E. and dip $20^{\circ}$ SE., are almost completely masked by overlying terrace gravel of Quaternary age. The sandstone consists of yellow and red arkose, thin bedded and marked by mud cracks. The largest pebbles observed are half an inch in diameter. The clay beds, which are few, are of yellow color. These rocks are similar to the deposits of the present Gila River-and are not so thoroughly cemented as the Tertiary sediments east of Wellton. It is possible that they are more thoroughly cemented phases of the older Pleistocene gravel that crops out near by.

\section{VOLCANIC ROCKS}

Distributed throughout the Papago country is a great series of volcanic rocks which range in chemical composition from siliceous

\footnotetext{
a Ross, C. F., Geology of the lower Gila region, Ariz.: U. I. Geol. Survey Prot. Paper 129 , p. 188,1922 .
} 
rhyolite to olivine basalt. In some localities, as in the Sand Tank and Sauceda mountains, they formed a great mantle of flows and tuffs which almost completely buried all the preexistent rocks. In the Growler, Ajo, Sauceda, Quijotoa, and Sand Tank mountains the thickness of lava is commonly 1,200 to 1,500 feet and may reach 2,000 feet. In other localities the lava is thin or lacking, and in the Tumacacori Mountains tuffs predominate over lava flows. All these lavas have been dislocated and dissected. The dissected slopes merge with the mountain pediment (see pp. 93-101) or are buried in alluvium, and this characteristic indicates that all the lavas are probably older than the Pleistocene. In contrast to them the Pleistocene basalt lies on top of the alluvium in the valleys and is but little dissected.

Most of the centers of eruption from which the Tertiary volcanic material emerges are either concealed by later flows or removed by erosion. Much of the lava may have been extruded from fissures, and volcanoes may never have been prominent features of the Tertiary landscape. However, Batamote Mountain has the form of a slightly dissected volcano, and the mountain south of Kaka appears also to be an old volcano.

The variety of rocks included in this series is illustrated by the work of Guild in the Tucson Mountains. ${ }^{6 s}$ He found rhyolite, rhyolite tuff, biotite-hornblende andesite, pyroxene andesite, pyroxenemica andesite, and several basalts.

In the Tumamoc Hills Tolman ${ }^{66}$ found the following succession, beginning with the youngest: (1) Basalt flows and intrusions, (2) rhyolite tuff, (3) two basalt flows, (4) andesite flows. These rocks he considered to be of Pleistocene age, but because they are uplifted, faulted, and dissected they are here mapped with the Tertiary.

In the Santan Mountains Schrader ${ }^{67}$ found 100 feet of olivine basalt overlying 200 feet of latite, which in turn rests on granite of the crystalline complex. These rocks increase in thickness toward the center of the Malpais Hills, in which they occupy an area of about 9 square miles. Basalt also occurs at Walker Butte and in Poston Butte and other outliers of the Santan Mountains.

South of the Salt River Mountains lies Jackson Butte, separated from the mountains by a plain more than 2 miles wide, mantled by alluvium. The top of the butte is a bed of agglomeratic vesicular basalt about 20 feet thick. The lower part of the butte, which is masked by a talus of large blocks of basalt, is composed af unconsolidated gravel and sand. There is no near-by source of the basalt,

\footnotetext{
as Guild, F. N., Petrography of the Tucson Mountains, Pima County, Ariz.: Am. Jour. Sci., 4th ser., vol. 20, pp. 313-318, 1905.

BB Tolman, C. F., Geology of the vicinity of the Tumamoc Hills : Carnegie Inst. Washington Pub. 113, pp. 67-82, 1909.

or Schrader, F. C., unpublished report on the Gila River Indian Reservation, Ariz.
} 
and it is possible that the gravel conceals the plug that occupies the neek through which the basalt rose. The gravel also is much less consolidated than most of the Tertiary formations. The basalt of Jackson Butte may easily be of early Quaternary age.

The same remarks apply equally to a somewhat similar outlier on the east side of the Maricopa Mountains 1 mile north of Estrella station. This outlier consists of two small hills capped with 20 to 30 feet of dull-red felsite, which rests on arkosic gravel that separates it from the underlying crystalline rocks. The felsite forms beds 2 to 3 feet thick, of which the upper one is full of holes like a vesicular basalt. The holes, however, are probably not due to the expansion of gases while the rock was hot but to the solution by weathering of some constituent of the rock. The gravel is similar to that of the present streams and is but a thin coating on an old surface of erosion that has been uplifted and now stands above the -level of the adjacent pediment.

QUATERNARY DEPOSITS

ALIUVIAL MATERIALS

GENERAL CHARACTER

The Pleistocene and Recent materials have been derived from the erosion of the present mountains and laid down by existing streams or their counterparts. The climate of Quaternary time has not been uniform, though doubtless it has been throughout of the arid type. Variations in climate may be assumed because of the known fluctuations throughout the world shown by the glaciation of large areas, and also because in Arizona there were permanent lakes where now there are only temporary lakes. ${ }^{88}$ The fluctuations in this region were, however, not so great as to bring about a humid climate. The change was only in the degree of aridity.

Thus the deposits of the different stages of Quaternary time are similar to one another and vary chiefly according to their topographic position. Near the mountains ephemeral streams build up alluvial fans of coarse, poorly assorted gravel. Farther down the slopes the sand streams deposit finer débris as sandy clay and fine gravel and sand. Near the middle of the valleys clay or sandy clay may predominate, though wind-blown sand and lenses of sand or gravel are also deposited, the material being dependent on the type of the axial stream. Thus if materials of one of the older Quaternary stages originally laid down near the mountains are exposed near recent

65 Meinzer, O. E., and Kelton, F. C., Geology and water resources of Sulphur Spring Valley, Ariz. : U. S. Geol. Survey Water-Supply Paper 320, p. 34, 1913. 
deposits of streams at a distance from the mountains the contrast between the two deposits is great. But deposits of the two stages laid down by essentially similar streams in corresponding portions of their courses may be so similar that it is impossible to tell them apart. In general those beds of alluvial material which stand above the general level and are now being eroded are regarded as belonging to the earlier stages, and these beds are commonly cemented with caliche. Much larger amounts of the older deposits must be buried under the modern alluvial plains, however, and concerning these deposits little is known except such facts as are disclosed by well records.

The Quaternary deposits fall into three divisions-older alluvium, younger alluvium, and Recent deposits. These divisions can not be definitely correlated with divisions of the Quaternary in other regions, however, nor can rigid application of these divisions be made within the Papago country.

\section{OIDER ALLUVIUM}

The older alluvium is exposed at only a few. widely separated localities, largely around the borders of the Papago country, though doubtless it lies buried beneath younger deposits in the greater part of the valley region.

Near Tucson red and partly cemented older alluvium is exposed near the base of the Santa Catalina Mountains at the mouth of Sabino Canyon. It is tilted and eroded, and on it rests the younger alluvium. ${ }^{6}$ Field work by the writer in 1920 and 1921 indicates that this red material should be correlated with similar fan conglomerates in the San Pedro Valley, which are of Pliocene age. Farther south, near Tubac, the bluffs along Santa Cruz Valley are doubly terraced, as shown in Figure 17 and described on page 111. The gravelly deposits of the upper level seem to belong to the older alluvium; the lower terraces can be correlated with a part of the terrace and flanking stream-built slopes near Tucson. Similarly near Nogales the rock plains which border both Santa Cruz River and Nogales Wash, especially on their lower portions, are mantled with gravel. Near the streams these plains stand as bluffs about 150 feet high. The gravel that caps the bluff probably belongs to the older alluvium, whereas that on the rock bench about halfway down the bluff belongs to the younger alluvium.

On Gila River east of its junction with Salt River no outcrops of the older alluvium were found, but west of this point Ross ${ }^{\text {to }}$ found

\footnotetext{
60 Smith, G. E. P., Ground-water supply and irrigation in the Rillito Valley: Arizona Univ, Agr. Exper. Sta. Bull. 64, pp. 89-90, fig. 57, 1910.

${ }^{70}$ Ross, C. P., op. cit.
} 
only small areas of tilted gravel in the margins of the Gila Bend Mountains.

South of Wellton, lying against the northern border of the Wellton Hills, is a small tract of gravelly alluvium, which forms a plain about 50 feet above the alluvial slope. The slope is graded with respect to the base-level of the terrace about 100 feet above the flood plain at Wellton. The tract of alluvium is obviously older than the slope, and the slope seems to be of the same age as the terrace, which is regarded as part of the younger alluvium.

North of Blaisdell and associated with an outcrop of red sandstone and clay of probable Tertiary age is a deposit of gravel composed of rudely sorted materials with pebbles 1 to 2 inches in diameter in beds that dip about $10^{\circ} \mathrm{W}$. The gravel has been beveled and more or less concealed by the outwash from the north end of the Gila Mountains. This outwash was deposited when Gila River stood at the level of the terrace of younger alluvium, and therefore the tilted alluvium must be older than the younger alluvium. It is, however, closely associated with the red sandstone and clay, and further work may show that both are Tertiary, or perhaps that both belong to the older alluvium.

In the interior valleys of the Papago country the older alluvium can be identified positively only in Altar Valley. In these valleys the mountain pediments have a thin coating of alluvium, part of which is still being augmented by streams, but some of it lies above the present streams and is partly consolidated. Along the axial stream and the main tributary of Altar Valley, however, it seems possible to distinguish the older alluvium, as is more fully discussed on page 114.

\section{YOUNGER ALLUVIUM}

Along Gila River there is a more or less continuous terrace from Gila Bend to Yuma. This terrace, cut into promontories by tributary streams, stands about 75 feet above the river. The surface is mantled with a coating of pebbles, in places only one pebble deep. Below the pebbles the terrace is composed of alternating beds of sand, clay, and gravel very similar to those laid down by the present river. The terrace therefore represents a period of aggrading of Gila River, at the conclusion of which the river stood at least 75 feet higher than it does now. All the tributaries were adjusted to this grade, and consequently the stream-built slopes of the adjacent mountains of the interrior valleys slope to the top of the terrace. The cutting down of Gila River to or perhaps below its present level changed the base-level of the tributary streams, which with increased grade have cut valleys through the terrace. This headward cutting has been very effective on some of the tributaries north of Gila 
River, ${ }^{71}$ but the tributaries on the south have been too feeble to dissect to any large extent the valleys which they drain. (See p. 103.)

Near Ligurta, 7 miles east of Dome, fossil bones were found on two promontories of the terrace that project into the flood plain of the river. The bones lay on the surface as part of the layer of pebbles resulting from the erosion of the materials which form the terrace. Near the river underlying beds are exposed in the bluff and consist of brown sand, gravel, and sandy clay similar to material now carried by Gila River. The clay has round, smooth concretions $\therefore$ to 12 inches in diameter. The brown sand has also many concretions, but they are rough on the surface and irregular in shape. A small sliver of bone was found in place in the brown sand, so that the bones are undoubtedly derived from it and probably are inclosed in the concretions. The bones were probably transported some distance before deposition, but it seems most reasonable to assume that the animals died on the river flood plain during the period of deposition of the brown sand.

A small collection of these bones was referred to J. W. Gidley, of the United States National Museum, who identified the phalanx of a horse (Equizs sp.) and the basal portion of the antler of a deer probably belonging to the genus Odocoileus. According to Doctor Gidley, "These fossils do not determine the age more closely than that they are Pleistocene, though the presence of the horse remains suggests one of the older phases of the Pleistocene."

In 1921 waterworn fragments of bone were found three-quarters of a mile east of Comobabi. (See Pl. VII and Pl. VIII, B.) At this locality the mountain pediment is developed on tilted fan conglomerate similar to the Tertiary conglomerate of other localities. Resting unconformably on this conglomerate is a bed of gravel about 10 feet thick, which lies about 30 feet above present stream grades and perhaps belongs to the older alluvium. The gravel contains boulders of all sizes up to 3 feet in diameter and is similar to the channel gravel in the present streams. The upper 2 feet is thoroughly cemented. with calcium carbonate (caliche). Below this part the cementation is less, and iron oxides are nearly as abundant as lime. The bones all occur in the lower 4 feet, and most of them were found in the lower 2 feet. The gravel was evidently deposited by the stream that eroded the pediment and presumably was deposited at or near the end of the period of erosion.

The fossils were referred to Doctor Gidley, who reports as follows:

In the lot of fragmentary remains obtained 55 miles west of Tucson the only determinable material consists of portions of three teeth representing the genus Equus. One of these, a nearly complete upper molar of the right side (cata-

${ }^{7}$ Ross, C. P., op. cit. 
$\log$ No. 10443, U. S. Nat. Mus.), I refer provisionally to Equus occidentalis, a species described by Leidy in $1865,{ }^{74}$ from Tuolumne County, Calif. The specimens are too incomplete and the species too little known to make this determination positive, but in size and general characters the Arizona tooth agrees very closely with the type of the California species.

On the basis of this material no positive statement can be made regarding the possible age of the beds from which it came, for two reasons: First, although Equus occidentalis is usually considered a Pleistocene species, the fact, so far as Doctor Gidley is aware, has never been proved; second, there is no good reason why this particular species may not have found its way into the southwestern United States in Pliocene time and continued its existence there into the Pleistocene.

A small rodent jaw from Robles Well, on the Ajo road 25 miles west of Tucson, said to have come from a depth of 212 feet below the surface, Doctor Gidley has carefully studied and finds it can not be distinguished from similar jaws of Neotoma albigulus, a species of wood rat now living in that general region. He therefore concludes that it must have fallen into the well by accident from the surface.

The Gila Valley east of the Sierra Estrella is bounded by bluffs 25 to 50 feet high which, though not so high as those farther west, seem, like similar terraces on Salt River, to correspond to the 75-foot terrace of the lower part of the river.

Near Tucson large parts of the dissected stream-built slopes which terminate at the flood plain of Santa Cruz River consist of the younger alluvium. Farther south the lower terraces at Tubac and the gravel on the lower bench in the vicinity of Nogales may be correlated with it.

In the interior valleys the same difficulties of correlation exist for the younger alluvium as for the older alluvium. There are at a number of points, however, low terraces which probably belong with this formation. These terraces are described in the section on the valleys (p. 107), where such explanations as suggest themselves are offered.

RECENT DEPOSITS

The Recent deposits comprise the sand and gravel in stream beds, the flood-plain deposits of the larger streams, and the deposits on the great flats of the interior valleys. These materials are all unconsolidated alluvium with minor amounts of wind-blown sand. They are more particularly described under the heading "Valleys" (p. 101).

7t Leidy, Joseph, Acad. Nat. Sci. Philadelphia Proc., 1865, p. 94. Gidley, J. W., Am. Mus. Nat. Hist. Bull., vol. 14, pp. 14-16, fig. 10, 1901. 
Two flows of basalt covering extensive areas were poured out of low cones during the Quaternary time. The great flow at Sentinel largely rests upon and protects the terrace of younger alluvium along Gila River and has been described by Ross. ${ }^{75}$ The other large area lies in the southern part of the Tule Desert just west of Las Playas. It is a northern extension of the volcanic plateau surrounding the Sierra del Pinacate of Sonora, and like that plateau appears to be of relatively recent geologic date. The volcanic character of the Sierra del Pinacate was first recognized by Father Eusebio Kino in his journey to the region in $1701 .^{78}$ A biologic exploring party under the leadership of D. T. MacDougal in 1907 made a map of the region, showing the boundaries of the lava fields and the position of the principal craters. ${ }^{77}$ Lumholtz $^{78}$ found a legend among the Papagos referring to eruptions and ash showers from the two higher peaks.

The portion of the Pinacate lava flow which extends across the international boundary is a low mesa about 6 miles from north to south and 5 miles from east to west. The mesa rises from 50 to 100 feet above the Tule Desert, and this elevation seems to measure the thickness of the olivine basalt of which it is composed. The margins are but little dissected and seem to be near or at the original limits of the flow. Small cones and craters dot the surface. One of the cinder cones, a crescent-shaped ridge about 50 feet high, is composed of very fresh-looking reddish slag, much of which was thrown out still molten and fell in pasty masses. Volcanic bombs are numerous. Though the bombs seem very fresh, the under side, where they lie on the surface of the ground, is covered by a film of calcium carbonate obviously derived from the weathering of the bomb. This coating or patina is thicker than that found on Papago artifacts in the neighborhood and indicates that the Pinacate flows of basalt are probably not of Recent age and do not belong within the period during which the Papagos have lived in the region. Some weight, however, may be given to Papago tradition with respect to Recent eruptions in the Sierra del Pinacate.

\section{STRUCTURE}

\section{SALIENT FEATURES}

The compressive movements of pre-Cambrian time can be recognized by the mashed condition of schist and phyllite, but the evi-

\footnotetext{
${ }^{75}$ Ross, C. P., op. cit.

${ }^{76}$ Bolton, H. E., Kino's Historical memolr of the Pimerfa Alta, vol. 1, p. 283, 1919. Kino also visited the Sierra del Pinacate in 1698 (1dem, vol. 1, p. 187) and in 1706 (idem, vol. 2, pp. 205 et seq.).

7 MacDougal, D. T., Across Papaguerta : Am. Geog. Soc. Buil., vol. 40, pp. 705-725, maps 1 and 2, 1908. Hornaday, W. T., Camp fires on desert and lava, map opposite p. 110, New York, 1908.

${ }_{78}$ Lumholtz, Carl, New trails in Mexico, p. 203, New York, 1912.
} 
dence of later folding has throughout the Papago country been destroyed by erosion. The scattered masses of Paleozoic rocks wert disturbed, dislocated, and in part engulfed in Mesozoic intrusions, but post-Paleozoic folding has not been recognized. The Mesozoic sedimentary rocks are much disturbed in the Patagonia region, ${ }^{70}$ where there is evidence of post-Cretaceous folding, but whether this movement extended westward into the Papago country is not known. Profound erosion had left a landscape of mountains of considerable elevation prior to the Tertiary lava flows, but the method of uplift of these mountains is not clear.
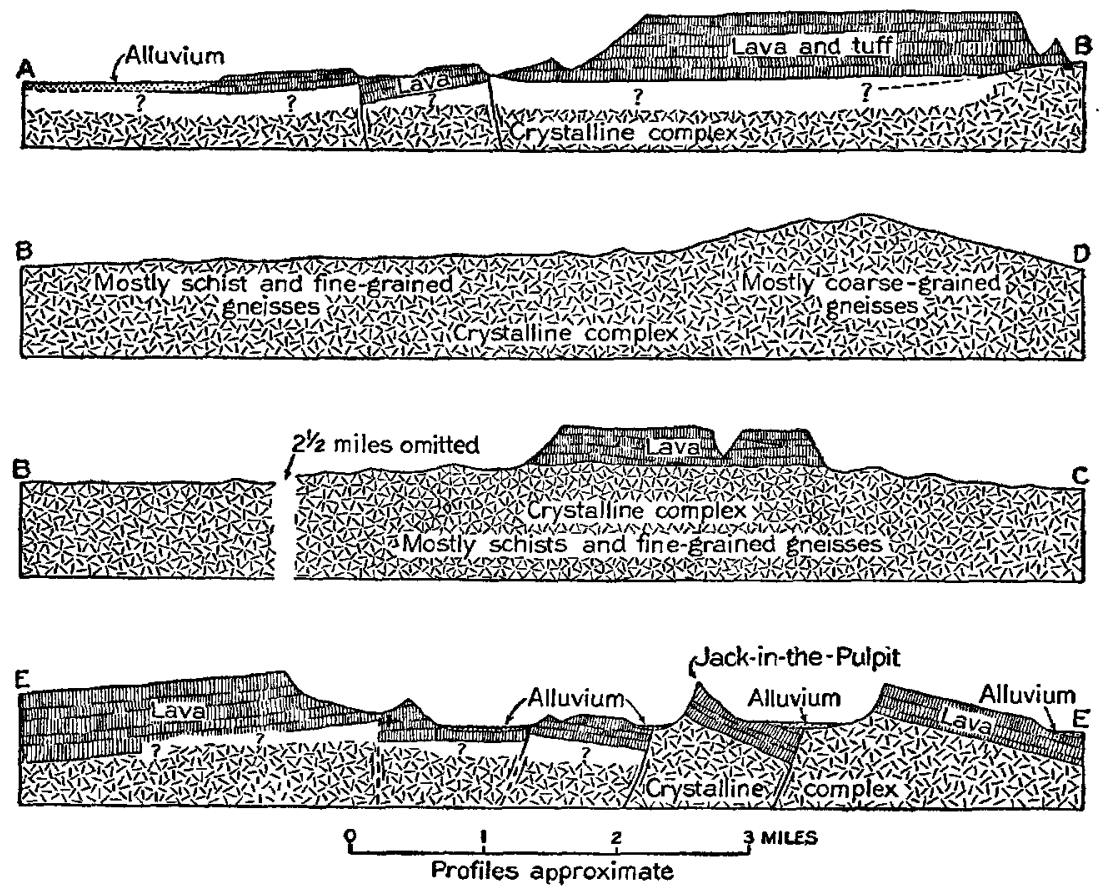

Figdre 2.-Geologic cross sections in the western part of the Sand Tank Mountains, Ariz.

Faulting on a large scale, however, took place at the end of the Tertiary period of volcanism. To the movement which produced the faults of this period the present mountains owe their elevation, though there is evidence of Pleistocene movement along the same structural lines. The nature of the faults can best be illustrated by citing examples.

\section{FAULTS}

\section{SAND TANK MOUNTAINS}

The Tertiary lavas of the northwestern part of the Sand Tank Mountains are evenly bedded, and their whole thickness may be as

Tchrader, F. C., and Hill, J. M., op. cit., p. 77. 
much as 2,000 feet. The eroded surface of the crystalline rocks appears to have been fairly smooth, and consequently the lavas are immense plates of rock which, as at present broken by faults, resemble great flakes of ice stranded on a shore by the wind. Toward the east the lava flows are less continuous, the total thickness is more variable, and the individual fault blocks as revealed by the attitude of the lava plateaus stand out less clearly.

The faults are of the normal type and trend in two directions-north and east. The geologic map (Pl. IX) and the cross sections in Figure 2 show the effect of faulting on the distribution of the lavas and in the topography. Sections $A-B, B-C$, and $B-D$ are arranged on a $Y$ of which $A-B$ is the stem; $A-B$ trends east, $B-C$ east-northeast, and $B-D$ east-southeast. The faults shown in section A-B trend west of north and are marked by valleys. Along section $B-L$

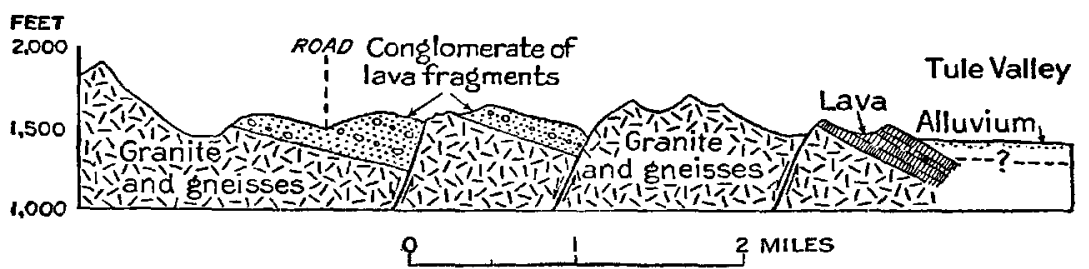

Figure 3.-Geologie cross section in the Tule Mountains, Ariz.

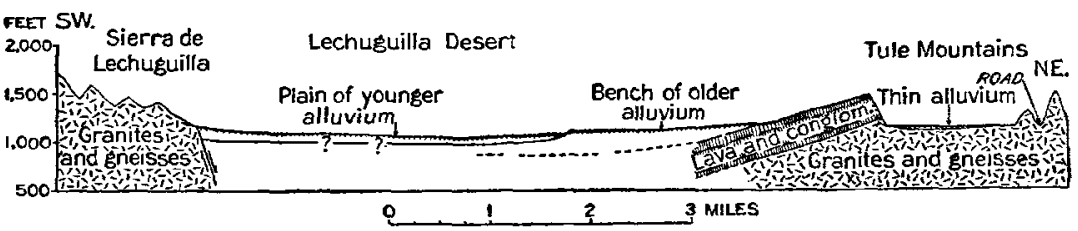

Figure 4.-Geologic cross section of the southern part of the Leehuguilla Desert, Ariz.

no lava appears, but a mountain of coarse-grained gneiss stands above the lavas which once covered it, at least in part. Along section B-C a lava plateau that has been uplifted, perhaps, but not tilted still resists erosion. Section E-E, which trends north, at right angles to section $A-B$, shows the effect of the faults that have an easterly trend. Tilting of the fault blocks is much more marked, and the underlying crystalline rocks are brought to the surface at the base of Jack in the Pulpit and the plateau south of it.

\section{TULE MOUNTARNS}

In the pass southeast of Tule Well block faults are well shown by the tilted lavas and lava conglomerate, which rest on a relatively smooth plain composed of the crystalline complex. The cross section in Figure 3, which extends from east to west about 2 miles south of Tule Well, brings out the character of these faults. On the west side of the same range and south of the road a great plate of lava 
and lava conglomerate about 750 feet thick dips westward under the Lechuguilla Desert (fig. 4). The contact with the crystalline complex is exposed along the eastern face of the ridge. Hills several hundred feet high project up into the lava and indicate the local irregularity of the surface over which the lava flowed. North of the road what seems to be the same lava caps the mountains at an altitude about 1,000 feet higher. (See Pl. XII, A.) As shown in Figure 4, the westward-dipping block of lava is bordered by a bench of alluvium about 50 feet above the level of the main Lechuguilla Desert. This bench of older alluvium indicates renewed uplift of the Tule Mountains in Pleistocene time, probably accompanied by faulting along the east front of the Lechuguilla Mountains. On physiographic evidence the Tinajas Altas Mountains, near by, are thought to have been reelevated in Pleistocene time (p. 76).

\section{GROWLER MOUNTAINS}

The portion of the Growler Mountains north of Growler Pass is a rather simple monoclinal fault-block mountain trending northwestward and about 20 miles long. In the picturesque western escarpment are exposed between 1,200 and 1,500 feet of Tertiary lava, tuff, and conglomerate resting on the crystalline complex, which crops out in places at the foot of the mountain front. The eastern slope is gentle, almost without canyons, and conforms to the dip of the lava sheet.

In Growler Pass there are at least five faults that trend almost due north, but the intervening blocks are rotated in different directions. In the easternmost block the beds are horizontal. In the others the dips are easterly in two and westerly in two. The complex structure of Growler Pass continues in the southern part of the Growler Mountains, which consists of large lava plateaus separated from one another by narrow canyons. The beds in each plateau dip at a different angle or in a different direction from those in neighboring plateaus, so that there must be a complicated system of faults.

\section{GEOLOGIC CLASSIFICATION OF THE MOUNTAINS}

\section{GENERAL ChARACTER}

The mountains of the Papago country consist either of more or less isolated elevated regions separated by broad valleys underlain by alluvium, or of groups or chains of mountains separated by rather narrow alluvium-filled valleys or canyons. To the traveler crossing the country on the Southern Pacific Railroad the ranges appear to be rather monotonous in their characteristics, showing a recurrent 
sameness which implies a common geologic history. They seem to consist wholly of small detached sierras having very similar topographic forms, composed of granite and other coarse-grained crystalline rocks, and to be largely buried in alluvium. This appearance, however, is the result of the fortuitous distribution of certain types of ranges along the route of travel. A further exploration of the Papago country shows that many of the mountains are capped with lava beds much younger than the granite and crystalline rocks already mentioned and have the typical fault-block form common to the ranges of Nevada. Other ranges consist of exceedingly complex plateaus, peaks, and pinnacles, generally carved from thick lava beds. The ranges are thus by no means uniform in their rock composition and topography, and they may be separated into groups according to their composition and structure. There are 68 mountain ranges and groups of hills in the Papago country, ${ }^{81}$ and 11 more that lie east of Santa Cruz River are represented on the geologic map (Pl. IX). Of these 79 ranges 15 can not be described, because they have not yet been sufficiently explored. A classified list of all these mountains is given on pages $77-79$.

MOUNTAINS COMPOSED LARGELY OF VOLCANIC ROCKS

The mountain ranges composed largely of volcanic rocks are 25 in number and consist in greater part of alternating beds of acidic and intermediate lavas, tuffs, and volcanic products of various sorts. With these lava beds in many places are associated stream-laid conglomerates, the pebbles of which consist of granite, other crystalline rocks, and lavas of various sorts. The lava beds seem to represent a general period of volcanism in Tertiary time, in which a large part of the Papago country was subjected to great flows of lava and enormous ash showers from numerous volcanic vents. The floods of lava were by no means uniform either in chemical composition or in total thickness of lava accumulated, but in a general way the resulting topographic forms are alike.

The mountains composed rargery of volcante rocks have been divided into three groups on the basis of their structure and resultant topographic form. The first group consists of two mountains which appear to owe their height in large part to the accumulation of lava around a volcanic center. They are, in other words, old volcanoes whose activity resulted in the building up of the lava plateaus. In these mountains little or no uplift has taken place and the original topographic form has been only slightly modified by erosion. The eleven mountains of the second group are long, narrow ranges which

a Bryan, Kirk, Geology and physiography of the Papago country, Ariz. (abstract) : Washington Acad. Scl. Jour., vol. 10, pp. 52-53, 1920. Different figures are given because a smaller area was included in the "Papago country." 
trend in a northwesterly direction. The lava beds have a general dip at right angles to the trend of the mountains. These mountains appear to be rather simple fault blocks or horst mountains. Certain of these mountains can be definitely shown to owe their elevation to faulting, and the others are assumed to be due to the same cause. It is probable that more detailed study would show that uplift by faulting produced all the mountains listed in this group. The third group consists of twelve mountains which have no general extension in one direction and are composed of disconnected plateaus and asymmetric ridges. They are thought to owe their elevation to faulting, but because of the great number of faults and because of variations both in displacement and in the direction of the several fault lines, they are so complex that their structure can be made clear only by detailed work. These mountains have a general shapelessness which is in great contrast to the simple forms of the mountains of the second group. Certain of them, such as the Tumacacori and Sand Tank mountains, constitute the largest areas of elevated country in the region. In parts of these larger ranges the lavas have been removed and the core of older crystalline rocks revealed.

MOUNTAINS COMPOSED LARGELY OF GRANITE AND SCHIST, WITH PATCHES OF VOLCANIC ROCKS

Twenty-two mountain ranges are composed largely of rocks belonging to the crystalline complex but have larger or smaller patches of volcanic rocks. The rocks of the crystalline complex are older than the Tertiary volcanic series, from which they are separated by a more or less uneven plane of erosion. In other words, the crystalline complex formed the surface upon which the volcanic rocks were laid down or through which they were intruded. The dominant rocks of the crystalline complex are granite, gneiss, and schist. Though a number of other rocks are found in the crystalline complex and there are areas of Paleozoic and Mesozoic sediments, the topographic expression is fairly uniform and the mountains are of the sierra type. In areal extent granite and gneiss predominate, and these rocks, whatever their age, produce similar topography throughout the region. These mountains are of two general types(1) ranges having a general extension in a northerly or northwesterly direction, rather narrow in comparison to their length, and having side slopes which, though exceedingly steep, are nearly equal on both sides; (2) small, more or less detached steep-sided hills arranged in groups with intervening alluvial or rock-floored plains. In the following classification this distinction in size is disregarded.

These mountains all have large or small masses of lava which by their position and inclination indicate that since their deposition they have been uplifted and dislocated. In other words, these mountains, 
though composed mostly of crystalline rocks, were once covered by larger or smaller masses of Tertiary lava. Since the lava was poured out the mountains have been uplifted and the lavas tilted at various angles. In the time that has elapsed since these uplifts the mountains have been so eroded as to conceal, to a greater or less extent, their similarity in origin and structure to the fault mountains of the first class.

\section{MOUNTAINS WITH NO KNOWN PATCHES OF VOLCANIC ROCKS}

Seventeen mountain ranges appear to be composed wholly of crystalline rocks. These mountains are typical desert ranges, whose characteristics have been frequently described and whose distribution along the common routes of travel has led to the belief that all the ranges of the Papago country are similar in character. In some of these mountains there are no areas of Tertiary lava. Other ranges, however, have been so little explored that it is possible and even probable that small patches of lava will eventually be discovered in them. Two ranges, including one classed in this group, have certain physiographic characteristics which show that they were rather recently uplifted. These are the Sierra Estrella and that part of the Gila Range south of Tinajas AltasiPass, sometimes called Sierra de las 'Tinajas Altas. Each of these ranges has an exceedinglyisteep front on' the east. This front is sinuous and cut by canyons, but eachicanyon has a lower portion separated from an upper portion by a falls. Above the falls there is an upland valley at a considerably lesser grade. The eastward-flowing streams then do not have a smooth, continuous grade, but one which is steep at the divide and becomes more gentle, then very steep, and gradually gentle again. (See p. 131 and fig. 27.) As the rock structure is essentially the same along the course of each stream, it seems to be an inevitable conclusion that the upper gradient was developed while these mountains were at a lower level, and that the lower gradient has been developed by the headward cutting of a new canyon by the stream since the reelevation. The time of this reelevation is uncertain, but it is thought to be Pleistocene and more recent than the uplifts that dislocated the Tertiary volcanic rocks.

The mountains of this type, which present little or no evidence of their origin and consist simply of ridges and detached hills of crystalline rock eroded into the sierra type of mountain, equal sided and more or less surrounded by the alluvium arising from their own dissection, are by no means typical examples of old-age desert erosion. The platform upon which the Tertiary volcanic rocks were laid down was not smooth but included relatively high hills and ridges, some of which rose 1,000 to 1,500 feet above the adjacent lowlands. These elevations are commonly composed of the harder 
rocks and appear to be genuine monadnocks, though the adjacent plains were not ordinary peneplains but confluent pediments. These plains, however, formed an erosion surface typical of a desert region, and the hills and ridges were desert mountains in the old stage of erosion. Upon the reelevation of the region that followed the great volcanism in Tertiary time, many of these desert ranges were resurrected and subjected to renewed erosion by the rejuvenated streams. Such lavas as may have capped parts of the mountains were first removed, and then erosion attacked the original mountains. The reelevation was in places so small or the topographic position of the mountains was such that erosion began approximately in the same place and with approximately the same base-level as in the previous cycle. The result was that an already old mountain was again eroded and retained rather than acquired the slopes characteristic of old age in desert erosion.

\section{SUMMARY OF CLASSIFICATION}

The classification of the mountains as above set forth is summarized in the following table:

\section{Classification of mountain ranges in the Papago country}

[Mountains east of Santa Cruz River but included in the area shown on the geologic map (PI. XII) are marked with an asterisk $\left(^{*}\right)$ to distinguish them from those belonging to the Papago country proper]

Class I. Mountains composed in large part of alternating beds of acidic and intermediate lava, tuff, volcanic conglomerate and agglomerate, and stream-laid conglomerate

\begin{tabular}{|c|c|c|}
\hline & Page & Plate \\
\hline $\begin{array}{l}\text { Group A. Mountains having a general conical form, smooth slopes, and quaquaversal } \\
\text { dips, apparently owing their altitude in large part at least, to accumulation: } \\
\text { Batamote Mountains } \\
\text { Mountain south of Kakg }\end{array}$ & \multirow{2}{*}{$\begin{array}{l}212 \\
229\end{array}$} & \multirow{2}{*}{ IIII } \\
\hline $\begin{array}{l}\text { Group B. Mountains having a general extension in one direction (northwest) and with } \\
\text { prevgiling dip in one direction or horizontal; fault-block and horst mountains: }\end{array}$ & & \\
\hline Ajo Mountains & \multirow{5}{*}{$\begin{array}{l}215 \\
207 \\
232 \\
210 \\
195 \\
235\end{array}$} & \multirow{9}{*}{$\begin{array}{l}\text { III } \\
\text { III } \\
\text { III } \\
\text { III } \\
\text { III } \\
\text { III } \\
\text { IV } \\
\text { IV } \\
\text { III } \\
\text { III } \\
\text { IV }\end{array}$} \\
\hline $\begin{array}{l}\text { Crater Mountains } \\
\text { Cubo Hills }\end{array}$ & & \\
\hline Dripping Spring Mountains-.. & & \\
\hline Growler Mountains. & & \\
\hline $\begin{array}{l}\text { La Lesna Mountains } \\
\text { Picacho Peaks }\end{array}$ & & \\
\hline Mesquite Mountains & \multirow{5}{*}{$\begin{array}{r}233 \\
228 \\
234 \\
60\end{array}$} & \\
\hline Mountains west of Perigua... & & \\
\hline Nariz Mountains............. & & \\
\hline Tempe Butte & & \\
\hline $\begin{array}{l}\text { Group C. Mountains having no general extension in one direction, composed of various } \\
\text { more or less disconnected plateaus and asymmetric ridges; complex faulted mountains } \\
\text { and disseoted plateaus: }\end{array}$ & & \\
\hline Artesa Mountains & \multirow{4}{*}{$\begin{array}{l}246 \\
207 \\
245 \\
244\end{array}$} & \multirow{11}{*}{$\begin{array}{l}\text { IV } \\
\text { IU } \\
\text { IV } \\
\text { IV } \\
\text { II } \\
\text { II } \\
\text { III } \\
\text { III } \\
\text { III } \\
\text { IV } \\
\text { IV }\end{array}$} \\
\hline Childs Mountains & & \\
\hline Cobabi Mountains & & \\
\hline Dobbs Butte and associated hills & & \\
\hline Hills southwest of Copeka Mountains & & \\
\hline $\begin{array}{l}\text { Mountains east of Perigua } \\
\text { Painted Rock }\end{array}$ & \multirow{6}{*}{$\begin{array}{l}229 \\
207 \\
213 \\
224 \\
211 \\
253 \\
251\end{array}$} & \\
\hline Pozo Redondo Mountains............. & & \\
\hline Sand Tank Mountains... & & \\
\hline Squceda Mountains and associated mountains & & \\
\hline Tucson Mountains a & & \\
\hline & & \\
\hline
\end{tabular}

- If the outlying hills are excluded, the main mass belongs in group $B$. 


\section{Classification of mountain ranges in the Papago country-Continued}

\section{Class II. Mountain: composed largely of pre-Tertiary rocks but with some masses of rocks of} Tertiary age

[Characteristic rocks: (1) Granite, gneiss, quartaite, schist, and phyllite, largely of pre-Cambrian age; (2) limestone and quartzite, of Paleozoic, usually Carboniferous age: (3) white and pink granite and monzonite, very coarse grained and pegmatitic, probably of Mesozoic age; (4) acidic intrusive and extrusive rocks, in places metamorphosed, probably of Mesosolc age; (5) acldic and intermediate intrusives of Tertiary age not easily distinguished from the rocks of subdivision 4.]

\begin{tabular}{|c|c|c|}
\hline & Page & Plate \\
\hline Aguila Mountains (Sierra de Aguila) .... & 193 & \\
\hline $\begin{array}{l}\text { Baker Peaks } \\
\text { Buckeye Hills }\end{array}$ & 197 & III \\
\hline Cabeza Prieta Mountains... & 190 & II \\
\hline Comobabi Mountains..... & 245 & IV \\
\hline Copeka Mountains & 235 & III \\
\hline Gunsight Hills....-.......... & 214 & III \\
\hline $\begin{array}{l}\text { Little Ajo Mountains } \\
\text { Maricopa Mountains }\end{array}$ & $\begin{array}{l}208 \\
220\end{array}$ & IIII \\
\hline Mountains near Papago Well & 198 & II \\
\hline $\begin{array}{l}\text { Quijotoa and associated mountains... } \\
\text { Quitobaquito Hills }\end{array}$ & 230 & III \\
\hline Table Top Mountains and associated mountains and hills & 222 & III \\
\hline Tinajas Altas Mountains & 189 & II \\
\hline Tule Mountains . . . .......... & 191 & II \\
\hline Vekol Mountains ........ & 228 & III \\
\hline Wellton Hills & 196 & III \\
\hline *Salt Rivar Mountains............... & & IIII \\
\hline * Santa Catalina group & 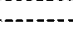 & III \\
\hline * Santa Rita group & & III \\
\hline *Tortolita Mountains & & \\
\hline
\end{tabular}

Class III. Meuntains composed wholly of the pre-Tertiary rocks mentioned under Class II, with no known association of the Tertiary lavas

\begin{tabular}{|c|c|}
\hline Agua Dulce Mountains. & 194 \\
\hline Aztec Hills & 197 \\
\hline Baboquivari Mountains and Coyote Mountaing & 247 \\
\hline Copper Mountains. & 199 \\
\hline 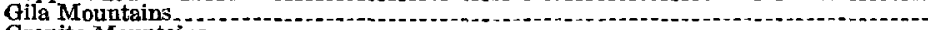 & 189 \\
\hline 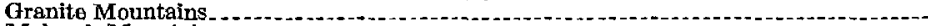 & 194 \\
\hline 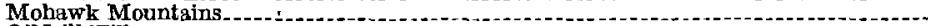 & 192 \\
\hline 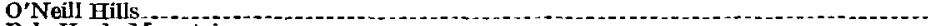 & 198 \\
\hline 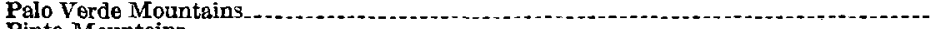 & 221 \\
\hline - & 192 \\
\hline n & 190 \\
\hline 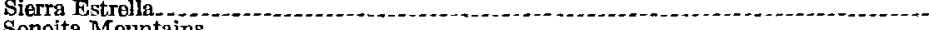 & 221 \\
\hline 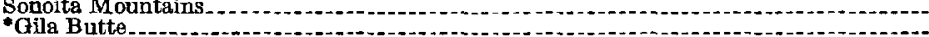 & 211 \\
\hline 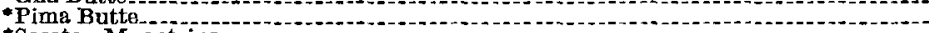 & \\
\hline Intains ${ }_{1}=y_{0}$ & \\
\hline Mountain & 243 \\
\hline
\end{tabular}

Mountain not well enough known to deseribe

Alvarez Mountains.

Cerro Colorado Mountains

(5)

Roskrum Mountains

Santa Rosa Mountains

Sawtooth Mountains.

Shoridan Mountains.

Sierra do Moreno.

Sierrita Mountains b.

Silver Ball Mountains.

Silver Roef Mo:1ntain.

Vaca Hills

Waterman Mountains

Waterman Mountains

\footnotetext{
- May belong in Class II.
} 
Classification of mountain ranges in the Papago country-Continued

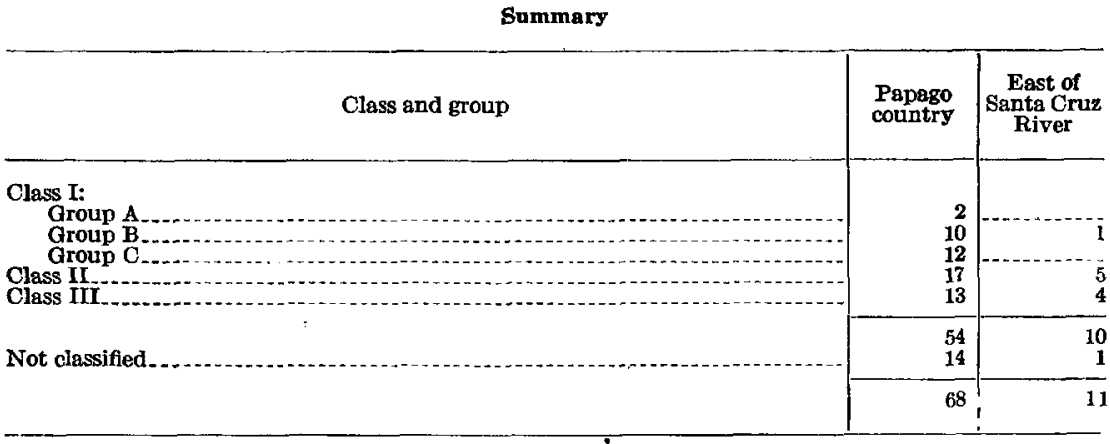

\section{PHYSTOGRAPHY}

\section{INELUENCE OF ARIDITY}

Erosion and sedimentation are the geologic processes now in action in the Papago country. The rate at which the processes operate, their manner of operation, and their products are controlled by the aridity of the region. The degree of aridity is extreme and is exceeded within the boundaries of the United States only in southeastern California. It is important that the discussion of processes that follows should be considered in respect to the climate of the region, for in other arid regions these processes differ in degree, method, and result.

In the Papago country the same high temperatures and insolation prevail over the whole area. With respect to mean annual precipitation, however, three divisions may be recognized. West of the Growler Mountains the annual precipitation ranges from $31 / 2$ to 5 inches; between the Growler and Baboquivari mountains it ranges from 5 to 10 inches; east of the Baboquivari Mountains it is more than 10 inches, although not much more except in the Tumacacori Mountains. Though precipitation increases with altitude, the smaller mountains, averaging 2 to 4 miles in width and 1,000 to 1,500 feet in height, appear to have little effect on storms, and their vegetation does not indicate any large increase in effective rainfall over that of the adjacent plains. This is particularly true in the area west of the Growler Mountains. The mountainous district including the Sand Tank and Sauceda mountains probably receives a somewhat greater precipitation than the adjacent plains, as indicated by gramma grass and a slightly more luxuriant vegetation at the higher altitudes. In the same way greater precipitation on the Baboquivari Mountains is shown by scattered live oaks and other small trees not characteristic of the plain. Increase of rainfall due to increase of altitude is best shown in the Tumacacori Mountains, 
where there are orchard-like forests of live oak and a thick cover of perennial grasses. Even here the ease with which soil is formed on tuffaceous rocks and the consequent slow run-off may have as great an influence in producing the relatively heavy vegetative cover as increased precipitation.

\section{MOUNTAIN SLOPES}

\section{DETERMINING CONDITIONS}

The mountains of the Papago country rise from the surrounding plain with startling abruptness. Even to the traveler familiar with the scenery of the western United States, the mountain slopes rising without transition from the surrounding plain seem incredibly steep. $^{82}$ Only in the distant view is it possible to realize that the surrounding plain rises gradually on all sides toward the mountains, which stand up like jagged ornaments on the ridge of a gable roof of low pitch. This appearance is due to contrast in angle of slope between the mountains and the plain. The angles of the mountain slopes range from $15^{\circ}$. to aimost $90^{\circ}$ from the horizontal; those of the plain from $1^{\circ}$. to $6^{\circ}$. Between these two sets of slopes there is usually no region of transition, either of intermediate slopes or of low foothills. In many ranges slopes that average $25^{\circ}$. to $30^{\circ}$ rise directly from the plain to the crest of the mountains. The factors which produced the mountain slopes must then differ radically from those which produced the plain.

The angle of slope is relatively constant for any one type of rock, whether on the border of the mountains or in the side walls of canyons. Even small, isolated hills have slopes of the inclination characteristic of the rock that composes them. This relation between slope and rock evidently is due not to forms inherited from the uplift of the ranges but to the action of the prevailing erosive processes on various rock types. These conditions have been stated by Lawson ${ }^{88}$ as follows: "(1) The hard-rock slopes of desert ranges which shed large spalls are steep, while those which shed small fragments have a low angle; (2) ranges composed of hard rock, which are thus naturally steep, maintain their steepness as long as the rock slopes endure."

The mountain slopes, owing to the long quiescence of the region, are in few places oversteepened by uplift or by changes in the courses of streams. They are the work of long-continued erosion, and the angle of slope is controlled by the resistance of rock to weathering in a region of warm and arid climate, with only 3 to 10 inches of

82 Hornaday, W. T., op. cit., pp. 38-39 (a humorous statement of this impression).

s Lawson, A. C., The epigene profiles of the desert: California Univ. Dept. Geology Bull., จol. 9, p. 29, 1915. 
I ainfall annually. In this region resistance to weathering is largely controlled by the physical properties of the rocks, as chemical action is of small importance because of the prevailing aridity. The spacing of joint cracks largely determines the size of the blocks or spalls that may be detached from the rock face, and in many types of rocks there is a significant relation between the size of block detached and the angle of the mountain slope, as noted hereafter. Resistance of rock to breaking up into small particles by direct weathering is of almost equal importance, and, together with the size, number, and durability of the large blocks, usually determines the angle of slope for any particular type of rock.

In the weathering that produces both large blocks and fine débris mechanical and chemical processes are involved, but alternate expansion and contraction due to changes in temperature are the most effective causes of rock disruption. The outer shell of rock, heated and expanded by the sun, parts from the cooler interior; or, cooled

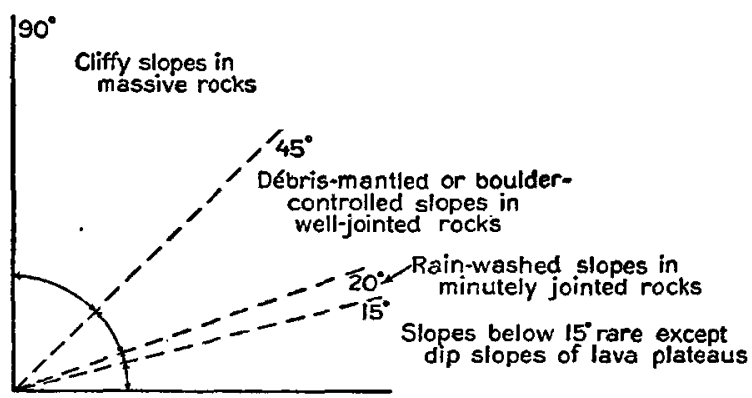

Frgure 5.-Diagram to show the range of mountain slopes

and contracted by the wintry desert night, it becomes too small for the warmer mass within. Each mineral grain, expanding and contracting under these same changes in temperature, parts from its neighbor. 'The disruption and disintegration of rock, complex in the interrelations of the several subprocesses and not wholly understood, is further complicated in its results by the differences in physical composition of the several kinds of rock.

The following analysis of the results of these complicated processes in the formation of mountain slopes and the sculpture of the desert ranges is a mere outline, in which only the outstanding features are treated.

\section{GRADES OF MOUNTAIN SLOPES}

Mountain slopes range in steepness from vertical cliffs to grades up which it is easy to ride a horse. Slopes can be divided into three groups-cliffy slopes, boulder-controlled slopes, and rain-washed slopes. The limiting angles and characteristic rocks of these groups are shown in Figure 5. Each group has certain common character- 
istics, although the dividing lines between them are arbitrary and can not be applied with strictness.

CLIFFY STOPES

Mountain slopes inclined between $45^{\circ}$ and $90^{\circ}$ from the horizontal are developed on granite, granite gneiss, massive lava beds, intrusive fine-grained porphyritic rocks, and arkosic conglomerate. These cliffy slopes are stable under the existing conditions of erosion, and the mountains composed of suitable rocks grow smaller in size but maintain the same angle of slope until they are totally reduced. The rocks are massive, with widely spaced joints, and the steepness of slopes seems to be related to the sparse jointing, for near by may be found the same rocks with more closely spaced joints undergoing erosion on gentler slopes. In sparsely jointed rocks joint blocks are not easily dislodged, and the mountain slope recedes either by undermining at the base or simply by surface disintegration and weathering of the rock wall. When at long intervals blocks are dislodged they have been so weakened by weathering that in falling to the base they break into fine rubble. Thus no talus forms at the foot of these slopes. Slopes of this type on arkose are shown in Plate $\mathrm{X}, A$, on massive lava flows in Plate $\mathrm{X}, B$, and on granite in Plate XVII, $B$.

BOUTDER-CONTROTIED SLOPES

Mountain slopes inclined between $20^{\circ}$ and $45^{\circ}$ from the horizontal are characteristic of most granites, granite gneisses, and horizontally bedded lava flows. The usual angle and the one which becomes fixed in the mind's eye as characteristic of granite mountains and dissected plateaus of bedded lavas lies between $30^{\circ}$ and $35^{\circ}$. The steeper slopes are usually interrupted by cliffs, and the gentler ones are interrupted by slopes of the next class, as shown in Plate XI, $A$.

Mountain slopes of this type composed of bedded lava flows consist of a cliff with talus below, successive cliffs with intervening talus, successive cliffs with smooth intervening slopes developed on tuff, continuous talus, or talus gullied and dissected. Very thick and massive lava flows resist the dislodgment of joint blocks and form cliffs. Whether these cliffs lie at the top or midway of the slope, they simply retard the recession of the mountain slope and increase its average steepness. The processes on the intervening talus slopes are similar to those described below.

Smooth slopes on tuff recede more rapidly than the cliffs above them, and the undermined blocks roll down over them. Only where such slopes are short stretches intervening between two steeper slopes are they free of rock waste. Where they are bare the processes of erosion on the tuff are those described for rain-washed slopes (p. 86). 
Bedded lavas under the attack of weather usually break into joint fragments from 2 to 6 feet in diameter, which, although easily dislodged, are comparatively resistant to disintegration and hence form a talus of rock waste that gradually mantles the whole mountain slope. 'The grade of the slope then becomes the angle of repose of the average-sized joint fragment (Pl. XI, $B$ ). Further erosion takes place by removal of the rock waste and formation of a new talus.

On certain mountain slopes part of the talus is removed by the formation of gullies, as shown in Plate XII, $B$. The mountain here illustrated consists of a cap of lava on a base of granite, and because

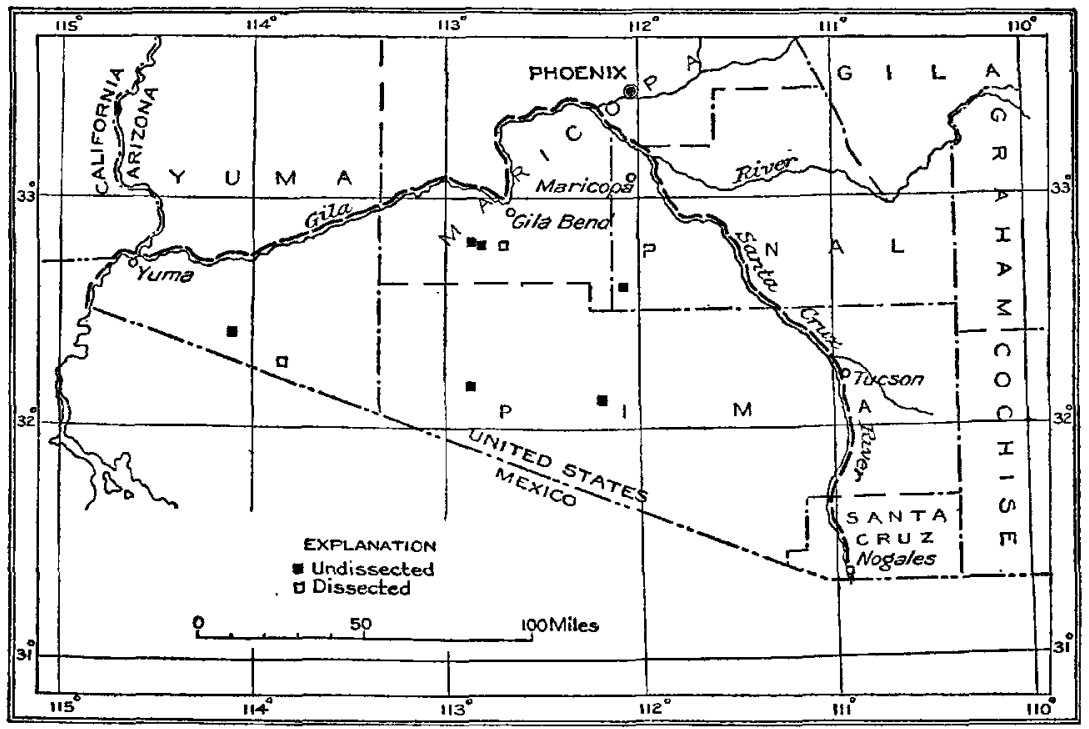

Figure 6.-Sketch map of the Papago country, Arizona, showing distribution, so far as observed, of gullied and ungullied mountains of approximately the same size

of the difference in color the gullied talus is easy to photograph. Other mountains similar in size and composed wholly of lava have like gullies with like triangular areas of unremoved rock waste. Figure 6 shows the distribution of gullied and ungullied mountains of flat-lying lavas of approximately the same size and height observed in the Papago country. Many others of both kinds exist, and only those observed are included.

No local lowering of base-level is evident at the foot of these mountains, and the formation of the gullies can be ascribed only to the work of unusually heavy local rains. The available weather records show that such storms occur. (See p. 31.) On two occasions the mean annual rainfall at Yuma has been equaled or exceeded by the fall in 24 hours. Imagination fails in contemplating what would 
happen if such an event should occur in a humid region. In the western United States such rains are well known under the term "cloud-bursts," and though the amount of water that falls is no greater than in many heavy rains of humid regions, the effect in erosion and in the sudden floods of streams justifies the name. If, on these mountains, the blocks of the talus and the bedrock have disintegrated until an unstable condition has been produced, a single cloud-burst would be competent to produce the gullies. Weathering and the normal rains combine to dislodge new fragments, which will in time fill the gullies and restore the original unbroken mantle of rock waste.

Confirmation of this explanation is obtained from the talus slopes of the ungullied mountains (Pl. XII, $A$ ). The greater part of the rock waste has been in position for a long time. The boulders are cracked, exfoliated, and pitted by the solution and removal of the ferromagnesian minerals. The under surfaces of the boulders are coated with calcium carbonate derived from solution of the minerals. Bushes grow between the boulders. Of these the most significant in indicating the stability of the slopes is palo verde (Parkinsonia microphylla), whose age on the slopes of Tumamoc Hill was found to range from 10 to 400 years. ${ }^{84}$ In contrast to this ancient rock waste strings and lenses of fresh rock waste occur on all slopes. The blocks are sharp-angled and more closely packed than those of the older rock waste and occupy positions corresponding to the gullies previously described.

The retreat of a talus slope on horizontally bedded lavas takes place by the slow production of the fragments that compose the talus blocks, by their decay, and by the creep of the rock waste from top to bottom of the slope. This slow process is occasionally interrupted by the catastrophic removal of large amounts of rock waste by a great storm, exposing a fresh rock surface from which rock waste is again gradually produced and the talus is replaced.

Granite slopes at angles between $20^{\circ}$ and $45^{\circ}$ also have a mantle of rock waste, although it is by no means so nearly complete as the talus on lava slopes, particularly on the steeper slopes. When protected by a talus of lava blocks granite has relatively gentle slopes, as shown in Plate XIII, $A$. The ordinary talus on granite slopes commonly consists only of a layer of granite boulders, and in many places scattered boulders and patches of boulders between protuberant knobs of the bedrock seem to determine the angle of the slope. The granite boulders range from 10 feet down to 1 foot in diameter, and all sizes may be found on a single slope, but in a gen-

84 Shreve, F., Establishment and behavior of the palo verde: Plant World, vol. 14, p. 293, 1911. 


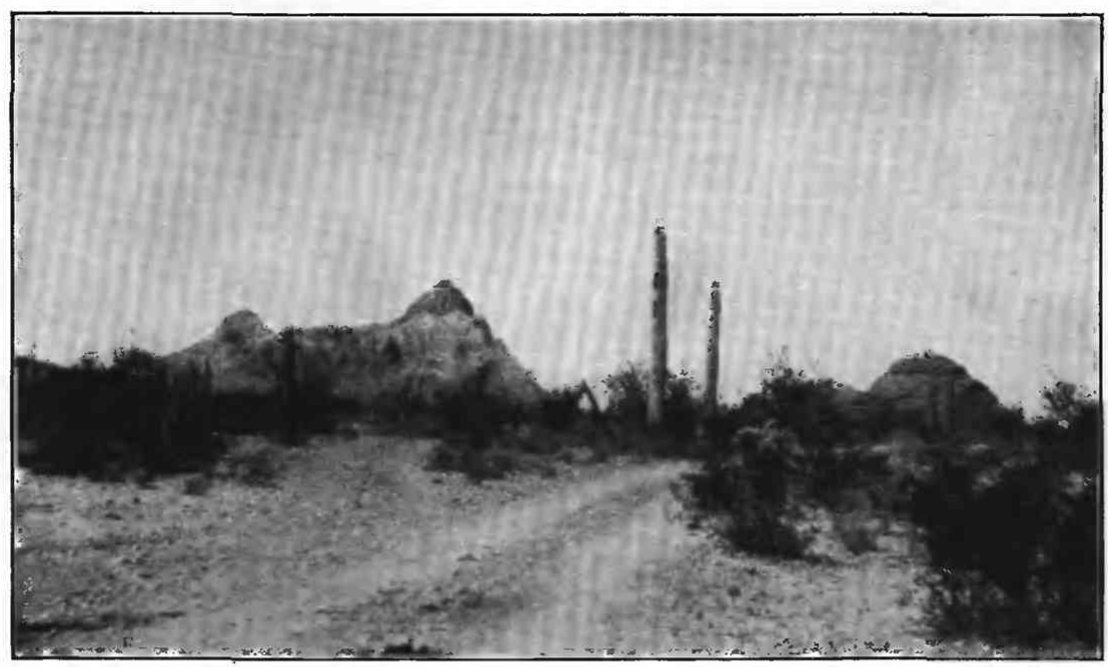

A. AJO PEAKS, FROM THE EAST

Cliffy slopes of Penasco Peak developed oa massive Tertiary conglomerates and dissected pediment in foreground. Exfoliation and niches on bosslike hill at the right

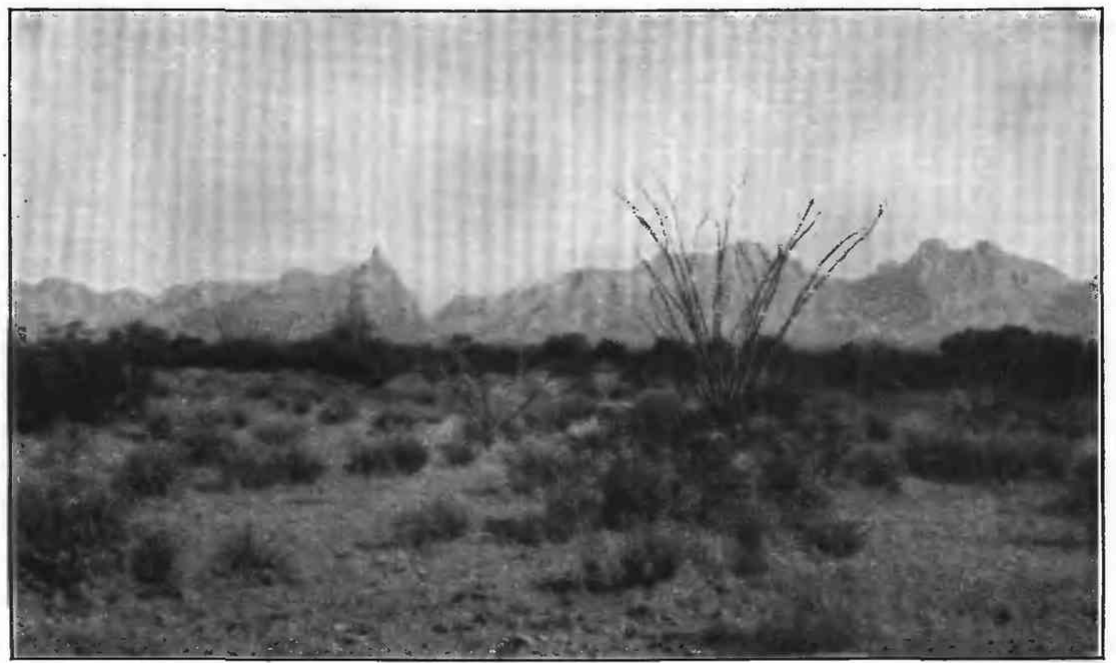

B. CLIFFY SLOPES OF MASSIVE LAVA FLOWS ON THE WEST SIDE OF THE AJO MOUNTAINS

Montezuma's Head in the left center 


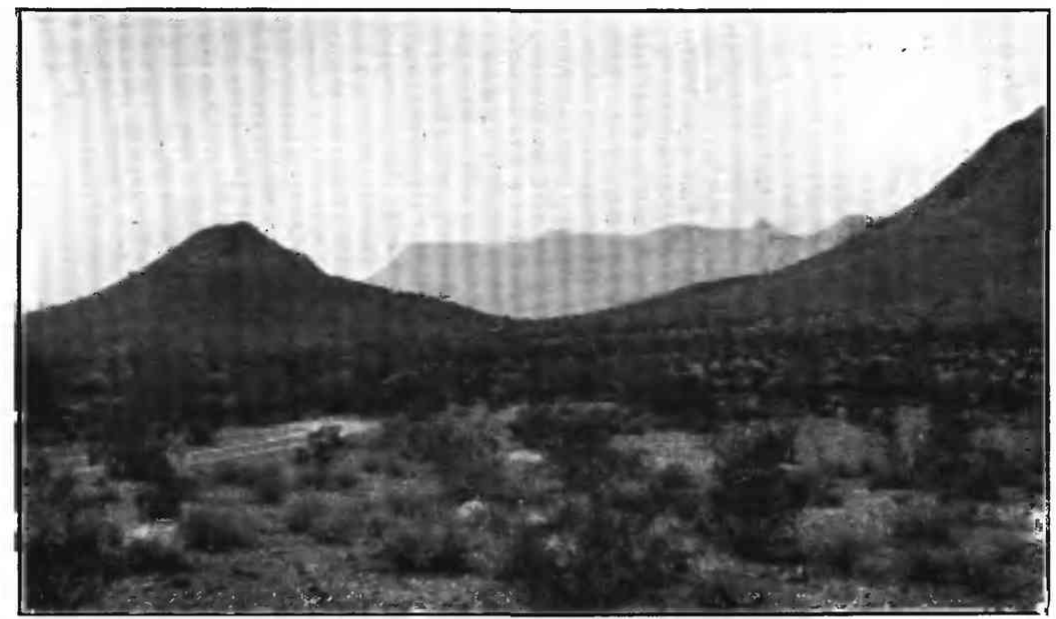

A. GROWLER MOUNTAINS, FROM BATES WELL

Looking north. Shows cliff and talus slope

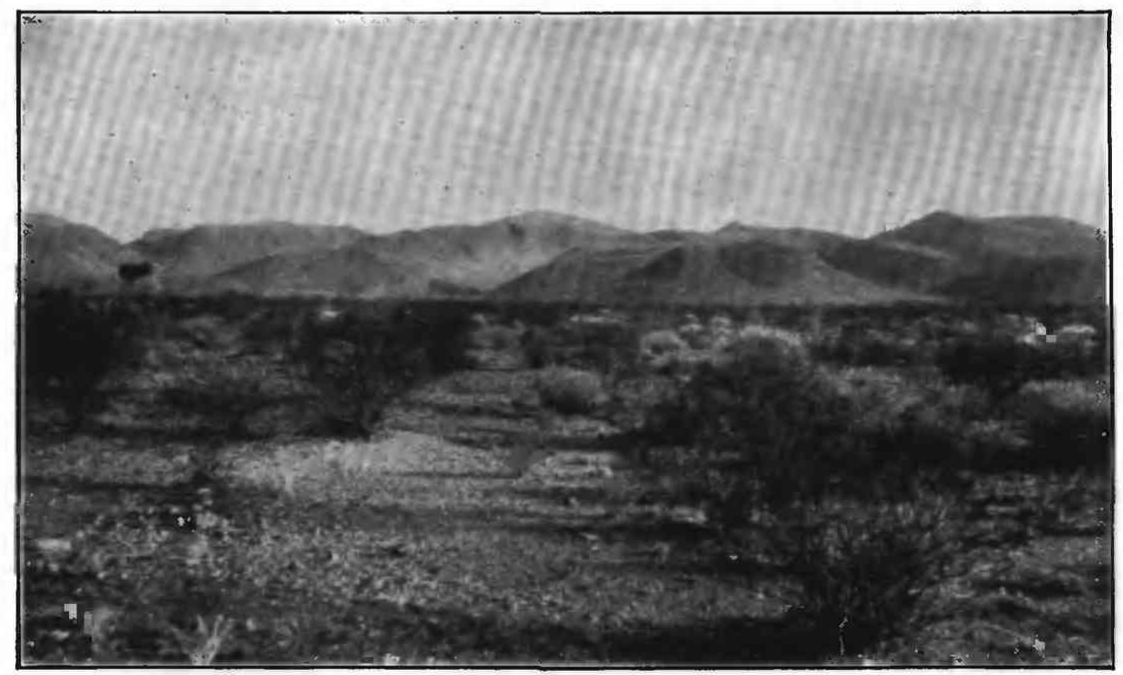

B. GROWLER MOUNTAINS SOUTH OF BATES WELL, FROM THE WEST

Unbroken, talus-controlled slopes developed on slightly tilted lavas 


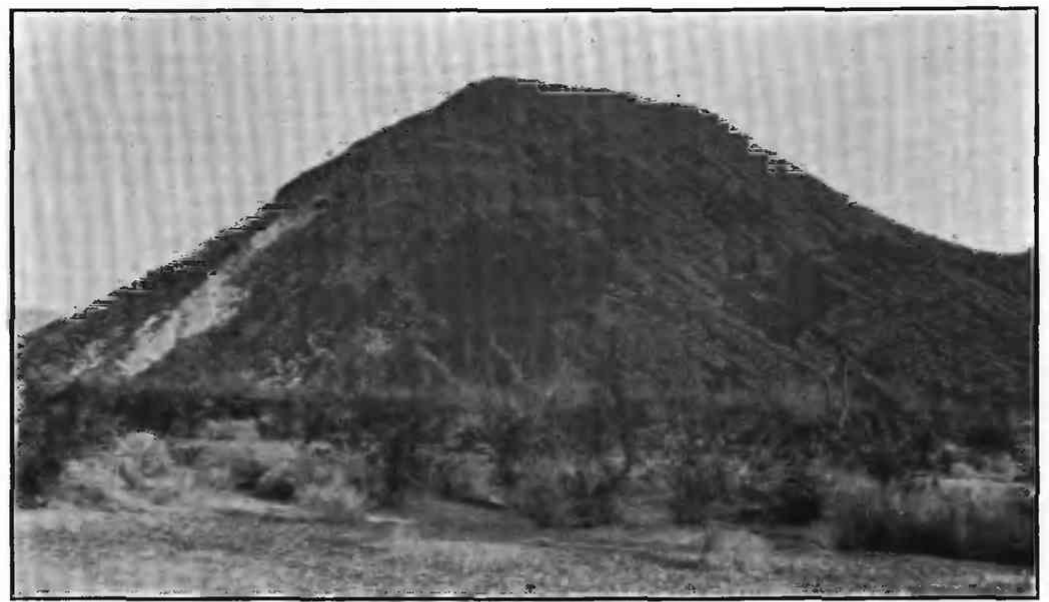

A. RAVEN BUTTE, FROM THE EAST

Shows talus of lava blocks of several ages. The clumps and lines of palo verde trees afford measure of age in contrast to the areas of black, fresh talus without vegetation. Talus removed on left by lateral cutting of stream

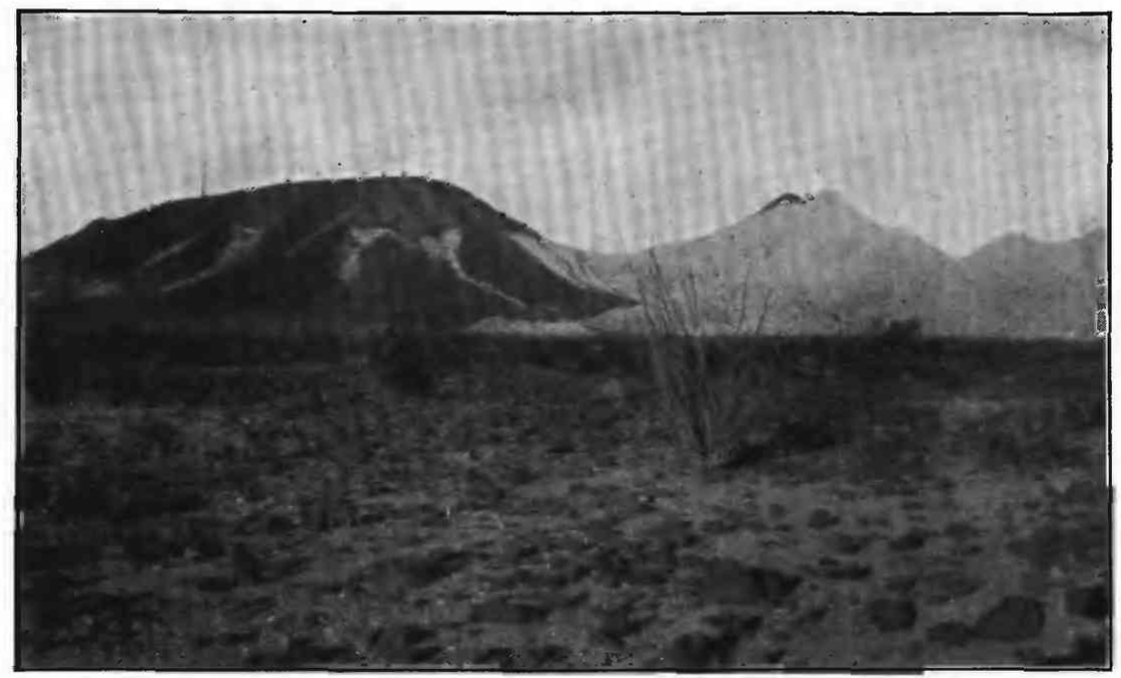

\section{B. LAVA-CAPPED MOUNTAIN IN THE CABEza PRIETA MOUNTAINS, FROM THE WEST}

Gullied lava talus and, to the right, mountain slope on granite with talus one boulder deep 


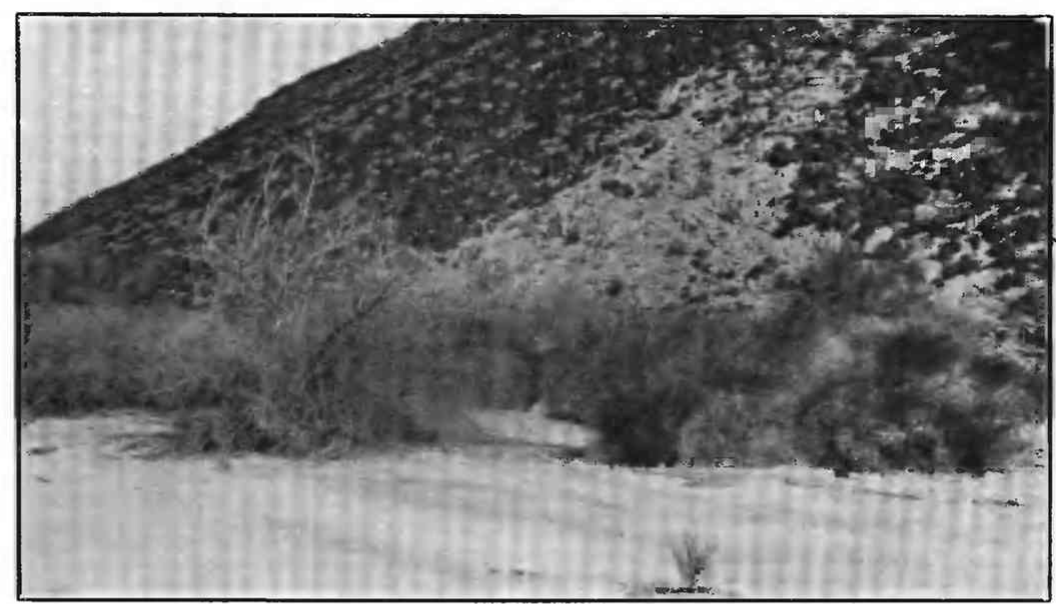

A. GRANITE SLOPE EXPOSED BY REMOVAL OF TALUS BY EPHEMERAL STREAM AT RAVEN BUTTE

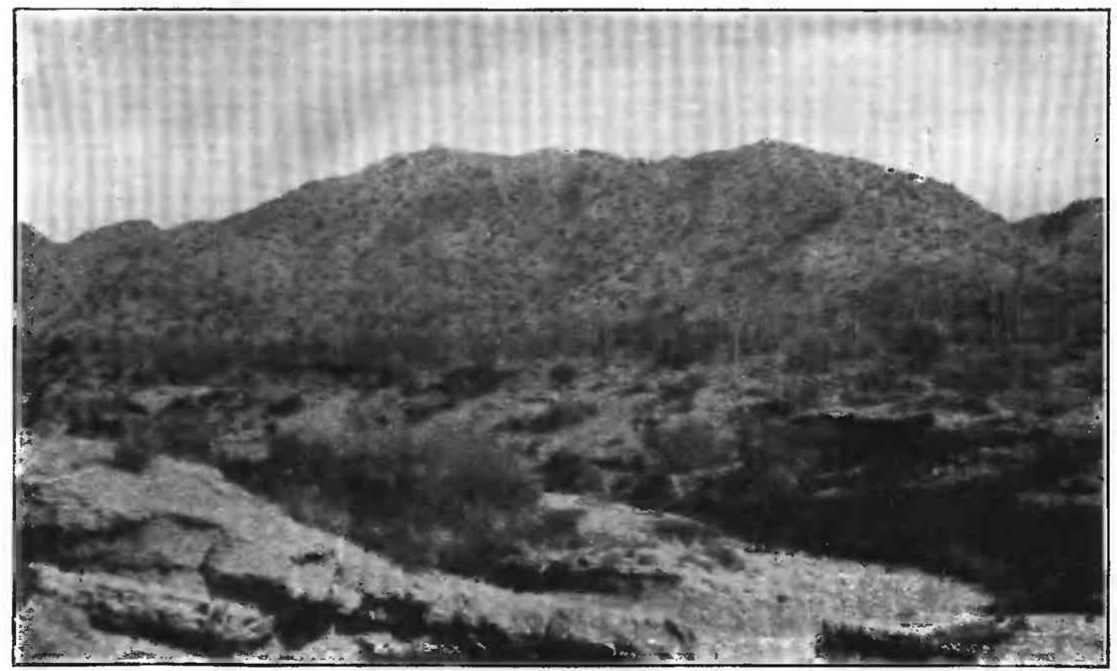

B. MOUNTAIN SLOPE AND DISSECTED PEDIMENT

View north across Sand Tanks, which are in the small canyon in the foreground 


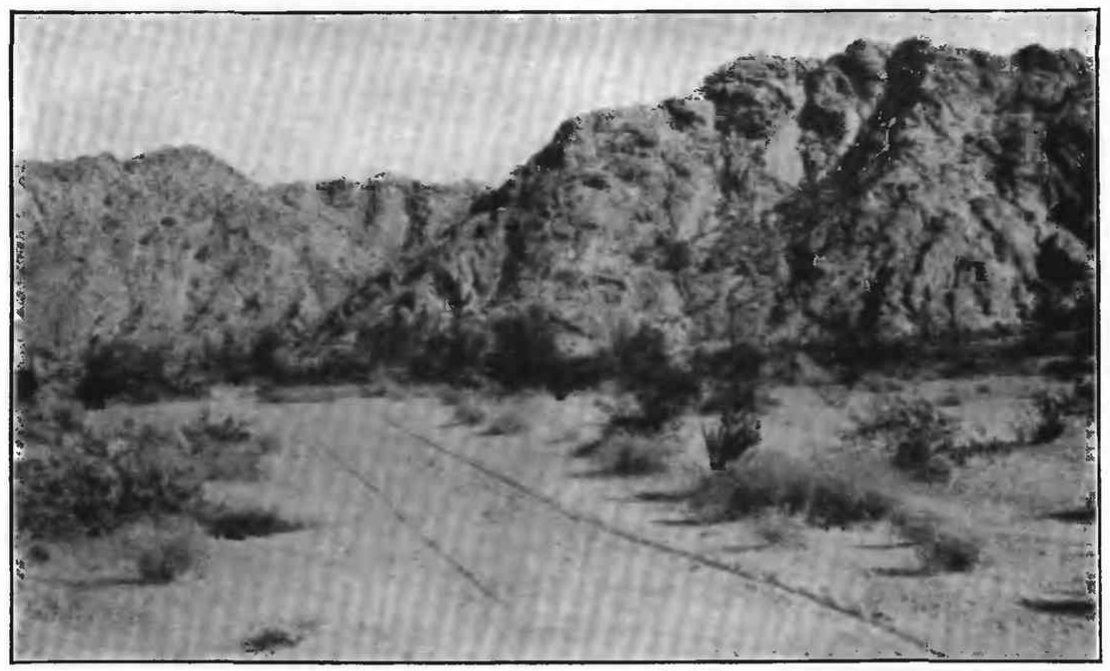

A. PASS WEST OF TULE TANK

Niches in a granite mountain slope of the cliffy type due to massive jointing

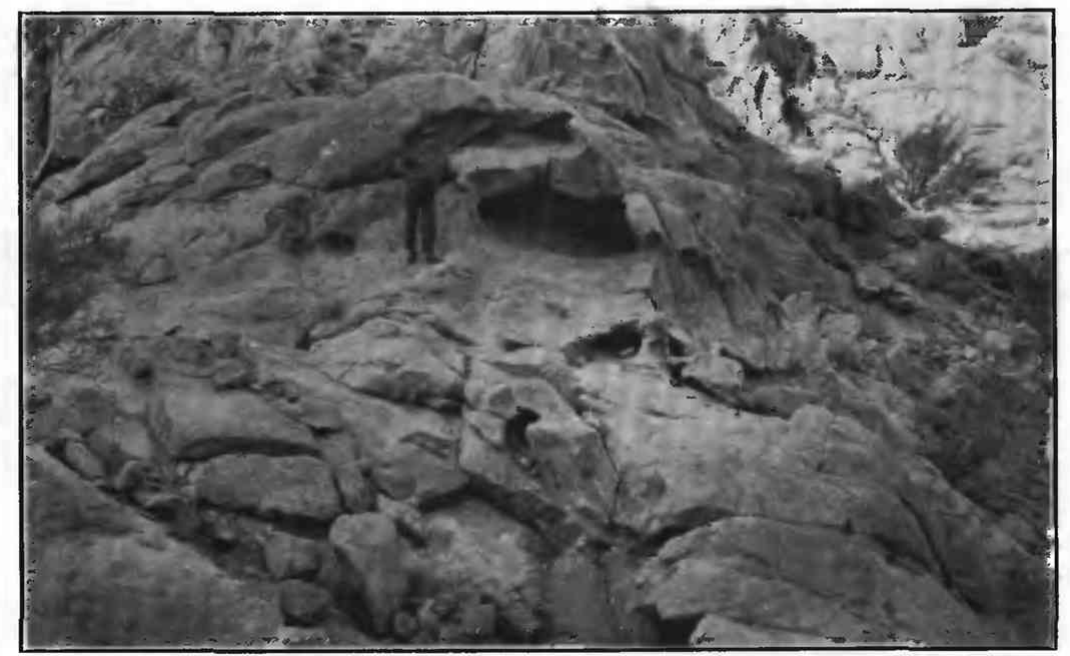

B. NICHES IN GRANITE AT TINAJAS ALTAS 


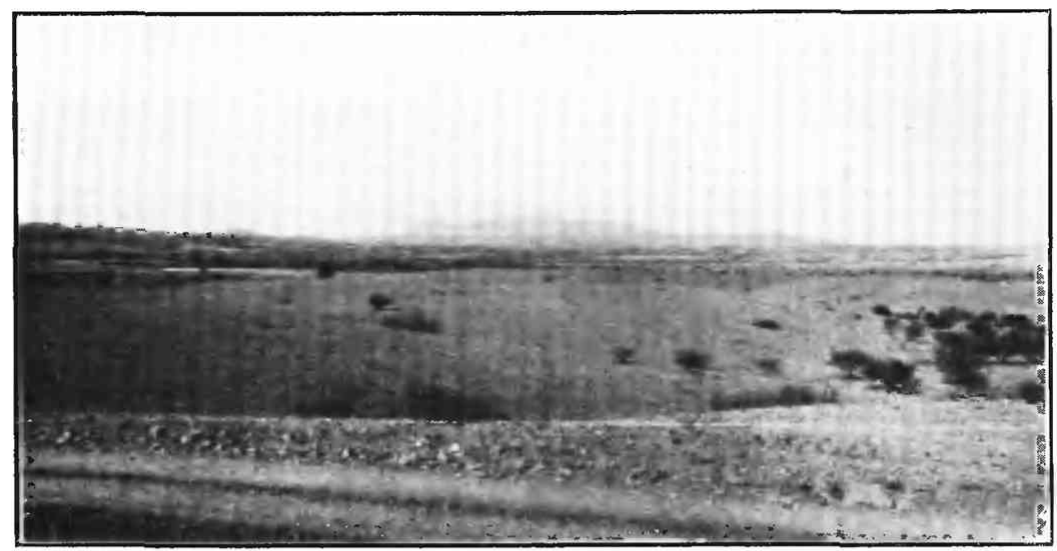

A. HEADWATER BASIN AND DISSECTED PEDIMENT IN THE TUMACACORI MOUNTAINS

Arivaca Creek in middle ground; Cerro Colorado Mountains in background

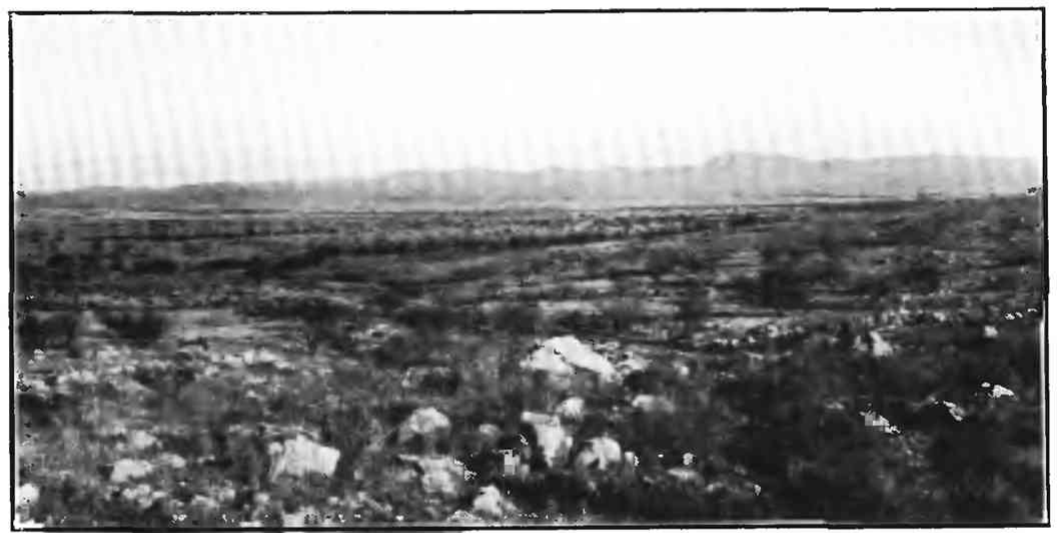

B. SASABE FLAT, AT SOUTH END OF ALTAR VALLEY

A slightly dissected pediment

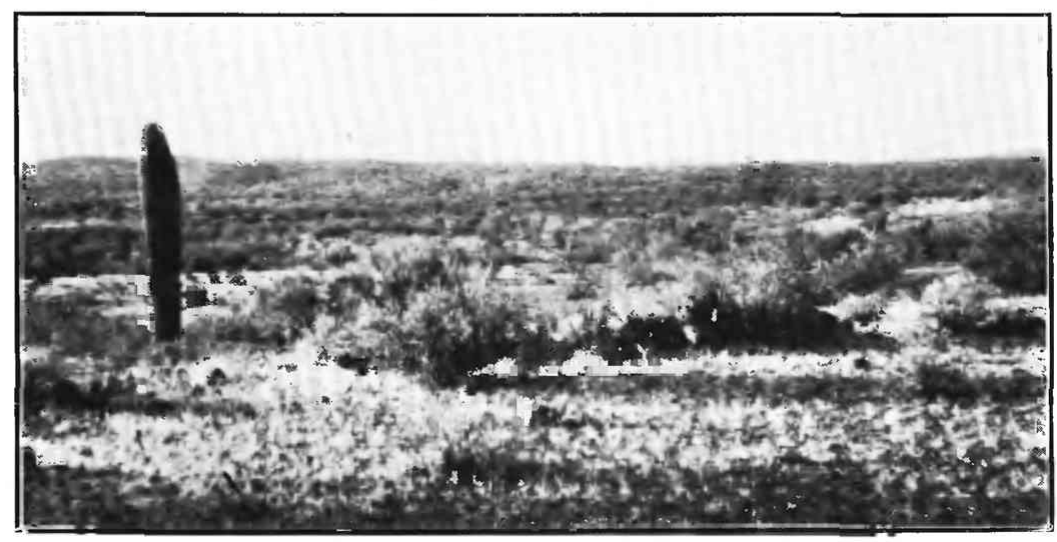

C. DISSECTED PEDIMENT BETWEEN SIERRA BLANCA AND BROWNELL MOUNTAINS 
eral way the size of the boulders is proportional to the grade of the slope. Large boulders mantle steep slopes, and small boulders gentle slopes. As the size of the boulder is determined primarily by the spacing of joints, fine-grained granite and most granite gneisses, which usually have closely spaced joints, yield smaller boulders and consequently produce gentler mountain slopes than coarsegrained granite and gneiss.

Many of the granite boulders have a brown or blackish color from the so-called "desert varnish," which is associated, in granite at least, with the deposition of limonite in the outer 1 or 2 inches of the rock. This outer crust is in many boulders a shell which covers a completely disintegrated interior so soft and crumbling that the minerals may be picked apart with the fingers. Many boulders also are cracked, and some are completely split, many of them in two or three directions. Still others are being reduced by exfoliation. Concentric shells of rock split off by expansion and contraction from the interior are in turn disrupted and cast off. On many mountain slopes the boulders are so weather beaten and ancient in appearance that it seems that they could not possibly have been produced by any process now in action, but that, laid on the slope in some ancient time, they have ever since been slowly rotting and disintegrating.

The bedrock on which the boulders lie is not only as thoroughly disintegrated as the interior of the boulders, but is covered with loose fragments of a similar kind. The fine débris forms a loose film over the surfaces between boulders. The fragments slip under the foot, and new pieces crumble from the bedrock continually. Disintegration of the bedrock proceeds most rapidly along joints, but is effective everywhere. Every rain sets in motion down the slope trains of this fine débris. As the slope steepens locally by the removal of the fine débris, the boulders roll down to find new lodgment lower on the slope or at its base. In this movement many boulders already disintegrated within the outer crust are shattered into fragments. Under the conditions normal to the region few boulders reach the bottom of the slope. At the base of a few slopes no boulders are found; in other places there are a few scattered blocks, usually of large size, but great heaps of boulders do not occur. The absence of such talus heaps is one of the causes of the abrupt change in grade between the mountain slope and the plain at its foot.

As the bedrock of the mountain slope disintegrates, and the rain washes away the fine fragments, protuberances of the bedrock are left that consist of the most compact rock between the most widely spaced joints. The protuberances are cut loose from the bedrock by the same processes that formed them, and a new crop of boulders comes into existence. 
By these slow but continuous processes the mountain front recedes, maintaining its angle of slope according to the spacing of joints and the granular structure of the granite. The same great storms that affect the slopes of lava mountains must, however, fall on granite slopes also. Although no direct evidence has been obtained, these storms must hasten the slow processes recounted above.

RAIN-WAEHED SLOPES

Mountain slopes at angles less than $20^{\circ}$ from the horizontal are rare in the Papago country. They are developed on the least resistant rock, which, probably occurring in relatively small amounts, has been largely removed by erosion. The mountains are composed almost wholly of the resistant rocks, which thus dominate the mountain slopes and keep them at a relatively high angle, the gentle slopes occurring on hills and as parts of mountains.

Closely jointed gneiss, schist, phyllite, and felsite form gentle slopes. The closely spaced cracks absorb and retain more rain than the widely" spaced -cracks developed in rock of other types. These rocks also are more affected by chemical action, because they contain relatively large amounts of ferromagnesian minerals or glass. The processes of mechanical action, because of the smaller size of the joint fragments and smaller grain of the component minerals, tend to produce finer rock débris. This finer débris is readily moved by rain wash on a flatter slope than that on which the coarser material derived from granitic rocks can be moved. The joint fragments, being smaller, are also more easily moved, and instead of falling are undermined and carried away by rain wash.

Tuff and shale also develop gentle slopes. The products of the weathering of these rocks are fine and rather easily produced, so that the angle of the slope is determined largely by the grade on which rain wash can transport débris. Certain tuffs, however, are so compact that they weather slowly and hence form steep slopes, the angle being determined wholly by the rapidity with which particles are detached from the matrix.

\section{CANYON CUTTING}

In the previous sections the recession of slopes has been considered. Slopes are formed where rocks are more or less homogeneous, but the larger irregularities in composition or in spacing of joints provide places where rain water is concentrated. When water flows in streams larger than the tiny rills referred to above as rain wash the rock is eroded by corrasion. Erosion by streams takes place at a rate faster than that of slope recession, and to this fact is due muchi of the diversity of mountain topography and all the larger features of mountain sculpture in the Papago country. 
Corrasion is wear by water running in a stream and the rock débris which it transports upon the stream bed, and it is assisted by corrosion, or solution of the rock, so far as this may be accomplished by the passing water. The stream therefore cuts downward in a narrow groove, and in homogeneous material the walls are essentially vertical. Slumping and the processes of slope formation previously described operate to widen the cut so that in time each stream flows in a rather broad valley. As there is a limiting grade below which a given quantity of water can not transport a given quantity of material, corrasion of the bed can proceed only until this grade is reached, and further lowering is prevented by the deposition of sediment. A stream which has reached this grade in any part is said to be graded.

The way in which canyon cutting produces the sierra type of mountain in homogeneous rock (not in rocks having distinctive structures) under the climatic conditions of the Papago country is shown in Figure 7, A to C. In block $A$ an original rectangular block of rock has been affected by erosion so that the face of the block has receded to the angle of $45^{\circ}$, assumed for the purpose of the diagram to be the slope normal for this type of rock. During the same time little notches have been cut at positions determined arbitrarily in the diagram but in nature by a combination of factors such as concentration of water on the plateau and position of easiest erosion. In block $\mathrm{B}$ the notches have developed into canyons whose side walls have the same slope of $45^{\circ}$, while the end and sides of the spur have receded but little because of the slow rate of slope recession. In block $\mathrm{C}$ slope recession has carried back the point of the spur or ridge between the canyons, and the side walls of the canyon have also been eroded by the same process. Corrasion has lengthened the canyon. At the mouth of the canyon and at the foot of the ridge a small pediment has been formed by the processes described on page 96 . By the recession of the canyon walls the crests of the ridges between canyons have been reduced below the level of the original block. The ridges, then, have a slope which is a function of the original length of the block, the length of the canyons, the spacing of the canyons, and the angle of the mountain slope. In block $\mathrm{C}$ the canyons from opposite sides of the block have met, and the heads now assume the grade of the mountain slope, though previously they had a steeper slope because of the more rapid rate of erosion by the headwater portion of the canyon stream.

The typical sierra, with its crenulated crest and projecting spurs, has been produced by the cutting of canyons and the recession of slopes. The simplicity of the diagram is not attained in nature, but the form is typical of many desert ranges. It will be noted that the three high points of the ridge rise to the original level of the plateau, 104211-25-8 


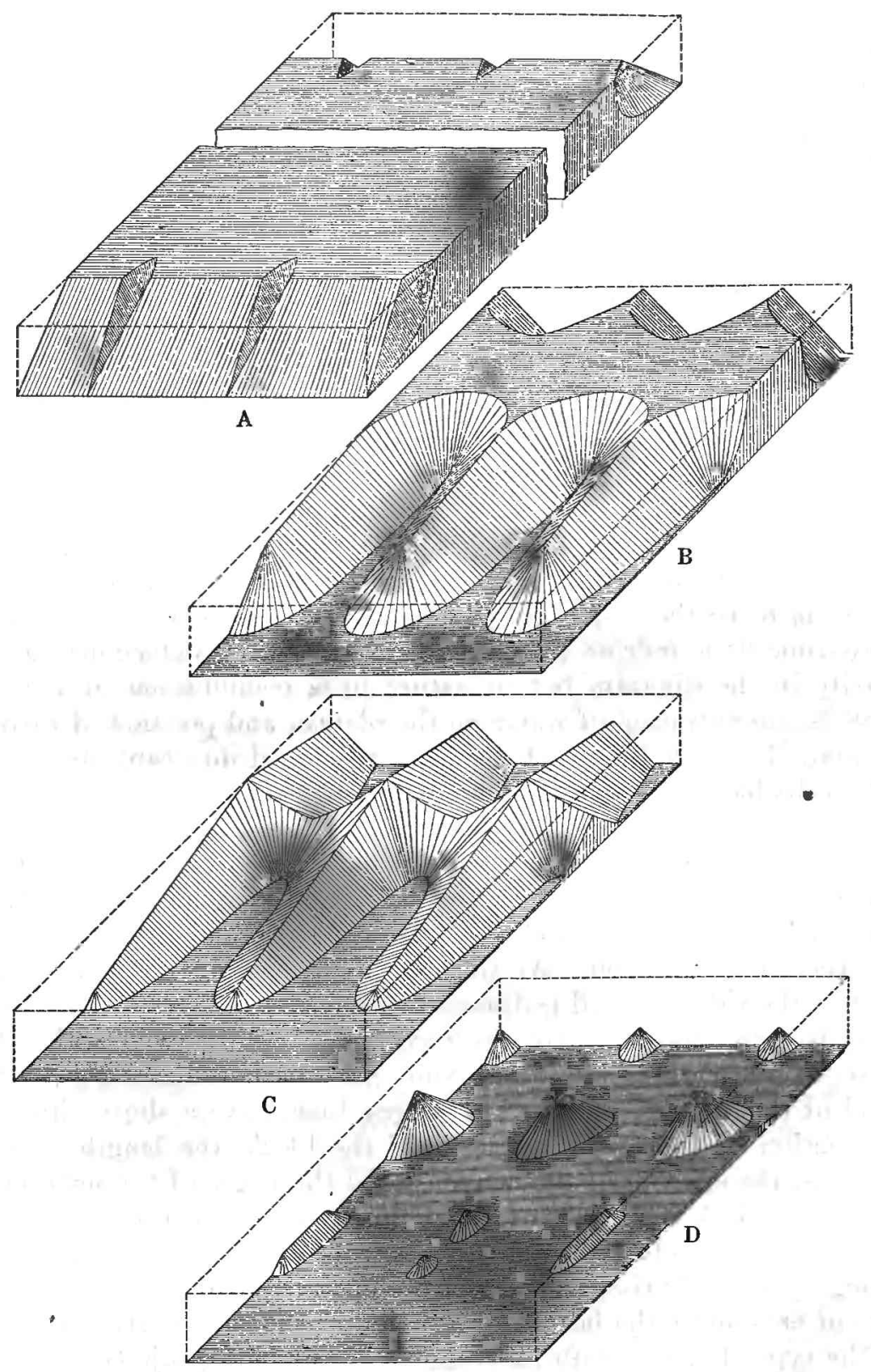

FIGURE 7.-Diagram showing three stages in the erosion of a block of the earth's crust to form the sierra type of mountain 
and that only when this form has been attained do the flat surfaces of the plateau disappear. This land form has then reached the stage of maturity in erosion, though the same form will be retained for some time after maturity. The reduction of a fault block to the sierra type of mountain will require somewhat less time than that of a corresponding mass of tabular shape. Therefore maturity in form of two ranges of mountains may not imply equal exposure to the action of erosion.

After the stage of maturity is reached stream erosion is of increasingly less importance in destroying mountains. Slope recession and the lateral cutting of the streams are the dominant processes. By the action of these processes the residual masses are reduced to isolated island-like hills, as in block D. Each of these hills retains the slopes characteristic of the rock and gradually decreases in size through slope recession assisted by the erosive action of streams in lateral migration over the plain. This is the old-age stage in erosion and is illustrated by many mountains of the region but particularly by the Sacaton Mountains (fig. 11). In the diagram, as in nature, the residual hills are strung out in lines between the original canyons. The divide between streams of the original two main drainages lies not on the hills but on a broad platform of triangular cross section, the mountain pediment described on pages 93-101. In block D, Figure 7, simple unbranched canyons are assumed, and consequently the larger residuals lie on the divide, but in nature the heterogeneity of even the most homogeneous rocks produces branched canyons whose erosive action leaves smaller residual masses on the divide, as described more particularly below.

\section{HEADWATER BASINS}

Although the erosive power of mountain streams is great when they are in flood, floods are so infrequent in the Papago country that widening of the valleys takes place slowly. The steep grades necessary to transport débris prevent the formation of meanders, and lateral cutting is at a minimum. The lower section of a mountain canyon, once the stream is brought to grade, is in consequence relatively stable in cross section, and the side walls recede by the slow processes of slope recession.

At the entrance of a tributary, however, there are two spurs, each bounded by one slope of the main canyon and one of the tributary. Here the recession of mountain slopes is doubly active, as on the spurs of block $\mathrm{C}$ of Figure 7 . Near the divide several tributaries usually unite to form the main stream, and the corrugated surface between them affords the optimum conditions for slope recession. Hence, at such junctions headwater basins are formed. 
If two or more streams develop such basins on either side of the divide, the divide may be reduced long before the rock mass lying between the lower portions of the streams is reduced. The production of headwater basins is accelerated, especially at the beginning of the process, by the more abundant rainfall that is characteristic of the higher parts of a range.

Development of these headwater basins is a common phenomenon in the Papago country, and part of one is shown in Plate XV, $A$. Many mountains consist of groups of isolated hills, more or less irregular in size and height, scattered on plains that rise to low divides which lie in the position of the original mountain crests and constitute merged headwater basins, or mountain pediments. Illustrations of these features are given under the heading "Mountain pediments" (p. 93).

\section{MINOR EROSIONAL FEATURES}

The minor phenomena of erosion throw light on the processes that produce the larger features and the more common land forms. Of these phenomena the small caves or niches characteristic of certain mountain slopes are especially interesting.

Niches in coarse granite are common in the Tule and Tinajas Altas mountains. As shown in Plate XIV, $A$, the niches are distributed from top to bottom of the mountain slope and range in size from holes 6 inches in diameter and 2 inches deep to caves 6 to 8 feet across at the mouth and 2 to 4 feet deep (PI. XIV, $B$ ). In the cove at Tinajas Altas the niches may be conveniently studied. The granite, which on fresh fracture is white with a pinkish cast, has a mottled brown surface, in places rounded and bosslike between the joints. The brown color is due to the deposition of limonite in a crust usually about 2 inches thick. The niches are without this crust and thus have evidently been formed at a later date. The typical form is shown in Figure 8. The roof and back walls have a rough surface, from which scales and fragments of rock can be easily detached. The floor is usually firm and smooth and always slopes abruptly and continuously from the rear of the niche to the outside. On it are loose scales that have dropped from the roof and back walls.

The niches appear to be the work of insolation and solution, which, beginning at a place in the surface but poorly protected by the ironstained crust, work inward, loosening successive flakes and chips. These fall and slip down the smooth floor, doubtless moving more easily when rain beats into the opening. Wind also may assist in removing the débris, but as the chips are ordinarily from a quarter to half an inch in diameter and an eighth of an inch thick, the wind is probably not an effective agent. The retreat of the back wall is not 
rapid. Some idea of the rate may be gained from the niche illustrated in Figure 8. The inscription, "Josefa Jacob[a] Martin Abril 16, 1874," is evidently that of a traveler with the date of her visit. It is painted on the rock with a paint made from the juices of a local bush and iron rust by a process well known to the Mexicans and Indians of the country. When visited, October 21, 1917-13 years after it had been written-the inscription was in almost perfect condition except for the last "a" in "Jacoba," which was lost by chipping of the back wall. In September, 1920, the "a " in "Josefa" had also disappeared and parts of other letters had been obliterated.

Niches very similar in appearance occur on the surfaces of the fantastic rocky hills carved from Tertiary arkosic conglomerate

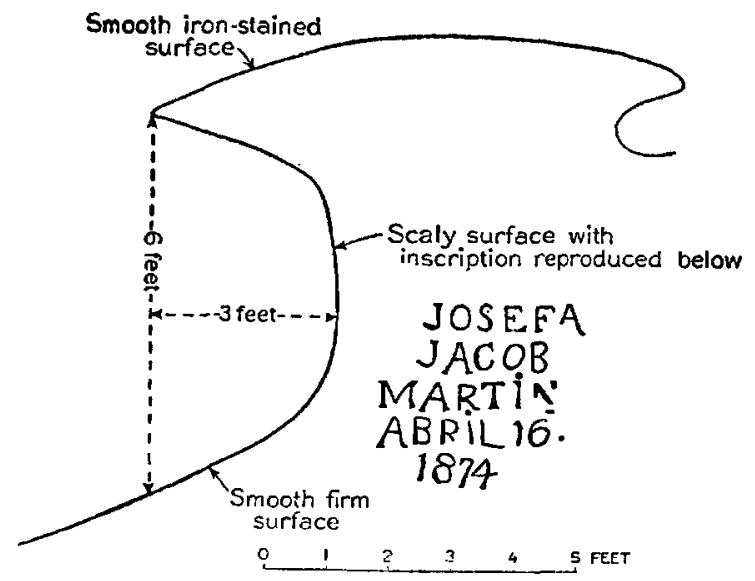

Figure 8.-Cross section of niche in granite at Tinajas Altas, Ariz.

$(\mathrm{Pl} . \mathrm{X}, A)$. These niches were studied in the Papago Saguaro National Monument, 7 miles east of Phoenix, where they are associated with rock shelters. The rock shelters are from 3 to 25 feet across and have an overhang of 3 to 10 feet; the niches are from 3 inches to 3 feet in diameter and from a few inches to 3 feet deep, the depths being more or less proportional to the size of the opening.

As shown in Figure 9, the shelters are due to erosion along the inclined bedding planes and joints. With the removal of certain joint blocks by exfoliation and disintegration, others are left standing with an overhang. Once the overhang is formed, erosion of the back wall begins through solution of the cement and even of the constituent boulders by rain water, which is absorbed by the overlying bare rock and thence seeps down and emerges in the shelter. These rock shelters are therefore formed in the same way as those in northern Arizona described by Gregory. ${ }^{85}$

${ }^{85}$ Gregory, H. E, Geology of the Navajo country : U. S. Geol. Survey Prof. Paper 93, pp. 133-134, 1917. 
'The niches occur at intervals in the rock surfaces, and some are so small that they appear to be due to the dislodgment of single boulders from the matrix, and others appear to be due to solution

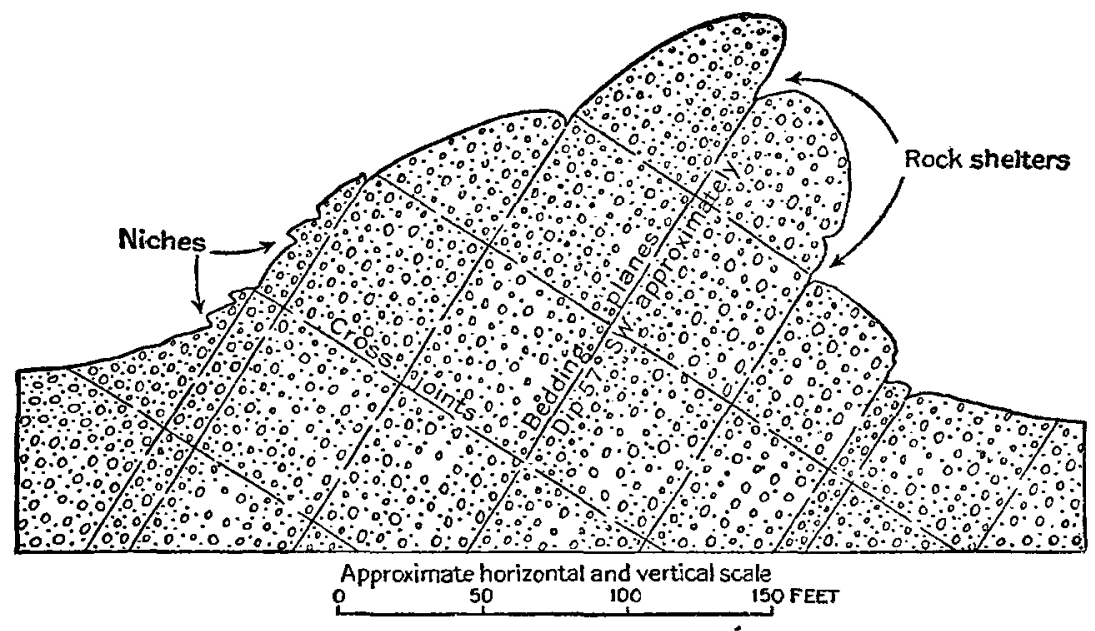

Figure 9.-Diagram illustrating weathering of Tertiary arkose conglomerate in the Papago Saguaro National Monument, Ariz.

along joint planes. Those of the predominant type are excavated in the rounded rock surfaces and may have no connection with joints. Their form is shown in Figure 10. The roof of many of them is covered with red clay or a film of lime carbonate. The lower half

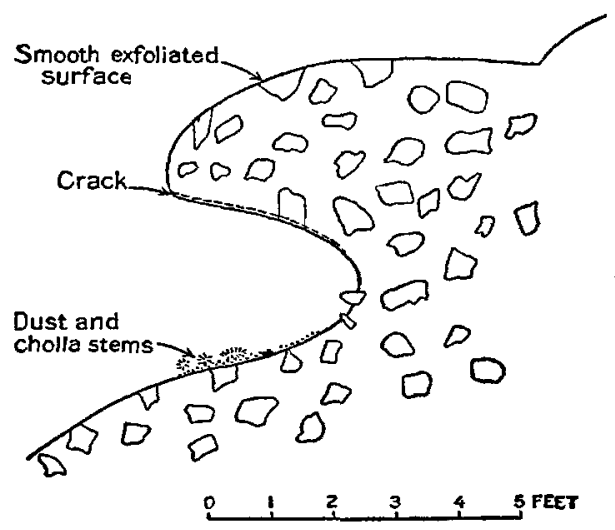

Figure 10.-Cross aection of a niche in coarse conglomerate, Papago Saguaro National Monument, Ariz.

inch to 1 inch of rock is separated from the main mass by a crack, and this flake can easily be detached. The back wall is usually rough, boulders of the conglomerate projecting into the niche. The floor slopes outward rather steeply and in many niches is covered with dust and fragments of rock. Joints of the cholla cactus (Opun- 
tia sp.) are usually scattered about the floor, for the niches are favorite haunts of the trade rat. The process of formation is clear. Beginning with a small cavity where a boulder has pulled loose from the matrix or where the cement has been dissolved at some particularly porous place, the niche is enlarged inward by the crumbling of the back wall and by the scaling of the roof, both due largely to seepage of rain water through the rock and consequent solution of the rock cement. The débris falls to the floor, along which it slides to the exit, transported principally by rain wash and water that trickles from the back wall.

Isolated pillars and monuments to which the Mexican gives the general name peñascos are commonly formed by the dissection of lava flows; less commonly they are formed in granite. In lava the formation. of pillars is controlled by vertical joints in thick nearly horizontal beds. Pillars capping small buttes and mesas or isolated by erosion from a cliff are the common forms and add much to the picturesqueness of the plateau type of mountains. One of the best known of these pillars is Montezuma's Head, in the Ajo Mountains, which on distant view resembles a square-shouldered bottle (Pl. $\mathrm{X}, B)$.

Pillars of granite usually consist of some massive portion of the rocks from which the surrounding more closely jointed rock has been removed. Once isolated and attacked mainly by changes in temperature, a pillar resists the weather for a long time. Such a pillar on the crest of the Maricopa Mountains can be seen from the base of the Sierra Estrella across the whole width of the Jornada de las Estrellas.

\section{MOUNTAIN PEDIMENTS}

\section{CHARACTER}

In general, the mountains of the Papago country rise from plains which are similar in form to the alluvial plains that commonly front mountains of an arid region, but large parts of the plains are without alluvial cover and are composed of solid rosk. These plains constitute a land form that is distinct and requires a name. "Mountain pediment" has been chosen as the name for such a plain of combined erosion and transportation at the foot of a desert mountain range. The plain ordinarily surrounds and slopes up to the foot of the mountains, so that at a distance the mountains seem to be merely ragged projections above a broad triangular mass-the pediment or gable of a low-pitched roof. This metaphor was first used by McGee ${ }^{86}$ but applied to only one of many plains of this type that he described. The same metaphor was also used by Weed ${ }^{87}$

so McGee, W J, Sheet-flood erosion : Geol. Soc. America Bull, vol. 8, pp. 92, 110, 1897.

s7 Weed, W. H., U. S. Geol. Survey Geol. Atlas, Folio 56, p. 1, 1899. 
in describing the Little Belt Mountains of Montana, which are surrounded by gravel-capped plains of erosion that, though developed in a region much less arid, resemble the plains cut on rock in the Papago country. "Mountain pediment" as a term replaces "subaerial platform" and in part "suballuvial bench" as defined by Lawson. ${ }^{88}$ It appears preferable because it is less awkward and because it expresses the intimate relation of the plain to the mountain without unnecessary implications as to origin.

The normal mountain pediment has a smoothly sloping surface, more or less covered by alluvium and broken only by scattered

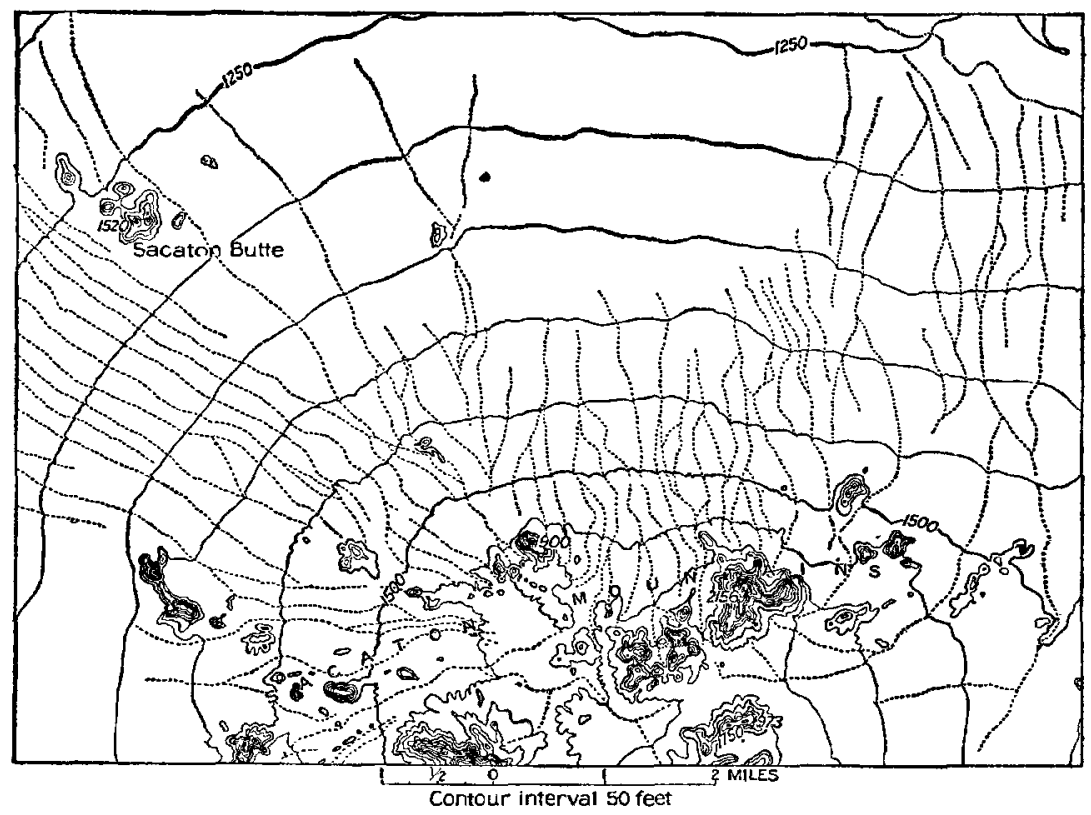

Frgure 11.-Map of part of the Sacaton Mountains, Ariz.

hills which rise abruptly from its surface, and in many of which are prolongations of the intercanyon ridges of the mountains. Unfortunately no maps that cover large areas of normal pediment are available. The northern slope of the western part of the Sacaton Mountains is shown in Figure 11. The plains around the hills and small mountains are cut on rock, but the northern part of the area shown has a heavy burden of alluvium. Schrader ${ }^{89}$ states that "subaerial or nearly subaerial eroded bedrock floor **** seems to continue to within 3 miles of Casa Blanca," or to the vi-

\footnotetext{
88 Lawson, A. C., The epigene profiles of the desert: California Univ. Dept. Geology Bull. vol. 9, p. 34, 1915.

80 Ṡchrader, F. C., unpublished manuscript.
} 
cinity of Sacaton Butte. (See fig. 11.) Similarly Figure 12 shows a pediment dissected by small canyons. This dissection is not so great, however, as to obscure the general form of the pediment.

The angle of slope of pediments ranges from about 50 feet to 200 feet to the mile. It is noticeable, however, that in any one mountain range the slope of the pediment is steeper opposite the smaller canyons and very much flatter opposite the large canyons. The parts opposite the intercanyon portions of the mountain front are steeper than the parts opposite canyons, and they commonly slope

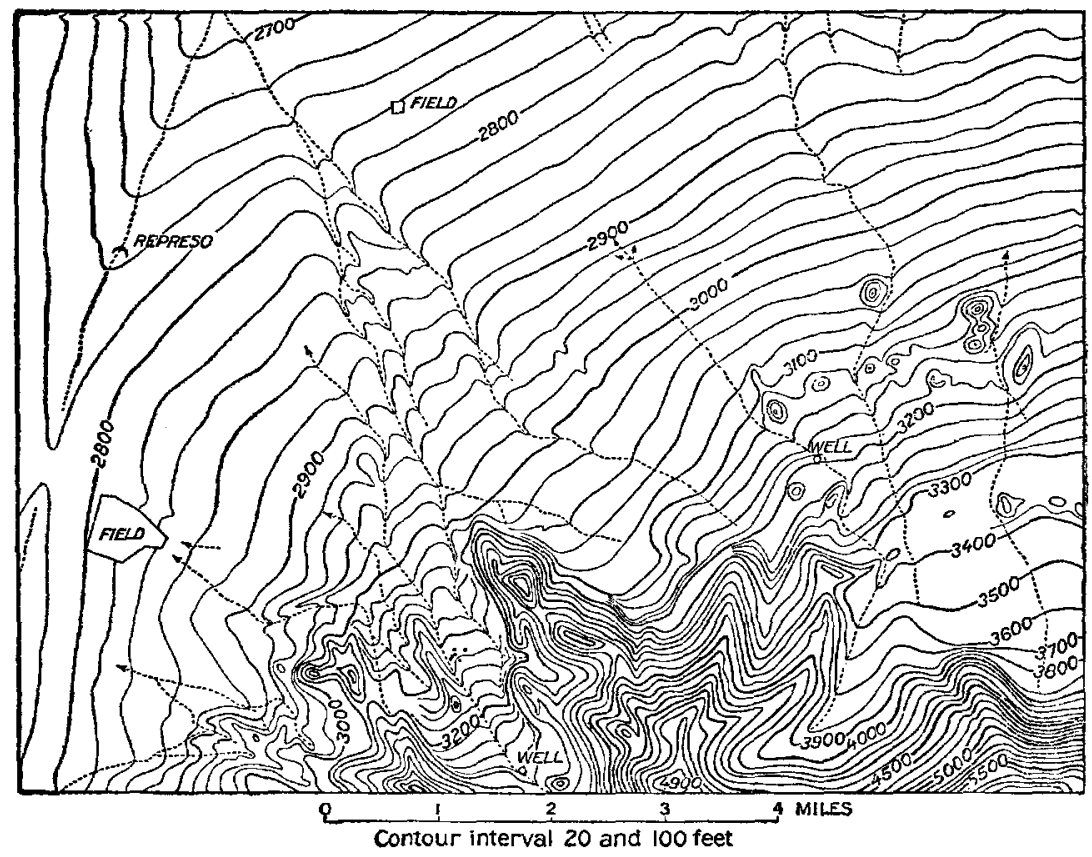

Figere 12.-Map of the northern border of the Baboquivari Mountains, Ariz. Made for the United States Indian Service by Percy Jones, jr.

not only outward from the mountains but toward the stream channels, which emerge from the canyon mouths.

Exceptions to this general condition occur, for at the mouths of certain canyons the pediments have steep slopes, especially in the direction of the axes of the streams. This exception seems to be due to especially resistant boulders which have been brought down by the stream and dropped at the canyon mouth, causing the stream to spread and lose its carrying power. The boulders, until they weather into fragments small enough to be moved, protect and preserve a slope steeper than is normal to the pediment. 
The formation of pediments in the Papago country has been very generally interrupted by a new cycle of erosion, and the processes may now be observed only in localities of small extent. These processes will be briefly stated. At the base of a mountain front débris is swept outward by ephemeral streams which head in the mountain canyons and by small rills which originate through the concentration of rain wash at the base of the mountain slope. These streams are not permanent or even intermittent; they operate only during or immediately after a rain.

A the base of a mountain slope the fine débris washed down by rains is moved forward by little rills toward the larger streams. As the supply of débris is small these rills are not fully loaded and are effective erosive agents, tending to reduce the height of interstream areas. The grade of the rills and of the smaller streams is steeper than that of the larger streams, because all are underloaded by about the same proportion, and therefore the larger volumes of water transport their loads on the lower gradients. As a result of this relation of stream grades, the pediment, cut and molded by these streams, has a lower slope opposite the larger canyons than opposite the smaller canyons. Also, the parts of the pediment opposite the intercanyon ridges have a steeper slope away from the mountains and in addition slope toward the adjacent streams.

The pediment is greatly increased in extent by lateral migration of the streams at and below the mouths of the canyons. The irregularities of the pediment are removed, the higher places being eroded and the lower filled with débris and protected. The lower parts of the canyons are also widened by undermining the slopes of the intervening spurs. ${ }^{90}$ When the spurs become narrow they are cut through by slope recession on both sides, and hills are left standing as outliers on the pediment. These solitary hills are worn away with extreme slowness. Their erosion depends entirely on the gradual disaggregation of the rock which composes them and on the movement of the débris over the pediment during rains. The hills retain the same steep slopes as the original mountain but grow gradually smaller until the last remnants are masses of boulders or single rocks projecting above the general level.

The development of the pediment is therefore due to erosion, which may be summed up under three heads-(1) lateral planation by the streams issuing from the canyons, (2) rill cutting at the foot of mountain slopes, (3) weathering of outliers and unreduced remnants, with transportation of the débris by rills. These processes can not operate below a level determined by the grade necessary to

Do Paige, Sidney, Rock-cut surfaces of the desert ranges: Jour. Geology, vol. 20, p. 450, 1912. 
transport débris away from the mountains. All inequalities below this level will be filled up just as those above it are eroded. Thus the pediment is a slope of transportation and is usually covered with a veneer from 18 inches to 5 feet thick of débris in transit.

As transportation of relatively fine material by water is the essential factor in the formation of the pediment, in contradistinction to the erosion of mountain slopes, which is largely controlled by the movement of large boulders, it is obvious that the pediment grows most rapidly along the major streams. In every indentation in the mountain front and in places where streams emerge from the canyons onto the plains the rate of formation of the pediment is rapid, and consequently extensions of the pediment into the mountains are common. These extensions consist of branching valleys, many of which are 2 miles or more in width and reach far into the interior of the mountain mass. The erosion of the mountains at the headwaters of many streams is much faster than in the lower portions of the same streams, for there is obviously more water pouring down the mountain slopes of the larger mountain masses, and feeble streams are incapable of much planation. Consequently the headwater slopes may recede more rapidly than the side walls of valleys. The extension of the pediment may thus divide the original mountain into groups of detached hills separated by relatively broad surfaces cut on rock, as in the Sacaton Mountains (fig. 11).

\section{CONCEALED PEDIMENTS}

Mountain pediments are normally covered by a more or less continuous film or veneer of alluvium in transit by streams. This veneer is seldom over 2 feet in thickness. However, a change in the local base-level or other conditions may cause the streams to aggrade and bury or conceal the pediments under a thick mantle of alluvium. Identification of a concealed pediment is difficult, for the surface has the form of a normal alluvial slope and there is no surface indication of the buried rock floor. Accurate knowledge of the form of the floor can come only from excavations and wells.

\section{COALESCING PEDIMENTS}

When in the dissection of a desert range the headwater divides have been reduced the mountains consist only of detached hills which project from united or coalescing pediments. The formation of coalescing pediments begins in the old-age stage of erosion of desert mountains, and when the projecting hills have been removed the grades will be almost stable. 


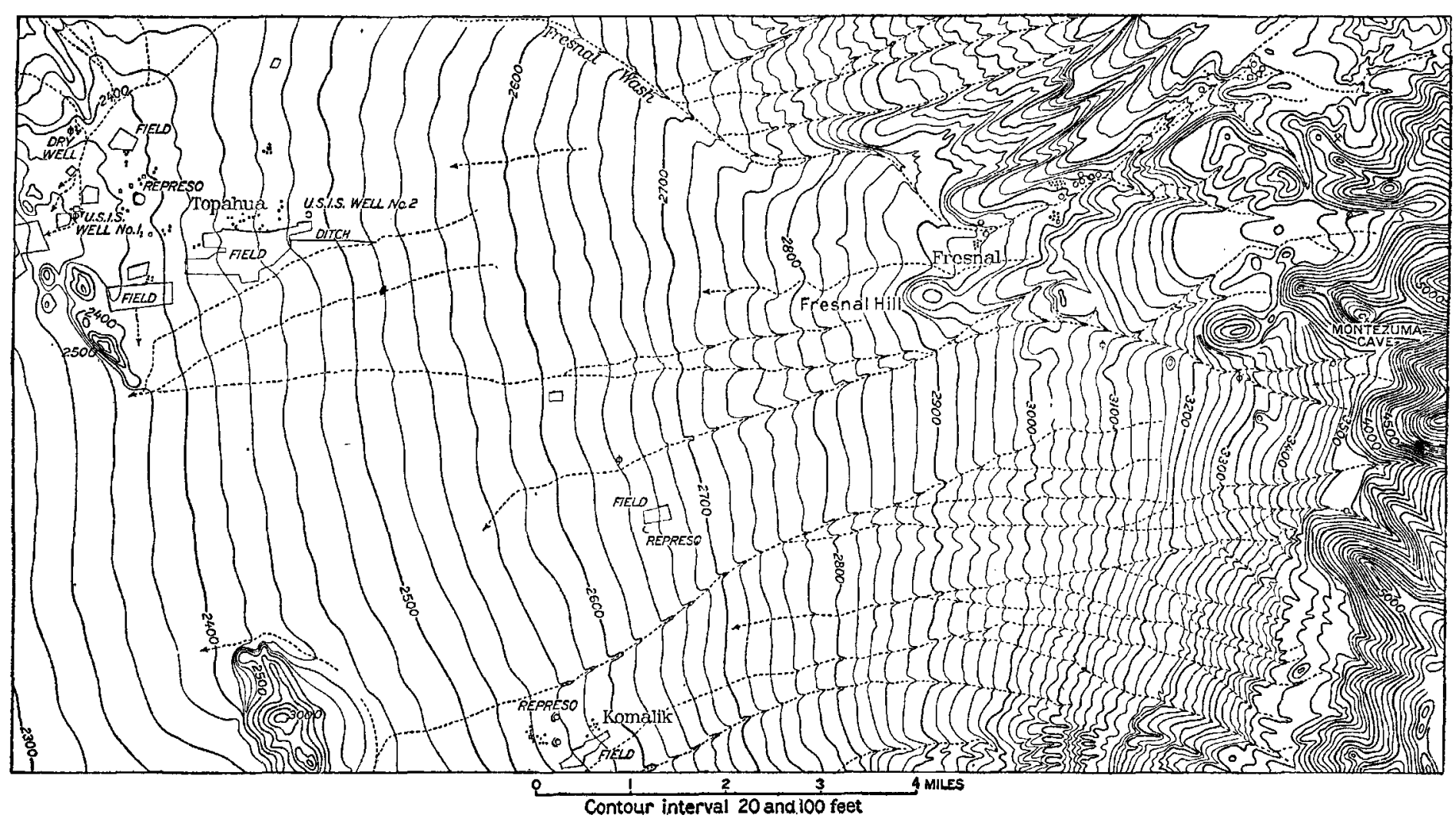




\section{DISSECTED PEDIMENTS}

If the base-level of erosion of streams flowing from the mountains is lowered, the streams carry their load of débris with ease on the increased gradient and begin to dissect the mountain pediment. Narrow canyons are cut by the streams; the canyons begin to form near the center of the basin within or on the margin of the alluvial plains and increase in length by headward erosion. As the little canyons increase in length and complexity the pediment is carved into a maze of small hills with intervening sharply cut valleys, and the original surface is preserved only in the tops of hills or interstream areas.

Dissection of the pediment may be brought about by uplift of the mountain mass, as in the Burro Mountains, N. Mex., ${ }^{p 1}$ or the trunk stream may intrench itself and thus lower the base-level. At the north end of the Gila Mountains dissection of the narrow pediment is due to the lowering of Gila River in late Pleistocene time. Similar lowering of Santa Cruz River near its junction with Gila River has caused the dissection of alluvial fans and a very narrow pediment at the north end of the Sierra Estrella.

However, dissection of pediments due solely to lowering of a trunk stream is the exception in the Papago country; yet the pediments are commonly dissected, as shown in Plates $\mathrm{X}, A ; \mathrm{XII}, B$; and XV. Near or within the mountain borders each stream passes over falls or through rapids into a steep-walled canyon. The walls are rock, in many places capped with a few feet of gravel, and average about 10 feet high (PI. XIII, $B$ ). Near the mountain they may be from 20 to 150 feet high, but downstream they become lower, and near the outer border of the pediment they gradually fade out in broad plains of alluviation, as shown in Figure 13.

This type of dissection of the pediment has taken place generally, irrespective of the conditions of erosion and sedimentation in the adjacent valleys. In some valleys, such as the upper part of Altar Valley, where the axial stream runs in a trench, the canyons of the pediment connect with similar canyons in the alluvial plains and with the axial trench. Dissection of the pediment in this locality may not, however, be ascribed wholly to lowering of the local base-level, but the dissection of the pediment and the dissection of the valley by its axial stream are doubtless due to the same cause. In the northern part of Altar Valley there is no middle trench, yet the pediment on the northern border of the Coyote Mountains and also in the Tucson Mountains is dissected. Thus the trench of the axial stream fades out downstream, as do also the little canyons of the pediment. (See p. 109.)

o1 Paige, Sidney, op. cit., pp. 444 et seq. 
The lower margin of a mountain pediment is generally mantled with alluvium, which can be seen resting on the rock, both being dissected by the streams. This alluvium is therefore older than the undissected alluvial plains characteristic of the northern part of the Altar Valley and the interior valleys of the Papago country. What is the relation of this older alluvium to the extension of the pediment under the valley and to the original rock floor? The relations which are thought to be general in the Papago country are shown in Figure 14. It is believed that during the deposition of the older alluvium there was a gradual rise by aggradation of the middle portions of the valleys, accompanied by the erosion of a convex suballuvial bench. The alluvium then remained essentially stationary, occupying a slope of transportation of the available débris toward the local base-level. The planation of the pediment took place during this time. The dissection of the pediment by small canyons occurred after the completion of the pediment, and in that process the edges of the older alluvium were eroded, but the great mass in the middle portions of the

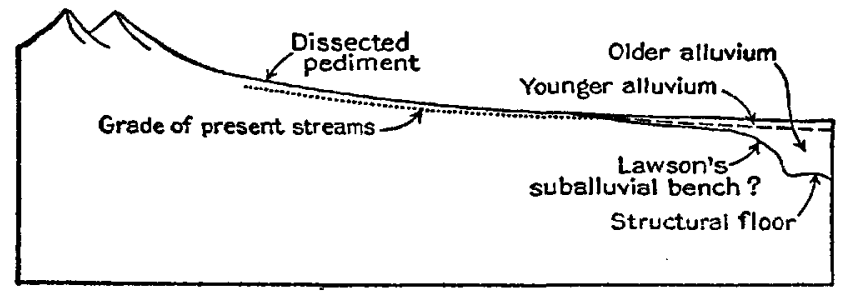

Figure 14.-Diagram showing the structural relations assumed for a typical valley in the Papago country, Arizona

valleys was either slightly buried or perhaps simply reworked by streams. The strict correlation of this older alluvium with that found in the valleys of Gila and Santa Cruz rivers has not been made but is discussed on page 67 .

The two cross sections in Figure 15 present the best data available regarding the rock floor of the valleys. Section $\mathbf{A}-\mathrm{B}$ crosses the area represented in Figure 12 to the Santa Rosa Well, which is 920 feet deep and does not reach the rock floor. To provide the requisite depth of alluvium at the well the rock floor under the alluvium from the edge of the pediment must be convex upward, and an error of as much as 2 miles in the location of the edge of the pediment will not vitiate this conclusion. Section C-D runs from the crest of the mountains westward across the area shown in Figure 13 through the United States Indian Service wells. Well No. 2 is 602 feet deep and does not reach rock, but well No. 1 reaches rock at 100 feet. An even greater convexity of the rock floor must be assumed here, and the depression in which well No. 2 is sunk can not drain through the pass in the Artesa Mountains, like the present streams. 
The rock floors in both sections $\mathbf{A}-\mathbf{B}$ and $\mathbf{C}-\mathbf{D}$ have been drawn smoothly convex as if they were suballuvial benches, but it seems probable that their form is, in part at least, structural.

\section{VALLEYS}

\section{STRUCTURAL ORIGIN OF VALLEYS}

Betwe en the mountains of the Papago country lie great plains or valleys. They resemble the valleys of $\mathrm{humid}$ regions only in that they are bounded by higher land and contain the main lines of drainage. They are actually broad plains floored with alluvial material, which rise gently to the mountains on e ither side. Commonly they descend in the direction of an axial stream, though some of them drain through more than one outlet. They constitute about 80 per cent of the area of the region.

In previous pages it has been shown that of the 64 mountains whose structure is partly known, 25 have been uplifted and faulted, and 21 of these have been uplifted in the same period and doubtless by the same process. The valleys seem to be the blocks of the earth's crust which

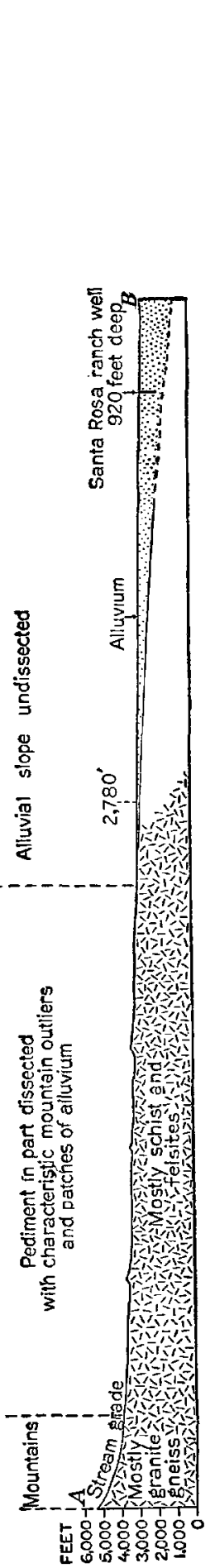

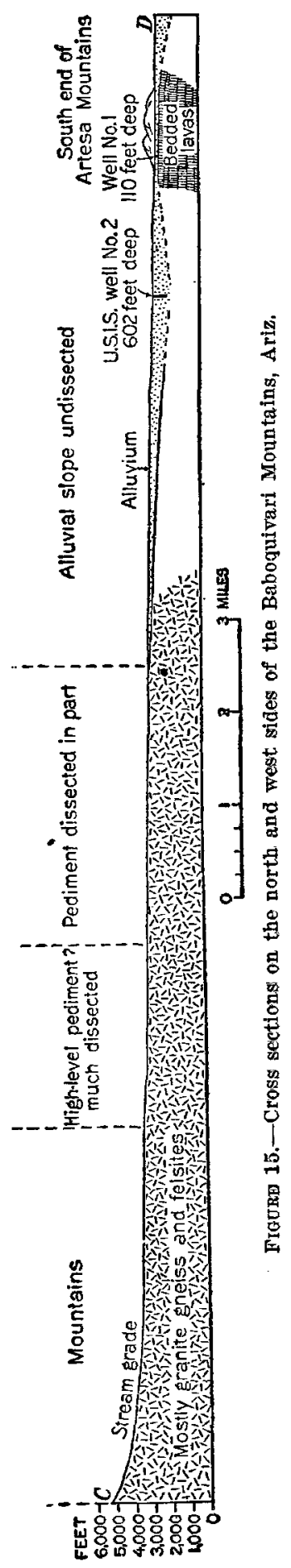


were down-faulted at the same time that the mountain blocks were uplifted. The evidence pointed to this structural relationship is of many kinds.

The valleys are prolonged in the general direction of the mountains and in the direction of what are presumed to be the major fault lines. In many places the lavas which make the mountains, or small patches of lava which are remnants of larger masses that once capped the mountains, dip toward the valley. Dips of this character were observed at one or more localities in each of 13 valleys. In many of the valleys isolated buttes of lava stand far out from the mountains, though the mountains may have been stripped of the lava which once covered them. A well in the Valley of the Ajo struck lava at a depth of 173 feet, and a well in the valley between the Crater and Sauceda mountains found lava at 615 feet. In both places deformation, presumably accompanied by faulting, must be postulated to account for the presence of lava.

The inference that the structural valleys may have been profoundly modified by erosion before the initiation of valley filling can not be denied. It is, however, not supported by evidence in this region.

\section{PROCESSES OPERATING IN THE VALLEXS}

The physiographic processes now in operation in the valleys are largely those of transportation and deposition of sediment. Erosion, which is the dominant process in the mountains and on the pediments, is inoperative in the valleys except on their borders. Thus on the edges of most pediments the alluvium is dissected by the streams that form the little rock canyons of the pediments, and at the mouths of some of the mountain canyons, where there is no pediment, the streams are incised in the alluvium from 5 to 20 feet. The areas of dissection, however, are small. The slopes from the mountains are molded to grades determined by the amount of water in the ephemeral streams and by the supply of sediment. The wind plays a subordinate part, shifting relatively small quantities of sand from place to place.

\section{FEATURES OF THE VALLEY FLOORS}

\section{DRAINAGE}

In spite of the excessive aridity of the Papago country, the valleys, except the southern part of Tule Desert, drain to the sea. Part of them are tributary to the Santa Cruz-Gila system and others to Sonoita River, which reaches the Gulf of California south of the Pinacate Mountains. ${ }^{22}$ A few of the valleys are drained by more

${ }^{82}$ Lumholtz, Carl, op. cit., map. 
than one stream, but the typical valley is lozenge-shaped, with a main stream in the axis of the lozenge, toward which the ephemeral streams from the surrounding mountains flow and the alluvial fans built by these streams slope.

\section{AXIAI STREAMS}

The residue of the floods from the mountains that is not absorbed or evaporated on the alluvial slopes is carried off by the main or axial streams of the valleys. It is probable that there are years when the residue is insufficient to cause the water to flow out of the valley into some other valley, but when there is sufficient water it flows from valley to valley and finally into the sea. The chargacter of these streams can best be brought out by the description of examples.

One of the longest drainage lines, though in numerous places poorly defined, runs from the Baboquivari Mountains southwestward to Sonoita River. The water from Fresnal Canyon, on the west flank of the Baboquivari Mountains (see map, Pl. IV), goes slightly northwestward through the dissected pediment and then spreads over the plain, the larger part, however, going through the gap at the south end of the Artesa Mountains and irrigating the fields of Topahua. In this part of the course there is no definite channel, the water spreading over broad flats. West of Topahua several channels branch out. The water from all of them, when sufficient, reaches Valshni Wash, which runs northwestward through Kavolik toward Tonukvo. The surface in the vicinity of Kavolik is very flat, and some water probably joins Big Wash and goes directly west to join the main drain of The Great Plain north of Serventi Well. Valshni Wash almost fades out as a definite channel before reaching Tonukvo, but the larger floods undoubtedly go through to this place, whence there is a small channel and a series of smooth flats through Copeka to Quijotoa Valley, north of the Copeka Mountains. This channel becomes very indefinite but joins the equally indefinite main drain of Quijotoa Valley southwest of Hardimui. Thence indefinite channels go southward through. Comovo into Comovo Valley, at the south end of which there is a well-defined channel that carries all the water which reaches this part of Quijotoa Valley past the southern point of the Mesquite Mountains. Here the water spreads and very inconspicuous channels carry it and that which drains from the west slope of the Mesquite Mountains across The Great Plain past Camote into Sonoita River. The drainage thus traced has a length from the crest of the Baboquivari Mountains to Sonoita River of about 70 miles. 
The times when water traverses the whole distance must be comparatively rare. Small floods probably flow down the definite channels and then spread out over the broad flats and sink into the ground or evaporate. The continuous drainage line is probably maintained only by successive floods coming down tributaries.

A similar long drainage line begins with a stream that heads in granite hills east of Barajita Valley and flcws about. 3 miles northwestward to a narrow gap south of Walls Well. In this part of its course there is a small, sandy channel which gives way in places to smooth areas of clay. From the gap and thence through Walls Well and westward for a mile or more there is a well-defined arroyo about 50 feet wide with banks 2 to 4 feet high. This channel disappears in the alluvial slopes of the Valley of the $A j o$ and is replaced by numerous smaller channels which lead westward toward Growler Pass. Just east of the pass is an extensive flat with clayey soils and a forest of mesquite trees, and here the small channels fade out. Two fairly definite channels flow into this flat from the southeast and northeast. By rather vague and indefinite channels in the flat the waters unite into a single channel with a gravelly bed which is about 50 feet wide and has banks from 3 to 4 feet high. This arroyo persists through Growler Pass and extends to a point about 3 miles southwest of Bates Well, where it fades out into minor channels. These channels in turn join the main wash of Growler Valley, which pursues a northwesterly course for about 30 miles to the Mesquital, an adobe flat that is similar to the one east of Growler Pass and lies southeast of the southern point of the Aguila Mountains. - From the Mesquital a channel leads to the axial stream of San Cristobal Valley. This axial stream has a well-defined channel about 50 feet wide trending northwestward, but near Garcia Well it fades out into an adobe flat which gradually increases in width until 9 miles farther on, at the Southern Pacific Railroad, it is almost 2 miles wide. Around the borders of the flat are low bluffs which are 2 to 5 feet high near Garcia. Well and increase to 20 feet in height near the railroad. In this flat the channels are very small, but at the railroad a channel about 20 feet wide and 3 to 4 feet deep begins, which increases in width and depth until it reaches the flood plain of Gila River.

\section{TRIBUTARY STREAMS}

The tributary streams that discharge into the axial streams are all of the ephemeral type and are active only during or immediately after rains. Near the mountains they commonly run in well-defined channels; farther down the slope they divide into several channels or spread out into broad sheets. 
McGee has recorded in great detail a sheet flood which he observed in 1894 on one of the tributaries of Santa Cruz River. This tributary rises in the Santa Rita Mountains, crosses the dissected pediment and the dissected alluvial slope, and joins the flood plain of the Santa Cruz on a broad, smoothly sloping plain with a grade of 150 feet to the mile. McGee's description, ${ }^{33}$ somewhat condensed, follows:

During the 1894 expedition a moderate local rain occurred. The rainfall was perhaps one-fifth of an inch, sufficient to moisten the dry ground, and was probably greater in the adjacent foothills of Santa Rita Range. Within half an hour a roar was heard in the foothills, rapidly increasing in volume; the teamster set out along the road up the [Santa Cruz] valley at best speed; but before he had gone 100 yards the flood was about him. The water was thick with mud, slimy with foam, loaded with twigs, dead leaflets, and other flotsam; it was seen up and down the road in either direction, fully half a mile in all, covering the entire surface save a few islands protected by exceptionally large mesquite clumps. The torrent advanced at race-horse speed at flrst, but, slowing rapidly, died out in irregular lobes not more than a quarter of a mile below [west of] the road; yet, though so broad and tumultuous, it was nowhere more than about 18 inches and generally only 8 to 12 inches in depth. The front of the flood was commonly a low, lobate wall of water 6 to 12 inches high, and it was evident that most of the water first touching the earth as the wave advanced was immediately absorbed and as quickly replaced by the oncoming torrent rushing over previously wetted ground. Such were the conspicuous features of the sheet flood-a thick fllm of muddy slime rolling viscously over a gently sloping plain; and this film was a transformed stream still roaring through a rugged barranca [canyon] only a few miles away. For perhaps five minutes the sheet flood maintained its vigor and even seemed to augment in volume; the next five minutes it held its own in the interior, though the advance of the frontal wave slackened and at length ceased, and in half an hour from the advent of the flood the ground was again whitening in the sun, save in a few depressions where muddy puddles still lingered.

The after effects of the flood were the accumulation of flotsam against the upper sides of clumps of shrubbery, ant hills, and ground-squirrel mounds; from these the limits of the flood could be traced, showing that it nearly blended with other similar floods from neighboring barrancas and arroyos. A less striking effect was the accumulation of a nearly continuous fllm of sediment, chiefly flne sand or silt. This fllm was usually an inch or less in thickness, though sometimes it lined depressions to depths of several inches.

Floods of the type described seem to be normal to the region. On the upper parts of the alluvial slope they flow in linked and shifting channels, but farther down, where they have dropped all the coarse sediment and are carrying only sand and mud, they spread out in broad sheets. Concentration of these sheets by permanent or temporary obstacles may cause the formation of a channel, but many of these channels are discontinuous, and there are broad flats without channels.

${ }^{\text {9s }}$ McGee, W J, Sheet-flood erosion : Geol. Soc. America Bull., vol. 8, pp. 100-101, 1897. 
The broad flats that are formed by deposition from sheet floods are floored with sandy clay or, in local parlance, adobe. Hence they are called adobe flats.

The channels in the flats are of two types-shallow sandy channels ordinarily 2 to 5 feet wide and 3 inches to a foot deep, and deep channels from 5 to 6 feet deep and 15 to 30 feet wide. Parts of these larger channels may have a clay bottom and hold water for a time after rains or floods. Other shallow basins or pans, apparently produced largely by the trampling of animals, also hold water, and these two types of pools are called charcos. (See pp. 121-123.)

Orchard-like forests of mesquite are common on adobe flats. Usually the trees grow along the channels, and not uncommonly these lines of trees are paralleled by similar lines of dead or dying trees that mark the position of channels which have now disappeared. The adobe flats of Vekol Valley, however, are bare of trees and are covered by hummocks of "galleta" grass. Scraggly bushes of mesquite and unusually large creosote bushes separate the grassy adobe flat from the alluvial slope covered by vegetation of the normal type, dominated by the creosote bush.

Adobe flats are of all sizes. Many small ones 30 to 40 feet wide and a few hundred feet long occur along streams otherwise marked by channels. Others cover square miles of country and when flooded are temporary gently moving sheets of water. The surface when dry is normally hard and smooth and somewhat streaked in appearance owing to the presence of fine crenulations in the direction of flow. There are also bits of rubbish collected on the upstream side of every obstruction.

\section{PLAYAS}

The only temporary lake in the region lies on the international boundary and receives the drainage of the southern part of Tule Desert. The locality is called Las Playas, and the bed of the temporary lake is a good example of a playa-a flat area occasionally flooded by water which stands and evaporates. The surface is crossed by mud cracks, which break the dark clay soil into large blocks. Many of the cracks are 3 to 4 inches wide at the surface and extend downward at least 3 feet. The edge of the barren flat is marked by scrubby mesquite bushes clustered about the charcos and channels that occur at the places of entrance of tributary streams.

\section{WIND DEPOSITS}

In the area west of Ajo, on the whole the driest part of the region, wind-blown sand is fairly common. The Yuma Desert is almost 
completely mantled with sand from 1 to 10 feet deep. The presence of grass and bushes and the general shapelessness of the dunes indicate that the movement of sand is not rapid. The eastern margin of the Yuma Desert and the west side of the Gila Mountains are drained by a stream flowing northward to Gila River, and along this stream erosion is sufficiently active to prevent the deposition of sand.

In the flood plain of Gila River there are many groups of low dunes composed of sand derived from the broad sandy river channels. These dunes are commonly fixed in position by clumps of mesquite.

Along the eastern margin of the Iechuguilla Desert, Tule Desert, and Mohawk Valley are belts of sand dunes, which appear to be the residue of sand accumulated by the winds after sweeping the entire width of the valleys. The belt of dunes is particularly conspicuous at the south end of the Pinta Mountains. In this locality the dunes are invading the mouths of the mountain canyons and impeding stream erosion. A belt of wind-blown sand from a quarter of a mile to a mile wide surrounds the Pinacate plain. Growler Valley and the Valley of the Ajo are almost free of wind-blown sand, but patches of drifted sand occur on the Sentinel Plain and around its margin.

In the Quijotoa Valley, The Great Plain, and the plain near Copeka there are areas of wind-blown sand. The sand is usually only from a few inches to 4 feet thick and lies on the clayey surface of extensive adobe flats. The irregular distribution of the sand impedes the drainage and helps to break up and spread the floods. In making the artificial ponds of Tonukvo, Copeka, Comovo, and Camote the Papago Indians have taken advantage of the partial damming of channels in the adobe flats by wind-blown sand.

Interference with stream channels is perhaps the most notable effect of wind work in this region. In many localities channels in which water ran six months or a year before are blocked by low dams of wind-blown sand from 6 inches to a foot high. The next flood will probably take a new course, which will in turn be blocked. Thus the wind assists in the further diversion of streams which are already likely to be diverted under the laws of stream action.

\section{TERRACES}

Many of the streams of the Papago country now flow below the level of deposits which they have laid down in past time. They flow in trenches bordered by bluffs leading to a broad terrace which, con- 
forming to the grade of the alluvial slope, extends to the mountains. Some streams have deposited material at more than one level and thus are bordered by several terraces.

\section{TERRACES OF GILA RIVER}

The valley of Gila River contains many terraces which parallel the river. The highest terrace is represented only in a few localities by small benches or by the tops of isolated hills and is composed of the material already described as older alluvium (p. 66). The lower terrace is well developed along the whole length of the river and is bounded on the lower side by bluffs about 75 feet high. It is composed of alluvium deposited in part by the river itself and in part by side wash from the ephemeral tributaries of the river. This material is referred to as the younger alluvium (p. 67). Below the terrace is the flood plain of the river, with its recent deposits. These relations were recognized by Lee, ${ }^{95}$ who correlated the alluvium of the higher terrace with similar material on Colorado River, which he called the Temple Bar conglomerate, ${ }^{96}$ and the lower terrace would thus be the equivalent of the Chemehuevis gravel of the same river. The older alluvium, which corresponds perhaps to only a part of the Temple Bar conglomerate, lies at various altitudes and is tilted in a number of localities, as at the north end of the Gila Mountains, 5 miles north of Blaisdell, south of Wellton, and in Tonto Basin. ${ }^{97}$ Near Mesa a well 1,305 feet deep penetrates only alluvium and shows that the valley fill extends more than 100 feet below sea level. $^{98}$ As Gila River could not excavate a valley below sea level, earth movements must have followed the deposition of the older alluvium. Doubtless to these movements and the subsequent extensive erosion may be attributed the small size of the outcrops of the older alluvium and their inequality in height. Field work in San Pedro Valley in 1920 and 1921 indicates that a large part of the deeper valley fill is of Tertiary age and older than the older alluvium.

The younger alluvium, of Chemehuevis age, forms a well-defined terrace and indicates that in Pleistocene time the river filled its valley to a level of about 75 feet above its prevent elevation. The data for the age of the younger alluvium are presented on page 68 .

as Lee, W. T., Underground waters of the Salt River valley, Ariz.: U. S. Geol. Survey Water-Supply Paper 136, p. 112, 1905.

${ }^{96}$ Lee, W. T., Geologic reconnaissance of a part of western Arizona : U. S. Geol. Survey Bull. 352, p. 18, 1908.

${ }^{g}$ Lee, W. T., Underground waters of Salt River valley, Ariz.: U. S. Geol. Survey Water-Supply Paper 136, p. 112, 1905.

98 Idem, p. 115. Additional evidence from well records is given by Ross, C. P., The lower Gila region, Arizona: U. S. Geol. Survey Water-Supply Paper 498, pp. 77-84, pl. 12, 1923. 
Since that time the river has cut a valley through the deposits of Chemehuevis age and is again depositing material on its flood plain. Early reports indicate that up to about 1880 the Gila flowed in a relatively deep channel through its flood plain, overflowing it only in times of flood. There was also a considerable low-water flow. At present the channel is a sandy waste with many tortuous subsidiary channels, constantly shifting in position, and there is no low-water flow except in favored places. There seems to be a greater proportionate load of sediment, which under present conditions is silting up the channel..$^{98}$.

\section{TERRACES OF ALTAR AND SANTA CRUZ VALLEYS}

Santa Cruz Valley and its tributary, Altar Valley, which lies parallel to and west of it, are marked by several common features. Altar Valley lies between the Baboquivari and Coyote mountains on the west and the Tumacacori, Cerro Colorado, Sierrita, and Tucson mountains on the east and drains north to Abra Valley and thence to the Santa Cruz. It is about 40 miles long and ranges in width from 8 to 15 miles. The head of the valley from Buenos Aires south and for 3 to 4 miles out from the mountains on the west side as far north as Las Moras and on the east side as far north as the San Luis ranch is a plain cut on rock-a mountain pediment. (See Pl. XV, B.) About 4 miles south of Buenos Aires is the divide which separates the drainage going south past Sasabe into Mexico. It is smooth and flat. The head of the valley consists of confluent pediments formed by streams from the adjacent mountains, some of which flow north and others south.

Pediments border the east side of the valley and are probably extensive. On the west, however, from Las Moras to the Coyote Mountains, the pediment is narrow and the plains are covered by very coarse alluvium. Along the Coyote Mountains the exposed pediment is from half a mile to 3 miles wide.

The headwater streams in the pediment areas are incised in narrow valleys from 10 to 50 feet deep. These trenches lead from all the mountain canyons to an axial stream which, originating in the union of Arivaca Creek and the stream which follows San Luis Canyon, runs north almost to the Anvil ranch. Each trench is a flat-bottomed valley from a quarter of a mile to $11 / 2$ miles wide. The loamy bottom is marked by a well-defined arroyo with banks from 2 to 6 feet in height. The bluffs of the trench have their maximum height of about 75 feet near Buenos Aires, decreasing in height upstream and downstream. Near the Anvil ranch the bluffs are about

${ }^{90}$ Ross, C. P., op. cit. In this paper a complete description of the terraces. of Gila River is given. 
20 feet high, and thence northward they fade out rapidly, so that at the Robles ranch there is no sharp separation between the plain of alluviation of the main stream and those of its tributaries.

The trench of the main or axial stream shows no definite terrace, but a terrace is common on the tributaries, though owing to the "accidents" of erosion it is absent in many places. West of Pozo Nuevo the tributary valleys are from a quarter to half a mile wide. Each valley has a flood plain in which the stream is intrenched about 10 feet, like the axial stream. Above the flood plain is a terrace about 15 feet high, and then a narrow flat, followed by a gentle slope to the level of the plains, 35 to 40 feet higher.

Near Arivaca the flood plain of Arivaca Creek is bounded by low bluffs about 20 feet high, which constitute the face of a narrow discontinuous terrace. About 40 or 50 feet above the terrace lies a rolling plain cut on rock, which is part of a well-developed mountain pediment. This plain is well shown in Plate $\mathrm{XV}, A$, a view north across Arivaca Creek east of the town of Arivaca. At the town the creek now runs in a trench about 200 yards wide and 15 feet deep. This trench has been formed within recent time, for the flood plain was once a marshy flat. Lieutenant Michler ${ }^{1}$ visited Arivaca in July, 1855, and his narrative states that "numerous springs lie concealed among the tule," a phraseology which implies that there was a swamp with rushes or "tule" at this locality.

Santa Cruz River rises in Arizona at the southern base of the Canelo Hills and flows southward through a broad depression called the San Rafael Valley, between the Patagonia and Huachuca mountains. Crossing the international boundary, the river describes a loop of 30 miles and reenters the United States 6 miles east of Nogales. At the second crossing of the international boundary the stream has an altitude of about 3,700 feet, and thence northeastward to Calabasas its grade is 40 feet to the mile. Near Calabasas the Santa Cruz is joined by Nogales Wash, sometimes called Potrero Creek, which flows northward from Nogales, and by Sonoita Creek, which heads on the east side of the Santa Rita and Patagonia mountains. This part of the Santa Cruz Valley is a broad lowland about 17 miles wide from the base of the Patagonia Mountains to Atascosa Ridge, in the Tumacacori Mountains. The lowland is composed of long ridges and flat-topped spurs extending from the bordering mountains toward Santa Cruz River and its tributaries. Similar ridges slope from the divide between Nogales Wash and the river. The culminating point of this divide is Mount Benedict, a bold, somewhat conical mountain. Between the ridges are sharp-walled

${ }^{1}$ Emory, W. H., Report on the United States and Mexican boundary survey, vol. 1 , p. 119,1857 . 
terraced canyons which lead to the flat inner valleys along Santa Cruz River and its two main tributaries. The flat floor of Nogales Wash is from an eighth to half a mile wide, a moist and fertile meadowland which narrows in places but grows wider downstream until it merges into the similar floors of the inner valleys of Santa Cruz River and Sonoita Creek. In these flat meadows the streams have cut narrow, steep-sided gullies from 10 to 30 feet deep.

The bluffs bordering these flood plains show a double terrace, the upper one coincident with the sloping ridges and the lower about

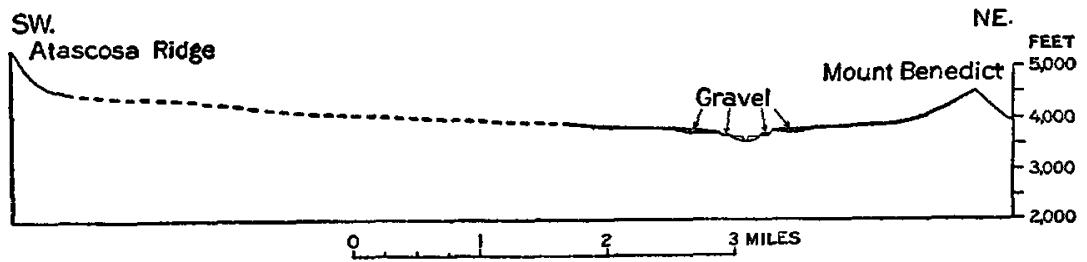

Figure 16.-Cross section of part of Santa Cruz Valley (Nogales Wash), Ariz.. from Mount Benedict to the Tumacacori Mountains

50 feet above the flood plains. These relations are shown in Figure 16. The upper terrace is in places covered with thin alluvium. The lower terrace is everywhere capped with 10 to 20 feet of gravel.

From Calabasas to the mouth of Sopori Creek Santa Cruz Valley is from 8 to 12 miles wide. Long dissected slopes lead down to an inner valley bounded by bluffs. Near the mountains the side streams flow in deep gorges through narrow pediments, and lower down they

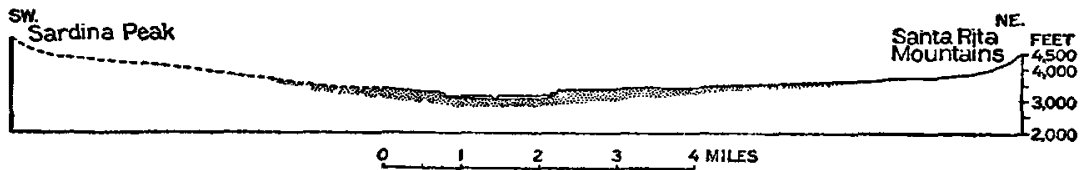

Fiqure 17.--Cross section of Santa Cruz Valley from Sardina Peak to the Santa Rita Mountains near Tubac, Ariz.

occupy flat-bottomed valleys bounded by bluffs of alluvium. The floors of the tributaries join and merge with the flood plain of Santa Cruz River. This flood plain is 1 to 2 miles wide, and through it the stream flows in a steep-walled channel from 10 to 20 feet deep. The cross section in Figure 17 shows the character of the slopes and the form of the inner valley near Tubac, a location typical of this portion of the valley. The cross section brings out the double terracing of the valley, but these terraces, though of approximately the same height as those farther upstream, are unlike them in being composed wholly of alluvium.

$104211-25-9$ 
Forty miles to the north, near Tucson, the inner valley, with its flood plain and the narrow trench in which the river runs, is bounded by ragged bluffs about 25 feet high, as shown in Figure 18. From the top of these bluffs the alluvial slopes sweep upward to the mountains. There is no second terrace, but vague irregularities in these slopes have been interpreted by Huntington ${ }^{2}$ as the remnants of an older valley filling. A reconnaissance in 1920 and 1921 indi-

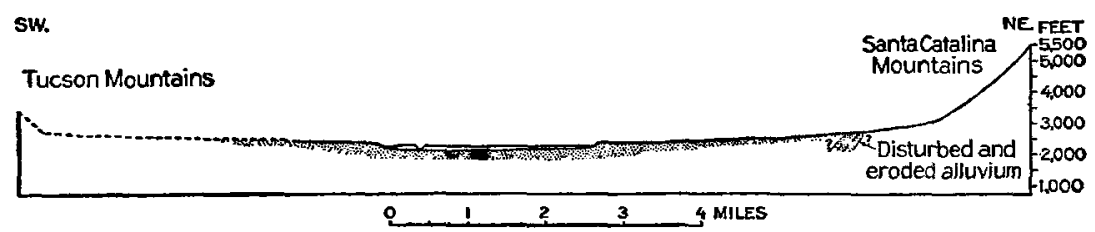

Figune 18.- Cross section of Santa Cruz Valley at Jaynes, Ariz.

cates that near the mountains there are two levels at which pediments have been formed. The lower level probably coincides with the terrace near 'Tucson.

From Tucson northward the bluffs bounding the inner valley of the river decrease in height, and near the north end of the Tucson Mountains they disappear. Similarly, the trench in the flood plain becomes shallower, and Santa Cruz River in flood spreads widely over great adobe flats in which the main channel is so obscure that its mapping is arbitrary. Figure 19 is a cross section through Toltec,

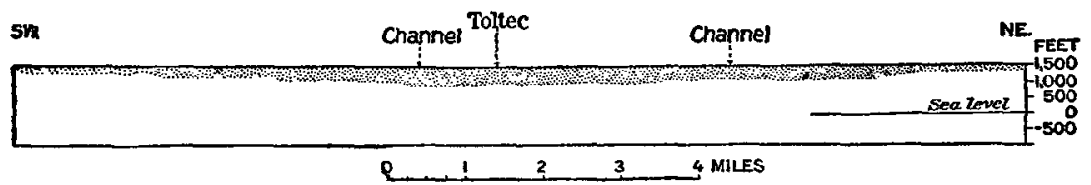

Frgure 19.-Cross section of Santa Cruz Valley near Toltec, Ariz.

where the river has two main channels, which are, however, very shallow and seldom hold all the flood waters. The great flats of Santa Cruz River merge with those of its tributaries. The stream that drains Altar and Abra valleys has, like the others, lost the terracing characteristic of its headwaters. The flats of Santa Cruz River lie at or only slightly above the level of the bluffs along Gila River, which are about 50 feet high in the stretch from Florence to Gila Crossing. The flats were evidently developed when Gila River flowed at the level of these bluffs. The lowering of Gila River has affected its tributary in its lower portion only, where for a distance of 5 or 6 miles upstream from the junction near Gila Crossing

auntington, Ellsworth, The climatic factor: Carnegie Inst. Washington Pub. 192. p. 24, 1914. 
Santa Cruz River lies in a shallow valley 10 to 50 feet below the surrounding plain.

The physiographic features of Santa Cruz River, just recounted, are similar to those of Altar Valley. From Calabasas southward the Santa Cruz Valley and its tributary valleys consist of dissected pediments sloping from the bordering mountains to a terraced inner valley. The topography is similar to that near Arivaca and in the southern part of Altar Valley. The events recorded by this topography seem to be (1) long-continued erosion following the original uplift of the mountains and forming extensive mountain pediments; (2) deposition of alluvium on the lower portions of the pediments in a period of deposition either following the first period of erosion or concurrent with it; (3) erosion of an inner trench at the level of the terrace, shallower but wider than the present trench; (4) deposition on the floor of this trench in a second period of deposition either following the second period of erosion or concurrent with it; (5) erosion of the inner valley to a depth slightly below the flood plain; (6) deposition of the silt and sand of the flood plain in a third period of depression either following the third period of erosion or concurrent with it; $(7)$ erosion of the trench or channel in the flood plain. The last event has taken place within historic time and is discussed more fully in a later paragraph.

The cross section at Tubac resembles the part of Altar Valley near Secundino Well, where the bluffs of the inner valley are of alluvium. The terrace, however, is not well developed in Altar Valley except in certain tributary streams. (See p. 110.) The events recorded are similar in sequence to those recorded farther south and fall into seven stages, but deposition has been far more effective than erosion, especially in the earlier stages.

The cross section near Tucson (fig. 18) probably indicates the same sequence of events, but the reddish faulted and eroded alluvium near the mountains can not be correlated with the alluvium capping the dissected pediments near Calabasas or the great body of alluvium of the dissected alluvial slopes near Tubac, as it is doubtless of Tertiary age. The alluvium of the sloping plains and terrace can not be separated into an older and a younger division without further field work.

The cross section near Toltec (fig. 19) shows deposition only, and the Santa Cruz Valley in this part of its course resembles Altar Valley at the Robles ranch. Not even the recent channel trench persists into the Santa Cruz flats, and the history of this part of the Santa Cruz Valley, so far as it is recorded in the surface features, is one of uninterrupted deposition. 
The recency of the cutting of the channel trench of Santa Cruz River in the stretch between Calabasas and Tucson was first pointed out by Spaulding ${ }^{3}$ and has been studied in detail by Huntington. ${ }^{*}$

The apparent significance of this recent trenching, not only on Santa Cruz River but on other streams in the Southwest, has been discussed in another paper. ${ }^{5}$

\section{TERRACES IN THE INTERIOR VALLEYS}

Pumpelly ${ }^{6}$ was the first to observe that the valleys west of the Baboquivari Mountains are undissected compared to those east of these mountains. The dissection of the pediments and the upper parts of the alluvial slopes has already been mentioned (pp. 99-101). Vekol Valley, however, presents some anomalous features. The main stream, after passing through extensive flats covered with "galleta" grass where deposition is going on, enters, near the Brush Corral, a shallow trench. The trench is from 5 to 10 feet below the adjacent slopes and is from 100 to 300 feet wide. The floor of the trench is formed of a deep loamy or sandy clay soil and supports a thicket of large mesquite trees. The stream is still further intrenched in a channel from 5 to 10 feet deep and apparently no longer covers the plain in time of flood. This arrangement of slightly dissected alluvial slopes, low bluffs flanking a flood plain, and a channel trench continues northward for about 10 miles and then fades out, so that at Mobile, on the Southern Pacific Railroad, 18 miles farther north, the stream has several channels, none of which are well marked. In miniature, then, there is reproduced on this stream the physiography of the Santa Cruz at Tucson, and in similar fashion the terraces fade out downstream.

Somewhat similar but vaguer terraces were observed on the stream that drains the southern part of Barajita Valley. A gravel-covered hill about 10 feet high, which gives the name to Charco de la Lomita, and similar hills near Totobit Tanks and at other localities may be vestiges of terraces of a like kind now destroyed or largely buried in the present cycle of sedimentation in the interior valleys.

\section{GEOLOGIC AND PHYSIOGRAPHIC HISTORY}

\section{PRE-TERTIARY EPISODES}

The geologic history of the Papago country begins in the obscurity of early pre-Cambrian time. In this area, as in other parts of Arizona, a thick series of rocks was deposited by water, but later pressure

\footnotetext{
spaulding, V. M., Distribution and movements of desert plants : Carnegie Inst. WashIngton Pub, 113, p. 9, 1909.

Huntington, Ellsworth, op. cit., pp. 33-34.

- Bryan, Kirk, Erosion and sedimentation in the Papago country, Arizona: U. S. Geol. Survey Bull. 730, pp. 77-80, 1922.

- Pumpelly, Raphael, Mineralogical sketch of the stlver mines of Arizona: California Acad. Sci. Proc. vol. 2, no. 127-139. 1863.
} 
and heat converted the original sediments into schists, and only the bare fact of their deposition is recorded. Enormous masses of molten material, now found as bodies of granitic rock, were intruded into the sediments in pre-Cambrian time and aided in changing them into schists. Then followed a long period of erosion, which, so far as the evidence goes, continued to the beginning of Cambrian time. The later pre-Cambrian, known from the Grand Canyon ${ }^{7}$ and lower Gila regions, ${ }^{8}$ has not yet been differentiated in the Papago country and may be absent.

Paleozoic time seems to have been an era of quiet in respect to earth movements, with spreading seas that lapped over the region from the southeast. The expansion of the sea from the southeast is recorded by the occurrence of Cambrian, Devonian, and Carboniferous rocks in the Santa Rita Mountains and of Cambrian and Carboniferous rocks in the Tucson Mountains, but in general west of Santa Cruz River only Pennsylvanian rocks have been found. The absence of Paleozoic rocks from the region west of Ajo and from the lower Gila region seems to imply either that these regions remained above the Paleozoic seas or that they were particularly affected during the succeeding revolution, when folding and erosion took place in the area east of Santa Cruz River.

Early Mesozoic time was in other parts of Arizona marked by the deposition of continental deposits, many of them indicating arid conditions. No sedimentary record is available in the Papago country, except in the Tucson Mountains, but the Paleozoic rocks were dislocated and large parts of them removed before the Mesozoic igneous intrusions took place. The igneous activity of Mesozoic time included extrusion of lava and intrusion of large batholithic masses. Hardly had this activity ceased when deposition by streams began. The area of deposition, however, covered only the southeastern part of Arizona, toward the early Cretaceous sea. In this area folding and overthrusting took place in post-Cretaceous time. The Papago country may also have been involved in these movements, but continuous erosion down to Tertiary time has largely obliterated the evidence.

\section{TERTIARY LANDSCAPE}

The Tertiary history of the region is notable for its striking events and is represented by a profusion of rocks. The details of this history can not be given, however, for lack of evidence. Three glimpses of the region during this period are revealed.

\footnotetext{
7 Noble, L. F., The Shinumo quadrangle, Grand Canyon district, Ariz.: U. S. Geol. Survey Bull. 549, pp. 37-60, 1914.

${ }^{\&}$ Ross, C. I', op. cit., p. 20.
} 
At the beginning of Tertiary time uplift and erosion began and the major features of the present time were rudely blocked out. It is not likely that this uplift was simultaneous over the whole area, but the present high land seems to have been elevated, and deposition by streams took place in local basins.

Of the deposits of Tertiary time, the beds in Adobe Canyon, in the Santa Rita Mountains, are known to be Eocene. The other Tertiary sedimentary rocks can not be definitely dated, but they testify to the climatic and physiographic conditions of the time. All the beds are arkosic - that is, they are composed in part of undecomposed grains of feldspar. Rudely bedded, unsorted, in places with large boulders, they must have been laid down by torrential, probably ephemeral streams under climatic conditions very similar to those of the present day. They commonly rest on the eroded surface of the underlying rocks, and the basal beds are made up largely of material derived from local sources. The beds consist of the coarse detritus derived from the erosion of desert mountains, laid down on the flanks of these mountains. The succeeding lava flows extended, in places, over the Tertiary conglomerate and usually far beyond it, covering the mountains in whole or in part. As uplifted and exposed by erosion, the surface on which the conglomerates and volcanic rocks rest is in many places smooth, but protuberances stand from a few feet to as much as 1,500 feet above the general level. The elevations were low residual mountains of the sierra type, surrounded by pediments leading down to the basins in which the conglomerates had accumulated. The end of the Tertiary volcanic period found this topography masked by lavas accumulated to maximum thicknesses of 2,000 feet.

Much more work will be necessary to determine the areas that were once covered by lava. In the central part of the region the lavas were almost continuous, and the district including the Sand Tank, Sauceda, Ajo, and Growler mountains seems to have been one of the great lava fields of Tertiary time. In other localities, such as the Maricopa and Salt River mountains, the lavas were thin, and probably there were some areas without lava.

Between the areas of accumulation of lavas were doubtless basins in which streams deposited the gravel now found interbedded with the lavas. Farther north, in the lower Gila region, there were brackish waters in which limestone was deposited. ${ }^{\circ}$

The third glimpse of Tertiary time shows the region after the period of faulting, in which great strips and blocks of the earth's crust had been uplifted and tilted to form the present mountains and similar blocks and strips had been relatively depressed to form

- Ross, C. P., Geology of the lower Gila region, Ariz.: U. S. Geol. Survey Prof. Paper 129, pp. 189-190, 1922. 
the valleys. In the Papago country no evidence has been found by which this uplift can be dated. In other parts of southern Arizona the major part of the valley fill, composed of gravel, sand, and clay eroded from the mountains, is of Pliocene age.

\section{PLEISTOCENE AND RECENT TIME}

The later history of the region is largely one of erosion of the mountains and sedimentation in the valleys. Both of these processes have operated at varying, rates, and the Pleistocene comprised two cycles of erosion and sedimentation and part of a third, which was completed in Recent time.

No evidence has been brought forward as to the date of formation of the trough of Gila River, nor the extent to which it may have been enlarged or deepened by erosion. In this trough more than 1,500 feet of alluvium has been deposited, including a remarkably persistent clay bed ${ }^{10}$ discovered in well drilling. This clay seems to have been laid down in a body of still water concerning which nothing definite is known. After the deposition of the clay more alluvium was deposited by streams until the valley was filled to a level about 150 feet above the present river level. This older valley fill was probably completed in Pleistocene time, although it may have been begun in Tertiary time. A period of erosion set in, and a central trench was excavated by Gila River to a depth below the present level. Renewed deposition, largely by Gila River, filled the inner valley to a level about 75 feet above the present river level. On the basis of the fragmentary bones found at Ligurta (p. 68), this episode is considered to have taken place in Pleistocene time. Erosion then again set in, and a second inner trench or valley was excavated. In the broad flood plain of this inner valley Gila River now flows. Channel changes that seem to indicate renewed deposition began in the late eighties and are still in progress. ${ }^{11}$

Santa Cruz River, though a tributary of Gila River, has a somewhat different history. On the lower river only deposition is recorded; the upper river has a complicated history, as pointed out on pages 110-114. The trough was probably first formed in Tertiary time, and a valley fill, now represented only by small outcrops of conglomerate, was deposited in late Tertiary, probably Pliocene time. Faulting uplifted the mountains, which owe their present height to this movement. Three periods of erosion coincident with or followed closely by three periods of deposition, together with the recent erosion of the channel, make seven episodes in Pleistocene time. As previously pointed out (p. 109), Altar Valley seems to have had a history similar to that of Santa Cruz Valley. In the greater part

${ }^{10}$ Ross, C. P., op. cit. (Water-Supply Paper 498), p. 90.

11 Idem, p. 64 . 
of the Papago country, however, the history appears to have been simpler. After the uplift of the mountains and the coincident formation of the valley troughs, the mountain areas have been the scene of continued erosion producing extensive areas of pediment. The valleys have been continually filled with the débris of this erosion or, having been filled, have served as areas over which débris may be slowly transported. The erosion of the mountain areas was accelerated at some stage in Pleistocene time, and the little canyons of the pediment were formed.

The simple history just recounted was interrupted by faulting of the Tinajas Altas Mountains and Sierra Lechuguilla, with uplift of part of the valley fill. The Sierra Estrella was also uplifted. More detailed study may discover records of other events that will make the history of the interior valleys and ranges of the Papago country as complex as that of the bordering Gila and Santa Cruz valleys. It is possible, however, that the alternate erosion and sedimentation of the main river systems of southern Arizona were due to fluctuations of climate in Pleistocene time and that these fluctua. tions had little effect on the more arid Papago country.

\section{SURFACE WATER}

The problem of finding water for man and beast increases in difficulty with the aridity of a region. In southwestern Arizona and southeastern California aridity reaches its climax in the continental area of the United States, and consequently sources of water supply which in more humid regions are wholly or almost entirely neglected are here of great importance. In the following pages is presented a study of the characteristics of watering places due to rainfall and direct run-off, in contradistinction to wells, which are dependent on the circulation of water in the ground.

Watering places in this arid region are of equal importance to the scant population and the traveling public. Travel proceeds from watering place to watering place, settlements are located at or near water, and consequently even the map reflects the importance of water supply. Walls Well, Bates Well, and Coyote Water are American place names; Agua Caliente and Pozo Redondo record the travel and settlement of the Spanish. Cubo, Tonukvo, and Moivavi are watering places and Papago rancherías whose equivalent names in Fnglish would be Big Pond, Ridge Pond, and Many Wells.

\section{STRFAIIS AS WATERING PLACES}

STREAMS IN GENERAL

Streams vary in importance as sources of water supply according to their size and habit of flow. In southwestern Arizona there are 
no large, permanent streams except Colorado River. All the other streams are intermittent, interrupted, or ephemeral.

\section{INTERMITTENT AND INTERRUPTED STREAMS}

Intermittent streams flow for a part of the year, usually for a month or more. This period of flow is fairly definite in its time and usually comes in the spring, after winter rains or the melting of snow, or follows the summer rains. No very large streams of this character can originate in such a region as southwestern Arizona. Such streams commonly have their headwaters either in humid regions or in large areas of mountainous country, which are not found within this portion of the arid belt. Such a stream is Gila River, which rises in the rugged and wooded Mogollon Mountains of western New Mexico. The muddy floods of this river have been a constant temptation to the agricultural speculator from the days of the primitive Pimas throughout the period of settlement by the whites.

Many intermittent streams are also interrupted-that is, they have a permanent flow over short stretches of their courses throughout the year. It is this characteristic of Gila River which has made its valley the best practicable route from the Rocky Mountains to California across the southern desert region. Throughout its length are stretches that have perennial water, and at these localities there has been more or less permanent settlement and irrigation.

The eastern section of the river valley was inhabited before the coming of the Spanish by the Pimas and their near kin, the Papagos; the western section by the Maricopas and Yumas. Irrigation enterprises along this river are described by Olberg. ${ }^{12}$

Similarly, Santa Cruz River, which rises in the relatively high mountains east of Nogales, is a more or less continuous watering place from the international boundary to Tucson. Throughout this portion of the valley irrigation was practiced by the aboriginal Sobaipuris and perhaps also by Papagos. North of Tucson there is no permanent watering place on the Santa Cruz much above its junction with the Gila, but throughout this territory a certain amount of flood-water irrigation has always been carried on. In other words, this interrupted stream, through the upper part of its course, has a small permanent flow, but in the lower part it is wholly intermittent.

Sonoita River is the only interrupted stream rising in the Papago country. Drainage from Baboquivari Valley and Quitojoa Valley proceeds by a circuitous route through the Great Plain to unite with similar ephemeral streams in Sonora to form the Sonoita. The

\footnotetext{
12 Ross, C. P., The lower Gila region, Arizona: U. S. Geol. Survey Water-Supply Paper 498, pp. 95-10s, 1923.
} 
channel is dry except for occasional floods for more than 25 miles, to a point a short distance above Sonoita, where water appears in the channel as a clear stream 12 feet wide and 1 foot deep. Thence westward for about 15 miles to Agua Dulce water flows in the channel at various places. South of Quitobaquito a float measurement made on September 30, 1917, showed a flow of 0.72 cubic foot a second, or 320 gallons a minute. West of Agua Dulce water is found by digging in the channel at Agua Salada, Las Positas, and Batamote, all in Mexico.

\section{EPHEMERAL STREAMS}

Ephemeral streams flow only during or after rains and as an immediate result of the rain. The largest of them rise on the steep and rocky sides of mountains or on the broad slopes of higher alluvial plains and form continuous drainage channels for distances of 50 to 80 miles. (See pp. 103-104.) They furnish water for drinking by man and stock for only short periods, but these periods are important, for they may permit journeys into districts that are at other times without water, and they enable stock, immediately after a rain, to spread out into territory where they are in normal times unable to graze. It is a characteristic feature of desert farming that a comparatively large amount of irrigation is carried on by means of flood waters. For this type of agriculture the conditions of aggradation that prevail in most of the valleys are peculiarly favorable. In many parts of the arid West the channels of the ephemeral streams are intrenched from 5 to 40 feet below the adjacent flood plains, making irrigation by flood waters extremely difficult. However, where aggradation is taking place, as in most of southwestern Arizona, the flood waters spread from one side to another of the narrow valleys between the hills or over vast alluvial slopes at the foot of mountains. Such sheet floods may be utilized for irrigation with more than usual success. The Papago from prehistoric time to the present has been dependent for his living upon crops raised by this method of farming. In this region ephemeral streams are therefore by no means an unimportant part of the water supply.

\section{LAKES AND PONDS}

In humid regions lakes and ponds are common. Glaciated regions are characteristically dotted with lakes. In arid regions, on the contrary, lakes are relatively rare, not because there are in such regions no sufficient causes to produce lake basins but because the

${ }^{13}$ Lumholtz, Carl. New trails in Mexico, p. 394; see also pp. 161, 200, 245, 281, New York, 1912. 
basins formed are rapidly filled up and obliterated by sediment brought in by muddy streams, or they may be but seldom filled with water by feeble streams, or they may be rapidly dried up by excessive evaporation. The chief causes of lake basins in an arid region are earth movements, the blocking of valleys by sediment brought in by tributary streams or by wind-blown sand, and the scouring out of hollows by wind erosion.

The lakes and ponds that occur in such a region are therefore important. In all southwestern Arizona the only natural water bodies large enough to be called ponds are the sloughs and shallow lakes along Colorado River. At Susuta, however, 2 miles south of the international boundary, near Camote, there is a pond about 500 feet in diameter. It lies in a circular hollow surrounded by sand dunes. The sandy clay of the surrounding plain has been excavated by the wind to a depth of 3 or 4 feet. Water collects from rainfall in the pond and on the slopes of the adjoining dunes. The principal source is, however, water that falls as rain on the sand of the dunes and percolates through the sand to the pond. Surrounding the water is a

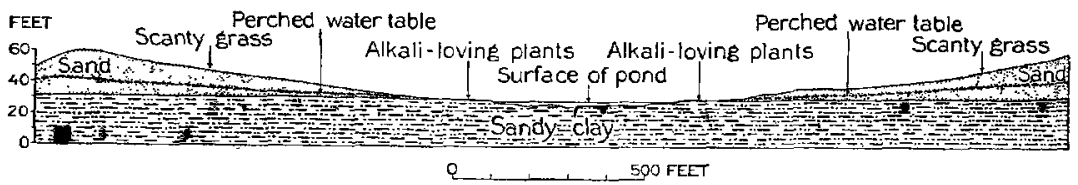

Fraune 20.-Cross section throngh the northern pond at Susuta, Sonora

belt of alkaline soil with characteristic alkali-loving plants, the concentration of alkali salts being due to the continual evaporation of this seepage at the base of the dunes. These relations are shown in Figure 20.

\section{CHARCOS}

In the Papago country the term "charco" is applied to natural water holes in adobe flats and washes, but in other parts of the Southwest the same type of water hole is called a "mudhole" or "mud tank" or is not distinguished from other types of tanks or "tanques." "Charco" is a Spanish word signifying a pool of standing or stagnant water and has the advantage of being a distinctive name. The word "tank" may be reserved for a natural reservoir in rock.

Charcos are found as single pools or a series of pools along streams that deposit fine-grained material, usually sandy clay or adobe. They vary from shallow pans 18 inches wide by 6 feet long to depressions 5 to 6 feet deep, 15 to 30 feet wide, and more than 1,000 feet long. (See Pl. XVI, A.) 
The adobe flats in which charcos occur are the result of sedimentation from flood-water streams that spread as a thin sheet of water over large tracts of country and deposit mud as sediment. This process produces smooth plains that have a gentle slope in the direction of the drainage and are generally unmarked by channels or at most have very insignificant channels 2 to 5 feet wide and a few inches deep. In places where the current is exceptionally swift, however, part of the mud laid down by past floods is removed and a relatively large channel is formed. It is characteristic of these channels that they begin with a series of little mud cliffs, 6 to 18 inches high, which lead down to numerous small channels and rill marks chat combine into a single channel which pursues a somewhat sinuous course in the direction of the drainage and finally ends more or less abruptly, perhaps, in a vertical wall 3 to 5 feet high. It is evident that concentration of the current of a flood that normally spreads in broad sheets over the flat digs the original channel, and movement of water into this channel toward the end of the flood or during minor floods causes erosion of the fanlike set of miniature canyons at the upper end (Pl. XVI, B). The lower end of the channel is fixed at a place where the current again becomes less swift owing to the spreading of the flood to occupy a larger cross section. The channels thus formed are depressions below the general level of the adobe flats, and water may remain in them after the passage of the flood. Whether water does so remain depends upon the porosity of the bottom of the channel. If the channel has been eroded below the adobe to some bed of sand or fine gravel, water will easily drain away underground. If, however, the channel is entirely in the usual fine-grained, claylike adobe, water will seep away more slowly. The principal losses will then be from evaporation or, in some circumstances, from use by stock and wild animals.

In this fashion the larger charcos are formed. The smaller ones, however, usually occur along some relatively small stream that spreads out over part of its course in a small flat. These flats, many of which are grassy, are as a rule only a few feet wide and a few yards long. Channel cutting of the kind previously described sometimes takes place in these flats, and many of the smaller charcos seem to be due to a breaking of the grass cover which allows erosion to take place over a very small area. Other holes seem to be due almost wholly to the activities of animals, both wild and domestic, which come to feed in the flat immediately after the rain. Very shallow pools of water attract them; they drink the muddy water. roll in the mud, and trample and compact the bottom. Thus a somewhat deeper hole is formed which, when the next rain comes, will hold water for a longer time, and thereby undergoes the same 
processes for a longer period. The maximum depth below the surface that may be thus attained seems to be about 2 feet.

In South Africa Passarge has found large basins which seem to be due wholly to the activities of animals. He has called the process of formation zoogenous erosion. The animals are rhinoceroses, elephants, buffalo, and wild hogs, whose size and weight, being greater than those of Arizona animals, probably make possible the greater depth and size of the African basins. ${ }^{14}$

The larger charcos are, however, the only ones of great importance to travelers, because only these hold sufficient water to last for more than a few days after a rain or are relatively permanent in position from year to year. Generally, even the largest charco is never quite full, holding not more than 3 or 4 feet of water. When one of these large charcos has once been formed it tends to be relatively long-lived, for the trampling of animals protects its bottom from seepage, in the same fashion that the bottom of a reservoir is puddled, and this trampling also increases the resistance to erosion of the bed of the charco. The trails which animals make in going to and from water are usually 3 inches to a foot deep and tend to turn the water toward the charco. However, a change in the main current of the flood waters may leave the charco on the edge of the floods, where it is very likely to become gradually filled up and obliterated. There are certain localities where a charco will be recurrent because floods are normally constricted in this part of their course. Such places are common along the foot of some isolated hill in an alluvial plain near the main flood channel. A somewhat similar rocky projection of the wall of a valley will produce the same result. If for any reason the charco is temporarily filled up, a new one will form within a short distance.

Still other charcos are formed by the natural damming 'of the channel in an adobe flat. The mud hole near the Brush Corral in the Vekol Valley is due to the damming of the narrow channel of the main drain of the valley, at the lower end of a grassy flat, by coarse gravel and sand brought in by a tributary stream. The lower end of this narrow channel remains full of muddy water after a flood and forms a charco.

\section{ROCK TANKS}

\section{DEFINITION}

A rock tank is a watering place consisting of a cavity or depression in rock which fills periodically with rain or flood water. Most Mexicans and many Americans use the Spanish word "tinaja," meaning a bowl or jar, in speaking of a rock tank. In Egypt rock

14 Passarge, Ṡiegfried, Die Kalahari, p. 660, Berlin, 1904. 
tanks are.known by the Arabian name "galt." 15 In the Algerian" Sahara the Arabian words "r'dir" and "guelta" and the Berber equivalent "aguelman" are used for rock tanks..15a In Australia somewhat similar tanks are called "gnamma holes," and explanations have been offered for their origin differing in detail from the explanations given in the following paragraphs. ${ }^{16}$ These cavities may occur either away from stream channels or in stream channels.

ROCK TANKS AWAY FROM STREAM CHANNALS

In mountains or hills small rock pockets are found which are due to the unequal weathering of rock surfaces. They range in size from depressions a few inches across and half an inch deep to pans 5 to 20 feet across and 6 to 8 inches deep. In northern Arizona tanks of this kind have been found on the plateaus east of Lees Ferry and attributed to wind erosion. ${ }^{17}$ Such pockets hold water for longer or shorter periods after a rain. They are of little value as water supplies, yet the experienced hunter and traveler knows well how to take advantage of these tanks for the few hours or days when they hold water.

\section{ROCK TANKS IN STREAM CHANNELS}

The largest rock tanks are those due to irregularities in the rocky beds of streams, which hold pools of water after floods. These irregularities are produced by eddies of the current, which tend to erode the stream bed unequally. They are probably no more common in ephemeral streams than in the permanent streams of humid countries. The beds of ephemeral streams are, however, exposed throughout their length during the greater part of the year, and on this account undrained hollows or depressions in them are easily found.

The common depressions are of five types-joint-block cavities, scour depressions, riffle hollows, potholes, and plunge pools. (See fig. 21.)

\footnotetext{
${ }^{18}$ Ball, John, The geography and geology of southeastern Figypt, p. 240, Egypt Survey Dept. (Min. Fin.), 1912.

15a Gautier, E. F., Sahara algérien, in Gautier, E. F., and Chudeau, R., Missions au Sahara, vol. 1, pp. 15-16, 1908 .

18 Talbot, H. W. B., The country * * * embracing parts of the Northern Coolgardie and East Murchison gold fields: Western Australia Geol. Survey Bull. 45, pp. 38-39, 1912. Maclaren, Malcolm, Notes on desert water in western Australia: Geol. Mag., new ser., dec. 5, vol. 9, pp. 301-304, 2 figs., 1912. Woodward, H. P., A geological reconnaissance of a portion of the Murchison gold fleld: Western Australia Geol. Survey Bull. 57, pp. 33-35, 1914. Jutson, J. T., Note on the "dimpling" of granite hills in subarid western Australia: Roy. Soc. Victoria Proc., new ser., vol. 33, pp. 108-110, pl. 5, 1921.

${ }^{17}$ Bryan, Kirk, Wind erosion near Lees Ferry, Ariz. : Am. Jour. Scl., 5th ser., vol. 6, pp. 299-301, 1923.
} 
Most rocks are divided into blocks by sets of intersecting fractures or joints. The impact of the current and of the sediment which it carries tends to break out blocks of rock in the stream channel. This process of plucking results in irregularities of the stream channel, as shown in Figure $21, \mathrm{~A}$. Where the joints are widely spaced the blocks are large, and the cavities are correspondingly large. Closely spaced joints, however, produce a rough but comparatively even-floored channel. It is obvious that very wide spacing of joints will produce joint fragments too large to be easily removed and that for any stream there is an optimum spacing of the joints that will produce the maximum roughness of channel floor. In these cavities water remains after a flood, but few of them are of great importance as watering places. Commonly the

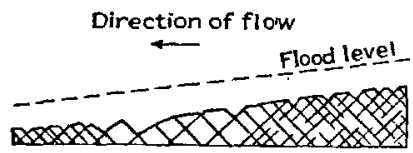

A Joint-block irregularities

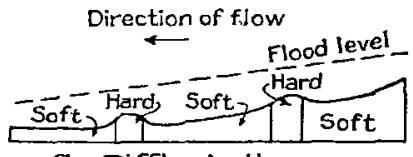

C Riffle hollows
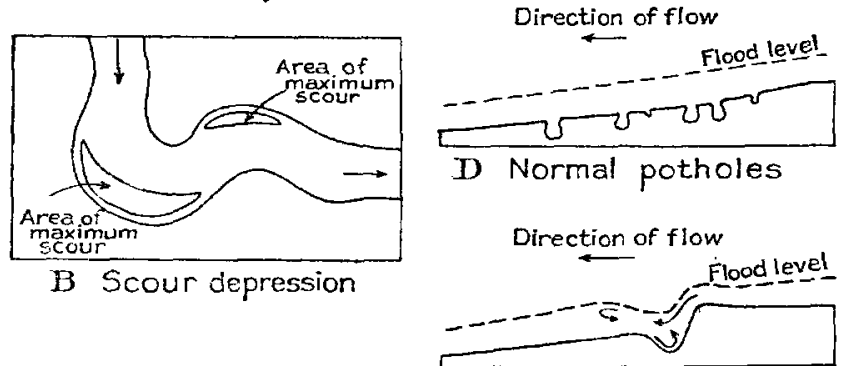

E Plunge pools

Frgure 21.-Diagram showing five types of depressions in channels

process of joint-block plucking is combined with the processes detailed in the following paragraphs. A favorable spacing of joints is essential for the production of the larger rock tanks. The fractures must also be water-tight or nearly so in the bottom and walls of the tank, else the water will drain away rapidly. In some tanks it is evident that joints on the upper side of the cavity are open and that through them small amounts of water seep into the tank for short periods after floods.

Where the channel of a stream is curved the swiftest thread of the current is near the outside of the bend. The maximum erosive force of the current is exerted over a crescentic area in the bend, as is shown in Figure 21, B. Such an area is likely to be scoured below the grade of the stream, producing a hollow of the type here called scour depressions. In combination with joint-block plucking and the formation of potholes this scouring process is likely to 
form good-sized tanks in hard rock. A scour depression in relatively soft hardpan appears to be the cause of one of the water holes in the Vekol Valley, Maricopa County (fig. 22). This consists of a hollow at the point of an elbow in the sandy channel of the stream. A cavity in the underlying hardpan holds water after a flood. The pool of water is 6 by 4 feet, 2 feet deep, and lies under the bank. Seepage from the sand of the stream channel and from the sandy clay of the banks maintains the water for a considerable time after adjacent charcos have dried up. The water does not last very long, for the level fell $1 \frac{1}{2}$ feet between September 20 and September 22, 1917.

Riffle hollows occur where the bed of a stream is composed of alternate layers of hard and soft rock, as illustrated in Figure 21, C. Erosion of the softer rock is carried below the grade established by the harder rocks, which project in the stream bed and constitute obstacles to the stream flow. Such hollows are commonly from 3 to 12 inches deep and vary in size according to the spacing of the

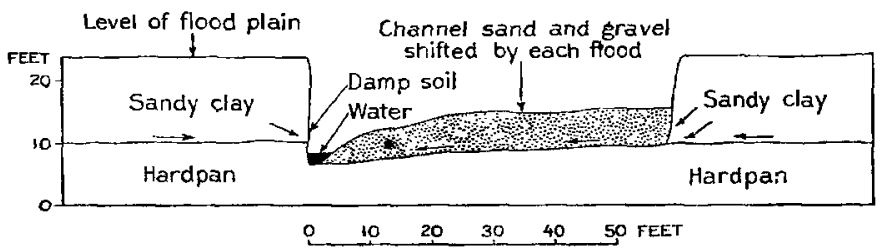

Figure 22.--Cross section of the stream channel and water hole in the Vekol Valley, Ariz.

harder portions of the rock in the stream bed. Riffle hollows make very shallow pools unless they are deepened by pothole action or unless they grade into plunge pools.

A pothole is formed by the grinding or drilling of an original hollow in a stream bed by sand, pebbles, or boulders rotated by the current. The top of a pothole is nearly circular, and the diameter generally increases below, as shown in Figure 21, D. The diameter may range from 3 inches to 10 feet or more and the depth from 6 inches to 8 feet or more. ${ }^{18}$ Potholes are developed in all streams that are actively eroding their channels in consolidated rocks, but they are more likely to be found in gorges and below waterfalls. They are thus associated with and grade into plunge pools.

A plunge pool is formed by the impact of water and the sand and gravel which it carries at the foot of a waterfall (fig. 21, E). A fall differs from the changes in grade of a stream bed described in connection with riffle hollows in that it is usually high enough to cause a flexure in the flood surface of the stream. Consequently, a very

${ }^{18}$ Elston, F. D., Potholes, their variety, origin, and significance; Sci. Monthly, vol. 5, pp. 554-567. 1917 ; vol. 6, pp. 37-51, 1918. 


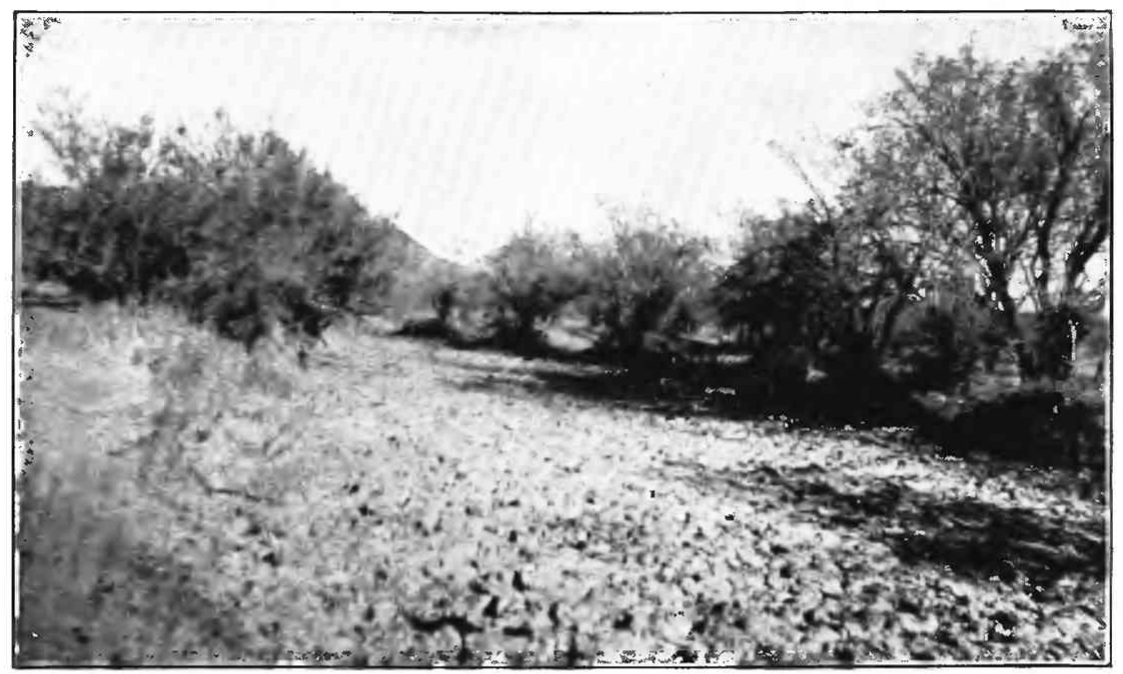

A. CHARCO NEAR POZO REDONDO

The cattle-trampled water hole has been dry about a month

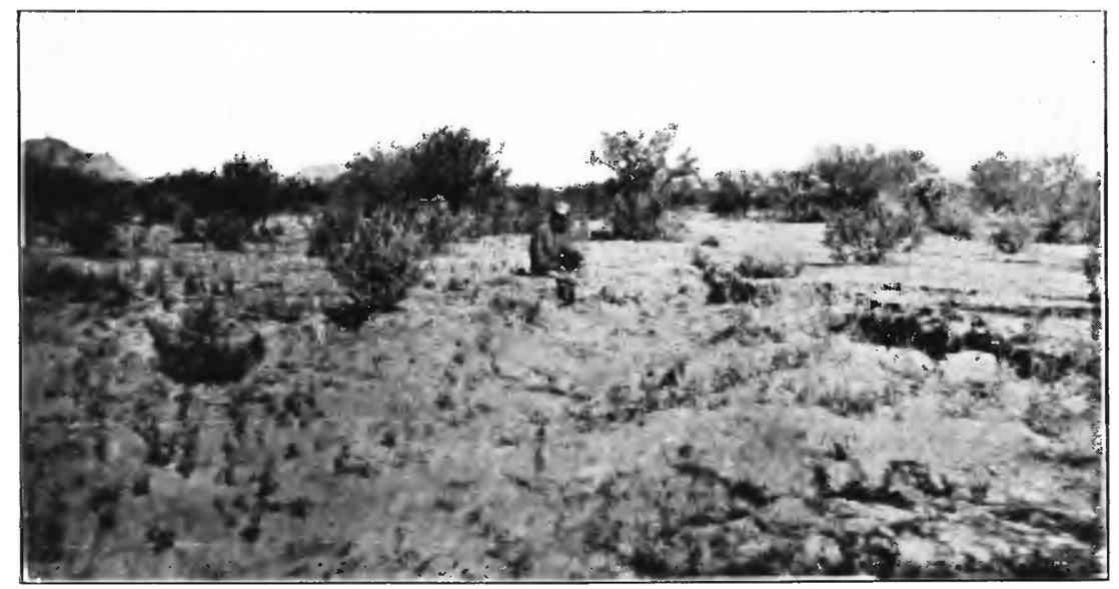

B. MINIATURE CANYONS NEAR HEAD OF CHARCO, LA QUITUNI VALLEY 


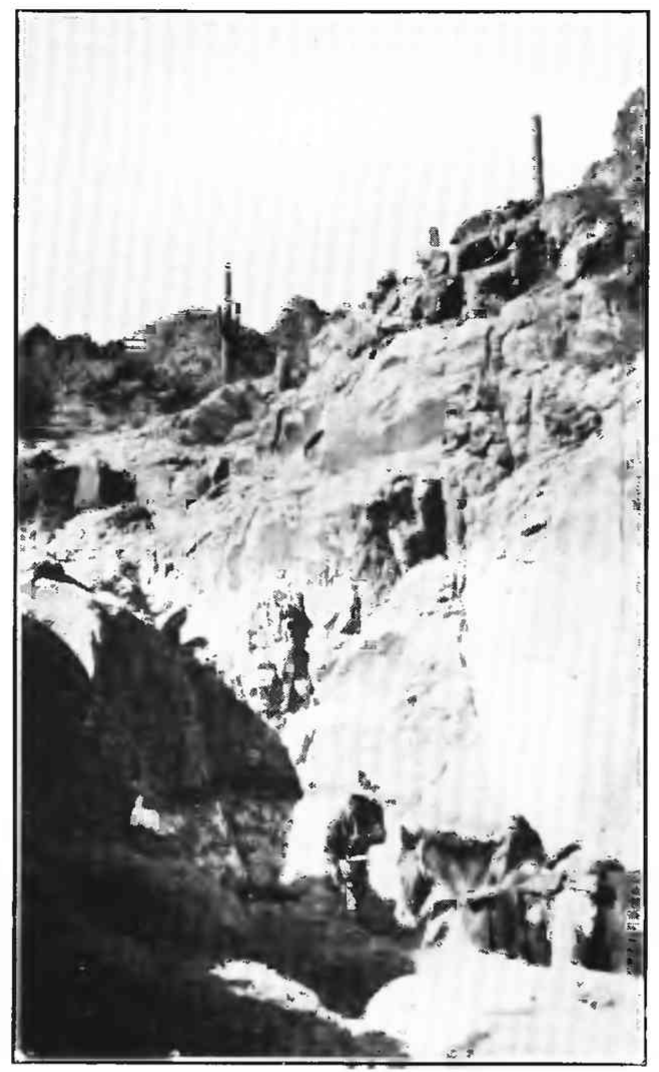

1. BLACK TANKS

John Merrill watering his horse in the nearly empty tank

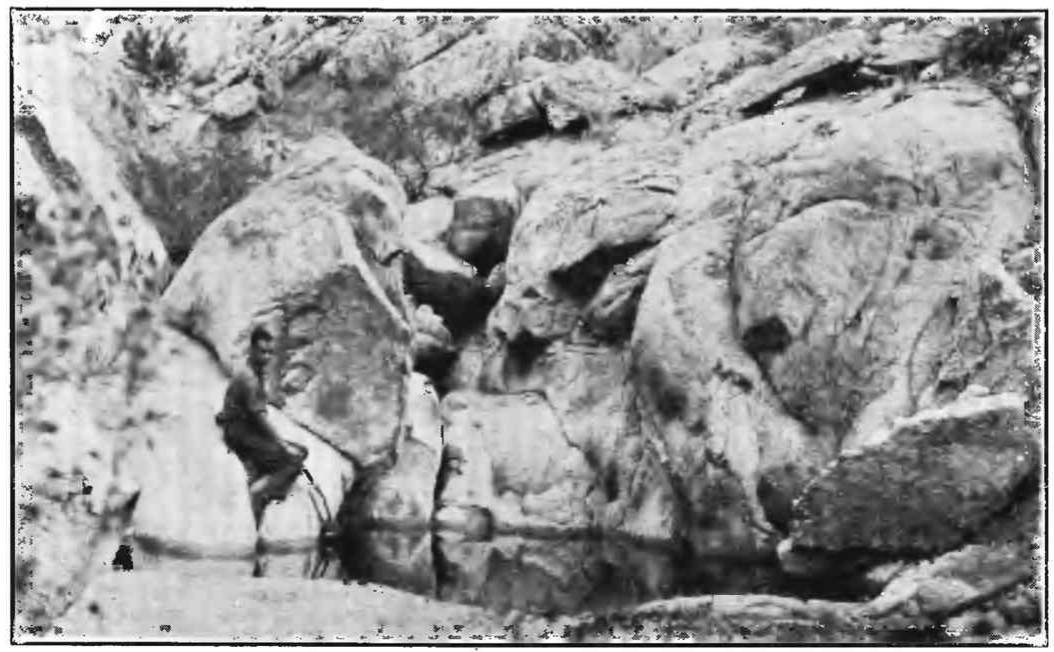

B. TULE TANK ABOUT A WEEK AFTER A RAIN 


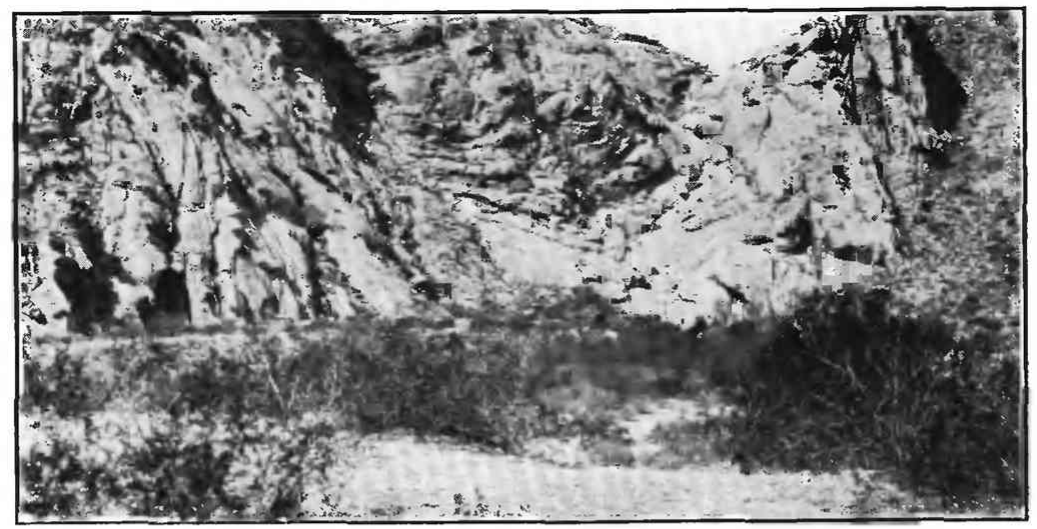

A. TINAJAS ALTAS

View of the falls from the terrace in the cove, showing the steep section of the stream in which the tanks occur

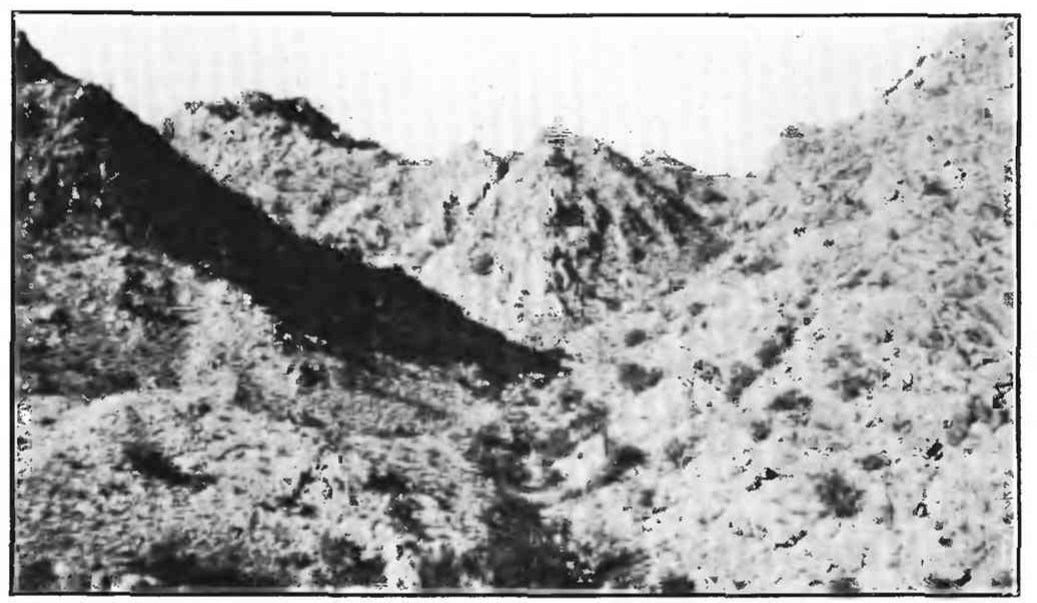

B. OPEN MOUNTAIN CANYON ABOVE THE FALLS AT TINAJAS ALTAS Photograph by C. G. Puffer

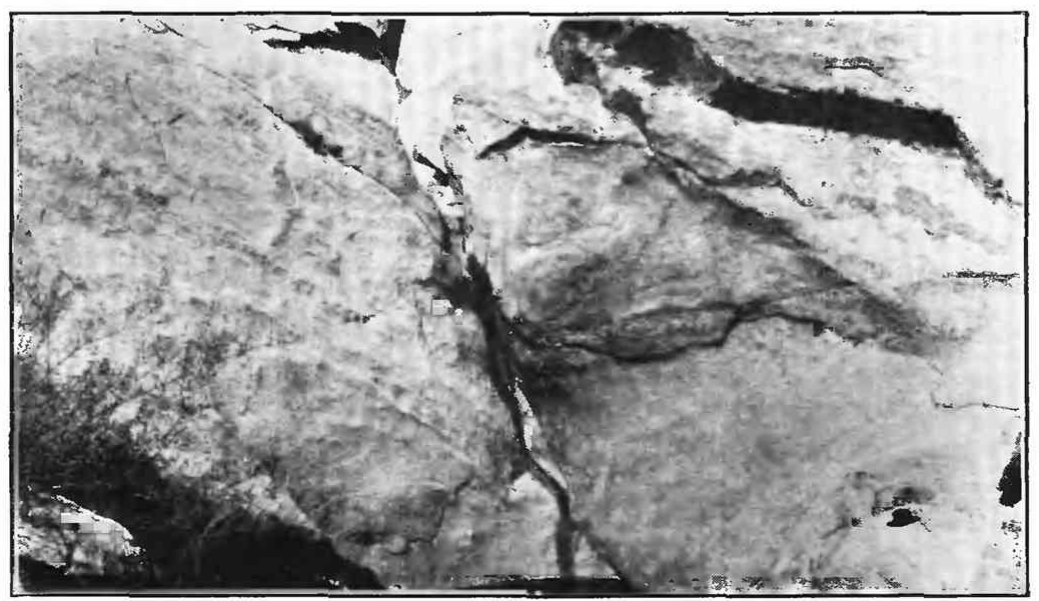

C. THE LOWER TANK AT TINAJAS ALTAS ABOUT A WEEK AFTER A RAIN

Note trickle of water entering tank from joint crack 


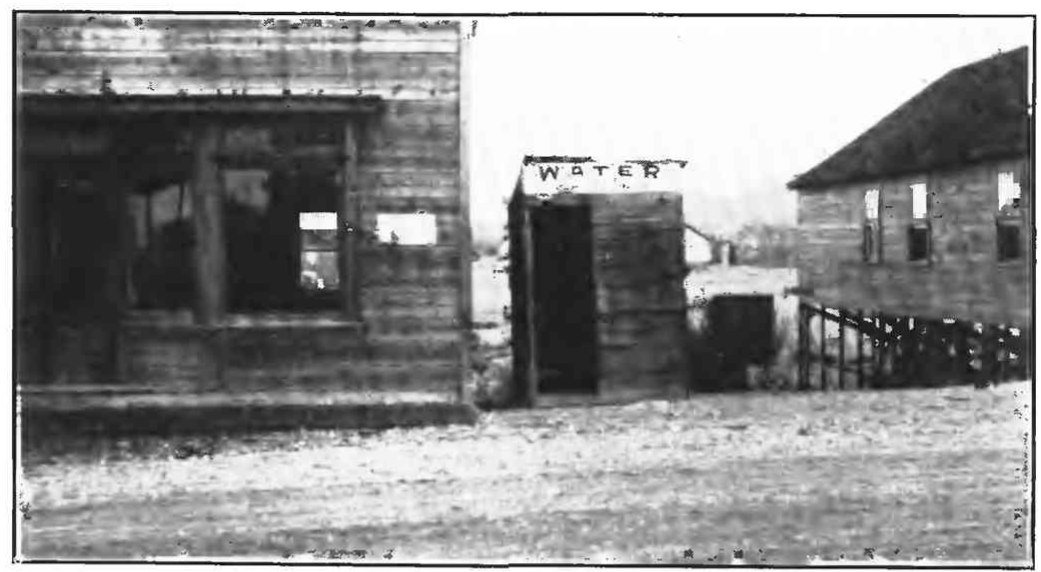

A. STAND FOR SELLING WATER ON MAIN STREET OF CLARKSTOWN

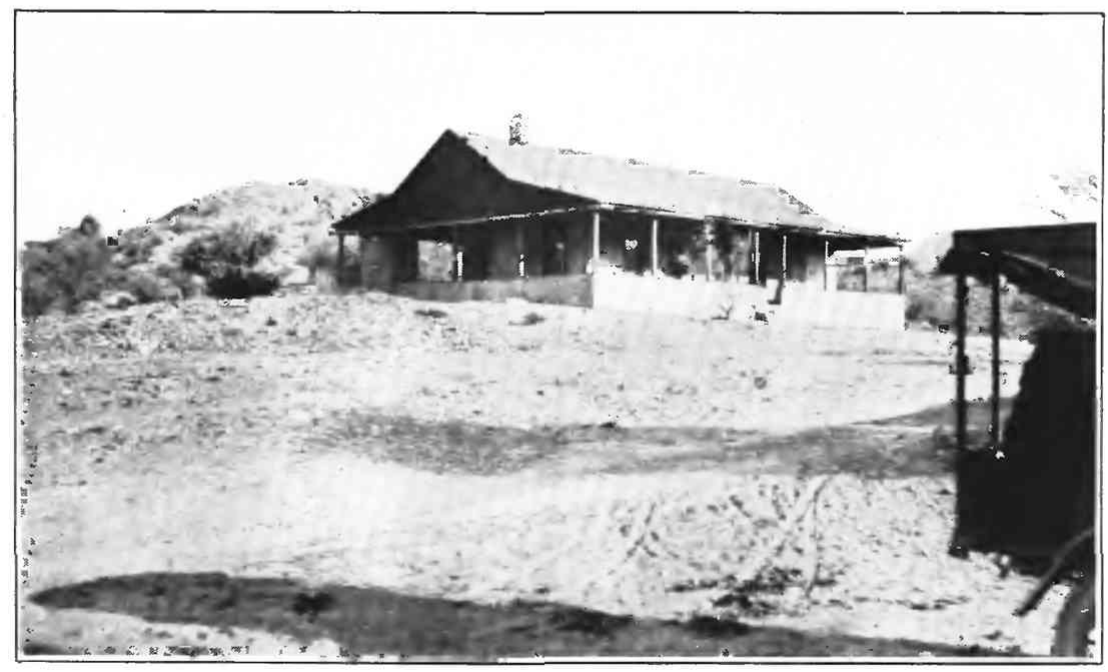

B. HOUSE IN OLD AJO

Showing spacious riof, equipped with gutters to catch rain water, and metal tank into which the gutters drain 
great velocity, accompanied by eddies and back currents, is present at the foot of the fall. The erosive effect at the foot of the fall increases with the discharge of the stream in flood and the quantity and character of the sediment carried. Streams of the size common in southwestern Arizona are competent to erode pools about 10 to 20 feet in diameter and 3 to 10 feet deep. The shape of the pool depends on the character of the rock and the amount of modification due to joint-block plucking and pothole formation. Plunge pools form the largest type of channel irregularity and consequently hold the largest pools of water. Most of the larger rock tanks are of this class.

\section{PHYSIOGRAPHIC RELATIONS OF ROCK TANKS}

From the foregoing discussion it is obvious that the largest rock tanks are plunge pools at the foot of falls, and that even channel depressions of the other type are likely to be larger in the parts of a stream near falls and rapids. The factors governing the occurrence of falls are thus of importance. Falls are found in southwestern Arizona at localities of at least three types-where there are marked differences in the ability of adjacent parts of the rock to resist erosion; where dissection of a mountain pediment on a new grade produces headwater falls; and where renewed uplift of fault-block mountains produces falls on a stream that crosses the fault line.

FALLS DUE TO DIFFERING RESISTANCE OF ROCKS TO FROSION

Falls due wholly to an unusually resistant rock were found in only one locality in the Papago country and on a minor scale; but the site of falls due to other causes-may be determined by a resistant bed. as in the lower falls of Baker Tanks, southeast of Wellton, Yuma County. The variety of circumstances surrounding tanks and the association of tanks of different types is well illustrated by this watering place. The tanks are in a streamway that leads in a northwesterly direction on the southwest flank of the Baker Peaks. Below the tanks the stream channel lies in a small canyon 150 feet wide and about 25 to 30 feet deep. Above the tanks the channel is but 2 to 3 feet below the adjacent plains. Between these two parts of the stream is a stretch of falls and rapids about 1,000 feet long, which is shown in Figure 23. The rock in which these falls occur is a coarse arkosic conglomerate, which strikes $\mathrm{N}$. $77^{\circ} \mathrm{W}$. and dips $65^{\circ} \mathrm{SW}$. The bulk of the material is a granitic débris with pebbles one-eighth to one-half inch in diameter. The rock is banded and cross-bedded and contains many large boulders, singly or in groups and lenses. The boulders are from 3 inches to 3 feet in diameter and are more or less rounded joint fragments of granite and gneiss. The 
bedding is massive, but there are numerous joints, some of which are slickensided.

Since its deposition the conglomerate has been tilted and eroded so that its cut edges now form part of the pediment of the adjacent Baker Peaks. As in other parts of southwestern Arizona, the pediment is dissected. Headwater cutting of a new canyon by the stream is the cause of the falls. As shown in Figure 23, there is a narrow gorge in the conglomerate beginning 150 feet southeast of the windmill. In this gorge are falls and rapids. From the windmill west for 150 feet is another narrow gorge from 10 to 20 feet wide with walls 10 feet high, the bed of which is a plunge pool. This is filled with coarse sand to a depth said to be more than 20 feet. The windmill

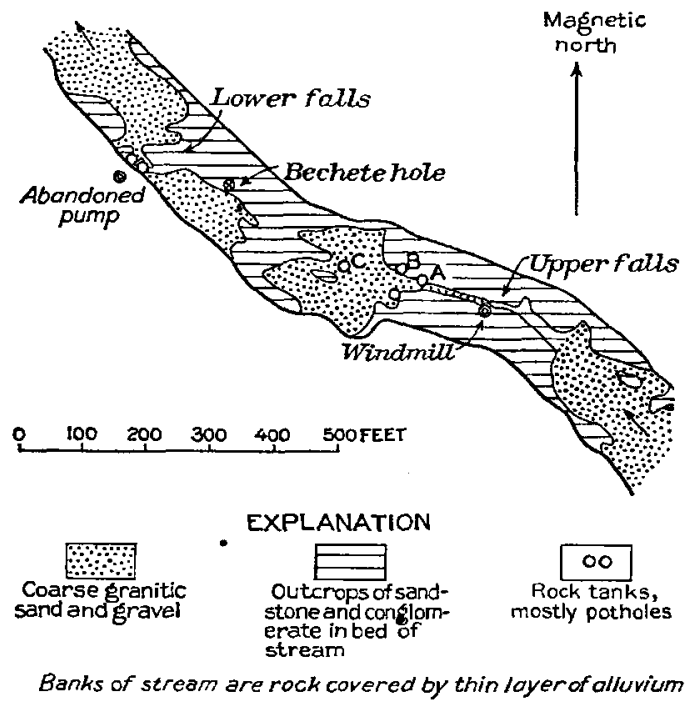

Fioure 23.-Sketch map of Baker Tanks, Ariz.

pumps water from a pipe sunk in the sand. At the lower end of the little gorge, at the points marked $\mathrm{A}$ and $\mathrm{B}$ in Figure 23, are potholes, about 3 feet in diameter, developed along joint planes. Below the gorge is a flat about 500 feet long, which ends in a second fall. The flat has an irregular rock floor, the hollows in which are covered with sand. These hollows are due to irregular erosion. At the point marked $\mathrm{C}$ there is a hollow somewhat deeper than the others in which water may usually be found by digging away the sand.

The second or lower fall is about 6 feet high and is caused by two beds of very coarse conglomerate that resist erosion somewhat better than the rest of the rock. The downstream bed of coarse conglomerate has been largely cut through; the upstream bed has been cut at only one point, near the abandoned pump. At this place two very perfect potholes about 10 feet in diameter have been formed at one 
side of a narrow gully in the rock. Each holds about 4 feet of water, though the total depth of each is about 10 feet. Below the fall is a plunge pool covered with sand, in which water can be found by digging.

The influence of a notably soft rock in the production of falls is shown at Tabaseca Tank, ${ }^{19}$ which lies in an arroyo that drains the northern flank of the Chocolate Mountains in sec. 31, T. 7 S., R. 14 E., San Bernardino base and meridian, Riverside County, Calif. The arroyo lies in a narrow gully about 10 feet below the level of the surrounding plain, which is part of a slope cut on rock and extending along the front of the mountains. The plain is underlain by rhyolite, which, in the vicinity of the tank, is broken along a fault plane that crosses the stream and dips upstream about $25^{\circ}$ (fig. 24). Shearing and decomposition by water percolating along the fault plane have changed the originally hard rhyolite to soft, claylike gouge about 1 foot thick. The gouge of the fault in its slight resistance to stream

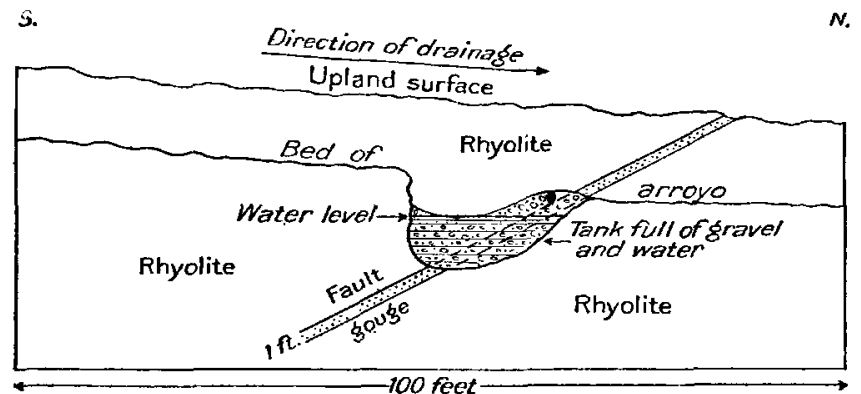

Figure 24,--Section along stream channel at Tabaseca Tank, Riverside County, Calif.

action is similar to any other soft rock. As the stream cuts down its bed the triangular block on the upstream side is constantly undermined by the ease with which the clay gouge is eroded. With the waterfall once initiated, the formation of a plunge pool is made easy by the presence of the soft layer, and the channel is excavated below grade. The pool is about 20 feet in diameter and is filled with gravel and boulders. Water is found in the gravel throughout the year unless campers have drawn too heavily on it.

FALLS DUE TO CHANGES IN STREAM GRADE

The pediments of this region, described on pages 93-97, are generally dissected. Straight-walled narrow canyons have been cut by most of the streams issuing from the mountains. (See pp. 99-101.) These little canyons increase in length by headward erosion. At the head of each little canyon is a fall or rapids which marks the separa-

w Brown, J. S., The Salton Sea region, Calif.: U. S. Geol. Survey Water-Supply Paper 497, pp. 248-249, 1923. 
tion between the old grade and the new. These relations are brought out in the accompanying diagram (fig. 25).

As each stream that heads in the mountains suffers such a change in grade there are many falls. Though not every fall produces a plunge pool large enough to make an effective watering place, the prevalence of falls due to the dissection of the mountain pediment

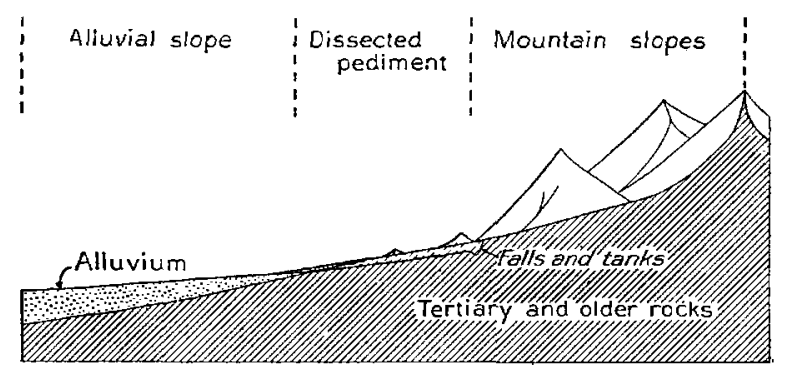

Figure 25.-Diagram showing the production of falls and tanks by erosion of inountain pediment on a new grade

is the principal reason for the large number of rock tanks in the desert region. The local conditions at each fall determine the size and effectiveness of the plunge pool and associated potholes as watering places. The variety of these conditions can best be illustrated by an example.

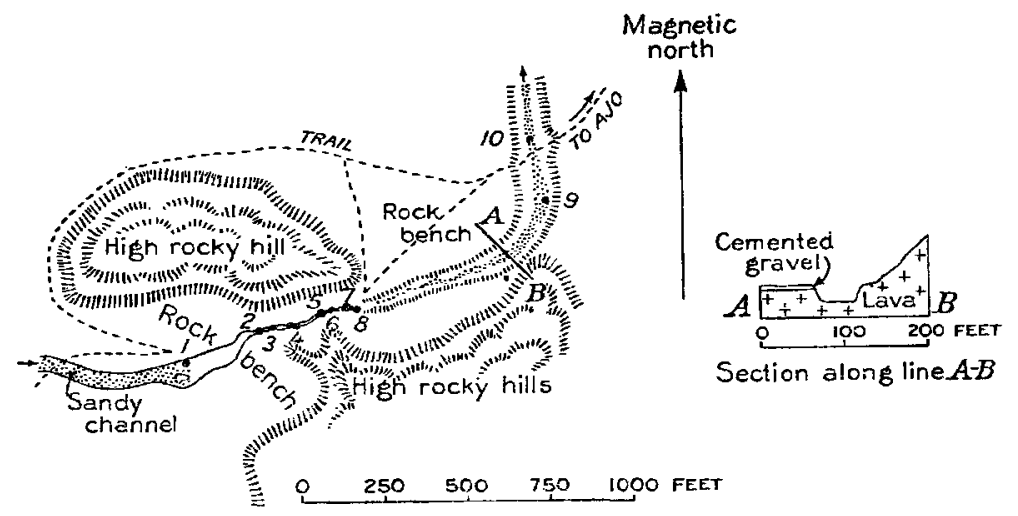

FIgURE 26.--Sketch map of the Black Tanks, Crater Mountains, Ariz.

Black Tanks (Plate XVII, $A$ ) is a well-known watering-place in the Crater Mountains. The tanks consist of a series of plunge pools, numbered from 1 to 8 in Figure 26, with two very temporary water holes, marked 9 and 10. The stream has a sandy bed about 2 feet below its flood plain in the open valley above and west of the tanks. Below the falls section, with its eight tanks, the stream flows in a steep-walled gully with banks from 10 to 20 feet high. The falls and rapids extend about 500 feet, with a total drop of about 50 feet between the upper and lower channels of the stream. 
Throughout this stretch the stream runs in a rocky gorge of variable width. The individual falls are determined by the resistance of the horizontal layers of lava that form the bedrock. The larger plunge pools are from 4 to 5 feet deep and 10 to 15 feet wide. On either side of the channel is a rock bench that ranges in width from 50 feet to several hundred feet. This bench slopes gently upward to the foot of the steep slopes of the hills (fig. 26, cross section). On the north side of the stream below the tanks the bench is covered with 2 to 3 feet of cemented gravel. The rock benches extend around the hills and are continuous with similar rock benches that connect with the mountain pediment. It is evident that Black Tanks are the headwater falls of the new canyon that is working headward in an old valley with gentle slopes, which was formed at the same time as the neighboring sloping plain or mountain pediment and forms part of it. Baker Tanks (p. 127) and many others belong to this type.

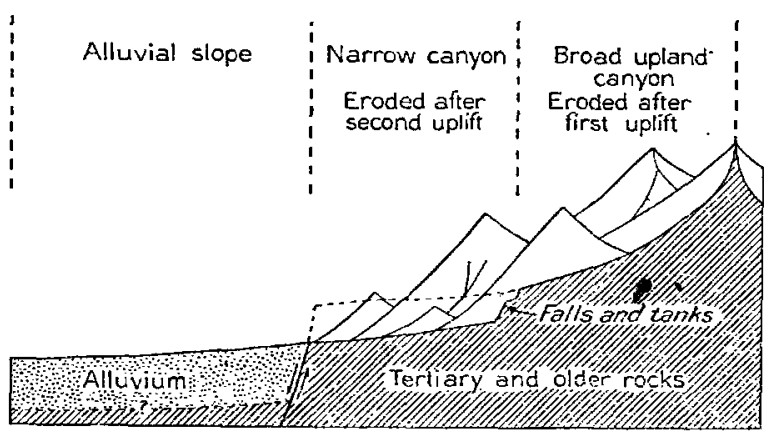

Fysyes 27.-Diagram showing production of falls and tanks by renewed uplift of eroded fault-block mountains

\section{FALLS DUE TO RENEWHD UPLIFT}

Most of the mountains of southwestern Arizona are narrow uplifted strips of the earth's crust bounded by faults on one or both sides. After each uplift streams cut canyons and established smooth grades from the crest of the mountains to the adjacent valleys. In certain ranges renewed uplift took place on one side of the mountains only, probably along the same fault plane on which the original uplift occurred. This uplift resulted in flattening the old stream grades in the higher part of the mountains and produced a cliff or fault scarp across the stream channels on that side of the range. Streams immediately began to cut headward through this fault scarp, and it has generally been' removed. However, in certain ranges, the Sierra Estrella and the Tinajas Altas Mountains in particular, the new grade has not yet reached the crest of the range and is separated from the old by falls, as illustrated in Figure 27. 
The famous Tinajas Altas (Pl. XVIII, $A$ ) is the only watering place that can be definitely ascribed to this cause, but it is thought that a number of other tanks, including Tule Tank (PI. XVII, $B$ ) and Heart Tank, were probably formed in the same way.

Schrader ${ }^{20}$ has noted a number of rock tanks on the east flank of the Sierra Estrella at altitudes of 2,000 to 3,000 feet. The topographic map of the Maricopa quadrangle shows that in a number of these canyons the stream grade between altitudes of 1,500 and 3,000

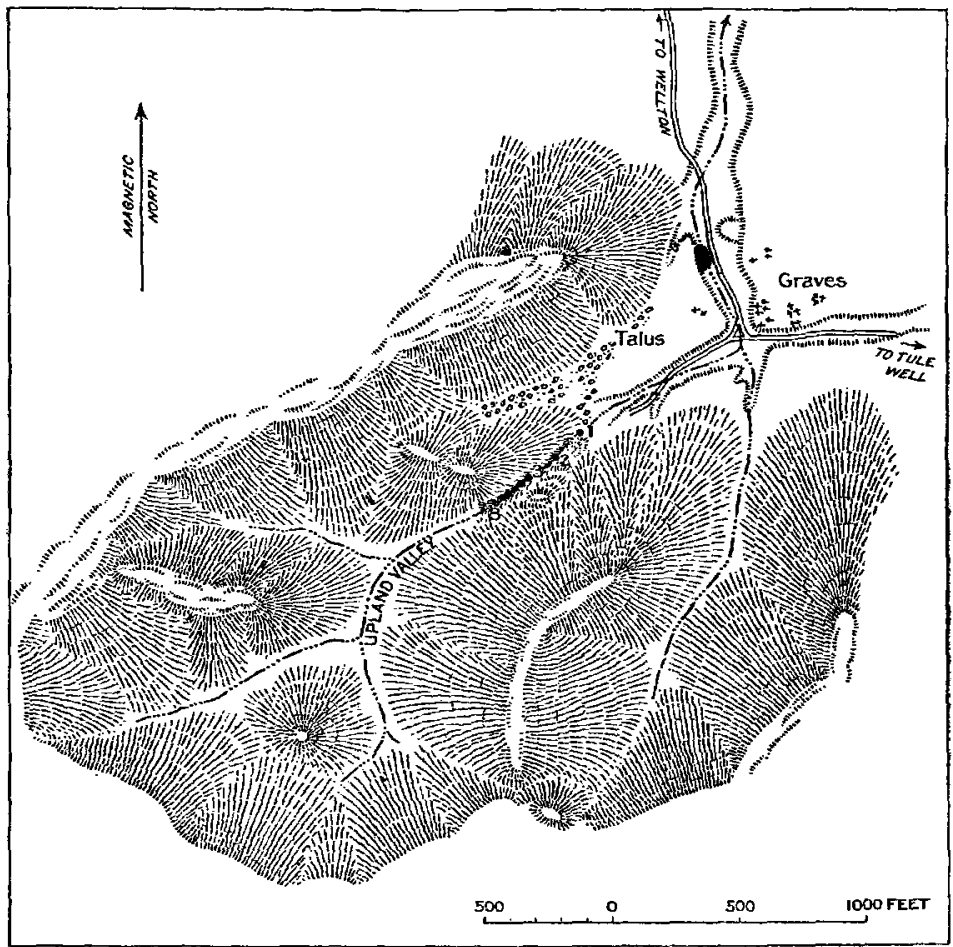

FIGure 28.-Sketch map of Tinajas Altas. From plane-table sheet by Kirk Bryan and sketch by C. G. Puffer

feet is so steep as to give rise to almost continuous falls. Above 3,000 feet the grade is flat and the canyon is wide, with gentle slopes. There is thus good evidence that the Sierra Estrella has been rejuvenated by block faulting, and that the tanks are plunge pools and potholes associated with falls due to the dissection of the fault scarp.

The Tinajas Altas (see pp. 413, 421) consist of eight tanks, distributed for 500 feet along a stream course so steep that it may be considered an almost continuous series of falls. The map in Figure 28

20 Schrader, F. C., report on the Gila River Indian Reservation, Ariz., as to the mineral or nonmineral character of its lands, 1918 (unpublished manuscript in files of U. \$. Geol. Survey). 
shows that the falls occur in an indentation of the mountain front and that a considerable drainage area lies above the falls. This upland valley, as shown in Plate XVIII, $B$, has relatively gentle slopes, and the grade of the stream through it is in marked contrast to the grade in the falls section, which is approximately 1 to 1 . The rock of this part of the mountains is a coarse pegmatitic granite. Most of the surfaces are stained brown from the deposition of limonite, especially in the cove of Tinajas Altas. In such places there are many caves, reentrants, and pinnacles, which add much to the pictur-

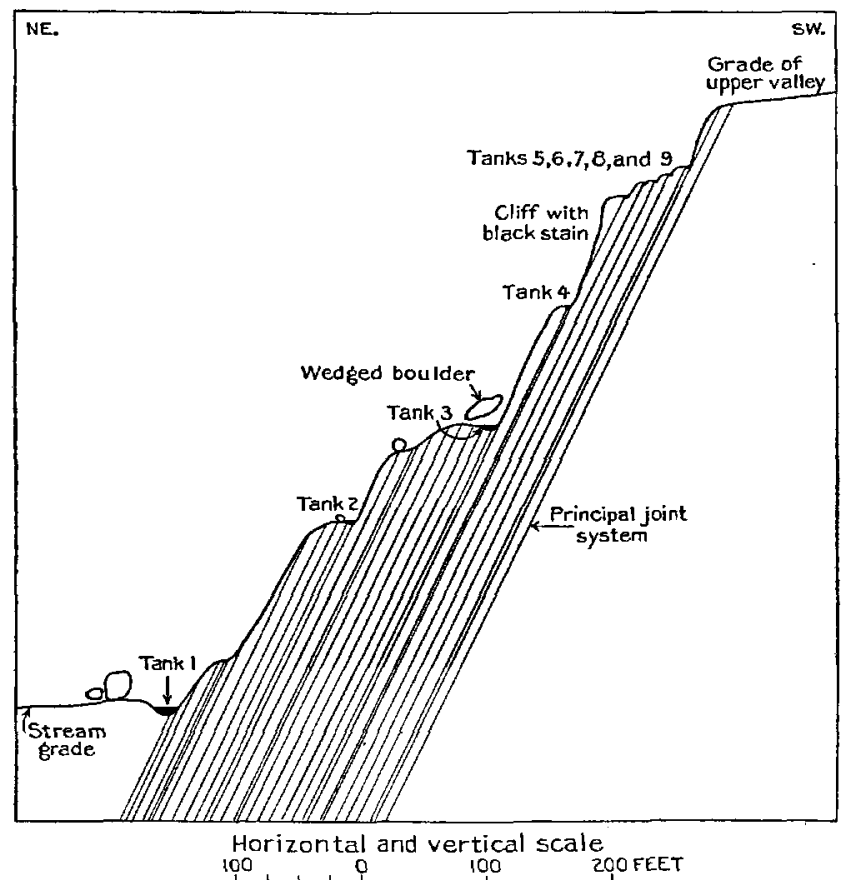

FrGURE 29.-Diagrammatic profile of falls of Tinajas Altas

esqueness of the mountain slopes. The details of the falls and the form and location of the plunge pools are largely affected by the joints of the granite. The master joints strike N. $2^{\circ} \mathrm{E}$. and dip $65^{\circ} \mathrm{NE}$., and they divide the granite into great slabs from 2 to 10 feet thick. A less perfect system has a strike N. $80^{\circ}$ E. and an almost vertical dip. The profile of Figure 29 is made from the plane-table location of the tanks and an aneroid determination of the altitude of the top of the falls by C. G. Puffer. It shows that in general the falls are parallel to the dip of the joints and that the plunge pools occur at places where the joints are closely spaced. In plan, also, the course of the stream is controlled by the joints, as 
shown in Figure 30. The steepest grades are parallel to the minor: joint system, and the flattest grades to the master joint system. The plunge pools are on the steps developed at the intersections of the joints. The lower tank (No. 1 in fig. 28; see 'also Pl. XVIII, $C$ ) fills with sand after a flood, and therefore the water lasts longer than in the others. It seems likely also that a considerable quantity of water is fed to this tank by seepage from the joint cracks in the granite, as shown in Plate XVIII, $C$. The second tank is accessible by climbing along a cable fastened to the rock about 75 feet south of the channel. The position of this tank is marked by the round boulder shown in Plate XVIII, $A$. From the second tank the third is easily reached. The fourth and higher tanks are very inaccessible and are little used except by mountain sheep, many of which fall into the water and drown.

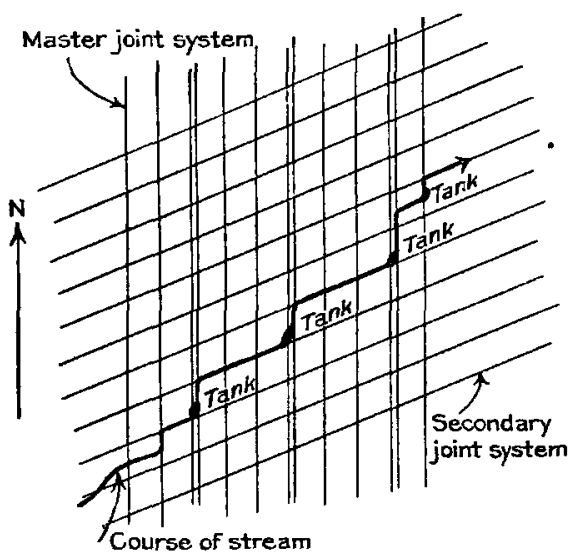

FIGURE 30.-Idealized diagram to show effect of joint system on course of stream and position of tanks at Tinajas Altas

\section{SAND TANKS}

Sand tanks are a variety of rock tanks, formed in stream channels in the several ways above outlined and differing from other rock tanks only in being filled with sand. They are produced when the tail end of a flood carries sufficient sand to fill the cavity; when the later part of the flood is relatively clear the rock tank contains little sand. The sand thus deposited is saturated with water. The upper portion quickly dries, but because the pore spaces between the grains are relatively large and capillary action is unable to bring the water to the surface, further evaporation does not take place. Though for the same size of cavity the volume of water in a sand tank is less than a fourth that in a rock tank, the water commonly remains in it for a longer period after a flood. The use of the water by animals is restricted by the necessity of digging holes down to the water level 
and throwing the sand out of the tank. Coyotes are able to do this with great ease, but horses, burros, and cattle have great difficuity in digging in the sand. Many rock tanks, on the other hand, are so accessible to wild animals and stock that within a few days after they are full all the water has been used.

For instance, at Black Tanks tanks 7 and 8 (fig. 26; see also Pl. $\mathrm{XVII}, A$ ) are commonly filled with sand, and water is obtained by digging. The basins are relatively shallow, and though No. 8 is considered the better of the two, in neither does water last all the year. Tank 4 , however, is usually swept clean by a flood and makes a large pool. But as Nos. 1, 4, and 5 are accessible to stock the water that collects in them is rapidly used up under ordinary circumstances. When, however, as sometimes happens, a flood leaves No. 4 tank full of sand, the water in the sand will last throughout the year. Nos. 2, 3, and 6 are too small to be of moment. Nos. 9 and 10 are very shallow. Thus, in dry seasons water is more likely to be found in the sand tanks (Nos. 7 and 8) than in the clean rock tanks.

\section{CHARACTERISTICS OF WATER IN TANKS}

The water of tanks, on being replenished after rains, is at first muddy, but it rapidly clears, and then by the growth of algae and the decay of organic matter it becomes foul. Sand tanks are likely to have somewhat better water than others, because the sand protects the water from sunlight and contamination. The two analyses given in the table below are probably a fair indication of the chemical characteristics of tank waters. Both samples were obtained in October, 1917. Coyote Water is a place in the axial stream of the Lechuguilla Desert about 8 miles east of Tinajas Altas, where water can be obtained by digging about 4 feet into the sand. The sample from Tinajas Altas (tank No. 1) was collected in October, 1917, after a long dry spell, when the water was particularly foul. In September, 1920, however, the water was sweet and pleasant to the taste.

Analyses of water from water holes

[Analyzed by A. A. Chambers and C. H. Kidwell. Parts per million]

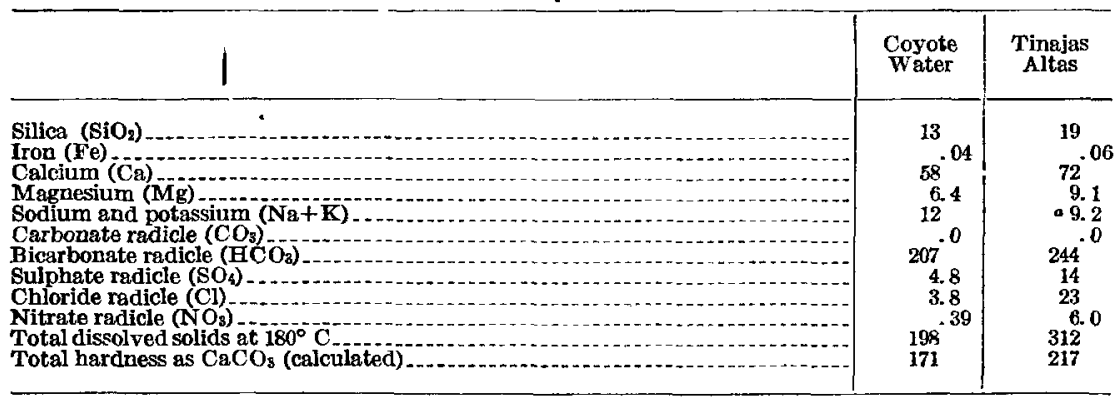

" Calculated. 


\section{DIRECT UTILIZATION OF RAIN WATER}

RAIN WATER SHED FROM ROOFS

The saving of rain water by various devices has long been practiced in localities where other supplies are inadequate or of poor quality or taste. Many prospectors' tents are equipped with gutters that direct rain water shed from the tent roof into cans and other receptacles.

In and around Ajo during the long period of development of this camp miners and prospectors have contended against the disadvantage of inadequate water supply. Not only was the amount of water small, but many of the wells furnished water containing salts of copper. During the period of construction of the plant of the New Cornelia Copper Co. in 1914 and 1915 the population of the camp was about 5,000 , and drinking water was sold by the bucket in stands such as that shown in Plate XIX, $A$, and peddled on the streets by hucksters. To make up the deficiency in well water, nearly every house was equipped with gutters and tanks to save rain water. A common form of apparatus is shown in Plate XIX, $B$, which is a photograph of a house in the part of the town now called Old Ajo. Cistern water of this kind was used for drinking and cooking only and thus made to last for a considerable length of time.

Wherever the need is great enough, roofs for the sole purpose of collecting rain water might be erected. Such structures have been used successfully on roads in the deserts of Australia. ${ }^{21}$ In Sandoval County, N. Mex., a shed with a roof 14 by 20 feet equipped with gutters and a 500-gallon tank supplied water for two men and a saddle horse.

\section{WATER CATCHES}

"Water catch" is a term in use in Bermuda, India, and other British colonies for a natural or artificial surface constructed solely for the collection of rain water. ${ }^{22}$ Such a system of obtaining water has many advantages, and before considering details of construction some examples will be described.

\section{USE OF WATER CATChES}

The water catches that have been in use in southwestern Arizona are all preexisting structures that have been adapted to special use during times of stress. In 1911 and 1912 and part of 1913 a water catch was used for a part of the water supply at Ajo. Samuel Clark

21 Gregory, H. E., Australia, the lonely continent: Nat. Geog. Mag., vol. 30, p. 554, 1916 ; also personal communication.

22 Gregory, H. E., The Navajo country : U. S. Geol. Survey Water-Supply Paper 380, p. 120, 1916. See also Mehren, E. J., Engineering impressions of Bermuda: Eng. NewsRecord, vol. 92, pp. 523-525, 1924 . 
was then operating a lease on the mining property called the Ajo Consolidated, and the existing wells and cisterns gave an inadequate water supply. A concrete-lined sump 10 by 12 feet and 4 feet deep was constructed in an abandoned prospect drift (fig. 31). This drift had been driven into a side hill from the bed of one of the short gulches leading down from the summit of the Little Ajo Mountains. A small boulder dam diverted the flood water of the gulch into the drift. A screen kept out the larger rubbish, but a large amount of organic matter, leaves, and twigs was carried into the sump. This material decayed and gave the water a vile taste and smell. However, at the end of three or four months putrefaction ceased and the water became clear and wholesome and was an important addition to the water supply.

At the Fortuna mine, 15 miles south of Blaisdell, in Yuma County, there are three water holes which supplement water taken from the

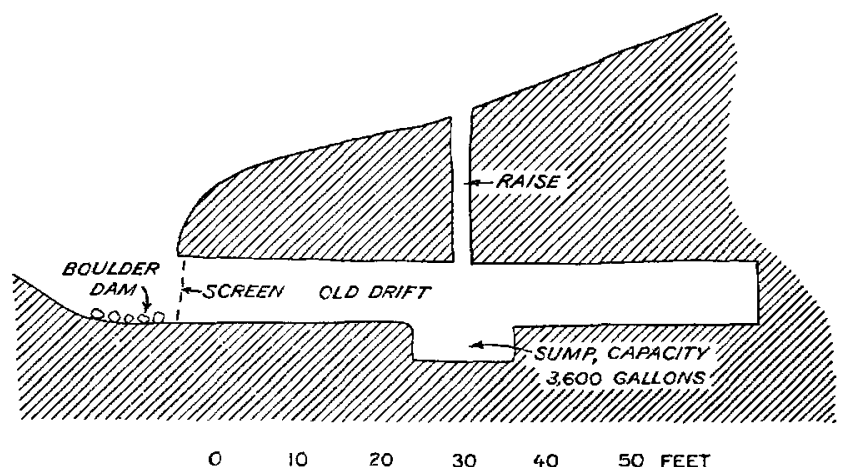

Figure 31. - Diagram showing water catch at old Ajo

main shaft of the mine. All three were dug as prospect holes, and their subsequent use as water catches has arisen during the last 15 years. During this period the mine has been shut down, and the pipe line from Blaisdell has been abandoned. Two of the holes are about 200 yards east of the mine, in the main gulch. One of these is a vertical shaft at one side of the streamway. It fills with flood water, but because rats and other small animals continually fall in and drown the water is not used. The other hole is an inclined shaft parallel to the schistosity of the rocks, which dip into the hillside. It is on the south side of the canyon about 75 feet above the stream bed. Rain water drains to this prospect hole from a hillside. The drainage area is about 200 feet wide and 750 feet long. It is a rocky boulder-strewn slope inclined between $40^{\circ}$ and $50^{\circ}$ from the horizontal. Rubbish of various kinds, leaves, and twigs are carried into the hole, and putrefaction is active after a rain. Rats seldom drown here, probably because the inclined shaft allows easy entrance and 
exit, so that they can come and drink without danger of falling into the water. The water does not become fit to drink for two or three months after a rain. At the time of visit the water was clear but slightly colored and had a pleasant taste. The surface was covered with floating clots of brown algae, mostly collected around the bodies of dead bees. There were also drops of crude oil, which had been put on to prevent the breeding of mosquitoes. The third hole is southwest of the mine, among some small hills. It is an inclined shaft 6 by 8 feet and said to be about 50 feet deep. The water drains from a basin having an area of about 25,000 square feet into a hole 4 by 8 by 5 feet deep; thence it flows more slowly through a dry wall about 4 feet thick into the shaft. 'The wall was originally laid to prevent slumping into the shaft but now forms an admirable screen

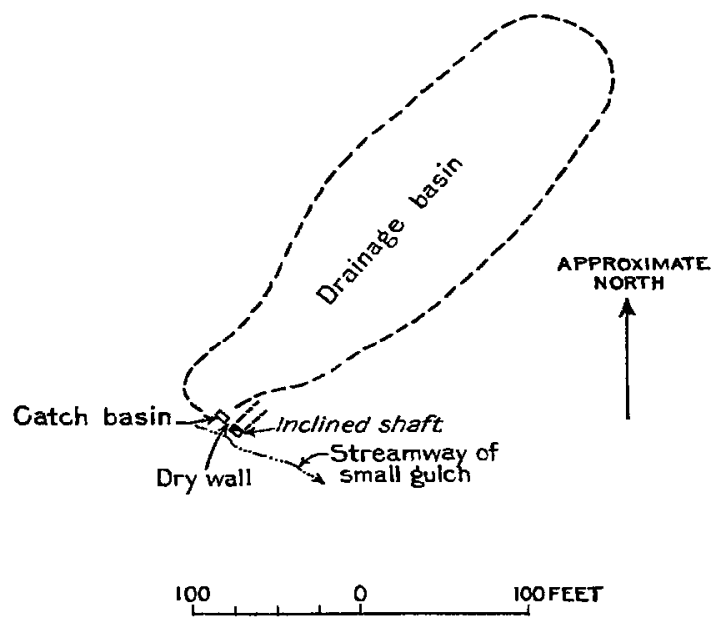

FigUR 32. - Sketch map showing drainage area at water catch near Fortuna mine, south of Blaisdell, Ariz.

for straining out clay and trash. The whole arrangement is shown in the accompanying sketch map (fig. 32) and in Plate XX, $B$. The drainage area is covered with loose blocks of rock from 4 inches to a foot in diameter, and below them is a scanty soil. A few bushes are scattered at intervals of 5 to 10 feet. The mouth of the old prospect hole is surrounded by a fence, and in Plate $\mathrm{XX}, B$, the drainage area lies to the reader's left of the prospect hole and of the man seated on the hillside. Because dirt and trash are arrested and do not go into the hole the water in it sweetens more rapidly than in the others. At the time of visit it was clear and palatable but had a faint brown color. If the drainage slope were thoroughly cleared of growing plants, all the loose rock stacked in piles, and the thin soil swept up and carried off, this would make an admirable water catch. 


\section{CONSTRUCTION OF WATER CATCHES}

The construction of a water catch involves the selection and preparation of a site and the construction of a cistern or container. The site selected should have the maximum of bare rock surface and the minimum of soil and vegetation. It is obvious that such requirements can be met most generally by mountain slopes. Excessively large drainage areas should be avoided, because of the expense involved in cleaning and fencing them. Granite and gneiss are most likely to furnish suitable surfaces. Lava is likely to have many cracks, and some lava beds are so porous that the run-off from them in small showers is likely to be almost nothing. Places can be found, however, where the lavas are very thick, uniform, and free from cracks. Certain massive conglomerates, such as those which form the Ajo Peaks, erode with great bare rock surfaces, but they absorb considerable rain, so that on such rock larger drainage areas should be provided.

Where the rock surface does not drain naturally to a single outlet, masonry or concrete walls should be built to direct the water. The cracks in lavas may of course be cemented, or wholly artificial surfaces of concrete may be constructed on hillsides of soft material, but it is thought that in general the expense involved in such work is too great. On ordinary rock surfaces all the bushes should be cut, the soil swept up, and loose rock piled. Free movement of rain water can then take place, and a minimum of dirt and trash will be carried to the cistern. A strong fence, preferably of woven wire, should be provided to prevent contamination of the surface by animals.

The cistern or water container may be built above or below ground. The simplest arangement is a shaft, similar to those at the Fortuna mine, but the difficulty of providing a suitable screen to prevent the entrance of trash with the water and to exclude animals is great. A cistern built partly or wholly above ground has the advantage that water is readily taken from the bottom and suitable screens may be provided. Figure 33 shows such a cistern, 13 feet square and 10 feet high (inside measurements), providing a storage capacity of 12,000 gallons. It requires 30.8 cubic yards of concrete, which, with a mixture of 1 cement to 2 sand and 3 gravel and plastered inside, will require 56 barrels of Portland cement. If reinforced with iron rods spaced 8 inches apart it will require 690 feet of half-inch rods.

\section{AREA OF WATER CATCH REQUIRED}

The area of prepared surface required to fill a given cistern is difficult to estimate. It is obvious that the smoother and less absorptive the surface and the greater the slope the more efficiently 
will the water catch work. At the Fortuna mine the catchment surfaces are very imperfect, yet the smallest, having a surface of only 25,000 square feet, furnishes enough water to fill the prospect hole, which has a capacity of approximately 15,000 gallons.

\section{SANITARY CONSIDERATIONS}

Rain water is practically free from mineral salts, and in sparsely settled regions it lacks disease germs. If conveyed over a bare rock surface to a clean tank or cistern, it remains clean and palatable. At Ajo and the Fortuna mine the water saved by the water catches

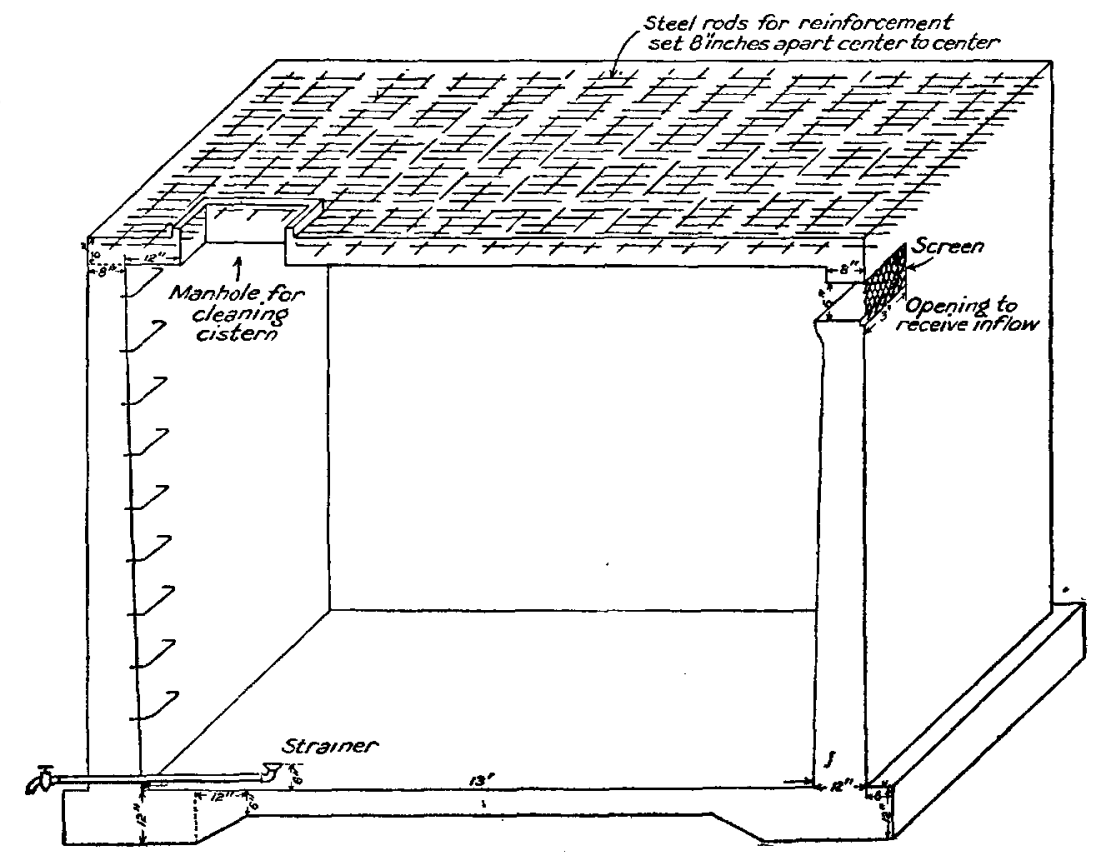

FrguRE 33.-Reinforced-concrete cistern for water catch. Designed by A. J. Ellis

contains trash and vegetation of various kinds, which rots or putrefies. This putrefaction is due to bacteria that live in darkness, for in all the examples cited the stored water is protected from direct sunlight. When the available vegetable matter has been consumed by the bacteria no further action can take place. The water is then free from disease germs and only slightly discolored by organic matter. If the water were stored in open pans or reservoirs and not protected from sunlight, other bacteria and many algous plants would grow in the water, die, and in turn decompose. Thus a continuous process would keep the water unfit for drinking. It is therefore essential that light should be excluded from the cistern. Any leaves or twigs that pass the protective screen will be decomposed in a 
single period, at the conclusion of which the water will be fit for drinking. The cleaner the water catch the shorter this period will be. With thorough precautions against admitting any organic matter to the cistern, no putrefaction will ensue.

All bodies of water in the desert attract animals, and many watering places are defiled by their dead bodies or excreta. The smooth, shelving sides of rock tanks are veritable death traps for mountain sheep. As the water gets low the sheep take greater and greater risks in drinking, and some of them fall in and drown. Rats, mice, and rabbits are similarly trapped. Efficient screening is the best protection against contamination by animals, because by using a sufficiently fine mesh bees may also be excluded. Bees are common in the desert, hiving in the caverns and crannies of the rock. At most watering places they drown in large numbers, and their dead bodies give water an unpleasant taste and odor. In a cistern of the design recommended above the same screen that excludes trash serves to exclude animals also.

The chance of introduction of disease germs into cisterns is much reduced in a desert region because of the sparse population. Even crude devices such as those at the Fortuna mine (p. 137) are not likely to be contaminated by disease germs. Travelers may protect themselves if water from such a supply looks particularly foul by boiling it before use. Boiling will probably make the danger from disease germs negligible but will hardly increase the palatability of really foul water.

\section{RESERVOIRS}

\section{PURPOSES}

In southwestern Arizona many small reservoirs for the storage of flood water are built by individuals and small companies, largely without expert advice. The number of such enterprises could be increased with great benefit to the region. The following paragraphs review the conditions under which dams must be built and point out the best practice. Large irrigation and power projects are not likely to be considered for most of the region, because of the absence of great rivers. Moreover, such enterprises present many special problems in engineering and finance, the correct solution of which can be arrived at only by large organizations with a competent technical staff.

The problems involved in the construction of the smaller reservoirs vary somewhat according to the purposes for which they are built. Four general purposes are common-supplies for mines, stock-watering places, domestic supplies, and irrigation.

Mines require comparatively large quantities of water for milling operations and the use of the people employed. Shallow wells in 
the hills near by usually suffice for prospecting, but when larger operations begin adequate water-supply systems must be installed. The mines of the region are at the edge of or within the mountains. Wells of good yield can be obtained only near the centers of the larger valleys, at a distance from the mines. Water obtained from such wells must be pumped against a high head through a long pipe line. The old mines at Welden, in the Quijotoa Mountains, Pima County, and the Fortuna mine, in the Gila Mountains, Yuma County, were so supplied. The recently developed water supply for the New Cornelia Copper Co. at Ajo, Pima County, is an example of this solution of the problem. However, reservoirs to store the flood waters of mountain canyons may often be equally advantageous. The Allison mine, in the Baboquivari Mountains, Pima County, and the Montana mine, in the Tumacacori Mountains, Pima County, have masonry dams and reservoirs.

Reservoirs for stock-watering places are usually small and are built in the edge of the mountains or more commonly in the plains. Their location is fixed by the position of grazing lands and the absence of other supplies, but there is more latitude in choice of location than in reservoirs for mine supply. At many places in the foothills the location for a reservoir may be so chosen that the dam will have a rock foundation, or at least a rock spillway. Such reservoirs resemble reservoirs in the mountains. Reservoirs in the plains have their special problems, which are discussed at length below. As stock-watering places reservoirs have many advantages. for if properly located and built they require attention only at infrequent intervals and are likely to have the most water during the season when the grass is best. They are relatively inexpensive, and so many locations are available that the stock can be widely spread over the range, with the great advantage of preventing overgrazing of parts of the region while other parts remain undergrazed. The reservoirs are full just after rains, and the stock can use the forage around them, while the vegetation in areas around permanent water is growing under the most advantageous conditions.

The use of reservoirs for domestic water supplies is not common among the white population, except at certain mines where the drainage area is usually free of contamination and where reasonable sanitary precautions are taken. The Papago Indians, however, commonly use reservoir water for household purposes, while tending their flood-water fields and cattle. The sanitary conditions of their reservoirs are usually unsatisfactory. The reservoirs are all shallow unlined pools, in which is collected all the refuse of a wide area at the time of filling. The cattle also are allowed to wander at will over the banks and in the water. The water is consequently 
always muddy and frequently foul. The United States Indian Service has attempted to remedy the worst conditions by installing troughs which are connected with the reservoirs by buried pipe lines and at which stock can be watered away from the reservoir. The Indians, however, consider this refinement unnecessary and except under compulsion allow the troughs to get out of repair and the cattle to drink from the reservoir as before.

The storage of flood water for irrigation seems at first thought a most natural method of development in a dry country in which the work of flood water stands out so prominently to even the casual traveler. On every hand are large channels in which driftwood, overturned trees, and great boulders testify to the passage of large quantities of water. Yet the difficulties of profitable storage of water in amounts sufficient for irrigation in this region are very great. The available reservoir sites are few, and some of them are useless because of difficulties in construction, others because the total water discharged from the drainage area is insufficient to fill the reservoir. All flood-water projects suffer also from the disadvantage that the desert flood waters carry so much sand and silt that the reservoir will soon fill with sediment and thus be useless. An irrigation enterprise based solely on the storage of flood waters from the ephemeral streams of the desert is an extrahazardous venture, which should be undertaken only with a thorough knowledge of local conditions and with expert advice.

RESERVOIRS IN THE MOUNTAINS AND FOOTHIILS

A mountain reservoir is usually built at a constriction of a valley above which there is a sufficient basin to form the reservoir. Rock toundations are available or can usually be obtained by trenching the loose sand and gravel in the bottom of the valley. The drainage area must be large enough to supply the water required. Unfortunately, data on the flow of streams are available for only a few places in the Papago country. It is thought, however, that for most of the mountain areas an annual rainfall of 10 inches can be assumed, and that of this amount 20 per cent can be regarded as run-off available to fill the reservoir. Very large spillways are necessary. The drainage area should be either well cloaked with grass or so rocky that the flood waters carry but little sediment, else the reservoir will soon fill up. The kind of dam to be built, whether earth, rock fill, masonry, or concrete, is an ordinary engineering problem whose solution depends on local costs and available labor. ${ }^{23}$ In the foot-

23 Fortier, Samuel, and Bixby, F. L., Earth-fill dams and hydraulic fill dams: U. S. Dept. Agr. Office Exper. Sta. Bull. 249, pt. 1, 1912 ; Timber dams and rock-fill dams: Idem, pt. 2, 1912. 
hills there are many small reservoir sites which differ from those in the mountains in that rock foundations are as a rule not available. Earth dams are also easier to build at such sites because of the abundance of soft material at hand. Such sites resemble those in the plains and valleys, described below, but many of them afford better conditions for construction because sites are available for rock spillways.

Certain possibilities of location in foothill regions are illustrated by two reservoirs in Pima County. Artesa Pond (Pl. XXVI, $A$ ) is created by an L-shaped embankment projecting outward and upstream from a rocky spur. Flood waters gathered in the northern part of the Baboquivari Valley flow westward around the north end of the Artesa Mountains. At this part of their course they spread over an adobe flat without definite channel. The open end of the L-shaped embankment intercepts part of the flood, and the excess flows around the embankment. Plate XXI, $A$, is a view of an unnamed reservoir in the hills east of Dobbs Butte. The drainage of a large area to the west (left in the view) spreads over an adobe flat from which it escapes through two gaps in the hills to Altar Valley. In the southern gap has been placed the dam, with its ends resting on the rock of the hills. No spillway is provided, for the excess water flows out through the northern gap.

\section{ReservoIRs IN THE PlatNS AND VALLEYS}

In the alluvial plains and valleys no foundations exist for masonry or concrete dams, and thus only earth dams can be built. The reservoirs are commonly small and shallow, though in exceptional locations large ponds can be made. Most of these reservoirs are used for watering stock. The American cattleman calls such a reservoir a "tank"; the Mexican uses the word "represo" (literally dam) and also "charco."

Reservoirs may be constructed either directly on a stream channel or at one side. It is obvious that if a dam is built across a channel the reservoir must be sufficiently large to hold all the water carried by the stream, or else a spillway must be provided. A successful spillway requires care in building and must be kept in repair. Its capacity also must not be exceeded by the largest flood, or the earth dam is overtopped and breached. The very large number of failures of reservoirs of this type in all parts of the arid West testify to the difficulties encountered in meeting these requirements. Southwestern Arizona contains an exceptionally large number of streams that have so small a flow that all or nearly all the water carried by each stream may be held in a single reservoir. The lake at Buenos Aires, in Altar Valley, is the largest and best example of such a 
reservoir. Even here a spillway is provided, and in exceptional years it is required. Many smaller represos built on small streams rising within the alluvial plains are equally successful in holding all the water of a single flood.

A reservoir at one side of a stream channel depends for its water supply on a diversion dam and ditch or simply on flood water that overflows the channel. The streams of the alluvial slopes of southwestern Arizona are peculiarly favorable for reservoirs of this type. After issuing from the little canyons that cross the pediments surrounding most of the mountain ranges the streams spread out in numerous diverging channels. In many places these ephemeral streams carry only fine material, mostly mud with a minimum of

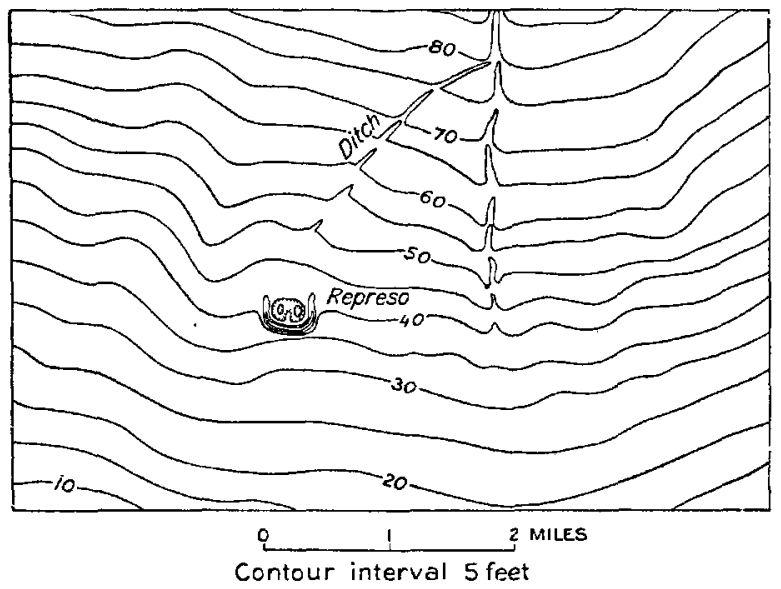

Figurm 34.-Diagrammatic map showing location of represo at one side of main floodwater channel

sand and gravel. Such localities are particularly favorable, because of the relatively low velocity of the floods and the possibjlity of water-tight reservoirs. Channels hardly exist; the floods spread as broad sheets of mud-laden water. Usually the main thread of the current runs between natural levees in a shallow channel somewhat above the level of the surrounding plain. The natural levees form broad low ridges similar to the channel ridges of Sacramento Valley, ${ }^{24}$ though not so marked.

The form of such a channel ridge is shown in Figure 34, which is a diagrammatic map of a typical alluvial slope, based on the conditions at Big Fields, in the Papago country. The contours are modeled on those shown on an excellent map of this part of the Papago Reservation made by Percy Jones, jr., for the United States

24 Bryan, Kirk, Geology and ground-water resources of Sacramento Valley, Calif.: U. S. Geol. Survey Water-Supply Paper 495, pp. 28-30, 1923. 
Indian Service. In addition to the ridge along the main flood channel there are other low ridges which mark the former location of the flood channel. In the low ground between such an old ridge and the present channel ridge is the reservoir, confined on the lower side by a $U$-shaped embankment. This reservoir receives water through a ditch from the flood channel, but during large floods no ditch is necessary, for the natural overflow from the channel will be caught by the open embankments of the reservoir.

The main streams of the larger valleys have beds of two typesbroad indefinite flats marked by shallow discontinuous minor channels, and beds that lie in definite channels with bordering flood plains of various width on either side and these flood plains in turn bordered by bluffs. The beds of the first type are particularly suitable for small reservoirs; the floods spread widely and have a low velocity, and a low embankment will turn the necessary flood water to a reservoir. The slopes, however, are so gentle that usually only the excavation made to form the embankment will contain water of sufficient depth to be valuable. The represos at Pisinemo (Pl. XXI, $B$ ) and at Copeka $(\mathrm{Pl}, \mathrm{XX}, A)$ are of the $\mathrm{U}$ shape common in these localities. In many places it is possible to enlarge a charco and thus gain an increased capacity with small effort. Sand dunes occur on some of these broad flats. They divert the flood waters by tortuous routes within the flat and in places create basins favorable for reservoirs. The Papago ponds or represos at Tonukvo and Comovo (Pl. XXII, $A$ ) are built in such sites.

In the valleys close to and tributary to Gila River and in the valleys that are surrounded by mountains higher than the average the stream beds are of the second type and lie in flood plains bordered by bluffis. On such a stream the concentration of flood waters usually maintains a well-defined channel, with banks from 5 to 10 feet high. A diversion dam is necessary to obtain water for a reservoir located either in the flood plain or at the mouth of a tributary valley breaking through the bluffs. Properly constructed reservoirs in such localities are very successful, but they require a great deal more upkeep and attention than reservoirs along streams of the type described in the preceding paragraph.

An ingenious method of obtaining a water supply for small reservoirs has proved successful in the Sitgreaves National Forest, in northern Arizona. ${ }^{25}$ The run-off from road ruts is diverted by a low mound across the road and conveyed through a short ditch to the reservoir. The reservoirs are small and are usually built on a gentle

\footnotetext{
${ }_{2 \mathrm{~s}}$ Personal communication from Hugh M. Bryan, formerly grazing examiner, U. S. Forest Service.
} 


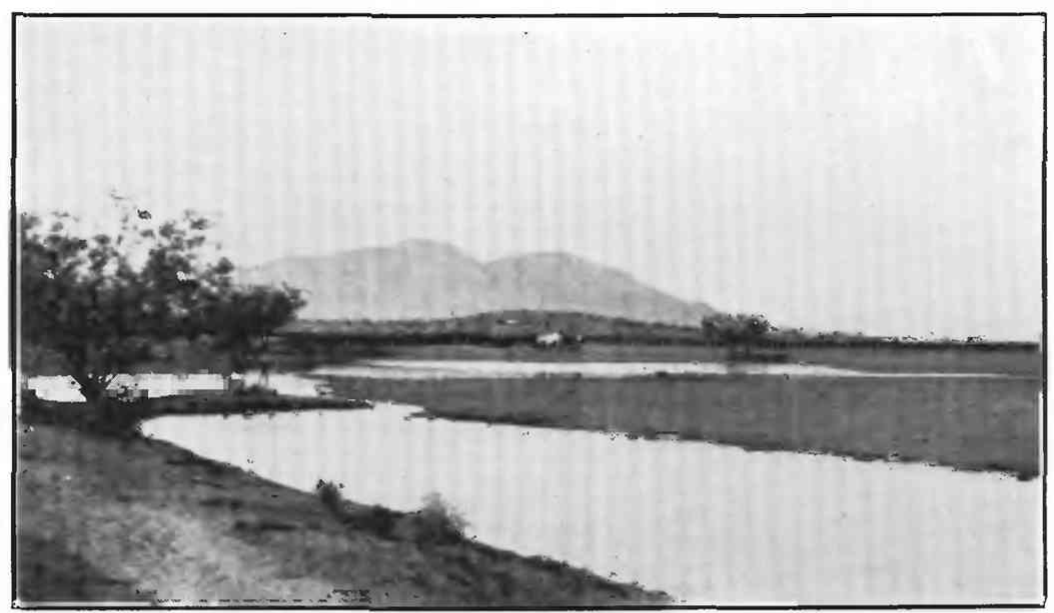

A. REPRESO AT COPEKA

South mountain of the Quijotoa Mountains in the background

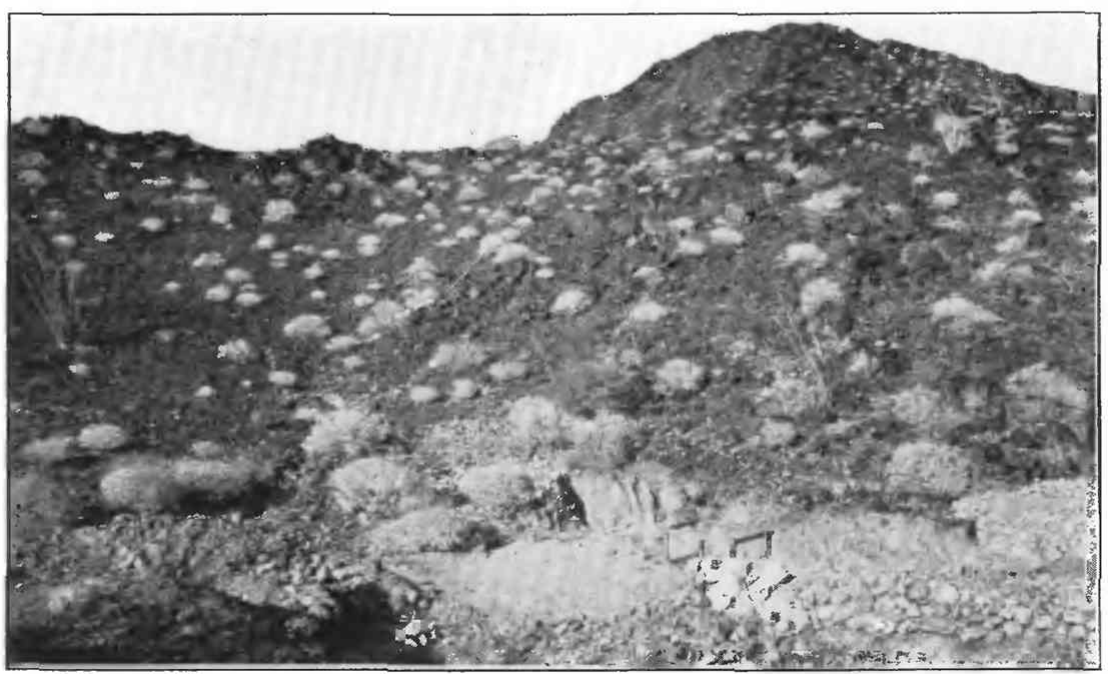

B. WATER CATCH AT FORTUNA MINE 


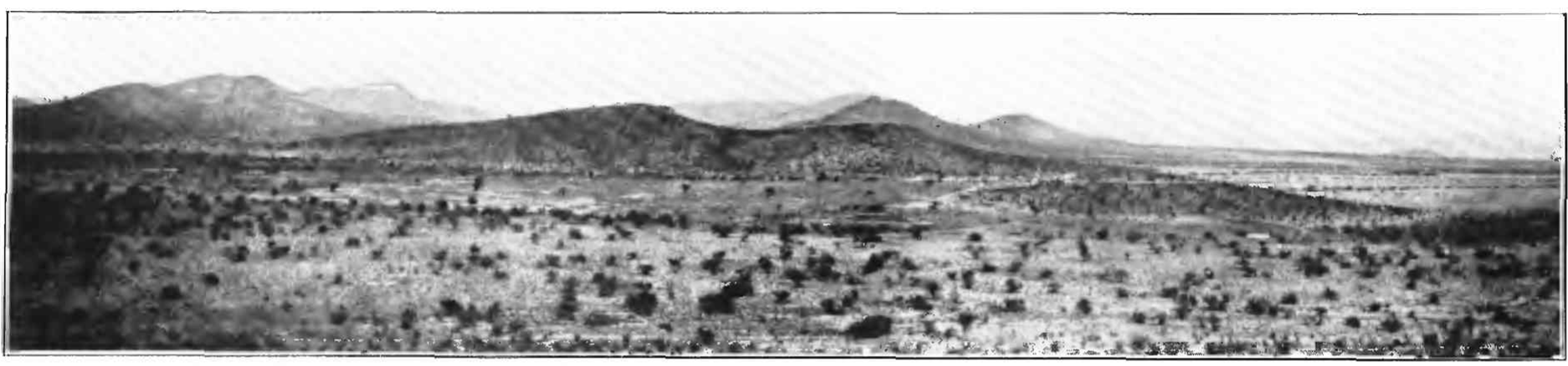

A. REPRESO IN HILLS SOUTH OF DOBBS BITTE

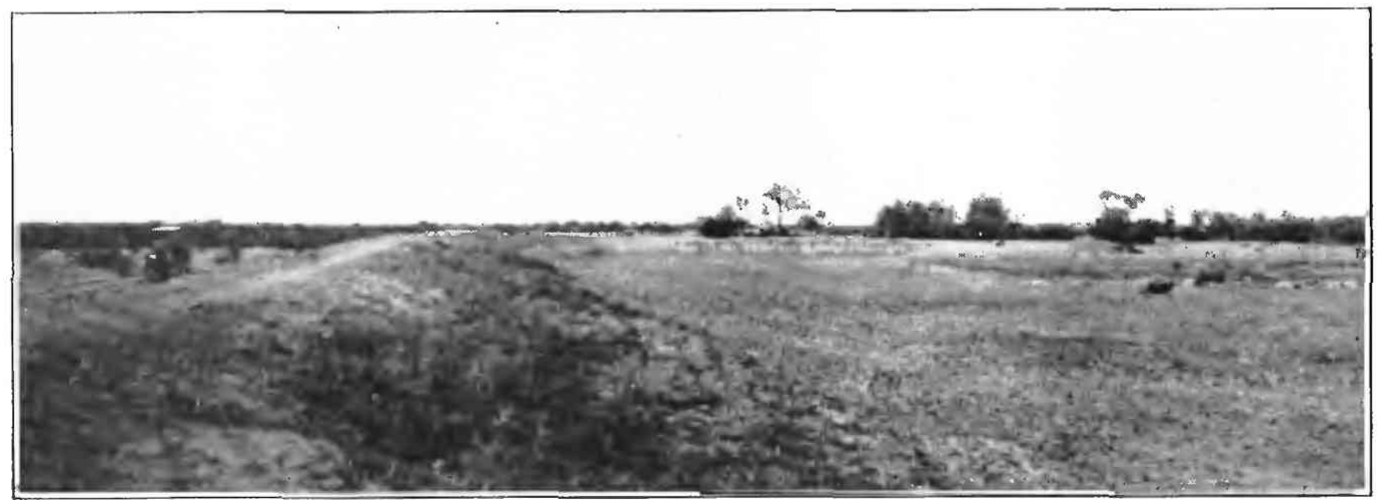

B. REPRESO AT PISINEMO 


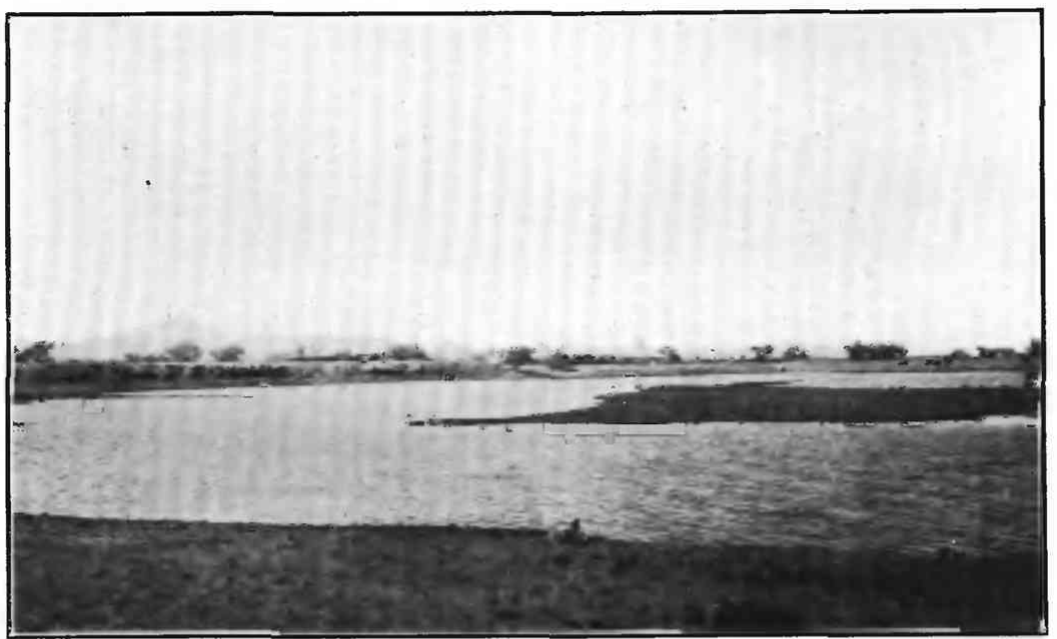

A. REPRESO AT COMOVO

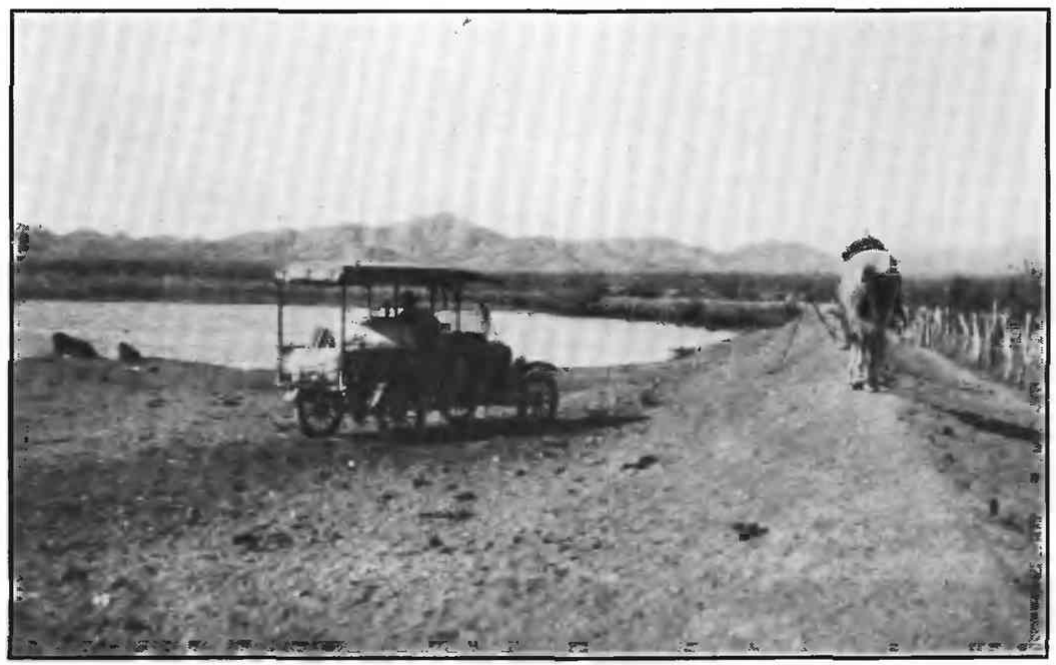

B. COMPARTIDERO, A REPRESO USED FOR WATERING CATTLE

Note the brush fence for wave protection. This repraso retains all the water shed from the drainage area and has no spillway 


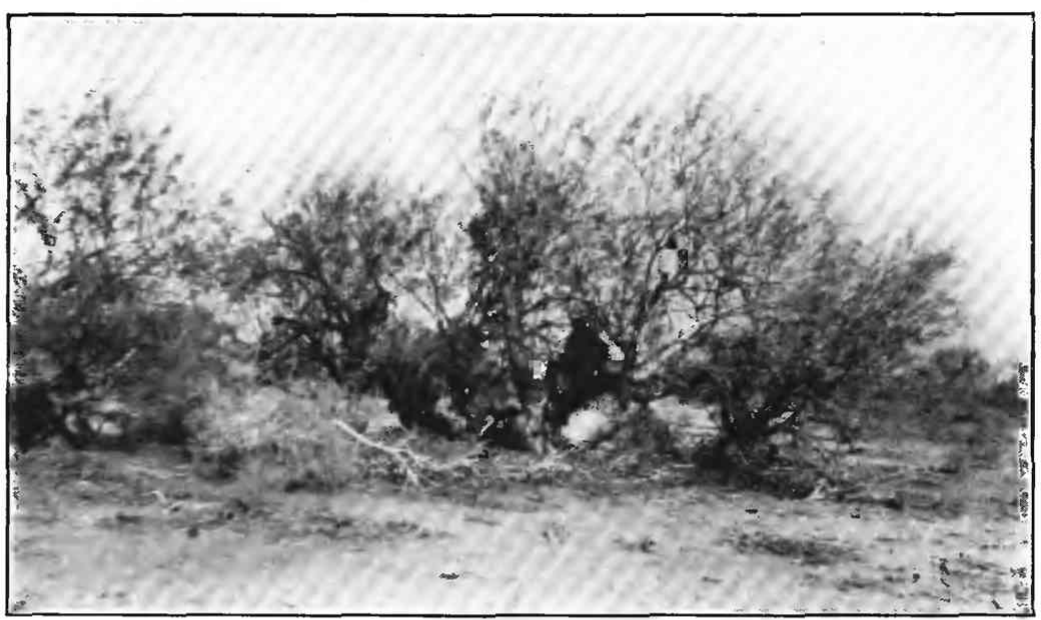

A. MESQUITE TREE OF SPRAWLING HABIT SOUTH OF CASA GRANDE RUINS, WHERE DEPTH TO GROUND WATER IS ABOUT 40 FEET

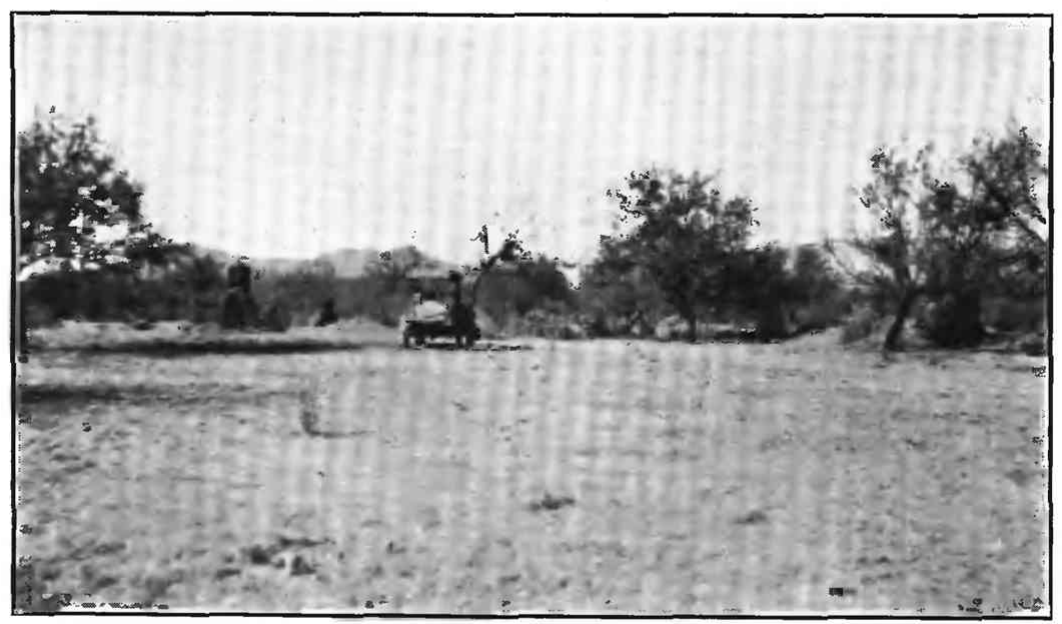

B. MESQUTTE TREES OF UPRIGHT HABIT AT FRESNAL WELL, WHERE DEPTH TO GROUND WATER IS MORE THAN 60 FEET 
slope below a steeper slope, as shown in Figure 35. The run-off from a large area of hillside can thus be obtained. Road ruts are much more successful conveyors of such run-off than plowed ditches, because traffic on the road keeps them packed hard and free of vegetation.

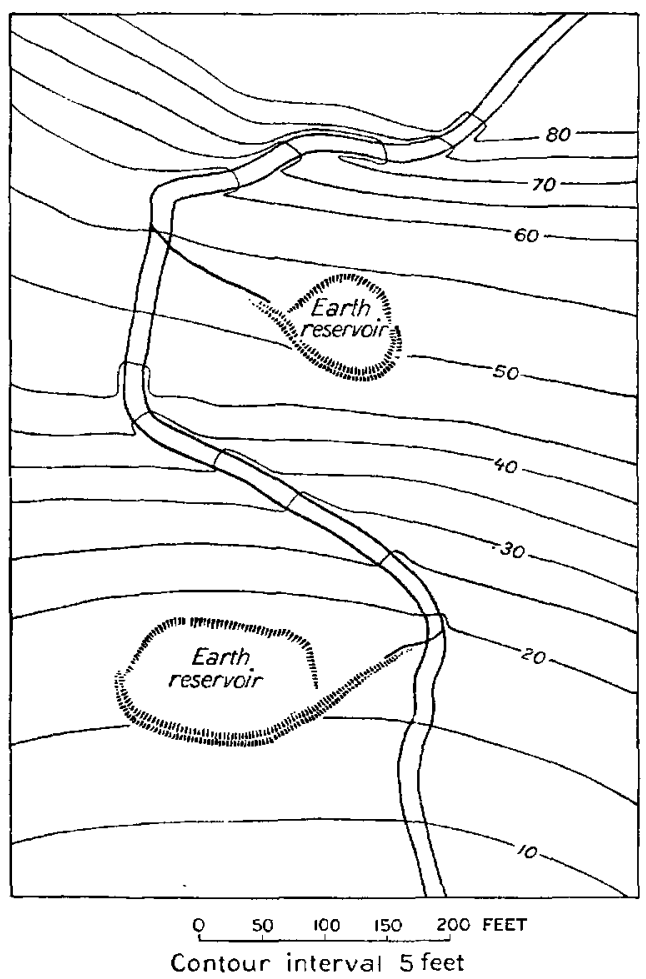

Figure 35.-Idealized map showing use of run-off from road ruts and relation of reservoirs to slopes

\section{CONSTRUCTION OF RESERVOIRS}

Useful as the reservoirs or represos of the Papagos are, both to the Indians and to the wayfarer, their usefulness is impaired by faulty construction. In general a Papago represo consists of an earth dam, ronstructed with scrapers and having a more or less irregular height and width and a horseshoe shape. The material of the embankment is taken from the upstream side, the capacity of the reservoir being thereby increased. In many represos the only water stored is held in the borrow pits, because the ends of the embankment do not continue far enough up the slope to hold any considerable quantity of water. (See fig. 36.) The embankment also is made with a very steep slope on both sides and usually has no wave protection. 
A properly designed earth dam should have a slope on the water face of not over 1 in 3 . On the rear face the slope may be as steep as 1 in $11 / 2$. A firm bond to the underlying ground should be obtained by removing from an area at least 6 feet wide, in line with the future crest of the dam, all vegetation and loose soil for a depth of at least 6 inches, and by digging in the area thus cleaned a trench at least 2 feet deep and filling it with new material similar to that

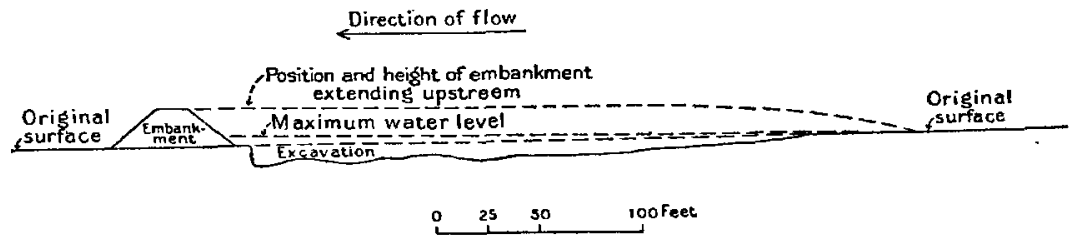

Figure 36.-Profile through typical Papago represo

to be used in the dam. On many adobe flats, however, simple plowing will be sufficient. The crest of the dam should not be less than 5 feet above the bottom of the spillway except in a small reservoir, where a height of 3 feet is sufficient. A type of cross section that has proved successful in Wyoming and South Dakota ${ }^{28}$ is shown in Figure 37.

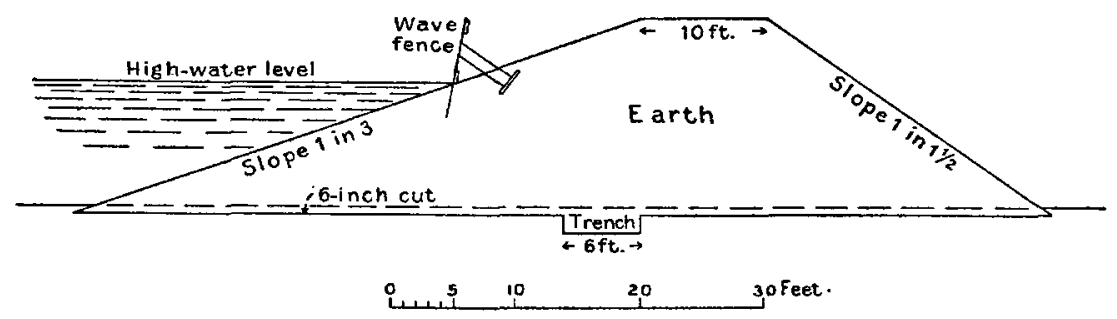

Figure 37.-Cross section of earth dam

\section{PROTECTION OF THE EMBANKMENT}

An earth dam should be protected by a fence from loose stock, which destroy the smooth slopes and often wear trails deep enough to lower the dam considerably. In a large reservoir waves rapidly erode the dam, especially if the water body lies on the windward side of the dam. Protection against waves can be made by riprapping with rock or brush or by building a wave fence.

A wave fence is constructed of 1 by 10 inch boards 8 feet long, pointed at one end and driven into the embankment at high-water level. The boards are driven in as close together as possible, about 3 feet in the ground, at a slope of about 5 in 1 away from the water.

\footnotetext{
26 Hermann, F. C., Small reservolrs in Wyoming, Montana, and South Dakota: U. S. Dept. Agr. Office Exper. Sta. Bull. 179, 1907.
} 
The fence should be made rigid by two strings of 1 by 10 inch boards, one nailed near the top and the other near the bottom of the fence. Braces fastened to deadmen should also be installed. Wave fences are very effective and with ordinary repairs will last in this region seven or eight years.

Brush protection of the face of the dam, if properly constructed, is as good as a wave fence, and the large quantities of mesquite, palo verde, and creosote brush available in most localities in southwestern Arizona make this the natural and cheapest thing to use. The brush should be made up in bundles about 1 foot in diameter and of any convenient standard length. At least two layers of bundles should be laid at right angles to each other on the face of the dam, and the whole should be firmly wired to strong stakes driven into the dam. This form of brush protection will probably be more effective than the brush fences that have been used on a number of dams. The wear on an embankment by waves in spite of brush fences, also the damage done by loose stock, can be seen at Compartidero represo (PI. XXII, $B$ ).

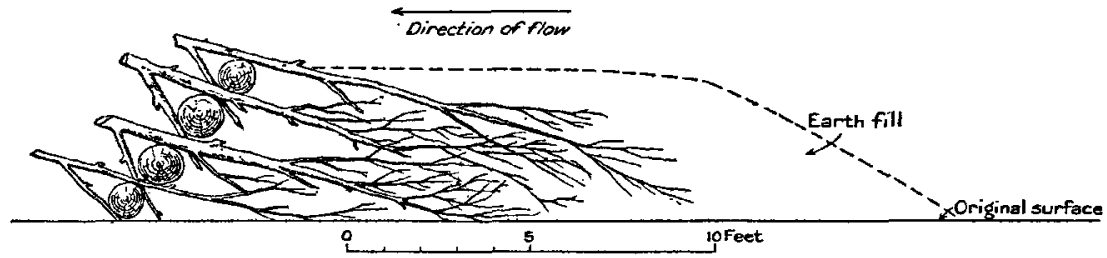

FigUre 38.-Diagram showing the use of logs and brush for diversion dams and splllways

DIVERSION DAMS AND PROTECTION OF SPILLWAY CHANNELS

Diversion dams in rocky channels can easily be constructed of plank or cribbing, or, if the expense is justified, of masonry. In channels where no firm foundation exists diversion dams are usually constructed of brush and rock held in place by strong stakes. Such dams are likely to be washed out by any flood. If the washout occurs during the only flood of the year that is sufficient to fill the reservoir, the consequences are serious.

W. E. Kibbey, formerly of the La Osa Land \& Loan Co., has used successfully the structure illustrated in Figure 38. The channel is cleared of loose sand, and the banks are cut in sufficiently to give a good bond. The largest logs obtainable are then laid end to end across the channel at the toe of the dam. Mesquite trees and large branches, each trimmed so that one branch makes a hook at the end, are laid over the logs with the hooks downstream, and the hooks are forced down over the logs as shown in the diagram. The dam is raised by laying successive rows of logs with broken joints and holding each row in place with brush. Each row lies upstream from the 
last, so that the face of the dam has a slope that tends to break the force of the flowing water. The crest should slope from the banks to the center so as to divert the water away from the ends of the dam. The upstream side of the dam is covered with earth, and each flood augments this material up to the level of the top of the dam. It is obvious that as water flows over the dam the transverse logs can not be loosened and carried away, because they are held by the hooks on the brush; and if the toe of the dam is undermined, the somewhat flexible structure will settle without, however, shifting in position. If the dam settles so far as to be ineffective, it may be built higher by adding one or two additional layers.

A reservoir that is built without a wasteway in the expectation that it will hold all the flood discharge of a stream may have a structure of the type just described built at one end of the dam. It

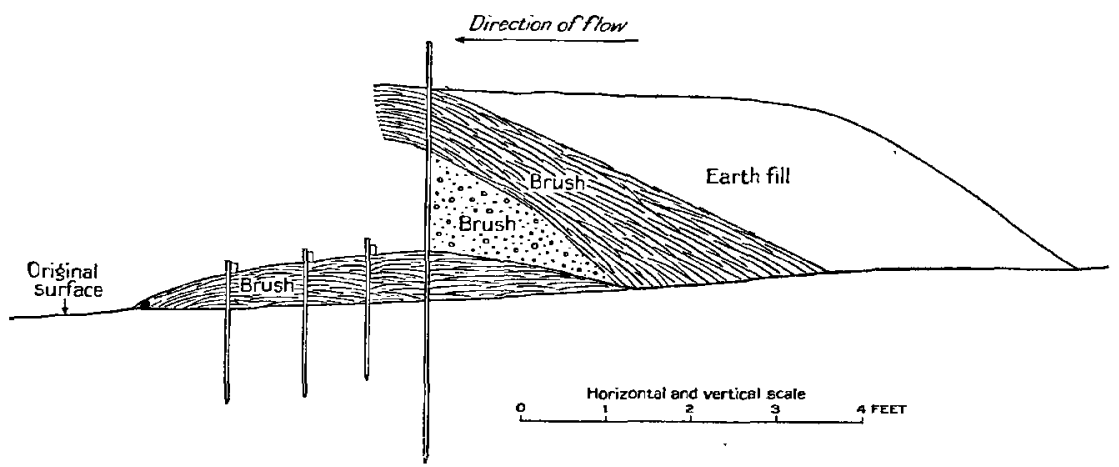

Figure 39.-Diagram showing construction of a water drop to prevent erosion in channels. The dotted pattern indicates bundles of brush laid at right angles to the others

can be completely covered with dirt and in the damp soil will rot very slowly. By leaving this part of the crest low or by opening it with a shovel a safe emergency spillway will be available for any exceptional flood that may threaten the dam. This device, installed by Mr. Kibbey in the dam of the lake at Buenos Aires, has been in successful use for a number of years.

Erosion in wasteways due to abnormally steep grades often menaces reservoirs. Where the site does not provide a rock spillway the waste water may cut a channel which, beginning in a sharp cliff, works up the spillway with great rapidity. A structure somewhat similar to the one just described has been used as a water drop to prevent such erosion. ${ }^{28}$ Figure 39 is a cross section of this structure, which was built of brush and old railroad iron. The larger posts were old boiler flues and the smaller stakes old bolts and fishplates. The brush was made up in bundles about a foot thick, with wire binding, and the bundles were wired to one another and to the stakes.

${ }^{28}$ Hermann, F. C., op. cit., p. 33, pl. 7, fig. 1. 
Where mesquite is plentiful, mesquite posts would probably be cheaper and equally serviceable. By concentrating the fall at one point the. grades of the other parts of the channel are reduced sufficiently to prevent erosion.

\section{DÉBRIS-FILLED RESERVOIRS AND ARTIFICIAL SPRINGS}

\section{ADVANTAGES}

Throughout southwestern Arizona evaporation from water bodies is excessive and the annual loss in open reservoirs is more than 5 feet. This loss is serious in small reservoirs and, together with the use of water by stray stock and wild animals, makes many rock tanks uncertain water supplies. Sand tanks of the same size do not suffer these losses and with proper protection are more sanitary. A small spring that arises from the fill of an old dam which has long been silted up is the principal source of water at the old mining settlement of Warsaw. ${ }^{29}$ If reservoirs full of clean sand and gravel could be constructed they would also have these advantages, though their water capacity would be less than a fourth of that of ordinary reservoirs. General plans for such reservoirs are proposed in the following paragraphs in the hope that they may be a guide in constructing watering places in localities where other water supplies are difficult to obtain.

\section{METHODS OF CONSTRUOTION}

The filling of such a reservoir must be composed of clean rock particles, preferably of nearly the same size, in order that the maximum porosity may be attained. To reduce expense, the dam must be so constructed as to permit the accumulation of the filling by natural processes as far as possible. In southwestern Arizona proper material for filling such reservoirs can be obtained only from streams in the mountains or in the belts of rocky plains around the mountains. In these localities the sand and gravel of the stream beds are clean and coarse and have about 25 per cent of pore space. An ordinary dam thrown across such a stream checks the current so much that not only sand and gravel but mud also is deposited. To obtain débris free of mud for the reservoir, the dam must be built up gradually, the current being allowed to rework the accumulation of each flood, or else a dam must be constructed that will check the current only enough to hold the coarse material and will let the finer material go through.

A dam of a type that may be built up gradually was constructed in California of boulders held in wire baskets. Chicken-yard netting

${ }^{29}$ Bryan, H. M., personal communication. $104211-25-12$ 
of 2-inch mesh and No. 14 gage galvanized-iron wire was used to inclose bundles of boulders, which were 2 feet wide, 1 foot thick, and 8 feet long. The bundles were laid side by side along the dam. In the second layer the bundles were staggered and lapped 4 feet inside the lower edge of the first layer. The downstream slope was thus 1 in 6 ; the upstream slope was 1 in 2 . The dam was 150 feet long and 35 feet high and resisted not only the weight of the débris behind it but a continuous overflow of flood water for a period of five weeks. ${ }^{30}$ Such a dam built up by adding one to three layers after each flood would be very effective and easy to construct. Its life is, of course, dependent on the time necessary to rust the wire netting and on the wear on the netting by boulders tumbled over the face of the dam. Individual baskets can be replaced, however, and when it becomes necessary a whole new face can be constructed.

In many mountain ranges there are places where the canyons after running on comparatively flat grades contract and then run on steep grades. These narrows are natural dam sites, and many of

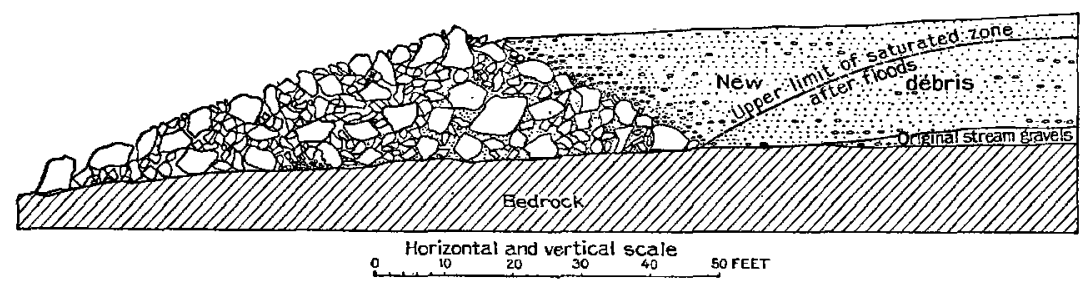

FIGURE 40.-Diagram showing rock-fill dam for an artificial reservoir

them are bordered by high cliffs. It seems probable that without much drilling, by taking advantage of open cracks and joints, the cliffs could be blasted down into the narrows. The mass of material thrown down would be of all sizes, but many of the blocks would be too large for the stream to move even in its greatest floods. As many large blocks as possible should be obtained. By shifting the material and relaying it, especially on the downstream face of the dam, the larger fragments could be made to protect the smaller. Floods on striking this dam would flow through, but with diminished velocity. The sand and gravel which they carried would be largely deposited in and behind the dam, while the mud would be carried through. Figure 40 is a cross section of a dam of this type, somewhat more regular in form than is absolutely necessary, though an effort should be made to makie the downstream face as flat as possible. A dam of this type merely reproduces the conditions found in many canyons, where great boulders too large for the stream to move block the channel and cause sand and gravel to accumulate behind them.

so Palmer, L. A., A novel débris dam : Min, and Sci. Press, July 10, 1915, pp. 43-46. 
The larger the blocks blasted down the more successful the project is likely to be. Such a rock-fill dam can be blasted down in a short time and with only a few men. On this account the project could be undertaken at distant and inaccessible spots, where the cost of transportation of water and supplies is great. The reservoir once filled with débris is stable unless the rocks of the dam are loosened during floods, and at each flood the débris will be saturated with water. The water will seep out at the toe of the dam as a spring for a time depending on the volume of the reservoir and the porosity of the material that fills it. The size of the reservoir must be regulated by local conditions, but it should be as large as possible. The porosity of the material will be somewhat less than 25 per cent, and the size of the pore spaces will depend on the size and arrangement of the rock particles. These conditions can be controlled in part during the process of filling. However, it is impossible to predict what size of pore space will be large enough to absorb water rapidly and yet allow the same water to flow out with sufficient slowness to produce a perennial spring. There is no question that the structure described above will produce a spring. The risk in constructing it lies in the possibility that the spring may have so large a flow as to exhaust the reservoir within a month or two after each flood.

\section{GROUND WATER}

The Papago country is bordered by two regions in which wells obtain water at shallow depths and in relatively large quantities. Along the northern border the valley of Gila River has large supplies of ground water, which have been described by Lee ${ }^{31}$ for the area from Florence to Salt River, and by Ross ${ }^{32}$ from this point west to Yuma.

Along the eastern border wells obtain water at shallow depths in the grassy flats of Nogales Wash and in the flood plain of Santa Cruz River from Calabasas to the north end of the Tucson Mountains. Ground water has been utilized extensively for irrigation on the Canoa ranch by the Continental Rubber Co. and near Tucson by the Tueson Irrigated Farms Corporation and private individuals. North of the Tucson Mountains the Santa Cruz flows in a broad plain which in the vicinity of Casa Grande is usually called the Casa Grande Valley. In this area many wells are being sunk to obtain water for irrigating long-staple cotton. The ground-water and irrigation possibilities of the Santa Cruz Valley from Calabasas

\footnotetext{
s1 Lee, W. T., The underground waters of Gila Valley, Ariz. : U. S. Geol. Survey WaterSupply Paper 104, 1904.

${ }^{82}$ Ross, C. P., The lower Gila region, Arizona: U. S. Geol. Survey Water-Supply Paper 498, 1923.
} 
to Gila River have for a number of years been under investigation by Prof. G. E. P. Smith, of the University of Arizona. The results of his work will be published as a bulletin of the Agricultural Experiment Station of the university.

The great area south of Gila River and west of Santa Cruz River has few wells. Moreover, the wells that reach water at shallow depths yield but small amounts, and in those of large yield the water lies so far below the surface that irrigation on a large scale is impracticable. Sufficient water can be obtained for use in mining, however, and for the number of cattle the region will support. The cattle industry has languished primarily because of the small amount of forage, which, except for the short-lived grasses that spring up after the rains, consists of browse. Consequently only a few cattle can be permanently supported at any single watering place. The present investigation, which is summarized below, has shown that a very large increase in the number of wells is possible, and that these wells will yield enough water to supply as many cattle as can be maintained on the available forage. The high prices for cattle prevailing from 1915 to 1919 and the use of better cattle ranges for dry farming accelerated the movement of stock raisers into the poorer forage areas. In spite of the temporary depression of 1920 and the following years this movement will eventually establish in the Papago country, outside of the areas set aside for the Indians, a permanent though sparse stock ${ }^{3}$-raising population.

In the following discussion the tables include only those wells for which rather complete data are available. Within the Indian reservations there are a large number of shallow dug wells used by the Indians, for which depth and location are known. Most of them lie off the main routes of travel and are of interest principally because they furnish additional proof that a great increase in the number of wells can be made in other parts of the region, particularly in the pediment areas at or within the borders of the mountains.

\section{SOURCE AND AMOUNT OF GROUND WATER}

The greater part of the water circulating in the ground within a. depth that makes it recoverable by man falls on the surface as rain or snow, sinks into the ground either directly or after running a short distance in a stream, and circulates in the ground under hydrostatic pressure. In a few places, one of which is noted below, the deep-seated waters of the earth's crust come to the surface. It is, however, much easier to observe and study the work of the deepseated water on the rocks than to demonstrate that any particular spring or well has water of such an origin. 
The amount of ground water in a region is governed by the climate, the character of the rocks, and the topography. The rocks merely form reservoirs to which water may be added or taken away. It is evident that a region in which precipitation, either as snow or rain, is small will have only small annual additions to its groundwater reservoirs, and it is only these annual additions which are a vailable to man.

In the Papago country the mean annual rainfall ranges from about 3 inches at Yuma to 12 inches at Tucson, an amount very small in comparison with the precipitation of more favored regions. The prevailing high temperatures lead to excessive evaporation from free water surfaces, which according to published records of observations made at Yuma by the United States Weather Bureau amounted to an average of 75 inches a year for a period of six years. The rain, to be conserved as ground water, must sink into the ground rapidly, or it will be lost by evaporation in the streams. All but one of the basins of the Papago country have watercourses that drain to the sea, but the loss of water from the region through these streams is probably small. Most of the water that falls as rain wets the upper soil and immediately evaporates; but a part reaches deeper soil zones, or the water table. A large share of the water that does not evaporate immediately is lost through transpiration from plants. No tests on the rate of transpiration have been made, but the devices for protection from excessive transpiration exhibited by all the desert plants indicate that such losses of water are much heavier than in other regions. Each plant, then, whose roots lie in the belt of soil moisture or reach ground water helps to reduce the annual supply of available ground water.

The Papago country, like much of the rest of the western United States, consists of valleys filled with alluvium lying between ranges of mountains, but it is unlike many other areas in that the mountains receive almost as little rain as the intervening valleys. The mountains are, however, composed of almost impervious rocks that can not absorb any large part of a rain, and therefore they contribute water to the valleys in the form of floods or ephemeral streams. The reservoirs of porous alluvium in the valleys receive that part of the rain which is not lost by direct evaporation, evaporation from streams, evaporation from the soil, transpiration from plants, or runoff in streams that terminate outside of the area. The total of this annual increment is small, and thus the possibilities of obtaining large supplies of water for irrigation are also small. Many more wells than now exist can be dug, however, and eventually wells may be located close enough together to make all the land available for grazing, but the development of large tracts irrigated by ground water is impracticable. 


\section{VEGETATION AS AN INDICATOR OF GROUND WATER}

It is a matter of common observation that certain plants require more water than others and that certain plants tend to grow in lines fringing streams or in colonies and bands where water is close to the surface. The use of plants as indicators of the existence or depth of ground water is, however, beset with pitfalls. Most species have a considerable range in water requirements, and it is difficult to fix the limits of range. Again, other factors, such as unsuitable soil, floods, or fire, may cause the absence of a species from a localty in which the water requirements are met.

Salt grass grows only in moist soil, and its presence may usually be considered a reliable indication that the ground is saturated within 10 feet of the surface. It occurs sparingly along Santa Cruz River but is abundant in the ciénaga near Gila Crossing, along Gila River, and near a number of springs. The absence of salt grass in the central parts of the interior valleys of the region is due to the greater depth to permanent water in those areas.

Mesquite has in some parts of Arizona great value as an indicator of shallow water. ${ }^{33}$ Along Gila and Santa Cruz rivers the mesquite groves undoubtedly draw a large part of their supply of water through their roots from the underlying water table. In the interior valleys, however, mesquite trees and even large groves of mesquite exist where the ground water is from 60 to several hundred feet deep and thus seem to be dependent wholly on rain and flood water. It is noticeable, however, that the mesquite in these localities is more erect and more treelike than the mesquite of the areas of shallow ground water. This contrast is evident in the photographs reproduced in Plate XXIII. The tree shown in $A$ is typical of the mesquite groves south of the Casa Grande Ruins, where the depth to water ranges between 30 and 40 feet. The sprawling habit is perhaps more common in this locality than near Tucson but is characteristic of most of the trees in Gila Valley west of Gila Bend. The tree shown in $B$ is one of a group at the abandoned Fresnal ranch, where the ground water is more than 60 feet below the surface, and has the upright habit typical of trees in the interior valleys of the region, though most of them are somewhat smaller.

Other desert plants are thought to be indicative of shallow ground water. Of these, batamote (Baccharis glutinosa), desert willow (Chilopsis linearis), and the cherioni or wild china tree (Sapindus marginatus) are the best known, and their virtues as water indicators are extolled by the old settlers of the region, largely on the basis of supposed Papago wisdom in regard to water. It seems likely that

3 Meinzer, O. E., and Kelton, F. C., Geology and water resources of Sulphur Spring Valley, Ariz.: U. S. Geol. Survey Water-Supply Paper 320, p. 183, 1913. 
these plants require somewhat more water than mesquite, catsclaw, palo verde, and palo fierro, but this need can be supplied by small amounts of water stored in joints and fractures in the rocks or held above a bed of clay or other compact material in alluvium, which would be insufficient to supply a well. Along the border of the Baboquivari and Tumacacori mountains the cumaru or hackberry, especially the large species Celtis occidentalis, which grows to a height of 50 feet, the Arizona sycamore (Plantanus wrightii), and the leatherleaf ash (Fraxinus velutina) are found near springs and seeps and may be taken as reliable indicators of ground water. The cottonwood (Populus fremontii) is found only in the flood plains of Nogales Wash, Santa Cruz River, Arivaca Creek, Sonoita River, and Gila River. Another species (Populus macdougalii) which is indistinguishable by the layman from the common cottonwood, is found on Colorado River below Yuma. The cottonwood is a reliable indicator of shallow ground water, but it requires so much moisture that its absence is not a sign that water is lacking.

In locating wells the evidence of the presence of water furnished by the native vegetation should be given due weight, but to locate-a well at a certain place on the evidence of a single cherioni tree, for example, may lead to failure. The presence of the tree may, however, confirm a judgment arrived at by a consideration of the conditions under which water occurs. These physical conditions, most of which depend on the character and structure of the rocks, are reviewed on pages $167-188$.

\section{QUALITY OF GROUND WATER ${ }^{\text {s4 }}$}

During the progress of field work samples of water were collected for analysis from 2 springs, 1 stream, 2 water holes, and 25 wells. The analyses were made in the water-resources laboratory of the United States Geological Survey by A. A. Chambers and C. H. Kidwell. The analyses of the two spring waters and the only stream water, Sonoita River, are given on pages 163 and 167. The analysis of water from the Blankenship Well is reprinted in the section in which the analyses of waters from shallow wells in alluvium are discussed.

\section{METHODS OF ANALYSTS}

The analyses given in the tables (pp. 163, 167, 172, 176, 184, 185) were made substantially according to the methods outlined by Dole. ${ }^{35}$

\footnotetext{
${ }^{34}$ In the preparation of this section the author has benefited by the complete revision of his original draft by W. D. Collins.

${ }_{85}$ Dole, R. B., The quality of surface waters in the United States east of the one hundredth meridian: U. S. Geol. Survey Water-Supply Paper 236, 1909.
} 


\section{COMPCTATIONS}

In some analyses sodium was not determined, but the amount chemically equivalent to the excess of the acids over the sum of the calcium and magnesium is reported as "calculated." The computations and classifications of analyses in this paper follow the system which has been in use in publications of the United States Geological Survey for a number of years. They are discussed at length by Stabler ${ }^{36}$ and by Dole ${ }^{37}$ in earlier publications.

Total hardness $(\mathrm{H})$ is the calcium carbonate equivalent to the total calcium and magnesium and is calculated by the formula $\mathrm{H}=2.5 \mathrm{Ca}+4.1 \mathrm{Mg}^{.38}$

The scale-forming ingredients are assumed to be silica and such compounds of calcium and magnesium that the total quantity is given by the formula $\mathrm{SiO}_{2}+2.95 \mathrm{Ca}+1.66 \mathrm{Mg}$.

The quantity of ingredients that may cause foaming in boilers is calculated at 2.7 times the combined quantities of sodium and potassium.

.The alkali coefficient $(k)$ is that proposed by Stabler. It represents the depth in inches of water that would yield, upon evaporation, sufficient alkali to render a 4 -foot depth of soil injurious to the most sensitive crops.

\section{CLASSIFICATION}

The chemical character is given in symbols showing the predominating groups of basic and acid radicles. Ca represents calcium and magnesium together, $\mathrm{Na}$ includes sodium and potassium, and $\mathrm{CO}_{3}$ the carbonate and bicarbonate radicles.

Classification for domestic use, for boilers, and for irrigation follows the usage of the publications by Dole and Stabler already cited.

It is based on consideration of quality with reference to permanent living conditions. Hardness entirely unobjectionable for drinking may cause a water to be classed as poor for domestic use because it requires excessive soap consumption in laundering, and iron that will separate out and make the water turbid, or stain enamel ware and plumbing, or produce iron stains on articles washed in it may cause the water to be classed as much poorer for domestic use than it is merely for drinking.

\footnotetext{
Stabler, Herman, Some stream waters of the western United States, with chapters on sediment carried by the Rio Grande and the industrial application of water analyses: U. S. Geol. Survey Water-Supply Paper 274, pp. 165-181, 1911.

s7 Mendenhall, W. C., Dole, R. B., and Stabler, Herman, Ground water in San Joaquin Valley, Calif.: U. S. Geol. Survey Water-Supply Paper 398, pp. 50-82, 1916.

3 The figures used with chemical symbols in this discussion represent parts per million of the radicles.
} 
Many of the wells and other sources of water represented by the analyses have so small a yield that it is unlikely that they will be used either to supply boilers or for irrigation, but the classification of existing water supplies will be of value to those who may in the future attempt to obtain larger supplies in the same localities. The main use of water in the region is for drinking by men and animals; the characteristics of the waters for this purpose are discussed in the paragraphs that follow.

\section{POTABILITY OF WATERS}

Aside from the possibility of contamination with disease-producing bacteria, whether or not a water is good to drink is largely a matter of opinion. To those who live in regions where very pure and lightly mineralized waters abound a small amount of salts or organic matter is noticeable and distasteful. On the desert the traveler has little choice and must drink what is available, and the permanent inhabitant is so hardened to water contaminated with mineral salts or organic matter that he accepts without question water which elsewhere would be considered unfit for human consumption.

The impurities in water are suspended matter, dissolved mineral salts, and dissolved organic matter.

Suspended matter consists of fine sand, silt, clay, bacteria, and rubbish of various sorts. It is common in the water of streams in food, of charcos and rock tanks, and sometimes of wells. The careful man will boil and strain water that contains noticeable amounts of suspended matter, although such matter may not be harmful in itself, unless it includes disease-producing bacteria. The Papagos have since prehistoric time depended on the muddy

- water of charcos while tending their crops in the summer. They are a strong and handsome race, growing to more than average height when well fed and free from diseases introduced by the whites. Muddy water is commonly used for watering stock, and, though animals will normally choose clear water in preference, it is doubtful whether muddy water, unless it is also foul, has any deleterious effect on them under range conditions.

The analyses given in this report show the amounts of different mineral constituents dissolved in the waters. The total amount expressed in the tables as total dissolved solids varies between wide limits. The lower the mineral content the more acceptable the water will be to most consumers, but the upper limit of tolerability differs with different persons. 
The waters of the Papago country are not excessively high in mineral content: the average of 21 wells and 2 springs is 442 parts per million total solids. Four other wells have more than 1,000 parts per million total solids. Two of these, the wells at the Black Prince mine and the Sam Clark water shaft, are sunk in rocks adjacent to mineral ground and within the limits of mining claims. High mineral content is not uncommon in such places.

Garcia Well, in the San Cristobal Valley, one of the four wells mentioned above, is a dug well which at the time of sampling contained less than a foot of water but was being deepened. It is a common experience that the water first struck in a well is more salty than that lower down. Probably the withdrawal of water from the deepened well will remove the soluble matter immediately adjacent to the well, and travelers will in the future find the water much less salty than is shown in the analysis.

Tule Well, on the Camino del Diablo, has water generally regarded as brackish and bad, but it was used extensively by the International Boundary Survey in 1893 and 1894 without known deleterious effects. Prospectors at the present time use the water, and though it is not suitable for persons in delicate health travelers who are sufficiently able-bodied to travel in the region will probably suffer no ill effects.

Most wells in the desert are unprotected and are visited only at intervals. Much trash is blown or washed into them, and animals and insects fall in and drown. Many Papago wells are equipped with rawhide buckets for lifting the water. These buckets, made from green hides, are unsanitary. Travelers will occasionally find the water of a well putrid from the decay of material that has fallen in. This decay takes place largely through the work of bacteria in the water, and if the sun has access to the water during part of the day many microscopic plants and animals may live and thrive in it, and the water may be continually foul. Foul waters such as those described do not necessarily contain disease germs. They may produce intestinal disorders, but diseases, such as typhoid and cholera, can be produced only by the characteristic germs. Fortunately, the scant population, the great dryness of the air and soil, and the almost constant sunshine of this region are factors that work constantly to limit the number of disease germs and prevent their introduction into foul waters. Though these waters are suitable habitats for the growth of disease germs and are disagreeable in themselves, travelers will find that they do not necessarily carry disease. Precautions should be taken, however. It will be found convenient to have several receptacles for water and to fill those from which water is used for drinking only from wells that 
seem to be sanitary. Other receptacles from which water for washing, cooking, and filling the radiator is taken may be filled from charcos, represos, and suspected wells when the necessity arises. The boiling of water intended for drinking is a good precaution -easily carried out, because of the large amount of firewood along the roads. Water from all the wells used by the Papagos, except drilled wells maintained by the United States Indian Service, should be boiled.

\section{SPRINGS}

The springs that were studied in this region are of two typesfracture springss ${ }^{30}$ which depend on water derived from rainfall and stored in the fractures that are characteristic of certain types of rocks, and fissure springs, ${ }^{40}$ which depend on fissures that penetrate the deeper parts of the earth's crust and allow deep-seated waters to rise to the surface.

The small amount of ground water and the excessive losses by evaporation wherever it approaches the surface probably account for the small number of springs and of types. Time did not permit the study of the numerous springs of the Tumacacori Mountains, where above an altitude of 4,500 feet the rainfall is sufficient to produce ground-water conditions quite unlike those of the rest of the area.

\section{FRACTURE SPRINGS}

The characteristics of fracture springs can be best brought out by the description of examples.

Dripping Spring ( $\mathrm{Pl}$. XXIV, $A$ ), is on a hillside in an indentation of the northeast side of the Dripping Spring Mountains, below a small pass in whitish rock which forms the "puerto blanco" (white gateway). The approach to the spring leads through a valley that opens off of the Valley of the Ajo. High palisaded buttes stand in this valley, like guards before the mountains, and between them the road winds southward to the spring. The character of the rocks and the topography make this a picturesque and attractive spot.

The water flows from cracks in the rock into a cave with an entrance 6 feet high and 4 feet wide; within the cave widens to 8 feet and is about 5 feet deep. A small concrete dam has been built across the entrance, and from this dam a pipe leads to the foot of the slope. The water is milky and opalescent and has a temperature of $69.5^{\circ} \mathrm{F}$. At the end of the pipe line is a small pool fed by it, and a well dug in rock, 54 feet deep and 28 feet to water. The watering

${ }^{3}$ Bryan, Kirk, Classification of springs : Jour. Geology, vol. 27, p. 557, 1919.

10 Idem, p. 532. 
place is covered by mining claims belonging to the owners of the Dripping Spring mine, half a mile southwest. The amount of water is sufficient to supply a few men only.

The rocks near the spring are a series of beds of lava and tuffs: which have a general dip to the south. The tuffs make white bands on the mountain side, which are in marked contrast to the purple and brown lava, but even the tuffs have in places a reddish-brown color due to a cavernous surface rust of silica about 2 inches thick. Where this crust is broken through the softer rock inside readily weathers and falls out, forming many small caves and reentrants.

Dripping Spring emerges from a light-green pitchstone dotted with small round red specks called spherulites. The pitchstone is. broken into thin sheets along a system of fractures that strike $\mathrm{N}$. $44^{\circ} \mathrm{E}$. and $\operatorname{dip} 30^{\circ} \mathrm{S}$. Along these fractures the pitchstones is altered to a greenish-yellow or pink porcelain-like rock, in which the
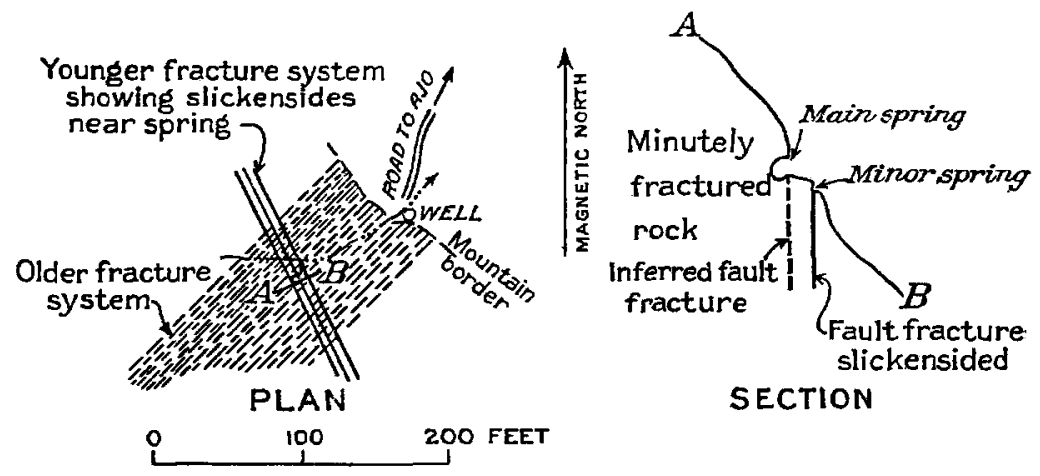

SECTION

FIgUne 41.-Diagram showing the relation of fracture systems to Dripping Spring

spherulites show plainly. Crossing this system of fractures is a later system that strikes N. $26^{\circ} \mathrm{W}$. Along and within these fractures red and white chalcedony has been deposited. Vugs lined with quartz crystals are also present. This alteration was probably accomplished by waters that circulated through the fissures, not only here but at other localities in the vicinity. Most of the concretions and pieces of chalcedony and agate that abound in this vicinity have been weathered from this set of fractures.

These waters have long since ceased to flow, and the present spring is due to rain water that collects in the cracked and fractured rocks and comes to the surface by way of the secondary set of vertical fractures mentioned above. At certain places these fractures have been reopened by movement since the water that deposited the quartz and chalcedony ceased to flow. Sufficient rock flour or gouge was produced by the later movement to make these fault fractures, at least locally, efficient dams to the circulation of ground water. The relation of the spring to the two sets of fractures is shown in Figure 
41. The fault fracture through which the main spring issues can not be seen, but a small spring in a little niche in the pitchstone, immediately adjacent, is due to one of these fault fractures that is marked by a small cliff about 25 feet long and 20 feet high, slickensided throughout its length. (See fig. 41, section.) Its rubbed and polished surface bears testimony to the movements that have taken place along these fractures.

The following analysis of the water of Dripping Spring shows that it is a sodium-silicate water. The high content of silica and the suspended silica that gives the water a millky and opalescent appearance are due to the rather soluble character of the pitchstone in which the spring occurs.

\section{Analysis and classification of water from Dripping Spring}

tCollected Oct. 2, 1917 ; analyzed by A. A. Chambers and C. H. Kidwell. Parts per million except as otherwise designated]

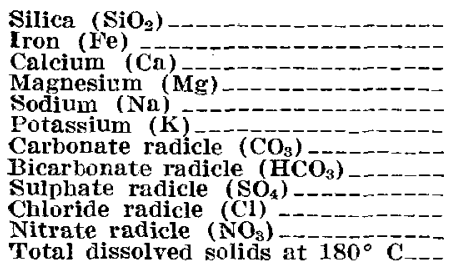

\begin{tabular}{r|}
101 \\
6.7 \\
4.6 \\
2.9 \\
69 \\
3.8 \\
34 \\
44 \\
14 \\
22 \\
24 \\
384
\end{tabular}

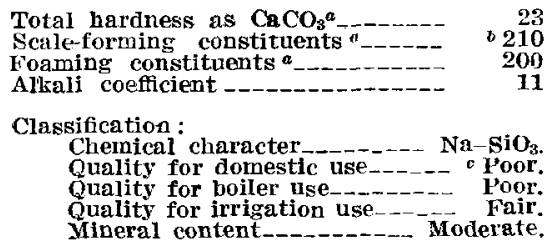

a Calculated.

Includes 92 parts per million suspended silica $\left(\mathrm{SiO}_{2}\right)$.

- Poor on account of excesisive iron; otherwise good.

The spring called Agua la Vara is on the northeast side of the Coyote Mountains, about 1 mile south of Dobbs Well. In December, 1917 , it formed a pool of water without overflow. It is in a stream bed about 50 feet upstream from a dug well. The gneiss of this locality is massively jointed, and from the joints water was seeping in a number of places. These fractures undoubtedly feed the spring and well. Agua la Vara lies in the falls portion of one of the streams that dissects the mountain pediment and thus bears the same relation to the topography as the rock tanks described on page 129 and illustrated by Figure 25. Below the falls the little eanyon is about 75 feet deep, and in its walls are exposed beds of red sandstone, shale, and calcareous rock that dip about $40^{\circ} \mathrm{N}$. These beds are separated by a fault from the gneiss that forms the upper part of the mountain pediment and the mountain slope. The head of the little canyon intercepts the ground water flowing in the fractures of the gneiss down the slope of the pediment. Doubtless the red shale and sandstone just below the falls are less pervious than the fractured gneiss and assist in concentrating the flow of water at the falls.

Springs and seeps, many of which have been converted into wells, are common in similar topographic positions. La Alina, 5 miles 
southwest of Agua la Vara, and Coyote Well, 3 miles west, each in the falls section of a stream dissecting the pediment of the CoyoteMountains, appear to be springs converted into wells. The sameexplanation will probably apply to most of the springs on the west side of the Baboquivari Mountains.

In the deep canyon on the north flank of Squaw Tit Peak, about 4 miles south of Stouts Well, there is a small spring. It consists of a pool of water in heavy-bedded lava, which in September, 1917, had no outflow. The pool seems to have been enlarged artificially to storethe seepage from a number of fractures in the rock. South of the spring the steep mountain side, composed of complexly fractured lava, rises about 2,000 feet. From the water circulating in these fractures the water of the spring is derived.

\section{FISSURE SPRINGS}

The deep-seated waters of the earth's crust come to the surface at only a few places. Near active volcanoes such waters, expelled from molten rock during crystallization, reach the surface as springs. Not all hot springs near volcanoes, however, are due to such water, forundoubtedly some hot springs are fed by surface waters that comeinto contact with uncooled igneous rock and then rise to the surface. Perhaps the greater number of volcanic springs carry a mixed water, part of it derived from rainfall and part expelled from crystallizing igneous rock. Far from active volcanoes other hot springs are located' on faults which, because of the recency of movement along them, constitute channels that allow the deep-seated waters of the earth to rise. These springs have been called fault springs. ${ }^{41}$ On the other hand, there are springs similar in type which do not lie on known faults and yet which resemble fault springs. Such fissure springs are represented in the Papago country by a single example, Quitobaquito Spring.

Quitobaquito (see p. 426) is probably the largest and certainly the most interesting of the springs in the Papago country. It is just west of boundary monument No. 172 , about 60 yards from the boundary, on the United States side (Pl. XXIV, $B$ ). From the two principal openings a ditch leads the water to a pond, which with two or three adobe buildings and a small weed-grown alfalfa field. are in Mexico. Mexicans, Papago Indians, and at times Americans have lived here, but the division of the water and of the available cultivable land between the two countries has prevented permanent settlement.

The spring is in a cove on the southern border of the Quitobaquito. Hills, which are composed of rock belonging to the crystalline complex. There are two main spring openings, and both show evidence

1 Bryan, Kirk, op. cit., p. 533. 


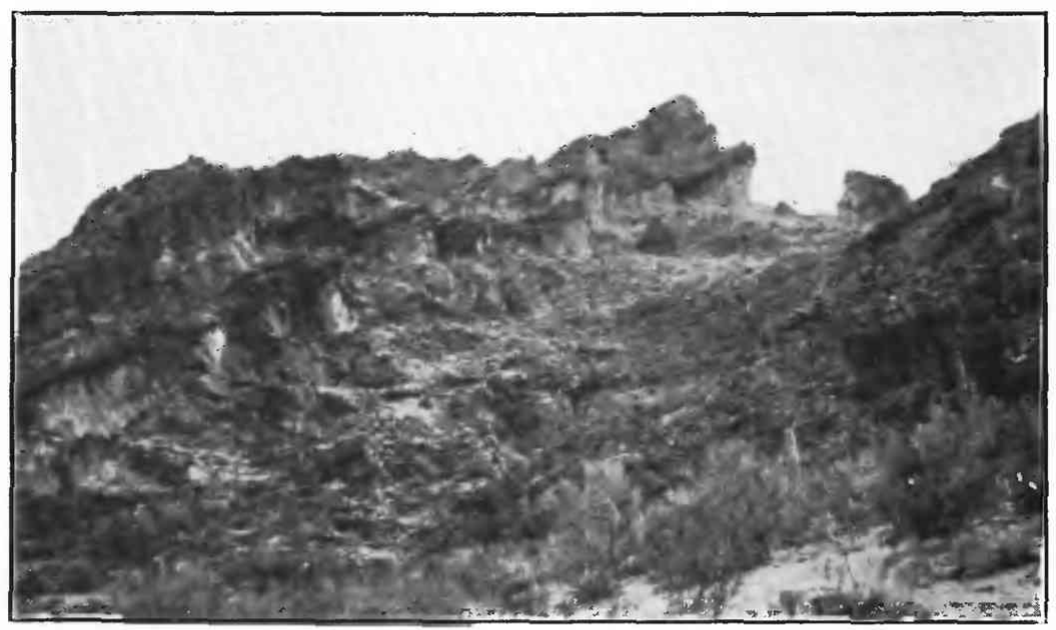

A. DRIPPING SPRING:

The little saddle at the top is the Puerto Blanco; the spring lies in the slope, hidden by bushes

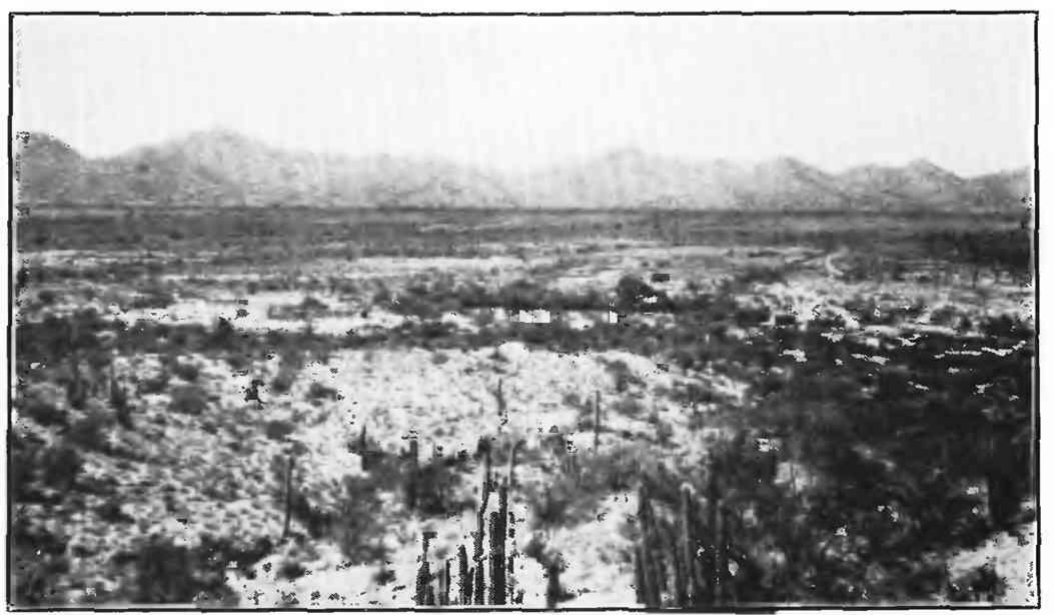

B. QUITOBAQUITO, FROM THE HILLS ON THE NORTH

The springs are on the right, concealed by mesquite trees; the pond and fields in Mexico; Sonoita River in middle ground 
U. S. GEOLOGICAL SURVEY

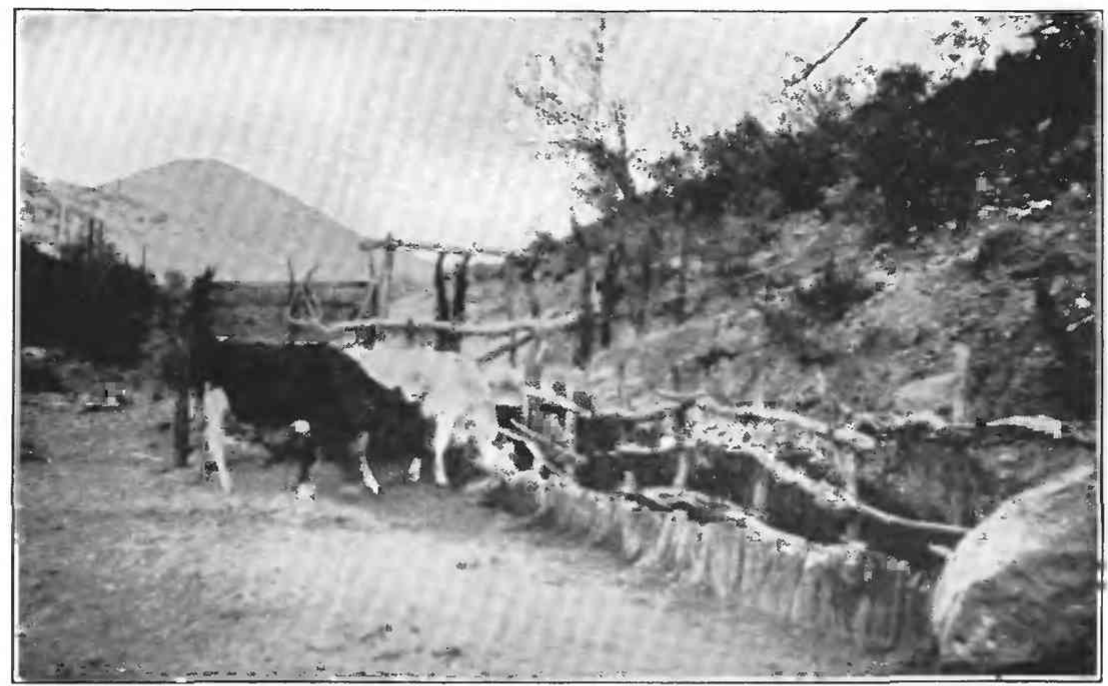

A. СОСНIBO

Shows typical head frame and trough of a Papago well

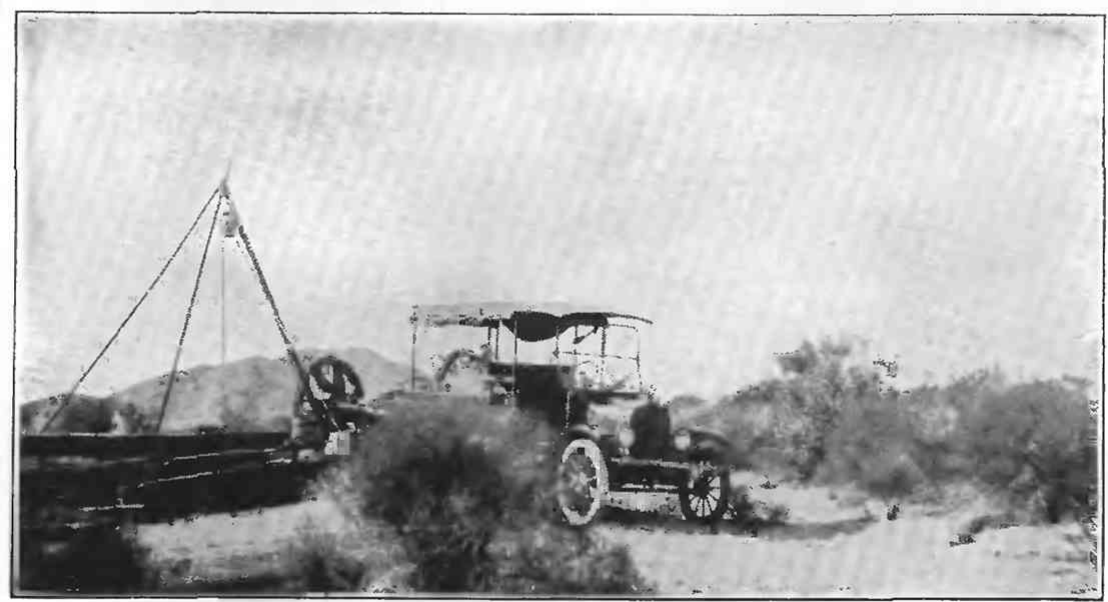

B. PAPAGO WELL

Shows U. S. Geological Survey automobile hooked to the cable prepared to draw water from this deep well 
of excavation to increase and concentrate the flow. The larger and more northerly opening has a pool about 2 feet deep and is shaded by an overhanging bank. The temperature of the water was $80.3^{\circ} \mathrm{F}$. on September 30,1917. In the other spring opening the water can be seen emerging from joint cracks in a pinkish granite. The temperature of the water was $80^{\circ} \mathrm{F}$. on the same date. The combined flow from the two openings was measured in the ditch by floats and found to be 43 gallons a minute.

The two spring openings lie in a line of seepage marked by a small bench that skirts the granite hills for a distance of about half a mile. Alkaline soil and mesquite bushes mark this line, which trends north of west, approximately parallel to the international boundary. The flow from the spring openings, 43 gallons a minute, is probably not half as much as the amount of water that escapes from the ground by evaporation. The source of this water can not be the drainage basin of Sonoita River, for the river, which is threequarters of a mile to the south, is fully 100 feet lower, and underground circulation between the river and the spring is prevented by granite outcrops. The water must therefore come either from the Quitobaquito Hills, to the north, or from a deep source within the earth's crust. The hills are composed largely of granite and gneiss and extend about 5 miles slightly west of north from Quitobaquito, with an average width of 1 mile. Even by making the assumption that a flat fault or fissure extends through the hills and dips gently to the south, along which all the ground water of the hills might collect to come to the surface in the belt of seepage at Quitobaquito, it is doubtful if the quantity of water issuing from the spring could be obtained. The temperature of the water implies an origin below the level of ordinary ground water, as is shown in the following table:

Temperature of Quitobaquito Spring and other springs and wells in the Papago country

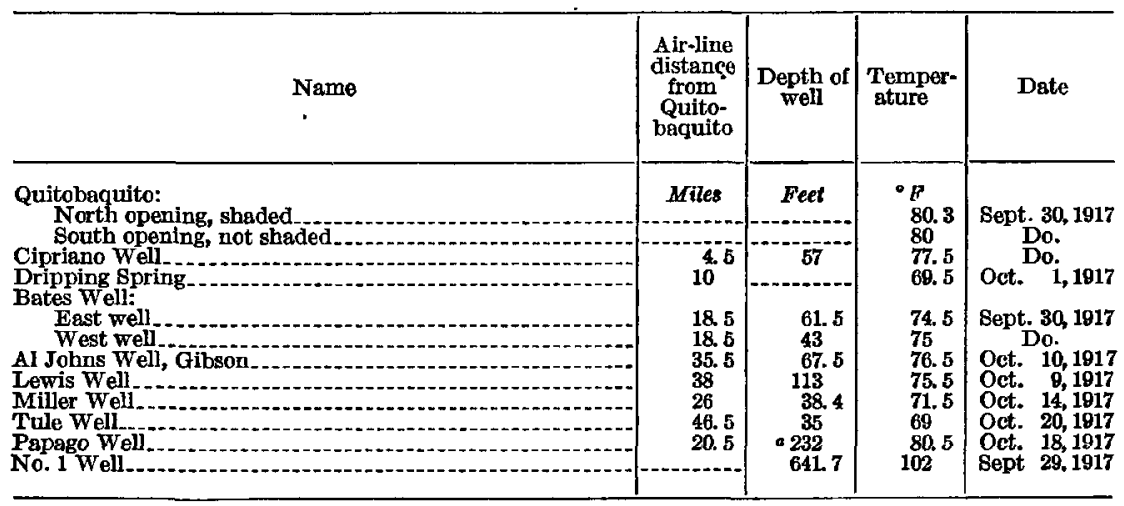

- Depth to water in drilled well, total depth not known. 
All the wells and springs in the surrounding region for which data are available have temperatures lower than Quitobaquito Spring except No. 1 Well and Papago Well. The mean annual temperature of the air for Ajo, the nearest station to Quitobaquito, 33 miles to the north, may be estimated from the records for 1915 to 1918. The average of these years is $69.1^{\circ} \mathrm{F}$. For the same years at Yuma the average is $70.8^{\circ}$, which is $1.5^{\circ}$ below the mean of $72.3^{\circ}$ for all years observed at Yuma. The departure of the four-year average from the yet undetermined mean of Ajo may not be the same as that at Yuma nor in the same direction, but it is probably of the same order of magnitude. This average $\left(69.1^{\circ}\right)$ may then be taken as correct within $1^{\circ}$ or $2^{\circ}$ plus or minus. The Al Johns Well, in Gibson, less than a mile from the weather station of Ajo, had a temperature of $76.5^{\circ}$ on October 16,1917 , near the middle of the day. The temperature of this well is exceeded in only one of the other shallow wells-Cipriano Well. That well was, however, nearly dry on September 30,1917 , the date of measurement, containing only 1.4 feet of water, and its temperature was probably affected by the air temperature. This water of shallow wells is commonly a few degrees warmer than the mean annual temperature of the air, but the Quitobaquito water is $8^{\circ}$ or $9^{\circ}$ warmer still. The temperature of the Quitobaquito Spring is also above that normal for shallow ground waters in this area. The abnormal temperature and the lack of any local source for the water in the granite from which the spring flows make it reasonably certain that the water is not derived from rainfall but rises from a fissure penetrating the deeper crust. Near the surface this fissure probably merges with the numerous joints and fractures of the surface rocks. The water then comes to the surface by numerous openings in the broad zone of seepage and is cooled by contact with the surface rocks, so that it emerges with only a small excess of temperature above the normal.

Analysis of a sample of the spring water taken October 1, 1917, shows no special distinctions from other ground waters but considerable differences from the water of Sonoita River. The following table gives the analyses of samples from (1) the main opening at Quitobaquito; (2) Blankenship Well, 12 miles southeast of Quitobaquito (see table, p. 181) ; and (3) Sonoita River at low stage 11/4 miles south of Quitobaquito: 
Analyses of waters from Quitobaquito Spring and near-by sources

Analyzed by A. A. Chambers and C. H. Kidwell. Parts per million except as otherwise designated

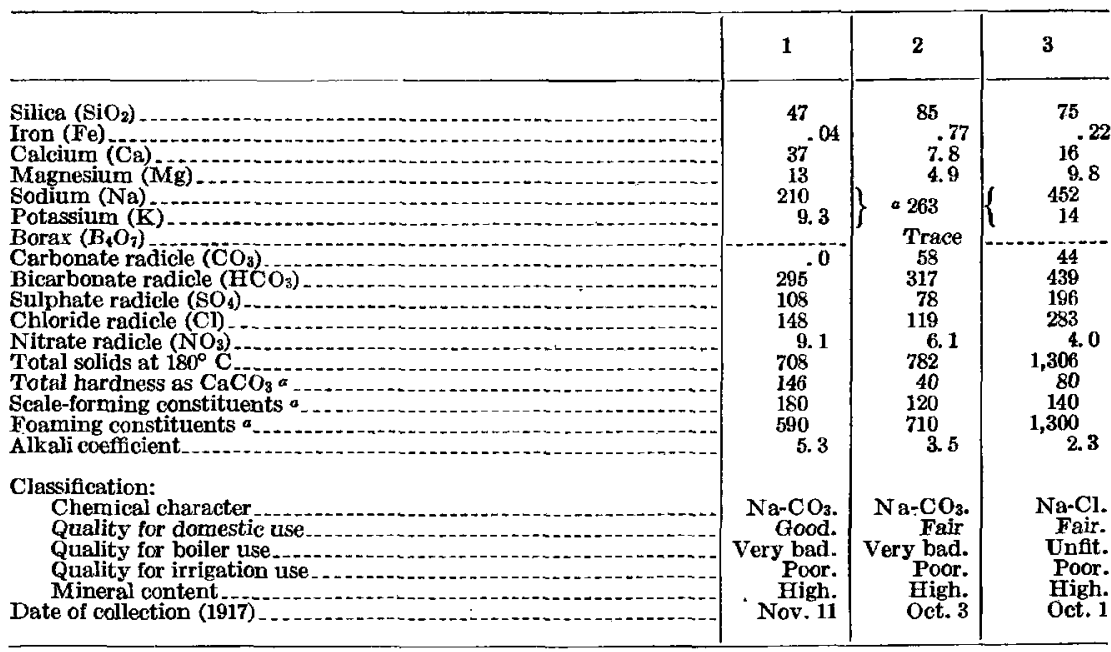

a Calculated.

\section{WATER IN THE CRYSTALLINE COMPLEX}

The crystalline rocks of pre-Cambrian and Mesozoic age, which together may be grouped as the crystalline complex, crop out largely in the mountains and surrounding pediments. The pore spaces in such rocks are few and so small that the rocks are practically impervious to water. Near the surface of the ground these rocks are, however, broken by numerous fractures and joints. The origin of these fractures is complex; many are due to weathering (p. 81), others to relief of load, compressive and tensional strains, faulting, cooling, or other causes. Whatever its origin, each fracture is a sheetlike opening capable of receiving and holding a film of water. Where these fractures are numerous and open, wells may be profitably dug.

The wells in the crystalline rocks of Connecticut have been closely studied. ${ }^{42}$ The rocks of the Papago country are very similar to those of Connecticut in the number, size, and character of their fractures. The total quantity of water is much less in the Papago country than in Connecticut because of the smaller precipitation. Of 237 wells studied in Connecticut only 3 are recorded as obtaining no water; of 137 wells whose yield is known only 17 furnish less than 2 gallons a minute, or enough to supply 200 head of cattle if pumped continuously. The most significant result of drilling in Connecticut is the determination of a limit in depth below which it is not profitable

22 Gregory, H. E., and Ellis, E. E., Underground water resources of Connecticut: U. S. Geol. Survey Water-Supply Paper 232, pp. 54-76, 91-94, 1909. 
to go. The fractures, joints, and seams in the rock become fewer and less open as depth increases, and it has been found that below 200 feet there are usually not enough open water-bearing joints to furnish water for a well. The same generalization may be made for the crystalline rocks of the Papago country.

Wells in the crystalline rocks in the Papago country are commonly dug by the ordinary methods of sinking shafts. Such a well has the advantage that its large area cuts a great number of fractures. The well is also a reservoir that stores water, which may seep slowly out of the crevices. It is a common practice to run drifts or galleries from the bottom of the well. This is usually done in dry seasons when necessity compels, and the work is then easy because there is little or no difficulty in keeping water away from the workings. The object of. a gallery is to intercept more joints and fractures and thus obtain additional seepage into the well. A gallery also provides additional storage for water, which may be pumped out rapidly and then allowed to accumulate between pumping periods.

The characteristics of wells dug in the crystalline complex are shown in the following table: 
Characteristics of certain wells dug in crystalline rock in the Papago country

\begin{tabular}{|c|c|c|c|c|c|c|c|c|c|}
\hline \multirow[b]{2}{*}{ Name or location } & \multicolumn{3}{|c|}{ Depth (feet). } & \multirow{2}{*}{$\begin{array}{c}\text { Depth } \\
\text { to the } \\
\text { water } \\
\text { level in } \\
\text { the well } \\
\text { (feet) }\end{array}$} & \multirow[b]{2}{*}{$\begin{array}{c}\text { Date of } \\
\text { measurement }\end{array}$} & \multirow[b]{2}{*}{ Kind of rock } & \multirow[b]{2}{*}{ Topographic position } & \multirow[b]{2}{*}{ Amount of water } & \multirow[b]{2}{*}{ Remarks } \\
\hline & $\begin{array}{l}\text { In } \\
\text { allu- } \\
\text { vium }\end{array}$ & $\underset{\text { rock }}{\text { In }}$ & Total & & & & & & \\
\hline $\begin{array}{l}\text { Clark water shaft, Ro- } \\
\text { wood. }\end{array}$ & $10 \pm$ & $105 \pm$ & 115 & 10 & & Rhyolite ....... & $\begin{array}{l}\text { Pediment, on bank of ar- } \\
\text { royo. }\end{array}$ & 4,000 gallons daily & $\begin{array}{l}\text { Town supply of Clarks- } \\
\text { town (Rowood post } \\
\text { office); for analysis see } \\
\text { p. 172. }\end{array}$ \\
\hline $\begin{array}{l}\text { McNeil Well } \\
\text { AI Johns Well, Gibson.- }\end{array}$ & $\begin{array}{l}1 \pm \pm \\
10 \pm \\
(a)\end{array}$ & $60 \pm$ & $\begin{array}{l}50 \\
70 \\
67.5\end{array}$ & $\begin{array}{l}10 \\
20 \\
59.5\end{array}$ & 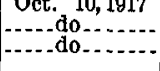 & 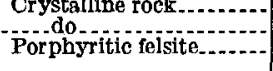 & $\begin{array}{l}\text { Pediment, in arroyo... } \\
\text { Pediment... }\end{array}$ & Went dry in 1916 & $\begin{array}{l}\text { Old prospect hole. } \\
\text { Gallery 50 feet west, dug }\end{array}$ \\
\hline $\begin{array}{l}\text { Ross Johnson Well, } \\
\text { Gibson. }\end{array}$ & (a) & -........ & 75 & & & Hornblende porphyry & --_-_do & $\begin{array}{l}\text { Sufficient for } 2 \text { or } 3 \\
\text { families. }\end{array}$ & Gallery 25 feet Iong. \\
\hline Cook \& Landro Well... & $2 \pm$ & $40 \pm$ & 42 & 21.8 & Oct. 10,1917 & Porphyritic felsite....... & $\begin{array}{l}\text { Pediment, in arroyo } 25 \text { feet } \\
\text { deep. }\end{array}$ & $\begin{array}{l}\text { Very little water in } \\
\text { dry seasons. }\end{array}$ & \\
\hline $\begin{array}{l}\text { Well } 2 \text { miles west of } \\
\text { Cook \& Landro Well, } \\
\text { Tule Well, Little Ajo }\end{array}$ & & 35 & 35 & 16.5 & Oct. 11,1917 & $\begin{array}{l}\text { Hornblende schist..... } \\
\text { Schist.......... }\end{array}$ & Pediment, in arroyo.... & Supplies windmill & Dug by Thomas Childs. \\
\hline $\begin{array}{l}\text { Mountains. } \\
\text { Pozo Blanco............ }\end{array}$ & $2 \pm$ & 47 & 49.2 & 30.8 & Nov. 22,1917 & Granite .............. & $\begin{array}{l}\text { royo } 10 \text { feet deep. } \\
\text { Pediment, } 10 \text { feet above }\end{array}$ & & $\begin{array}{l}\text { about } 1913 \text {. } \\
\text { Supplies } 4 \text { or } 5 \text { Papago } \\
\text { families. }\end{array}$ \\
\hline $\begin{array}{l}\text { Well at Black Prince } \\
\text { mine. } \\
\text { Dobbs Well }\end{array}$ & $\begin{array}{c}0 \\
10 \pm\end{array}$ & $\begin{array}{l}10 \\
52 \pm\end{array}$ & $\begin{array}{l}10 \\
62\end{array}$ & $\begin{array}{c}7 \\
47.5\end{array}$ & $\begin{array}{l}\text { Nov. 23, } 1917 \\
\text { Nov. 26, } 1917\end{array}$ & $\begin{array}{l}\text { Pegmatite and schist...- } \\
\text { (?) }\end{array}$ & $\begin{array}{l}\text { In gulch on east side of } \\
\text { Sierra Blanca. } \\
\text { Near stream in dissected }\end{array}$ & Small ...... & $\begin{array}{l}\text { For analysis see p. } 172 . \\
\text { Desert watering place; }\end{array}$ \\
\hline Alamo Well ................ & (........ & 42 & 42 & 40 & Dec. 21,1917 & Brecciated felsite......... & pediment......................... & ......do do........... & Supplies small Papago \\
\hline Ronstadt Well $\ldots . . . . . .$. & $10-$ & (?) & 47.9 & 25.3 & Dec. 11,1917 & Minutely Jointed felsite. & $\begin{array}{l}\text { Pediment, on bank of ar- } \\
\text { rovo } 10 \text { feet deep. }\end{array}$ & & Windmill and small en- \\
\hline Garcia, E & $5 \pm$ & $20 \pm$ & 25 & 15.9 & ................ & Gneiss?................... & Broad swale in pediment.- & Supplies windmill..... & La Osa Land \& Loan \\
\hline $\begin{array}{l}\text { Oro Blanco Well, in } \\
\text { town. } \\
\text { Stouts Well............. }\end{array}$ & $\begin{array}{l}(?) \\
(?)\end{array}$ & (b) & 73.5 & $\begin{array}{l}43.8 \\
23.9\end{array}$ & Sept. 17,1917 & $\begin{array}{l}\text { Crystalline rock at bot- } \\
\text { tom. } \\
\text { schist. }\end{array}$ & $\begin{array}{l}\text { Along stream in dissected } \\
\text { pediment. } \\
\text { Pediment, on bank of } \\
\text { stream which is not in- }\end{array}$ & (.....do do & For analysis see p. 172 \\
\hline $\begin{array}{l}\text { Tule Well, south of Ca- } \\
\text { beza Prieta Moun- } \\
\text { tains. }\end{array}$ & (?) & $35 ?$ & 35 & 27.3 & Oct. 19,1917 & $\begin{array}{l}\text { Tufaceous portion of } \\
\text { andesite. }\end{array}$ & $\begin{array}{l}\text { Near stream channel in } \\
\text { pediment. }\end{array}$ & 500 gallons daily....... & $\begin{array}{l}\text { Desert watering place; } \\
\text { for anaiysis see p. } 172 .\end{array}$ \\
\hline
\end{tabular}


The table shows that water occurs in many types of crystalline rock. A large number of wells, however, are dug in felsites and porphyries, some intrusive and others ancient lavas, presumably of Mesozoic age. These rocks are intricately fractured. The joints in many places are so close together that the rock is broken into blocks from 1 to 2 inches in diameter. Close jointing seems to be the determining factor in producing successful wells in these rocks. The prospective well digger should therefore select a place where the rocks are broken by numerous and closely spaced fractures. Such localities are most likely to be found in areas of felsite and schist.

The table shows also that the greater number of these wells are on the pediments that flank the mountains (see pp. 93-101), commonly in or near stream courses. Certain practical reasons have much to do with the location of these wells. Wells dug for stock watering places must be near grazing areas and in a place where they can be reached by easy trails. The rough mountains are therefore avoided. Many mines and prospects are located in the pediment or just at the foot of the mountains, because the ore-bearing rocks are commonly somewhat less resistant to erosion than the granite and gneiss and are thus more likely to occur in the pediment than in the mountains. The location of wells along streams is practical common sense, for a flood on an ephemeral stream contributes to the water in the rocks of a locality as much or more than a rain. Along the streams is. found the heaviest vegetation, which is kept alive by this flood water. Certain desert plants also are thought to indicate ground water, as discussed on page 156 , and in some parts of the region there are seeps in wet weather that are favorable localities for devaloping wells. One who wishes to dig a well in the crystalline rocks, giving weight to the evidence of vegetation or of seepage, should place his principal reliance on a careful inspection of the locality for the purpose of finding an area of minutely fractured rocks which is so situated as. to receive water from the floods of a wash or ephemerai stream that has a large drainage area.

The rocks of the crystalline complex are very diverse in type, and it is therefore to be expected that well waters derived from cracks and joints in these rocks should also differ chemically. Dobbs Well and Stouts Well, with total dissolved solids of 667 and 579 parts per million, are typical well waters of the crystalline complex. In both waters dissolved silica is high and bicarbonate is the principal acid. radicle. The water of Stouts Well is higher in iron and magnesium, doubtless derived from the schist in which the well is dug. The high nitrate content of this well water, which exceeds that of Dobbs Well 
by 14 parts per million, seems to be due, in part at least, to the close proximity of the watering trough and corral to the well.

The water obtained from the Clark water shaft, from which Clarkstown (Rowood post office) has been supplied, is a calcium-sulphate water of high mineral content. It is unfit for boiler use and consumes excessive amounts of soap. The principal objection of consumers to this water has been a suspicion that it contains salts of copper, but a qualitative test failed to show the presence of copper.

From his well in Gibson Al Johns has been retailing water in Gibson and in Clarkstown in competition with water from the Clark water shaft. The well is dug through alluvium into rock along the main street of Gibson. The water has 562 parts per million of total dissolved solids, compared to 1,559 parts in the Clark water, and therefore is more pleasant to the taste. Like the Clark water, it gave no test for copper, but as the well is near dwellings it is sibject to the possibility of pollution which always exists in such circumstances.

The well near the Black Prince mine, dug originally as a prospect hole, has a calcium-carbonate water with total dissolved solids of 1,091 parts per million. The water is hard and will need to be softened for use in laundry work. The organic matter is high, but this is probably due to trash and dead bees which, because the well is uncovered, fall into the water. The well will be a satisfactory source of water for prospecting, but the amount of water is insufficient for a large mine.

The water of Papago Well is a sodium-carbonate water of moderats mineral content and can be used for all purposes. The well is a drill hole of considerable depth, and as the log is not known it mav penetrate lava and not crystalline rock. The sample was taken from the well with a bailer and is water that had been standing in the well for some time. A small amount of hydrogen sulphide was found in the water. Sulphur in this form and in small quantities is not harmful and may be readily removed by aeration. 
Analyses and classification of water from wells in crystalline complex

[Analyzed by A. A. Chambers and C. H. Kidwell. Parts per million except as otherwise designated]

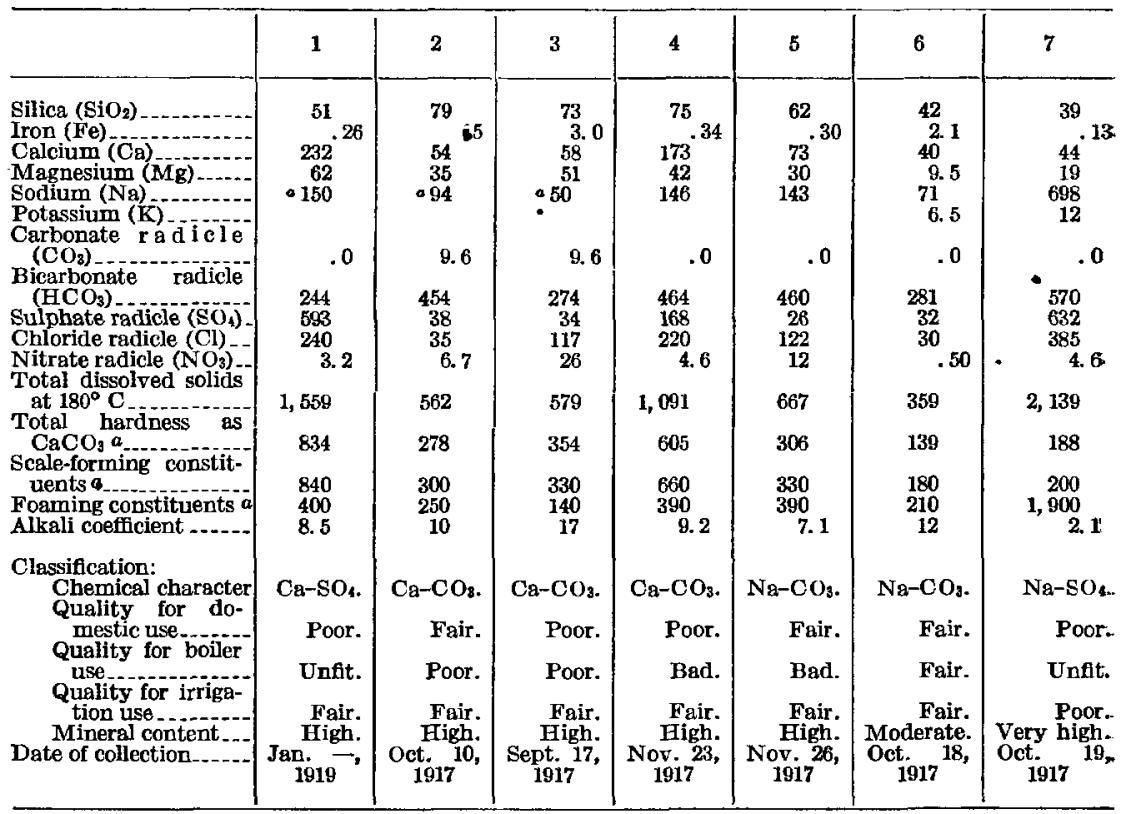

a Calculated.

1. Clark water shaft, Clarkstown (Rowood post office).

2. Al Johns Well, Gibson.

3. Stouts Well.

4. Black Prince mine.

5. Dobbs Well.

6. Papago Weli. (Contains hydrogen sulphide $\left(\mathrm{H}_{2} \mathrm{~S}\right)$.)

7. Tule Well, south of Cabeza Prieta Mountains.

\section{WATER IN THE SEDIMENTARY ROCKS}

The sedimentary rocks in the Papago country are of three typeslimestone, shale, and quartzite of Paleozoic age; sandstone and shale of Mesozoic age; and conglomerate of Tertiary age (Pl. IX). The areas of outcrop of these formations are small, and only a few wells are known to have been sunk in any of them.

The limestone of Paleozoic age is well jointed, and at the surface the joints are open. It seems likely that rain water is readily absorbed and that wells of sufficient depth should obtain water in these rocks. The water will, however, be more heavily mineralized than that found in the crystalline rocks. Near Snyders Hill a 6-inch drilled well 500 feet deep in Paleozoic limestone encountered water at 200 feet. From this well 4,000 gallons was pumped daily during the construction of the county road in 1917.

So little is known of the Mesozoic sandstone and shale that no predictions as to their water content can be made. They occur, however, largely in the Tumacacori Mountains, an area which is 
comparatively well watered and in which storage reservoirs can be profitably used. (See p. 141.)

The Tertiary conglomerate includes rocks that differ greatly in porosity, even in a single outcrop. The coarse-grained beds that are not too thoroughly cemented should, however, be good water bearers, and such beds occur in all the areas in which these rocks crop out. About 4 miles east of Walls Well is a dug well 5 feet square and 59 feet deep, in which water stands 7.2 feet from the surface. The surface rock is tuffaceous conglomerate interbedded with lava. This material is not greatly unlike other outcrops of conglomerate, except that it seems to be more porous. The yield of the well is not known, but it is certainly sufficient for prospecting, the purpose for which the well appears to have been dug.

\section{WATER IN THE TERTIARY VOLCANIC ROCKS}

The Tertiary volcanic rocks range in thickness from 50 to 2,000 feet and are composed of lava, tuff, and stream-laid conglomerate. The lava ranges from massive beds 50 to 300 feet thick with few joints or openings to beds laid down in plates 1 to 2 feet thick and having many joints. The rock of either the thick or the thin beds may be dense and compact or vesicular and scoriaceous. Some of the tuff beds are coarse grained and porous; others are so fine grained or so thoroughly cemented as to be impervious to water. The conglomerate likewise, though normally porous, may be cemented and impervious. A formation composed of rocks that differ so much in type and thickness obviously differs from place to place in its ability to absorb and hold water. In general, however, the surface layers are broken by numerous open joints, and in outcrops having a thickness of more than 200 feet there are usually beds of lava, tuff, or conglomerate having sufficient pores, vesicles, or joints to make excellent water bearers. The attitude of the bedding and the area and attitude of the outcrop are of prime importance to the prospective well driller.

Fortunately, the marked stratification of the rocks is generally not concealed by soil or vegetation, and the intelligent layman may therefore readily determine the essential factors. These factors may be summarized as follows: A large area of the rocks should be exposed to rainfall or a smaller area to flood waters; the exposed portion of the rocks should be porous or much fractured and should communicate by pores or fractures with the porous beds below; the lower part of the block of volcanic rocks should be below the general level of drainage, so as to make a reservoir that will hold ground water.

A relatively small number of wells draw water from the Tertiary volcanic rocks, though some of these are among the most successful in the Papago country. 
The municipal supply of Ajo and the water necessary for the operation of the large mill and leaching plant of the New Cornelia Copper Co. at Ajo are drawn from No. 1 well, which ends in volcanic rock. In 1913 the New Cornelia Copper Co. drilled four wells in a search for an adequate supply for the town of Ajo and the company's projected plant. No. 1 well, near the north end of the Valley of the Ajo, gave the most promising results. The log showed about 200 feet of alluvium and below that alternating beds of various lavas to the bottom at 1,348 feet. Between 645 and 664 feet the log showed 19 feet of "gravel," which was water bearing. A test with an air lift yielded 200 gallons a minute, with no evidence of diminution in flow and so quick a recovery on the cessation of pumping that the drawdown could not be measured. Accordingly, work was begun on a two-compartment shaft 6 by 12 feet at a point 100 feet south of the drill hole. This was sunk to 651 feet. At 645 feet a pump chamber 21 by 41 feet and 14 feet high in the clear was cut south of the shaft, and a drift was run to the drill hole on the north. Another chamber was excavated to one side of the pump chamber as a sump. The apparatus installed consists of two vertical centrifugal pumps direct connected to vertical motors, which pump from the shaft to the sump. From the sump the water flows by gravity to the suction pipe of a double-acting cylinder pump direct connected to a motor. This pump lifts the water to the surface and thence through a pipe line to a 500,000-gallon tank on Reservoir Hill, above the mill at Ajo, 7 miles away. The pressure on the pump cylinders is about 590 pounds to the square inch, and the total lift including friction is 1,475 feet. The yield of the plant is 800 gallons a minute. The combined $\log$ of the shaft (to 651 feet) and well (from 651 to 1,438 feet) is as follows:

Log of Well No. 1, New Cornelia Copper Co.

\begin{tabular}{|c|c|c|c|c|c|}
\hline & $\begin{array}{l}\text { Thick- } \\
\text { ness }\end{array}$ & Depth & 1 & $\begin{array}{c}\text { Thick- } \\
\text { ness }\end{array}$ & Depth \\
\hline & & Feet & & Feet. & Feet \\
\hline $\begin{array}{l}\text { Sand--- } \\
\text { Gravel.-. }\end{array}$ & $\begin{array}{r}11 \\
5\end{array}$ & $\begin{array}{l}11 \\
16\end{array}$ & $\begin{array}{l}\text { Red lava in layers } 1 \text { foot thick } \\
\text { Hard black lava }\end{array}$ & $\begin{array}{l}16 \\
11\end{array}$ & $\begin{array}{l}337 \\
348\end{array}$ \\
\hline Soft $\mathrm{se}$ & 44 & 60 & Soft decomposed lava-............ & & 354 \\
\hline Adob & & 64 & Hard red lava......... & 19 & 373 \\
\hline Sand. & 84 & 148 & Soft red lava & 28 & 401 \\
\hline Silt & 7 & 155 & Red lava, hard and shiny. & 10 & 411 \\
\hline mon the & 9 & 164 & Soft red lava & 34 & 445 \\
\hline lime lbase of the al- & & & obe dirt.- & & 451 \\
\hline porous lava & 29 & ${ }_{202}^{173}$ & $\begin{array}{l}\text { Soft red lava..... } \\
\text { Black lime }\end{array}$ & $\begin{array}{l}19 \\
39\end{array}$ & $\begin{array}{l}470 \\
509\end{array}$ \\
\hline Dark. & 13 & 215 & Hard red lava-..- & i1 & 520 \\
\hline Red l: & 5 & 220 & Hard black lava...- & 24 & 544 \\
\hline & 10 & 230 & Soft & 10 & 554 \\
\hline Bla & 32 & 262 & Hard & 33 & 587 \\
\hline Dar & 12 & 274 & Water strotg" & 64 & 651 \\
\hline Hedp & 16 & 2990 & "Gravel water strata"... & $\begin{array}{r}13 \\
456\end{array}$ & 664 \\
\hline $\begin{array}{l}\text { Harc bolac } \\
\text { Soft red }\end{array}$ & 18 & 315 & “Red malpais"........ & $\begin{array}{l}456 \\
120\end{array}$ & 1,340 \\
\hline Magnesia lime............ & & 321 & "Black malpais"-........ & 8 & I, 348 \\
\hline
\end{tabular}


Examination of the rocks in sinking the shaft revealed some of the errors in the well log. The alluvium is only 173 feet deep instead of 200 feet, and there are many variations in the character of the lava beds. The "gravel" shown in the original log was found to be a soft red lava. Detailed examination of this lava shows that it is a flow breccia and consists of irregular fragments of vesicular lava embedded in a matrix of finely porous lava. It is evidently a lava flow which when poured out on the surface contained gases that caused it to expand in a molten froth. This froth, congealing on the surface of the flow, was continuously engulfed in the unsolidified material below, until the whole flow consisted of rubble of partly solidified vesicular masses contained in a matrix of similar material. The rock is very porous, and many of the cavities are large. It is an ideal water bearer.

Two miles west of the Gunsight ranch, at the place known as Jaques ranch, is an old well. It was dug to supply water for the Gunsight mine during its period of activity from 1874 to 1882 . It was 280 feet deep and cribbed with timber. The cribbing was burned, and the well was reopened by David Disque in 1914 to use the water for irrigation, but a flood from the arroyo near by caused the well to cave a second time. It was partly reopened in 1917 by Jaques \& Para. In October, 1917, the well was 5 feet square, cribbed with lumber, and 166 feet deep, and the depth to water was 160.8 feet. The well is said to yield sufficient water to supply a windmill. The pile of waste thrown out of this well is mostly lava similar in type to that in the hills to the west, so that it seems certain that the water is derived mostly from 'Tertiary volcanic rocks that do not crop out.

Cochibo (Pl. XXV) is a watering place belonging to José Manuel, a Papago, who dug two wells in 1913, 30 feet apart, at the bottom of a narrow canyon cut in Tertiary volcanic rocks on the east side of the Ajo Mountains. The north well is 14.9 feet deep and had water at 13.0 feet from the top of the curb, or 3 feet above the bed of the stream. These measurements were made on November 14, 1917, and at that time the adjacent rocks were damp, so that it seems likely that the wells were dug at a place where there has always been a wet-weather seep. The wells are dug in friable and intricately jointed flow eccia, which probably derives its water supply from the rain absorbed in the heavy talus of the mountain side to the south and from the infiltration of flood waters of the stream.

Only two analyses of water from wells in the Tertiary volcanic rocks were made in this investigation. The well of the United States Indian Service at Indian Oasis penetrates alluvium and then goes into volcanic rocks. The water is of the calcium-carbonate type and 
is bad for boilers, but it is satisfactory for domestic purposes, though it is sufficiently hard to require considerable soap for laundry work.

The water from Cochibo is a calcium-carbonate water and if used in boilers would produce a large amount of scale. For domestic use it is satisfactory, except for its hardness.

These two analyses are not conclusive regarding the waters of the Tertiary volcanic rocks and merely indicate that they are likely to be of carbonate type.

Analyses and classification of water from wells in Tertiary volcanic rocks [Analyzed by A. A. Chambers and C H. Kidwell. Parts per million except as otherwise designated]

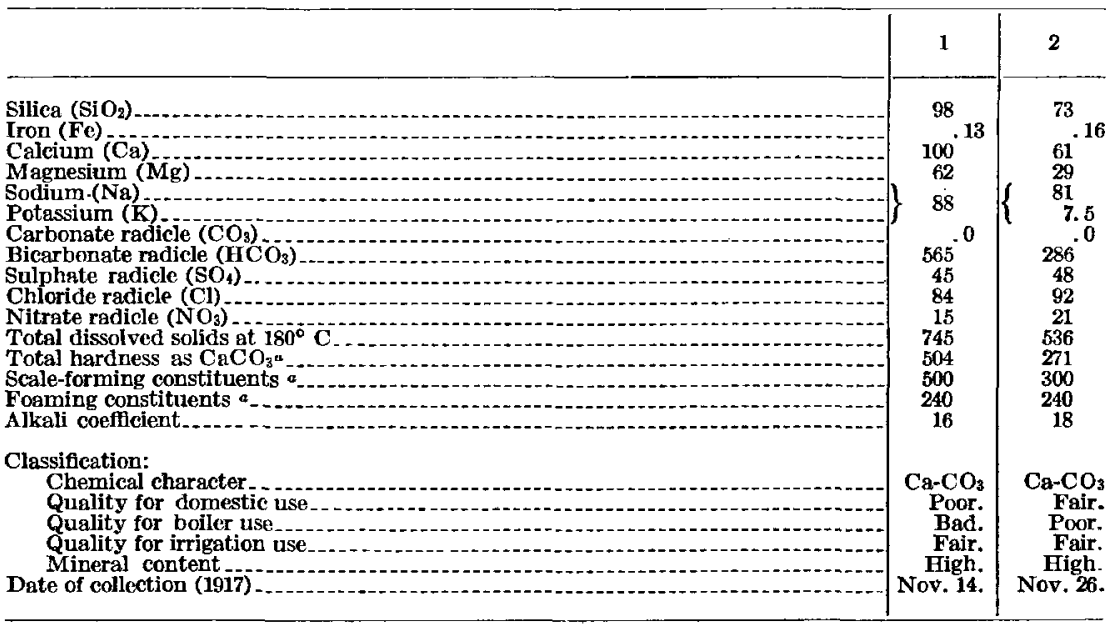

a Calculated.

1. Cochibo, sample from north well of two dug wells.

2. Government well at Indian Oasis (Sells post office).

\section{WATER IN THE ALLUVIUM}

\section{CHARACTER OF THE ALLUVIUM}

The valleys of Santa Cruz and Gila rivers and the interior valleys of the Papago country are underlain by alluvium. The relatively loose and consolidated character of this material makes it a fit medium for absorbing rain and flood waters. The same characteristics enable water to move readily through the interstices of the alluvium toward low areas and the sea.

The alluvium of the interior valleys has been derived from the erosion of the mountains and consists of coarse and fine débris ranging from boulders 6 inches or in some localities 2 or 3 feet in diameter to fine mud and clay. It has been carried into the valleys by streams of the same kind as those which at present discharge their muddy flows into the valleys. The alluvium is in consequence coarser around the periphery of each valley than in the center, though strings and lenses of coarser material, which represent old stream channels, are found in the central parts of the valleys. The 
processes and stages in deposition of the alluvium are discussed on pages 65-70. The characteristics of the alluvium as revealed by drilling are shown in the following logs of wells drilled by the 1 United States Indian Service for the benefit of the Papago Indians:

\section{Logs of United States Indian Service vells in Papago country}

Chiu-Chuschu

\begin{tabular}{|c|c|c|}
\hline & $\begin{array}{c}\text { Thick- } \\
\text { ness }\end{array}$ & Depth \\
\hline Silt and sand & Feet & Feet \\
\hline Sand. & $\begin{array}{r}18 \\
4\end{array}$ & 18 \\
\hline Coarse gravel. & 26 & \\
\hline Caliche & 22 & 70 \\
\hline Coarse wash gravel and pebbles; no fine sand & 18 & 88 \\
\hline Indurated clay & 2 & 90 \\
\hline Coarse wash gravel as above & $\begin{array}{l}4 \\
8\end{array}$ & 94 \\
\hline Soft sandy clay & 42 & 154 \\
\hline Granitic gravel, one-quarter to one-half inch in diameter; occasional strata of smooth & & \\
\hline Wash gravel & 66 & 220 \\
\hline $\begin{array}{l}\text { Granite. } \\
\text { Grated gramue... }\end{array}$ & & \\
\hline
\end{tabular}

Nore.-Drilled Jan. 27 to Mar. 4, 1915, by Southern California Drilling Co.; casing, No. 12 gage sheet iron, 16 inches in diameter, to 84 feet; No. 10 gage sheet iron, 10 inches in diameter, from 81 to 220 feet; perforated from 70 to 95 feet and from 150 to 220 feet; cost $\$ 976.97$.

\section{- Cocklebur}

Silt and sand.
Clay
Sand and gravel.
Clay and gravel.
Cemented gravel and boulders
Yellow clay
Cemented gravel and boulders
Fine gravel
Cemented gravel.
Granitic gravel...
Granite.

Note.-Drilled Mar. 9 to 30, 1915, by Southern California Drilling Co.; casing, No. 14 gage sheet iron, 10 inches in diameter, to 174 feet; perforated from 150 to 174 feet; cost $\$ 682.02$.

Jackrabbit

Silt and sand
Clay,
Caliche.
Clay Clay and gravel mixed; some water.
Cemented gravel and boulders
Decomposed quartzite.
Quartzite.

Note-_Drilled Apr. 3 to 23, 1915, by Southern California Drilling Co.; casing, No. 14 gage sheet iron, 10 inches in diameter, to 110 feet; perforated 80 to 106 feet; cost $\$ 555.36$.

\section{Kukomalik}

Top soil.

Clay and gravel

Clay.

Cement and gravel (water)

Clay and gravel

Coarse gravel; very little sand

Note-Drilled Sept. 1 to Oct. 2, 1915, by Southern California Drilling Co.; casıng, No. 14 gage sheet iron, 10 inches in diameter, to 218 feet; perforated 170 to 200 feet; cost $\$ 867.51$. 
Logs of United States Indian Service wells in Papago country-Continued

Quajote

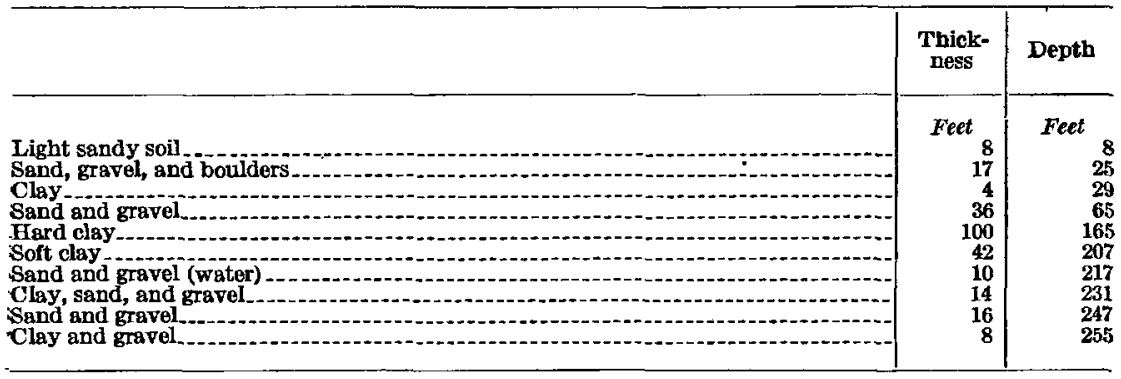

Note.-Drilled Oct. 5 to Nov. 23, 1915, by Southern California Drilling Co.; casing, No. 12 gage sheet iron, 10 inches in diameter, to 255 feot; perforated 238 to 255 feet; cost $\$ 1,010.68$.

\section{Santa Rosa}

Top soil.

Clay and gravel

Clay.

Cravel (water at 283 feet which rose to 274 feet)

Cement gravel.

\begin{tabular}{r|r}
16 & 16 \\
2 & 18 \\
265 & 283 \\
05 & 378 \\
13 & 391 \\
\hline
\end{tabular}

Note.-Drilled Apr. 27 to June 12, 1915, by Southern California Drilling Co.; casing, No. 14 gage sheet iron, 10 inches in diameter, to 378 feet; cost \$1,449.02.

\section{Anegam ।}

Light sandy soil
Sand and gravel
Clay and gravel.
Sand and gravel
Clay - Calliche
Clay and gravel
Coarse sand and gravel (water)

Note -Drilled June 12 to Aug. 28, 1915, by Southern California Drilling Co.; casing, No. 14 gage sheet iron, 10 inches in diameter, to 238 feet; cost $\$ 946.22$.

Topahua (east well)

Soil

Boulders and gravel

Streaks of dark-yellow clay

Boulders and gravel with clay

Clay and bonlders

Boulders

Clay and gravel

Clay -

Clay and boulders

Clay and gravel

Gravel -...-...--

Clay and gravel

Boulders

Clay and gravel

Clay.

Clay and grave

Gravel and boulders

Clay and gravel.

8
7
7
7
7


Logs of United States Indian Service wells in Papago country-Continued

San Miguel

\begin{tabular}{|c|c|c|}
\hline & $\begin{array}{l}\text { Thick- } \\
\text { ness }\end{array}$ & Depth \\
\hline Reddish clay_-.---.-..--.-- & Feet ${ }_{40}$ & Feet ${ }_{40}$ \\
\hline $\begin{array}{l}\text { Gravel and clay............ } \\
\text { Whitish clav }\end{array}$ & $\mathbf{5}$ & $\begin{array}{r}45 \\
175\end{array}$ \\
\hline $\begin{array}{l}\text { Wnitish clay } \\
\text { Caliche }\end{array}$ & & 185 \\
\hline Reddish clay & 78 & 263 \\
\hline $\begin{array}{l}\text { Reddish clay, caliche, and boulders } \\
\text { Reddish clay. }\end{array}$ & 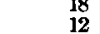 & 2983 \\
\hline Caliche and boudders & 57 & 350 \\
\hline Sandy formation, streaks of clay and caliche; some gravel & 18 & 368 \\
\hline $\begin{array}{l}\text { Clay, gravel, and sand } \\
\text { Clay galiche }\end{array}$ & ${ }_{12}^{22}$ & $\begin{array}{l}390 \\
402\end{array}$ \\
\hline Clay, gravel, sand, and fow boulders & 183 & 585 \\
\hline Sand and gravel; water at $585 \mathrm{fer}$ & & \\
\hline
\end{tabular}

Note.-Drilled Apr. 23 to May 20, 1917; cost $\$ 2,733$.

\section{DEPTH OF THE ALLUVIUM}

The depth of the alluvium in the Papago country varies between wide extremes. Over considerable areas it is a thin film covering and concealing an eroded rock floor; near the centers of the larger valleys it probably attains a considerable thickness and forms a valley fill comparable to that in Gila Valley, where wells penetrate more than 1,700 feet of unconsolidated material.4

At No. 1 Well, near the north end of the Valley of the Ajo, only 173 feet of alluvium was found, as shown in the log on page 174 . Childs Well, 5 miles farther south, is more than 820 feet deep and wholly in unconsolidated alluvium. Similarly, No. 3 Well, in Childs Valley farther down the same drainage line, 7 miles from No. 1 Well, shows 500 feet of alluvium. Midway Well, in the valley between the Crater and Sauceda mountains, penetrates at least 450 feet of alluvium, and the 165 feet of "sandy rock" below this recorded in the log may also be alluvium, though Tertiary sandstone and conglomerate are not improbable at this horizon.

Log of the Miduay Well

Cemented gravel, clay, and boulders

Sandy rock

Malpais

\begin{tabular}{|r|r}
\hline $\begin{array}{c}\text { Thick- } \\
\text { ness }\end{array}$ & Depth \\
\hline Feet & Feet \\
450 & 450 \\
165 & 615 \\
116 & 731 \\
\hline
\end{tabular}

Note.-Drilled by E. R. Liner for New Cornelia Copper Co. in 1915; depth to water, 615 feet, Aug. 17 to Oct. 4, 1915, and 607 feet, Oct. 24, 1915; yield on test, 400 gallons a minute; machinery dismantled in 1917.

Four of the Indian Service wells reached the rock floor of the valleys at the following localities and depths: Chiu-Chuschu, 228 feet; Cocklebur, 196 feet; Jackrabbit, 123 feet; Topahua No. 1, 100

48 Ross, C. P., op. cit., p. 79. 
feet. All these wells are near the mountain borders or in small valleys. Near the centers of the larger valleys wells have not struck rock.

DEPTH TO WATER IN THE ALLUVIUM

The number of wells in the region is very small, and in consequence statements regarding depth to water that will be generally applicable can not be made. In the gaps in the mountains and in small valleys filled with alluvium but more or less. surrounded by rocky hills the depth to water varies and seems to be determined wholly by local conditions. The subject is further discussed under the heading "Shallow wells" below. For the larger valleys no generalization can safely be made except that the water level is commonly deep.

The relation of the water level in wells to the surface levels in the Valley of the Ajo is brought out in the following table, compiled from data obtained by the New Cornelia Copper Co.:

Relation of altitude of surface and water level in certain wells in valley of the $A j o$

\begin{tabular}{|c|c|c|c|c|}
\hline Well & $\begin{array}{l}\text { Distance } \\
\text { from } \\
\text { Childs } \\
\text { Well in } \\
\text { direction of } \\
\text { drainage }\end{array}$ & $\begin{array}{l}\text { Depth to } \\
\text { water }\end{array}$ & $\begin{array}{c}\text { Altitude } \\
\text { of surface } \\
\text { above sea } \\
\text { level }\end{array}$ & $\begin{array}{l}\text { Altitude } \\
\text { of water } \\
\text { above sea } \\
\text { level }\end{array}$ \\
\hline $\begin{array}{l}\text { Childs Well } \\
\text { No. } 1 \text { Well } \\
\text { Batamote well } \\
\text { No. } 3 \text { Well } \\
\text { Midway well }\end{array}$ & \begin{tabular}{r|r} 
Miles \\
5 \\
8 \\
12
\end{tabular} & $\begin{array}{l}\text { Feet } \\
820 \\
641.78 \\
54.5 \\
460 \\
607\end{array}$ & $\begin{array}{l}\text { Feet } \\
1,600 \\
1,411.67 \\
1,335 \pm \\
1,220.75 \\
1,160\end{array}$ & $\begin{array}{l}\text { Feet } \\
780 \\
769.89 \\
1,280 \pm \\
760.75 \\
553\end{array}$ \\
\hline
\end{tabular}

An inspection of this table shows that the surface falls 380 feet in the 12 miles from Childs Well to No. 3 Well. The water level in No. 3 well is only 20 feet lower than that in Childs Well. On such a grade there can be but little movement, and it must be concluded either that the ground water in this area is almost stagnant or that its direction of movement does not conform to that of the surface drainage. The water in Batamote Well stands some 500 feet higher than the water in adjacent wells and appears to be derived from a perched water table (p. 181). Midway Well, in the valley between the Crater and Sauceda mountains, has a water level about 200 feet lower and seems to penetrate an entirely separate body of ground water.

SHALLOW WELLS IN THE ALLUVIUM

Wells of small depth obtain water from alluvium in two situations-in the larger valleys, in gaps and passes, and in small 
valleys more or less inclosed by rocky hills. The principal wells of this type are listed in the following table:

Characteristics of principal shallow wells aug in alluvium in Papago country

\begin{tabular}{|c|c|c|c|c|c|}
\hline Name & Depth & $\begin{array}{l}\text { Depth } \\
\text { to } \\
\text { water }\end{array}$ & Date & Amount of water & Remarks \\
\hline $\begin{array}{l}\text { Bates Well: } \\
\text { East well. }\end{array}$ & Feet & Feet & 307017 & Never drv & Dug he Bat \\
\hline West well ... & 43.0 & 37 & do do & $\begin{array}{l}\text { About } 20,000 \text { gallons } \\
\text { daily. }\end{array}$ & $\begin{array}{l}\text { Dug by C. G. Puffer and } \\
\text { Reub Daniels, 1915; } \\
\text { for analysis see p. 184. }\end{array}$ \\
\hline Powers Well_... & 135.0 & & $\ldots$ do_....... & Dry & Dug by Fred Powers, \\
\hline $\begin{array}{l}\text { Cipriano Well: } \\
\text { North well }\end{array}$ & 57.0 & 55.6 & do & Goes dry some years & \\
\hline South well & 35.0 & 34.5 & do do...... & (?) & Not completed. \\
\hline Cherioni well ..... & 72.0 & 72.0 & Oct. $\quad 1,1917$ & 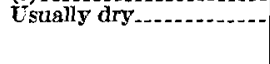 & $\begin{array}{l}\text { Dug by Reub Daniels, } \\
\text { 1916; one or two gal- } \\
\text { leries. }\end{array}$ \\
\hline Blankenship Well. & 65.0 & 54.4 & Oct. 3,1917 & & $\begin{array}{l}\text { Dug by Lon Blanken- } \\
\text { ship, 1917; for analysi } \\
\text { see p. 167. }\end{array}$ \\
\hline Darby Well & 95.4 & - 83.4 & Oct. 10,1917 & $\begin{array}{l}\text { Supplies windmill with } \\
\text { 3-horsepower auxiliary }\end{array}$ & $\begin{array}{l}\text { Irrigates small garden; } \\
\text { for analysis see p. } 184 .\end{array}$ \\
\hline Lewis Well & 97.2 & 88.2 & Oct. 9,1917 & $\begin{array}{l}15 \text { gallons a minute for } \\
\text { short time. }\end{array}$ & $\begin{array}{l}\text { Water level rose to } 40 \\
\text { feet after rain in sep- } \\
\text { tember, } 1917 \text {; galleries, } \\
25 \text { feet north, } 20 \text { feet } \\
\text { south; for analysis see } \\
\text { p. } 184 \text {. }\end{array}$ \\
\hline $\begin{array}{l}\text { W. G. Miller (west } \\
\text { well). }\end{array}$ & 38.4 & $a 26.0$ & Oct. 14,1917 & 7 gallons a minute & Windmill and auxiliary \\
\hline Walls Well _ - & 46. 0 & 19.3 & do & Never dry & $\begin{array}{l}\text { Dug by Fred Wall about } \\
\text { 1870; deepened by pros- }\end{array}$ \\
\hline Gunsight ranch..... & 115.4 & 54.0 & Oct. 15,1917 & $\begin{array}{l}\text { Supplies windmill ex- } \\
\text { cept in dry seasons. }\end{array}$ & $\begin{array}{l}\text { Rock at bottom of well; } \\
\text { dug by Haynes; for }\end{array}$ \\
\hline $\begin{array}{l}\text { Batamote } W \text { e } 11 \\
\text { (north well). }\end{array}$ & 90.0 & 54.5 & Sept. 27,1917 & $\begin{array}{l}\text { Supplies windmill ex- } \\
\text { cept in dry years. }\end{array}$ & $\begin{array}{l}\text { Auxiliary gas engine; two } \\
\text { galleries, each } 18 \text { feet; } \\
\text { for analysis see p. } 184 \text {. }\end{array}$ \\
\hline
\end{tabular}

$a$ When pumping.

Batamote Well and Cherioni Well may be taken as types of shallow wells in the larger valleys. Both are situated along streams that carry flood waters out of the Valley of the Ajo through gaps. Batamote Well may even be considered to lie within the gap separating the Valley of the Ajo and Childs Valley. Cherioni Well lies in the adobe flat just east of Growler Pass. According to the statements of men who dug the wells or the galleries, the water in both localities occurs in more or less cemented gravel just above a very compact clayey gravel or hardpan. The hardpan seems to prevent the downward passage of the water, and both wells at Batamote Well show a marked rise immediately after floods on the adjacent stream. The same phenomena probably occur at Cherioni Well, for when it was first dug there appeared to be a good deal of water, which, however, failed in the next dry season. The hardpan is 
probably not extensive enough 'to hold sufficient water to supply the well. The site of Cherioni Well was chosen because of the presence of a large cherioni tree. In this instance the tree indicated water at shallow depth, but not in sufficient quantity to be valuable.

Bates Well is in Growler Pass, in an alluvial flat bordered by low rocky hills. Two successful wells have been dug here. Walls Well and the near-by Miller Wells are similarly located. These wells draw water from small bodies of alluvium occasionally refilled with water from floods. Other wells similarly located may not be successful, however, for a number of unpredictable factors may intervene. The alluvium in the gap or small valley may be too thin or too compact and thoroughly cemented to supply a well. It may also drain too rapidly. Powers Well, 7 miles southwest of Bates Well, seems to be admirably located. It lies near the mouth of a small valley inclosed in hills in a flat over which pour flood waters from a considerable area on the west side of Growler Mountains. This well obtains no water at a depth of 135 feet. Yet its location is very similar to that of Lewis Well. in which the water stands at 88.2 feet, and to that of Cipriano Well, in which the water stands at 55.6 feet. It seems likely that the shallow water in the alluvium of the little valley in which Powers Well is situated drains away through the lavas or through a deep body of alluvium to the water table of Growler Valley.

The ground-water conditions in San Cristobal Valley are unlike those of other valleys. The three wells in this valley are listed in the following table:

Wells in san Cristobal Valley

\begin{tabular}{|c|c|c|c|c|}
\hline Name & $\begin{array}{l}\text { Distance } \\
\text { south from } \\
\text { Gila River }\end{array}$ & Method of sinking & Depth & $\begin{array}{l}\text { Depth to } \\
\text { water }\end{array}$ \\
\hline $\begin{array}{l}\text { Pimeria Well } \\
\text { Garcia Well } \boldsymbol{b}_{-} \\
\text {Whites Well_- }\end{array}$ & $\begin{array}{r}\text { Mriles } \\
9 \\
13 \\
19\end{array}$ & \begin{tabular}{|} 
Drilled_-_--_- \\
Dug \\
\end{tabular} & $\begin{array}{l}\text { Feet } \\
700 \\
47 \\
126\end{array}$ & $\begin{aligned} \text { Feet } \\
a 54.1 \\
46.3 \\
121.5\end{aligned}$ \\
\hline
\end{tabular}

a From top of casing, 6 feet above the surface.

- For analysis see p. 184 .

These wells are situated along the trough of the valley, and it is evident that there is a definite water table at relatively shallow depth which slopes in the same direction as the valley floor, but more gradually toward Gila River. Additional wells may be sunk in this valley with assurance of success. 
The waters from seven wells of shallow depth in the alluvium are alike in being of the calcium-carbonate type and having only a moderate mineral content, as shown in the following table:

Character of waters from shallow depths in alluvium in Papago country

[Based on 7 analyses, Nos. 1 to 6 and No. 9 in table on page 184. Parts per million]

\begin{tabular}{|c|c|c|c|}
\hline & Average & Maximum & Minimum \\
\hline 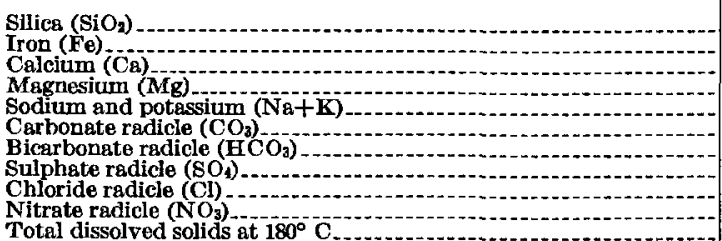 & $\begin{array}{l}47 \\
71^{.48} \\
21 \\
6.0 \\
258 . \\
28.17 \\
6.9 \\
349\end{array}$ & $\begin{array}{r}57 \\
1.7 \\
101 \\
26 \\
57 \\
17 \\
345 \\
42 \\
119 \\
15 \\
588\end{array}$ & $\begin{array}{r}24 \\
46 \\
6.9 \\
7.4 \\
174 \\
6.0 \\
3.8 \\
218^{.0}\end{array}$ \\
\hline
\end{tabular}

These wells, with the exception of that at Oro Blanco, are all in the Valley of the Ajo or at its border. Their low mineral content seems to be due to the short period which these waters remain in the alluvium, as shown by the quick response of water level in the wells to rainfall and floods.

Two analyses of water from shallow wells in alluvium are not included in the average given above. The water from Garcia Well, in the San Cristobal Valley, probably has an abnormally high mineral content, as explained on page 160. Blankenship Well lies in the drainage basin of Sonoita River, on the international boundary. The analysis shows its water to be a sodium-carbonate water of high mineral content. The foaming constituents are high and make the water very bad for boiler use, and the high content of sodium carbonate would require care in irrigation. For domestic use and watering stock, the purposes for which the well was dug, the water is satisfactory, in spite of a total content of dissolved solids more than twice the average of the other waters from shallow wells in alluvium. 104211-25-14 
The following table presents analyses of all samples collected from shallow wells in the alluvium:

\section{Analyses and classification of water from shallow wells in alluvium in Papago country}

[Analyzed by A. A. Chambers and C. H. Kidwell. Parts per million except as otherwise designated]

\begin{tabular}{|c|c|c|c|c|c|}
\hline & 1 & 2 & 3 & 4 & 5 \\
\hline 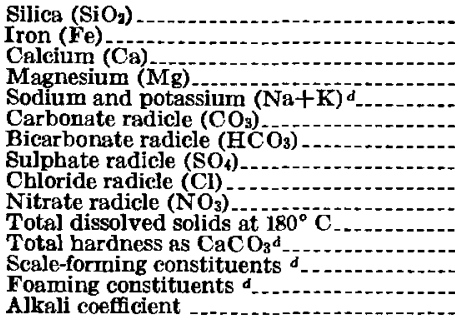 & $\begin{array}{l}51 \\
63^{.47} \\
11 \\
11 \\
12 \\
227 \\
6.8 \\
3.8 \\
8.6 \\
277 \\
203 \\
260 \\
30 \\
95\end{array}$ & $\begin{array}{l}{ }^{47} .08 \\
26 \\
57 \\
525 \\
32.0 \\
42 \\
119 \\
5.7 \\
588 \\
359 \\
390 \\
150 \\
17\end{array}$ & $\begin{array}{c}43 \\
51.28 \\
6.9 \\
7.4 \\
7.2 \\
174 \\
8.6 \\
3.8 \\
3.3 \\
1218 \\
156 \\
200 \\
20 \\
260\end{array}$ & $\begin{array}{l}52 \\
1.7 \\
73 \\
15 \\
16 \\
17 \\
237 \\
14 \\
22 \\
14 \\
357 \\
244 \\
290 \\
43 \\
90\end{array}$ & $\begin{array}{l}57 \\
84^{-12} \\
17 \\
13 \\
345^{\circ} \\
12 \\
7.8 \\
1.5 \\
351 \\
280 \\
330 \\
35 \\
120\end{array}$ \\
\hline $\begin{array}{l}\text { Classification: } \\
\text { Chemical character } \\
\text { Quality for domestic use } \\
\text { Quality for boiler use } \\
\text { Quality for irrigation use } \\
\text { Mineral content } \\
\text { Date of collection (1917) }\end{array}$ & $\begin{array}{l}\text { Ca-CO} \\
\text { Good. } \\
\text { Poor. } \\
\text { Good. } \\
\text { Moderate. } \\
\text { Sept. 28. }\end{array}$ & $\begin{array}{l}\text { Ca-COs } \\
\text { Fair. } \\
\text { Poor } \\
\text { Fair. } \\
\text { High. } \\
\text { Oct. } 10 .\end{array}$ & $\begin{array}{r}\mathrm{Ca}-\mathrm{CO}_{3} \\
\text { Good. } \\
\text { Fair- } \\
\text { Good. } \\
\text { Moderate. } \\
\text { Oct. } 9 .\end{array}$ & $\begin{array}{l}\text { Ca-CO3 } \\
\text { Fair. } \\
\text { Poor. } \\
\text { Good. } \\
\text { Moderate. } \\
\text { Oct. 15. }\end{array}$ & $\begin{array}{r}\mathrm{Ca}-\mathrm{CO}_{3} \\
\text { Fair. } \\
\text { Poor. } \\
\text { Good. } \\
\text { Moderate. } \\
\text { Oct. I4. }\end{array}$ \\
\hline & & 6 & $7 a$ & $8^{b}$ & $9 \mathrm{c}$ \\
\hline 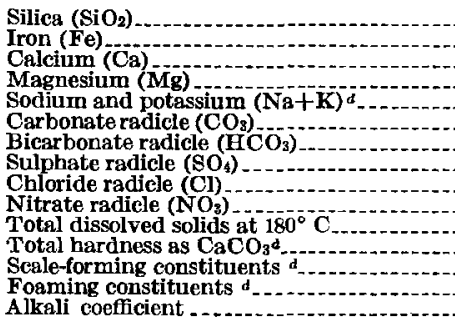 & & $\begin{array}{l}56 \\
82.54 \\
13 \\
9.1 \\
5.5 \\
282 \\
12 \\
9.0 \\
15 \\
346 \\
258 \\
320 \\
25 \\
200\end{array}$ & $\begin{array}{c}85 \\
7.77 \\
7.8 \\
4.9 \\
263 \\
58 \\
317 \\
78 \\
119 \\
6.1 \\
782 \\
40 \\
120 \\
710 \\
3.5\end{array}$ & 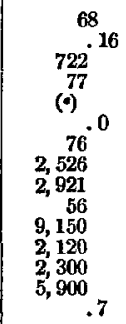 & $\begin{array}{l}24 \\
46 \\
15 \\
31 . \\
214^{.0} \\
27 \\
29 \\
306 \\
176 \\
180 \\
84 \\
60\end{array}$ \\
\hline $\begin{array}{l}\text { Classification: } \\
\text { Chemical character } \\
\text { Quality for domestic use } \\
\text { Quality for boiler use } \\
\text { Quality for irrigation use } \\
\text { Mineral content- } \\
\text { Date of collection (1917) }\end{array}$ & & $\begin{array}{r}\text { Ca-CO, } \\
\text { Good. } \\
\text { Poor. } \\
\text { Good. } \\
\text { Moderate. } \\
\text { Sept. } 30 .\end{array}$ & $\begin{array}{l}\text { Na-CO3 } \\
\text { Fair } \\
\text { Very bad. } \\
\text { Poor. } \\
\text { High. } \\
\text { Oct. 3. }\end{array}$ & $\begin{array}{r}\text { Na-Cl. } \\
\text { Unfit. } \\
\text { Unfit. } \\
\text { Bad. } \\
\text { Very high. } \\
\text { Nov. } 3 .\end{array}$ & $\begin{array}{r}\text { Ca-COs } \\
\text { Good. } \\
\text { Fair. } \\
\text { Good. } \\
\text { Moderate. } \\
\text { Dec. 11. }\end{array}$ \\
\hline
\end{tabular}

Borax $\left(\mathrm{B}_{4} \mathrm{O}_{7}\right)$, trace.

- Milligrams per liter.

- Hydrogen sulphide $\left(\mathrm{H}_{2} \mathrm{~S}\right)$ present.

- Calculated.

- Determined. Sodium (Na), 2,172; potassium (K), 23 parts per million.

f By summation.
1. Batamote Well, north well of two.
2. Darby Well.
3. Lewis Well.
4. Gunsight ranch well.
5. W. G. Miller's west well
6. Bates Well, west well of two
7. Blankenship Well.
8. Garcia Well
9. Well at Oro Blaneo. 
DFEP WELLS IN THE ALLUVIUM

The wells in the area from Gunsight Pass east to Robles Pass are listed in the following tahle:

Characteristics of deep drilled wells east of Gunsight Pass

[Not including the Indian Service wells]

\begin{tabular}{|c|c|c|c|c|c|}
\hline Name & Location & $\begin{array}{l}\text { Diam- } \\
\text { eter }\end{array}$ & Depth & $\begin{array}{c}\text { Depth } \\
\text { to water }\end{array}$ & Remarks \\
\hline Serventi Well ........... & Great Plain & $\begin{array}{l}\text { Inches } \\
\text { (?) }\end{array}$ & $\begin{array}{r}\text { Feet } \\
450\end{array}$ & $\begin{array}{r}\text { Feet } \\
100\end{array}$ & Abandoned; temperature of \\
\hline Old Quijotoa Well... & $\begin{array}{l}\text { Southern Santa Rosa } \\
\text { Valley. }\end{array}$ & 6 & 465 & (?) & A bandoned; drilled in 1914 . \\
\hline Old Ventana ranch well & Baboquivari Valley_... & 4 & 790 & (?) & A bandoned. \\
\hline Old Fresnal ra & $\begin{array}{l}\text { Northern Baboquivari } \\
\text { Valley. }\end{array}$ & 6 & 786 & $60+$ & $\begin{array}{l}\text { Abandoned, but reopened by } \\
\text { U. S. Indian Service in } 1917 \text {. }\end{array}$ \\
\hline Reward mine & $\begin{array}{l}\text { Northern border ve- } \\
\text { kol Mountains. }\end{array}$ & (?) & 840 & (?) & $\begin{array}{l}\text { Probably drilled largely in } \\
\text { rock. }\end{array}$ \\
\hline Warren Bros. . ..... & Altar Valley & $6 \frac{1}{4}$ & 380 & $200 \pm$ & $\begin{array}{l}\text { Plunger pump and 6-horse- } \\
\text { power gas engine; 10,000 to } \\
12,000 \text { gallons daily. Put in } \\
\text { for construction of road; } \\
\text { probably abandoned. }\end{array}$ \\
\hline Robles ranch & ....do_ & $(?)$ & (?) & (?) & \\
\hline & -..-don-. & (?) & $200 ?$ & (?) & $\begin{array}{l}\text { Stock watering place. } \\
\text { Domestic and stock. }\end{array}$ \\
\hline $\begin{array}{l}\text { Anvil ranch we } \\
\text { Palo Alto }\end{array}$ & 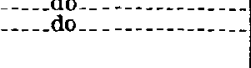 & (?) & $\begin{array}{l}350 \\
400 \pm\end{array}$ & $\begin{array}{r}300 \\
(?)\end{array}$ & $\begin{array}{l}\text { Domestic and stock. } \\
\text { Domestic and stock; plunger } \\
\text { pump and 15-horsepower gas }\end{array}$ \\
\hline Pozo Nuevo Well. & .....do_. & 8 & $400 \pm$ & (?) & $\begin{array}{l}\text { Stock; plunger pump and } 12- \\
\text { horsepower gas engine. Tem- } \\
\text { perature } 77.5^{\circ} \mathrm{F} \text {; for analysis } \\
\text { see p. } 188 \text {. }\end{array}$ \\
\hline Secundino Well & . & 8 & $400 \pm$ & (a) & $\begin{array}{l}\text { Stock; plunger pump and 12- } \\
\text { horsepower gas engine; for } \\
\text { analysis see p. 188. }\end{array}$ \\
\hline Buenos Aires Well.- & ...do... & 8 & $400 \pm$ & (?) & $\begin{array}{l}\text { Stock; plunger pump and 15- } \\
\text { horsepower gas engine; for } \\
\text { analysis see p. } 188 \text {. }\end{array}$ \\
\hline
\end{tabular}

a Flows in piet seasons.

An inspection of this table in connection with the table of the Indian Service wells on page 186 shows that water has been found in all the larger valleys except Quijotoa Valley, in which no wells have been drilled. The water is, however, far below the surface. The wells in Altar Valley, extending from Robles ranch south to Buenos Aires, are all successful. The normal level of water is about 200 feet below the surface, though precise measurements were not obtainable. Secundino Well, however, flows in wet seasons, and this fact indicates a large fluctuation in the water table.

The Southern Pacific Co. recently drilled a well at Mobile, in the valley between the Sierra Estrella and the Maricopa Mountains. The well is 452 feet deep, and the water in it stands 400 feet from the surface. The alluvium is very compact, and some beds are reported as "rock," as shown in the following log: 


\begin{tabular}{|c|c|c|}
\hline & Thickness & Depth \\
\hline $\begin{array}{l}\text { Sandy clay mixed with gravel. } \\
\text { Rock } \\
\text { Cemented clay and gravel } \\
\text { Rock } \\
\text { Clay and gravel. } \\
\text { Water, sand, and gravel }\end{array}$ & $\begin{array}{r}\text { Feet } \\
230 \\
40 \\
60 \\
61 \\
30 \\
31\end{array}$ & $\begin{array}{r}\text { Feet } \\
230 \\
270 \\
330 \\
391 \\
421 \\
452\end{array}$ \\
\hline
\end{tabular}

Note.-Drilled July 1 to Sept. 8, 1918; casing 115/8 inches in diameter, perforated with $1 / 2$-inch drilled holes for lower 30 feet; water stands at 400 feet.

The same company drilled a well in the pass west of Estrella station at Ocapos siding in 1918 but failed to get sufficient water. 'The well was 541 feet deep and obtained water from gravel between 527 and 541 feet, which rose to 502 feet. This is the second attempt to obtain water in this pass. A well reported to be 250 feet deep was dug west of Estrella station, also without success. The failure of these wells seems to be due to the fact that only a small area drains into the pass and that the alluvium is of great depth and drains rapidly to the great body of alluvium just west of the pasw in the direction of Gila Bend.

Few data are available regarding the yield of the older wells. 'Tests of the Indian Service wells have been made, and the results of these tests, together with other data essential to estimating the value of similar wells, are presented in the following table:

Essential data on the pumping plants of the United States Indian Service on Papago Reservation

\begin{tabular}{|c|c|c|c|c|c|c|}
\hline Location & $\begin{array}{l}\text { Depth } \\
\text { of well }\end{array}$ & $\begin{array}{c}\text { Depth } \\
\text { to wa- } \\
\text { tor level } \\
\text { in well }\end{array}$ & $\underset{\text { Draw- }}{\text { down }}$ & Yield & Kind of pump & $\begin{array}{l}\text { Gas engine, make, and } \\
\text { horsepower }\end{array}$ \\
\hline Chiu Chuschu... & $\begin{array}{l}\text { Feet } \\
-228\end{array}$ & $\begin{array}{l}\text { Feet } \\
57\end{array}$ & $\begin{array}{l}\text { Feet } \\
10.7\end{array}$ & $\begin{array}{c}\text { Gallons per } \\
\text { minute } \\
690-1,200\end{array}$ & 15-inch Layne \& Bowler & \multirow{7}{*}{$\begin{array}{l}\text { 15-horsepower, W e st- } \\
\text { ern. } \\
\text { 4-horsepower, C o m- } \\
\text { mercial. } \\
\text { Do. } \\
\text { Do. } \\
\text { Do. } \\
\text { 6-horse power, F a ir } \\
\text { bank-Morse. } \\
\text { 6-horsepower, R a w } \\
\text { leigh-Schryer. } \\
\text { 4-horsepower, R a w } \\
\text { leigh-Schryer. }\end{array}$} \\
\hline Cocklebur & 196 & 150 & (?) & 23.8 & $\begin{array}{l}\text { turbine centringal. } \\
\text { M yers single-acting }\end{array}$ & \\
\hline $\begin{array}{l}\text { Jackrabbit } \\
\text { Kukomalik }\end{array}$ & $\begin{array}{l}123 \\
218\end{array}$ & $\begin{array}{c}73 \\
163.3\end{array}$ & $\begin{array}{r}17.3 \\
1.5\end{array}$ & $\begin{array}{r}9.0 \\
25.8\end{array}$ & Luitwe & \\
\hline Quajote_. & 255 & 209.7 & 4.9 & 25.7 & plunger, No. 1004. & \\
\hline & & & & & $\begin{array}{l}\text { Luitweiler plunger, No. } \\
\text { 1205. }\end{array}$ & \\
\hline Santa Rosa_-- & 391 & 274 & (?) & 33.3 & Luitweiler plunger-_.... & \\
\hline Indian Oasis... & 83 & 41 & (?) & $4-5$ & Plunger & \\
\hline
\end{tabular}


With the exception of the well at Chiu Chuschu, which is north of the Silver Reef Mountains and on the border of Santa Cruz Valley, all the wells have small yields, from 4 to 35 gallons a minute. This water must be lifted from 40 to 270 feet. The high lift and low yield make irrigation on a commercial scale impossible. Similar wells, however, may be dug profitably for domestic supply, watering livestock, and irrigating small gardens around ranch homes.

Of the seven samples of deep-well waters from the alluvium analyzed, five came from the Altar Valley and two from the vicinity of Ajo. The deeper waters of the Altar Valley are of good quality. The total dissolved solids range from 211 to 249 parts per million. The proportions of the different mineral constituents are similar, but the water from the southernmost well at Buenos Aires and that from the northernmost, the Warren Bros. well nearest to Robles ranch, contain slightly less calcium and more sodium than the others, so that they are classed as sodium-carbonate waters; the Secundino, Pozo, Mulvo, and Palo Alto waters are classed as calcium-carbonate. This difference in composition is reflected in the classification for irrigation, the two with larger proportions of sodium being carried over the line from good to fair on account of the larger quantities of sodium.

Childs Well, in the Valley of the Ajo, and No. 3 Well, in Childs Valley, lie along the same drainage line and have similar waters of the sodium-chloride type. Their mineral content of 632 and 610 parts per million, respectively, is more than twice that of the wells of Altar Valley, and perhaps the difference is due to the greater aridity of this part of the Papago country. The water of both is satisfactory for domestic use and watering stock, though the iron content of No. 3 Well is great enough to make some difficulty with rust stains in laundering. Water that has stood for two or three days in the tank, however, will give no trouble from this cause. There is a trace of borax in this water. For irrigation both waters are of fair quality, though it is unlikely that they will be so used except for small house gardens. 
Analyses and classification of water from deep wells in alluvium in Papago country

Analyzed by A. A. Chambers and C. H. Kidwell. Parts per million except as otherwise designated ]

\begin{tabular}{|c|c|c|c|c|c|c|c|}
\hline & 1 & 2 & 3 & 4 & 5 & 6 & 7 \\
\hline $\begin{array}{l}\text { Silica }\left(\mathrm{SiO}_{2}\right) \\
\text { Iron }(\mathrm{Fe})\end{array}$ & 58 & 29 & ${ }^{34}$ & 32 & 36 & $42_{35}$ & 33 \\
\hline Calcium (Ca) & $\begin{array}{l}3.7 \\
14\end{array}$ & 15 & $28^{-93}$ & $38^{-06}$ & $37^{-08}$ & $48^{-35}$ & $25^{-04}$ \\
\hline Magnesium $(\mathbf{M g})$ & 3.9 & 3. 7 & 5.0 & 7.2 & 5.7 & 9.6 & 4.9 \\
\hline $\begin{array}{l}\text { Sodium (Na) } \\
\text { Potassium (K) }\end{array}$ & 187 & a 203 & 49 & 41 & 32 & 24,4 & 48 \\
\hline Carbonate radicle $\left(\mathrm{CO}_{3}\right)$ & 17 & .0 & & .0 & .0 & $\begin{array}{r}4.2 \\
.0\end{array}$ & $\begin{array}{r}3.4 \\
.0\end{array}$ \\
\hline Bicarbonate radicle & & & & & & & \\
\hline$\left(\mathrm{HCO}_{3}\right)$ & 106 & 140 & 158 & 210 & 166 & 199 & 183 \\
\hline $\begin{array}{l}\text { Sulphate radicle }\left(\mathrm{SO}_{4}\right) \\
\text { Chloride radicle (Cl) }\end{array}$ & 93 & 103 & 29 & 19 & 14 & 11 & 7.2 \\
\hline $\begin{array}{l}\text { Chloride radicle }(\mathrm{Cl}) \\
\text { Nitrate radicle }\left(\mathrm{NO}_{3}\right)\end{array}$ & 152 & 185 & 18 & 11 & 10 & 11 & 12 \\
\hline Nitrate radicle $\left(\mathrm{NO}_{3}\right)_{-}$ & 19 & 13 & 3.5 & Trace & 8.1 & 3.1 & 2.4 \\
\hline $\begin{array}{l}\text { Total dissolved solids at } \\
180^{\circ} \mathrm{C}\end{array}$ & 610 & 632 & 240 & 249 & 211 & 246 & 223 \\
\hline Total hardness as & & & & & & & \\
\hline $\begin{array}{l}\mathrm{CaCO}_{3} \mathrm{a}- \\
\text { Scale-forming constitu- }\end{array}$ & 51 & 53 & 80 & 124 & 116 & 159 & 83 \\
\hline ents a & 110 & 79 & 120 & 160 & 160 & 200 & 120 \\
\hline $\begin{array}{l}\text { Foaming constituents }{ }^{a} \\
\text { Alkali coefficient }\end{array}$ & 620 & $\begin{array}{l}550 \\
6.7\end{array}$ & $\begin{array}{r}140 \\
14\end{array}$ & $\begin{array}{r}120 \\
20\end{array}$ & $\begin{array}{l}86 \\
29\end{array}$ & $\begin{array}{l}76 \\
35\end{array}$ & $\begin{array}{r}140 \\
15\end{array}$ \\
\hline $\begin{array}{l}\text { Classification: } \\
\text { Chemical character }\end{array}$ & $\mathrm{Na}-\mathrm{Cl}$ & $\mathrm{Na}-\mathrm{Cl}$ & $\mathrm{Na}-\mathrm{CO}_{3}$ & $\mathrm{Ca}-\mathrm{CO}_{3}$. & $\mathrm{Ca}-\mathrm{CO}_{3}$. & $\mathrm{Ca}-\mathrm{CO}_{3}$ & $\mathrm{Na}-\mathrm{CO}_{3}$ \\
\hline use & Poor. & Good. & Good. & Good. & Good. & Good. & Good. \\
\hline $\begin{array}{l}\text { Quality for boler use- } \\
\text { Quality for irrigation } \\
\text { Mineral content }\end{array}$ & $\begin{array}{l}\text { Very bad. } \\
\text { Fair. } \\
\text { High. }\end{array}$ & $\begin{array}{l}\text { Very bad. } \\
\text { Fair. } \\
\text { High. }\end{array}$ & $\begin{array}{l}\text { Fair. } \\
\text { Fair. } \\
\text { Moderate. }\end{array}$ & $\begin{array}{l}\text { Faur. } \\
\text { Good. } \\
\text { Moderate. }\end{array}$ & $\begin{array}{r}\text { Far. } \\
\text { Good. } \\
\text { Moderate. }\end{array}$ & $\begin{array}{l}\text { Faur. } \\
\text { Good. } \\
\text { Moderate. }\end{array}$ & $\begin{array}{l}\text { Fart. } \\
\text { Fair. } \\
\text { Moderate. }\end{array}$ \\
\hline Date of collection (1917) .. & Nov. 29. & Nov. 12. & Dec. 2. & Dec. 10. & Dee. 10. & Dec. 4. & Dec. 11 \\
\hline
\end{tabular}

a Calculated.

1. No. 3 Well.

2. Childs Well

3. Warren Brothers west well.

4. Palo Alto Well.

5. Pozo Nuevo Well.

6. Secundino Well.

7. Buenos Aires Well.

\section{GROUND-WATER CONDITIONS BY AREAS}

For the purpose of giving a detailed treatment of ground-water conditions in the Papago country the region has been divided into five arbitrarily bounded areas or strips, extending south from Gila River to the Mexican boundary.

\section{WESTERN PORTION}

\section{LOCATION, TOPOGRAPHY, AND GEOLOGY}

The western portion includes all the area west of the Growler Mountains and the town of Sentinel. The climate is the most arid of the whole region; probably no place in the plains has an average rainfall of more than 5 inches a year. The mountains rise only 1,000 to 1,500 feet above the plains and seem to get but little more rain than the plains. They are without trees or perennial grass.

The region contains the Gila, Tinajas Altas, Copper, Cabeza Prieta, Tule, Pinta, Mohawk, Aguila, Agua Dulce, and Growler moun- 
tains, Baker Peaks, and the Wellton, Aztec, O'Neill, and Quitobaquito hills, together with the unnamed hills or small mountains around Papago Well. The valleys or plains are the Yuma Desert, Lechuguilla Desert, Mohawk Valley, Tule Desert, San Cristobal Desert, Growler Valley, and Sentinel and Pinacate basalt plains.

\section{MOUNTAINOUS AREAS}

GILA MOUNTAINS

The Gila Mountains have a northwest trend, which persists from Gila River the whole length of the range $(25$ miles) and through the Tinajas Altas Mountains, often considered part of the Gila Range, for 15 miles into Mexico. The Gila Mountains range in width from 2 to 7 miles and are marked by sharply incised canyons of about equal length on both sides of the range. The highest crest rises about 2,000 feet above the plain, but there is no marked crest line, the highest points of one side not being easily recognized on the other.

The northern part of the mountains is composed mostly of schist and gneiss, intruded by pinkish granite; the southern part has large amounts of light-colored granite. No outcrops of Tertiary lavas are known, but tilted sediments of supposed Tertiary and Pleistocene age, found at the north end of the mountains (p. 63), indicate that the range was uplifted at the same time as the other mountains of the region, and if the identification of disturbed Pleistocene sediments is correct these movements have continued later here than in many other ranges.

Around the north end of the range and for 5 miles on the east side and 10 miles on the west side the alluvium at the foot of the mountains is dissected by streams working to the base-level of Gila River. A narrow mountain pediment from a few hundred yards to 2 miles wide is exposed by this dissection. The outer part of this pediment is covered by alluvium from 5 to 30 feet or more in thickness. The pediment seems to have been cut during a period of rising level of alluvium in the adjacent valleys.

\section{TINAJAS aLTAS MOUNTAINS}

The Tinajas Altas Mountains are separated from the Gila Mountains by a broad gap and in turn are divided into two parts by a similar gap, through which there is a wagon road. They maintain the same northwest trend as the Gila Mountains but are more deeply incised by canyons.

The dominant rocks are light-colored granite and gneiss. Near the watering place called Tinajas Altas the granite is particularly coarse 
grained and massively bedded. (See p. 132 and Pls. XIV, $B$, and XVIII.) At the north end of the mountains about 200 feet of lava is exposed in Raven Butte (Pls. XII, $B$, and XIII, $A$ ). The beds of lava dip gently toward the valley and are the remnants of much larger bodies. This outcrop demonstrates uplift of the mountains at the end of the Tertiary volcanic eruptions. The upland valleys of the eastward-flowing streams have already been cited as evidence of Pleistocene uplift of the mountains, probably by faulting along the east side (p. 76). On the east side of the range there is no evidence of a mountain pediment, except in the coves or reentrants at canyon mouths, a condition which is in accordance with the postulate of Pleistocene faulting.

SIERRA DE LA IECHUGUTLIA

The Sierra de la Lechuguilla lies between the Cabeza Prieta and Tinajas Altas mountains, at the south end of the Lechuguilla Desert. The range is close to and parallel with the Gila Range and has a general northwest trend. It is about 10 miles long and 4 miles wide. The international boundary crosses the mountains about 5 miles from the north end.

The Sierra de la Lechuguilla is composed of granite and similar coarse-grained crystalline rocks. The slopes are steep and rise abruptly 1,500 to 2,000 feet from the adjacent plains. No outcrops of Tertiary volcanic rocks are known to exist in this range.

\section{COPPER MOUNTAINS}

The Copper Mountains, a typical range of the sierra type, forio part of the eastern border of the Lechuguilla Desert. They begin about 3 miles south of Baker Peaks in a narrow prong and extend southeastward 13 miles to a similar point. Between the south end of this range and the north end of the Cabeza Prieta Mountains there is a gap about 2 miles wide dotted with small ragged hills. The range is about 4 miles wide, and the high points occur near the widest part. The main peak rises about 2,000 feet above the adjacent plains.

No remnants of the Tertiary volcanic rocks are known to be associated with or to occur near the Copper Mountains. The topography is the result of erosion of granite and granitoid rocks of the crystalline complex. A well-defined pediment is present along the western border and in the passes at the north and south ends of the range.

\section{CaBfza PRIETA MOUNTAING}

The Cabeza Prieta Mountains are a irregular group of mountains about 10 miles in diameter from east to west and the same distance from north to south. They are imperfectly separated from the 
Tule Mountains on the south by the broad hill-dotted pass in which lie Tule Well and Tule Tank. The general shapelessness and lack of definite trend of the mountains as shown on the map may be due in part to lack of knowledge. Accounts of travelers indicate that there are several passes through the mountains, and it may be that these passes divide the mountains into parts each of which has a recognizable trend.

Cabeza Prieta (black head), the high part of the range, is composed of light-colored granular crystalline rock capped by lava. The lava cappings occur also on other mountains of the range. (See p. 83 and Pl. XII, B.) Northeast of Tule Well a considerable part of the mountain is composed of lavas, which have an estimated thickness of 1,000 feet and are tilted to the east in several parallel ridges cut by a series of north-south faults. On the west flank of the range are two small buttes of lava which dip westward into Lechuguilla Valley.

The mountains appear to have been once covered with an extensive and thick series of lavas of Tertiary age and to have suffered from very extensive and complicated post-Tertiary faulting, to which is due much of the present height of the range. Supposed Pleistocene uplift is discussed below in connection with the Tule Mountains.

\section{TULE MOUNTAINS}

The Tule Mountains consist of more or less detached ridges and sierras, which are large and bold in Mexico but become lower on the broad pass that separates this range from the Cabeza Prieta Mountains.

The Tule Mountains are composed mostly of granite and gneiss, but on the western border is a monoclinal ridge of lava in which at least 500 feet of beds are exposed. In the pass are lava, lava conglomerate, and arkose conglomerate. (See p. 72.) Both the sedimentary and the volcanic rocks are thought to be of Tertiary age, and by their present attitude, which is well brought out in the geologic sections (figs. 3 and 4), they indicate intense and complicated faulting after the Tertiary volcanic epoch. The bench of older alluvium on the west side is raised about 50 feet above Lechuguilla Desert. (See fig. 4.)、This elevated and dissected bench of alluvium seems to indicate uplift in Pleistocene time. The uplift was, however, not sufficient to affect the grades of the streams in the pass, which seem to be working at grade on a mountain pediment of the normal type, developed through the merging of headwater basins of streams draining to Lechuguilla and Tule deserts. 
The Pinta Mountains are a range 25 miles long extending from the O'Neill Hills northwestward. The range is a narrow comb of sharp peaks, probably not more than 2 miles wide at any point: The highest summits rise 1,500 to 2,000 feet above the adjacent valleys. The slopes are steep, and many narrow canyons lead from the plains to the crest of the range.

The Pinta Mountains are remarkable in the sharp division between the two kinds of rocks of which they are composed. The southern part of the range is formed of dark-gray, almost black rocks, reported by prospectors to be black gneiss and schist. Doubtless these rocks are similar to the hormblende gneiss in the vicinity of the Fortuna mine. In the northern part of the range is a pinkishwhite granite, similar in color and topography to the white granite of the Cabeza Prieta Mountains and the vicinity of Tinajas Altas. The black and white rocks are separated by a very conspicuous contact at the center of the range. Many details of this contact are visible at a distance of 7 miles, and the division between the two parts of the mountain can be seen for 25 to 30 miles. Great stringers of the granite extend horizontally into the darker rock, where some fork and branch and all gradually thin out. The contact is the result of the intrusion of the granite in a molten state into the gneiss. This intrusion took place far beneath the surface, and the exposure of the contact testifies to the large amount of erosion that has since ensued. So far as known lava of Tertiary age does not occur in these mountains.

MOHAWK MOUNTAINS

The Mohawk Mountains extend southwestward from the vicinity of Mohawk station on the Southern Pacific Railroad about 18 miles to a gap, and then continue with the same trend for about 7 miles more. The southern division is on some maps called the Mohawk Range.

The northern division of the Mohawk Mountains is a narrow range not over 4 miles wide at the widest part, which tapers at both ends, and the most northerly part is a high rocky hill isolated from the main mass by a narrow pass in which the railroad lies. Because the grade of the track is downhill in both directions from this pass, railroad men speak of it as Mohawk Summit.

The Mohawk Mountains are composed largely of granite and similar coarse-grained crystalline rocks. To the massive jointing and resistant character of these rocks the steep slopes of the mountains are due. 
A narrow mountain pediment surrounds the mountains. During its formation a number of hills were detached from the main mass, and these now fringe the mountain border. Such isolated hills are the one just south of Mohawk station and one near the Red Cross mine, on the east side of the mountains. The mountain pediment, like others of the region, is dissected, as is well shown in the pass at Mohawk Summit, where steep-walled trenches cut 20 to 30 feet deep along the streams are in marked contrast to the smooth curves of the old valleys that connect with and form part of the pediment. Along the west side of the Mohawk Mountains erosion and dissection of the mountain pediment is retarded by drifting sand. This sand, swept forward by westerly winds, mantles the east side of the valley and reaches up to the very foot of the mountains.

The southern portion of the mountains is divided from the northern portion by a low pass 2 miles wide marked by three rather prominent hills. This portion is said to be about 7 miles long and is separated by a pass from an unnamed range which extends 15 miles farther southeast. The so-called Mohawk Range is broader but not so high as the northern portion of the Mohawk Mountains. It is composed of similar granitic rock and has similar topographic forms.

AGLILA MOUNTAINS

The Aguila Mountains, known among the Mexicans and some Americans as Sierra de Águila, form a small range which begins about 10 miles southeast of Aztec on the Southern Pacific Railroad and extends about 10 miles farther southeast. On many maps these mountains. are confused with $n r$ included in the Granite Mountains farther south.

The northern part of the range is a great lozenge-shaped plateau of lava about 3 miles long. It is highest on its southwestern point and slopes gently to the northeast. The western front is a great cliff and talus slope, which gradually decreases in height to the north end of the plateau. In the same fashion the cliff and talus of the plateau extend around the south end and decrease in height more rapidly to the east. This plateau is commonly called Malpais Hill. The eroded edges of the constituent lava beds appear along the western face. The slope to the northeast corresponds to the dip of the beds.

South of the plateau the mountains extend in a hook about 4 miles long to a gap through which the road passes. Near the plateau the hills are low, and then begins a remarkable series of peaks, whose sides rise sheer for several hundred feet and whose forms are so fantastic that they are often called " the Eagletails." This metaphor is derived by analogy from the Eagletail Mountains, north of Gila 
River, and from the name of the principal watering place, Eagle Tank. The principal rock of the peaks is porphyritic andesite. ${ }^{44}$ To the jointing of this rock the fantastic erosion forms are doubtless due. South of the gap three low and somewhat inconspicuous hills extend to the south about 3 miles.

The Aguila Mountains appear to be the remnant of an earth block faulted and tilted after the Tertiary volcanic eruptions had ceased. Of the original block only Malpais Hill remains. The rest of the range is carved from rocks of the crystalline complex and probably also from intrusive rocks contemporaneous with the Tertiary lava.

GRANITE MOUNTAINS

The Granite Mountains lie about 25 miles southeast of Stoval on the Southern Pacific Railroad and the same distance northwest of Bates Well. On many maps they are confused with the Aguila Mountains (Sierra de Águila), or the two ranges are combined under a single name.

The range has a general trend in a northerly or northeasterly direction, and the main mass is about 5 miles long. According to reliable prospectors, the whole extent of the range is about 10 miles, and from a point near the center of the west side a range of small mountains extends about 5 miles to the west. 'These mountains are called Devils Hills or Sierra del Diablo. From a distance the Granite Mountains have the sawtooth outline and sierra type of topography characteristic of the erosion of granite and similar coarse-grained crystalline rocks. Prospectors report that the range is composed wholly of "hungry" (hard and barren) granite.

AGUA DULCE MOUNTAINS

The Agua Dulce Mountains are named from Agua Dulce, on Sonoita River, where ground water comes to the surface. From this point the mountains extend northwestward about 18 miles in a great curve. The trend is almost due north where the range crosses the international boundary but swings to the west, so that south of the Papago mine it is almost due west.

The mountains consist of three parts of about equal length, which are divided by narrow passes. Each of the parts is a lozengeshaped mountain mass of the sierra type of topography. The plains rise steeply to the foot of the mountains, and there appears to be an extensive mountain pediment. The topography of the mountains and the rock waste found in Growler Valley, to the north, indicate that these mountains are composed wholly of the coarsegrained granitic rocks of the crystalline complex.

14 Jones, E. L., fr., personal communication. 
.The Growler Mountains are a range about 40 miles long, which lies west of the Valley of the Ajo. The range is divided into two rather distinct parts by the pass at Bates Well, known as Growler Pass.

The northern part of the range is a rather simple asymmetric ridge extending from Growler Pass in a northwesterly direction to Childs Valley, west of No. $3 \mathrm{Well}$. The eastern slope of the ridge is smooth and gentle, parallel to the inclination of the Tertiary lava beds that cap the mountains. This slope merges rather gently with a narrow alluvial valley cut off from the main valley of the Ajo by a series of hills and small mountains-an unnamed ridge about 4 miles long just north of Bates Well, the Little Ajo Mountains, and Childs Mountain.

The western slope of the Growler Mountains is very steep, a veritable façade sweeping northwestward from Growler Pass in a slightly sinuous line. (See Pl. XI, A.) The façade begins at the crest of the ridge with a rim rock of lava beds and descends in cliffs and talus slopes to the Growler Valley, a drop of about 1,500 feet in a distance of about 1 mile. Alternate bands of varicolored lava and tuff ranging from yellow-white to purple-red combine with the crenulations of the mountain front to make this façade a picturesque and imposing sight. The simplicity of the façade is broken by three hills at the base of the mountains. Sheep Tank Peak lies about 16 miles northwest of the Growler mine. It is visible from all parts of the valley between the Growler Mountains and Papago Well as far north as the Granite Mountains and is the landmark for Sheep Tank, which nestles against its northern flank. The peak is conical, very sharp and pointed at the top, and situated at the foot of the façade just west of a deep canyon. This peak appears to have been part of the mountains which has been isolated by the headward cutting of the stream that carved the canyon. About 8 miles northwest of the Growler mine a small ragged hill lies close to the foot of the mountains just north of a trail over the crest. From a distance this hill appears to be made up of granite and to be part of the base on which the lava rests. Halfway between this hill and the Growler mine is the most prominent and significant break in the uniformity of the western façade. Here there is a black butte a mile long and half a mile wide, with a rather gentle slope on the southwest side and a steep northeastern face. (See Pl. XI, A.) In this face may be seen the outcropping edges of the lava beds that form the hill, dipping sharply to the southeast. At the base these beds rest on rocks of the crystalline complex (granite, gneiss, etc.), which form a tongue of rough, hilly country connecting the butte with the base of the 
Growler Mountains. Thence southward and connecting with similar rocks at the Growler mine the crystalline rocks are exposed.

The lava beds of the Growler Mountains and of the butte rest on the eroded surface of the crystalline rocks and form parts of a once continuous lava field. As they dip in opposite directions, however, it is evident that the two parts have been dislocated, presumably along a fault that trends northwest along the front of the mountains, through the hilly tongue that connects the butte and the main mountain mass. That the uplift and dislocation are due to faulting and not folding seems certain for two reasons-an unbelievably abrupt fold would have been necessary to accomplish the movement; and as faulting can be demonstrated for part of the range, on the east side of Growler Pass, it is probable that all the movement was accomplished by this means.

The hills on the north side of Growler Pass begin on the east with a low-capped mesa; then follows a high mountain made up largely of limestone and quartzite, presumably of Paleozoic age; and then a high conical hill composed of lava beds that dip sharply to the west and rest on rocks of the crystalline complex. This conical hill is separated by a low pass from the eastward-dipping lava beds of the main part of the Growler Mountains. It is evident that a fault passes through this gap and that a second fault lies between the limestone hill and the lava mesa.

South of Growler Pass the Growler Mountains consist of plateaus and ridges, which extend to Cipriano Well. The plateaus are carved from the bedded volcanic rocks of Tertiary age, and their flat tops are inclined at various angles according to the inclination of the constituent lavas. (See Pl. XI, B.) The ridges are also made up of lava, but the original plateau from which they were carved has entirely disappeared, erosion having left only jagged crest lines and palisaded summits. In general the dip of the beds is toward the east on the east side of the mountains and toward the west on the west side, but there are numerous exceptions. This part of the range is a group of fault blocks, each more or less isolated by the erosion of canyons and open valleys along the bounding faults.

\section{WELLTON HIITS}

The Wellton Hills lie 6 miles south of the town from which they are named. They divide the Lechuguilla Desert from the valley of Gila River, though the drainage from the desert finds its way through them to the Gila. The hills occupy an area about 6 miles in diameter over which they are scattered singly or in groups. Many of them are buttes, but the largest hilly area, which lies west of the road between Tinajas Altas and Wellton, is more than 3 
miles long. The hills rise from 50 to 500 feet above the flat-bottomed valleys that pass between them. Many of the hills east of the road are carved from lava of Tertiary age, which is not, however, shown on the map (Pl. IX). Other hills are composed of rocks of the crystalline complex, and granite, granite gneiss, and schist were found. The Wellton Hills appear to be the remnants of a complexly faulted elevated area which erosion has reduced to isolated hills. Between the hills are smooth plains cut on rock which correspond in age to the other mountain pediments of the region. This pediment, however, is largely covered with alluvium brought down by streams from the south.

BAKER PEAKS

The Baker Peaks are an irregular group of hills about 2 miles in diameter on the edge of the Gila Valley 7 miles southeast of Wellton. They comprise three prominent conical peaks, which, because of their height and isolation, are visible for many miles in all directions.

The Baker Peaks are composed of granitoid rocks of the crystalline complex and are characterized by a strong westward-dipping sheeting. These rocks contributed the material to form the great series of arkose sandstone and conglomerate which lies at the south-" ern foot of the hills, around Baker Tanks (pp. 127-128).

It seems probable that the conglomerate once extended over a large part of the Baker Peaks mass and has been removed by erosion during Pleistocene time, with the formation of a mountain pediment that cuts across the Tertiary conglomerate and into the underlying crystalline complex. Here, as in other mountains, the streams are now cutting sharp gorges in the mountain pediment.

AZTEC HILLS

The Aztec Hills lie about 3 miles west of Aztec station on the Southern Pacific Railroad. They consist of four somewhat isolated masses strung out in a line about 5 miles long. The northernmost hill is the largest and highest, and its sharp summit makes it a landmark over all the San Cristobal Valley.

The hills are composed of granite and granitoid rocks of the crystalline complex. As they lie on the strike of the Aguila Mountains, further study may show that their uplift is connected with the uplift of that range. During a survey in this region in 1923 E. C. La Rue ${ }^{45}$ observed a large number of hills that form an almost continuous chain between the Aztec Hills and the Aguila Mountains.

45 Personal communication. 
The O'Neill Hills are a detached group of little mountains 4 miles west of Papago Well. North of O'Neill Pass are two detached groups of hills, in all about $11 / 2$ miles long. They rise abruptly 150 to 300 feet from the surrounding plain. South of the pass a group of hills extend about 4 miles southeast. Their summits are from 300 to 700 feet above the adjacent plain. To the southwest are a series of detached hills and a prominent mesa.

The O'Neill Hills appear to be buried in the alluvium carried out toward Las Playas from the vicinity of Papago Well and the west end of the Agua Dulce Mountains. There is practically no transitional slope from the plains to the hillsides. These hillsides are themselves notably steep, becanse they are carved from coarsegrained rock, which in O'Neill Pass is a granodiorite. The other hills appear to be formed of the same or similar material.

There is no direct evidence that these hills were uplifted in the general period of faulting that affected most of the region. However, the prominent mesa 5 miles southwest of O'Neill Pass is composed of almost horizontal lava beds. It is probable that further study would show that this mesa is the remnant of a once large lava field that covered all or most of the O'Neill Hills. Erosion has removed so much of the covering rocks that the original form and structure of the hills are greatly obscured.

HILLS NEAR PAPAGO WELL

A number of mountains and hills lie north of the west end of the Agua Dulce Mountains, in the vicinity of Papago Well. The main group of hills occupy an area measuring 9 miles from east to west and 5 miles from north to south. Through this area passes the road from Bates Well to Las Playas (p. 419).

The mountains around Papago Well consist of steep-sided hills that rise abruptly from intervening lowlands. These lowlands are usually covered with alluvium, but in many places bedrock is exposed. Their general slope is away from the Agua Dulce Mountains to the north, east, and west. All the hills but one are composed of granite or coarse granite gneiss of the crystalline complex. The larger hills are commonly three to five times longer than wide and taper at the ends. The highest point of each hill is at or near the middle. Each hill is then a miniature mountain of the sierra type, whase very steep slopes are due to resistance to erosion of the constituent rock. Papago Hill, on the west slope of which is situated the Papago mine, rises 900 to 1,000 feet above the base and is the most conspicuous of the group. The hills directly west of Papago Well differ from the others in being an irregularly rounded clump. 
Directly south of the well is a small hill about 400 feet high composed of lava. The upper layer is a black basalt, and the total thickness of lava exposed is about 400 feet. The beds dip about $20^{\circ} \mathrm{SW}$. This lava is part of a once more extensive capping of the Tertiary volcanic rocks which formerly mantled the region. Only this fragment, faulted down between higher blocks, remains. The strike of the lava is parallel to the trend of Papago Hill and of two other groups of hills. The trend of four other hills is almost at right angles, and the remaining clump has no definite trend. It seems probable that these trends are the lingering expression of the trends of blocks that formed an intricate fault complex.

On this complex, and controlled by its structure, the original drainage began erosion, and here, as in other parts of the region, a mountain pediment was developed. This pediment had its upper limit in the Agua Dulce Mountains, of which this area was a foothill belt. An elaborate system of intersecting valleys was developed largely at the expense of the volcanic rocks, of which only the small fragment previously mentioned remains. The hills are the unreduced remnants of the original fault complex, and their forms and trends are an inheritance from a more or less rectangular system of faulting. The pediment is now largely concealed by débris brought down from higher levels and is not so elaborately dissected as the pediments in certain other areas. Trenching of the pediment is, however, well marked 2 miles east of Papago Well.

At distances of 6 and 13 miles north and 10 miles northwest of Papago Well are three isolated groups of hills. These hills were not visited, but their topography is similar to that of other granite hills of the region, and they may be related in origin to the mountains above described.

\section{QUITOBAQUITO HILLS}

The Quitobaquito Hills extend northward from the international boundary for 5 miles and are nowhere more than 2 miles wide. They rise about 500 feet above the surrounding plain. The hills trend slightly west of north, parallel to the Growler Mountains but offset to the west. The north end of the hills is composed mostly of schist and fine-grained intrusive rocks; the south end mostly of granite. Ng outcrops of Tertiary lavas are known, but the similarity in trend and close association with the Growler Mountains indicate that these hills were uplifted at the same time.

\section{VALIEY AREAS}

YUMA DESERT

The Yuma Desert is a plain that extends west from the Gila and Tinajas Altas mountains to the bluffs that separate it from the flood plain of Colorado River. On the north it is bounded by bluffs that 
border the flood plain of Gila River. The plain is 12 miles wide at the north and increases in width to more than 40 miles along the international boundary.

The plain consists of unconsolidated sediments and slopes from the mountains toward the west. Near the mountains the sediments are coarse, unweathered rock débris brought down by the ephemeral streams which drain the western slopes. Near Gila River and especially on the west near Colorado River the material is finer and was in part laid down by the rivers or may even be in part marine. Beginning at Yuma the plain is divided into a lower bench from 50 to 100 feet above the flood plain of Colorado River and a higher bench that is from 50 to 150 feet higher. The lower bench increases in width and definiteness to the south and is about 15 miles wide along the international boundary. At Yuma and at the State rifle range, 5 miles southeast of Yuma, knobs of granite gneiss belonging to the underlying crystalline complex project through the alluvium.

The Yuma Desert is mantled with wind-blown sand, probably derived largely from the flood plain of Colorado River. The movement of this sand seems to be slow and insufficient to prevent the growth of a sparse vegetation or to prevent the erosion of the plain by a tributary of Gila River which flows northwestward along the west side of the Gila Mountains from the Fortuna mine to Blaisdell.

LECHUGUTLLA DESERT

The Lechuguilla Desert is a valley extending in a northwesterly direction from the international boundary to Gila River, between the Tinajas Altas and Gila mountains, on the west, and the Tule, Cabeza Priet'a, and Copper mountains and Baker Peaks, on the east. It is about 9 miles wide and 35 miles long. The floor of the valley is drained by an axial stream which, throughout the greater part of its course, has a well-defined channel about 100 feet wide but is not dissecting the plain. North of the Wellton Hills the main stream and others are dissecting the valley deposits. The same condition of dissection exists along the northeastern border of the Gila Mountains. The present level of the valley is determined not by the present base-level but by Gila River when it stood at the level of the terrace of younger alluvium. The valley deposits must therefore be largely of this age, covered by a veneer of more recent materials. The older alluvium is exposed in 'a bench along the west side of the Tule Mountains (p. 72) and perhaps also in a similar bench north of the Wellton Hills. The older alluvium seems to be somewhat coarser than recent deposits of the same area. Around the borders of the valley there is some dissection of the upper part of the alluvial 
slopes. At Tinajas Altas the stream is incised about 20 feet below the general level of the fan, but the trench fades out about half a mile from the mountain front.

\section{MOHAWK VALLEY}

The Mohawk Valley comprises the great plains that lie east of the Cabeza Prieta and Copper mountains and west of the Mohawk Mountains and the area farther southeast between the Pinta Mountains and the Mohawk and Granite mountains. This valley is 15 miles wide near the Southern Pacific Railroad and extends some 35 or 40 miles to the southeast.

The valley is bounded on the north by the flood plain of Gila River, which stands about 100 feet lower than the general level of the plains. Only a mile or two of the northern part of the valley is dissected by the tributaries of Gila River. The drainage level of the valley was established with reference to the level of the younger alluvium in the terrace of Gila River and has not since been changed.

As far south as the north end of the Pinta Mountains the drainage goes northwestward and crosses the Southern Pacific Railroad near Colfred. The southeastern part of the valley may drain northeastward into San Cristobal Valley.

The eastern border of the valley is mantled by wind-blown sand. The sand near Mohawk seems to be largely derived from Gila River.

TULE DESERT

The Tule Desert lies between the Tule and Cabeza Prieta mountains on the west ane the Pinta Mountains and O'Neill Hills on the east. It increases in width from 5 miles at the north end to about 10 miles at the international boundary in a total length of about 30 miles. The southeast end of the valley has many scattered hills and contains also the Pinacate Plain.

The northwestern part of the valley is thought to drain into the Mohawk Valley, but the greater part drains to an ephemeral lake or playa known as Las Playas. This playa is a mesquite-bordered flat of mud-cracked clay about 2 miles in diameter in which water remains for a few days after a rain. Its southern border was not thoroughly explored, and whether or not it drains southward into Mexico in times of high water is not known. A considerable area along the northern border of the Agua Dulce Mountains and around Papago Well drains through the O'Neill Hills to Las Playas.

The character of the material underlying the Tule Desert is not lnown, partly from lack of exploration and partly because the alluvium is nowhere dissected along the southern border of the valley. The extrusion of the basalt of the Pinacate Plain in late 
Pleistocene time seems to be the cause of this inclosed drainage, which occurs in no other place in the Papago country. It seems likely that clay beds like the present deposit in Las Playas will not be found in depth and that the axial stream of the old drainage went southward into Mexico in the region now covered by the Pinacate Plain.

\section{GROWLER VALLEX}

The Growler Valley has somewhat indefinite boundaries. The name covers all the plains region west of the Growler Mountains, east of the Agua Dulce and Granite mountains, and southeast of the Aguila Mountains.

Receiving drainage from the larger part of the Valley of the Ajo through Growler Pass, Growler Valley drains northwestward. through an adobe flat called Mesquital, between the Granite and Aguila mountains. The sediments that fill the valley are undissected, and little can be inferred as to their composition in depthThe present streams are carrying rather fine material. In the middle of the valley, where it is crossed by the Tucson-Yuma road, the axial stream carried nothing over 2 inches in diameter in 1917. The heavy rains of September, 1920, produced floods which cut a channel. 3 to 4 feet deep at this point and revealed pebbles as much as 4 inches in diameter.

\section{SAN CRISTOBAL VALIEY}

The San Cristobal Valley lies between the Mohawk Mountains or the west and the Aguila Mountains and Aztec Hills on the east. The Granite Mountains limit the valley on the southeast, and the bluffs of Gila River bound it on the north. The valley is about 15 miles wide and 30 miles long.

As in the other valleys that border on Gila River, the general level of this valley is adjusted to the level of the terrace and not to the present flood plain of the river. The axial stream of the valley, however, has cut back as far as the Southern Pacific Railroad at Stoval. South of the railroad the stream lies in an adobe flat in which there are only insignifeant channels. The flat is bounded by bluffs which are especially noticeable on the east side, being about. 20 feet high near Stoval, but which decrease gradually and disappear 8 miles to the south, near Garcia. Well. This trenching of the valley floor seems to be an adjustment to a new base-level, which has not been definitely correlated. (See p. 104.) It was effective only for 8 miles south of the Gila, and the remaining slopes and grades of the valley are in accord with a slightly higher baselevel. 
The great plains area south of Gila River, east of the Aztec Hills and Aguila Mountains, and northwest of the Crater Mountains is largely occupied by the Sentinel Plain. This plain is due to a great sheet of lava, of somewhat variable thickness, which was extruded from numerous local craters over alluvial plains. The plains had been built up to the level of the terrace along Gila River, about 100 feet above the present flood plain, by ephemeral streams. The lava disarranged this drainage and even dammed the river for a time." Part of the original drainage reached Gila River west of the lava in the depression between Aztec and Stanwix. The drainage of the Childs Valley and adjacent areas, however, may have been diverted to the San Cristobal Valley.

\section{GROUND-WATER RESOURCES}

The data on climate given on pages $29-40$ show that this region is remarkably arid. The annual rainfall on the plains areas probably at no place exceeds 5 inches. Concurrent with this aridity is a sparseness of vegetation much greater than in other parts of the Papago country. It may also be assumed that the total amount of ground water is proportionately smaller. The existing watering places are shown in the following table:

Watering places in the area vest of the Growler Mountains

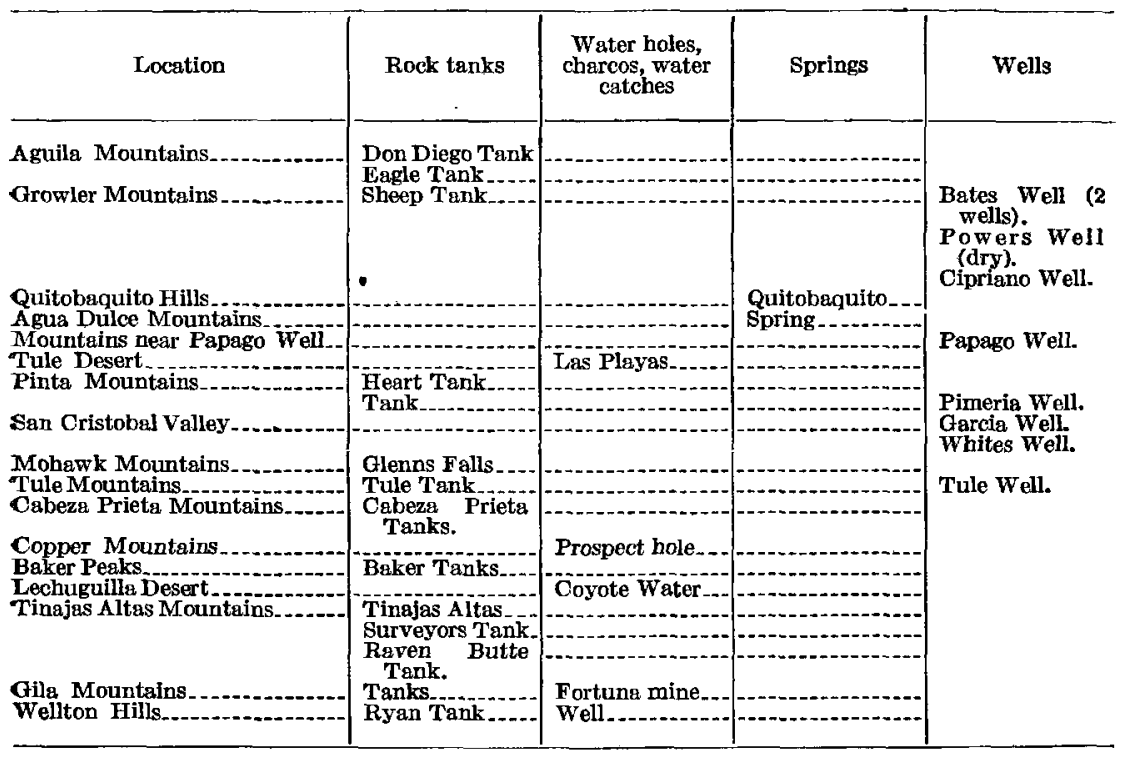

${ }^{40}$ Ross, C. P., The lower Gila region, Arizona: C. S. Geol. Survey Water-Supply Paper 498 , p. 74, 1923 . 
Of the two springs shown in the table, Quitobaquito is altogether exceptional and, as has been pointed out on page 164, may not be dependent on local rainfall. The spring in the Agua Dulce Mountains is described by local people as a small seep and is of little importance. The wells at present in existence are inadequate in number either for travelers or for watering stock. Progress in digging new wells will, however, be slow because of the poor range. The following paragraphs summarize the prospects for new wells.

The Growler Valley has the ordinary desert vegetation. The major part is covered with an almost pure stand of creosote bush and is without feed for cattle except when annual grasses spring up after rains. It seems likely that deep wells would obtain water along the center line of the valley, but it is doubtful whether the forage is valuable enough to warrant the expense. The best location would probably be at or near the Mesquital, where mesquite beans would furnish a reliable stock food. It is also not improbable that the underground drainage follows the surface drainage and that water may be shallow at this locality. The best locations, however, will be found along the west side of the Growler Mountains and Quitobaquito Hills, where dug wells in the crystalline rocks will probably furnish small but adequate supplies of water. These rocks occur south of Bates Well, near Cipriano Well, and west of the Quitobaquito Hills. There are almost continuous outcrops along the nairrow mountain pediment north of Growler Pass. Wells in the small valleys between the lava mesas of the southern part of the mountains along the road from Bates Well to Quitobaquito would make available some fair range not now reached by cattle from Bates and Cipriano wells. The record of Powers Well (p. 182) shows the risk involved in sinking such wells. It is thought, however, that wells located in positions more nearly surrounded by hills or wells drilled into the lavas will be more successful. Wells agt or near the mouths of the larger canyons on the mountain pediment along the northeast side of the Agua Dulce Mountains would probably obtain water from the crystalline rocks.

The log of the Papago Well is not known, and this well is consequently less valuable as an indicator of ground-water conditions. A drilled well west of the black hill south of this well should penetrate lava and receive water traveling down the dip of the lava beds. The small valleys between the scattered hills in the vicinity of Papago Well contains a relatively large amount of browse and would support a few head of cattle. Dug wells in these valleys drawing water from alluvium and the underlying crystalline rocks should be successful. However, according to local information, a hole dug in one of the valleys proved to be dry. 
Large amounts of water of good quality are obtained by deep wells at Sentinel, ${ }^{47}$ and there is also a well at Aztec. It is doubtful whether the grazing is sufficiently good to justify, solely for stock water, the expense of wells or the heavy pumping lift, and it seems likely that the depth to water increases toward the south. In the rock-floored plains of the Aztec Hills and about the Aguila Mountains there are doubtless a number of localities where wells could be dug in crystalline rocks and would yield sufficient water to provide for the cattle the range would support. West of Papago Well, at the eastern entrance or in O'Neill Pass, there appears to be a good location for a well. The flood waters spread widely, and there is a relatively large amount of browse. It seems likely that there are pockets in the bedrock which are saturated by flood waters and drain slowly. A well in this locality would seem to have a chance of obtaining water in much the same fashion as Bates Well, in Growler Pass.

Near Las Playas the range is poor, and it is doubtful whether a deep well that might obtain water would be profitable, as the scanty forage could readily be used when the charcos were full of water after rains, if cattle were located near by on permanent water.

West of Las Playas the range is so poor that it seems unlikely that a stock industry can exist. Tule Well has been in existence a good many years, and no one, since the unknown philanthropist who first dug the well, has ever attempted to live there permanently. As prospecting continues, miners will doubtless dig other wells in the little valleys of the pass between the Tule and Cabeza Prieta mountains. If large mines are developed the problem of water supply will be difficult. A deep well south of the Camino del Diablo in the Lechuguilla Desert should, however, obtain water in the lava. (See p. 72 and fig. 4.)

San Cristobal Valley, as pointed out on page 182, seems to have a well-defined water table, and the three wells already dug there can be developed to supply water for all the cattle that the center of the valley can support. Additional wells along the east front of the Mohawk Mountains dug in the crystalline rocks of the mountain pediment should be successful. With a well in the Aztec Hills and one or two in the Aguila and Granite mountains; the whole valley could be used for grazing. For a small area near Stoval the warm climate and the possibility of growing Egyptian cotton may justify the development of ground water, but although the pumping lift is not excessive for this crop the supply of water is probably not great.

Near Wellton small herds of cattle are watered at Baker Tanks in dry years when feed is short in the Gila Valley. The tanks will

47 Ross, C. P., op. cit., pp. $79-80$. 
supply about 200 head for two or three months. Dug wells in the Tertiary conglomerate near these tanks are likely to be successful, and enough good wells can probably be obtained to permit complete utilization of the plains west and south of Baker Peaks. Dug wells should also obtain water in the plains underlain by rock between and among the Wellton Hills. Drilled wells are fairly certain of success north of the hills. A number of years ago such a well was drilled by James Chappell 7 miles southwest of Wellton, in which water stood at 224 feet from the surface. The well was used for watering cattle for one season and then abandoned.

The Yuma Desert has little value for grazing. Wells are, however, being dug there by homesteaders, who expect either to receive water from the Yuma reclamation project or to pump for irrigation. Water stands from 80 to 100 feet below the surface near the western margin of the desert. Near the eastern margin it is doubtless deeper and the relatively impervious bedrock is more likely to be struck in wells. The Fortuna mine, during its period of activity, was supplied by a pipe line from a dug well 40 feet deep near Blaisdell, in the Gila flood plain. The shaft of the mine has water in it, and this demonstrates that wells in the crystalline rocks at the mouths of the larger canyons of the Gila Mountains will generally obtain water.

WEST-CENTRAL PORTION

IOCATION, TOPOGRAPHY, AND GEOLOGY

The west-central portion of the Papago country consists of a narrow strip east of the Growler Mountains and west of the Ajo and Sauceda mountains. This strip of country has a somewhat greater rainfall than the area to the west. The average annual rainfall at Gila Bend is 6.01 inches, and the short record at Ajo gives an average of 11.12 inches. It seems likely that a longer record will reduce the average for Ajo, but undoubtedly the effective rainfall in the higher plains country south of Gila River is substantially greater than that at Gila Bend. The higher parts of the mountains have patches of perennial grass and doubtless a slightly greater rainfall. These areas are small, and because of the porous character of the lavas of which most of these mountains are composed the increased rainfall does not produce a proportionate effect on the vegetation, and most of the ranges are as barren as those farther west.

This area contains the Painted Rock, Crater, Childs, .Little Ajo, Dripping Spring, Sonoita, Sauceda, Batamote, Pozo Redondo, and Ajo mountains and the Gunsight Hills. The valleys are the Gila Bend Plains, the valley between the Crater and Sauceda mountains, Childs Valley, the Valley of the Ajo, La Abra Valley, and Sonoita Valley. 


\section{MOUNTATNOUS AREAS}

PAINTED ROCK MOUNTAINS

By C. P. Ross

The Painted Rock Mountains are a small range in Maricopa County about halfway between Gila Bend and Sentinel, between Gila River on the north and the Southern Pacific Railroad on the south. This range is roughly 11 miles long and 3 miles wide. The portion of the range visible from the road is composed of lava flows of probable Tertiary age. The cap rock of many of the mountains is basalt, but most of the lavas are of much less basic composition. The gravel fans extending out from these mountains contain subordinate amounts of granite pebbles, so that such rocks must occur in the interior of the range.

The blocks of lava composing this range are tipped at various angles, indicating faulting with tilting of the blocks in several different directions. This structure, coupled with the considerable differences in resistance of the lava flows, has resulted in mountains and hills of weird and irregular shapes.

\section{CRATER MOUNTAINS}

The Crater Mountains lie north of Childs Valley, in which No. 3 Well is located, and west of the Tucson, Cornelia \& Gila Bend Railroad. The mountains are named from a locality on the Ajo-Gila Bend road which is called "The Crater" but is the headwater basin of a stream that flows north into the valley north of the Crater Mountains. The palisaded cliffs of this basin are eroded from almost horizontal lavas and resemble the encircling walls of a volcanic crater.

The Crater Mountains are about 10 miles long and 5 miles wide and are parallel in trend to the Batamote and Sauceda mountains. They consist of mesas and buttes carved from almost horizontal lavas, which rise 200 to 800 feet above the adjacent valleys. At the northeast end of the range, about 2 miles east of Black Tanks, the lavas rest on crystalline rocks.

ChILds mountary

Childs Mountain is a group of plateaus and ridges that lie south of Childs Valley and north of the Little Ajo Mountains. The eastern part of the mountain consists of an asymmetrical ridge of bedded lavas which rises about 2,000 feet above the Valley of the Ajo and has a gentle dip slope on the east and an abrupt escarpment on the west. The whole eastern border of the ridge is formed by a cliff and 
talus slope about 200 feet high. This slope is a measure of erosion since the tilting of the lavas, and near the south end of the mountains there is a well-defined mountain pediment which merges with that of the Little Ajo Mountains. Near Batamote Well and in Childs Valley the pediment is concealed by alluvium. The western portion of the mountain consists of plateaus of nearly horizontal lava separated from one another by deep canyons.

LITTLE AJO MOUNTAINS AND ADJACENT HILLS

The Little Ajo Mountains are situated at the edge of the Valley of the Ajo near the north end. They consist of three groups of hills separated from one another and from the Ajo Peaks and Black Mountain by strips of rolling country scored by small canyons and arroyos. The main mass lies west of the town of Ajo and has a general extension east and west. It is 5 miles long and about 2 miles wide but tapers to a sharp point on the west. The highest peaks rise about 1,000 feet above the adjacent base. Southwest of this mass and on the other side of a pass about 1 mile wide is a similar group of hills about 2 miles in diameter. East of Old Ajo is Reservoir Hill, a ridge $1 \frac{1}{2}$ miles long and half a mile wide. These three groups of hills constitute the Little Ajo Mountains proper. They are composed of granite, gneiss, and various acidic and intermediate intrusive rocks of the crystalline complex. Here, as in other parts of the region, the crystalline complex is overlain by Tertiary rocks. The contact begins south of Old Ajo and runs west along the pass south of the main mass of the mountains and east. along the southern point of Reservoir Hill. The cover rocks begin with coarse conglomerate, which dips to the south. The conglomerate has an arkosic matrix with pebbles of granite and various felsites from 6 inches to 2 feet in diameter.

From this area of conglomerate rise the Ajo Peaks, four sharppointed and conspicuous mountains. The most northerly is called Peñasco Peak and is a little less than a mile long in a north-south direction and a quarter of a mile wide. It rises by a series of cliffs about 1,000 feet above the adjacent country to a monolithic pillar of rock (PI. X, $A$ ). From this circumstance it derives its name (peñasco, Spanish for an isolated rock pillar). South of Peñasco Peak and slightly offset from it is a similar eminence about 11/4 miles long and a quarter of a mile wide at the base. Two peaks cap this mountain, of which the more southerly is a straight-sided pillar of rock, like a great horn, so high and isolated as to make it the most conspicuous landmark in the vicinity of Ajo from all points south and east. The fourth peak lies west of the others and is about a quarter of a mile in diameter at the base. It is visible 
only from the northwest and south, being concealed by the other peaks from many points of view. It is neither so high nor so striking in appearance as the others. The Ajo Peaks are residual elevations above the Pleistocene plain that surrounds them. Their steep slopes and sheer cliffs are due to the massive bedding and freedom from joints of the conglomerate. The southerly dip of the beds makes the northern slopes by far the steeper. These slopes rise like a great set of stairs, each riser being made of some particularly massive bed of conglomerate. The sheer cliffs are from 10 to 150 feet high. The general red of the rock is spotted and blotched by the great boulders of varying hue, which stand out like plums in a pudding.

Southeast of the Ajo Mountains proper, and separated from them by a valley about 2 miles wide, is Black Mountain. It is about 3 miles long and $11 / 2$ miles wide and is shaped like a gabled roof. The northerly point of the ridgelike summit is the highest point. At the south end are two outliers, of which the more southerly has three well-defined summits, much lower, however, than the main mountain. Black Mountain, is composed of horizontal lava beds of Tertiary age. The terraced outcrop of the beds, forming parallel bands around the mountain, and the brown-black color of the weathered surfaces, tinged with red, combine to give the mountain a most striking appearance.

The hill and ridge south of Black Mountain are composed of the same horizontal lavas, which apparently are younger than the conglomerate that forms the Ajo Peaks. Presumably also they overlie the conglomerate conformably. These assumptions imply that Black Mountain and its outliers to the south form an earth block bounded by faults, which not only was not rotated like the adjacent block on the west but was uplifted several hundred feet less.

Surrounding the main mass of the Little Ajo Mountains is a platform that slopes from the base of the mountain to the alluvial plains. At a distance this platform has the appearance of an alluvial slope of rather steep inclination, but on close examination it is seen to be underlain by rock, which in many places crops out and in others is buried by a few inches to several feet of coarse alluvium. Each of the streamways leading from the mountain canyons has cut a trench through the alluvium and into the bedrock. These trenchlike little canyons are from 25 to 50 feet deep near the mountains and gradually decrease in depth to the points where the rolling country merges with the alluvial plains. Not only the main streams have such canyons, but many of their tributaries also. The mountain pediment is thus carved into an intricate series of hills and ridges.

The rolling country occupies the pass between the Little Ajo Mountains and Childs Mountain, on the north, extends about half a 
mile northeast of Ajo, 2 miles east to Levy's ranch, and about 3 miles south from the main mass of the mountains between Black Mountain and the Ajo Peaks, extends through the pass west of the peaks, and continues on the west side of the main mass for about 2 miles, to the vicinity of Tule Well. 'The most characteristic and interesting section lies between Black Mountain and the Ajo Peaks. Over an area of about 10 square miles the hills and ridges rise to accordant levels. The bedrock is of two kinds in the northern part, coarse conglomerate dipping to the south, and south of this a belt of granite and other crystalline rocks, brought up by a nearly east-west fault south of the Locomotive Peaks. South of this belt of crystalline rocks the conglomerate reappears but does not crop out over any large area. In addition to the Ajo Peaks there are other eminences above the monotonous level of the rolling country. The Locomotive Peaks, the most notable, consist of a mass of curiously shaped conglomerate, which when viewed from the north is thought to resemble the head end of a locomotive. The peculiar shape of this mass of rock is due to weathering along joint and bedding planes in the massive conglomerate. West and south of the Locomotive Peaks are two rounded hills that lack the fantastic forms of those peaks because they are formed from the more closely jointed crystalline rock.

The sloping pediment of the Little Ajo Mountains and the region just described are the remnants of a mountain pediment that was probably completed in Pleistocene time. Since the completion of the pediment and its covering by a greater or smaller amount of alluvium the streams have cut the small canyons already described, and a large but indefinite amount of alluvium has been deposited on the edge of the plain.

\section{DRIPPING SPRING MOUNTAINS}

The Dripping Spring Mountains are a small range between the Ajo and Growler mountains. They separate the Valley of the Ajo from La Abra Plain. These mountains have passed under various names, largely because they were confused with other mountains of the neighborhood. The mountains are about 8 miles long and from 1 to 3 miles wide. They have a general northwesterly trend. All the mountains seen consist of lava and tuff beds. In the vicinity of Dripping Spring many of the lavas were originally obsidian and are now converted into green pitchstone. The dip is not uniform in amount or direction, but the larger masses dip to the southwest. (See Pl. XXIV, A.) These mountains are thought to be a somewhat complex fault block that has been uplifted along a fault or number of faults on the northeast side. 
The Sonoita Mountains are a small range of hills about 5 miles long, having a northerly trend. They extend from Sonoita River about 3 miles into the United States. The hills are composed of granite, gneiss, and schist.

SAUCEDA MOUNTAINS AND ASSOCIATED MOUNTAINS

The Sauceda Mountains are about 25 miles long and trend in a northwesterly direction from the vicinity of Sauceda to Black Gap. On the east a clump of high hills intervenes between the Sauceda Mountains and the southwestern edge of the Sand Tank Mountains. On the south the Sauceda Mountains merge by a series of connecting plateaus into the mountains west of Perigua and the Batamote Mountains. West of Black Gap, at the north end of the range, lies a small clump of mountains, as yet unnamed.

The Sauceda Mountains consist almost exclusirely of lava flows. Many of the beds lie horizontal; others are tilted. In some places the beds are uniform in thickness and in composition; in others there is great variation in thickness of individual beds, the same lava bed ranging from a few feet to 100 feet within a few hundred yards. Likewise soft tuff and hard felsite alternate or replace each other laterally. These variations in character and attitude of the lavas account for variable response to erosion and the consequent multiplicity of forms found in the mountains.

The northeastern front of the Sauceda Mountains is a cliff and talus slope which extends from the pass at Sauceda to a point within about 8 miles of Black Gap. From this bluff the plateaus rise to the sonthwest toward the crest of the range. From a distance the top of the mountains appears to be a relatively smooth plain which rises gradually to Hat Mountain. In fact, however, deep canyons penetrate into the plateaus. One group opens eastward in a broad valley that connects with the pass at Sauceda; the other groups unite in a much larger valley which forms the deep indentation in the mountains between Black Gap and Deadman Gap. Thus the mountains are divided into two more or less parallel and highly irregular groups of plateaus and mountains.

The highest part of the northerly group is a mountain just east of Black Gap. This mountain slopes from its irregular but narrow crest downward on all sides, like the roof of a tent from the ridgepole. The lava beds are rather regular in thickness, lie horizontal, and weather to a purple-brown. They crop out as a series of cliffs, which run around the mountain in bands. Rocks loosened from the cliffs once mantled all the lower parts of the mountain in great piles of slide rock and talus. Relatively recent gullies have cut into this mantle of talus and reexposed the rocky, steplike slopes beneath. 
The remnants of the old talus now persist as triangular patches between the gullies. (See p. 83.)

Nearer Black Gap are two high, flat-topped hills, whose lava beds dip to the south. The gap itself is about half a mile wide, and beyond it is a group of hills and small mountains, which are described in a later paragraph.

The southern group of plateaus, in the eastern and central part of the range, are by far the highest part of the mountains. They are capped by Hat Mountain, at an altitude of 3,482 feet, a landmark visible all the way from Gila Bend on the north to $\Lambda$ jo on the south. Hat Mountain derives its name from its fanciful likeness to a hat. It is a round mesa about one-eighth of a mile in diameter, wholly encircled by vertical cliffs. It appears to be the remnant left from the erosion of a very thick horizontal lava sheet. West of Hat Mountain the southern prong of the range protrudes between the broad valley which separates it from the northern prong and the larger valley which separates the Sauceda Mountains from the Batamote Mountains. The southern prong ends abruptly at the group of small hills that contains Deadman Gap. In this prong the plateau character is lost, and both crest and flanks of the ridge are exceedingly rough. This roughness appears to be due to original irregularity in bedding and to complicated faulting that tilted the lava flows at high angles and in various directions.

West of Black Gap is a small clump of mountains about 3 miles long. They trend almost due north, at a considerable angle to the trend of the Sauceda Mountains. Near the gap are two flat-topped buttes capped with basalt. The lava dips gently to the southwest and forms a low clifi around the tops of the hills. Unbroken talus slopes of large boulders extend from the cliffs to the base. North of the buttes the main mountain mass is made up of granite and has the irregular summits and canyoned slopes characteristic of the sierra type of mountain. Northeast of the main mass are several small lava hills. These hills rise from a concealed pediment that slopes from the mountains to the Gila Bend Plains. These mountains and hills were obviously elevated by a somewhat different uplift from the Sauceda Mountains. They differ also in that the ccver of lava over the crystalline rocks was thinner, and consequently those rocks have been exposed by erosion. Their association with the Sauceda Mountains seems, then, to be more or less accidental.

BATAMOTE MOUNTAINS

The Batamote Mountains close in the Valley of the Ajo on the northeast. They consist of a broad, flat cone, somewhat nicked at the top by erosion and scored by canyons, which surmounts a pedestal 
of plateaus and sloping mesas of somewhat irregular shape. The mountains extend from a small pass north of Pozo Redondo in a bulbous crescent about 14 miles to Batamote Well. They are separated from the mountains to the east by Pozo Redondo Valley and are bounded on the north by a wide valley east of The Crater.

The conical shape of the main mass and the quaquaversal dip of the constituent lava flows indicate that the Batamote Mountains were a center of eruption at the time of the outpouring of the Tertiary lavas. Since the cessation of volcanic activity the upper part of the cone has been sculptured by erosion and deep canyons have been cut in the flanks. The interstream areas, however, seem to be part of the original surface-a relatively smooth plain parallel to the irregular but gentle quaquaversal dip of the lavas and tuffs. These lavas and tuffs have been cut back along sinuous lines by cliff erosion. The indentations are more pronounced on the eastern margin, where the mountain fronts on the Pozo Redondo Valley, but a cliff and slope from 100 to 500 feet high, covered with boulders of lava, forms the characteristic border of the range.

At a point about 2 miles north of the south end of the mountains the lavas appear to be about 300 feet thick, and their base, resting on crystalline rock, is exposed. In othex places the lavas extend under the adjacent valleys and are doubtless thicker. Similar lavas are found in No. 1 Well at a depth of 173 feet (p. 174).

The Batamote Mountains are not, then, due simply to accumulation, but since the cessation of volcanic activity sharp downwarping has taken place along the west side. On the east side uplift seems to have occurred, doubtless along a fault coincident with Pozo Redondo Valley. Certainly the eastern slopes of the mountains are somewhat less steep than the western, a fact more easily attributable to deformation than to any original difference in the gradient on which the lava was laid down.

\section{POZO REDONDO MOUNTAINS}

The Pozo Redondo Mountains extend from the Gunsight ranch north 11 miles to a narrow gap which separates them from the Batamote Mountains. This range is a collection of mesas and small plateaus of various heights. It is about 3 miles wide in the northern two-thirds and then tapers abruptly to a narrow ridge of varying height about 1 mile wide. This ridge ends in two very sharp and conspicuous mountain peaks.

The border of the mountains is an almost continuous cliff and talus slope-very sinuous, with long promontories and isolated spurs, on the northwestern border and relatively smooth elsewhere. However, the height of the cliff and slope ranges from 100 to 1,500 feet. On 
the north and east the border slope is generally low. Near the middle of the west side it is notably high, a relatively small-topped mesa rising sheer from the plains.

The various heights of the plateaus and mesas of these mountains, together with differences in strike and dip of the lava beds of which they are composed, indicate that uplift took place along a complex set of fractures. Variation in amount of uplift along these fractures resulted in a complex topography, which has been still further complicated by later erosion.

GUNSIGHT HILLS

Under the name Gunsight Hills will be described all the broken country lying between the Pozo Redondo and Ajo mountains, an area 6 miles north and south by about 15 miles east and west.

The western boundary is a low, lava-capped mesa about 4 miles long. The highest point is about 300 feet above the adjacent plains. The mesa is 1 mile wide near the south end and tapers northward. Steep cliffs and talus slopes encircle the ridge, and the flat top has a gentle inclination northeastward which is parallel to the dip of the lavas.

Fast of this mesa is a belt of rolling country dotted with a few hills, which rises eastward for about 2 miles. The rolling country is then divided by a series of hills that begin south of the Gunsight ranch and continue to Walls Well. The principal hill rises about 500 feet.above the adjacent country. At its northern base is the Gunsight mine. Granite and gneiss are the principal rocks, but there are also various fine-grained intrusives.

East of the road between the Gunsight ranch and Walls Well, about 2 miles southeast of the Gunsight mine, is an irregular ridge of lava 2 miles long, in which the lava beds dip northeast. The hills from this point east to Charco en Medio consist of rocks of the crystalline complex. They are low and are separated from one another by broad valleys and stretches of rolling country.

East of Charco en Medio an alluvium-floored valley leads eastward between two groups of hills. The northerly group is composed largely of lava beds, which dip at low angles and in various directions. On the northern edge is Ninemile Peak, a conspicuous landmark on the Pozo Blanco road. This peak is composed of lava, which dips to the south. The group of hills south of Charco en Medio is made up largely of granite and gneiss. It extends about 5 miles east of this place, and its many summits are visible over the whole plain from Comovo to Cubo.

Just east of Walls Well, and cut off from the north end of the Ajo Mountains by a very narrow canyon, is a high, sharp peak of almosi horizontal lava beds. Just east of it the road between Walls Well 
and Cubo passes over a notch. East of the notch is another low ridge of lavas similar to those of the peak.

The distribution and attitude of the rocks show that the Gunsight Hills area is complexly faulted. The fault blocks that stood highest have been largely stripped of their lava capping, while the lavas of the lower blocks have been in part preserved. Erosion continued until broad valleys and lowlands were formed, such as that south of the Jaques ranch and west of Charco en Medio. These areas were part of the mountain pediment and, as in other mountains, have since the formation of the pediment been cut into a maze of small canyons by further erosion under changed conditions. Erosion was prevented and the pediment concealed, however, east of the Gunsight ranch by floods of sediment brought in from regions farther east.

AJO MOUNTAINS

The Ajo Mountains are a prominent range 15 miles southeast of Ajo. They trend about N. $20^{\circ}$ W. and are about 15 miles long and 7 miles wide. From the southern point a smaller range extends about 7 miles and ends abruptly at Sonoita River, just across the international boundary. This part of the mountains is named on many maps Sierra de Santa Rosa.

The Ajo Mountains consist of a main ridge flanked on the east by discontinuous ridges which in many places are not distinctly separated from the main ridge. On the west, however, is a relatively low subsidiary ridge about 6 miles long, which is separated from the main mass by the well-defined Alamo Valley, so named from the principal watering place.

At the north end of the range the main ridge is neither so wide nor so high as the eastern ridge. It is, however, marked by a conspicuous pinnacle of rock which resembles a square-shouldered bottle. This peak is called Montezuma's Head (Pl. X, $B$ ). It is a distinctive landmark from all points north and west. On the eastern ridge almost due east of Montezuma's Head is a very high, sharp pinnacle which is visible from points east of the mountains for about 20 miles.

The Ajo Mountains are composed of lavas of Tertiary age, which are about 2,000 feet thick. They dip $20^{\circ}-30^{\circ}$ NE. This high dip has facilitated erosion, for both the bedding planes and the columnar jointing are inclined to the horizon, hence a joint block once loosened is easily removed. The mountains have been carved into a maze of canyons and are notable for their extreme roughness and many wild and picturesque summits.

The Ajo Mountains are a fault-block range uplifted along a fault running northwestward through Alamo Valley. The western 104211-25-16 
ridge is a subsidiary, parallel block. On the north a cross fault cuts off the range and brings the crystalline complex to the surface at Walls Well. East of Walls Well the lavas are horizontal in the conspicuous conical mountain north of the Walls Well wash. This mass is obviously separated from the Ajo Mountains by a fault. On the east, also, the mountains are bounded by faults, for the Cubo Hills consist of lavas having a very much smaller inclination to the east. Near Cochibo the horizontal lavas of the southern division of the Cubo Hills are separated from the inclined lavas of the mountains by a very narrow gap which is the site of a fault.

\section{VALLEY AREAS}

GILA BEND PLAINS

The Gila Bend Plains extend north from the Sauceda Mountains to the flood plain of Gila River. The eastern boundary is formed by the Sand Tank and Maricopa mountains and the western by the Sentinel Plain. The plains are roughly 20 miles in diameter and consist of long, unbroken alluvial slopes extending from the mountains northward to the river. Near Gila Bend and for 1 or 2 miles south of the railroad the streams are depressed from 10 to 50 feet below the general level and are feebly dissecting the plain. The slopes over most of the plain are, however, those of combined sedimentation and transportation and are adjusted to a higher level of Gila River, as in other parts of the region.

VALLEY BETWEEN CRATER AND SAUCEDA MOUNTAINS

The unnamed valley between the Crater and Sauceda mountains is from 8 to 9 miles wide and about 20 miles long. It drains northwestward, presumably into the Gila Bend Plains, but has not been sufficiently explored to confirm this statement.

The log of the Midway Well (see p. 179) shows 450 feet of cemented gravel, clay, and boulders and 165 feet of "sandy rock" overlying lava. The moderate thickness of alluvium in this well, Jocated near the axis of the valley, indicates that the alluvium cover of the valley is thin. The "sandy rock" reported in the $\log$ may be a Tertiary conglomerate or the lower and more compact part of the alluvium. In either event the lava encountered at the bottom of the well is doubtless part of the same formation as the bounding mountains and indicates that the valley is a down-faulted block between the adjacent up-faulted blocks.

CHIUDS VALLEY

Childs Valley lies between the Crater and Childs mountains and is similar in character to the valley just described. Near No. 3 Well it is about 3 miles wide, but it widens westward and merges 
into The Great Plain south of the Sentinel Plain. Childs Valley receives the drainage from a large part of the Valley of the Ajo and from part of the north side of the Batamote Mountains. The floor of the valley is largely covered with the creosote bush and its associated plants, but the coves and flat-bottomed canyons of the bordering plateaus have a fair growth of grass.

VALLEX OF THE AJO

The Valley of the Ajo is about 35 miles long and from 10 to 12 miles wide. It is bounded by the Growler, Childs, Batamote, Pozo Redondo, Ajo, and Dripping Spring mountains. The Little Ajo Mountains form part of the western boundary but project into the valley and are more or less surrounded by it.

The valley drains through two outlets-a northern outlet near Batamote Well into Childs Valley and a southern outlet through Growler Pass. The divide between the two drainage areas lies near the southern point of Black Mountain and in a general view is indistinguishable from the rest of the valley floor.

North of the Little Ajo Mountains the valley appears to be synclinal in structure, as the lavas of the Batamote Mountains on the east and Childs Mountain on the west dip toward the center of the valley, where similar thick lava beds were encountered in No. 1 Well at a depth of 173 feet (p. 174). Whether the structural depression thus recorded was accomplished by folding or by faulting has not been determined. South of the Little Ajo Mountains lava beds in the bordering mountains in a general way dip toward the valley (east) in the Growler Mountains and away from the valley (east and southwest) in the Ajo and Dripping Spring mountains. The lavas of Black Mountain and most of the fault blocks of the Pozo Redondo Mountains are, however, horizontal. The lavas in the narrow ridges southwest of Black Mountain dip to the west, and those in the elongated mesa south of Lewis Well dip to the east. Thus in the southern part of the valley the structural depression seems to have been accomplished by complicated block faulting, which has doubtless left under the alluvial cover a highly irregular structural floor.

\section{CA ABRA VILIEY}

La Abra Valley ("the open place") is a triangular area about 10 miles on a side. The Quitobaquito Hills and Growler Mountains form the northwest side, the Dripping Spring and Sonoita mountains form the east side, and the whole area slopes to the south side, which is bounded by Sonoita River. La Abra Valley has slopes determined by the ephemeral streams that drain from the moun- 
tains to the river. Part of the plain is a pediment flanking the Quitobaquito Hills and Sonoita Mountains, but over the greater part of the plain the alluvium is sufficiently thick to conceal the underlying floor.

\section{SONOITA VALLEY}

The part of the Sonoita Valley that lies in the United States is an alluvial slope about 10 miles wide, which is bounded on the west, north, and east by the Sonoita, Dripping Spring, and Ajo mountains, respectively. The ephemeral streams from these mountains drain to Sonoita River, which lies just south of and parallel to the international boundary. Doubtless near the borders of the mountains there are areas of pediment, but on a general view the plains appear to be wholly covered with alluvium.

\section{GROUND-WATER RESOURCES}

The water resources of this area seemed to the early traveler meager enough. Quitobaquito and Dripping springs, described on pages 161-167, and a few rock tanks were the only natural watering places. Wells were dug at the Ajo mines in the fifties. Bates Well, Walls Well, and Batamote Well were added probably in the seventies, and in recent years many new wells have been dug concerning which adequate details are given on pages 161 and 181 .

The Gila Bend Plains are bordered on the north by the flood plain of Gila River, where water is obtained at shallow depths. As shown by the railroad wells at Gila Bend ${ }^{48}$ water can be obtained by deep wells over the northern portion of the plains. In 1919 A. H. Stout drilled a well on Quilotosa Wash that is 4 inches in diameter, 170 feet decp, and has water at 158 feet. In 1920 he raised and sold from the fields at this well $\$ 1,000$ worth of hay. The vegetation of this area is scanty, however, and it is questionable whether the grazing alone will justify the expense of wells. Drilling in the lavas in the western margin of the Sand Tank Mountains will probably be successful, and shallow wells may obtain water near Black Gap, where the bedrock is close to the surface. Such wells would open to grazing the best portions of the plains.

The valley between the Sauceda and Crater mountains has no shallow water, but the Midway Well (p. 179) shows that water can be developed by deep drilling. One well south of Deadman Gap and another north of it would open all the available range.

Childs Valley is underlain by water-bearing beds, as shown by No. 3 Well (p. 180). The available range can be reached by cattle watering at this well or at Batamote Well. The cattle watered at 
this well in 1917-1919 exhausted the range, and the well was abaudoned in 1920. A well or wells at the northern point of the Growler Mountains or near the west end of the Crater Mountains would allow grazing farther away from No. 3 Well. Water can probably be obtained by drilling at the foot of the lava plateau or in the valleys that indent their borders.

The Valley of the Ajo has a number of wells in its northern part. Batamote, No. 1, and Childs wells can furnish water for all the cattle which the range will support. The wells dug in rock in the pediment of the Little Ajo Mountains, the Cook \& Landro Well, the Steel Well, the well in the gap south of Childs Mountain, the Tule Well, the Cardigan Well, and the Darby Well are so located as to develop all the available range. Another well in the pediment of Childs Mountain, 2 miles north of the Cook \& Landro Well, could obtain a supply of water sufficient for a few cattle, but it is doubtful whether it would be of value to anyone not also in control of the Batamote Well. Similarly the well being drilled in 1920 in the gap between Pozo Redondo and Batamote mountains would be advantageous to the owner of Childs Well, though the available range is not sufficient for an independent ranch. In the southern part of the valley, near the charcos on the Bates Well trail, there is a considerable area which could be opened to cattle by a well. A drilled well in this locality would strike the lavas and obtain water, but the success of a dug well is less certain. $A$ deep well in the center of the valley south of the road between Bates Well and Walls Well would open a large area,just as ChiIds Well has done farther north. Cherioni Well was an attempt to open this area. In the edge of the Dripping Spring Mourtains a dug well will obtain water from rock in the narrow pediment, or the well at Dripping Spring might be developed into a reliable supply. There is an area of fair grass in the pass on the Sonoita road between the Dripping Spring and Ajo mountains. A well in this locality would penetrate lava and if sufficiently deep would obtain water.

There are no wells in La Abra Valley. Dug wells suitably located will obtain water in the pediments of the bordering mountains, and it seems likely that water can be obtained from the alluvium at moderate depths near the international boundary.

The Sonoita Valley is now being opened for cattle by Blankenships Well, which is dug 65 feet into the alluvium and in which water stands 54 feet below the surface. There is also a well at Dowling, about 1 mile to the west. Two or three other wells spaced at intervals along the international boundary should be equally successful in obtaining water at shallow depths either in alluvium or in rock and would enable cattle to use all the available forage. 


\section{CENTRAL PORTION}

LOCATION, TOPOGRAPHY, AND GEOIOGY

The central portion of the Papago country consists of the area east of Gunsight Pass and west of the La Lesna, Quijotoa, Vekol, and Palo Verde mountains. Within this strip of country there are no rainfall stations. In general, the rainfall probably does not exceed that of the west-central portion immediately to the west.

This area contains the Buckeye Hills, Maricopa Mountains, Sierra Estrella, Palo Verde Mountains, Table Top and associated mountains, Sand Tank, Vekol, and Sheridan mountains, mountains west and east of Perigua, mountains southwest of Kaka, Quijotoa and associated mountains, Cubo Hills, Mesquite, Nariz, Copeka, and La Lesna mountains, and hills southwest of Copeka Mountains. The valleys are the valley between the Maricopa Mountains and the Sierra Estrella, sometimes called Jornada de las Estrellas, Vekol Valley, Perigua Valley, Pozo Redondo Valley, Quijotoa Valley, Barajita Valley, Comovo Valley, La Quituni Valley, and The Great Plain.

\section{MOUNTAINOUS AREAS}

BUCKEYE HILLS

By C. P. Ross

The Buckeye Hills are on the south side of Gila River opposite the town of Buckeye. They are composed principally of granite but appear also to contain a small amount of schist. Powers Butte, an outlier of these hills, near Arlington, is composed of much younger rock, mostly flat-lying beds of lava, probably of Tertiary age. Tertiary rocks, both volcanic and sedimentary, are also found at the Gillespie (formerly Enterprise) dam, at the west end of the Buckeye Hills.

\section{MARICOPA MOUNTAINS}

The Maricopa Mountains consist of a northern part about 20 miles long with a maximum width of 5 miles and a southern part about 15 miles long and of similar width. The two parts of the range have a north-northwest trend and are separated by a broad alluvium-floored pass, through which runs the Southern Pacific Railroad.

The northern part of the range has precipitous slopes, a broken topography, and several outlying hills and small mountains. There is also a pass about 5 miles north of Estrella, through which the old stage road led. The mountains are composed of crystalline rocks. Near Estrella, at the south end of this part, the prevailing rock is a granitic intrusive similar to the Mesozoic rocks of other parts of the region. 
The east side of the mountains north of Estrella is flanked by a mountain pediment practically undissected by streams. In addition to numerous outliers of crystalline rock, there is a hill capped by a lava flow overlying gravel. The gravel rests on an erosion surface only a few feet above the present pediment, but the lava is tilted to the east. The mountains were therefore elevated after the extrusion of the lava. In contrast to the east side, the west side of the mountains seems to be deeply buried in alluvium, and in the pass alluvium occurs to a depth of more than 500 feet (p. 186).

The southern part of the mountains is composed of rocks similar to those in the northern part. It is not known whether there are any outcrops of lava.

SIERRA ESTRETLA

The Sierra Estrella is a prominent mountain range with a northwest trend and except for the outlier noted below consists of a single compact ridge 25 miles in length by 3 miles in width, rising 3,000 feet or more above the plains. Montezuma's Head, altitude 4,337 feet, near the south end, is the highest point, though North Peak, at the other end of the range, is of about the same height. Southwest of the south end of the mountains and separated from it by a pass, about a mile wide, is a short parallel ridge sometimes called the Enid Mountains. This ridge begins 2 miles north of Enid station and has a length of 6 miles and an average width of 1 mile.

The main ridge is composed of rocks of the pre-Cambrian complex intruded by later, presumably Mesozoic granitoid rocks. The dominant structural features dip to the south. The steepest slopes are, however, on the northeast side of the mountains, and there are many cliffs, cascades, and rock tanks at altitudes of 2,000 to 3,000 feet. Above these altitudes many of the canyons are open and have greater grades. This topography indicates comparatively late uplift by faulting along the northeast side of the mountain (p. 131).

Climbing this range is arduous work, and many of the slopes can be ascended by a pedestrian only with the greatest difficulty. Much of the topography and scenery is as rugged, wild, and grand as any found in the Rocky Mountains of the United States or Alaska.

PAIO VERDE MOUNTAING

The Palo Verde Mountains are a small range lying south of Enid station on the Southern Pacific Railroad and about 7 miles west of Maricopa. The mountains are 6 miles long and at no place more

40 The description is a digest from an unpublished report on the Gila. River Indian Reservation. as to the mineral or nonmineral character of its Iands. by Frank $C$. Schrader, 1918. 
than a mile wide. The highest point is 2,117 feet above sea level and about 800 feet above the base of the mountains. Streams have cut deep canyons into the range, and the reentrants at each canyon make the ground plan of the mountains extremely ragged in outline.

The Palo Verde Mountains are composed wholly of granite and granitoid rocks of the crystalline complex. No indications of deformation are present. The eastern face of the mountains at the north end is very steep and precipitous and has no large canyons. It may easily be a fault scarp. However, no continuous fault scarp has been preserved from erosion.

TABLE TOP AND ASSOCKATED MOUNTAING

Table Top Mountain is the dominant summit of a belt of more or less mountainous country extending from the south end of the Palo Verde Mountains 25 miles to the vicinity of Vekol. On the west is the Vekol Valley, and on the east is a depression between Table Top and the mountains west of Cocklebur. The Table Top Mountains extend north and south about 5 miles on each side of Table Top. South of these mountains there is a gap about 2 miles wide, beyond which is a small group of hills called on some maps the Little Table Top Mountains. North of the Table Top Mountains are a number of disconnected hills and small mountains, as yet unnamed.

The Table Top Mountains are a group of peaks and ridges which rise above the steep slopes of their surrounding mountain pediment. The pediment lies between 500 and 750 feet above the Vekol Valley. The lower parts of the slopes are covered with alluvium, but here, as in other mountains, the upper parts are bare rock. The pediment is dissected by streams into a maze of small canyons.

Table Top Mountain is a flat-topped peak that rises to an altitude of about 4,000 feet. The flat top is about half a mile in diameter and is bounded by a sheer cliff. From the cliff steep talus slopes extend to the base. The mountain top is composed of horizontal lavas, which weather to a deep black. West of Table Top is an inclined mesa composed of similar lavas that dip sharply to the southwest. The smooth top of this mesa is $2 \frac{1}{2}$ miles long and is bounded on all sides by a cliff and talus slope. South of the mesa are three peaks, each composed of lava beds. Erosion has obliterated their flat tops, however, and the middle peak is particularly conical and sharp. About half a mile east of Table Top is an inclined mesa in which the lava beds dip gently to the east.

Extending northwest from Table Top is a mountain about 4 miles long, whose highest summit is almost as high as Table Top. This mountain and several adjacent hills are composed of granite and granitoid rocks of the crystalline complex. Its topography is 
in marked contrast to that of the other members of the mountain group.

At the northwest end of the last-mentioned mountain lies Antelope Peak. This peak has a steep, conical base about three-quarters of a mile in diameter, which is surmounted by a sharp nubbin of rock that rises 1,000 feet above the adjacent rolling country. The height and somewhat isolated position of Antelope Peak make it a conspicuous landmark. The upper part of the peak is composed of lava beds, which dip about $40^{\circ} \mathrm{W}$. Below them and forming the slope of the mountain are exposed coarse-grained crystalline rocks.

The history of these mountains is similar to that of others of the region. Upon the eroded crystalline complex of pre-Cambrian rocks and later igneous rocks were laid down the Tertiary lavas. The surface on which the lavas were deposited was by no means smooth, and the high mountain north of Table Top seems to be a mountain of this old surface now resurrected. In the period of faulting and elevation that followed the outpouring of the lava the area was broken into fault blocks, probably of a complicated pattern. The disposition and dip of the remaining lavas are the result of this faulting.

The individual members of the Table Top Mountains are separated by mature valleys or broad lowlands. It is evident that after uplift the mountains were subjected for a long period to erosion that resulted in the formation of a mountain pediment with many extensions into the mountains. Recent canyon cutting has dissected the pediments, as in other parts of the Papago country.

The so-called Little Table Top Mountains are a group of small lava-capped hills and mesas. The lavas are mostly horizontal, and at the southern edge of the hills they rest on rocks of the crystalline complex along the border of the Vekol Mountains.

North of Antelope Peak there is a group of lava-capped plateaus about 2 miles in diameter. Through a narrow gap in the plateaus passes the road from Maricopa to the Vekol Valley. The lava dips about $10^{\circ} \mathrm{SW}$. Coarse-grained arkosic conglomerate crops out in the arroyo in the vicinity of the water hole shown on the map (Pl. IV) and may be seen in alternate white and black bands interbedded with lava in the hill north of the road. At the extreme eastern tip of the hill the contact of the lava and the underlying granite is exposed.

East and north of this remnant of the lava all the hills and mountains are composed of the crystalline complex. Most of them consist of coarse granite and have the characteristic steep slopes and sharp summits that result from the erosion of this rock. The largest 
mountain lies north of the road and is about 5 miles long. North of it are a number of isolated clumps of hills which reach within 2 miles of the Palo Verde Mountains. About 5 miles to the northwest is a group of hills of similar rock. Between these hills and Antelope Peak there is about 10 square miles of rolling country which is part of the dissected mountain pediment. A similar lowland forms the pass and extends in more or less disconnected fragments around all the hills. At the east end of the pass, where the road turns sharply northeast, the streams change their habit. In the pass they are intrenched in the rocks in little canyons 5 to 25 feet deep. East of the pass and along the east side of the hills the streams begin to deposit sediment. Well-defined channels are lost, and during floods the water moves as a thin sheet. In consequence, the pediment on this side of the hills is buried in alluvium. The eminences of the pediment project above the alluvial plain as.isolated buttes. It seems probable, however, that the alluvium is not more than 100 feet thick along the east side of the hills in an area 8 miles long by 3 miles wide.

SAND TANK MOUNTAINS

The Sand Tank Mountains are a group of plateaus and mountains which lie between the Gila Bend Plains and the Vekol Valley. They are separated from the Maricopa Mountains on the north by some open, butte-dotted country and end on the south at the narrow canyons in which lie Kaka and Moivavi. As no local name for these mountains exists, they have been named for the best-known and until recently the only watering place, Sand Tanks.

The Sand Tank Mountains will be described in four divisionsthe northwestern plateaus, the eastern plateaus and mountains, the southern plateaus, and the associated rolling country.

The northwestern plateaus have a complicated fault structure, discussed on page 71 and illustrated by Figure 2. The region is dominated by a high sloping lava plateau, about 4 miles from east to west and $2 \frac{1}{2}$ miles from north to south. Because of its appearance from a distance this may be called Blue Plateau. The southern and western rim rises about 1,500 feet above the pass to the south. The façade below the rim is a steep slope marked by cliffs and slide rock. The lava weathers to a deep brown-black, which gives the plateau a peculiarly somber and impressive appearance. In front of the façade and separating it from the pass are two ridges almost as high as the plateau and composed of the same sequence of lavas. They are evidently parts of the original mass of the plateau, now separated from it by erosion. The top of the Blue Plateau is parallel to the dip of the lava beds and slopes gently to the northeast, 
where it ends in an escarpment facing northeast. This escarpment is capped by a rounded butte, which, from its appearance, may be called Round Top Butte. The escarpment of Round Top Butte trends northwestward and is eroded from lavas having a slight dip to the southwest. The dip of the lavas changes about 1 mile south of Round Top Butte. This point is the site of a small fault or fold.

North of Round Top Butte is a low plateau or mesa that slopes to the south and southwest and ends in an escarpment in front of which is a conical butte capped with a very small pillar of rock. The escarpment faces low broken country from which projects the remarkable Double Butte. This butte consists of a pedestal on which are two hornlike masses of rock. It is visible from Gila Bend, Black Cap, and Bosque, on the west and north, and from the road along the front of Antelope Peak, on the east.

West of Blue Plateau are two small mesas, each about a mile wide, which slope gently west and have escarpments that face east. The western mesa has an escarpment on the west that borders the alluvial slope of the Gila Bend Plains. In both these mesas the lavas dip gently to the west and northwest, in marked contrast to their dip in the Blue Plateau. It is evident that these mesas are fault blocks, uplifted along faults that lie in the narrow canyons along their eastern margins.

South of Blue Plateau and the gap are three somewhat irregular ridges. Each has abrupt slopes on the north side and smooth and gentle slopes on the south side. In each ridge the northern escarpment is formed by the erosion of the edges of lava beds, and the smooth back slope is parallel to their dip. The most northerly of these ridges is $41 / 2$ miles long and decreases in width from $1 \frac{1}{2}$ miles at the west to about half a mile on the east. This ridge is rather irregular in height and in only a few places rises to 500 feet above the adjacent valley. It is obviously a fault block separated by a fault from Blue Plateau on the north and by a similar fault from the next ridge on the south. The irregularities in elevation of the ridge are probably not all due to differences in erosion. Various minor faults probably exist. The second of the three ridges is marked at its end by a most remarkable pinnacle of volcanic rock, at the base of which the lavas rest on the crystalline complex. This high butte has been named Jack in the Pulpit. The pinnacle is apparently an eroded remnant of the topmost lava bed at the highest point of the ridge. In this ridge also the lava beds dip to the south. The third ridge is separated from the second by a valley in which lies a fault, for in this ridge also the lava beds dip to the south. This ridge is about 3 miles long and half a mile wide. Its northeasterly point is higher than Jack in the Pulpit and reaches nearly the altitude of Blue Plateau. 
The highest parts of the Sand Tank Mountains are along the eastern front. They consist of both mountains and plateaus. The plateaus begin south of the road east of Sand Tanks with a high, ragged mesa about $1 \frac{1}{2}$ miles in diameter. This mesa is composed of almost horizontal lavas, which rest on gneiss and schist of the crystalline complex. The contact is exposed at intervals along the northwestern border wherever it is not concealed by talus from the cliffs above. South and west of this mesa for a distance of 2 miles in both directions are a number of similar mesas more or less connected and in general lower. Separated from them by a deep canyon and high pass is Squawtit Peak, which has an altitude of about 4,000 feet and is the highest point in the Sand Tank Mountains. This peak is a narrow ridge that rises rather gradually from the west. On the north, east, and south it is bounded by precipitous cliffs. From the eastern face projects the peculiarly shaped pinnacle of rock to which the mountain owes its name. The lavas of Squawtit Peak dip to the northwest, but in the ragged plateaus and mesas on the south the dip is to the south. These dips are so gentle- $5^{\circ}$ to $15^{\circ}$-that they may easily be due to the original slope on which the lava was laid down. The great mass of the lavas at this point-about 2,000 feet thick-and the presence of flow breccia and agglomerate lead to the belief that this locality was a center of eruption. Elevation and erosion have combined to produce the present rugged and picturesque topography.

The intricate topography just described is in marked contrast to the simplicity of the northwestern plateaus. The areas differ also in character of rocks and in altitude. The lavas of the eastern section are very irregularly bedded. Individual beds may be 200 feet thick in one place and only a few feet thick 100 yards distant. They vary, also, in resistance to erosion and in their dip. These complexities seem to be all accounted for by the proximity of the vent from which the lava came forth. The western lavas are, on the other hand, evenly bedded, being composed of the more fluid material, which could spread over great distances. Their original dips were probably low. As erosion varies in intensity with altitude and with the position of the headwaters of streams, the eastern plateaus have been more dissected than the northwestern.

North of the gap and road is a high mountain, which borders the gap for about 6 miles and is at its widest point about 11/2 miles wide (P1. XIII, $B$ ). The light-brown canyoned slopes of this mountain are very different in appearance from the lava mesas near by. The mountain is composed of gneiss and granite of the crystalline complex. It appears to be an old mountain of the Tertiary landscape, now stripped of its cover of lava and resurrected. About 4 miles 
northeast of this mountain is a group of small mountains similarly formed of crystalline rock and presumably with the same history.

South of the divisions already described the Sand Tank Mountains consist of plateaus of two types-rough and irregular plateaus and pinnacles and smooth plateaus. The irregular plateaus and pinnacles extend over an area about 6 miles square south of Squawtit Peak. They appear to be similar in origin and history to the plateaus in the vicinity of the peak. The smooth plateaus slope to a low escarpment that borders the Vekol Valley. The southern boundary of the mountains is a great escarpment of horizontal lavas 500 to 1,000 feet high, which overlooks the low plateaus and peaks adjacent to Kaka.

Hilly, rolling country lies between the northwestern and eastern plateaus and borders the mountains east of Stouts Well. The rolling country forms a lowland in the center of the mountains which slopes west from the divide east of Sand Tanks to the Halfway Corral. The hills and ridges that compose it are underlain by rocks of the crystalline complex, mostly gneiss, schist, and basic igneous rock. Similar country extends north to the vicinity of Round Top Butte. On the south there are a series of lava-capped buttes which separate this belt of rolling country from a similar belt west of Squawtit Peak. Throughout the lowland the tops of the hills and ridges rise to the same general level in any one locality. This level is an erosion surface or pediment developed during Pleistocene time by the same streams and under essentially the same conditions as now exist. This plain is in places nearly at the same level as the plain on which the lavas were laid down. At the base of Jack in the Pulpit, however, it is approximately 500 feet lower. Since the formation of the plain the streams have cut narrow canyons 10 to 50 feet below the level of the original surface. The canyons are deeper near the hills and decrease in depth to the west.

East of the eastern plateaus is a similar belt of pediment about 8 miles from north to south and about 4 miles wide. The rocks are mostly schists and fine-grained basic intrusives. Near Stouts Well several hills project 100 to 300 feet above the general level, but farther east the pediment has a very smooth upper surface except for the three hills mentioned below. All the streams from the mountains and many of their tributaries have cut valleys below the level of this Pleistocene erosion surface. Thus the pediment is exceedingly rough in detail, though at a distance it appears to be a smooth plain sloping from the mountains to the valley. The eastern edge of the pediment is mantled with alluvium and fades gradually into the Vekol Valley. There are three notable hills which rise above the general level. They owe their height to superior resistance to erosion. The westernmost hill is composed of limestone, which in 
this climate is a very resistant rock. (See p. 56.) The other two hills are formed of horizontal lavas and appear to be remnants of the volcanic rocks that form the high plateaus to the west.

\section{VEKOL MOUNTAINS}

The Vekol Mountains lie east of the Vekol Valley and immediately south of the Little Table Top Mountains. They are an irregular group about 6 miles in diameter. North of the mountains is the Papago ranchería of Bitter Well, and south of them is the similar village of Copperosity. The Vekol mine is on the north side of a broad canyon that indents the western border of this group. The north wall of this canyon begins as a ridge about 200 feet high, which increases in altitude to the southeast. This ridge is composed mainly of limestone that dips about $20^{\circ} \mathrm{SW}$. (See p. 56.) On the north the limestone and the associated quartzite rest on granite of the pre-Cambrian complex. The limestone is a remnant of a widespread series laid down by Paleozoic seas and deformed by faulting. Erosion had removed all but small fragments of the limestone series in forming the surface on which the Tertiary lavas were laid down. It is probable, because limestone is relatively resistant, that this ridge was a considerable eminence at the time of the lava outflows. At present it is a great monocline with a steep northeastern front and a gentle back slope. The total height of the front is about 1,500 feet. The ridge resembles a fault-block range such as the Growler Mountains in form but is in fact a resurrected, not an original feature. East and southeast of the Vekol mine is a group of sharp and irregular peaks, which were not visited and whose structure is not known.

In the open mouth of the canyon, 2 miles southwest of the Vekol mine, is a hill about 500 feet high and a mile in diameter. It is composed of lavas that dip to the southwest and is the only remnant of the faulted and eroded Tertiary volcanic rocks observed.

SHERIDAN MOUNTAINS

The Sheridan Mountains, also called the Cimarron Mountains, are an irregular mass about 8 miles from north to south and 5 miles wide. Several large reentrants mark the borders of the mountains. From a distance the mountains appear to be composed mostly of granitoid rocks. West of the mountains are several outlying hills and small mountains, of which some, at least, seem to be made up of tilted lava beds.

MOUNTAINS WEST OF PIRIGUA

The mountainous area between Perigua and Pozo Redondo extends from Charco de la Lomita north for 15 miles and is about 8 miles 
wide. It is separated from the Pozo Redondo Mountains by the narrow Pozo Redondo Valley and merges into the Batamote Mountains about 10 miles north of Pozo Redondo. On the east is a broad alluvium-filled valley which contains Perigua, Road Runner, Emita, and Toapit. At the north this mountainous area is not sharply separated from the Sauceda Mountains.

The northern part is a group of high, more or less flat-topped plateaus. Along the west side, however, north of Pozo Redondo, there is a ridge with very jagged summits and many conspicuous pinnacles. Red, white, and pink lavas and tuffs crop out as conspicuous bands of color. From Pozo Redondo to Charco de la Piedra the plateaus slope gently southwestward and end in low cliffs along the edge of the plains.

The southeastern part of the mountains is a definite unit. A narrow gap lies between it and the main plateaus. This part of the mountrins in a double-crested ridge about 4 miles long, with a single small ridge as an extension to the southeast. The ridges consist of Tertiary lava beds, which dip gently to the northeast and are evidently uplifted along two parallel faults. One fault lies along the western face, and the other between the two parallel ridges. The underlying crystalline complex is exposed in the small ridge at the extreme southeast end, near Charco de la Lomita.

\section{MoUntains East of phigigua}

East of Perigua is an unnamed group of mountains about 10 miles long. At the north end they are about 8 miles wide and abut directly against the unnamed domal mountain southwest of Kaka. From the northern part they taper to a blunt point at the south end. East of Perigua is a narrow gap through which the road to Kaka passes. Two miles south a second gap is occupied by the road to Pozo Blanco.

'The mountains consist of turreted buttes and small mesas carved from essentially horizontal lavas. Along the western border the crystalline complex is exposed. The mountains are, then, the result of the erosion of a plateau consisting of a plate of Tertiary lava from 500 to 1,000 feet thick, which rests on the crystalline complex. Dissection of the plateau has progressed to the mature or perhaps postmature stage.

\section{MOLNTAIN SOLTHWEST OF KAKA}

About 5 miles southwest of Kaka is a high, rounded mountain not yet named. It is 20 miles southwest of Vekol and 40 miles southeast of Gila Bend. It is a smooth dome 4 miles in diameter and rises about 1,500 feet above the surrounding region. The somber slopes of the mountain are covered with boulders of the underlying lava, 
weathered to a rich brown-black. The surface is marked by very faint and rounded depressions along the drainage lines. No deep canyons were observed. In this singular lack of dissection it is in marked contrast to the ragged peaks on the northwest, to the pinnacles of the Castle Mountains on the east, and to the relatively broad alluvium-filled valleys of the adjacent lava plateaus. The lack of cliffy outcrops is taken to indicate that the surface is in general agreement to the dip of the lavas. This dip appears to be the original dip assumed by the molten lava as it poured from a vent at the center of the mountain. The lack of dissection implies that this volcano was active at a considerably later period than other centers of eruption. Closer study than could be made in the hasty examination on which this description is based may show that volcanic activity continued here into Pleistocene time.

\section{QUIJOTOA MIOUNTAINS}

The Quijotoa Mountains lie between Santa Rosa Valley and Quijotoa Valley. Under some definitions the name Quijotoa includes all the mountains and hills from the depression west of Anegam to South Mountain; in the present treatment only the mountains south of the road between Pozo Blanco and Covered Wells are included. Thus defined the Quijotoa Mountains are about 12 miles long and 6 miles wide and are divided into three main parts. The northerly portion, without specific name, is about 5 miles long and consists of a typical sierra that rises by smooth, rolling brownish slopes to a series of summits on a northwest-southeast line, of which the culminating point is considerably the highest and dominates the rest. In the northern part the rocks are slate, schist, and gneiss. Débris brought down by streams on the west side indicates that the main mountain mass is composed of similar material.

The central portion is Ben Nevis Mountain (p. 352), a high, irregular mass of volcanic rock, which rises by precipitous clifis from the surrounding rolling hills. In a canyon to the south and west of this mountain lie the Weldon mine and on the east the Quijotoa mine, once centers of intense mining activity.

The extreme southern part of the range consists of South Mountain, an oval mass about 3 miles long and 2 miles wide. It rises abruptly from the plains on the west, south, and east sides and is connected to the rest of the mountains by a narrow tongue of rolling hills. (See Pl. XX, B.) The precipitous cliffs rise 1,200 to 1,500 feet in almost vertical walls. Easily visible at a distance are the great sheets of lava from which the mountain is carved. They have a slight inclination to the northeast, and hence the west and south sides of the mountain are slightly steeper than the east. The almost 
horizontal parting and columnar jointing of the lava sheets combine with the purplish red of the rock to make South Mountain a most spectacular landmark, recognizable at great distances and productive of wonder and emotion on closer approach.

On the western flanks of the Quijotoa Mountains are two slightly isolated hills--Black Butte, west of Weldon, and an unnamed hill west of Pozo Blanco. Both are composed largely of lava. The unnamed hill is capped by basalt, and its basal lavas rest on the eroded surface of the crystalline rocks that make up that portion of the mountains. It is evident that these buttes and probably also Ben Nevis and South Mountain are remnants of a more extensive series of lava flows that ance capped the whole range. Since uplift erosion has stripped away all but these remnants and deeply carved the underlying rock so that the method of uplift is uncertain. The somewhat steeper slopes of the eastern face of the range suggest that the last uplift was due to faulting on that side.

\section{SIEARA RLANCA}

The Sierra Blanca is an oval mass about 5 miles from north to south and 4 miles from east to west, lying north of Pozo Blanco. It rises abruptly from the plains on the west and with almost equal abruptness from the rolling country that separates it from the Quijotoa and Brownell mountains. The main mass of the mountain is carved from white and gray granite and granitic gneiss; hence the name, which means " white mountain." The superior resistance to erosion of granite and gneiss over the schist and slate of the adjacent country accounts for the steep and rugged slopes, which are in so marked a contrast to the northern part of the Quijotoa Mountains. It seems probable that this resistance to erosion was effective before the great lava eruptions, and that in consequence the Sierra Blanca was an island in a sea of lava, submerged slightly if at all.

\section{BROWNELL MOUNTAINS}

North of Covered Wells is a group of hills and small mountains that extend northwestward for about 5 miles. On all sides they merge into rolling country, of schist and gneiss on the south and west and of lava on the south and east, near Covered Wells. The hills are residual eminences above the rolling country that is the partial peneplain described in the next paragraph.

\section{NONMOUNTAINOUS UPLAND}

North of Brownell post office is a rolling country with scattered eminences like Lone Mountain and with buttes of volcanic rock on its western border, which extends northward about 10 miles to the 
Sheridan Mountains. This tract is related in its origin to the similar belt of rolling country about 4 miles wide between the Brownell Mountains and the Sierra Blanca, to that along the road between Pozo Blanco and Covered Wells, and to the marginal portion of the Quijotoa Mountains from Pozo Blanco south to Black Butte. In all these areas the rolling countyy has a monotonous and even sky line, broken only by small hills of slight altitude which increase in number near the mountains proper. (See Pl. XV, $O$.) It consists of flat-topped and smooth-topped hills and ridges separated from one another by narrow canyons and arroyos from 10 to 150 feet deep. Near the small canyons the surface is commonly underlain by gravel from 2 to 8 feet thick, but near the center of the hills and ridges rock crops out. The canyons, which are from 10 to 50 feet wide, are deepest near the mountains and become gradually shallower near the junction of the rolling country with the adjacent valley plains.

This rolling country is a dissected pediment, the result of erosion that began with the uplift of the mountains. The lava covering was stripped back and the crystalline complex exposed. Where this series of rocks was most susceptible to erosion the pediment was complete; the more resistant rocks stood out as hills and mountains. Near the Black Prince mine, 21/2 miles north of Pozo Blanco, the crystalline complex included red slate, phyllite, schist, and blocks of crystalline marble, with various basic intrusive rocks. It is obvious that such rocks are rather easily eroded. The pediments in the area between the Sierra Blanca and Brownell Mountains became confluent and formed a partial peneplain, which has since been dissected by the small canyons already noted.

\section{CUBOO HILLS}

Between the Ajo and Mesquite mountains is a group of hills and mesas which, for the purposes of description, will be called the Cubo Hills, after the adjacent Papago village. The hills are divided into four groups by gaps or passes.

The most northerly division is a narrow lava mesa whose northern tip is 5 miles east of Walls Well. The mesa is a little less than half a mile wide and extends in a southeasterly direction $31 / 2$ miles to the gap at Cubo. The lavas of which this mesa is composed dip slightly to the east and northeast, and consequently the western face is slightly higher and steeper than the eastern.

The gap at Cubo is about a mile wide and is dotted with small hills and outcrops of lava rock, especially at the west end. South of the gap is the second division. It is about 4 miles long and more irregular in outline and in height than the first division. It has 
the same northwesterly trend but is offset to the northeast about 1 mile. The lavas of this division have a general though irregular dip to the east, and in consequence the western escarpment is some. what higher than the eastern.

The second division is separated from the third by a narrow gap through which water from Barajita Valley reaches Comovo Valley. The third division begins west of the second division, overlaps it somewhat, and has a trend more nearly due north. This group of mesas is somewhat higher on the west than on the east side and is notable for a very prominent conical hill at the south end. Through the third gap, at the south end of this group, runs the road from Cochibo to Charco Colorado. This gap is very narrow, and the water drains both ways from a divide at about its middle. The fourth and most southeasterly division of the Cubo Hills is about 4 miles long and 2 miles wide. It is a collection of low and irregular mesas of almost horizontal lavas.

The lavas of the Cubo Hills belong to the Tertiary flows and are laid down on the eroded surface of the crystalline complex, as in other parts of the area. In most places the contact is hidden, but in the third gap the crystalline complex is exposed, apparently because of an eminence in the floor over which the lavas flowed and the consequent thinness of the lava cover at this point.

The Cubo Hills are in a broad way parallel to the complex fault blocks of the Ajo and Mesquite mountains. It seems probable, therefore, that the dislocation and tilting of the lava beds that compose these hills may be due to the same faulting. The detail of their boundaries may be ascribed to the great period of erosion that followed the faulting and to the partial burial that has resulted since sedimentation began in the adjoining valleys.

The three gaps, however, are so regularly spaced and are so nearly parallel in direction that they can not be due entirely to erosion. It seems probable that each is the site of a fault. If the offset at the first gap and the overlap at the second are significant, then these faults are younger than the main northwest-southeast faults. For this inference, however, there is no confirmatory evidence. It seems more likely that the faults had no great throw but merely shattered the lavas and made easy the erosion and formation of the gaps.

MESQUTTE MOUNTAINS

The Mesquite Mountains are about 12 miles long and 6 miles wide near the north end, whence they taper to the southeast and end in a very narrow line of hills. The southeastern point is about 6 miles from the international boundary at Camote. On the west they are 
separated from the Cubo Hills by a narrow valley and on the southwest they face La Quituni Valley.

The northern and wider part of the mountains has three prominent peaks separated from one another and from the main mass by rather broad canyons. The most easterly peak is carved from Tertiary lava flows, which are tilted sharply to the east. Other parts of this division of the range are formed of granite and other rocks of the crystalline complex.

The main mass and highest portion, of which the Indian name is Mamatotk, occupies the middle third of the mountains. It is a flattopped, steep-sided mass of lava and tuff. The lava flows have a gentle dip to the northeast, and the cliffs on the west side are therefore somewhat bolder and higher than those on the east.

South of Mamatotk are several small plateaus and ridges, which decrease in width toward the southeast point and are composed of lava beds that lie horizontal or dip northeast.

The Mesquite Mountains appear to be a fault strip whose greatest uplift was at the north end. Here the base of the Tertiary lavas has been exposed, and even at a distance blocks of lava standing at various angles indicate rather complicated faulting. Mamatotk and the ridges south of it appear to be a single wedge-shaped horst slightly more elevated on the west than on the east, also more at the north than at the south, but definite evidence of the faulting, aside from the dip of the beds, was not found.

NARIZ MOUNTAINS

Only the northern part of the Nariz Mountains extends into the United States. This part consists of a high asymmetric ridge about 3 miles long. From the point of this ridge a narrow mesa, Los Cerritos de la Angostura, extends northwestward toward the Ajo Mountains and separates La Quituni Valley from the valley called Bahía de Santa Rosa.

All the rocks exposed are Tertiary lavas, which dip about $20^{\circ} \mathrm{SW}$. in the main ridge. In consequence, the northeast face is a bold escarpment with cliffs of lava and long, boulder-strewn talus slopes. In the low ridge northeast of the main ridge are two gaps. The more southerly is called Angostura, and through it flood water from La Quituni Valley passes to Bahía de Santa Rosa. Menegers Dam is located in this gap. The next gap, the Garambulla, is higher, and through it runs the road.

The Nariz Mountains appear to be part of a tilted fault block uplifted along the northeast side by a fault parallel to those of the Ajo Mountains. No evidence of faulting except the tilting of the lava beds was found. 
The Copeka Mountains are a group of hills about 8 miles long which lie between Comovo and Tonukvo. The most conspicuous peak is a high conical mass about 2 miles in diameter, which rises about 1,000 feet above the adjacent plains. From this peak low hills extend northwestward toward Comovo. The southeastern part of the group is a ridge about 2 miles long, which trends northeast. This ridge is called Chiweton Hill, and the pond of Tonukro at its eastern foot often goes by the same name. Between Chiweton Hill and the rest of the mountains is a narrow pass through which runs an old road from Copeka to Camote.

The main mass and the conical mountain already referred to are formed of coarse-grained granite. Just west of Copeka, however, is a small hill capped with Tertiary lava. Other remnants of the lava beds are doubtless present.

The mountains have been so much eroded since their uplift that practically all the lava capping which they doubtless once had has been destroyed. The general northwesterly trend of the hills is parallel to that of the strike of the lava beds in the small mountains to the northwest and of the similar beds in the Mesquite Mountains. The Copeka Mountains thus appear to be the remnant of a very thoroughly eroded fault block.

LA LESNA MOUNTAINS

La Lesna Mountains form the eastern boundary of The Great Plain. Their north end lies about 5 miles north of the international boundary and 7 miles west of Tecolote. From this point they extend about 20 miles into Mexico. These mountains were not visited. From a distance they appear to be a rather simple fault block of lava beds of Tertiary age. The dip is to the east, and the outcropping edges of the lava beds form a picturesque façade of reddish cliffs on the west side of the mountains.

HHLS SOUTHWEST OF COPEKA MOUNTAINS

Southwest of the Copeka Mountains is a group of hills and small mountains 6 miles long by 3 miles wide, which have a general northwesterly trend. None of the summits rise more than 400 feet above the surrounding plains. The highest points are grouped together toward the west, and separated from them by a flat-bottomed valley are three buttes which lie northeast of Serventi Well.

Certain of these hills appear from a distance to be formed of rocks of the crystalline complex, but the three eastern buttes and several of the western group are formed of lava. The dip is about 
$10^{\circ}$ NE. The hills are obviously part of a fault block, probably not lifted so high as the Copeka Mountains but parallel to them. In a general way this block was parallel to the south end of the Mesquite Mountains. Erosion has destroyed the original form, however, and the deposition of alluvium from the Copeka Mountains and other points north and east has partly buried the hills. The areas between summits which in other mountains of the region are occupied by the rolling country of the dissected mountain pediment are in these hills broad mesquite-covered adobe flats and washes.

VALIEY AREAS

JORNADA DE LAS ESTRELLAS

The Jornada de la Estrellas, or valley between the Sierra Estrella and the Maricopa Mountains, is about 30 miles long and 12 to 13 miles wide. The valley is interrupted by numerous hills, especially south of the Southern Pacific Railroad. North of the railroad the outlying hills or small mountains seem to be parts of the Maricopa Mountains, to which they are joined by a mountain pediment.

The valley is drained by Waterman Wash, which receives the flood waters of Vekol Valley, is crossed by the railroad in a broad flat with numerous small channels, and then gains a definite channel about 100 feet wide and leads north. to Gila River near Buckeye. The channel of Waterman Wash has a floor of coarse sand, and neither the axial stream nor its tributaries carry débris over 6 inches in diameter. If conditions similar to those of the present existed during the filling of the valley the bulk of the alluvium is relatively fine grained. The new Southern Pacific Well at Mobile bears out this conclusion, as no very coarse beds were encountered in it.

Log of Southern Pacifie Well at Mobile

\begin{tabular}{|c|c|c|}
\hline & Thickness & Depth \\
\hline $\begin{array}{l}\text { Sandy clay mixed with gravel. } \\
\text { "Rock" } \\
\text { Cemented clay and gravel } \\
\text { "Rock" } \\
\text { Clay and gravel- } \\
\text { Sand and gravel, water bearing }\end{array}$ & $\begin{array}{r}\text { Feet } \\
\mathbf{2 3 0} \\
40 \\
60 \\
61 \\
30 \\
\mathbf{3 0}\end{array}$ & $\begin{array}{r}\text { Feet } \\
230 \\
270 \\
330 \\
391 \\
421 \\
451\end{array}$ \\
\hline
\end{tabular}

Note.-Drilled July 1 to Sept. 8, 1918; casing 115 inches in diameter, perforated in lower 40 feet with half-inch drilled holes. Water stands at 400 feet from the surface.

VEKOL VALLEY

The Vekol Valley lies west of the Vekol and Table Top mountains and east of the Sand Tank Mountains. The south end is closed by the small hills and mountains east of Kaka, but the north end merges into the valley to the north, called Jornada de las Estrellas. 
The valley is from 5 to 6 miles wide. The valley floor consists in the southern part of two grassy flats and in the northern part of a narrow flood plain along the main stream. (See p. 114.) These peculiarities and the great width of the adjoining mountain pediments, especially east of the Sand Tank Mountains, are unusual among valleys of the Papago country.

\section{PERIGUA VALLEX}

The Perigua Valley is about 5 miles wide and 17 miles long. The northern boundary is made up of ragged hills and sharp peaks which form the transition between the Sauceda and Sand Tank mountains. High plateaus of Tertiary lava bound it on the east and west, and it opens into the plains of the Quijotoa Valley on the south.

The axial stream has no definite channel but follows a succession of broad adobe flats. The alluvial slopes from the mountains on either side have gentle grades and merge very gradually into the central flats. The many smooth flats and the absence of channels make the floor of the valley suitable for flood-water farming, and the open groves of mesquite trees are interrupted by clearings of modern and abandoned fields.

The hill at Perigua and other hills in the floor of the valley indicate that the rock floor is not everywhere deep and that wells may show that the alluvium is of only moderate depth.

POZO REDONDO VALLEY

The Pozo Redondo Valley is about 14 miles long and from 1 to 4 miles wide. It lies between the Batamote and Pozo Redondo mountains on the west and the mountains west of Perigua on the east. North of the gap between the Pozo Redondo and Batamote mountains the valley floor is interrupted by hills and in part is a dissected pediment developed on crystalline rocks. South of the gap the valley floor is covered with alluvium deposited by an axial stream that flows north and drains through the gap into the Valley of the Ajo. The thickness of the alluvium is not known, but a small hill of lava along the stream a mile north of Pozo Redondo indicates that the floor is, in part at least, formed of lava.

QUIJOTOA VALLEY

The Quijoton Valley lies east of the Cubo and Gunsight hills, south of the mountains bordering Perigua Valley, west of the Sierra Blanca and Quijotoa Mountains, and north of the Copeka and Mesquite mountains. It is one of the largest areas of plains in the Papago country, being roughly 20 miles in diameter. The drainage from Perigua Valley unites with that from the valley north of the Gunsight 
Hills, and a third tributary is received from the plains northwest of the Sierra Blanca. This constitutes the main drainage line of the valley, which runs to Comovo and receives numerous tributaries from either side, as well as the stream that passes Copeka and joins the main stream north of Comovo (p. 103). In spite of the large tributary area, the main stream has no definite channel but spreads over a series of adobe flats marked by small channels only. The center of the valley is in consequence a very smooth plain which slopes about 10 feet to the mile from the north toward Comovo and from Copeka to Hardimui. Parts of this central plain are covered with a veneer of wind-blown sand, usually not over 2 feet thick. The alluvial slopes are narrow. The widest and steepest alluvial fans with coarsest deposits are opposite the highest of the bordering mountains, as along the west side of the Quijotoa Mountains. Small ranges and hills form most of the border of the valley, and consequently the alluvial slopes are in general notably lower and narrower than in other valleys.

BARAJITA VAIIEY

The Barajita Valley is 13 miles long and 4 miles wide and lies between the Ajo Mountains and the parallel Cubo Hills. The slopes of the valley are dominated by the streams that flow eastward from the Ajo Mountains, and the floor slopes east to a depression marked by adobe flats parallel to the Cubo Hills. Here the streams have gentle grades and carry only sand and clay. The flood waters of this valley drain through four water gaps. The northern part of the valley drains west through a gap between the north end of the Ajo Mountains and an outlying conical hill south of Walls Well, the central part through two gaps in the Cubo Hills, and the southern part through the gap between the south end of the Cubo Hills and the Ajo Mountains. The first three streams show simple aggradation only, but the last, with its tributaries, is intrenched from 5 to 20 feet below the alluvial floor and becomes an aggrading stream only on issuing into La Quituni Valley.

The Barajita Valley seems to be wholly structural in origin, lying between the highly tilted block of the Ajo Mountains and the slightly tilted parallel block of the Cubo Hills. The lavas of the two ranges are doubtless part of a once continuous sheet. If the dip of the lavas in the Ajo Mountains were prolonged to meet the fault plane presumed to exist along the west side of the Cubo Hills, the structural depression would be more than 2,000 feet deep, which may be taken as a measure of the possible depth of alluvial fill.

COMOVO VALLEY

The Comovo Valley is a roughly triangular area about 10 miles long which tapers from a width of 4 miles near Comovo to an in- 
considerable width at the south end of the Mesquite Mountains, about 10 miles to the south. It is a southern prolongation of the Quijotoa Valley between the Mesquite and Copeka mountains, and through this prolongation the drainage of the larger valley goes into The Great Plain. The alluvial slopes converge toward the axis of the valley, through which there is a narrow adobe flat as far south as Mesquite Charcos. South of this point the stream has a welldefined channel and is flanked directly by alluvial slopes.

LA QUITUNI VAMLEX

La Quituni Valley lies southwest of the Mesquite Mountains, south and southeast of the Cubo Hills and Ajo Mountains, and north of the Nariz Mountains. It is separated from The Great Plain merely by a low divide of alluvium and from the Bahía de Santa Rosa, which lies mostly in Mexico, by a low ridge, the Cerritos de la Angostura. The valley is an irregularly shaped area about 10 miles from north to south and about 6 miles from east to west. The valley drains through the gap at Angostura by means of numerous ephemeral streams arranged like the ribs of a fan. The principal streams come from the gap at the south end of the Cubo Hills and from the gap east of the hills and form in the valley extensive adobe flats, which constitute the reason for the ranchería of La Quituni (p. 412). The eastern part of the valley is mantled by a thin layer of wind-blown sand.

\section{THE GREAT PLAIN}

The Great Plain is an irregular area west of La Lesna Mountains and south of the Mesquite Mountains and the hills southwest of the Copeka Mountains. The plain slopes gently to Sonoita River, which lies in Mexico a few miles south of and parallel to the international boundary. The streams that come into the plain from Comovo Valley and from the vicinity of Serventi Well carry the drainage from a vast territory. They are, however, strictly aggrading streams and flow through adobe flats with very indefinite channels. $A$ thin layer of wind-blown sand covers large areas. Near the bourdary the sand is deep and lies in low dunes 5 to 20 feet high.

\section{GROUND-WATER RESOURCES}

The ground-water resources of the central portion of the Papagu country have not been developed. Nowhere in this portion is it likely that supplies sufficient for irrigation can be obtained, but wells for watering stock or for domestic supply in the vicinity of temporales will be successful. 
In the part of the Jornada de las Estrellas north of the railroad W. P. Beloat put down a number of wells in 1910 and 1912 for watering stock. (See Pl. VI.)

Data on wells of W.P. Beloat in Jornada de las Estrellas

[Collected by C. P. Ross]

\begin{tabular}{|c|c|c|c|c|c|c|c|}
\hline \multicolumn{3}{|c|}{ Location } & \multicolumn{3}{|c|}{ Well } & \multicolumn{2}{|c|}{ Equipment } \\
\hline Section & $\begin{array}{l}\text { Town- } \\
\text { ship }\end{array}$ & Range & Diameter & Depth & $\begin{array}{l}\text { Depth to } \\
\text { water }\end{array}$ & $\begin{array}{l}\text { Size of } \\
\text { cylinder }\end{array}$ & Engine \\
\hline $\begin{array}{r}14 \\
30 \\
9\end{array}$ & $\begin{array}{l}2 \mathrm{~s} . \\
2 \mathrm{~s} . \\
3 \mathrm{~S} . \\
2 \mathrm{~s} .\end{array}$ & 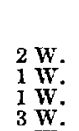 & $\begin{array}{c}\text { Inches } \\
6 \\
6 \\
6 \\
4\end{array}$ & $\begin{array}{r}\text { Feet } \\
260 \\
260 \\
325 \\
101\end{array}$ & $\begin{array}{c}\text { Feet } \\
175 \\
165 \\
260 ? \\
86\end{array}$ & $\begin{array}{c}\text { Inches } \\
23 / 4 \\
3 \\
3\end{array}$ & $\begin{array}{c}\text { Horse- } \\
\text { power } \\
21 / 2 \\
6 \\
4\end{array}$ \\
\hline & & & & 264 & & & \\
\hline
\end{tabular}

Three of these wells successfully supply the small pumps with which they are equipped. At the place known as the Beloat ranch, in sec. 9, T. 3 S., R. 1 W., a second well 265 feet deep was dry. Two wells 101 and 264 feet deep had so little water that they were considered unsuccessful. It is evident that in this valley there is a deep water table that gradually increases in depth below the surface from Gila River southeast to Mobile, where the depth to water in the railroad well is 400 feet (p. 236). Large quantities of water probably can not be obtained, because of the generally fine-grained and compact valley fill. The existing wells, supplemented by suitably placed represos and by shallow wells dug in the crystalline rocks at the borders of the adjacent mountains, should form an adequate water supply for all the cattle the range will support.

The large areas of pediment in the Sand Tank Mountains are suitable for cattle raising, but the rocky surface is hard on the feet of cows, and watering places must be close together. Mesquite Tank, originally a rock tank and seep at the foot of falls in lava, has been developed into a well. The Zona or Jitney mine, 4 miles southwest of Mesquite Tank, is now used as a well. The Sand Tanks are used for watering cattle that are driven from Stouts Well to Gila Bend. A well has been dug 200 yards west of the original tanks. It is 75 feet deep and has water at 60 feet. Numerous wells could be dug in the basin between the northwestern and eastern plateaus and a faur percentage of them would be successful. Stouts Well (see p. 169) is dug in the crystalline rocks of the pediment east of the mountains. It was dry for a time in May, 1920, but commands the range along the lower slopes of the mountains and the western part of the pediment. The dry well 9 miles to the southeast is dug 40 feet deep near the edge of the grassy flat of Vekol Valley. Here, as in other valleys, 
a deep well would probably obtain water. Two such wells, one in the southern grass flat and another near the water hole in the narrow flood plain of the northern part of the valley, would make available the exceptionally good grazing of the central part of the valley. The depth at which water would be obtained, however, can not be predicted.

Along the road between Maricopa and Covered Wells, in the pass through the mountains north of Antelope Peak, there is a good well site. Near the water hole lavas interbedded with conglomerates dip gently westward. A well west of the water hole should obtain water in these rocks.

The Indian population that centers at Sauceda and Moivavi depends for permanent water on dug wells at these places. That at Moivavi is 32 feet deep and 4 feet to water, and that at Sauceda 18 feet deep and 6 feet to water. Deep-drilled wells at the fields of Kaka or in Perigua Valley would almost certainly encounter lava and should obtain sufficient supplies of water. Such wells would make migration unnecessary for these people and increase the number of cattle they could keep.

The dug well at Pozo Redondo, 76 feet deep and 37 feet to water, commands most of the range in the valley within the Papago Indian Reservation. The supply is inadequate, however, and a new well was being dug near by in 1917. The arm of the Quijotoa Valley north of the Gunsight Hills is largely occupied by the strip of land between the two parts of the Indian reservation and is open to settlement. The western part of this range is controlled by the well at Gunsight ranch (p. 181). Deep wells would be necessary to develop water.

In the Gunsight Hills enlargement of the represo at Charco en Medio and the digging of well in the crystalline rocks or in the patches of lava and conglomerate, like the well 2 miles west of Charco en Medio, will enable all the range to be used.

The shallow dug wells at Barajita and Cochibo water cattle which graze largely in the Barajita Valley. One or two more similar wells will probably supply all the cattle the valley can support. The summer ranchería of Cubo was in 1917 without permanent water. A deep well drilled into the underlying lavas here should be successful.

The extensive pediments that surround the Quijotoa Mountains and lie between these mountains and the Sierra Blanca and Brownell Mountains are suitable grazing areas and offer numerous sites for dug wells in rock. Fortunately the region has seen much mining activity, and prospectors have dug many wells. There are six dug wells between San Antone and Weldon; two wells at Black Butte, 117 and 62 feet deep; a well at Horseshoe; one at Brownell; four at Covered Wells; a small well at Spear's store; and one well in the village at Pozo Blanco and two others near by. Although per- 
haps only one in three of the wells dug into rock in the pediments of the Papago country is a good well, with a water supply for more than 50 head of cattle, the large number of wells in this area is a demonstration that wells will eventually be obtained sufficient for all the cattle the area can support.

No wells have been dug in the extensive plains of the Quijotoa Valley except the Stanley Well, northwest of the Sierra Blanca. This well was being deepened in 1917. The numerous summer rancherías and extensive groves of mesquite with abundant beans make a permanent water supply most desirable for the Indian population. Deep wells will probably obtain sufficient water.

The Comovo Valley is probably underlain by the lavas that dip toward it in the Mesquite Mountains. The depth of the alluvium is uncertain, but deep wells would probably obtain water from the alluvium and certainly from the underlying lava.

Serventi Well, in the northern part of The Great Plain, is 420 feet deep and has water at a depth of 190 feet. The temperature is reported to be $135^{\circ}$, and the well is said to penetrate lava. Lava crops out in a small hill a mile to the north. This well commands a wide area of very good grazing land and in conjunction with several represos similar to that at Camote would be adequate for all the cattle the area can support.

With the completion of Menegers Dam La Quituni Valley will have a sufficient supply of water for stock, but wells will be necessary to furnish water for domestic purposes. As in other valleys, deep wells should be successful here, and dug wells should obtain water in the crystalline rocks that form the narrow pediment along the south- . west side of the Mesquite Mountains.

\section{EAST-CENTRAL PORTION}

\section{LOCATION, TOPOGRAPHY, AND GEOLOGY}

The east-central portion of the Papago country consists of the area east of the Quijotoa and La Lesna mountains and west of the Baboquivari and Silver Bell mountains. Within this area Indian Oasis, with a mean annual precipitation of 13.35 inches, is the only rainfall station, but this record covers only a few years of relatively large rainfall. Probably the rainfall for the area does not greatly exceed that of the two sections immediately west except in the higher parts of the Baboquivari Mountains and in the south end of the Baboquivari Valley, where the general altitude of the plains is about 2,500 feet.

The region contains Casa Grande Mountain, the Silver Reef Mountains, mountains west of Cocklebur, the Sawtooth, Slate, Silver Bell, Waterman, and Roskruge mountains, Dobbs Butte and associated 
hills, Santa Rosa Mountains, Vaca Hills, North and South Comobabi, Cobabi, Artesa, and Alvarez mountains, Las Animas Hills, Sierra de Moreno, Coyote, Quinlan, and Baboquivari mountains.

The valleys are Santa Cruz Valley (Casa Grande section), which bounds the region on the north, the valley south of Cocklebur, Santa Rosa Valley, the valley north of the Baboquivari Mountains, the Baboquivari Valley, the plains west of Indian Oasis, and Tecolote Valley.

\section{MOUNTAINOUS AREAS \\ CASA GRANDE MOUNTAIN}

Casa Grande Mountain, also called Arizola Mountain, is a small but compact range 3 miles southeast of the town of Casa Grande. The range is about 3 miles long and 2 miles wide in the widest part. It rises abruptly about 1,000 feet above the smooth Santa Cruz flood plain to an altitude of 1,450 feet.

SILVER REEF MOUNTAINS

The Silver Reef Mountains are a small group of more or less detached hills and small mountains that begin about 9 miles southwest of Casa Grande Mountain. If all the mountains between Chiu Chuschu and Jackrabbit are included under this name, the belt of hills has an extension of 10 miles in a southwesterly direction. There are at least two passes through the hills.

MOUNTAINS WEST OF COCKLEBTR

The mountains west of Cocklebur are a small detached group about 6 miles long and 3 to 4 miles wide. They rise between 800 and 900 feet above the surrounding plain.

SLATE MOUNTAINS

The Slate Mountains, also called Sierra Prieta, are a range 8 miles long with a maximum width of 5 miles. The range has a distinct trend slightly east of north. The highest summit has an altitude of 3,300 feet, which is about 1,600 feet above the plains at the foot of the mountains.

SAWTOOTH MOUNTAINS

The Sawtooth Mountains are a small group of more or less scattered hills about 4 miles from north' to south. The highest point has an altitude of 2,600 feet, which is about 1,000 feet above the adjacent plains.

SILVER BELI MOt'NTAINS

The Silver Bell Mountains are a small range about 7 miles long, with northwest trend. They lie southwest of the town of Silver Bell. 
The highest point is about 4,000 feet above sea level, or 1,500 feet above the adjacent plains. Small more or less scattered hills extend 10 miles northwest of the town, and similar hills the same distance northeast to Sasco, where the largest clump is named the Samaniego Hills. Near Silver Bell the mountains consist of Mesozoic intrusive rocks of granitic type, and southeast of the town there are considerable areas of Paleozoic limestone and quartzite, ${ }^{50}$ which belong to a thick series of supposed Carboniferous age ( $p .55)$.

WATERMAN MOUNTAINS

The Waterman Mountains are a small group of more or less detached hills southeast of the Silver Bell Mountains. They rise perhaps 800 feet above the surrounding plains.

ROSKRUGE MOUNTAINS

The Roskruge Mountains are a group of more or less detached hills which lie in a northwest-southeast line about 10 miles long between the Waterman Mountains and the hills north of Dobbs Butte.

DOBRS BUTTE AND ASSOCIATED HILLS

Dobbs Butte is a high and prominent hill northeast of Coyote Mountain, on the southern edge of a group of hills about 7 miles from east to west and about 10 miles from north to south, which lie south of the Roskruge Mountains. Dobbs Butte is composed of lava beds having a slight dip to the east. The lava weathers to a brownblack. Two miles to the west is a butte almost as high, which, because of its gay coloring, may be called Variegated Butte. This butte is composed of lava and tuff, which dip to the southeast. Red, pink, white, and yellow bands of color mark the position of the various beds. The hills north and east of these buttes are composed of lavas tilted at various angles. Some hills show the bright colors of Variegated Butte, but most of them are a dull brown, like Dobbs Butte. This group of hills is a complexly faulted region, as shown by the various dips observed. In addition erosion has obscured the structure and complicated the topography.

SANTA ROSA MIOUNTAINS

The Santa Rosa Mountains are a detached range lying south of the Slate Mountains. The range is about 10 miles long and not over 5 miles wide and has a trend slightly west of north. The highest point has an altitude of 4,500 feet and rises about 2,500 feet above the adjacent plains.

so Stewart, C. A., The geology and ore deposits of the Silver Bell mining district, Arizona : Am. Inst. Min. Eng. Trans., vol. 43, pp. 24-290, 1913. 
The Vaca Hills are a detached group of small hills lying southeast of the Santa Rosa Mountains and northeast of the Comobabi Mountains. The highest point rises to an altitude of about 3,700 feet, which is about 1,000 feet above the adjacent plains.

\section{COMÓBABI MOUNTAINS}

The Comobabi Mountains are divided into two parts by a broad pass of rolling hills. The North Comobabi Mountains form a rather irregular sierra, trending northwest, about 10 miles long and 3 to 4 miles broad. The highest point rises about 2.000 feet above the adjacent plains. The South Comobabi Mountains are a shapeless mass of peaks and ridges about 7 miles in diameter. The highest points rise about 1,500 feet above the base of the mountains. In both parts of the mountains the bare brown slopes have the soft outlines characteristic of the erosion of the less resistant gneiss and schist of the crystalline complex, and the foot of the mountains and the pass between the two parts is a sloping plain underlain by rock and now scored by narrow gullies and small canyons. No remnants of the Tertiary volcanic rocks were seen, but their presence in the Cobabi Mountains, a few miles to the west, and in numerous buttes in the valley east of the Comobabi Mountains indicates that this region was not wholly free from the floods of Tertiary lava. Tilted conglomerate occupies a large area in the pass (p. 60.) The South Comobabi Mountains have a relatively even sky line, and it is possible that their higher summits are remnants of the somewhat irregular erosion surface which elsewhere underlies the lavas. Under such a hypothesis it would be assumed that the lava capping has been stripped away since the uplift of the mountains.

\section{COBABI MOUNTAINS}

The Cobabi Mountains lie west of the South Comobabi Mountains and about 10 miles north of Indian Oasis. They are ragged hills about 500 feet high and 3 miles in diameter, and south of them are a series of buttes and ragged hills about 5 miles long. The Cobabi Mountains and associated hills are separated from the South Comobabi Mountains by a lowland 2 to 3 miles wide, which slopes westward from the foot of the South Comobabi Mountains. In this lowland are the Papago villages of Nolic and Wickchoupai and the Picacho mine.

The Cobabi Mountains were seen only at a distance. They have the ragged summits and palisaded cliffs characteristic of the erosion of the Tertiary lavas. The hills to the south are carved from the same rocks. The mountains and associated hills appear to be the 
thoroughly dissected summit of a complex fault block or group of fault blocks which had an intermediate altitude between the high block of the South Comobabi Mountains and the much lower block that presumably underlies the valley to the west.

ARTESA MOUNTAINS

The Artesa Mountains are a group of hills 6 miles in diameter between Indian Oasis and Topahua. In their northern portion they consist of ragged mesas, peaks, and ridges, the escarpments of which in general face north. The rocks are lava flows, presumably of Tertiary age. In general the dip is horizontal or inclined to the south. It is probable that the Artesa Mountains are the upper portion of one of the blocks of a fault complex that underlies the surrounding plains.

ALVAREZ MOUNTAINS

The Alvarez Mountains are a clump of hills about 6 miles from north to south and 4 miles from east to west, lying southwest of the Artesa Mountains. The highest points rise to an altitude of about 2,900 feet, which is about 600 feet above the adjacent plains. In general, their topography is similar to that of the Artesa Mountains.

LAS ANIMAS HIIIS

An isolated clump of hills about 7 miles south of the Artesa Mountains is known as Las Animas Hills. They are about 2 miles long and a mile wide. The highest altitude is about 3,000 feet, which is about 600 feet above the adjacent plains.

\section{SIERRA DE MIORENO}

The Sierra de Moreno projects only a short distance into the United States. The range is bold and precipitou's and rises to an altitude of 4,200 feet, which is 1,400 feet above the adjacent plains.

COYOTE MOUNTAINS

The Coyote Mountains are an eastern extension of the Quinlan Mountains, which form the north end of the Baboquivari Mountains. Two broad canyons and a pass through relatively low hills divide the two ranges. From north to south the Coyote Mountains are 6 miles long. The width is $41 / 2$ miles near the south end.

The mountains are composed of banded granite gneiss of a prevailing white or light-gray color. Parallel to the banding is a system of joints or fracture planes which divide the rock into layers from 2 to 10 feet in thickness. There are less perfect joints at right angles to this master system. The banding and the master joint 
system dip to the east. The eastern slopes of the mountains are more or less parallel to the dip of the master joint system; the western slopes to the cross fracture. Consequently the crest of the mountains lies about a mile from the western boundary and about 3 miles from the eastern. The Coyote Mountains have in a rude but unmistakable fashion the general form of a monocline of sedimentary rock.

\section{BABOQUIVARI MOUNTAINS}

The Baboquivari Mountains are the longest range in the Papago country. The range trends north and south and extends south from Coyote village 30 miles to Prescimido Pass. From this pass southward the mountains are lower and merge into the Palo Verde Mountains of Mexico. In width the mountains range from 4 to 10 miles, and the crest line is very continuous and has an altitude of 5,500 to 6,500 feet. The highest point in the region, the square tower of Baboquivari Peak, 7,740 feet above sea level, ${ }^{\text {,1 }}$ is the culminating point of this crest line. The north end of the mountains is paricularly wide, is marked by precipitous slopes, and often goes under the name Quinlan Mountains.

In spite of their great altitude, the mountains are not forested. The typical desert flora of palo verde, mesquite, and ironwood is, however, replaced at higher levels by clumps of evergreen oaks and other shrubs indicating a slight increase in precipitation. Cottonwood, sycamore, ash, and cumaru trees, as solitary individuals or small groves, are found around springs on the flanks of the mountains. Greater altitude with accompanying increased cold eliminates palo fierro and sahuaro from the east side of the mountains. At the north end palo fierro occurs in scattered clumps where conditions of air drainage are good.

The Baboquivari Mountains are composed of rocks of the crystalline complex. The characteristics of the mountain slopes vary with the nature of the rock. The north end of the range, composed of granite and granitic gneiss, is high, precipitous, and rough. Farther south less resistant gneiss and schist produce smoother slopes with lower grades. The striking summits are due to massive outcrops of fine-grained intrusive rocks. Many of these are porphyritic felsites which seem to be unmetamorphosed. They appear to be the hardened plugs of volcanoes and may be of Tertiary age. Baboquivari Peak and the near-by Mount Mildred are carved from such rock.

The northern and western borders of the Baboquivari Mountains have well-developed pediments from $11 / 2$ to 3 miles wide. The pediments extend into the mountains in deep coves and reentrants

51 Map of southern Arizona, showing Indian villages and reservations, $U$. S. Indian Service, Irrigation Division, 1915. 
along the courses of the major mountain canyons. Such a reentrant is the cove at Babokuk, which is 2 miles long and 11/2 miles wide at the mouth (fig. 12). A number of small hills project above the pediments, but in general the slope is regular and smooth from the mountain front to the alluvial plains. The streams, where they cross the pediments, are incised in small canyons, as in other mountains.

Near Fresnal are numerous hills that rise above the level of the pediments, and certain of them are long, smooth-topped ridges between streams (fig. 13). The ridges slope downstream and seem to represent an older and higher pediment of which only small remnants remain.

The eastern border of the mountains is likewise sinuous, and the mountain slopes join sharply the plains at their foot. In a few places along the northern part of the range the pediment is exposed. In general, however, alluvium covers the pediment (p. 109). South of Baboquivari Peak the pediment is from half a mile to 3 miles wide, and on the divide south of Buenos Aires it extends across the valley and is continuous with the pediment of the mountains east of Altar Valley (p. 251). South of the divide, toward Sasabe and San Fernando, the pediment is extensive and covered with level, thin patches of alluvium. (See Pl. XV, B.) It is dissected by the tributaries of Altar River, of which the largest passes through Las Moras and San Fernando. Near San Fernando the valley of this stream is about 40 feet deep, and west of the settlement it expands in a broad flat. At San Fernando it passes through a narrow canyon, which is a proposed dam site.

VALLEY AREAS

SANTA CRUZ VALIEY (CASA GRANDE SECTION)

The Santa Cruz Valley from the vicinity of Picacho south has already been described (p. 110 and figs. 16-19). Thence smooth alluvial slopes lead down to the Santa Cruz flood plains from all the country to the south.

\section{VAIIEY SOUTH OF COCKLEBUR}

Cocklebur lies between the Silver Reef Mountains and the unnamed mountains to the west. South of the town is a valley about 6 miles wide, which receives the drainage from Santa Rosa Valley. A wide alluvial slope opens to the west north of the Vekol Mountains and through the gap north of the Slate Mountains. A valley in which there is a considerable alluvial fill east of the Slate and Silver Reef mountains discharges its flood waters into this valley. 
Santa Rosa Valley is about 40 miles long and about 10 miles wide. It trends north, between the Quijotoa, Brownell, and Sheridan mountains on the west and the Comobabi, Cobabi, Santa Rosa, and Slate mountains on the east. The northern two-thirds of the valley drains north through Kukomalik to Cocklebur. The southern part drains south around the south end of the Quijotoa Mountains into the Quijotoa Valley. The divide is a broad flat near which is the temporal called Sikulhimatk.

VALLEY NORTH OF BABOQTIVARI MOUNMANS

North of the Baboquivari Mountains and between the Roskruge, Waterman, and Silver Bell mountains on the east and the Comobabi and Santa Rosa mountains on the west is a broad plain 30 miles from north to south and about 20 miles wide. A number of small buttes and hills dot the plain, but the greater part is covered with alluvium. The edges drain south to the Baboquivari Valley, west into the Santa Rosa Valley, and north to the vicinity of Green's reservoir, but the greater part drains northeast into Altar Valley.

BABOQUTVARI VALLEY

The Baboquivari Valley lies on the west side of the mountains of the same name and is about 30 miles long. In a general way the Sierra de Moreno and the Alvarez and Artesa mountains form the western boundary. The west side of the Baboquivari Mountains has an extensive pediment from 1 to 5 miles wide. West of the pediment the alluvial plains slope gently westward. So much more débris comes from the Baboquivari Mountains than from the smaller ranges that the outward sweep of this alluvium controls the slope, which extends westward without a corresponding slope from the mountains on the west, except from the Sierra de Moreno and the South Comobabi Mountains. The streams on passing from the pediment to the alluvial slope lose their dissecting habit and form extensive adobe flats, which, with the resulting flood-water fields, are characteristic of the floor of the valley.

PLAINS WEST OF INDIAN OASIS

The plains west of Indian Oasis occupy an indefinite area west of the Artesa Mountains and south of the Quijotoa Mountains. They are compound alluvial slopes built up on average grades of less than 25 feet to the mile by the stream that drains the southern part of the Santa Rosa Valley, the stream that drains the northern part of the Baboquivari Valley and flows west through Indian Oasis, and Valshni Wash, which flows northward from the vicinity of Kavolik. 
The sediment carried by these streams ranges from fine mud to fine gravel, and the plains consist of alluvial fans, some with vague channel ridges (see p. 145 and fig. 34), and an extensive adobe flat. Near Copeka and Tonukvo, at the east end of the Copeka Mountains, there is a veneer of wind-blown sand.

TECOLOTE VALLEY

The Tecolote Valley is a more or less circular area about 10 miles in diameter between the Alvarez and La Lesna mountains. The drainage from the cove between La Lesna and the Sierra de Cobota in Mexico flows north through the valley and northwest into The Great Plain. The streams in the Tecolote Valley are aggrading and carry fine sediment on low gradients. There are extensive adobe flats and many flood-water fields.

\section{GROUND-WATER RESOURCES}

The ground-water resources of the east-central portion of the Papago country are partly developed. There are numerous dug wells in the mountains and a comparatively large number of deep drilled wells in the valleys. The deep wells are listed on page 185, and logs are given for most of those recently drilled on pages 17\%179.

In the Casa Grande Valley wells of large yield suitable for irrigation are obtained with pumping lifts of 40 to 60 feet. The well problems of this valley are outside the scope of this report. On the plains that rise toward the Silver Reef Mountains wells suitable for stock-watering places can be obtained, as shown by the well at ChiuChuschu, which, however, has a large enough yield for irrigation.

In the villages to the south drilled wells have been almost uniformly successful in obtaining water. The water is deep, however, and the yield of the wells is small. The conditions are set forth in detail on pages $186-187$.

The existing wells of the area supplemented by a few new wells located at strategic points will provide for all the cattle the range will support and for the needs of the Indian population. The activity of the Indian Service has already solved most of the problems of water supply, and complete development depends only on the increasing ability of the Indians to use modern methods and on adequate appropriations.

In this part of the Papago country the areas available for settlement by whites lie in the vicinity of the Santa Cruz Valley, where, as stated in a previous paragraph, stock water can be obtained at reasonable depths, and in the valley north of the Baboquivari Mountains. The latter area is occupied by the West Coast Cattle Co.

Near the Baboquivari Mountains water is obtainable by dug wells in rock, such as Dobbs Well (p. 169), and in alluvium and rock, such 
as Haynes Well, now caved. In 1919 a well was dug at San Vicente which is 75 feet deep in alluvium and does not penetrate rock. It supplies a windmill.

In the valley to the north water is obtained with deep wells, as at the Santa Rosa ranch and at Aguirre. These wells, supplemented by represos, such as that at Compartidero, are probably ample to furnish water for stock.

\section{EASTERN PORTION}

\section{IOCATION, TOPOGRAPHY, AND GEOLOGY}

The eastern portion of the Papago country consists of the area east of the Baboquivari and Silver Bell mountains.

The plains in the southern part of this area stand at altitudes of 3,000 to 3,500 feet and consequently have a somewhat greater rainfall than other parts of the Papago country. The mean annual rainfall in the Santa Cruz Valley decreases from south to north, being 14.15 inches at Nogales, 11.85 inches at Tucson, and 6.57 inches at Casa Grande. The station at the Ronstadt ranch, in the Altar Valley, has a mean of $\mathbf{1 7 . 6 5}$ inches for an incomplete five-year record.

The area contains the Tumacacori Mountains, which consist of several more or less independent units, and the Cerro Colorado, Sierrita, and Tucson mountains. The valleys are the Altar, Abra, and Santa Cruz valleys; the last includes the valley of Nogales Wash.

MOUNTATNOUS AREAS

TUMACACORI MOUNTAINS

The Tumacacori Mountains are a complex group consisting of several more or less independent units and not sharply separated from the Sierra del Pajarito in Sonora. North of the international boundary the mountain area is about 25 miles from east to west and 20 miles from north to south.

The eastern portion consists of a ridge with a definite northerly trend, which rises about 1,000 feet above the dissected slopes that border the valleys of Santa Cruz River and Nogales Wash. Atascosa, Sardina, and Diablito mountains are well-defined summits on this ridge. Atascosa Mountain is the highest point in the area, having an altitude of about 6,500 feet. Through this ridge there are a number of practicable passes. West of the eastern ridge is a tangled mass of mountains drained by deep canyons that lead north to Arivaca Creek and south into the headwaters of Altar River. In a general way the summits reach a general level except for Chiminea Mountain, Bartolo Mountain, Montana Peak, and Fraquita Peak, which rise 250 to 500 feet higher in flat, cliff-encircled summits. 
With the exception of these cliffs, the slopes of this part of the mountains are smooth and soil covered, with a good growth of grass and scattering oak trees. The deep soils are developed principally on tuffs, which form the tops of the mountains. In the canyons crystalline rocks and a great series of arkosic sandstones are exposed (see p. 57), and the slopes are steeper and more broken. West of Coches Ridge the irregular clump of hills sometimes called the San Luis Mountains are bare and rocky.

North of the mountains just described is a great area of dissected pediment, which forms the headwater basin of Arivaca and Sopori creeks (p. 89 and Pl. XV, $A$ ). The spirelike summits of the Cerro Colorado Mountains close in this basin on the north. On the west the mountains southwest of Arivaca Creek and the Guijas Mountains north of the creek shut off the basin from Altar Valley. These small mountains are composed largely of crystalline rocks and have a well-defined northwest trend. This trend in the Guijas Mountains is probably of structural origin, for Guijas Wash follows a fault line that separates Tertiary volcanic rocks from the crystalline complex on the southwest. ${ }^{22}$

\section{CERRO COLORADO MOUNTAINS}

The Cerro Colorado Mountains are an irregular clump of reddish peaks about 5 miles in diameter. The peaks rise from a conical platform of sloping plains, which are presumably pediments. These mountains are thought to be made up chiefly of Tertiary volcanic rocks.

SIERRTTA MOUNTAINS

The Sierrita Mountains consist of a roughly circular area of mountainous country about 7 miles in diameter. Adjacent to this area of the sierra type of topography are a number of hills and groups of hills, which are residual eminences above the pediments that surround the main mass. The highest peak rises about 2,500 feet above the upper part of the pediment. The mountain slopes are without forests.

According to Ransome, ${ }^{53}$ the Sierrita Mountains have an intrusive core of fine-grained biotite granite which forms the main mass. On the west the granite is intruded in a great series of schists with limestone lenses. This rock series, of undetermined age, rests unconformably on granite presumed to be pre-Cambrian. The foothills and much of the mountain pediment on the west side is underlain by these rocks. On the east side of the mountains the granite is intrusive into pre-Cambrian granite, Paleozoic limestone and quartzite, and a series of red and green shales and thin quartzites of presumed Mesozoic

52 Larsen, E. S., personal communication.

5o Runsome, F. L., Ore deposits of the Sierrita Mountains, Pima County, Ariz.: U. S. Geol. Survey Bull. 725, p. 409, 1922. 
age. Andesite also occurs. An extensive pediment extends from the mountains eastward to Mineral Hill, Twin Buttes, and the Tinaja Fiilils. It is described by Ransome ${ }^{54}$ as follows:

For at least 5 or 6 miles from the mountain front this plain had in general a rock surface thinly covered here and there by alluvial detritus. The plain is not perfectly even but is trenched by shallow arroyos and is surmounted by clusters of conspicuous hills, some of which rise as much as 700 feet above its general surface.

\section{TUCSON MOUNTATKS}

The Tucson Mountains, including the Black Hills, at the south end, extend about 25 miles in a direction slightly west of north. They have an irregular border, particularly on the west side, and there are numerous passes and detached hills. The width ranges from half a mile to 6 miles.

The most striking topographic features of these mountains are the irregular and precipitous summits of the main range, with cliffy slopes developed on tilted rhyolitic and andesitic lava flows and plugs. This wild and desolate topography contrasts sharply with the flat-topped somber Black Hills and Tumamoc Mountains, capped by basalt flows. The eastern slopes of the mountains are slightly less steep than the western, in harmony with the prevailing dip of the lava flows that make up the main mass. The western front of the mountains consists of Paleozoic limestone and quartzite and Mesozoic shale and quartzite, ${ }^{55}$ which are intruded by granite rocks and rhyolite plugs. Wasson (Amole) Peak, the highest point, is composed of one of these rhyolite plugs.

On the west side of the mountains is a narrow pediment veneered by gravel above which rise a number of outlying knobs, of which the Picacho de la Caleria, northwest of the mountains, and Snyders Ifill, to the southwest, are the most notable. On the east is Tumamoc Mountain, capped by horizontal basalt and tuff and having somber talus-covered slopes. The Black Hills and the buttes near San Xavier Mission are composed largely of horizontal basalt flows and have a similar topography.

\section{VALLEY AREAS}

\section{ALTAR VALLEY}

The Altar Valley is about 45 miles long and from 10 to 15 miles wide. The Pozo Verde, Baboquivari, and Coyote mountains form a continuous mountain barrier on the west side. On the east side the

\footnotetext{
54 Op. Cit., p. 412.

Ex Jenkins, O. P., and Wilson, E. D., A geological reconnaissance of the Tucson and Amole mountalns: Arizona Univ. Bull. 106 (Geol. ser., No. 2), 1920.
} 
Tumacacori, Cerro Colorado, Sierrita, and Tucson mountains, separated by broad passes, form a discontinuous boundary. The southern part of the valley drains to Altar River in Mexico. The broad divide south of Buenos Aires and the adjacent parts of the valley are underlain largely by hard rocks with a veneer of gravel. North of the divide the axial stream runs north to Abra Valley in an inner trench described on page 109. The grassy plains of this valley are in marked contrast to the scrub-covered plains of other valleys. The value of the forage has led to the establishment of numerous ranches. (See pp. 374-376.)

ABRA VALLEY

Abra Valley is a broad plain that lies between the Roskruge, Waterman, and Silver Bell mountains on the west and the Tucson Mountains on the east. It has an indefinite boundary on the south, where the Tucson-Ajo road is usually considered the arbitrary dividing line. On the north it has an equally indefinite boundary in the slopes that lead down to Santa Cruz River. The axial stream of Altar Valley passes into Abra Valley with a very indefinite channel, but farther north, where it forms the axia] stream of Abra Valley, it is dissecting the plain in places and continues through the valley to a junction with Santa Cruz River.

SANTA CRUZ VATIEX

The Santa Cruz Valley is a complex unit lying east of the Tumacacori, Cerro Colorado, Sierrita, and Tucson mountains. The San Cayetano, Santa Rita, and Santa Catalina mountains, which form the eastern boundary, are high, continuous, and relatively wellwatered ranges that are in marked contrast to the ranges on the west. Santa .Cruz River carries relatively large quantities of water and in some parts of its course is perennial. (See p. 119.)

The plains and terraces of the valley are described on page 109. The flood plain of the inner trench has a shallow water table, and here are located most of the farms and ranches. Above Calabasas Santa Cruz River and its tributary Nogales Wash are bordered by grassy meadows. The hills are covered with perennial grass, and springs and wells are numerous.

GROUND-WATER RESOURCES

The deep wells of Altar Valley are discussed on page 185. They are doubtless sufficiently numerous to water all the cattle the valley will support, but if necessary other equally successful wells can be drilled along the trough of the valley. In order to use all the range successfully, however, additional water supplies near the mountains are necessary. The present dug wells at the mouths of 
canyons in the narrow pediment on the east side of the Baboquivari Mountains are evidence that additional wells can be obtained. There are also a number of places where small reservoirs can be constructed. On the Sasabe Flat, south of Buenos Aires, deep drilled wells will probably be unsuccessful, but dug wells in the rock plains or in the beds of ephemeral streams will obtain water. There are excellent places for reservoirs where rock spillways can be obtained, as at San Fernando. On the east side of the valley the pediments are extensive, and dug wells can be sunk with success in the beds of all the larger washes. For several miles north of Guijas Wash the rocks are mostly lava, and it is possible that properly located drilled wells will obtain larger and more permanent supplies.

Abra Valley has a meager vegetation, and it may be that the wells at the Robles, Abra, and Cocoraque ranches and along Santa Cruz River are sufficient for the cattle the range will support. Deep drilled wells will obtain water in the center of the valley. There are now at least two represos in the valley, and improvement of these structures may be sufficient to permit the use of the range. The western slope of the Tucson Mountains should furnish sites for dug wells, but there are large areas of limestone which may be drained of water by underground outlets. In this vicinity there are numerous old mines and prospects, some of which may furnish enough water to serve as wells.

The ground-water problems of the Santa Cruz Valley are outside the scope of this report. Increase of irrigation and of population in this valley should, however, direct increasing attention to the full use of adjacent range. Numerous wells will then be dug along the mountains. The extensive pediment east of the Sierrita Mountains is favorable for such wells, and there are numerous abandoned mining shafts that could be used as wells.

\section{GUIDE TO WATERING PLACES}

\section{DISTRIBUTION AND TYPES OF WATERING PLACES}

The watering places of the Papago country differ widely in the quantity and character of water and in the facilities they afford travelers. Certain types of watering places are almost peculiar to the region; they are rare elsewhere.

The valley of Santa Cruz River and its tributary Nogales Wash from Nogales north to Tucson is an almost continuous watering place, containing many wells. During a large part of the year the bed of Santa Cruz River and the Gila Valley from Florence west to Gila Crossing and from Buckeye to Gila Bend carry water. In the irrigated area around Phoenix, which is supplied with water 
by the Roosevelt dam, there are numerous canals, and at each farm house there is at least one well, so that a traveler may consider this area a continuous watering place.

In the area south of Gila River and west of Santa Cruz River the watering places are few and springs are very rare. Many of the settlements, especially those around mines, draw their supplies from wells, but the greatest number of wells have been put in as stockwatering places. In the Altar Valley and in the rolling country between the detached mountains east of it stock-watering places are so numerous that the traveler will have no difficulty in obtaining water. West of the Baboquivari Mountains watering places are scarce, and supplies other than wells become valuable.

Wells in this region are generally of two kinds-shailow dug wells and deep drilled wells. Many wells of both types are described on pages 167-188. The dug wells are commonly excavated in rock, although a few penetrate alluvium only. They are located in or along the border of the mountains. The yield of these wells is not great, and many holes have been dug without obtaining water. In general, if water is found it is ample for travelers. Travelers should, however, carry a bucket and 50 to 75 feet of rope, for many of these wells are not provided with any equipment. The sanitary character of the water is usually good, but wells that are unprotected and little used are sometimes contaminated by the bodies of rats and other small animals that fall in and drown. The traveler should be on the watch for such pollution. The Papagos draw water from wells in rawhide buckets. These buckets are made from fresh hides, and the hair rots off only with time. The fastidious traveler will boil water from Indian wells. Plate XXV, $A$, shows a typical dug well used by the Papagos.

Deep drilled wells are usually located in the broad valleys. The greater number are stock-watering places of American cattlemen or wells maintained by the United States Indian Service for the Papago Indians. The water is excellent in quality and free from contamination when pumped. The traveler, however, will not always arrive at these wells when the pumper is present and will be compelled to use the water from the storage tank or reservoir. A casual inspection will show whether the reservoir is maintained in a sanitary condition. Great care should be taken to allow no water to waste and to close properly all gates which were closed and leave open all gates which were open on arrival. No man who is careless about gates can have friends in a cow country. The difficulties of obtaining water from an unequipped deep well are shown in Plate $\mathrm{XXV}, B$, and recounted on page 335 .

Rock tanks, called in Spanish "tinajas," are natural cavities in the rocks which retain water for longer or shorter periods after rains. 
The traveler will find these useful watering places and will be especially dependent on them in the area west of Ajo (pp. 123-135 and Pl. XVII). The length of time in which water will be found at any tank depends on the season. Travelers should seek local information when they know that they are to be dependent on tanks. The water is sometimes foul from the growth of green algae or from the bodies of bees that fall in and drown. It is unlikely, however, that disease germs are present, for these tanks are seldom visited. The almost constant sunshine is also a great antiseptic agent. The socalled sand tanks are rock tanks that are filled with coarse sand in which the water is found by digging. They are less likely to be foul than rock tanks, and as the sand prevents evaporation the water commonly lasts longer.

Charcos are pools of water that occur along the channels where flood waters spread out over adobe flats. They range from a few inches to fully 5 feet in depth (see pp. 121-123 and Pl. XVI) and from about 5 to 30 feet in width, and some of them are more than 1,500 feet long. They hold water from a few days to several months after rains. During this time they are commonly used by wild animals and range stock. The traveler will usually find the water foul and muddy, but in many large areas it is the only water to be had, and if it is boiled before using it is a safe if not a palatable drink.

Represo is a general term for a small earthen dam that impounds flood water. American cattlemen include such dams under the generic term "tank." Represos are commonly built in adobe flats, and frequently only the borrow pit, from which earth was taken to make the dam, holds water. Even the larger ponds are only from 2 to 5 feet deep. In area they range from mere mud puddles to ponds 600 feet wide and 2,000 feet long. (See pp. 144-151 and Pl. XXI.) The water in some represos is as evanescent as that in the smaller charcos. The larger ponds hold water for several months after a flood. If properly boiled the water of the larger represos is a satisfactory and welcome supply.

In a few localities flood water is collected in old prospect holes. Within the hole, protected from sunlight, the organic matter in the water rots completely, leaving clear water with a faint brown tint. During the rotting process the water is unfit to drink, but after it has "sweetened" it is acceptable. (See pp. 136-141 and Pl. XX, B.) The deliberate construction of such cisterns has not been undertaken, and those in existence are the result of accident. These structures are likely to increase in number in the driest parts of the region.

Along the Southern Pacific Railroad many section houses have no wells but are provided with cisterns, which are filled from tank cars. The water is good. and the cisterns are kept in excellent condition. 
As the supply is limited, however, great care is exercised in using the water. Travelers are allowed to obtain it, but this privilege should not be abused. It is to these cisterns that the accompanying road logs refer when the statement is made: "Water at the section house in emergencies."

\section{TYPES OF ROADS}

Except in the vicinity of towns little has been done to improve the roads of southern Arizona. They are usually only natural highways where first one and then another traveler has made his way across the country with good or ill fortune. Owing to the many open plains without natural obstacles, the dry climate, the consequent scanty vegetation, and the porous but compact soil portions of such unimproved or natural roads are very good. Stretches can be found where an automobile can make 40 miles an hour without trouble.

In the Gila and Santa Cruz valleys improved roads are being constructed near the larger towns by the counties, and there are a number of through routes constructed or projected by the State. Much of this construction is excellent, good bridges, culverts, and concrete dips being provided, and in many places good road metal has been hauled in. As only one such road exists in the area south of the Gila Valley and west of the Santa Cruz Valley, travelers in this region must depend on the natural roads. The characteristics of these roads vary according to the type of country they traverse. They have been divided into four classes to which names have been given to facilitate road descriptions in the logs. These classes are called mountain roads, malpais roads, plains roads, and river-bottom roads.

\section{MOUNTAIN ROADS}

The mountain roads run through mountains of various types and consequently have somewhat varying characteristics. Some work has been done on most of these roads to make them passable for automobiles or heavily loaded wagons. Under the provisions of law much assessment work is done on the roads to mining claims, and travelers will find those to or adjacent to prospects in fair condition. Mountain roads are constructed on rock, residual soil, thin alluvium, or caliche. In consequence they are seldom muddy but frequently rough. The grades are usually steep, but long hills are rare. However, there are many very steep short grades in and out of gulches. The crossing of such little canyons with walls 10 to 25 feet high and - sandy or gravelly bottoms presents the principal difficulty in traveling on roads of this type.

MALPAIS ROADS

Roads passing over mesas capped by lava or "malpais" are in goneral comparatively good. Steep grades, bad washes, and heavy 
sand are rare. Depressions in the surface of the lava may become filled with sand, making rather heavy going. Such stretches are usually short and seldom present serious difficulties. The roadbed may, however, be rough and hard on tires. The principal difficulty is usually the ascent to the mesa, which, in addition to being steep, may be covered with drifted. sand or loose boulders.

\section{PLAINS ROADS}

By far the greater length of road and the greater number of roads lie in the alluvium-filled valleys or plains of the desert. The traveler comes to know these roads as the typical desert or plains roads. Generally alluvium makes good, well-drained roads. Off the track of previous travelers, however, the ground is soft and the going heavy. Only lightly loaded automobiles and wagons ean make progress. Cutting across the plains without a road should not be attempted with an automobile except by experienced travelers.

The plains road varies somewhat according to the part of the valley in which it lies. Near the mountains the alluvium is likely to be coarse and compact; the streamways are arroyos with banks 2 to 10 feet high floored with coarse, deep sand. The road is then like a mountain road, rough but firm and difficult only at the streams. Midway of the alluvial slopes the alluvium is commonly softer and finer grained. It is easily washed during rains, and road ruts may be cut so deep as to leave high centers or be filled with soft sand that impedes travel. The streamways are washes, with banks 1 to 2 feet high and with bottoms filled with fine, often deep sand.

Near the centers and along the troughs of the valleys many of the roads run through adobe flats of fine-grained sandy clay, or through areas of low sand dunes. The adobe flats when dry make a good, smooth roadway for light traffic but are easily cut up, so that the road becomes dusty and full of chuck holes. When wet they are seas of slimy and slippery mud into which vehicles sink from 2 inches to a foot. When the flat is dry these ruts, made in wet weather, are very hard on automobile tires. The sandy areas are seldom impassable, but progress is slow. The axial stream of a valley is generally a serious obstacle to travel. In some valleys it is merely an unusually large channel in an adobe flat. It is then easy enough in dry weather, but the steep clay banks when wet are often impassable for automobiles. In other valleys the axial stream is a broad arroyo with steep banks and sandy channel.

\section{RIVER-BOTTOM ROADS}

Roads along the courses of rivers have generally been cleared of the mesquite, and a few culverts have been built. The roadbed is made of the fine-grained sandy clay and loam of the flood plains, and if well graded it makes an excellent road in dry weather provided 
there is little traffic. The material is so soft, however, that welltraveled roads in river bottoms soon become badly rutted, very dusty, and full of chuck holes in dry weather and so muddy in wet weather as to be almost impassable. These roads may also pass over the gravel benches along the river. Here the alluvium is coarser and more compact than it is in the flood plain, and the roads are similar in character to plains roads. They must, however, go in and out of the numerous tributaries, each with its dry and sandy channel. It is common to find two parallel roads along a river valley, one following the flood plain and the other the gravel benches. Which road is the better will depend on the season, the weather, and the amount and character of the traffic. Fortunately, newly constructed roads are replacing most of the valley roads.

\section{GOOD, FAIR, .AND BAD ROADS}

The use of the adjective "good" with regard to natural roads is, of course, subject to criticism, as perhaps none of them deserve it. However, a road that is called "good" in this region is one free from bad grades and mudholes and with no washes difficult to cross. On such a road an average speed of 12 to 20 miles an hour can be made without danger in an automobile. Heavy loaded wagons can make the journey with comparative ease.

On a "fair" road experienced drivers with good automobiles and all kinds of horse-drawn vehicles can get through, but travel is rough, and only slow time can be made.

A "bad" road has heavy grades or washes that are difficult to cross, heavy wind-blown sand, or many adobe flats and washes, or a combination of these disadvantages. The natural conditions are such that only slow time can be made with any kind of vehicle. Automobiles are liable to get stuck in all kinds of weather and almost surely in wet weather.

- In a number of places in the logs it is stated that a road is impassable to automobiles. By this is meant that such obstacles were seen or are known to exist that automobiles can not get through without building a new road. A road described as very difficult should not be attempted except with adequate preparations for emergencies, and, if possible, with an experienced driver.

\section{ROAD SIGNS}

The traveler will find many signs on all the well-traveled roads of Santa Cruz and Gila valleys, also in the area of the Salt River irrigation project. These signs have been put up by local advertisers, automobile clubs, and county authorities. In the desert the most reliable and permanent signs were put up in connection with this investigation. They will be found in 89 localities, shown on Plates II-IV by the symbol T. 
In addition to the more substantial signboards, there are many small boards put up by prospectors and travelers. At road corners will be found also a wooden box, a tin can, a pile of stones, a rag tied to a tree, or some other crude mark. It is a point of desert etiquette not to disturb these marks.

\section{ROAD DIFFICULTIES AND SUGGESTIONS FOR SURMOUNTING THEM}

On the comparatively short stretches of constructed road in southwestern Arizona travel involves only the hardships and problems usual in other parts of the United States. The roadbed may be rough and dusty but is always passable, and supply stations are found at frequent intervals. On the long routes over unimproved roads supply stations and even water are found only at infrequent intervals, and the roads are so poor that accidents and breakdowns are a commonplace occurrence. Unless the traveler is prepared for emergencies minor accidents are likely to have serious consequences. To go 12 hours without water is a hardship, and 24 hours is likely to prove fatal.

Automobile traffic is constantly increasing, and inexperienced persons confident in the perfection of their conveyances continually attempt to use the desert routes, usually with success. The traveler by wagon is commonly a habitue of the desert, to whom advice is superfluous. The following remarks, in consequence, apply to automobile travel exclusively.

WATER

Ample water should be carried. The amount should pe great enough to fill the radiator at least once, in case of a leak. Human consumption of water is very great on account of the heat and the dryness. Two gallons per man per day is a minimum requirement. The Survey party of two men used in September for all purposes, including drinking, cooking, washing, and filling the radiator, from 9 to 13 gallons a day.

More than one receptacle should be provided so as to give a reserve in case of a leak or accident. Canvas water bags are very effective in keeping water at a pleasant temperature for drinking, but they are hard to carry afoot, and they waste water. One or more metal canteens should be provided for use on side walking trips or if it is necessary to walk to get help.

\section{GASOLINE AND SPARE PARTS}

Garages at which even simple repairs can be made or the commonest spare parts obtained are separated by great distances. The car should be in as good condition as possible before starting a journey, and enough tools and spare parts should be taken to make minor repairs on the road. Gasoline should be carried in at least 
one container in addition to the tank attached to the car. A leak in the gas line will not then exhaust the entire supply. Fewer miles per gallon can be expected on these roads than on boulevards, and the gasoline will not always be of the best quality. The Geological Survey car, a Ford touring-car chassis with light delivery-truck body, averaged about 6 miles to the gallon along the Camino del Diablo from Ajo to Yuma, whereas on good macadamized road 15 to 20 miles to the gallon was made. Sufficient oil should be carried to refill the crank case in the event of a leak.

\section{EQUIPMENT}

Certain tools are necessary for every journey. A shovel and an ax, perhaps also a pick, should always be carried. Roads which were easy to travel yesterday may be almost impassable to-day because of a rain of which the traveler can have no warning. A rope and tackle or one of the patented devices of this nature is likely to be necessary to pull the car out of a hole or up a steep bank.

A rope, perhaps the same as that used with the tackle, and a bucket are very useful in obtaining water from wells, which may be stripped of such equipment by vandals. A good lantern in addition to flashlights should be provided for use in making repairs at night. A few feet of baling wire should be carried for miscellaneous repairs.

It is advisable to carry a little food, even if the traveler intends to reach an eating house or hotel each night. Breakdowns, however trifling, cause delay, which, if the traveler had no food with him, is a hardship. For the same reason on most roads bedding should also be provided. A breakdown at nightfall is then a mere incident requiring a camp overnight, whereas otherwise it means long and irritating work in the dark and an anxious night drive. Those travelers who carry light camping equipment and are not dependent on local accommodations will, on the whole, have the least trouble. At many places meals may be obtained, but beds must generally be provided by the traveler.

\section{CHOICE AND EQUIPMENT OF ADTOMOBILE}

The Tucson-Phoenix and Tucson-Nogales highways have so much constructed roadway, and help and accommodations can be found at such short intervals, that an automobile of any type can make the trip. On the other roads the heavier and longer machines are at a disadvantage. A so-called light car with plenty of power is the best. Heavy tops are a disadvantage, and all equipment should be so chosen as to keep the weight as small as possible, balanced laterally, and confined between the front and rear wheels. Weight behind the rear wheels is a serious handicap. 


\section{CROSSING AN ARROYO OR WASH}

The ephemeral streams of the region have channels which are dry except for a few days a year. These channels are known as arroyos or washes. "Wash" or "dry wash" is the common local term. In the logs the term "arroyo" is used when there is a single definite channel with a sandy or gravelly bed and banks 2 to 10 feet high. "Wash" is used where the banks are low and there are numerous channels.

These streamways are the most common impediments to travel. During times of flood it is impracticable to attempt to ford them, and travelers must wait until the flow ceases. Such delays are rare and usually short, even during the rainy seasons. An arroyo, even if it does not carry water, has difficulties of two kinds - the banks are commonly steep, making an abrupt descent into and ascent out of the channel, and the bottom is covered with sand or gravel.

On well-traveled roads the banks have usually been worn or cut down so as to be passable. After a flood or on little-traveled roads it is a wise precaution to stop and look over an arroyo before attempting to cross. Time will often be saved by improving the road a little before starting, so that the car will not be stuck. Careful judgment in driving is nearly always required in order to go down the bank at a speed slow enough to avoid breaking a spring at the bottom and yet have momentum enough to cross the sand and make the ascent on the other side. A rather frequent difficulty with a Ford automobile in ascending the bank of an arroyo or other steep pitch is that the gasoline fails to feed from the tank to the carburetor. Banks steep enough to cause this trouble are usually short, and if the car is moving at a fair rate of speed, its momentum is often sufficient to carry it up. It frequently pays to back up the bank of the arroyo and try again. The double movement packs the sand so that sufficient speed can be maintained for the ascent, otherwise the car must be got to the top by the use of tackle or by shoveling down the bank.

Crossing the sandy or gravelly bottom is a problem in itself. The coarse gravels ordinarily give no trouble, but the finer the sand the more likely it is to be deep and soft. It is best to follow previous tracks with the highest speed consistent with the maximum power. If the car stops, back and try again, but do not under any circumstances allow the wheels to spin. Under the wheel tracks a layer of packed sand will be formed very much like a plow pan. This layer or wheel pan should not be disturbed. Usually the car does not break through it but is stopped by the friction of loose sand which falls in around the wheel. By repeated backing and going forward the pan is compacted and this loose sand thrown out of the way. If, however, no progress can be made, the loose sand should be shoveled 
away and a track made about 1 foot wide under the car for each pair of wheels and for about 10 feet in front of the car. In these tracks planks, canvas, or brush should be placed to give traction and then the car should be started. Planks are seldom available, and canvas wears out quickly from such treatment. Any available grass or brush will do, but the ubiquitous creosote bush, which has no other use, will be obtained most easily. The smaller bushy branches may be broken off with the hands in lengths of 1 to 2 feet and will be found to give sufficient traction when laid closely in the track. Plate XXVII shows the appearance of a wash just west of Papago Well after the passage of the Survey automobile. When it was certain that the car was stuck, the tracks were shoveled out and then filled with creosote bush, as just described, but enough brush was not laid at first, so that sufficient momentum was not gained to get out of the sand. The operation was repeated, part of the brush being relaid, and the machine was successfully driven out of the wash.

\section{CROSSING OTHER SANDY AREAS}

Areas of drifted sand present difficulties of the same sort as those encountered in the beds of arroyos and washes. The fine sand clings even more tightly to the wheels. It drifts into the wheel ruts within a few hours after the passage of a vehicle. On this account much traffic does not make the road better by permanently widening the wheel ruts, as it often does in washes.

The same kind of a wheel pan forms, however, and when the sand is 2 feet or more deep this wheel pan is the only salvation of the automobilist. To get out of the ruts is a calamity. When stuck the same methods can be used as for crossing washes. Where long stretches of sand are to be passed, a steady speed which will heat the engine the least should be maintained. The tires may be deflated to a pressure of 25 to 30 pounds per square inch, but while this device affords better traction it is hard on tires and should not be resorted to except when absolutely necessary. If the engine becomes heated, the automobile should be stopped at a favorable place and thus prevented from getting stuck in an especially bad place. The driver should never fight the sand. Speeding the engine and spinning the wheels accomplish nothing.

\section{ADOBE FLATS AND RIVER FLOOD PLAINS}

The ephemeral streams of the desert often have no definite channels but spread out in broad flats of sandy clay or adobe within which are only minor channels. Such flats are often covered with forests of mesquite and sometimes with "galleta" grass. The flood plains of the rivers are usually of similar though somewhat softer material.

In wet weather such places are likely to be "seas of mud," over which passage is difficult, if possible at all. Local advice should be 


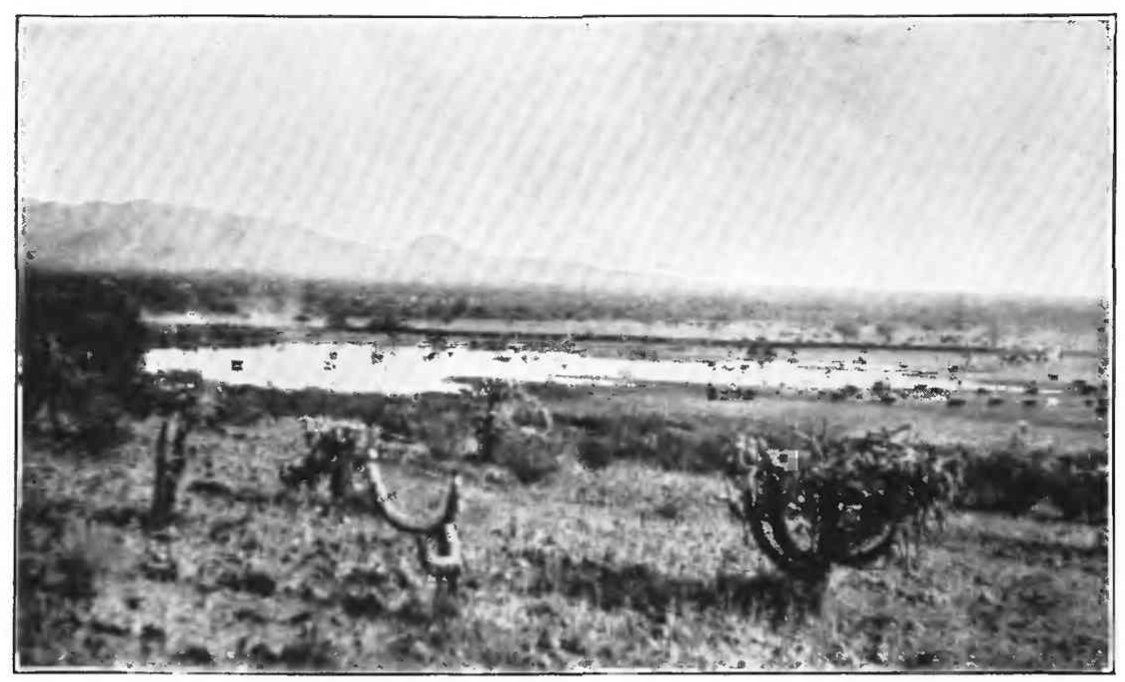

iA. ARTESA POND

Papago cattle watering at one of the largest represos in the region

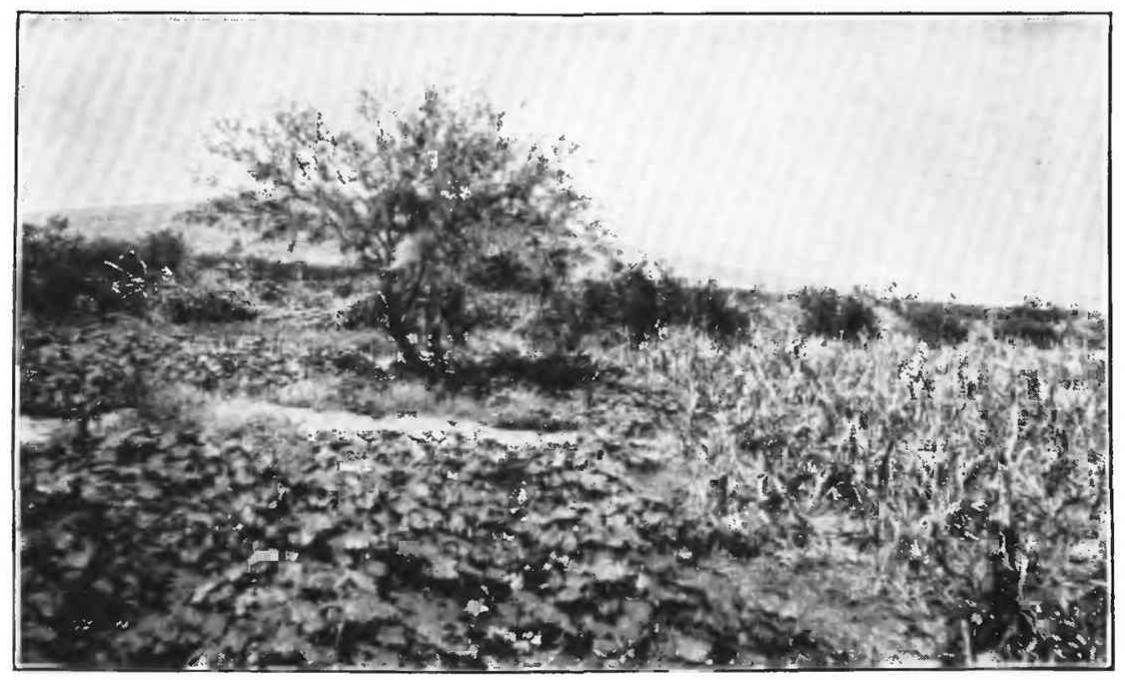

B. PAPAGO FARMING

A flood-water field or temporal near Toapit 


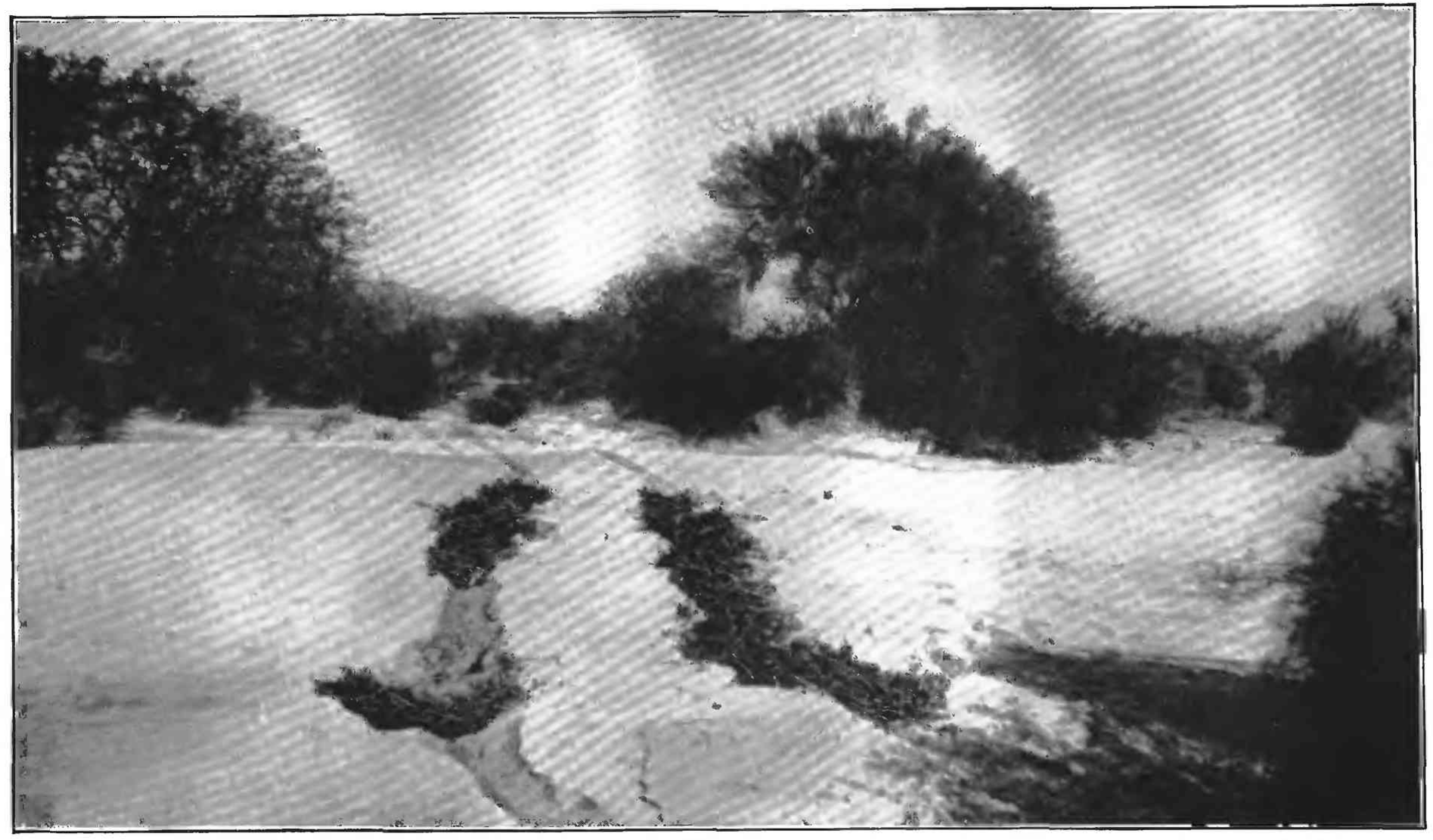

ROAD ACROSS A SANDY WASH DUG OUT AND CORDUROYED WITH BRUSH 
sought and carefully considered before attempting to cross. Fortunate indeed is the traveler who can make camp and wait for the great adobe flats of the Quijotoa Valley to dry.

In dry weather, especially if there is much travel, roads across adobe flats and river flood plains have deep ruts and many chuck holes. They are rough and dusty but have no dangers if traveled slowly. Very deep ruts let the machine down so far that the axles, transmission, and other low-hung parts are liable to strike the center of the road. Such roads are said to have "high centers." Though most common in adobe flats, high centers are found wherever there is excessive wear on the wheel ruts or where rain water washes them. No danger is more easily avoided or will wreck a machine more quickly.

Usually in adobe flats there is a choice of tracks which, crossing and recrossing each other, all lead to the same place. If the surface is hard and the car lightly laden, it is often possible to strike off in a new track and thus avoid the chuck holes. This should be attempted with caution, however, as the surface may not be as hard as it looks.

MOUNTAIN AND HILL AREAS

The difficulties of mountain areas are uncompromising. As a rule it is clearly either possible or impossible for a car to go to any given place. Around the borders or as basins within the mountains there are many areas of rocky, rolling country, where good roads are common. The interstream areas present no difficulties and can often be traveled without a road, although the wear on tires is excessive. The streams, however, lie in little rocky canyons with walls 10 to 30 feet high. They are often harder to cross than the arroyos of the valleys, and many are impassable.

\section{PLAN OF LOGS AND DESCRIPTIONS}

In the following pages are given, first, road logs that are intended to furnish accurate information about distances and principal points and are made brief enough to be convenient for the traveler whose time is short, yet sufficiently detailed, it is believed, to enable him without other guide to reach his destination safely. Logs of principal roads are given in both directions. Distances are stated in miles and tenths as measured by the Geological Survey party in traveling the road. All the signs mentioned in the logs are believed to be reliable. As the condition of many of the roads may have changed since the material for this book was collected, the traveler should, if possible, obtain local information as to a road before starting on a trip.

The logs are followed by more detailed descriptions of many of the routes and special features of the region. 


\section{ROAD LOGS}

\section{TUCSON-YUMA ROAD}

Travel from Tucson to California for many years has followed two main routes. The first route ran north to Gila River in the vicinity of the Pima villages, which lay along the river from Florence to Maricopa, and thence followed the river to the present site of Yuma. The other route ascended Santa Cruz River, crossed the present Mexican border to Saric or Caborca, and thence by way of Sonoita followed the Camino del Diablo across the desert into Yuma. The northern route was the easier in grades and in the presence of wood and water, but it was exposed to the raids of the Apaches. The southern route was dreaded because of recurrent disasters from lack of water.

At present the same distinction still holds in part, and travelers who desire comfort and safety will proceed from Tucson to Florence (pp. 293-297) and thence by way of Phoenix to Yuma, or in dry weather they may take the direct road from Tucson by way of Maricopa to Yuma (pp. 298-300).

The route to Yuma by way of Ajo, which is the modern representative of the old southern route, has been made possible by the increased number of watering places and is no longer dangerous in any sense. Travelers should, however, be prepared to camp and make road repairs. Two days' supply of water and sufficient gasoline for $\mathbf{1 5 0}$ miles of travel for automobiles are good insurance against trouble.

\section{OLD MAIN ROUTE}

\section{TUCSON TO YUMA (272.9 MMLES)}

[See pp. 272-276 for $\log$ in opposite direction]

The part of this road from Tucson to Ajo consists of a number of alternative routes which are covered by the following logs. The first 45 miles out of Tucson is the same for all routes. Of this distance the first 36 miles is a wellgraded macadamized road which was in excellent condition in 1921 and will undoubtedly be maintained in passable condition by Pima County. The last 25 miles has also been converted into a graded highway, of which the 15.5 miles from Gunsight ranch to Ajo is the same for all routes. By this new construction the distance from Gunsight ranch to Ajo has been reduced 1.3 miles. The $\log$ of the Pozo Blanco route has been adjusted for this difference, but travelers using the other logs should allow for it.

The old main route goes by way of Indian Oasis, Copeka, and Gunsight ranch to Ajo. The best present route is the Pozo Blanco route, which, branching off at the north end of Baboquivari Mountains, goes by way of Comobabi, Cobabi, Covered Wells, Pozo Blanco, and Gunsight ranch to Ajo. The old main route has three alternatives between Copeka and Gunsight ranch. The preferable road in ordinary weather is the Charco en Medio route by way of Pisinemo and Charco en Medio. This route is followed in the main log. The Cubo route branches from the Charco en Medio route at Pisinemo and goes to Gunsight ranch by way of Cubo, passing close to Walls Well. The Comovo route branches near Copeka and goes by way of Comovo and Cubo to Gunsight. It is likely to be the best route in wet weather. 
0.0 Tucson post office. Go north one block, turn west on Congress Street, and proceed westward, passing station of El Paso \& Southwestern Railroad on left.

0.4 Conerete bridge across Santa Cruz River.

0.6 Come into north-south road. Turn to left along base of Sentinel Hill. Right-hand road goes to Silver Bell.

3.8 Crossroads. Take road on west, which is a new macadam road leading through Robles Pass, for 22 miles into the desert. Road south goes to San Xavier Mission (see p. 285) ; road east goes to Indian school and connects with valley roads.

5.6 Quarry on left.

7.8 Fork. Road on left goes to Mile Wide Copper Co.

10.6 Snyders Hill, with quarry on left.

13.9 Well on left.

21.6 Well on right. These wells were drilled for supplying water for road building; not certain whether they will be maintained as watering places.

23.3 Robles ranch. Well and good water.

23.4 Fork. County signpost. Keep to right. Road on left leads to Sasabe, La Osa, and Arivaca. (See p. 287.)

25.0 Steel bridge over large arroyo.

31.1 Reverse fork. Road on left comes in from Indian field.

34.0 Crossroads. Keep straight ahead. Road on left comes in from Alamo, winter ranchería, and well. Water half a mile south on this road. Road on right leads to San Pedro, winter ranchería, and well (4 miles).

34.2 Reverse fork. Second road from Alamo.

36.0 Roadside mine. Miners' shacks and new shaft on left. Water and limited amount of supplies can be obtained here when mine is being operated. Graded highway extended a short distance beyond this point in 1920.

36.3 Dobbs Well on left. Water can be obtained with rope 55 feet long and bucket.

39.4 Fork. County sign. Keep to right. Left-hand road to Coyote, winter ranchería and well. Water half a mile by this road.

40.1 Cross faint road.

40.2 Reverse fork. County sign. Road from Coyote comes in on left.

41.0 Reverse fork. Faint road comes in on left.

43.6 Crossroads. Road on left from Coronel; road on right to Santa Rosa ranch.

44.0 San Vicente. Well, good water. Small store but no gasoline and limited amount of supplies.

45.1 Fork. Geological Survey sign. Take left-hand road through gate; righthand road is Pozo Blanco route, best route in 1920. (See p. 277.)

46.7 Road forks. County sign. Take right-hand road here. Left-hand road leads to Babokuk, winter ranchería, and well. Water 2 miles south on this road.

47.2 Crossroad leading from Babokuk to temporales.

47.7 Reverse fork. Road from Babokuk comes in on left.

50.1 Reverse fork. Faint road comes in on right.

52.6 Fresnal ranch. Well on right. County sign on left. Well now used by U. S. Indian Service, and water can probably be obtained at all seasons. 
54.0 Fork. Keep to left uphill to Papago hut at mile 54.3. Faint road on right along fence leads through fields to Jeowic, summer rancheria.

55.1 Road fork; county sign. Keep to right; left-hand road goes to Magdalena, Tucsoncito, and Topahua.

55.9 Reverse fork. Faint road comes in on right.

56.7 Cross faint road from Tusconcito to Jeowic.

59.0 Reverse fork. County sign on left. Road from Tucsoncito comes in on left.

59.4 Fork. Road on right goes to Artesa Pond, a quarter of a mile, no drinking water. (See PI. XXVI, A.)

59.5 Reverse fork. County sign on left; road from Topahua comes in on left; go up rocky hill.

60.9 Artesa, winter ranchería, well on right; better water half a mile farther at Indian Oasis.

61.3 Government school on left.

61.4 Indian Oasis, Sells post office. United States Indian Service well on right; Presbyterian Mission on left; meals can usually be obtained there; store on hill directly ahead, 0.4 mile by road; post office, supplies, and gasoline; good water can be obtained from Government Well, Presbyterian Mission Well, or Menegers Well. North and south routes to Big Fields begin at this point. Northern route is half a mile longer but often better. (See p. 276 for $\log$.) Consult storekeeper as to which road is in better condition. Following southern route, keep to left past Geological Survey sign (mile 61.6) between hill and fence. No permanent water until Gunsight ranch is reached (58 miles).

61.7 House on left.

62.1 Well on left; no water obtainable.

62.9 Double-road fork. Geological Survey sign. Take right (west) fork, following south side of fence to mile 63.2. Left fork goes to James Well; middle fork to Tecolote and Mexico.

63.2 Pass north and to right of fence corner.

71.0 Small earth dam (represo) on left, then corral.

71.3 County sign; bear to right with houses and fields on right.

71.4 County sign; continue westward on south side of fences.

73.9 Reverse fork; Geological Survey sign at Big Fields, summer rancheria. Alternate road from Indian Oasis comes in on right. (See p. 277.) Proceed westward.

80.7 Copeka. Summer rancheria. Road usually obliterated by trampling of cattle; pass between corral and hill. Water in the pond several months of the year; it should be boiled before drinking. Road leads south from this point to Tonukvo (2.6 miles). By crossing main drain of the valley just north of the pond and going westward toward the hills an old road will be found leading to serventi Well and Menegers Dam. (See p. 327.) Road to Ajo, turn to right (north) at corral.

80.9 Houses on right.

81.4 Cross small levee.

82.9 Road fork. Geological Survey sign. Keep to right. Road on left is Comovo route. (See p. 281.)

83.3 Faint road on right.

84.4 Road forks on left to house; keep to left.

84.9 Represo on left.

85.3 House on left; field on right. 
85.8 Field on right; then numerous crossroads and forks to Black Butte.

89.6 GeologicaI Survey sign. Follow around brush fence. Road comes in on left (southwest) from Comovo. (See p. 281.) Road goes northeastward on south side of temporal to Black Butte (8 miles).

89.8 Houses on right.

90.0 Hardimui. Summer ranchería. Geological Survey sign. No permanent water. Houses and represo on right. Bear to left; corral on right (east); houses on left.

90.4 CorraI on left.

90.6 Small represo.

93.0 Cross wash and follow left (west) of large represo into Pisinemo.

93.2 Pisinemo. Summer ranchería. Small represo on right; about 12 houses including small church and house with tin roof on left. No permanent water. Follow along south side of brush fence to corner. Road to Comovo goes southwest toward two small hills on plain on left side of house with tin roof (5.7 miles). Road to Pozo Blanco goes northeast by small represo (11.1 miles). Road to Black Butte goes east between the two represos ( 8.2 miles).

93.6 Road fork at southwest corner of brush fence. Geological Survey sign. Keep to right along fence; road on left is Cubo route. (See p. 280.)

93.8 End of fence.

95.3 Faint road on right.

96.8 Small charco on right.

101.8 Three small black hills a quarter of a mile north of road.

109.1 Cross difficult wash into gap between low hills.

109.6 Small charco on left (south).

110.1 Small charco on right (north).

110.7 Charco en Medio. Summer rancheria. Represo on left, usually dry; houses on hill to left. Continue northwestward on main traveled road. Road to Cubo goes to left (south) on west of represo. Road to Charco de la Piedra, very faint, on right, west of houses.

111.8 Charco on left.

113.2 Reverse fork. Road comes in on left.

113.7 Fork. Keep to right. Alternate road on left; no advantages.

114.0 Reverse fork. Geological Survey sign. Come into east-west road. This is the Pozo Blanco route, now an improved highway. (See p. 277.) Turn to left (west).

116.1 Reverse fork. Alternate road from Charco en Medio comes in on Ieft.

116.7 Cross wash.

118.7 Cross faint road.

118.8 Cross wash.

118.9 Reverse fork. Geological Survey sign. Come into well-traveled road. This is Cubo route. (See p. 280.)

119.3 Turn to right (northwest). Road from Gunsight mine, 1 mile distant, comes in here.

119.4 Gunsight ranch, also called BIair's ranch; Geological Survey sign. Good water in well on right of road. Continue through gate. Road to Pozo Redondo, Charco de la Piedra, and Perigua turns off on right up wash.

119.8 Come into highway. (See p. 277.) A faint road comes in on left from Gunsight mine. Left-hand road goes to Jaques ranch (0.7 mile), where water can usually be obtained, and to Lewis Well ( 3.1 miles), which has good water. This detour returns to main road in 6.4 miles. Smokestack of New Cornelia Copper Co.'s plant at Ajo visible to the northwest. 
124.7 Fork. Keep to left. Right-hand road to Childs ranch.

126.5 Reverse fork. Geological Survey sign. Road from Jaques ranch and Lewis Well comes in on left.

129.5 Fork. Keep straight on. Right-hand road leads to Childs ranch.

130.4 Faint road comes in on left.

131.5 Reverse fork. Old road comes in on left.

132.8 Fork on left to Darby Well (1.5 miles); then fork on right to Childs ranch (3 miles); turn downhill (north) and cross wash.

133.0 Road to Levy's ranch goes off on left; no well, but water can be obtained in emergencies.

133.9 Reverse fork. Well-traveled road comes in on right from Childs ranch (2.7 miles). Turn to left (west).

134.2 Reverse fork. Road from Darby Well comes in on left.

135.3 Clarkstown (Rowood post office) ; water supply, groceries, supplies, repairs, gasoline. Continue west on main street and turn to right (northwest) along fence of New Cornelia Copper Co.'s mill.

135.9 Reverse fork. Geological Survey sign. Turn to left across tracks and then to right into town. Road from Yuma and Gila Bend comes in on right.

136.2 A jo railroad station. Excellent water supply; hotels, stores, automobile supplies, repairs, gasoline, etc. From Ajo roads lead south to Sonoita, Sonora (see p. 342), west by the Camino del Diablo to Yuma (see p. 334), and north to Gila Bend and Phoenix (see p. 323). Best route to Yuma is by way of Sentinel; return to railroad crossing and Geological Survey sign, same as mile 135.9.

136.5 Geological Survey sign; bear north toward frame shacks.

137.3 Fork. Old road goes off on right.

137.7 Fork. Geological Survey sign. Take left-hand road; right-hand road leads to No. 1 well.

138.3 Cross railroad.

139.1 Reverse fork. Road from Gibson, a suburb of Ajo, comes in on left.

144.0 Cross railroad.

144.9 Batamote Well. Geological Survey sign. Good water in dug wells on right; next water 34 miles away.

145.4 Cross railroad. Fork. Geological Survey sign. Turn to left (southwest) parallel to railroad; right-hand road goes to Gila Bend (see p. 323); center faint road is abandoned.

145.6 Turn to right (west).

148.5 No. 3 well. Road usually obliterated by cattle tracks. Turn fence corner by well and drive north between corral and house. Deep drilled well; pumping plant abandoned in 1921, and water unobtainable by travelers.

150.1 Cross bad wash.

150.3 Abandoned road comes in on right; enter gap in hills.

151.0 Drift fence; close gate.

152.4 Drift fence; close gate.

152.9 Cross deep wash and rocky hill; follow along border of Crater Mountains, keeping the hills on the left.

157.4 Turn to left (northwest) around rocky point into gap.

158.2 Reverse fork. Geological Survey sign. Continue northwest through gap in hills. Road and trail lead from Black Tanks (1.7 miles) ; uncertain water. (See Pl. XVII, $A$. )

162.7 End of gap. Turn slightly right (north).

163.2 Begin to run on lava of Sentinel basalt plain. 
179.4 Brown's Hotel and store at Sentinel; water, rooms, meals, supplies, gasoline. Pass in front of hotel and proceed west.

179.9 Cross railroad; road fork. Geological survey sign. Turn to left along railroad track; center road leads to Agua Caliente; right-hand road goes east to Sentinel station and thence along railroad to Gila Bend. (See p. 317.)

186.6 Stanwix. Water in emergencies at section house.

188.4 Go downhil off Sentinel basalt plain.

194.4 Aztec. Water from railroad well. Geological Survey sign. Continue west on north side of track; considerable drifted sand. Road to Palomas (T miles) on right (north) ; road to Eagle Tanks crosses track and goes southwest.

206.4 Stoval. Water in emergencies at section house. Continue west along track; much drifted sand. Road to Garcia Well and Whites Well crosses milroad and goes south. (See p. 347.)

211.5 Fork. Continue west along track. Road to left crosses railroad and goes south to Red Cross mine (5 miles).

213.0 Turn to left under bridge to south side of track.

213.3 Turn to right under bridge to north side of track.

213.9 Mohawk. Water, limited amount of supplies, gasoline. Continue west through heavy drifted sand. Road leads north from Mohawk to Norton (7 miles). Difficult and waterless road leads south 52.5 miles to Papago Well.

217.5 Pembroke. Water in emergencies at section house; heavy sand to Colfred.

222.5 Colfred. Railroad siding.

231.4 Red hill on right of road.

235.7 Wellton, post office. Water, hotel, garage, supplies, gasoline. Camino del Diablo comes in on south. (See p. 334.) The main Phoenix-Yuma road $^{56}$ comes in on the east, and the two routes are the same from Wellton to Yuma. Go west between post office and hotel.

238.4 Turn to left (south).

238.9 Turn to right (west).

239.4 House with windmill on right; good water.

240.9 Reynolds well; good water on left.

243.0 Macadam road begins.

252.9 Dome. Post office, water, hotel, gasoline. Continue northwestward on macadam road. From Dome a road leads across the river to Castle Dome and other points in Yuma County. ${ }^{67}$

259.6 Blaisdell. End of macadam; water at Imperials Well, 0.7 mile northwest by sandy road. Road to Fortuna mine crosses railroad through gate and goes south. (See p. 348.) Turn west and follow best of many rutty tracks over soft ground in the flood plain of Gila River.

266.9 Windmill on left; water.

271.9 Cross railroad track and follow it into Main Street of Yuma to railroad station.

272.9 Yuma. Post office, water supply, hotels, repairs, gasoline, and supplies. From this town a bridge across Colorado River connects with roads to Los Angeles and San Diego. ${ }^{58}$

\footnotetext{
${ }^{50}$ Ross, C. P., Routes to desert watering places in the lower Gila region, Ariz.: U. S. Geol. Survey Water-Supply Paper 490-C, pp. 271-315, 1922.

${ }^{57}$ Ross, C. P., op. cit.

Bs Brown, J. S., Routes to desert watering places in the Salton Sea region, Calif.: U. $S$. Geol. Survey Water-Supply Paper 490-A, pp. 1-86, 1920.
}

$104211^{\circ}-25-19$ 
[See pp. 266-271 for log in opposite direction]

0.0 Yuma. Post office, hotels, supplies, gasoline, and repairs. Go south.

1.0 Cross railroad track to southern outskirts of town; turn to left (east).

6.0 Windmill on right; water. Follow best of many rutty tracks.

13.3 Blaisdell. Turn north on good macadam road. Water at Imperials Well, 0.7 mile northwest. Road to Fortuna mine goes through gate, crosses railroad, and goes south. (See p. 348.)

20.0 Dome. Post office, water, hotel, supplies, gasoline. Continue southward on macadam road. From Dome a road leads across the river to Castle Dome and other points in Yuma County.

29.9 End of macadam road. Go eastward by best track over soft valley road.

32.0 Reynolds Well. Good water on right.

33.7 House with windmill on left; good water.

34.0 Turn to left (north).

34.5 Turn to right (east).

37.2 Wellton. Post office, water, hotel, garage, supplies, gasoline. Camino del Diablo comes in on south. (See p. 338.) The main Phoenix-Yuma road branches off at this point. Continue east, keeping railroad on right.

41.5 Red hill on left of road.

50.4 Colfred. Railroad siding; heavy sand to Pembroke.

55.4 Pembroke. Water in emergencies at section house; heavy sand to Mohawk.

59.0 Mohawk. Water; limited amount of supplies, gasoline. Cuntinue east through gap. Road leads north from Mohawk to Norton. Difficult and waterless road leads south 52.5 miles to Papago Well.

59.6 Turn to right under bridge to south side of track.

59.9 Turn to left under bridge to north side of track.

61.4 Fork. Continue east along track. Road on right crosses railroad and goes south to Red Cross mine (5 miles).

66.5 Stoval. Water in emergencies at section house. Continue east along track; much drifted sand. Road to Garcia Well and Whites Well crosses railroad and goes south. (See p. 347.)

78.5 Axtec. Water from railroad well. Geological Survey sign. Continue. east along track. Road to Palomas ( 7 miles) comes in on left (north). Road to Eagle Tanks crosses track and goes southwest.

84.5 Go uphill to Sentinel basalt plain.

86.3 Stanwix. Water in emergencies at section house.

93.0 Fork. Geological Survey sign. Cross railroad and turn to left to Brown's Hotel (mile 93.5). Road on left leads from Agua Caliente; road straight ahead along track goes to Sentinel station and thence along railroad to Gila Bend. (See p. 317.)

93.5 Sentinel. Brown's Hotel and store; water, rooms, meals, supplies, gasoline. Pass in front of hotel and turn to right (southwest) across lava of Sentinel Plain.

109.7 Run off lava of Sentinel Plain across flat valley to gap in Crater Mountains.

110.2 Turn into gap.

114.7 Fork. Keep to left. Road and trail on right go to Black Tanks (1.7 miles); uncertain water.

sa Ross, C. P., op. cit. 
115.5 Turn to right (southeast) and follow along border of Crater Mountains, keeping hills on right.

120.0 Cross rock hill and deep wash into gap in hills.

120.5 Drift fence; close gate.

121.9 Drift fence; close gate.

122.6 Enter open valley; abandoned road forks to left; head toward well tower in middle of valley.

122.8 Cross bad wash.

124.4 No. 3 well; deep well ; pumping plant abandoned in 1921, and water unobtainable by travelers. Road usually obliterated by cattle tracks; turn to left at well and go southeastward up valley toward Batamote Mountains.

127.3 Turn to left along railroad track.

127.5 Reverse fork. Geological Survey sign. Turn to right and cross railroad track. Two roads come in at this fork, a faint abandoned road and the road from Gila Bend to Ajo (see p. 321), which is followed from this point into Ajo.

128.0 Batamote Well. Geological Survey sign. Good water in dug wells. Keep to right of wells.

128.9 Cross railroad.

133.8 Fork. Take left-hand road; road to right goes to Gibson, a suburb of Ajo, and is very difficult for automobiles.

134.6 Cross railroad.

135.2 Reverse fork. Geological Survey sign. Road from No. 1 well comes in on left.

135.6 Reverse fork. Old road comes in on left.

136.4 Reverse fork. Geological Survey sign. Cross railroad and turn to right in the town to Ajo railroad station (mile 136.6). Road comes in on left from Clarkstown and Tucson.

136.6 Ajo. Excellent water supply, hotels, stores, automobile supplies, gasoline, and repairs. From Ajo roads lead south to Sonoita, Sonora (see p. 410), west by Camino del Diablo to Yuma (see p. 334), and north to Gila Bend and Phoenix (see p. 323). Return to Geological Survey sign same as at mile 136.4.

136.9 Geological Survey sign. Turn to right, keeping mill of New Cornelia Copper Co. on right.

137.6 Clarkstown (Rowood post office) ; water supply, repairs, gasoline, and supplies. Continue east on Main Street.

138.7 Fork. Keep to left on improved highway. Road to right goes to Darby Well.

139.0 Fork. Turn to right. Road on left goes to Childs ranch (2.7 miles).

139.9 Road to Levy's ranch goes off on right; no well, but water can be obtained in emergencies. Go uphill.

140.1 Fork on left to Childs Well (3 miles); then fork on right to Darby Well (1.5 miles). Go southeast toward Gunsight Pass.

141.4 Fork. Old road goes off on right.

142.5 Fork. Faint road goes off on right.

143.4 Reverse fork. Keep straight on ; left-hand road comes from Childs ranch.

146.4 Fork. Geological Survey sign. Take left-land road. Road on right goes to Lewis Well (3.3 miles), good water, and Jaques ranch (5.7 miles). This detour returns to main road in 6.4 miles.

148.2 Reverse fork. Road comes in on left from Childs ranch ( 7 miles).

152.5 Crossroads. Geological Survey sign. Keep to left. Faint road on right goes to Gunsight mine. Road from Jaques ranch and Lewis Well comes in on right. 
153.5 Gunsight ranch, also called Blair's ranch. Improved highway is Pozo Blanco route to Tucson. (See p. 277.) Go through gate to Geological Survey sign. Good water in well on left. No permanent water for 58 miles by this ronte. Cross wash and bear to left, avoiding faint road which forks to right at mile 153.6 to Gunsight mine. This mine can be seen on the side of a large hill, a mile away. Road to Pozo Redondo, Charco de la Piedra, and Perigua (see p. 340) turns to left up wash from Geological Survey sign.

154.0 Fork. Geological Survey sign. Turn to left. Road on right is Cubo route. (See p. 280.)

154.1 Cross wash and faint road.

156.2 Cross wash.

156.8 Fork. Keep to left; road on right is an alternate road to Charco en Medio with no advantages.

158.9 Fork. Geological Survey sign. Turn to right.

159.2 Reverse fork. Alternate road comes in on right.

159.7 Fork. Keep to left.

161.1 Charco on right.

162.2 Charco en Medio. Summer ranchería; represo on right usually dry. Continue to east between houses and represo through gap in hills. Road to Charco de la Piedra, very faint, leads to left on west of houses. Road to Cubo goes to right on west of represo.

162.8 Small charco on left (north) of road.

163.3 Small charco on right (south) of road.

163.8 Cross difficult wash and swing to right out of gap in hills.

171.1 Three small black hilis a quarter of mile north of road.

176.1 Small charco left of road.

177.6 Faint road comes in on left.

179.1 Corner of brush fence. Follow along fence.

179.3 Reverse fork. Geological Survey sign. Turn to left around fence corner Keep house with tin roof on right to small represo of Pisinermo. Road which comes in on right at the fork is the Cubo route. (See p. 280.)

179.7 Pisinemo. Summer rancheria; small represo on the left, about 12 houses, including small church and house with tin roof. No permanent water. Keep large represo on left and go southeast.

179.9 Cross wash.

182.3 Small represo.

182.5 Corral on right.

182.9 Hardimui. Summer ranchería. Geological Survey sign. No permanent water. With houses and corral on left run near brush fence of temporal and follow along fence and then turn to left around corner of brush fence.

183.3 Geological Survey sign. Go straight ahead to southeast. Hold to main traveled road. Road on right (southwest) ieads to Comovo (5 miles). Road goes northeastward on south side of temporal to Black Butte (8 miles).

187.6 House on right; field on left.

188.0 Represo on right.

189.1 Faint road forks off on left.

190.0 Reverse fork. Geological Survey sign. Go southeast toward small hill in the plain. Road on right is Comovo route. (See p. 281.)

191.5 Cross small levee.

192.0 Houses on left. 
192.2 Copeka. Summer ranchería. Road usually obliterated by trampling of cattle. Pass between corral and hill, and turn to east. Water in pond several months a year. It should be boiled before drinking. Road learls south from west side of pond to Tonukvo (2.6 miles). By turning to right and crossing main drain of valley just north of pond and going westward toward hills an old road will be found leading to Serventi Well and Menegers Dam. (See p. 327.)

199.0 Fork. Geological Survey sign at Big Fields. Keep to right. Alternate road to Indian Oasis on left. (See p. 277.)

201.5 County sign. Keep on south side of fences of Big Fields.

201.6 County sign; bear to left.

201.9 Corral and then represo, usually dry, on right.

209.7 Pass north and to left of fence corner, then follow south of fields.

210.0 Double reverse fork. Geological Survey sign. Roads come in from Tecolote and Mexico and from James Well.

210.8 Well on right; no water obtainable.

211.2 House on right. Go between hill and fence.

211.4 Geological Survey sign.

211.5 Indian Oasis (Sells post office); United States Indian Service well on left. Presbyterian Mission on right. Meals can usually be obtained there. Good water can be obtained from Government Well, Presbyterian Mission Well, and Menegers Well near arroyo. Store is on hill on left of Geological Survey sign, 0.4 mile by road. Continue due east on main road.

211.6 Government school on right.

212.0 Artesa. Winter rancheria; well on left.

213.2 Top of rocky hill.

213.4 Fork at foot of rocky hill. County sign. Road from Topahua forks to right.

213.5 Reverse fork. Road comes in on left from Artesa Pond, a quarter of a mile; no drinking water.

213.9 Fork. County sign on left. Road from Tucsoncito comes in on right.

216.2 Cross faint road from Tucsoncito to Jeowic.

217.0 Fork. Faint road comes in on right.

217.8 Reverse fork. County sign. Road from Magdalena, Tucsoncito, and Topahua comes in on right.

218.6 Pass Papago hut on right and go downhill.

218.9 Reverse fork. Faint road comes in through fields from Jeowic.

220.3 County sign on right. Fresnal ranch on left. Well now used by United States Indian Service, and water can probably be obtained at all seasons.

222.8 Fork. Faint road on left.

225.2 Fork. Keep to left. Road on right goes to Babokuk, winter ranchería and well; water 2 miles southeast on this road.

225.7 Cross a road leading from Babokuk to temporales.

226.7 Reverse fork. County sign; go straight ahead through gate. Road comes in on right from Babokuk.

227.8 Reverse fork. Geological Survey sign. Pozo Blanco route (see p. 277) comes in on left.

228.9 San Vicente. Well, store with limited amount of supplies, no gasoline.

229.3 Crossroads. Road on left leads from Santa Rosa ranch (8.2 miles); road on right goes to Coronel (1.1 miles). A small masonry dam at this place holds water for a short time after rains. 
231.9 Faint road on right.

232.7 Fork. County sign. Keep to left, road on right goes to Coyote, winter rancheria, and well; water half a mile by this road.

232.8 Cross faint road.

233.5 Reverse fork. County sign. Road from Coyote comes in on right.

236.6 Dobbs Well on right. Water can be obtained with rope 55 feet long and bucket.

236.9 Roadside mine on left. Miners' shacks on right. Water and limited amount of supplies can be obtained here when mine is being operated.

238.7 Fork. Keep to left. Road on right goes to Alamo, winter rancheria, and well; water a quarter of a mile on this road.

238.9 Crossroads. Keep straight ahead. Road on right is second road to Alamo. Road on left goes to San Pedro, winter rancheria, and well (4 miles).

241.8 Fork. Keep to left. Road on right goes to Indian field.

243.5 Cross wash and travel on or beside graded road.

247.3 Beginning of macadam road, which continues for next 26 miles to Tucson.

247.9 Steel bridge over large arroyo.

249.5 Fork. County signpost. Stay on macadam road. Road on right to Sasabe, La Osa, and Arivaca. (For log see p. 287.)

249.6 Robles ranch. Well and good water.

251.3 Well on left.

259.0 Well on right. These wells were drilled for supplying water for road building; not certain whether they will be maintained as watering places.

262.3 Snyders Hill and quarry on right.

265.1 Reverse fork. Road from Mile Wide Copper Co. comes in on left. Thence through Robles Pass.

267.3 Quarry on right.

269.1 Crossroads. Turn to left. Road on right goes to San Xavier Mission; road straight ahead goes to Indian school and connects with valley roads.

272.3 Fork. Turn to right across bridge. Road straight ahead (north) goes to Silver Bell. (See p. 286.)

272.5 Concrete bridge over Santa Cruz River. Go eastward on Congress Street, passing station of El Paso \& Southwestern Railroad on right.

272.9 Tucson. Post office, hotels, garages, and supplies.

NORTHERN ROAD BETWEEN INDIAN OASIS AND BIG FIELDS

INDIAN OASIS TO GEOLOGICAL SURVEY SIGN AT BIG FIELDS (12.9 MILES)

[See p. 277 for $\log$ in opposite direction]

This road branches from the main road at Indian Oasis and returns to it at Big Fields. It is only about half a mile longer than the route described on pages 268 and 275 and is often in better condition. (For $\log$ from Tucson to Indian Oasis see pp. 267-268.)

61.6 Indian Oasis. Geological Survey sign. Drive north.

62.4 Cross arroyo. Menegers Well on right.

62.7 Hill and Papago houses on right; thence between fences to fence cormer. 63.0 Fence corner and fork. Turn to left (west) around fence corner. Road on right goes northwest to Iron Pipe, Quijotoa, Santa Rosa, and Casa Grande. (See p. 225.) 
66.0 Represo on right.

70.9 House on left; numerous crossroads and branches from here on. Keep fields on left and go west.

71.5 Houses on left.

72.2 Big Fields. Represo on right, usually dry. Keep houses and fields on left. Numerous minor forks and crossroads.

74.5 Reverse fork. Geological Survey sign. This is the same fork as at mile 73.9 by the main or southern route. (See p. 268.)

\section{GEOLOGICAL SURVEY SIGN AT BIG FLELDS TO INDIAN OASIS (12.9 MTES).}

[See p. 276 for log in opposite direction]

This road branches from the main Yuma-Tucson road at the Geological Survey sign just west of Big Fields and goes north of the temporales and houses to Indian Oasis. It is 0.6 mile longer but is often in better condition. (For log from Yuma to Big Fields see pp. 272-275.)

199.0 Fork west of Big Fields. Geological Survey sign. Keep to left, avoiding numerous minor forks and crossroads and keeping houses and fields on right. Route on right is the main or southern route.

201.3 Big Fields. Represo on left, usually dry.

202.0 Houses on right. Avoid numerous minor forks and crossroads. Keep fields on right.

202.6 House on right.

207.5 Represo on left.

210.5 Fence corner and reverse fork. Turn to right and go south between fences. Road from Iron Pipe, Quijotoa, Santa Rosa, and Casa Grande (see p. 325) comes in on left.

210.8 Hill and Papago houses on left.

211.1 Cross arroyo. Menegers Well on left.

211.9 Indian Oasis. Geological Survey sign. This is the same point as mile 211.3 on the main route. (See p. 275.)

\section{POZO BLANCO ROUTE}

\section{TUCSON TO AJO (126.6 MILES)}

[See pp. 278-279 for log in opposite direction] !

The Pozo Blanco route turns off the main road from Tueson to Ajo at the north end of Baboquivari Mountains and returns near Gunsight ranch. It is somewhat more hilly and in wet weather more passable than the old main road. Its principal advantage lies in the facts that the watering places are wells and that it has been recently improved. (For detailed log of road from Tucson to fork of Pozo Blanco route see p. 267.)

0.0 Tucson.

23.3 Robles Well.

36.3 Dobbs Well.

44.0 San Vicente.

45.1 Fork. Beginning of Pozo Blanco route. Geological Survey sign. Take right-hand road; left-hand road is old main road by way of Indian Oasis.

47.6 Fence corner; follow along north side of fence.

50.5 Fork. Road on right to Compartidero represo and Santa Rosa ranch, doep well. 
51.2 Gate. Turn to left through gate and then to right along south side of fence. Go to south of isolated Woods Hill into gap.

54.4 Comobabi. Winter ranchería, in pass between North Comobabi and South Comobabi mountains; two dug wells and village south of road. Proceed west along northern border of South Comobabi Mountains.

55.0 Divide. Go west.

59.4 Fork; keep to right. This and next road go to Cobabi, winter ranchería, dug well.

61.0 Fork ; keep to right.

62.0 Crossroads. Continue west. This and next two roads go to Cobabi and near-by mines.

64.9 Crossroads.

65.3 Crossroads.

68.6 Fields and houses on right for next half mlle.

70.3 Sikulhimakt. Represo inside of mesquite corral in center of Santa Rosa Valley. Go west on north side of represo. Road from Casa Grande to Tecolote and Mexico goes through this place.

71.1. Small represo on left. Follow main traveled road to west and northwest, avoiding numerous roads turning west to Horseshoe, Quijotoa post office.

76.3 Well. Most easterly well of village of Covered Wells.

76.7 Well.

78.1 Spears's store. Water, gasoline, oil, and supplies.

78.6 West wells of Covered Wells. Two dug wells, firm, hard road, hilly to Pozo Blanco. Avoid fork on right. (See p. 309.)

83.5 Pozo Blanco. Winter rancheria; well on right hand in corrals; water good but should be boiled. Go west toward gap on right hand (north) of large black hill. Road to Pisinemo goes off on left between houses and passes south of large black hill.

84.1 Reverse fork. Road comes in on right from Brownell and Black Prince mine.

85.1 Fork. Geological Survey sign. Take road on left across valley to small conical butte called Ninemile Peak; road on right leads to unnamed temporales and thence to Perigua.

89.6 Crossroads just east of abandoned temporal. Continue west.

93.2 Cross main drain of Quijotoa Valley. Small charco on right; abandoned temporal on left. New graded road begins near this point.

101.8 Ninemile Peak on left.

105.2 Reverse fork. Geological Survey sign. Charco en Medio route comes in on left.

106.3 Reverse fork. Alternate road from Charco en Medio comes in on left.

109.1 Reverse fork. Geological Survey sign. Cubo route comes in on left. From here road is same as that given in $\log$ of main route.

111.1 Gunsight ranch.

126.6 Ajo.

AJO TO TUCSON (126.4 MrLES)

[See pp. 277-278 for log in opposite direction]

The Pozo Blanco route turns off the old main road from Ajo to Tucson near Gunsight ranch and returns at the north end of the Baboquivari Mountains. It is somewhat more hilly and in wet weather more passable than the main road. Its principal advantage lies in the fact that the watering places are wells and thus more dependable in very dry weather. (For detailed log of road from Ajo to fork of Pozo Blanco route see pp. 273-274. 
0.0 Ajo.

16.8 Gunsight ranch.

17.3 Fork. Geological Survey sign. Cubo route comes in on left. (See p. 280.)

20.1 Fork. Keep to right. Road on left is alternate road to Charco en Medio.

21.2 Fork. Geological Survey sign. Keep to left. Main route through Charco en Medio on right.

25.2 Ninemile Peak on right.

35.1 Cross main drain of Quijotoa Valley. Small charco on left; abandoned temporal on right.

36.7 Crossroads just east of abandoned temporal ; continue east.

42.2 Reverse fork. Geological Survey sign. Keep straight on. Road on left leads from unnamed temporales and Perigua.

43.1 Fork. Keep to right. Road to right goes to Black Prince mine and Brownell.

43.7 Pozo Blanco. Winter ranchería. Well on left in corrals. Water good but should be boiled. Continue east through pass. Road from Pisinemo comes in on right.

47.3 West wells of Covered Wells. Keep wells on right and follow down rocky valley with scattered houses.

48.5 Spears's store. Water, gasoline, oil, and supplies.

49.9 Well.

50.3 Well. Most easterly well of village of Covered Wells. Avoid roads to left and turn southwest over gravelly slopes, then avoid several forks to right, which lead to Horseshoe, Quijotoa post office.

55.5 Small represo on right.

56.3 Sikulhimakt. Represo inside of mesquite corral in center of Santa Rosa Valley. Go east through abandoned fields toward pass between North Comobabi and South Comobabi mountains. Road from Casa Grande to Tecolote and Mexico goes through this place.

57.5 Fields and houses on left for next half mile.

61.3 Crossroads. Continue east. This and next two roads go to Cobabi, winter rancheria and dug well, and near-by mines.

62.7 Crossroads.

64.6 Crossroads.

65.6 Reverse fork. This and next road come from Cobabi.

67.2 Reverse fork.

71.6 Divide. Go down slope.

72.2 Comobabi. Winter ranchería in pass between North and South Comobabi Mountains; two dug wells and village south of road. Turn southeast toward north end of Baboquivari Mountains; road later turns east, sonth of isolated Woods Hill, and runs along south side of fence.

75.4 Turn to left through gate and go along north side of fence.

76.1 Fork. Keep along fence; road on left to Compartidero and Santa Rosa ranch.

79.0 Fence corner; turn to right.

81.5 Reverse fork. Geological Survey sign. From here the route is the same as the old main route. (See p. 275.)

\subsection{San Vicente.}

90.3 Dobbs well.

108.3 Robles well.

126.6 Tucson. 


\section{CUBO ROUTE \\ TUCSON TO AJO (138.7 MILES 60)}

[See below for $\log$ in opposite direction]

After passing through Indian Oasis and Copeka one may go from Pisinemo by way of Cubo to Gunsight ranch. This route is slightly better in dry weather and because it passes close to Walls Well the distance without water is 3 miles less. In wet weather the main drain of Quijotoa Valley on this route is alnost impassable for automobiles because of mud. (For detailed $\log$ of road from Tueson to Pisinemo see pp. 267-269.)

0.0 Tucson.

61.4. Indian Oasis. Nearest permanent water is Walls Well, 55 miles by this route.

80.7 Copeka.

90.0 Hardimui.

93.2 Pisinemo.

93.6 Fork at corner of brush fence. Geological Survey sign. Take left-hand road; right-hand road is Charco en Medio route.

96.4 Cross main drain of valley; steep clay banks, difficult in wet weather.

103.3 Small charco on right.

105.1 Small charco on right.

106.7 Reverse fork. Continue west into gap in hills. Geological Survey sign. Comovo route comes in on left. Second road comes in on left (south) from Charco Colorado, and Menegers Dam. (See pp. 333-334.)

107.2 Cubo. Charco on left; water for only a short period after rains; houses and corral on right. Continue west with field on left; then between fences. Road to Charco en Medio goes to right (east) of corral. (See p. 331.)

109.6 Reverse fork. At west end of gap. Geological Survey sign ; turn to right. Road on left comes in from Cochibo and Menegers Dam. (See p. 333.)

115.0 Faint road comes in on left.

115.4 Cross rocky gap.

115.6 Fork. Geological Survey sign. Left-hand road leads to Walls Well, nearest water 1 mile by this road; keep to right.

116.1 Cross a road from Walls Well to mining claims.

116.5 Reverse fork. Geological Survey sign. Road comes in on left from Walls Well.

121.4 Reverse fork. Geological Survey sign. Pozo Blanco and Charco en Medio routes come in on right.

121.9 Gunsight ranch.

138.7 Ajo.

\section{AJO TO TUCSON (138.7 MILES)}

[See above for $\log$ in opposite direction]

After passing through Gunsight ranch one may go to Indian Oasis by way of Cubo. This route is usually slightly better in dry weather, and because it passes close to Walls WeH the distance without water is 3 miles less. In wet weather the main drain of Quijotoa Valley on this route is almost impassable for automobiles because of mud. (For detailed $\log$ of road from Ajo to Gunsight ranch see p. 273,)

${ }^{60}$ Distance from Gunsight ranch to Ajo by new road is 15.5 miles, or 1.3 miles less than distance given. 
136.7 A jo.

153.5 Gunsight ranch.

154.0 Fork. Geological Survey sign. Keep to right. Road on left is main route by way of Charco en Medio (see p. 272) and Pozo Blaneo route (see p. 279).

158.9 Fork. Geological Survey sign. Keep to left. Road on right goes to Walls Well; nearest water 1 mile by this road.

159.3 Crossroad from Walls Well to mining claims.

159.8 Reverse fork. Geological Survey sign. Road from Walls Well comes in on right.

160.0 Cross rocky gap and go southeastward along eastern margin of Barajita Valley. Numerous charcos along road.

160.4 Faint road on right.

165.8 Fork. Geological Survey sign. Turn to left into gap in hills and proceed through and alongside of fields. Road on right goes to Cochibo and Menegers Dam.

168.2 Cubo. Charco on right; water for only a brief period after rains; houses and corral on left. Continue east from end of charco; hills and small field on right. Road to Charco en Medio goes north on east side of corral. (See p. 331.)

168.7 Double fork. Geological Survey sign. Keep to left. Middle road is Comovo route (see below); road on right (south) goes to Charco Colorado and Menegers Dam (see p. 332).

170.3 Small charco on left.

172.1 Small charco on left.

179.0 Cross main drain of valley; steep clay banks, difficult in wet weather.

181.8 Reverse fork at corner of brush fence. Geological Survey sign. Follow south side of brush fence, keeping house with tin roof on right, to small represo. Road which comes in on left is main route by way of Charco en Medio.

182.2 Pisinemo. Same as mile 179.7 by the old main route, (For detailed log see pp. 274-276.)

185.5 Hardimui.

194.7 Copeka.

214.0 Indian Oasis.

275.4 Tucson.

COMOVO ROUTE

TUCSON TO AJO (137.8 MILES 62)

[See p. 282 for $\log$ in opposite direction]

After passing through Indian Oasis and Copelza, one may go by way of Comovo to Cubo and the Gunsight ranch. This is really a variation on the Cubo route. It is little used because it is sandy between Copeka and Comovo, but in wet weather it has many advantages. (For $\log$ of route from Tucson to Indian Oasis see pp. 266-268.)

0.0 Tucson.

61.4 Indian Oasis. By this route the nearest permanent water to Indian Oasis is Walls Well (58.2 miles).

80.7 Copeka.

Distance from Gunsigbt ranch to $\mathrm{Ajo}$ is now 15.5 miles, or 1.3 miles less than distance given. 
82.9 Fork. Geological Survey sign. Turn to left across wash. Road on right goes to Pisinemo, main and Cubo routes. (See pp. 268, 270.)

83.7 Fence corner of Indian field on right.

87.6 Cross a road.

90.6 Double reverse fork. On right wooden cross on adobe platform." Go to right of pond toward white church. This fork is in a sandy area, and wheel ruts are usually obliterated by cattle. Roads go from here to Hardimui (5 miles) and Pisinemo (5.7 miles).

90.8 Comovo. Water in pond for several months during the year; should be boiled before drinking. Road obliterated by trampling of cattle; church and corral on left. Go west toward north end of Mesquite Mountains. Road to Mesquite Tank, Menegers Dam, and Mexico goes south from corral. (See p. 329.)

95.2 Hills of northern border of Mesquite Mountains follow on northwest side of hills.

104.7 Reverse fork. Geological Survey sign. Cubo route comes in on right. Road comes in from south slightly before Cubo route. It leads from Menegers Dam and Charco Colorado. (See p. 332.)

104.8 Field on left.

105.3 Cubo. From this point follow log given on page $\mathbf{3 4 8}$ to Gunsight ranch. 120.0 Gunsight ranch.

137.8 Ajo.

\section{AJO TO TUCSON (137.8 MIIES)}

[See pp. 281-282 for log in opposite direction]

After passing through Gunsight ranch and Cubo one may go by way of Comovo to Copeka and Indian Oasis. This is really a variation on the Cubo route. It is little used, because it is sandy between Comovo and Copeka, but in wet weather it has many advantages.

136.7 Ajo.

153.5 Gunsight ranch. Follow log on page 281 to Cubo. 168.2 Cubo.

168.7 Double fork. Geological Survey sign. Take middle road due east. Left-hand road is Cubo route (see p. 280), and right-hand road goes to Charco Colorado and Menegers Dam (see p. 332).

173.1 Northeast point of Mesquite Mountains. Go east to village visible across the plain.

182.6 Comovo. Water in pond for several months during the year; should be boiled before drinking. Road obliterated by trampling of cattle. Turn to left at church and go north of represo to a wooden cross on adobe platform near fork. Road to Mesquite Tank, Menegers Dam, and Mexico goes south from corral. (See p. 329.)

182.8 Double fork. Take right-hand road along base of Copeka Mountains. Middle road goes to Hardimui ( 5 miles) and road on left to Pisinemo (5.7 miles).

185.8 Crossroad.

189.7 Fence corner of Indian field on left.

190.5 Reverse fork. Geological Survey sign. Go southeast toward small sandy hill. This is Tueson-Yuma road, main and Cubo routes. Follow $\log$ on p. 274.

192.7 Copeka.

212.0 Indian Oasis. For detailed $\log$ of route from Indian Oasis to Tucson

273.4 Tucson. see pages $275-276$. 


\section{TUCSON-NOGALES HIGHWAY}

\section{TUCSON TO NOGALES (69.2 MHLES)"}

[See p. 284 for $\log$ in opposite direction]

Routes from Tucson to Nogales follow Santa Cruz Creek to Calabasas and thence go up Potrero Creek to Nogales. By cooperation between Pima County, Santa Cruz County, and the State of Arizona a well-graded and macadamized road was under construction in 1917. The $\log$ here presented was made before construction was complete, and certain details are now obsolete. The road is well marked, however, and wells will be found every few miles. Before the completion of the road it was a common practice to go to Nogales hy way of Mineral Hill and Twin Buttes. This rond and its junction with the Tucson-Nogales Highway is described on page 285 .

0.0 Tucson. Post office, water supply, hotels, garages, all supplies and re-

- pair parts. Go south from post office on Stone Avenue and at edge of town take macadam road going south.

2.9 Cross railroad, avoiding road on left.

5.0 Turn to left and then to right and follow railroad on west side.

11.5 Cross railroad to east side.

16.3 Turn sharply to right and then to left.

20.3 Sahuarito. Road comes in from west side of valley and Twin Buttes. (See p. 285.)

25.6 Cross to west side of railroad to Canoa ranch. Follow railroad.

29.4 Turn to right and cross Santa Cruz River.

30.4 Come into road on west side of valley and turn to left (sonth). Road on right comes from Twin Buttes. (See p. 285.)

37.4 Store and well. Crossroads. Keep straight on south. Road on right goes to Ward and other points in Sierrita Mountains. Road on left goes to Agua Caliente in Patagonia Mountains.

39.5 Fork. Keep to left. Right-hand road is northern road to Arivaca. (See p. 289.)

39.7 Reventon ranch.

40.1 Amado. Fork. Keep to right. Right-hand road goes to Arivaca. (See p. 289.)

41.2 Fork. Keep to right; road on left goes east to railroad.

42.6 Fork. Keep to right. Road on left goes to ranch in valley.

46.9 Tubac. Post office, numerous wells, stores. Go to left of church, turn, and keep post office on left.

48.7 Store and well. Avoid road that goes to left and continue south.

50.0 Tumacacori Mission on left. Water can he obtained from caretaker.

50.7 Beginning of graded road as completed in 1917.

51.5 House and wells on both sides of road for next 2 miles.

54.3 Schoolhouse on left.

59.2 Well on left.

60.4 Calabasas Store. Well on left.

61.9 Reverse fork and bridge across Potrero Creek. Road from Arivaca by way of Montana mine comes in on right. (See p. 291.)

63.4 Saxton Dairy. Well and good water.

63.9 Cross bridge and go through lane between rows of willow trees.

65.9 Ranger station and well on left. The forest ranger located here will give detailed information on roads in the mountains to the west.

66.2 Benedict railroad station on left. 
66.5 Monte Carlo Dairy on right. Well and good water.

68.0 Reverse fork.

68.4 Cross bridge over Potrero Creek.

69.1 Turn to right into Main Street, Nogales.

69.2 Nogales. Post office, water supply, hotels, garages, and supplies of all kinds.

\section{NOGALES TO TUCSON (69.2 MIIES)}

[See pp. 283-284 for log in opposite direction]

0.0 Nogales. Go north on Main Street.

0.1 Turn to right and cross railroad tracks.

0.2 Turn to left in front of Santa Cruz courthouse.

0.8 Cross bridge over Potrero Creek.

1.2 Fork. Turn to right and follow well-graded State highway.

2.7 Monte Carlo Dairy on left. Well and good water.

3.0 Benedict. Railroad station on right.

3.3 Ranger station and well on left. The forest ranger located here will give detailed information on roads in mountains to west.

4.5 Beginning of lane between rows of large willows.

5.3 Cross bridge.

5.8 Saxton Dairy. WeH and good water.

7.3 Cross bridge. Fork; keep to right along valley on graded road. Road to left is the Nogales-Arivaca road by way of Montana mine. (See p. 291.)

8.8 Calabasas store. Well on right.

10.0 Well on right.

14.9 Schoolhouse on right.

15.7 Houses and wells on both sides of roads for next 2 miles.

18.5 End of graded road as completed in 1917.

19.2 Tumacacori Mission on right. Water can be obtained from caretaker.

20.5 Store and well. Avoid road that goes to right and continue north.

22.3 Tubac. Post office, numerous wells, store. There are wells at each house north and south of the town. Turn to left at post office and then to right in front of church.

26.6 Fork. Keep to left. Road on right goes to ranch in valley.

28.0 Fork. Keep to left. Road on right goes east to railroad.

29.1 Amado. Fork. Keep to right. Left-hand road goes to Arivaca. (See p. 289.)

29.5 Reventon ranch.

29.7 Fork. Keep to right. Left-hand road goes to Arivaca. (See p. 289.)

31.8 Store and well. Crossroads. Keep straight on north down valley. Road on right goes to Agua Caliente in the Patagonia Mountains. Road on left goes to Ward and other points in the Sierrita Mountains.

38.8 Fork. Turn to right and cross Santa Cruz Creek to State highway on east bank. In 1917 the best crossing was 3 miles farther north. Follow on west side of railroad. Left-hand road goes north on west side and crosses at Sahuarito to rejoin this road at mile 48.9. (See p. 285.)

43.6 Cross to east side of railroad and follow well-graded road into Tucson.

48.9 Sahuarito. Road from west side of valley and Twin Buttes comes in on left. (See p. 285.)

52.7 Turn sharply to right and then to left.

57.7 Cross railroad and follow on west side of it.

63.7 Turn to left (west) and then to right (north).

66.3 Cross railroad and go north into city.

69.2 Tucson, 


\section{TUCSON-NOGALES ROAD BY WAY OF SAN XAVIER AND TWIN BUTTES}

\section{TUCSON TO NOGALES (75.3 MILES)}

[See p. 286 for $\log$ in opposite direction]

This road consists of an excellent graded highway to San Xavier Mission and a good desert road to Twin Buttes, from which it connects with the TucsonNogales Highway by two routes. Before construction had progressed so far on the Tucson-Nogales road this route was often preferred. The distances given are measured from the map.

0.0 Tucson. From the post office go north to Congress Street, then west, passing El Paso \& Southwestern Railroad station on left.

0.4 Santa Cruz River.

0.6 Come into north-south road. Turn to left along base of Sentinel Hill. Right-hand road goes to Silver Bell. (See p. 286.)

3.8 Crossroads. Continue south. Road on right (west) is Tucson-Yuma road; road on left (east) goes to Indian school and connects with valley roads.

7.2 Crossroad. Continue straight ahead. This is road from the valley to Robles ranch, 18 miles.

9.2 Graded road; turn to left (east) at this point to San Xavier del Bac at mile 9.6. Besides the church there is a small Papago village, wells, and the United States Indian Service agency. From San Xavier a road runs south to Sahuarito. However, there are so many crossroads and turnouts that persons without much local experience get lost. Continue south from turn at mile 9.2, avoiding roads that fork to left.

12.1 Fork at foot of black buttes; take left-hand road toward whitish hill about 8 miles across the plain to the west of south. Koad on right goes to numerous prospects in Sierrita Mountains and to Stevens, 22 miles, where there is good water.

20.1 Mineral Hill. Several mines in vicinity; water from wells, store, and gasoline, when mines are being worked. A road goes east to Sahuarito, 9 miles. From the store at Mineral Hill go southwest and then southeast over good road, which has, however, many short, steep grades and pitches. There are many prospects along this road, the branch roads to which are not shown on the map.

21.9 Fork. Take left-hand road to Twin Buttes, easily visible; right-hand road goes along east face of Sierrita Mountains.

27.0 Twin Buttes. Mine, connected with Santa Cruz Valley by short railroad; post office, store, gasoline, water supply when mine is being operated. Fork just east of town; take right-hand road going south of railroad; left-hand road goes to Sahuarito ( 7 miles).

31.5 Reverse fork. Come into north-south road in Santa Cruz Valley; from this point turn south toward Nogales; the road on left (north) goes to Sahuarito (5 miles).

36.5 Reverse fork. Come into Tucson-Nogales Highway ; continue south. This is mile 30.4 out of Tucson and is 38.8 miles from Nogales. (For $10 \mathrm{~g}$ into Nogales see p. 283.)

75.3 Nogales. 


\section{NOGALES TO TUCSON (75.3 MILES)}

[See p. 285 for $\log$ in opposite direction]

0.0 Nogales. Follow Nogales-Tueson Highway, log of which is given on page 284 .

38.8 Fork. Take left-hand ungraded road north; graded road turns to right and reaches Tucson in 30.4 miles.

43.8 Fork. Take left-hand road northwest; right-hand road goes north to Sahuarito and joins Tucson-Nogales Highway in 5 miles.

48.3 Reverse fork on east of Twin Buttes. Road from Sahuarito ( 7 miles) comes in on right. Go through town, which, when mine is running, has a post office, water supply, store, and gasoline, and go northwest over good road, which has, however, many short, steep grades and pitches.

53.4 Reverse fork. Road comes in on left. There are many prospects between this point and Mineral Hill, but the branch roads are not shown on the map.

55.2 Mineral Hill. Water from wells, store, and gasoline when mine is being worked. A road goes east from this point to Sahuarito (9 miles). Go slightly east of north over open plain to black buttes.

63.2 Reverse fork at foot of buttes. Road from Stevens and from numerous prospects in the Sierrita Mountains comes in on left. Stevens is 22 miles distant and has good water.

66.1 Fork. Come into graded road and go north; the graded road turns east to San Xavier del Bac at mile 66.5. Besides the church there is a small Papago village, wells, and the United States Indian Service agency.

68.1 Crossroads; continue north. This is road from the valley to Robles ranch, 18 miles.

72.5 Crossroads. Continue north around foot of Sentinel Hill. Road on right goes to Indian school and connects with valley roads; road on left is Tucson-Yuma road. (See p. 266.)

74.7 Fork. Turn to right (east) into Tucson; road straight ahead goes to Silver Bell. (See below.)

74.9 Cross concrete bridge over Santa Cruz River and go east on Congress Street.

\subsection{Tucson.}

\section{SILVER BELL ROAD}

The road from Tucson to Silver Bell is an important route which, because of the rapid development of the country, has undergone a number of changes in position. It was not traversed during this survey. The position as given on the map is, for the first 20 miles, the route surveyed by the county engineer. West of the Tueson Mountains the position is that given by township plats.

The Silver Bell road turns off to the north from the Tucson-Yuma road, 0.6 mile from the post office at Tucson. (See $\log$ on $p .266$.) It follows the west side of Santa Cruz Valley for 13 miles. About 9 miles out a road turns off to the left (west) through a gap in the Tucson Mountains and goes to Silver Bell by way of the gap between the Silver Bell and Waterman mountains. The character of this road is not known. The usual route continues for 4 miles down the valley and then turns west through a gap in the mountains, which are at this point rather narrow. West of the gap $4 \frac{1}{2}$ miles and about 20 miles out of Tucson the road forks. The right-hand road goes north of Silver Bell Mountains by way of Valenzuela and then crosses the railroad and turns south to the town. The exact location of this road was not obtained, but such roads as 
appear on township plats are shown on Plate IV. The left-hand road erosses Avra Valley to a well on the south side of the Silver Bell Mountains. Thence it goes through the gap between these mountains and the Waterman Mountains and turns north to Silver Bell. The total distance from Tucson to Silver Bell is about 40 miles.

\section{ROUTES IN AND TO THE ALTAR VALLEY}

There are three routes inta Altar Valley. The first of these runs from Tucson to Robles ranch and thence south along the axis of the valley to Sasabe, and the log is given under the name Tucson-Sasabe road. In 1921 a graded highway was under construction from Robles ranch south. The second route ascends the valley of Sopori Creek from the Tucson-Nogales road in Santa Cruz Valley to Arivaca and goes thence into Altar Valley. This is the oldest route, and the $\log$ is given under the name Arivaca road. The third route crosses the Pajarito Mountains from Nogales to Arivaca and the log is given under the name Nogales-Arivaca road.

\section{TUCSON-SASABE ROAD (70.9 MTLES) \\ TUCSON TO SASABE}

[See p. 288. for $\log$ in opposite direction]

Follow the Tucson-Yuma road through Robles Pass to Robles ranch over good macadam road. (For detailed $\log$, see p. 267.)

0.0 Tucson.

23.3 Robles ranch.

23.4 Fork. County sign. Turn to left (south) over fair road, crossing numerous washes. Road on right is Tucson-Yuma road. (See p. 267.)

28.6 King Well. House, corrals. Oeep well and pumping plant, iron tanks. 29.6 Hayfield on right in bottom land.

31.9 Anvil Ranch. Two deep wells and pumping plant. From this ranch roads run to Leon and Redondo. Go south, keeping left of wire fence.

33.9 End of fence. A road on left leads to Sierrita Mountains.

34.5 Bluffs on left.

36.1 Ruined house on right.

38.7 Palo Alto. Deep well and pumping plant on right, large iron tanks. Store on left.

39.4 Go through fence.

39.5 Represo on right.

40.4 Fork. Keep to right on graded road.

41.2 Fork. Keep to left on graded road.

41.7 Turn sharply to right (west) and cross main arroyo of valley.

42.6 Fork. Keep to right. Left-hand road goes to Espinoso Well (2.5 miles), Pozo Nuevo (4 miles), and Secundino Well (10 miles).

42.7 Crossroads. Keep straight on. This road goes to Otero ranch and Contreras.

48.6 Crossroads. Continue southwest. This is road from Pozo Nuevo to Ronstadt ranch. Going west on this road the first right-hand turn goes to Brown Well ( 4 miles). Taking the left-hand turn two valleys are crossed and then there is a fork in the third valley. The right-hand turn goes to Schaefer Well (9 miles) and Baboquivari mine (10 miles). These places are in a canyon which heads at the foot of Baboquivari Peak. The left-hand turn goes to Ronstadt ranch (10 miles).

$104211-25-20$ 
53.8 Reverse fork, at fence corner. Turn to right. Road comes in from Secundino Well ( 3 miles).

54.0 Fork. Wooden signboard. Keep to left. By right-hand road it is 0.9 mile to gate in north-south fence called the Ronstadt gate. From this gate go west 5.7 miles to forlss on edge of bluff. Down the bluff to the right 0.3 mile is the Ronstadt ranch and wells. Continue west through fence 1.3 miles to Las Moras ranch, headquarters of the La Osa Land \& Cattle Co.

55.0 Crossroads. Continue south. This is the road from Ronstadt gate to Figueroa ranch (5.5 miles). It is part of the direct route from Arivaca to Las Moras ranch. (See p. 289.)

55.9 Fork on south side of gate. Keep to right.

57.0 Numrerous crossroads in next mile.

59.5 Gate. Go through and follow south along west side of north and south fence.

61.5 Crossroads at fence corner. Continue south. This is road from Las Moras ranch to Buenos Aires Well and Aguirre Lake. It is 8 miles to Las Moras and 1.1 miles to Buenos Aires Well.

62.0 Fork. Keep straight ahead. Road on left is second road to Buenos Aires Well.

66.0 Fork. Keep to left. Right-hand road leads to La Osa, post office, water and store (2.5 miles).

68.5 Fork at gate. Go through gate.

68.6 San Fernando. Water, store, and United States customhouse. Road crosses into Mexico from San Fernando and is often preferred to the old road through Sasabe. Return to gate.

68.7 Gate. Turn to right (east) along fence to go to Sasabe. Road on left (west) comes from La Osa (1.6 miles).

70.7 Reverse fork. Go south between fences. Foad comes in from Garcia ranch and Arivaca.

70.9 Sasabe. A store on the boundary line; well three-tenths of a mile west.

\section{SASABE TO TUCSON (70.9 MILES)}

[See pp. 287-288 for log in opposite direction]

0.0 Sasabe, store on the boundary line; well 0.3 mile west.

0.2 Fork. Turn to left. Road on right goes to Garcia ranch and Arivaca. (See p. 292.) On account of fences travelers to Arivaca should go by route of this $\log$ to Buenos Aires and thence follow $\log$ on page 290 .

2.2 Gate and fork. Turn through gate.

2.3 San Fernando. Water, store, and United States customhouse. Road crosses into Mexico from San Fernando and is often preferred to the old road through Sasabe. Return to gate.

2.4 Go north. Road on left (west) leads to La Osa, post office, water, store (1.6 miles). Road on east (right) leads to Sasabe ( 2.2 miles).

4.9 Reverse fork. Road comes in on left from La Osa (2.5 miles).

8.9 Fork. Keep straight ahead. Road on right goes to Buenos Aires Well (1.2 miles) and thence to Figueroa ranch and Arivaca. (See p. 290.)

9.4 Crossroads. Keep straight ahead and follow west side of north and south fence. Road on right is second road to Buenos Aires. Road on left leads to Las Moras ranch and well (8 miles).

11.4 Gate. Go through and turn northeast.

12.9 Numerous crossroads in next mile.

15.0 Reverse fork on south side of gate. Go through gate. 
15.9 Crossroads. Keep straight ahead. This is road from Arivaca to Ronstadt gate and Las Moras. (See p. 290.)

16.9 Reverse fork. Wooden signboard. Road on left comes in from Ronstadt gate $(0.9$ mile). From this gate it is 5.7 miles to a fork on the edge of a bluff. Down the bluff to the right 0.3 mile is the Ronstadt ranch and well. Continue to left (west) through fence 1.3 miles to Las Moras ranch and well, headquarters of the La Osa Land \& Cattle Co.

17.1 Fork. Keep to left. The right-hand road goes to Secundino Well (3 miles).

22.3 Crossroads. Continue northeast. This road is from Pozo Nuevo to Ronstadt ranch and other places in the vicinity.

28.6 Crossroads. Keep straight on. This road goes from Espinoso Well to Otero ranch and Contreras.

28.7 Reverse fork. Turn to right and cross main wash. Right-hand road comes from Espinoso Well (2.5 miles), Pozo Nuevo (4 miles), and Secundino Well (10 miles).

29.2 Turn to left and follow down valley under bluffs.

29.7 Reverse fork.

30.5 Reverse fork.

31.4 Represo on left.

31.5 Go through fence.

32.2 Palo Alto. Deep well and pumping plant on left. Store on right.

34.8 Ruined house on left.

37.0 Follow east side of fence. Road on right to the Sierrita Mountains.

39.0 Anvil ranch. 'Two deep wells and pumping plant. Road leads from Anvil ranch to Leon and Redondo.

41.3 Hayfield on left.

42.3 King Well. House, corral, and deep well and pumping plant.

47.5 Reverse fork. County sign. Turn to left on main Yuma-Tucson road.

47.6 Robles ranch. For detailed log into Tucson see page 276.

70.9 Tucson.

\section{ARIVACA ROAD}

\section{AMADO TO RONSTADT GATE (33.6 MIEEB)}

[See pp. 290-291 for $\log$ in opposite direction]

This road starts from Santa Cruz Valley at its junction with Sopori Creek. Two roads lead up Sopori Creek, one on the north bank and the other on the south bank. The distance is virtually the same by either, but the south road was usually traveled in 19i7. The junction of the north road with the TucsonNogales road is 39.5 miles from Tucson and 29.7 miles from Nogales. The junction of the south road is 40.1 miles from Tucson and 29.1 miles from Nogales. The road "was not traversed between Sopori Junction and Arivaca, and distances are given as measured on the map for this part of the road. There are doubtless many more branch roads than are shown on the map.

0.0 Amado, by southern road.

4.0 Cross creek to north side and join northern road.

11.0 Moyza Well. Fork. Take right-hand road; left-hand road follows creek. Distance is 2 miles farther and there are numerous gates.

14.0 Fork. Keep to left past Tajo mine. Cerro Colorado mine is about 1 mile north of road at foot of Cerro Colorado Mountains. Road on right goes to Moreno ranch ( 5 miles). 
17.0 Reverse fork. Road comes in on right. This road goes north of the Guijas Mountains to Conte ranch (1 mile) and Robledo ranch (5 miles). Thence down Guijas Wash to Martinez ranch (6.5 miles) and to Secundino Well in the Altar Valley (10.5 miles).

19.8 Reverse fork.

21.0 Arivaca. Post office, water, supplies, hote, stores, gasoline. (For other roads out of Arivaca see p. 292.) To reach Altar Valley go west along main street, turn sharply to right at last house, and go west along north side of Arivaca Creek.

22.3 Go over rocky knoll.

23.0 Fork. Keep to right along bluff.

23.6 Go over rocky knoll.

24.2 Go up onto gravel bench.

24.9 Road on left leads to ranch house.

25.3 Go into creek and follow creek bed for eight-tenths of a mile. There is usually water in this part of the creek.

28.1 Figueroa ranch. No well here; water in emergencies only. Go west into valley.

28.7 Fork. Take right-hand road along south side of fence. Left-hand road is described in the log on page 292 .

29.9 Turn corner and go north through lane.

30.9 Go northwest.

33.6 Ronstadt gate. From this gate all points in Altar Valley can be reached. (See log of Tucson-Sasabe road, p. 287.)

\section{RONSTADT GATE TO AMADO (33.6 MTIES)}

[See pp. 289-290 for log in opposite direction]

This road runs from the Ronstadt gate, a central point in the Altar Valley (see p. 287), to the Santa Cruz Valley by way of Arivaca and Sopori Creek.

0.0 Ronstadt gate. For other roads from this gate see page 288. Go southeast.

0.7 Crossroads. Continue straight ahead. This is the Tucson-Sasabe road.

2.7 Turn south in lane between fences.

3.7 Turn east along fence.

4.9 Reverse fork. Cross valley. Road on right comes in from Aguajita (4.8 miles) and Buenos Aires (7.4 miles). (See p. 292.)

5.5 Figueroa ranch. No well here; water in emergencies only. Go east up Arivaca Creek.

7.5 Go into creek and follow creek bed for eight-tenths of a mile. There is usually water in the creek here.

8.7 Road on right goes to ranch house.

10.0 Go over rocky knoll.

10.6 Reverse fork.

11.3 Go over rocky knoll.

12.6 Arivaca. Post office, water supply, hotel, stores, gasoline. (For other roads out of Arivaca see p. 292.) Continue east.

13.8 Fork. Take left-hand road; road on right goes to Arivaca ranch and then down Sopori Creek and rejoins this road at Moyza. The distance is 2 miles farther and there are numerous gates. 
16.6 Fork. Keep to right; road on left goes north of the Guijas Mountains to Conte ranch ( 1 mile) and Robledo ranch $(5$ miles), thence down Guijas Wash to Martinez ranch (6.5 miles) and Secundino Well in Altar Valley (10.5 miles).

19.6 Reverse fork. Road on left comes in from Moreno ranch (5 miles); Cerro Colorado mine is about 1 mile north of road at foot of Cerro Colorado Mountains.

22.6 Moyza Well. Reverse fork. Follow northeastward down valley of Arivaca Creek. Road from Arivaca by way of Arivaca ranch and Papalote Well comes in on right.

29.6 Fork. Take right-hand road and cross over to south side of creek. Lefthand road follows north side and is about the same distance, but south side was preferred in 1917 .

33.6 Amado. Reach the main Tucson-Nogales road at mile 40.1 from Tucson and mile 29.1 from Nogales.

\section{NOGALES-ARIVACA ROAD}

\section{NOGALES TO ARIVACA $(43,5$ MILES)}

[Sẹe p. 292 for $\log$ in opposite direction]

This road leaves the Tucson-Nogales road just north of a bridge across Potrero Creek. It is maintained in passable condition for motor trucks as far as the Montana mine, when the mine is being worked. The heavy trucks, however, make the going rough, though the road is easily followed. It has long but not excessive grades. Impassable in 1921.

0.0 Nogales. See page 286 for detailed $\log$ of next 6.4 miles.

6.4 Turn to left off main road and go upgrade onto gravelly plateau.

9.0 Go down into valley and follow it.

12.9 Clark Well on right; good water.

13.8 Turn southwest out of valley over ridge and into another valley.

19.5 Turn sharp curve around end of Atascosa Ridge; water hole 50 feet south of road; water probably not permanent.

20.0 Represo 200 yards south of road; water not permanent. The Marmee mine is about 1 mile south of the road:

20.3 Seep on north side of road.

20.2 Crest of pass. The road now goes northwest into Bear Valley.

23.2 Faint road goes half a mile to left to Bear Valley ranch; water.

31.2 Montana mine. Water supply when mine is operating from three dug wells and two large reservoirs. Store and gasoline.

32.2 Jenkins ranch; well, store, gasoline.

33.0 Small spring in gulch.

33.2 Small spring on left of road.

33.7 Well on right of road.

33.8 Austerlitz. House and well, mining claim. From this place a rough road runs south to Warsaw (4 miles).

34.3 Partridge.

36.0 Oro Blanco. Post office, several wells.

42.5 Reverse fork. Turn north across Arivaca Creek. Road on left comes from Tully Well (11 miles) and Jarilla Spring (4 miles). From Jarilla Spring the road goes south into Mexico.

43.5 Arivaca. Post office, water supply, hotel, store, gasoline. From Arivaca go west to Altar Valley, following log given on page 290. 


\section{ARIVACA TO NOGALES (48.5 MILES)}

[See p. 291 for $\log$ in opposite direction]

0.0 Arivaca. From post office go west.

0.1 Turn south through lane and cross Arivaca Creek.

1.0 Fork. Turn to left; right-hand road goes to Tully Well (11 miles) and Jarilla Spring (4 miles). From Jarilla spring a road goes south to Mexico.

7.5 Oro Blanco. Post office, several wells.

9.2 Partridge.

9.7 Austerlitz. House and well, mining claim. From this place a rough road runs south to Warsaw (4 miles).

9.8 Well, left of road.

10.3 Small spring, right of road.

10.5 Small spring in gulch.

11.3 Jenkins ranch. Well, store, gasoline.

12.3 Montana mine. Water supply when mine is operating from three dug wells and two large reservoirs; store and gasoline. Go over ridge on well-graded road into Bear Valley.

20.3 Faint road on right leads half a mile to Bear Valley ranch; water.

23.3 Crest of pass at south end of Atascosa Ridge.

23.4 Seep on north side of road.

23.5 Represo, 200 yards south of road; water not permanent. The Marmee mine is about 1 mile south of the road.

24.0 Turn sharply to the left and go northeast. Water hole 50 feet south of road; water probably not permanent.

29.7 Go down valley.

30.6 Clark Well on left; good water.

34.5 Turn out of valley to right and go along gravel plateau.

37.1 Reverse fork. Come into Tucson-Nogales road. Go south and follow detailed log on page 285 .

\subsection{Nogales.}

\section{FIGUEROA RANCH TO BUENOS AIRES AND POINTS ON THE EAST SIDE OF ALTAR VALLEY}

From Figueroa ranch, near the junction of Arivaca and San Luis creeks, subsidiary roads go to various small ranches on the east side of Altar Valley. The roads are little traveled and have many steep but short grades. Many new fences will probably be built in the next few years and the details of the roads modified accordingly.

0.0 Figueroa ranch. No well here. Water in emergencies only. Go west into valley.

0.6 Fork. Samé as mile 28.7 of Arivaca road. (See p. 290.) Take left turn up San Luis Valley. Right turn goes to Ronstadt gate. (See p. 288.)

1.6 Turn to left out of valley. A faint road leads up the valley to San Luis ranch and Jarilla Spring. It is not known whether this can be traveled by automobile.

4.3 Reverse fork. Road comes in on left frour San Luis ranch (1.3 miles).

5.4 Aguajita. Well and windmill in clump of cottonwoods.

5.6 Fork. Keep to left.

6.5 Reverse fork.

6.7 E. Garcia Well. This is a stock-watering place. Continue west through gate in east-west fence. 
6.9 Fork. Keep to right.

8.0 Buenos Aires Well, a stock-watering place. Water from the well and from Aguirre Lake is used. West of this place 1 mile is the TucsonSasabe road. (For $\log$ see p. 287.) Go southeast from Buenos Aires to reach the watering places along the east side of the valley.

10.4 Reverse fork. Road from Sasabe comes in on right. Travelers to Sasabe should, however, not use this road because of fences. The main route south from Ronstadt gate is preferable.

10.9 Lopez ranch. Well. From this ranch a road goes southeast 3 miles to Canoa ranch and 4 miles south to $M$. Garcia ranch and well. From the latter place it is 5.4 miles by a very bad road to Sasabe.

\section{TUCSON-PHOENIX HIGHWAY}

A good automobile road between Tucson, the largest town in Arizona, and Phoenix, the State capital, has been the aim of road enthusiasts for a number of years. The road described in the following log follows the route most likely to be permanently improved. The present improvements are as follows: Beginning at Tucson, 40 miles of well-graded gravel road, with bridges and concrete dips; 27 miles of good desert road, brush cleared, and some work done with scraper; 1 mile of graded dirt road just south of Florence; 30 miles of desert road, brush cleared, and some work done with scraper between Florence and Higley; 15 miles of graded dirt road from Chandler to Mesa; 20 miles of paved road between Mesa and Phoenix.

\section{TUCSON TO PHOFNIX (131.3 MHLES)}

[See pp. 295-297 for $\log$ in opposite direction]

0.0 Tucson. (For other roads from Tucson see pp. 266-267.) Go north on Stone Avenue.

0.1 Turn to left (west) on Congress Street.

0.5 Turn to right (north) on Main Street.

1.1 Cross Southern Pacific Railroad.

1.4 Fork. Continue north, avoiding crossroads. Road on left goes along railroad to Casa Grande and Maricopa. (See p. 298.)

5.5 Bridge over Rillito Creek.

13.3 Store, water, gasoline.

14.7 Cross Gold Canyon Creek.

24.7 Walnut Well.

24.9 Fork. Take left-hand road. Right-hand road goes to Oracle (12 miles) and Winkelman (50 miles).

27.9 Fork. Keep to left.

31.9 Fork. Keep to right.

34.3 Small hill on left.

39.1 Simmons Well. Good water.

41.7 Fork. Keep to left. Road on right goes to Durham ranch.

43.2 Crossroads. Go straight ahead. Road on right to Davis ranch. Road on left to Red Rock., (See p. 299.)

44.1 Fork. Keep to right. Meneger ranch and well one-quarter of a mile to left. No water for 23 miles.

45.1 Reverse fork. Road comes in on right from Foreman ranch.

46.5 Small hill on right.

47.0 Small hill on right. 
47.6 Avoid numerous forks for next 6 miles and follow cleared and partly graded roadway.

66.7 Double reverse fork on south side of canal. Water usually in the canal. 66.8 Reverse fork. Road from Casa Grande (30 miles) comes in on left.

67.2 Reverse fork. Road from Casa Grande Ruins (9.2 miles) comes in on left. (See p. 297.)

68.3 Florence. Post office, water supply, stores, automobile supplies and repairs, gasoline. Go north and cross Gila River by concrete bridge.

70.8 Florence railroad station. Turn to left (west).

70.9 Fork. Take road on left and go under southern base of lava-capped Poston Butte.

72.6 Avoid roads going southwest into valley and turn northwest onto gravel bench.

75.9 Fork. Keep to right.

77.1 Fork. Keep to left. Lava-capped butte southwest and another northwest.

78.6 Grossroads. Keep straight ahead with mountains on left.

84.7 Turn to left around point of low hills projecting from the mountains.

86.3 Fork. Keep to left. Road on right goes to ranch a quarter of a mile from road.

92.7 Turn west along base of mountains, on east-west road.

94.0 Turn north at base of steep hills at northern foot of Santan Mountains.

94.2 Fork. Avoid road on left.

94.7 Wells on each side of road.

95.3 Fork. Keep straight on. Road on left cuts across desert to Chandler, from which it is 8.2 miles to Mesa.

95.9 Crossroads. Continue north.

97.7 Well on right.

99.2 Well on left.

99.8 Crossroads. Continue straight on.

100.8 Higley. Store, well, crossroads. Turn to left (west).

103.3 Cross ditch into irrigated district. From this point on into Phoenix wells are very numerous and water is so easy to obtain that individual wells are not mentioned.

103.7 Crossroads. Continue straight on.

104.7 Crossroads. Continue straight on.

105.7 Crossroads and power line. Continue straight on.

106.7 Crossroads. . Continue straight on.

107.7 Crossroads. Turn north along power line. Chandler, water supply, stores, gasoline, lies a quarter of a mile south.

108.7 Crossroads. Continue straight on (north).

109.7 Crosssroads. Continue straight on (north).

110.7 Crossroads. Continue straight on (north).

111.7 Crossroads. Continue straight on (north).

112.7 Turn east. The road west is the Base Line road to Phoenix (18.3 miles).

112.9 Turn north along power line.

113.4 Road on left.

113.9 Crossroads. Continue north.

114.4 Road on left.

114.9 Crosssroads. Continue north across railroad.

115.4 Crossroads. Turn to left (west) on paved road. Mesa, a quarter of a mile east, is pleasant town. Water supply, hotel, stores, garage, gasoline.

115.9 Crossroads. 
116.4 Crossroads.

117.4 Crossroads.

118.4 Crossroads.

119.4 Turn to right (north).

119.7 Turn to left (west).

120.1 Pacific Creamery on right, thence on main road into town of Tempe.

121.6 Tempe. Water supply, stores, garage, gasoline. Turn north on Main Street.

122.1 Turn west toward railroad and thence north across Salt River over concrete bridge and then turn westward through gravelly hills.

125.7 Cross canal and go west into Phoenix on bitumen-bound macadam road.

130.5 Turn south in outskirts of Phoenix to Adams Street.

130.8 Go west on Adams Street.

131.3 Phoenix. Water supply, hotels, stores, garages, etc. (For roads into the Papago country from Phoenix see pp. 313-317.)

\section{PHOENIX TO TUCSON (131.3 MLLES)}

[See pp. 293-295 for $\log$ in opposite direction]

0.0 Phoenix. Go east on Adams Street.

0.5 Turn to left (north) into Monroe Street.

0.8 Turn to right (east) on Monroe Street and go east on bitumen-bound macadam road.

5.6 Cross canal and follow paved road through gravelly hills; then turn south to concrete bridge over Salt River; turn to left (east) at end of bridge.

9.2 Tempe, water supply, stores, garage, gasoline. Turn to right (south) on Main Street.

10.7 Turn to left (east).

11.2 Pacific Creamery on left.

11.6 Turn to right (south).

11.9 Turn to left (east).

12.9 Crossronds.

13.9 Crossroads.

14.9 Crossroads.

15.5 Crossroads.

15.9 Crossroads. Turn to right (south) and follow along power line. Road east goes one-quarter of a mile to Mesa, water supply, hotel, stores, garage, gasoline, and thence to Roosevelt Dam and Globe.

16.4 Cross railroad and then crossroad. Continue south.

16.9 Road on right.

17.4 Crossroads. Continue south.

17.9 Road on right.

18.4 Turn to right (west).

18.6 Turn to left (east).

19.6 Crossroads.

20.6 Crossroads.

21.6 Crossroads.

22.6 Crossroads.

23.6 Crossroads. Turn to left (east). Chandler, water supply, stores, gasoline, lies one-quarter of a mile south.

24.6 Crossroads. Continue east. 
25.6 Crossroads. Continue east.

26.6 Crossroads. Continue east.

27.6 Crossroads. Continue east.

28.0 Cross ditch out of irrigated district. From this point on to Florence wells are far apart.

30.5 Higley. Store, well. Crossroads. Turn to right (south).

31.5 Crossroads. Continue south.

32.1 Well on right.

33.6 Well on left.

35.4 Crossroads. Continue south.

36.0 Reverse fork. Cut-off road comes in across desert from Chandler.'

36.6 Wells on each side of road.

37.1 Reverse fork.

37.3 Turn to left (east) at base of steep hills at foot of Santan Mountains.

38.6 Turn southeast.

45.0 Reverse fork. Road comes in on left from ranch a quarter of a mile off road.

46.6 Turn to right (southeast) afound point of low hills projecting from the mountains.

52.7 Crossroads. Continue southeast.

53.4 Reverse fork. Road comes in on left. Lava-capped butte southwest and another northeast.

55.4 Reverse fork. Road comes in on right.

58.7 Turn east in valley of Gila River toward Poston Butte, avoiding roads on right, which go into river bottom.

60.4 Reverse fork. Road comes in on right; Poston Butte on left (north).

60.5 Florence railroad station. Turn to right over concrete bridge and cross Gila River.

63.0 Florence. Post office, water supply, stores, automobile supplies and repairs, gasoline. Go south.

64.1 Fork. Keep to left. Road on right goes to Casa Grande Ruins (9.2 miles).

64.5 Fork. Keep to left across canal. Road on right on north side of canal goes to Casa Grande (30 miles).

64.6 Double fork on south side of canal. Take center road southeast across plain over fair desert road, cleared and partially graded. Avoid numerous forks. No water until Meneger's ranch is reached (23 miles) .

84.3 Small hill on left.

84.8 Small hill on right.

86.2 Fork. Keep to right. Road on left goes to Foreman's ranch.

87.2 Fork. Keep to left. Meneger's ranch and wGll a quarter of a mile on right; 5 miles to next water.

88.1 Crossroads. Road straight ahead. Road on left to Davis ranch. Road on right to Red Rock.

89.6 Reverse fork. Road comes in on right from Durham ranch.

92.2 Simmons Well. Good water.

97.0 Small hill on right.

99.4 Reverse fork.

103.4 Reverse fork.

106.4 Reverse fork. Oracle road comes in on left. Go south.

106.6 Walnut Well. 
116.6 Cross Gold Canyon Creek.

118.0 Store. Water, gasoline.

125.8 Bridge over Rillito Creek. Go south, avoiding crossroads.

130.2 Cross Southern Pacific Railroad tracks and continue south on Main Street.

130.8 Turn to left (east) on Congress Street.

131.2 Tum to right.

131.3 Tucson. Post office, water supply, hotels, garages, etc. (For other roads out of Tucson see pp. 266, 284, 285, 298.)

\section{CASA GRANDE RUINS ROAD}

\section{FLORENCE TO CASA GRANDE RUINS (9.7 MIIES)}

[See below for $\log$ in opposite direction]

0.0 Florence. (For other roads from Florence see pp. 294, 302.) Go south on Main Street.

0.5 Fork. Turn to right on soft dirt road. Road straight ahead is PhoenixTucson Highway. (See p. 296.)

2.1 Old Fraser ranch on right, with grove of mesnuite trees,

2.9 Road on left.

3.8 Clements ranch on right; well and pumping plant. This is the site of the abandoned town of Adamsville.

6.7 Road on right.

7.0 Crossroads. Keep straight on.

7.2 Reverse fork. Road comes in on left.

7.8 Follow on south side of wire fence.

8.6 Fork. Wooden sign. Take left-hand road.

9.6 Crossroads. Turn to left and pass between well and ruins.

9.7 Casa Grande Ruins. Caretaker in charge who will assist travelers. Good well and water supply. From Casa Grande Ruins one can go south 1.5 miles and strike the Casa Grande-Florence road 18.4 miles from Casa Grande and 12.6 miles from Florence. (See $\log$ on p. 302.)

\section{CASA GRANDE RUINS TO FLOREITCE (9.7 MILES)}

[See above for $\log$ in opposite direction]

0.0 Casa Grande Ruins. Go north between ruins and well. The ruins are 1.5 miles north of the Casa Grande-Florence road. (See $\log , \mathrm{p} .301$. )

0.1 Crossroads. Turn to right.

1.1 Reverse fork. Go east on south side of fence.

2.5 Fork. Keep to left.

2.7 Crossroads. Keep straight on.

3.0 Road comes in on left.

5.9 Clements ranch on left; well and pumping plant. This is the site of the abandoned town of Adamsville.

6.8 Road comes in on right.

7.6 Old Fraser ranch on left, with grove of mesquite trees.

9.2 Reverse fork. Turn to left on well-graded road and go north into town.

9.7 Florence. For other roads from Florence, see pages 294, 302 . 


\section{TUCSON-CASA GRANDE ROAD \\ TUCSON TO CASA GRANDE (66.8 MIILES)}

[See below for $\log$ in opposite direction]

This road parallels the Southern Pacific Railroad and thus follows the flats of Santa Cruz River. In dry weather it is generally smooth and easy to travel. In wet weather it is impassable on account of mud. By continuing along the railroad from Casa Grande to Maricopa (see log on p. 300), from Maricopa to Gila Bend (see $\log$ on p. 307), from Gila Bend to Sentinel (see log on p. 317), and thence along the Tucson-Yuma road (see log on p. 271), it is possible to reach Yuma from Tucson. This route is feasible only in dry weather and has no advantages over the Tucson-Yuma road by way of Ajo.

0.0 Tucson. (For other roads out of Tucson see pp. 266, 284, 285, 293.) Go north on Stone Avenue.

0.1 Turn to left (west) on Congress Street.

0.5 Turn to right (north) on Main Street.

1.1 Cross Southern Pacific Railroad.

1.4. Fork. Turn to left (northwest) and follow along but at some listance from the railroad.

7.9 Jaynes. Station and well on railroad. The road from this point parallels the railroad closely.

15.4 Weaver Well on west side of track.

17.6 Rillito. Railroad station and well.

23.1 Wakefield ranch. Cross railroad to southwest side and go northwest.

26.9 Naviska. A siding on the railroad.

33.2 Cross Arizona Southern Railroad, which goes southwest to Silver Bell. Road from Silver Bell comes in on left. (See p. 299.)

33.7 Red Rock. Post office, water, store, gasoline. Cross railroad and go northwest on northeast side of track. For other roads from Red Rock see page 299.

38.1 Wymola, railroad siding. Cross to southwest side of track. Picacho Peaks on left. At the north end of the peaks lie Blue Water Tanks, at one time the only watering place in these plains.

48.1 Picacho. Water, store; cross to northwest side of track and go northwest. In dry weather the road along the track can be traveled. At times there is a mudhole near McEloy and the detour by way of the Davis ranch as shown on map should be taken. This is about 3.3 miles longer. A road goes northeast from Picacho to Avenenti ranch (11 miles) and one goes southeast to Green's reservoir (13.5 miles) and Jackrabbit (24 miles).

53.1 Mcliloy, railroad siding.

58.1 Toltec. Station and railroad well from which water can be obtained.

62.1 Arizola, railroad station.

66.8 Casa Grande. Post office, water supply, stores, automobile supplies, repairs, and gasoline. (For other roads from Casa Grande see p. 300.)

\section{CASA GRANDE TO TUCSON (66.8 MCHES)}

[See above for $\log$ in opposite direction]

- 0.6 Casa Grande. (For other roads from Casa Grande, see p. 300.) Go southeast past railroad wateratank and keep on northeast side of railroad track.

4.7 Arizola, railroad station. 
10.7 Toltec. Station and rallroad well from which water can be obtained. In dry weather the road along the track can be traveled, but at times there is a mudhole near McEloy and the detour by way of the Davis ranch, as shown on the map, should be taken. This is about 3.3 miles longer.

13.7 McEloy, railroad siding.

-20.7 Picacho. Water, store. Cross to southeast side of track and go southeast. A road goes northeast from Picacho to Avenenti ranch (11 miles) and one goes southeast to Green's reservioir (13.5 miles) and Jackrabbit (24 miles).

28.7 Wymola, railroad siding. Cross to northeast side of track and go southeast.

33.1 Red Rock. Cross to southeast side of track and go southeast. Post office, water, store, and gasoline. (For other roads out of Red Rock see below.)

33.6 Fork. Keep to left and cross track of Arizona Southern Railroad, which goes southwest to Silver Bell. Road to Silver Bell on right.

39.9 Naviska, railroad siding.

43.7 Wakefield ranch. Cross railroad to northeast side and go southeast.

49.2 Rillito, railroad station and well. From this point into Tucson there are ranches along the Santa Cruz.

51.4 Weaver Well on west side of track.

59.9 Jaynes. Railroad station and well. The road from this point swings away from the railroad but parallels it.

65.4 Reverse fork in outskirts of town. Turn into Main Street and go south.

65.7 Cross Southern Pacific Railroad tracks and continue south.

66.3 Turn to left (east) on Congress Street.

66.7 Turn to right (south) on Stone Avenue.

66.8 Tucson. Post office, etc. (For other roads out of Tucson see pp. 266 , $284,285,293$.)

\section{ROADS OUT OF RED ROCK}

Red Rock is the supply point for cattle ranches to the east and for settlers along the Santa Cruz flats in the vicinity.

At least two roads go east. The northerly one crosses the Tortolito Mountains to Plummer's ranch, 12.5 miles, and crosses the Tucson-Phoenix Highway, 16.5 miles from Red Rock. The more southerly road goes southeast across the Tortolito Mountains for 16.5 miles and then turns southeast to a well 20 miles from Red Rock and reaches the Phoenix-Tucson Highway in the Canada del Oro by way of Lockas's ranch and Pusch's ranch, a total distance of 30 miles.

Southwest from Red Rock a road goes along the north side of the track of the Arizona Southern Railroad. It reaches Sasco, where a smelter is located 6.5 miles away, but the details of the road are not known and are not shown on the map (Pl. IV). Five miles from Red Rock, however, this road forks. The right-hand road goes through some ilelds and along the bank of Santa Cruz River to Green's canal and follows the canal to Green's reservoir. The lefthand road goes west for 2 miles and forks again. The right-hand road goes by way of the Sasco mine to Green's canal and thence to the reservoir. The lefthand road goes southwest through some hills to silver Bell. There are numerous crossroads and forks, but if the traveler will keep the railroad on his left and follow the main traveled road, he will have no difficulty. The distance from Red Rock to Silver Bell is about 20 miles. 


\section{ROADS OUT OF CASA GRANDE \\ CASA GRANDE TO MARICOPA (20.4 MILES)}

[See below for log in opposite direction]

The road from Casa Grande to Maricopa is like that from Casa Grande to . Tucson, open only in dry weather. It follows the flats of Santa Cruz River and is very muddy when wet. (For other roads from Casa Grande see pp. 298-299.)

0.0 Casa Grande. Cross to southwest side of track and follow railroad northwest.

10.5 Bon, railroad siding.

15.5 Nunez, railroad siding.

17.2 Cross to northeast side of track and go north.

17.5 Fork. Take left-hand road and go northwest toward railroad water tank at Maricopa, plainly visible. The right-hand road goes 8.3 miles to Casa Blanca, an Indian village on Gila River.

20.4 Maricopa. Post office, water, store, gasoline. (For other roads out of Maricopa see pp. $30 \bar{\tau}-313$.

\section{MARICOPA TO CASA GRANDE (20.4 NIIES)}

[See above for $\log$ in opposite direction]

0.0 Maricopa. (For other roads out of this town see pp. 307-313.) Go east from post office across plain at a distance of a quarter to half a mile from the railroad.

2.9 Reverse fork. Turn south. Roaid comes in on left (north) from Casa Blanca ( 8.3 miles), an Indian village on Gila River.

3.2 Cross railroad and go southeast on southwest side of track.

4.9 Nunèz, railroad siding.

9.9 Bon, railroad siding.

20.4 Casa Grande. Post office, water supply, hotel, automobile supplies and repairs. (For other roads frọn Casa Grande see pp. 298-307.)

\section{PHOENIX TO CASA GRANDE BY WAY OF SACATON (58 MTIES)}

[See p. 301 for $\log$ in opposite direction]

0.0 Phoenix. (For other roads from Phoenix see pp. 295, 308, 313-317.) Go east on Phoenix-Tueson Highway (see $\log$ on p. 295) to crossroads, 2 miles east of Chandler.

25.6 Crossroads. Turn to right (south) and follow power line. Road straight ahead (east) is Phoenix-Tucson Highway.

35.2 Turn to left (sontheast). Numerous roads. Keep north of canal toward south end of hill near Gila River.

41.6 Santan. Pima village. Turn to right (south) between fences across ford of Gila River toward Indian agency buildings, plainly visible. This ford should not be attempted when the river is in flood.

44.3 Sacaton. Wells. Indian agency. Turn to right around buildings and church and then to left. Go south on graded road up alluvial slope toward Sacaton Mountains.

49.2 Go through pass between detached rocky hills which form the Sacaton Mountains and south over fair plains road. 
54.7 Cross bed of Santa Cruz River. There are wooden culverts which usually are in poor condition after rains or a flood on the river; this crossing is difficult and local advice should be sought. Continue south.

58.0 Casa Grande. For other roads out of this town see pages 298-299, 300-307.

\section{CASA GRANDE TO PHOENIX BY WAY OF SACATON (58 MILES)}

[See p. 300 for $\log$ in opposite direction]

0.0 Casa Grande. Go northeast and then northwest to outskirts of town.

0.3 Go north on graded road.

3.3 Cross channel of Santa Cruz River. There are wooden culverts which are usually in poor condition after rains or a flood on the river; this crossing is difficult, and local advice should be sought. Continue north up alluvial slope over fair plains road.

8.8 Go through pass between detached rocky hills which form the Sacaton Mountains and then down alluvial slope over graded road.

13.7 Sacaton. Wells; Indian agency. Follow main traveled road north between fences across ford of Gila River. This ford should not be attempted when the river is in flood. Local advice should be sought.

16.4 Santan. Pima village on north bank of Gila River. Turn to left (northwest) on north side of canal. There are numberless roads; keep to the northwest toward power line visible in the distance.

22.8 Turn north along power line and avoid crossioads.

32.4 Come into east-west road. Turn west.

33.4 Crossroads.

33.9 Crossroads.

34.4 Crossroads. Turn north along power line and follow Tueson-Phoenix Highway. (See $\log$ on p. 294.) Chandler, water, stores, and gasoline, is a quarter of a mile south.

58.0 Phoenix. For other roads from Phoenix see pages 295, 3ns, 313-317.

\section{CASA GRANDE TO FLORENCE (31 MIIES)}

[See p. 302 for $\log$ in opposite direction]

This is a county road largely along section lines. It is well graded on soft alluvium. In wet weather it is very muddy and in dry weather dusty and full of chuck holes. There are many farms along this road, at each of which there is a well. Only a few of these are recorded in the log. (For other roads from Casa Grande see pp. 298, 303-307.)

0.0 Casa Grande. Go southeast from post office and turn east near railroad water tank to outskirts of town.

0.3 Beginning of county road going east along section line.

5.0 House and well north of road:

9.7 House and well north of road.

10.6 Turn to left (north), avoiding road straight ahead.

14.9 Turn to right (east).

15.4 Turn to left (north), avoiding road straight ahead.

17.4 Turn to right (east). Road straight ahead goes 1 mile north and 1.5 miles east to Casa Grande Ruins.

18.4 Crossroads. Continue east. Road on left goes north to Casa Grande Ruins (1.5 miles). From this place it is 9.7 miles from Florence. (See $\log$ on p. 297.) It is thus 1.4 miles shorter to go east to Florence by the ruins and frequently the road is better. 
19.9 House and well on right.

20.4 House and well on left.

20.9 House and well on left.

21.4 Road goes off to north.

21.5 Schoolhouse on left (north).

22.1 House and well on right.

22.3 Road goes off to north.

22.7 House and well on left.

23.3 Crossroads. Continue east.

24.3 Turn to left (north), avoiding road straight ahead.

24.7 Well on right (east).

25.3 Road on right.

26.3 Crossroads. Turn to right (east). House and well on southwest corner.

28.2 Turn slightly to left and go northeast along canal.

30.0 Reverse fork. Turn north on Tucson-Phoenix Highway.

30.5 Reverse fork. Casa Grande Ruins road comes in on left. (See p. 297.)

31.0 Florence. Post office. (For other roads out of Florence see pp. 293-297.)

\section{FLORENCE TO CASA GRANDE (31 MULES)}

[See p. 301 for $\log$ in opposite alrection]

0.0 Florence. (For other roads from Florence see pp. 293-297.) Go south on Main Street.

0.5 Fork. Continue south. Road to right is Florence-Casa Grande Ruins road. This road rejoins the Florence-Casa Grande road 12.6 miles west of Florence. It is 1.4 miles shorter to Casa Grande by the Ruins road and frequently it is an easier trip.

1.0 Fork on north side of canal. Turn to right (southwest) and follow along canal. Left-hand road is the Tucson-Phoenix Highway.

2.8 Turn to right (west) away from canal.

4.7 Crossroads. Turn to left (south). House and well on southwest corner.

5.7 Road on left.

6.3 Well on left (east).

6.7 Turn to right (west), avoiding road to left (east).

7.7 Crossroads. Continue west.

8.3 House and well on right.

8.7 Road goes off to north.

8.9 House and well on left.

9.5 School house on right (north).

9.6 Road goes off to north.

10.1 House and well on right.

10.6 House and well on right.

11.1 House and well on right.

12.6 Crossroads. Continue west. Road on right comes in from Casa Grande Ruins (1.5 miles). This place is 9.7 miles from Florence. (See log on p. 297.)

13.6 Turn to left (south). Road on right goes north 1 mile and then east 1.5 miles to Casa Grande Ruins.

15.6 Turn to right (west), avoiding road on left (east).

16.1 Turn to left (south).

20.4 Turn to right (west), avoiding road on left (east).

21.3 House and well north of road.

26.0 House and well north of road. 
30.7 Turn to left (southwest) on street to railroad water tank and then to right on Main Street.

31.0 Casa Grande. For other roads from Casa Grande see pages 298-307.

\section{CASA GRANDE TO POZO SAN LUIS, SONORA, BY WAY OF JACKRABBIT AND THE SANTA ROSA VALLEY (102 MILES)}

[See pp. 305-306 for log in opposite direction]

0.0 Casa Grande. Water supply, post office, hotels, supplies, automobile supplies and repairs. (For other roads from Casa Grande see pp. 298-307.) Cross railroad tracks and turn south by small concrete jail. The road has been graded for next 10 miles; travelers should use their judgment as to whether to follow on or beside grade.

8.5 Chiu-Chuschu. Winter rancheria, United States Indian Service well, good water. There are two routes to Jackrabbit; the usual route with easiest grades goes to the east of the Silver Reef Mountains by way of Ko-opke; the other goes to the west of the mountains by way of the Silver Reef mine. A road also leads west 9 miles to Cocklebur, winter ranchería and well.

11.0 Ko-opke. Well and a few houses by large fields on the left, mountains on the right.

13.4 Fork. Keep to right; a road on left goes to Armenta ranch and well (1 mile).

20.5 Reverse fork. The road from Chiu-Chuschu by way of Silver Reef mine comes in on right.

21.9 Fork. Keep to left; road on right goes north of hill to Orizaba mine (1.3 miles).

22.4 Fork. Keep to right; road on left goes 1.4 miles to United States Indian Service well, at Jackrabbit; Government employees and Indians dependent on this well for water form a new village which is replacing the old village of Taht Mahmeli.

22.7 Fork. Keep to left; road to right goes to Orizaba mine.

23.0 Jackrabbit mine, on hill south of road at north end of Slate Mountains. This mine once employed a large number of workmen. There are numerous prospects in the neighborhood, and doubtless many more roads and watering places than are shown on the map. From the mine go southwest along the hills.

24.0 Turning Point mine. To go to Santa Rosa Valley turn to left around point of hill, keeping Slate Mountains on left. A road comes in on right from Orizaba mine (1.7 miles) and from Cocklebur (9 miles). A road goes west ( 6 miles) to Quajote, a ranchería with extensive temporales and a United States Indian Service well. From Quajote a road goes north of Vekol Mountains 4 miles to Reward mine, where there are two wells, and thence 4 miles to Bitter Wells, winter rancheria, where there is a well. From the latter place it is 2.5 miles to Vekol. From Quajote a road also goes south of Vekol Mountains 10 miles to Copperosity, a winter rancheria with 2 wells, and thence to Isabella mine, 7 miles farther.

31.3 Beginning of village; temporales on left. Road comes in on right from Quajote (5 miles).

32.0 Kukomalik. Winter ranchería; United States Indian Service well on right. Continue south.

39.0 Crossroads. Turn to right toward center of valley.

104211-25-21 
44.5 Anegam. Rancheria; United States Indian Service well on bank of main arroyo of the valley, 1.5 miles east of the village. On account of this well there is now permanent water, and people will be found here at all seasons of the year. Go south between represos.

46.5 Santa Rosa. Summer ranchería; United States Indian Service well on west bank of main arroyo of valley, half a mile east of village. On account of this well there is now permanent water, and people will be found here at all seasons of the year.

47.0 Fork. Keep to right due south in center of Santa Rosa Valley; road to left goes southeast through summer rancheria of Akchin; 19 miles to Cobabi. As Santa Rosa is one of the oldest and most important Papago settlements there are doubtless many other roads not shown on the map.

60.0 Reverse fork. Road from Covered Wells comes in on right. This is part of Pozo Blanco route of Tucson-Yuma road. (See p. 277.) It is possible to go to Horseshoe (Quijotoa post office), where there is a well and store, by taking this road and turning to the left about 3 miles out; the total distance is 5.5 miles. Horseshoe is the center of present mining activity in the Quijotoa Mountains, and roads lead to all the principal mines and prospects. These roads are not shown on the map.

61.0 Sikulhimakt, represo and some houses. Keep straight on south. A road goes southeast to Cobabi. This is part of the Poxo Blanco route of the Tucson-Yuma road. (See p. 277.) A road goes west to Horseshoe (5.5 miles).

67.0 Kvitatk. Summer rancheria; no permanent water. This is the more eastern of two rancherias near the abandoned well and ruined pumping plant of the old Weldon mine. The western rancheria is called, in Papago, "Vainomkux," which is translated roughly as "Iron Pipe." The whole locality is sometimes called "Pumphouse." From each rancheria there is a road to San Antone, winter rancheria, with three wells, on the site of the abandoned mining camp of Quijotoa. This place lies at the foot of the mountains between South Mountain and Ben Nevis Mountain. The Weldon mine, now abandoned, lies 2.5 miles up the canyon, and from the wells near by, roads lead over the mountain to Black Butte, winter rancheria and well. The condition of these roads is not known. Quijotoa mine, on the north side of Ben Nevis, is 5 miles from Kvitatk. The road goes through Iron Pipe and 'branches from the San Antone road 2 miles out of that village. A road also goes east 5.5 miles to Nolic, winter rancheria with wells, which lies just southeast of Cobabi Mountains, a small group of reddish, rugged mountains. Another road goes southeast 14 miles to Indian Oasis. (See p. 325.)

To continue to Tecolote go south from Kvitatk, avoiding the many forks and crossroads, and cross a low drainage divide. South of this divide the road stays on the east of the main arroyo of the valley, which gradually swings west to round the point of South Mountain.

76.5 Cross main Tucson-Yuma road about three-fourths of a mile west of the Geological Survey sign at Big Fields. As this crossroad was not seen in traveling from Big Fields to Copeka it is likely that this part of the road is little used, and travelers leaving Kvitatk will probably land at Big Fields. In this event they should go to the south side of Big Fields and take the Indian Oasis-Menegers Dam road (see p. 326) until they come into this road at mile 78.5 . 
78.5 Crossroads. Continue south. This is Indian Oasis-Menegers Dam road. (See p. 326.)

79.3 Crossroads. Continue south. This is Copeka-Kavolik road. (See p. 328.)

87.0 Tecolote. Summer rancheria; large represo in which there is water for several months after a rain; no permanent water. Tecolote is the center of a maze of roads, of which the principal one is the Indian Oasis-Kavolik-Tecolote route into Mexico (see p. 324); others are from and to the various near-by temporales and summer rancherias. Go south on west side of represo.

90.8 Crossroads. Continue south.

92.3 Pass temporal and houses on left; avoid numerous forks and continue south.

94.3 International boundary monument 151 about a mile to the left (east). Go south into cove between La Lesna and Cobota mountains.

94.6 Reverse fork. Road from La Lesna Mountains comes in on right.

99.0 Cobota ranchería.

102.0 Pozo San Luis. Winter ranchería; well and permanent water. From Pozo San Luis roads lead to all the principal points in Sonora.

\section{POZO SAN IUIS, SONORA, TO CASA GRANDE BY WAY OF SANTA ROSA VALIEY AND JACKRABBIT (102 MILES)}

[See pp. 303-305 for log in opposite direction]

0.0 Pozo San Iuis. Winter ranchería; well and permanent water. Roads lead to this place from all the principal points in Sonora. Go northeast.

3.0 Cobota ranchería. Go north between La Lesna and Cobota mountains into open plain.

7.4 Fork. Keep to right. Road to left goes to north end of La Lesna Mountains.

7.7 International boundary monument 151 about a mile to the right (east). Go north, avoiding numerous forks.

9.7 Temporal and houses on right.

11.2 Crossroads. Continue north.

15.0 Tecolote. Summer rancheria; large represo in which there is water for several months after a rain; no permanent water. Tecolote is the center of a maze of roads, of which the principal one is the Indian Oasis-Kavolik-Tecolote route into Mexico (see p. 324); others are from and to the various near-by temporales and rancherias. Go north on west side of represo and east of corral, bearing to east of Quijotoa Mountains, visible across the plain.

22.7 Crossroads. Continue north. This is Copeka-Kavolik road. (See p. 328.)

23.5 Crossroads. Continue north; this is Indian Oasis-Menegers Dam road. (See p. 326.)

25.5 Crossroads. Tucson-Yuma road about three-quarters of a mile west of the Geological Survey sign at Big Fields. As this crossroad was not seen in traveling from Big Fields to Copeka, it is likely that this part of the road is little used, and travelers leaving Tecolote may land in Big Fields. In this event they will find a road leading from the represo on the north side of Big Fields and rejoining this road at Kvitatk. 
35.0 Kvitatk. Summer rancheria; no permanent water. This is the more eastern of two rancherias near the abandoned well and ruined pumping plant of the old Weldon mine. The western ranchería is called, in Papago, "Vainomkux," which is translated roughly as "Iron Pipe." The whole locality is sometimes called "Pumphouse."

Avoid the numerous crossroads and forks and go north between the represos of Kvitatk on the west side of arroyo, which flows north. From this place to Anegam the road follows the center of Santa Rosa Valley; plains road, very muddy in wet weather. For roads out of Kvitatk see page 325 .

41.0 Sikulhimakt, represo and some houses. Keep straight on north. (For roads out of this place see p. 278.)

42.0 Fork. Take left-hand road (north). (For right-hand road see p. 278.)

55.0 Reverse fork. (For road coming in on right see p. 304.)

55.5 Santa Rosa. Summer ranchería; United States Indian Service well on west bank of main arroyo of valley, half a mile east of village. On account of this well there is now permanent water and people will be found here at all seasons of the year. Avoiding forks and crossroads; go north.

57.5 Anegam. Summer rancheria ; United States Indian Service well on bank of main arrojo of the valley, 1.5 miles east of the village. On account of this well there is now permanent water and people will be found here at all seasons of the year. Go north between represos and turn to right (northeast) along south bank of large arroyo.

63.0 Crossroads; turn to left (north).

70.0 Kukomalik. Winter rancheria; United States Indian Service well on left. Continue north through village with temporales on right.

70.7 End of village; road from Quajote ( 5 miles) comes in on left.

78.0 Turning Point mine at north end of Slate Mountains. Turn to right around point of the mountains. Various roads come in here. (See p. 303.)

79.0 Jackrabbit mine, on hill south of road. (See p. 303.)

79.3 Reverse fork. Road comes in on left from Orizaba mine.

79.3 Reverse fork. Road comes in on right from United States Indian Service well at Jackrabbit. Government employees and Indians dependent on this well for water form a new village which is replacing the old village of Taht Mahmeli.

80.1 Reverse fork. Road comes in on left from Orizaba mine (1.3 miles).

81.5 Fork. Keep to right; the road on left goes by way of Silver Reef mine and rejoins this road at hiu-Chuschu. It is about the same length but has steeper grades.

88.6 Reverse fork. Road comes in from Armenta ranch.

91.0 Ko-Opke. Well and a few houses by large fields on right, mountains on the left.

93.5 Chiu-Chuschu. Winter rancheria; United States Indian Service well. good water. Go north through village on graded road. (For other roads see p. 303.)

102.0 Casa Grande. Water supply, post office, hotels, supplies, automobile supplies and repairs. (For other roads from Casa Grande see pp, 298-307.) 


\section{CASA GRANDE TO COCKLEBUR AND QUAJOTE (27.2 MILES)}

[See below for log in opposite direction]

This road was not traveled, and distances are given as measured on the map. (For other roads from Casa Grande see pp. 298-307.)

0.0 Casa Grande. Cross railroad tracks and go south on graded road.

2.0 Fork. Take right-hand road (southwest). The graded road continues south to Chin-Chuschu. (See log on p. 303.)

11.0 Well and Indian huts.

15.5 Cocklebur. Winter ranchería; two dug wells. Continue south. Road from Chiu-Chuschu on left (p. 303) and from Maricopa on right (p. 312).

20.1 Fork. Take right-hand road southwest. Left-hand road goes southeast 3 miles to Orizaba mine and 6 miles to Jackrabbit. (See p. 303.)

26.1 Corner of temporal. Go west along border of field and then south.

27.2 Quajote. Winter ranchería; United States Indian Service well. From this village a road goes north of Vekol Mountains 4 miles. to Reward mine, where there are tiwo wells, and thence. 4 miles to Bitter Well, winter ranchería, where there is a well. From Quajote a road also goes south of Vekol Mountains 10 miles to Copperosity, $a$ winter rancheria with two wells, and thence to Isabella mine, 7 miles farther.

\section{QUAJOTE TO COCKLEBUR AND CASA GRANDE (27.2 MILES)}

[See above for $\log$ in opposite direction]

0.0 Quajote. From the United States Indian Service well go north and turn east along northern border of temporal.

1.1 Turn northeast at corner of field.

6.1 Reverse fork. Road comes in on right from Orizaba mine ( 3 miles) and Jackrabbit ( 6 miles).

11.7 Cocklebur. Winter rancheria; two dug wells. Continue north and northeast.

16.2 Well and Indian huts.

25.2 Reverse fork. Turn north on graded road which comes in from ChinChuschu. (See p. 303.)

27.2 Casa Grande. For other roads out of this town see pages 298-307.

\section{ROADS OUT OF MARICOPA}

\section{MARICOPA TO GILA BEND (44.1 MILES).}

\section{[See p. 308 for $\log$ in opposite direction]}

This road, except for the short interval between Heaton and the Geological Survey sign west of Enid, is made of parts of the Phoenix-Maricopa road by way of Gila Crossing and the Phoenix-Gila Bend road by way of Gila Crossing.

0.0 Maricopa. Cross railroad track and go west toward gap between Sierra Estrella and Palo Verde Mountains, avoiding road to left, which goes to Akchin. (See p. 309.) Much drifted sand and many adobe flats.

4.0 Peblo Well. Good water. Turn northwest toward railroad.

6.9 Heaton. Switch on railroad. No houses. Cross railroad and turn west over fair desert road. Road north goes to Phoenix. (See p. 309.)

11.8 Enid, Water in emergencies at section house. Continue west. 
14.1 Reverse fork. Geological Survey sign. Road from Phoenix comes in on right. This point is mile 33.9 of $\log$ given on page 313 . Follow this west into Gila Bend.

44.1 Gila Bend. For other roads from Gila Bend see pages 313-324.

\section{GILA BEND TO MARICOPA (44.1 MILES)}

[See p. 307 for $\log$ in opposite direction]

0.0 Gila Bend. (For other roads from Gila Bend see pp. 313-324́.) Geological Survey sign. Follow Phoenix-Gila Bend road. (See p. 313.)

30.0 Fork. Geological Survey sign. Keep to right on north side of railroad. Left-hand road goes to Phoenix.

32.3 Enid. Water in emergencies at section house. Continue east.

37.2 Heaton. Switch on railroad. No houses. Turn to right (south) across tracks and go southeast, avoiding fork to left just south of track. Phoenix-Maricopa road comes in on left (north). This point is mile 29.1 .

40.1 Peblo Well. Good water. Turn east and follow main traveled road. avoiding numerous forks and crossroads. Much drifted sand and many adobe flats.

44.1 Maricopa. Post office, water, hotel, supplies, gasoline. For other roads from Maricopa see pages 307-313.

\section{PHOENIX TO MARICOPA BY WAY OF GILA CROSSING (36 MTIES)}

[See below for $\log$ in opposite direction]

Except the very roundabout route through Florence and Casa Grande any road from Phoenix to Maricopa involves fording Gila River. This can not be done when the river is in flood, and information should be obtained before starting. (For other roads from Phoenix see pp. 295, 300-301, 313-317.)

0.0 Phoenix. Take road to Gila Bend by way of Gila Crossing. (See p. 313 for log.)

16.5 Gila Crossing.

23.9 Fork. Geological Survey sign. Keep to left (south) across plain on good desert road. Right-hand road goes to Gila Bend.

25.2 Fork. Keep to right (south). Left-hand road goes to Maricopa also. The distance is 8 miles, but the road is said to be sandy and bad.

29.1 Heaton. Switch on railroad, no houses. Cross railroad and go southeast, avoiding fork to left just south of track. Road comes in on north side of track from Enid (4.9 miles) and Gila Bend. (See p. 307.)

32.0 Peblo Well. Good water. Turn east and follow main traveled road toward railroad water tank, avoiding numerous forks and crossroads. Much drifted sand and many adobe flats.

36.0 Maricopa. Post office, water, hotel, supplies, gasoline. (For other roads to Maricopa see pp. 307-313.)

\section{MARICOPA TO PHOENIX BY WAY OF GILA CROSSING (36 MTLLES)}

[See above for $\log$ in opposite direction]

0.0 Maricopa. Cross raitroad track and go west toward gap between Sierra Estrella and Palo Verde Mountains, avoiding road to left, which goes to Akchin. (See p. 309.)

4.0 Peblo Well. Good water. Turn northwest toward railroad. 
6.9 Heaton. Switch on railroad, no houses. Cross railroad and go north across plain on good desert road. From Heaton a road goes west to Gila Bend. (See p. 307.)

10.8 Reverse fork. Road from Maricopa (8 miles) comes in on right.

12.1 Reverse fork. Geological Survey sign. Road from Gila Bend comes in on left. For detailed $\log$ follow Gila Bend-Phoenix road from this point, which is mile 40.0 in that log. (See p. 314.)

18.5 Gila Crossing.

36.0 Phoenix. For other roads from Phoenix see pages 295, 300-301, 313-317.

MARICOPA TO VEKOL VALIEY, KAKA, AND COVRRED WELLS (78.7 MIIES)

[See pp. 311-312 for log in opposite direction]

This road is hardly a through route, in the commonly accepted sense. The road from Maricopa to Vekol Valley is, however, good and in common use by the Papagos and some prospectors. The road from Kaka to Covered Wells was not traveled, and distances are given as measured on the maps.

0.0 Maricopa. Post office, store, gasoline, water from railioad well. From post office, cross railroad at station and go southwest to well derricks visible across the plain. Many intersecting roads.

1.9 Turn into lane, between wire fences.

2.4 Akchin. United States Indian Service well and pumping plant. Similar plants half a mile west and south. Turn west along fence.

2.7 Turn sonthwest and cross north and south road at mile 3.0. This road goes south about 24 miles to Cocklebur. (See p. 312.)

5.0 Fork. Keep to left; road on right goes 0.7 mile to Drake's ranch, well and good water; last permanent water on this road for 71 miles. From Drake's ranch an old road leads around the south end of Falo Verde Mountains into the southern portion of the Jornada de las Estrellas. There is said to be a spring in a canyon below a cliff, 16 miles out on this road.

5.7 Crossroads. Keep straight on south along alluvial slope over fair plains road, crossing numerous washes, toward pass in rugged granite mountains. Road on right is second road to Drake's ranch; road on left goes to another ranch.

16.6 Cross arroyo and turn to right in pass.

17.0 Cross arroyo and go southwest across rolling country in open valley toward second pass in brown, flat-topped hills.

18.6 Beginning of second pass. Faint road goes off southeast toward Table Top Mountains.

18.8 Sand tank in arroyo on left of road. Water can be found here after rains by digging about 4 feet in the sand-not dependable. Continue west in narrow valley.

19.7 Turn sharply to left (south) over lava point.

20.0 End of lava, Go south over alluvial slope into Velkol Valley, toward small hill in center of valley. Antelope Peak on left.

22.9 Faint road comes in on right.

24.9 Go down bank into trench along main arroyo of Vekol Valley; granite hill on left.

25.4 Cross main arroyo; very sandy and bad crossing. Go south on west side of arroyo, through mesquite-covered flat.

26.0 Faint road crosses arroyo and goes toward Antelope Peak. 
28.2 Water hole. Water is found by digging in sand in sharp elbow of main arroyo below entrance of tributary; water for a few weeks after rains.

30.6 Brush corral on left; charco just south of corral on main arroyo; water only after rains. Go south over alluvial slope; grassy flats on the left.

32.9 Reverse fork. Geological Survey sign. Continue south. This road comes in from Stouts Well (9 miles), the nearest permanent water. (See p. 318.) Faint road crosses grassy flat at this point and leads to Vekol; not easily traveled.

33.1 Faint road on left.

34.5 Fork. Keep to right (south).

34.8 Fork. Keep to right (south) ; road on left goes to Vekol. (See p. 318.)

35.5 Faint road on right goes to spring and abandoned rancheria, under north side of Squaw Tit Peak. Spring has small but permanent flow. It is impossible to get within a mile of spring with an automobile, and difficult for a wagon. The trail from Stouts Well is badly washed but passable for horses (4 miles).

37.2 Faint road on right.

39.4 Small gravel hill on left.

40.4 Totobit Tanks. Road turns to left and crosses arroyo by gravel hill. Tanks are to left in channel of arroyo and consist of a number of plunge pools and potholes in black lava and conglomerate. Tanks hold a good deal of water and have water for a large part of the year.

40.6 Fork. Keep to left; right-hand road avoids village of Totobit.

40.9 Totobit. Summer rancheria; about 3 houses on gravel hill; temporales to the south and east. The Murray \& Lopez Well is 1 mile north, but no information is available concerning it. From Totobit go south over adobe flat.

41.4 Reverse fork. Road direct from Totobit Tanks.

45.3 Small charco on right of road. Bear to right into pass.

45.7 Charcos on right.

47.8 House on top of gravel hill. Sign in boulders on left of road: "San Jose, April 18, 1906." Go downhill past ruined represo into valley between basalt plateaus.

48.9 Charco on right of road.

49.2 Kaka. Summer rancheria in valley between lava plateaus; no permanent water. From Kaka roads lead to Moivavi and Emita (see p. 320). The road to Covered Wells was not traveled, and distances are given as measured on the map. Turn south and go through pass, avoiding fork on left, and continue south, keeping the mountain mass south of Kaka on the right.

57.2 Fork. Keep to left and turn southeast to south side of butte. Road to right goes through pass in lava plateaus to Perigua (13 miles).

58.2 Butte on left (north).

61.7 Cross southern spur of small mountains. Two natural windows in the rocks of these mountains.

65.2 Northeast corner of temporal. Go south along east side into rolling country between Sierra Blanca and Brownell Mountains. Most of the way is over rocky hills, with many short but steep inclines and pitches.

71.7 Reverse fork. Road from Charco de la Piedra comes in here. (See p. 341.) Probably more roads than shown, as this region has been actively prospected, Head toward south end of Brownell Mountains. 
76.2 West wells of Covered Wells; permanent water. Road comes in from Pozo Blanco. (See p. 277.) Go down rocky valley with scattered Papago houses.

78.7 Covered Wells. Store, two wells. From Covered Wells roads lead to Brownell, but their exact route is not known, to Horseshoe, and to points in Santa Rosa Valley.

\section{COVERED WELIS TO KAKA, VEKOL VALIEY, AND MARICOPA (78.7} MILES)

[See pp. 309-311 for log in opposite direction]

0.0 Covered Wells. Store, two wells. Go west up rocky valley, with scattered Papago houses.

2.5 West wells of Covered Wells; permanent water. Road forks just west of corral and wells ; take right-hand road northwest, over rolling country. Road rocky with many short inclines and pitches. There are probably many more roads than are shown on map, as this country has been actively prospected for many years. Distances are given as measured on the map as far as Kaka. Road to left goes west to Pozo Blanco. (See p. 277.)

7.0 Fork. Take right-hand road toward small rugged mountain ranges on north. Left-hand road goes northwest and crosses end of Sierra Blanca to Charco de la Piedra. (See p. 341.)

13.5 Northeast corner of temporal. Go west along north side and then northwest to south end of small ragged mountains. Two natural windows in the rocks of these mountains.

17.0 Cross southern spur of mountains and go northwest across plain toward lone butte.

20.5 Butte on right (north).

21.5 Reverse fork. Go north parallel to mountains on left and then through narrow pass. Road comes in on left from Perigua (13 miles).

29.5 Kaka. Summer rancheria, in valley between lava plateaus. No permanent water. Fields to the right; scattered houses. From Kaka roads lead to Moivavi and Emita. (See p. 320.) To go to Vekol Valley turn to right and go through pass on east.

29.8 Charco on left of road.

30.9 House on top of gravel hill ; sign in boulders on right of road, "San Jose, April 18, 1906." Ruined represo just west.

33.0 Charcos on left. Turn northeast down little valley.

33.4 Small charco on left. Go north into upper end of Vekol Valley.

37.3 Fork. Keep to right. Left-hand road goes direct to Totobit Tanks.

37.8 Totobit. Summer rancheria; about 3 houses on gravel hill. Temporales to the south and east. The Murray \& Mopez Well is 1 mile north, but no information is available as to the amount and value of the water. Turn west from Totobit.

38.3 Totobit Tanks. Cross arroyo and turn to right (north). The tanks are to the right in the channel of the arroyo and consist of a number of plunge pools and potholes in black lava and conglomerate. The tanks hold a good deal of water and have water for a large part of the year.

39.3 Small gravel hill on right. Road runs north on west side of grassy flats which occupy center of the valley.

41.5 Faint road on left. 
43.2 Faint road on left goes to spring and abandoned ranchería under north side of Squaw Tit Peak. The spring has a small but permanent flow. It is impossible to get within a mile of the spring with an automobile and difficult for a wagon. The trail from Stouts Well is badly washed but passable for horses ( 4 miles).

43.9 Reverse fork. Road from Vekol comes in on right. (See p. 319.)

44.2 Reverse fork.

45.6 Faint road on right.

45.8 Fork. Geological Survey sign. Keep to right. Road to Stouts Well turns off to left. Nearest water 9 miles by this road. (See p. 319.)

48.1 End of grassy flats. On right Brush corral. Charco just south of corral on main arroyo. Water only after rains.

50.2 Water hole. Water is found by digging in the sand in sharp elbow of the main arroyo below entrance of tributary; it lasts only for a few weeks after a rain.

52.7 Faint road crosses arroyo on right and goes toward Antelope Peak.

53.3 Cross main arroyo, very sandy and bad crossing, and go along west slope of lone rocky hill.

58.3 Go up bank onto gravelly alluvial slopes, then slightly east of north, with Antelope Peak on right.

55.8 Faint road on left.

58.7 Go onto lava, which is western projection of small lava hills.

59.0 Turn sharply to right into narrow pass.

59.9 Sand tank in arroyo on right of road. Water can be found here after rains by digging about 4 feet into sand. Go east in rolling rocky country to pass in granite hills ahead.

60.1 Faint road goes southeast toward Table Top Mountains.

61.7 Cross arroyo.

62.1 Cross arroyo and go north out of pass along alluvial slope over fair desert road, crossing numerous washes.

73.0 Crossroads. Keep straight on toward well derricks at Akchin. Road on left goes half a mile to Drake's ranch; well and good water. From this ranch an old road leads around south end of Palo Verde Mountains into southern portion of Jornada de las Estrellas. There is said to be a spring in a canyon below a cliff 16 miles out on this road. Road to right goes to another ranch.

73.7 Reverse fork. Second road from Drake's ranch comes in. Go north and east to center of three well derricks.

76.3 Akchin. United States Indian Service well and pumping plant. Similar plants half a mile west and south. Turn north tnrough lane on right of center well.

76.8 End of lane. Turn northeast toward railroad. Water tank at Maricopa easily visible. Take best of various roads.

78.7 Maricopa, post office, store, gasoline, water from railroad well. For roads from Maricopa see pages 300, 307-313.

\section{MARICOPA TO COCKLEBUR (27 MILES)}

This road goes southeast from the United States Indian Service wells at Akchin. These wells are 2.4 miles southwest from Maricopa and the well derricks are plainly visible. From these wells a road goes south and then turns southeastward across the plains to Cocklebur. About 3 miles from Cocklebur it crosses a spur from the mountains west of that place. The distance from Maricopa to Cocklebur is about 27 miles. (For roads from Cocklebur see p. 307.) 


\section{ROADS OUT OF GILA BEND}

\section{PHOENIX TO GILA BEND BY WAY OF GILA CROSSING (63.9 MILES)}

[See pp. 320-321 for log in opposite direction]

Two routes lead to Gila Bend from Phoenix, one by way of Buckeye, which crosses Gila River on the ford south of that village, and one which goes south on the bridge over Salt River and crosses the Gila at the ford between Salt River Mountains and the Sierra Estrella, called Gila Crossing. Neither route can be used during high water on the Gila. The ford. is likely to be treacherous at any time, but at Gila Crossing there is daily traffic, because of the Indian villages on either side of the river. If the machine gets stuck in the mud or quicksand, an Indian can usually be induced to bring his team and haul it out. The Indians ordinarily set a high value on their services.

0.0 Phoenix. Travelers should carry water for the whole trip, if possible. A well has been drilled at Mobile, 36 miles from Phoenix, and water can probaby be obtained there. Go south on Center Street and cross Arizona Eastern (Southern Pacific) Railroad tracks at mile 0.3 and concrete bridge over Salt River at mile 1.7. Avoid crossroads.

4.7 Turn to right (southwest) along north bank of Western Canal.,

6.4 Cross lateral and then main canal at bend and go along south bank of canal. One may also cross lateral and go west 1.3 miles and then turn southwest and cross Western Canal.

8.4 Geological Survey sign on south bank of Western Canal and edge of desert. Many wells at farms this far. Go southwest over good plains road through open gap between isolated hill and Salt River Mountains.

11.8 Williamson store. Abandoned store building and well; many roads come in and go out at this point. Take main traveled road south; sandy valley road.

14.3 Komatke. Indiun village. Geological Survey sign. Post office, small store, mission buildings of St. John's Chapel west. If water is necessary get it here. From this point take main traveled road south, keeping house with tin roof to left.

16.5 Geological Survey sign at head of lane going southwest to river. Follow latest and best-looking tracks over ford. Gila Crossing should always be given careful inspection. Low-powered and heavy automobiles should be cautious. There is usually water in the river at this point. At end of ford turn right and go through Pima village, following best track.

18.1 Cross Santa. Cruz River to gravel bench at foot of Sierra Estrella and go southeast along this bench. Santa Cruz River is here little more than an irrigating ditch. The crossing is treacherous and travelers should be cautious. There is heavy sand going in and out of the channel and mud at the bottom.

21.2 Fork. Keep to the right. The left-hand road goes along the margin of the Santa Cruz Cienaga, a low area of swamp and salt grass. By this road it is approximately 10 miles to Maricopa. It is, however, poor and sandy. Log of better road is given on page 308 .

21.9 Turn slightly and go south across plain.

23.9 Fork. Geological Survey sign. Take right-hand road toward south end of Sierra Estrella, skirting mountains over rough desert road. Lefthand road goes to Maricopa. (See p. 308.) 
31.3 Fork. Geological Survey sign. Take left-hand road toward railroad across adobe flat. Right-hand road goes west to small blackish mountains. It is the old stage road from Maricopa Wells to Gila Bend and is passable for 6 miles only.

32.1 Crossroads. Continue southwest.

33.9 Reverse fork. Geological Survey sign. Go west along railroad track. Road comes in along track from Enid and Maricopa.

36.1 Mobile; station and section house. Well.

45.7 Estrella station and section house. Water in emergencies. .

46.1 Cross railroad tracks and go west in pass.

50.2 Cross railroad track and go west toward small rocky hill.

51.3 Turn southwest to railroad.

53.6 Turn west along railroad and go down alluvial slope.

54.9 Bosque, station and section house; water in emergencies.

60.9 Coledon, station and section house; water in emergencies.

62.9 Turn to left across railroad tracks. Reverse fork on south side, road comes in from Mesquite Tank. (See p. 323.) Go west along track.

63.6 Double reverse fork. Geological Survey sign. Turn to right and cross canal and railroad track into town.

63.9 Gila Bend. Geological Survey sign. Post office, water, eating house, rooms, supplies, gasoline. (For roads from this town see pp. $307-308$, 313-324.)

\section{GILA BEND TO PHOENIX BY WAY OF GILA CROSSING (63.9 MILES)}

[See pp. 313-314 for log in opposite direction]

0.0 Gila Bend. Geological Survey sign. Travelers should carry water for the whole trip if possible. A well has been drilled at Mobile, 28 miles from Gila Bend, and water can probably be obtained there. Go south across railroad and canal to fork.

0.3 Double fork. Geological Survey sign. Turn to left (east).

1.0 Fork. Turn to left across railroad and go east on north side of track. Road on right, rather faint, goes to Mesquite Tank. (See p. 323.)

3.0 Coledon. Station and section house; water in emergencies.

9.0 Bosque. Station and section house; water in emergencies.

10.3 Turn northeast toward pass.

12.6 Turn east into pass.

13.7 Cross railroad tracks.

17.8 Cross railroad track at east end of pass.

18.2 Estrella station and section house. Water in emergencies. Go east on north side of track, going around railroad wye.

27.8 Mobile. Station and section house. Well.

30.0 Fork. Geological Survey sign. Turn to left across adobe flat; right-hand road follows along track to Enid and Maricopa. (See p. 308.)

31.8 Crossroads. Continue northwest.

32.6 Reverse fork. Geological Survey sign. Go north of hill and skirt southern end of Sierra Estrella. Old stage road from Gila Bend to Maricopa Wells comes in on left. It is impassable beyond black hills, 6 miles out.

40.0 Reverse fork. Geological Survey sign. Road comes in on right from Maricopa. (See p. 307.) Go north from this sign parallel to Sierra Estrella. 
42.7 Reverse fork. Road comes in on right from Maricopa (p. 307).

45.8 Cross Santa Cruz River. Among scattered Indian houses and fields, follow best-traveled road through Pima village to Gila River. Santa Cruz River at this point is little more than an irrigating ditch. The crossing is treacherous and travelers should be cautious. There is heavy sand going in and out of the channel and mud at the bottom.

46.4 Gila Crossing. Follow latest and best-looking tracks over ford. Gila Crossing should always be given careful inspection. Low-powered and heavy automobiles should be cautious.

47.4 Geological Survey sign at end of lane leading from ford, about half a mile from river. Go north on best-traveled road over sandy plain. Keep house with tin roof on right.

49.6 Komatke. Indian village. Geological Survey sign. Post office, small store. Mission buildings of St. John's Chapel west. If water is necessary get it there. Go north on main traveled road toward gap between isolated hill and Salt River Mountains.

52.1 Williamson store. Abandoned store building and well. Many roads coming in and out at this point. Go northeast by good desert road through gap.

55.5 Geological Survey sign on south bank of Western Canal. Numerous wells at farmouses from this point. Turn west and follow south bank of canal for two miles and then cross it, or cross canal and go northeast for seven-tenths of a mile and then turn east on south side of lateral.

57.5 Go northeast on northwest side of Western Canal.

59.2 Turn north between fences and farms, avoiding crossroads.

62.2 Cross Salt River on concrete bridge.

63.6 Cross railroad tracks.

63.9 Phoenix.

\section{PHOENIX TO GILA BEND BY WAY OF BUCKEYE (69.5 MHLES)}

[See pp. 316-317 for log in opposite direction]

By C. P. Ross.

0.0 Phoenix. Go west on Phoenix-Yuma road. (For detailed log see U. S. Geol. Survey Water-Supply Paper 490-C, p. 283.)

34.2 Buckeye. Post office, wells, hotel, stores, garage, gasoline. Go west.

34.5 Fork. Geological Survey sign. Turn south (left) on fair to good road. Road west leads to Palo Verde, Yuma, and Parker.

35.9 North bank of Gila River. The river can, under favorable conditions, be crossed by automobiles at this place. Do not attempt to ford when the river is in flood. It is frequently necessary, even when the river is almost dry, for automobiles to be towed across by horses. The sandy bed of the stream is about a mile wide here.

37.0 South bank of Gila River. Go south and west over fair to good desert road all the way to Gila Bend.

39.8 Fork. Take left-hand road (south), which is probably better. Road to right goes through farm lands under Gila Water \& Land Co. project. Water may be obtained at any of these farms.

40.8 Corner of cleared land. Go west along south border of cleared land.

42.3 Reverse fork. Road on right is same as right-hand turn at mile 39.8.

48.4 Reverse fork. Faint road, selđom used, comes in from Liberty.

53.2 Cross abandoned irrigation canal. Road passes through breaches in canal wall in a sharp $S$ curve. Careful driving necessary. 
54.4 Reverse fork at fence corner.

54.9 Abandoned house and store. Shallow dry well. Continue on main road. 56.9 Abandoned farm. Two dry wells. Continue straight ahead.

60.1 Unoccupied ranch. Well with windmill. Salty water could be obtained at times; unreliable.

62.2 Frandsen \& Knudsen's ranch. Well with very salty water, unfit for drinking, a quarter of a mile to right of road. Continue on main road.

64.1 Abandoned farm. Well caved and windmill out of order.

66.3 Reverse fork. Faint road on right.

66.8 Reverse fork. Road on right leads from ranch.

67.3 Reverse fork. Road on right leads from ranch.

69.5 Gila Bend. Geological Survey sign. Post office, water, eating house, rooming house, stores, gasoline.

\section{GILA BEND TO PHOENIX BY WAY OF BUCKEYE (69.5 MTLES)}

[See pp. 315-316 for $\log$ in opposite direction]

$$
\text { By C. P. Ross }
$$

0.0 Gila Bend. Geological Survey sign. Go north through town. The road all the way to Gila River crossing is fair to good desert road.

2.2 Fork. Turn to right on most traveled road; road on left leads to ranch.

2.7 Fork, Continue on main road; road on left leads to ranch.

3.2 Fork. Continue on main road, avoiding faint road on left.

5.4 Abandoned farm. Well caved and windmill out of order.

7.3 Frandsen \& Knudsen's ranch. Well with very salty water, unfit for drinking, a quarter of mile to left of road. Continue on main road.

9.4 Unoccupied ranch. Well with windmill. Salty water could be obtained at times; unreliable.

12.6 Abandoned farm. Two dry wells. Continue straight ahead.

14.6 Abandoned house and store. Shallow dry well. Continue on main road.

15.1 Fork. Continue straight ahead, avoiding faint road on left around corner of fence.

16.3 Cross abandoned irrigation canal. Road passes through breaches in canal wall in a sharp $\mathbf{s}$ curve. Careful driving necessary.

21.1 Fork. Continue on main road. Faint road on right leads to Liberty; seldom used.

27.2 Fork. Either road can be used. Take road on right, which is probably the better of the two. Farm lands uuder Gila Water \& Land Co. project are now entered. Water may be obtained at any of these farms.

28.7 Corner of cleared land. Go north along east border of cleared land.

29.7 Fork. Turn to right and go north and east. Road coming in on left is from farms in this project, and is the road encountered if the lefthand road at mile 27.2 is taken. Follow main traveled road; sandy but not difficult.

32.5 South bank of Gila River. The river can under favorable conditions he crossed by automobiles at this place. Do not attempt the ford when river is in flood. It is frequently necessary, even when the river is almost dry, for automobiles to be towed across by horses. The sandy bed of the stream is about a mile wide here.

33.6 North bank of Gila River. Continue due north on fair to good road.

35.0 Fork. Geological Survey sign. Turn east (right). Road west leads to Palo Verde, Yuma, and Parker. 
35.3 Buckeye. Post office, well, hotel, stores, garage, and gasoline. Go east $\{\quad$ on Phoenix-Yuma road. (For detailed log see U. S. Geol. Survey Water-Supply Paper 490-C, p. 289.)

69.5 Phoenix.

\section{GILA BEND TO SENTINEL (30 MILES)}

[See below for $\log$ in opposite direction]

By C. P. Ross

0.0 Gila Bend. (For other roads from Gila Bend see pp. 307-308, 313-324.) Geological Survey sign. Go west from sign and follow north side of railroad track. The road is all fair to good mesa and desert road.

0.9 Reverse fork. Road comes in from across track (south).

2.2 Turn slightly away from track.

3.8 Smurr. Station house on railroad about 0.4 mile south of road.

6.1 Turn west along old abandoned canal and cross small abandoned canal.

7.5 Turn southwest, following canal to railroad track.

8.7 Tum west along track.

9.2 Box-car houses along track just south of this point.

15.0 Piedra. Water in emergencies at section house.

22.1. Tartron. Water in emergencies at section house. Road south from Tartron goes to Rawley mines (14 miles).

29.0 Houses on north side of track. Reverse fork; road, usually obliterated, comes in on right from Jordon's ranch (11 miles). Go west of station to Geological Survey sign.

29.5 Railroad crossing. Geological Survey sign. Turn to left and cross railroad and go back (east) in front of Brown's Hotel to Sentinel station. At the sign a road comes in from Agua Caliente (14 miles), and along the track is the Tucson-Yuma road.

30.0 Sentinel. Water from railroad well. Store, hotel, gasoline.

\section{SENTINEL TO GILA BEND (30 MILES)}

[See above for log in opposite direction]

By C. P. Ross

0.0 Sentinel. Railroad station. (For other roads out of Sentinel see pp. 271, 272.) Go west in front of Brown's Hotel.

0.5 Railroad crossing. Geological Survey sign. Cross railroad and turn abruptly to right (east). Road on left is Tucson-Yuma road (see p. 339) ; that straight ahead leads to Agua Caliente (14 miles). Continue east along railroad. Opposite to railroad station the road is often not visible. Avoid road branching to left (north) to Jordon's ranch (11 miles) and keep along railroad track. The road from Sentinel to Gila Bend is all fair to good mesa and desert road.

7.9 Tartron. Water in emergencies at section house. Continue straight ahead (east) along railroad. Road south from Tartron goes to Rawley mines (about 14 miles).

15.0 Piedra. Water in emergencies at section house.

20.8 Box-car houses along railroad just south of this point.

21.3 Turn northeast away from railroad along abandoned irrigation canal.

22.5 Turn east, crossing small abandoned canal.

23.9 Turn southeast, leaving canal.

26.2 Smurr. Station house on railroad about 0.4 mile south of road. 
27.8 Road comes close to railroad. Continue east.

29.1 Fork. Continue straight ahead, avoiding road forking to right across railroad.

30.0 Gila Bend.

GILA BEND TO VEKOL (46.3 MHLES)

[See p. 319 for log in opposite direction]

The road from Gila Bend to Vekol follows an old Indian trail, but its present form is largely due to the permanent supply of water obtained at Stouts Well. The road is rough and has many sharp curves and steep pitches. Only light and short automobiles in good condition can make the trip.

0.0 Gila Bend. Geological Survey sign. Cross railroad tracks west of station and then old canal.

0.3 Fork. Geological Survey sign. Take road to southeast, fair road across alluvial plains.

2.8 Fork. Take left-hand road; has small board sign reading "To Stouts Well." Right-hand road is Gila Bend-Pozo Blanco road by way of Sauceda. (See p. 320.)

13.0 Wire corral to left, hill to right on entering gap in the mountains. Follow up narrow valley between lava plateaus.

13.4 Cross large arroyo, heavy sand.

16.6 Halfway corral on left. Road hilly and rocky from this point.

19.3 Dim trail goes north from this point to Mesquite Tank. (See pp. 323-324.)

22.8 Sand Tanks. Rock tanks on left of and about 30 feet below the road in large arroyo. Good water except during very dry seasons or when tanks have been used for watering cattle. The road goes east through the gap. The traveler going east usually takes the right-hand road, which has a very heavy grade. It is, however, usually easier to make than the heavy sand of the arroyo on the left-hand road.

25.6 Drift fence. Go through gate and leave open or closed as found. The road now descends in bed of dry stream for a little over a mile. It is very rough, and careful driving is necessary.

28.2 Fork. Keep to right; left-hand road avoids Stouts Well.

29.3 Stouts Well. Good and permanent water in well. Usually someone will be found at the cattle ranch established at this well. Go east outside of fence and along arroyo. The road is very bad and often obliterated by cattle tracks.

30.7 Reverse fork. This road comes directly from the gap, avoiding Stouts Well.

31.9 Limestone hill on right.

36.6 Dry well on right.

38.3 Fork. Geological Survey sign. Turn to right (south) on main north and south road in Vekol Valley. This is the Maricopa-Covered Wells road. (See p. 309.)

38.4 Faint road to left.

38.8 Cross arm of grassy flat.

39.9 Faint road to left.

40.4 Fork. Take road to left toward Vekol visible against hillside across the valley. The road straight ahead is the Maricopa-Covered Wells road and goes south to Totobit and Kaka. (See p. 309.)

42.7 Fork. Keep to right. 
43.1 Ruined house on right.

45.3 Reverse fork. Road from Bitter Well comes in.

46.3 Vekol. Abandoned mining town. Caretaker here part of time; when he is present water can be obtained. From Vekol a road goes to Bitter Well (2.5 miles) and thence to Reward mine. (See p. 307.)

\section{VEKOL TO GILA BEND (46.3 MIILES)}

[See pp. 318-319 for log in opposite direction]

0.0 Vekol. Abandoned mining town. Caretaker here part of time; when he is present water can be obtained. From Vekol a road goes to Bitter Well. (See p. 307.)

1.0 Fork. Keep to left. Ricght-hand road around point of hill goes to Bitter Well. (See p. 307.)

3.2 Ruined house on left.

3.6 Reverse fork. Go northwestward across grassy flats of Vekol Valley.

5.9 Reverse fork. Turn north on Maricopa-Covered Wells road. (See p. 309.)

6.4 Faint road on right.

7.5 Cross arm of grassy flat.

7.9 Faint road on right.

8.0 Fork. Geological Survey sign. Turn to left. Road north goes to Maricopa. (See p. 309.)

9.7 Dry well on left.

14.4 Limestone hill on left.

15.6 Fork. Keep to left over very bad road, along arroyo. This road is often obliterated by cattle tracks. Road on right goes directly to pass, avoiding Stouts Well.

17.0 Stouts Well. Good and permanent water in well. Usually someone will be found at the cattle ranch established at this well. Turn north from well.

18.1 Reverse fork. Direct road comes in from fork at mile 15.6. Turn west up pass over very bad road in bed of dry stream.

20.7 Drift fence. Go through gate and leave open or closed as found. Go down the west silope. Take right-hand turn and go down sandy bed of arroyo. This stretch of sand is about a mile long, but the left-

- hand road has an impossibly steep grade for westbound automobiles.

23.5 Sand Tanks. Rock tanks on right of and about 30 feet below road in large arroyo. Good water except during very dry seasons or when tanks have been used for watering cattle.

27.0 Dim trail goes north from this point to Mesquite Tank. (See p. 323.)

29.7 Halfway corral on right. Road goes west in narrow valley between lava plateaus. Good except for a few sandy washes.

32.9 Cross large arroyo; heavy sand.

33.3 Hill on left an 1 wire corral on right. Turn to right (northwest) out of gap on desert road.

43.5 Reverse fork. Small wooden sign. Gila Bend-Pozo Blanco road by way of Sauceda comes in on left.

46.0 Reverse fork. Geological Survey sign. Cross old canal and railroad tracks.

46.3 Gila Bend. Geological Survey sign.

$104211-25-22$ 


\section{GILA BEND TO POZO BLANCO BY WAY OF SAUCEDA (63.7 MILES)}

[See p. 321 for $\log$ in opposite direction]

This road leads from Gila Bend into the heart of the Indian country. It is a difficult but not an impossible route for automobiles.

0.0 Gila Bend. Cross railroad tracks west of station and old canal.

0.3 Fork. Geological Survey sign. Take road to southwest.

2.8 Fork. Take right-hand road and go south toward gap between Sand Tank and Sauceda mountains. Left-hand road goes to Stouts Well and Vekol and is marked by small wooden sign. (See p. 318.)

24.0 Point of plateau on right. Cross arroyo and enter pass.

26.3 Pass close under hill to right in narrow pass.

28.1 Small springs on right of road and Papago houses.

28.8 Sauceda. Winter ranchería; well on right of road. Permanent water. This is one of the largest of the Papago settlements. From Sauceda roads go to Moivavi, winter ranchería and well, and direct to Kaka, summer ranchería. The location and character of these roads are not known. One can go to Kaka, however, by turning off the road here described at Emita, and from there get within 4 miles of Moivavi by automobile. (See p. 309.) To go to Perigua and Pozo Blanco, continue southwest up valley from well at Sauceda through a pass. Top of pass is about $4 \frac{1}{2}$ miles from Sauceda, and on coming into Perigua Valley road makes a sharp bend to right (west) at base of hill.

35.8 Reverse fork. Road comes in on right, which is impassable for automobiles for 2 miles.

36.3 Fork. Keep to left and go south in center of valley toward isolated hill at Perigua. This road and many others go to Toapit, summer rancheria; no permanent water. As charcos and temporales shift year by year there are many roads. (See Pl. XXVI, B.)

36.8 Emita. Summer ranchería; no permanent water. Continue south on west side of temporal.

40.5 Road Runner. Summer ranchería; no permanent water.

42.8 Perigua. Summer ranchería, houses on east sicle of isolated hill; no permanent water. Road to Pozo Blanco goes east between temporales toward conical peak. Numerous forks and crossroads. A road also goes southwest to a gap and thence to Pozo Redondo. (See p. 341.)

43.6 Cross adobe washes. Charcos near this point hold water for short time after rains.

43.8 Fork. Take right-hand road; go southeast. The left-hand road goes east through pass 11 miles to junction with road from Maricopa to Covered Wells. (See p. 309.)

44.4 Cross wash.

46.1 Small hill on right, thence through adobe flat with mesquite trees into pass between lava-capped mesas.

49.2 Top of low pass. Go down alluvial slope, soft and sandy, and thence southeast across Quijotoa Valley.

51.2 Crossroads. Go straight ahead toward south end of Sierra Blanca. East-west road goes from Charco de la Piedra to Covered Wells. (See p. 341.)

56.7 Mowepa. Summer ranchería. Houses, represo, fields, no permanent water. Go south of represo and corral and north of church and turn southeast. Anotber road goes south from this point to other temporales. 
62.2 Reverse fork. Geological Survey sign. Go east into pass between Sierra Blanca and Quijoton Mountains. Pozo Blanco route of Tucson-Yuma road comes in on right. (See p. 277.)

63.1 Fork. Keep to right; left-hand road goes to Black Prince mine and Brownell.

63.7 Pozo Blanco. Winter ranchería; well in the corrals on the left.

\section{POZO BLANCO TO GIIA BEND BY WAY OF SAUCEDA (63.7 MILES)}

[See pp. 320-321 for log in opposite direction]

0.0 Pozo Blanco. (For other roads from this place see pp. 277, 329.) Go west on Tucson-Yuma road.

0.6 Reverse fork.

1.5 Fork. Geological Survey sign. Take right-hand road toward lava plateau northwest across Quijotoa Valley.

7.0 Mowepa, summer rancheria. Houses, represo, fields; no permanent water. Go south of corral and represo and north of church, and turn northwest toward gap in plateau.

12.5 Crossroads. Keep straight on, up alluvial slope, soft and sandy, into pass between low lava mesas.

14.5 Top of pass. Go down into adobe flats with mesquite trees. Small hills on left, plateaus on right.

17.6 Close under small hill on left.

19.3 Cross wash.

19.9 Reverse fork, under big conical peak; turn across Perigua Valley to isolated hill.

20.1 Cross adobe washes; charcos along these washes. Go south of wire fence and thence north to houses on side of hill.

20.9 Perigua. Summer ranchería; no permanent water. Go north up valley. Road to Pozo Redondo and Ajo goes southwest. (See p. 341.)

23.2 Road Runner. Summer ranchería; no permanent water. Continue north up valley.

26.9 Emita. Summer rancheria; no permanent water. Avoid roads on left, which go to Toapit, summer ranchería, and go north up center of valley toward pass in mountains.

27.4 Reverse fork.

27.7 Fork. Turn to right, to northern base of hill, and then swing north through pass. Road on left impassable for antomobiles.

34.9 Sauceda. Winter ranchería; well with permanent water. Go on down valley.

35.6 Small springs on left of road. Go on down open valley and strike west

- of north across Gila Bend Plains.

60.9 Reverse fork. Road from Vekol and Stonts Well comes in on right.

63.4 Road junction. Geological Survey sign. Cross canal and railroad track. 63.7 Gila Bend.

\section{GITA BEND TO AJO (42.3 MILES)}

[See p. 323 for $\log$ in opposite direction]

The road from Gila Bend to Ajo is a good desert road which has considerable traffic. Its present location dates only from the building of the Tucson, Cornelia \& Gila Bend Railroad. Prior to that time a number of variations were used. The principal one of these is the Gaskill road. This road is now aban- 
doned and it is doubtful if it can be traveled over its full length. It goes north from Ajo on the east of No. 1 well and crosses a low and narrow part of Batamote Mountain. It then goes due north to a point east of Midway Well, where it swings west to Deadmans Gap and continues on the east side of the railroad, crossing the western part of the Sauceda Mountains about 1.5 miles east of Black Gap. Thence it crosses the Gila Bend Plains. This part of the road is badly washed and has many high centers. (For other roads from Gila Bend see pp. 307-308, 313-324.)

0.0 Gila Bend. Post office, water, eating house, rooms, supplies, gasoline. Go south and cross railroad tracks west of station and old canal.

0.3 Fork. Geological Survey sign. Turn to right; for left-hand roads see pages $314,318,323$.

0.7 Fork. Keep to right across railroad tracks; left-hand road is Gaskill road.

0.8 Cross railroad and turn southwest toward Black Gap.

1.3 Reverse fork.

2.1 Fork. Keep to left. Right-hand road goes to Stout's ranch and well. No other watering place for 31.5 miles.

2.6 Turn west on south side of fence and cross Quilotosa Wash.

3.1 End of fence.

3.5 Cross wash.

10.3 Small hill on right of road.

15.1 Black Gap.

15.8 Cross sandy wash.

19.3 Cross railroad into Deadmans Gap. Just after crossing railroad Gaskill road comes in on left and $\mathbf{1 . 5}$ miles farther goes off again to left near a clump of small hills. In both places the road is so faint that some travelers may not notice it.

23.2 Cross to west side of railroad.

23.4 Midway Well on left near track. No equipment on this well, and travelers can not obtain water.

28.1 Enter gap in Crater Mountains. This erosional valley looks much like a volcanic crater, and is usually called "The Crater."

30.3 Out of gap into open valley.

32.4 Reverse fork at railroad crossing. Geological Survey sign. Cross railroad to east side and enter gap. Two roads come from right at sign. The first one is abandoned, the other, which comes in parallel with track, goes to No. 3 Well and Sentinel. (See p. 270.) On east side of track a faint road goes to a temporal and connects with Gaskill road.

33.6 Batamote Well. Geological Survey sign. Good water in dug wells on left.

34.5 Crosis railroad.

39.4 Fork. Keep to left. Right-hand road goes to Gibson, a suburb of Ajo. It is very rough for automobiles.

40.2 Cross railroad to east side.

40.8 Reverse fork. Geological Survey sign. Road from No. 1 well comes in on left.

41.2 Reverse fork. Abandoned Gaskill road comes in on left.

42.0 Reverse fork. Geological survey sign. Cross railroad and turn to right into town.

42.3 Ajo. Excellent water supply; hotels, stores, automobile supplies, repairs, gasoline, etc. 


\section{AJO TO GILA BEND (42.3 MTLES)}

[See pp. 321-322 for $\log$ in opposite direction]

0.0 Ajo. (For roads from Ajo see pp. 270, 273, 334-348.) From railroad station go south and turn to left across railroad track.

0.3 Fork. Geological Survey sign. Turn to left (north). Right-hand road goes to Clarkstown, Gunsight ranch, and Tucson. (See p. 273.)

1.1 Fork. Keep to left. Abandoned Gaskill road on left.

1.5 Fork. Geological Survey sign. Keep to left. Right-hand road goes to No. 1 Well.

2.1 Cross railroad to west side.

2.9 Reverse fork. Rough road from Gibson, a suburb of Ajo, comes in on right.

7.8 Cross railroad.

8.7 Batamote Well. Geological Survey sign. Good water in two dug wells on right. No watering place for 31.5 miles. Go north through gap between Batamote and Childs mountains.

9.9 Cross railroad. Double fork. Turn to right (north) toward gap in Crater Mountains. Middle road is abandoned. Left-hand road goes to No. 3 Well and Sentinel. (See p. 270.) On east side of tracks a faint road goes east to a temporal and joins Gaskill road.

12.0 Enter gap in mountains. This erosional valley looks much like a volcanic crater and is usually called "The Crater."

14.2 Out of gap.

18.9 Midway Well on right near track. No equipment on this well, and travelers can not obtain water.

19.1 Cross to east of railroad and turn to left (north) into Deadmans Gap. The Gaskill road comes in on right south of the gap and leaves on north. In both places it is so faint that some travelers may not notice it.

23.0 Cross railroad to west side.

26.5 Cross sandy wash and go into Black Gap.

27.2 Black Gap. Gila Bend visible to the north.

32.0 Small hill on left of road.

38.8 Cross wash.

39.2 Turn on south side of fence and cross Quilotosa Wash.

39.7 Turn to right (north) along fence.

40.2 Reverse fork. Road comes in across fields from Stout's ranch and well.

41.0 Fork. Keep to right.

41.5 Cross railroad to east side.

41.6 Reverse fork. Gaskill road comes in.

42.0 Reverse fork. Geological Survey sign. Cross canal and railroad into town.

42.3 Gila Bend. Post office, water, eating house, rooms, supplies, gasoline.

\section{GIIA BEND TO MESQUITE TANK}

[See p. 324 for $\log$ in opposite direction]

0.0 Gila Bend. Go south cross railroad and canal to fork.

0.3 Double fork. Geological Survey sign. Turn to left (east) on Gila BendPhoenix road. 
1.0 Fork at railroad crossing. Turn to right (southeast) toward north end of small granite mountain.

7.7 North end of small granite mountain. Turn south into valley.

17.5 Double Butte lies west of road.

17.9 Turn southwest and then south.

20.2 Mesquite Tank. Small ranch. Well under low falls in bed of rocky arroyo.

\section{MESQUITE TANK TO GILA BEND}

[See p. 323 for $\log$ in opposite direction]

0.0 Mesquite Tank. Small ranch. Well under low falls in bed of rocky arroyo. Go north across arroyo.

2.3 Turn north into valley on east side of Double Butte.

2.7 Double Butte lies west of road.

12.5 North end of small granite mountain. Turn west into Gila Bend Plains.

19.2 Reverse fork at railroad crossing. Go west on south side of track.

19.9 Double reverse fork. Geological Survey sign. Turn north across canal and railroad.

20.2 Gila Bend. Geological Survey sign.

\section{ROUTES IN THE BABOQUIVARI AND TECOLOTE VALLEYS}

The Baboquivari Valley lies on the west side of the mountains of the same name and is bounded on the west by the Sierra de Moreno, Las Animas Hills, and Artesa Mountains. The northern boundary is the constriction between the South Comobabi and Baboquivari mountains. South of the Tucson-Yuma road by way of Indian Oasis, which crosses the northern part of the valley, the roads are the direct result of the habits of the Indians. None of them have been run with a speedometer, and they are mapped as shown on the excellent detail sheets of the United States Indian Service made by Herbert V. Clotts, Percy Jones, jr., and Roy A. Goodman.

At the foot of or in the western canyons of Baboquivari Mountains are 14 settlements or winter rancherias, of which the principal ones are San Juan, Chuapo, Ventana, Fresnal, Bears Wells, and Hendricks Well. Fresnal is a very large village about midway in the mountains. It lies in a canyon, and the houses are scattered for 4 miles up the canyon. This village seems to have been originally supplied by springs or perhaps a small stream but now depends on 18 dug wells.

At an average distance of 6 miles from the mountains lie the summer rancherías Magdalena, Tucsoncito, Topahua, Komalik, Chulik, and San Miguel. Each has its near-by fields or temporales. There are also a few small and isolated temporales without names. San Miguel now has a permanent water supply because of the Indian Service well. The Indian Service wells at Topahua have no equipment. Thus for most of these localities water is obtained solely from represos and charcos. Some of these are large and hold water for several months in a year.

Roads run from each winter rancheria to the temporales cultivated by that village, usually the nearest ones. An almost continuous road also runs along the line of summer rancherias from north to south and then at San Miguel swings southeast to Lopez Well and store and to Pozo Verde, a large winter ranchería in Mexico.

The drainage of the Baboquivari Valley goes north of the Alvarez Mountains, and along Valshni Wash and Fresnal Wash, which carcy this drainage, are 
numerous temporales. The corresponding summer rancherias are Vamori and Burro Pond, east of the Alvarez Mountains; Kavolik, north; Rocky Point, south; and San Rafael, west. Vamori has a permanent water supply from the Indian Service well and pumping plant and is connected by roads with San Miguel (11 miles), Fresnal (14 miles), Topahua ( 7 miles), and Indian Oasis (14 miles). Burro Pond is 3 miles from Vamori and is connected with it and Topahua by a maze of roads. Kavolik is 8 miles northwest of Vamori. From this village it is 10 miles to Indian Oasis, 7 miles to Big Fields, and 14 miles to Tonukvo. (See $\log$ on p. 328.) Rocky Point is 6 miles southwest of Vamori and 14 miles by direct road from San Miguel. San Rafael is 4 miles northwest of Rocky Point. It may also be reached from Vamori by going north of Alvarez Mountain 11 miles.

West of Alvarez Mountains is a group of temporales and summer rancherías which center around Tecolote midway between the last-named mountains and the north end of the Sierra La Lesna. Tecolote is on the road from Casa Grande to Pozo San Luis. (See p. 303.) It is 16 miles from Indian Oasis. A road also runs from Tecolote around the north end of the Sierra La Lesna into Mexico. The other temporales are connected by a maze of roads with each other, with Tecolote, with two wells in the Sierra La Lesna, and with Kavolik, San Rafael, and Rocky Point. Roads from these temporales join the Casa Grande-San Luis road and thus provide for travel from these places to Cobota and San Luis in Sonora.

\section{ROADS NORTH AND SOUTH FROM INDIAN OASIS}

Indian Oasis (Sells post office) was founded by Joseph Meneger, who dug the first well and who for many years conducted a store and trading post at this place. At first because of the store and now because of Government buildings and schools, this locality has long been a center for travel in the Papago country. The following paragraphs review the routes leading out of Indian Oasis:

From the Geological Survey sign east of Meneger's store a road goes north 1.4 miles across the arroyo and between fences to a fence corner and fork. The left fork goes west to Big Fields (for $\log$ see p. 276) ; the right fork goes northwestward about 4 miles toward some sharp red hills to a fork on the far side of an abandoned well. At this fork the left-hand road continues northwest $9 \frac{1}{2}$ miles to Kvitatk, a summer ranchería on the Casa Grande-Pozo San Luis road. (See p. 303.) A number of crossroads lead from Big Fields to Nolic. The total distance from Indian Oasis to Kvitatk is 15 miles. The right-hand road at the fork by the abandoned well goes north 6 miles to Nolic, where there are three dug wells, and 7 miles to Santa Cruz, where there are three dug wells. Wickchoupai, where there is a dug well, is $1 \frac{1}{2}$ miles south of Santa Cruz. There are doubtless roads between these rancherias that are not shown on the map.

The Golden Age mine is $4 \frac{1}{2}$ miles north of Artesa Pond. From Indian Oasis go east from the Geological Survey sign 2 miles on Tucson-Yuma road (see p. 268 ) and turn north on the east side of the pond.

Roads lead south from Indian Oasis on both sides of Artesa Mountains. The western roads are reached by going west on the Tucson-Yuma road (see p. 268) 1.5 miles to a double road fork with Geological Survey sign. The righthand road going west is the Tucson-Yuma road. The middle road is the Indian Oasis-Menegers Dam road. (See p. 326.) The left-hand road forks almost immediately, the left fork going east to James Well, 4.7 miles from Indian Oasis, and continuing from James Well across the mountains to the eastern 
part of Topahua, 10 miles from Indian Oasis; the right fork continues along the west base of Artesa Mountains 4.6 miles to a crossroad. By keeping to the left the western temporales of Topahua are reached 9.5 miles from Indian Oasis, and by continuing south and avoiding crossroads Vamori is reached 14 miles from Indian Oasis.

On the east side of the Artesa Mountains two roads go southeast from Artesa Pond, 2 miles east of Indian Oasis on the Tucson-Yuma road. (See p. 268.) Either road will do provided the traveler turns sharply south at the point of the mountains $2 \frac{1}{2}$ miles from Artesa Pond. A maze of roads intersect here. Select the best traveled and go southeast 6 miles to the eastern part of Topahua, where connections are made with the numerous roads of the Baboquivari Valley. (See p. 324.)

\section{MISCELLANEOUS ROUTES BETWEEN QUIJOTOA MOUNTAINS AND GUNSIGHT PASS}

\section{INDIAN OASIS TO MENEGERS DAM (42.9 MIIES)}

[See p. 327 for $\log$ in opposite direction]

To go from Indian Oasis to Menegers Dam follow the Tucson-Yuma route by the southern road to Big Fields for 10.4 miles to the represo south of Big Fields. (For $\log$ see p. 268.)

0.0 Indian Oasis.

10.4 Big Fields. Represo on left of road, ustally dry. On west side of corral which is just west of represo turn southwest. Road for next 4.4 miles was not run, and mileages are measured from map.

12.3 Fork. Take right-hand road.

13.3 Crossroads. Keep straight on. This is road from Iron Pipe to Tecolote. (See p. 303.)

14.8 Crossroads. Keep straight on. This is road from Tonukvo to Kavolik. See p. 328.)

15.5 Mesquite thicket. Mesquite in orchard-like groves along this road for several miles.

23.4 Reverse fork. Road from Copeka comes in here. (See p. 327.) Rocky hill on right.

24.6 Cross small sand dune.

25.6 Fork. Keep to right past rocky hill smaller than the last and proceed over sandy plain. On south side of this hill is a charco which has water for a short period after rains. The road on left goes to Serventi Well (1.3 miles). It is impossible to obtain water from this well.

33.4 Reverse fork. Road from Comovo comes in on right. (See p. 329.)

33.8 Camote. Summer ranchería. There is a large, horseshoe-shaped represo 400 feet across the base and inclosed in a brush fence. Behind the dam, and in the charco which it is intended to improve, water remains for several months after a rain. The locality is very sandy, and cattle obliterate wagon tracks. To go to Menegers Dam proceed north of the represo and slightly north of west over sandy plain. From Camote a road goes southeast to Susuta and thence to other points in Sonora, Mexico. Go on south side of corral passing boundary monument 156 on the left over very sandy road. Susuta is a pond in the sand dunes about 500 feet wide, and is dry only in very dry years.

35.0 Scattered mesquite trees. 
39.4 Top of low divide between the Great Plain and La Quituni Valley. A charco called "Charco de Conejos" lies near this divide. From this point the road swings slightly to the north toward the west end of Nariz Mountains, through scattered, orchard-like groves of mesquite.

42.9 Menegers Dam. Water collects in the borrow pit of this uncompleted dam for several months after a rain. (See p. 332.)

\section{MENEGERS DAM TO INDIAN OASIS (42.9 MIILES)}

[See pp. 326-327 for log in opposite directlon]

0.0 Menegers Dam. Go slightly north of east, then east, through groves of scattered mesquite trees.

2.5 Divide between La Quituni Valley and the Great Plain. A charco called "Charco de Conejos" lies near this divide.

7.9 Leave scattered mesquites and go over sandy, treeless plain

9.1 Camote. Summer rancheria. Pass charco and represo on right, houses on left, to corral. Water in the represo for several months after a rain. Very sandy, and roads usually obliterated by cattle tracks. Turn to left (northeast) at Corral. Road to south of corral goes to Susuta (2.5 miles).

9.5 Fork. Take right-hand road; left-hand road leads to Comovo. (See p. 329.)

17.3 Reverse fork on east side of little rocky hill; charco on south side of hill which has water for a short time after rains. Road from right comes from Serventi Well (1.3 miles). No water.

18.3 Cross small sand dune.

19.5 Fork on east side of rocky hill. Keep to right. Mesquite in orchardlike groves along this road for several miles. Road to left goes northeast to Copeka. (See p. 327.)

27.4 End of mesquite thickets.

28.1 Crossroads. Keep straight on. This is road from Tonukvo to Kavolik. (See p. 328.)

29.6 Crossroads. Keep straight on. This is road from Iron Pipe to Tecolote. (See p. 303.)

30.6 Reverse fork.

32.5 Represo on south side of Big Fields. Turn east at corral and go between represo and fences. (For details see $\log$ on p. 275.)

42.9 Indian Oasis.

\section{COPEKA TO SERVENTI WELI (8.9 MILES)}

[See p. 328 for log in opposite direction]

0.0 Copeka. (For other roads from Copeka see pp. 268, 275, 328.) Go west from hill on north side of represo, crossing adobe wash, and then go southwest toward gap between hill called "Chewetun" and main part of Copeka Mountains. An old road will be found which is badly washed but hard and easily traveled.

3.3 Top of divide. Go down alluvial slope into adobe flats with salt bushes and some drifted sand.

6.8 Rocky hill on right in mesquite-covered adobe flats.

7.9 Reverse fork. Road from Indian Oasis comes in on left. For log see pages 326-327. 
8.1 Fork on east side of small rock hill. Turn to left. Road on right goes to Camote." (For log see p. 330.) There is a charco on the south side of this hill, which holds water for some time after rains.

8.9 Serventi Well. Small house and well with drilling rig on place. Usually impossible to obtain water, because no one lives here and there is no adequate apparatus.

\section{SERVENTI WELI TO COPEKA (8.9 MTIES).}

[See pp. 327-328 for log in opposite direction]

0.0 Serventi Well. Go northeast to rocky hill.

0.8 Reverse fork on east side of hill. Turn to right.

1.0 Fork. Turn to left and go through adobe flats to gap in Copeka Mountains.

2.1 Rocky hill on left.

5.6 Top of divide. Turn to right toward Copeka, easily visible after crossing the divide.

8.9 Copeka. (For roads from Copeka see pp. 268, 275.)

\section{COPEKA TO KAVOLIK BY WAY OF TONUKVO (16.3 MIIES)}

[See below for log in opposite direction]

0.0 Copeka. Summer ranchería. Represo and large pond, in which water will be found for several months after rain. (For other roads out of Copeka, see pp. 268, 275, 327.) From small sandy hill and corral go west and turn south on west side of pond and thence go southeast over good road, which is very muddy when wet.

2.6 Tonukvo. Summer rancheria. Represo and large pond, in which water will be found for several months after rain. Turn on north side of represo and go south of east over good desert road.

5.7 Crossroads. Continue straight on. This is road from Indian Oasis to Menegers Dam. (See p. 326.)

7.8 Fork. Keep to right. Left-hand road goes to Big Fields.

8.0 Crossroads. Continue southeast. This road is from Casa Grande to San Luis, Mexico. (See p. 303.)

9.3 Temporal on right.

13.7 North end of temporal. Turn to right (south) on east side of field. Reverse fork; here road comes in from Big Fields (6 miles).

14.6 Crossroads. Continue on. This is road from Indian Oasis to Tecolote. 15.8 Complex crossroads in outskirts of Kavolik. Turn to left to represo.

16.3 Kavolik. Summer ranchería. Represo and large pond.

\section{KAVOLIK TO COPEKA BY WAY OF TONUKVO (16.3 WIIES)}

[See above for $\log$ in opposite direction]

0.0 Kavolik. Summer ranchería. Represo and large pond. Go southwest from represo.

0.5 Complex crossroads. Turn north.

1.7 Crossroads. Continue north on east side of temporal. This is road from Indian Oasis to Tecolote.

2.6 North end of temporal and fork. Take left-hand road around end of temporal and then go north of west. The right-hand road goes to Big Fields (6 miles). 
7.0 Temporal on left.

8.3 Crossroads. Continue north of west. This is road from Casa Grande to San Luis, Mexico. (See p. 303.)

8.5 Reverse fork. A road from Big Fields comes in.

10.6 Crossroads. Continue straight on. This is road from Indian Oasis to Menegers Dam. (See p. 326.)

13.7 Tonukvo. Turn on north side of represo and go north on west side of adobe flat.

16.3 Copeka. Come in on west side of represo and turn to right to small sand hill and corral. (For roads out of this place, see pp. 268, 275, 327.)

\section{POZO BLANCO TO PISINEMO (11.1 MILES)}

[See below for log in opposite direction]

0.0 Pozo Blanco. From well at corrals go southwest between the scattered houses toward south side of big lava-covered hill.

2.2 Southern point of hill.

2.7 Cross big wash, then go southward along alluvial slope on west side of Quijotoa Mountains, crossing numerous washes, over fair plains road.

4.3 Faint road on right.

9.4 Faint road on left.

9.5 Fork. Keep to right.

10.6 Reverse fork.

11.1 Pisinemo. Small represo on right. No permanent water. (For logs of roads from Pisinemo see pp. 269, 275, 280-281.)

\section{PISINEMO TO POZO BLANCO (11.1 MILES)}

[See above for $\log$ in opposite direction]

0.0 Pisinemo. Go northeastward, keeping small represo on left.

0.5 Fork. Turn to right.

0.6 Faint road on right. Turn eastward and then north, following along alluvial slope parallei to Quijotoa Mountains, crossing numprous washes, over fair plains road.

6.8 Faint road on left.

8.4 Cross big wash and go on east side of large lava-capped hill.

8.9 East point of hill, thence between the scattered houses of Pozo Blunco to well.

11.1 Pozo Blanco. (For logs of roads from Pozo Blanco see pp. 277-279. 320-321.

\section{COMOVO TO CAMOTE (14.6 MULES)}

[See p. 330 for $\log$ in opposite direction]

0.0 Comovo. Go west from church and turn south on east side of corral into Comovo Valley on east side of Mesquite Mountains.

1.5 Fork. Keep to left.

1.8 Fork. Keep to left. These forks go to west side of fields.

2.3 Go between fences. Houses of temporal of Comovo on right.

2.7 Pass end of fence on left.

4.1 Mesquite Charcos on left about 0.4 mile. These charcos extend along the arroyo for some distance and are likely to have water for one or two months after rains. $A$ faint road branches off on right toward gap in Mesquite Mountains north of Mamatotk Mountain. 
9.0 Southerly point of Mesquite Mountains on right. Come into adobe flat, where road is likely to be obliterated after rains. A trail comes in on northwest from Mesquite Tank ( 6 miles). The so-called tank is probably a spring and the water is permanent. It is 3 by 3 by 7 feet long and is in a cave in the face of a white cliff, near a verty green mesquite tree easily visible from Camote. A horse can drink from the tank but must back out of the cave. Charcos are said to exist along the trail about $1 \frac{1}{2}$ miles from the point of the mountains. Near this point also a road is said to lead off on the right directly to Menegers Dam.

12.1 The plain is covered with drifted sand from here to Camote.

13.4 Reverse fork. Road from Indian Oasis comes in on left. (See p. 326.)

14.3 Camote. Keep to right of corral and go west.

14.6 Represo and charco of Camote. Water here for 2 or 3 months after rain unless a great deal has been used by stock. (For road out of Camote see pp. 326-327.)

\section{CAMOTE TO COMOVO (14.6 MILES)}

[See p. 329 for $\log$ in opposite direction]

0.0 Camote. From represo go east to corral.

0.3 Corral. Turn northeast with corral on right.

1.2 Fork. Take road on left; road on right goes to Indian Oasis. (See p. 326.)

2.5 End of sand; road shortly runs into adobe flat where tracks are obliterted during rains. Go toward gap between Mesquite Mountain and hills on right.

5.6 Southerly point of Mesquite Mountain on left. (See above for roads and trails from this point.)

10.5 Mesquite Charcos on right (two-fifths of a mile). Faint road on right leads toward gap in Mesquite Mountain.

11.9 Fence corner on right. Go north between fences of temporal of Comovo. 12.3 End of fences, house on the left. Go north toward Comovo, visible from this point.

12.8 Reverse fork.

13.1 Reverse fork.

14.6 Comovo.

\section{CHARCO EN MEDIO TO CUBO (7.5 MLLES)}

[See p. 331 for $\log$ in opposite direction]

The road from Charco en Medio to Cubo is little used but is easily traveled with all kinds of vehicles. The nearest permanent water is a well near a prospect 2 miles west of Charco en Medio. A little-traveled but passable road leads from Charco en Medio past this well to Walls Well, 7 miles.

0.0 Charco en Medio. Go south between represo and corral toward pass in hills. Water in represo for only a short time after rains.

1.4 Reverse fork; road comes in on right.

2.1 Top of divide. Go down slope toward easterly point of Cubo Hills.

4.2 Cross numerous washes for next quarter of a mile.

6.1 Reverse fork.

6.2 Reverse fork.

7.5 Cubo. Pass corral on right to charco, which holds water only for short time after rains. At this point reach Cubo route of Tucson-Yuma road. (See p. 280.) 


\section{CUBO TO CHARCO EN MEDIO (7.5 MLES)}

[See p. 330 for log in opposite direction]

0.0 Cubo. Leave charco and go north on east side of corral and small field, keeping Cubo Hills on left.

1.3 Fork. Keep to left.

1.4 Fork. Keep to right.

3.1 Cross numerous washes for next quarter of a mile, then enter granite hills and go up gentle grade.

5.4 Top of divide. Go down slope into basin in Gunsight Hills.

6.1 Fork. Turn to right.

7.5 Charco en Medio. Represo on right, corral on left. Reach TucsonYuma road (p. 266) in front of houses.

\section{WALLS WELL TO MENEGERS DAM AND MEXICO}

From Walls Well roads lead through the pass into the Barajita Valley and thence south along the east side of the Ajo Mountains to the Mexican border in the vicinity of Menegers Dam.

\section{WAILS WELL TO MENEGERS DAM BY WAY OF COCHIBO (27.2 MILES)}

[See p. 333 for $\log$ in opposite direction]

0.0 Walls Well. Winter ranchería; well; about 10 houses. Millex's ranch is a quarter of a mile west of the rancheria. He has two wells; there is a greater supply of water and it is more sanitary. From Walls Well take right-hand road.

1.0 Reverse fork. Geological Survey sign. Come into Cubo route of TucsonYuma road (see p. 280) and follow it for 7.5 miles.

1.2 Cross rocky gap.

1.6 Faint road on right. This road leads to Barajita, winter rancheria, where there are two wells ( 6 miles). Keep to left along eastern part of Barajita Valley for Cubo and Menegers Dam. Road on left goes to Cubo. (See p. 280.)

7.0 Fork. Geological Survey sign. Keep on south. Road on left goes to Cubo.

7.3 Rocky hillock on right; then cross wash.

7.5 Crossroad. This is one of numerous roads from Cubo to Barajita, not shown on map.

8.5 Fork. Keep straight on south. Road on right goes to Barajita (6 miles).

9.3 Faint road on right.

9.6 Charcos on left common for next mile.

10.4 Corral on left and just south of it represo. This is new represo on site of old charco. Water probably lasts only a few days after rain. Faint roads go off in various directions near the represo. A trail said to be passable for wagons leads southwestward through a gap in Cubo Hills to Charco Colorado (6 miles). For Cochibo continue south with hills on left.

11.1 Charcos on left.

13.9 Fork. Keep to right. Road on left goes through gap in hills to Charco Colorado (2.8 miles). It is a good road for automobiles and, for persons not desiring to go by way of Cochibo, it is the best route to Menegers Dam from this point.

14.1 Reverse fork of same road. 
14.3 Charco on right.

14.5 Turn southwest onto gravel benches.

16.4 Reverse fork. Turn to right up narrow canyon for water; by keeping to the left 0.8 mile will be saved on total distance to Menegers Dam.

16.5 Corral and Papago houses on right.

16.8 Cochibo. Winter rancheria with two wells; good water but should be boiled. (See Pl. XXV, A.) The principal Indian here is Jose Manuel, and the well is sometimes known by his name. A horse trail leads from this place to Sonoita, Sonora. Return down canyon.

17.2 Fork. Same as mile 16.4. Turn to right, keeping along base of mountains toward gap at south end of Barajita Valley.

21.0 Out of hills; bear south toward gap between Nariz and Ajo mountains.

24.4 La Quituni. Summer ranchería; two houses; usually no water here except immediately after rains, when charcos are full. Numerous roads; keep temporal on right and hear to left to strike road from Charco Colorado, which lies east of drainage line.

25.0 Reverse fork. Road from Charco Colorado comes in on left.

26.7 Marin's represo; out of repair and will not hold water. From a point near Marin's represo a road goes southwest over a pass in the Cerros de Angostura called "Garambullo" into the Santa Rosa Valley to Santa Rosa, Sonora.

27.2 Menegers Dam. The dam is an earthen embankment across a gap in the Cerros de Angostura, still in process of construction in 1917. In the borrow pit water collects after rains and remains for several months. From this point roads lead south on the east side of the Nariz Mountains to Nariz, Sonora ; east to Camote and Indian Oasis (see p. 327), and northeast to Mesquite Charcos and Comovo. (See p. 330.)

\section{WALLS WELI TO MENEGERS DAM BY WAY OF CUBO AND CHARCO COLORADO (27.2 MIIES)}

[See pp. 333-334 for log in opposite direction]

0.0 Walls Well. Follow same route as given in $\log$ of road by way of Cochibo. (See p. 331.)

7.0 Fork. Geological Survey sign. Turn to left into gap in the Cubo Hills and follow between fields to east end of gap.

9.4 Cubo. Charco on right; water for only a short period after rains. Houses and corral on left. Continue east. Road to Charco en Medio goes north on east side of corral. (See p. 331.)

8.9 Double fork. Geological Survey sign. Take right-hand road and turn south around point of hill; middle road goes to Comovo (see p. 282) ; left-hand road goes to Pisinemo (see p. 280). Go south in valley between Mesquite Mountains and Cubo Hills. The road from Cubo to Charco Colorado was not run, and distance is given as measured on map.

17.9 Charco Colorado. Summer rancheria, two houses on little hillock, pass to the left of them. No permanent water. Road comes in on right from Barajita Valley; it is 2.9 miles to Walls Well-Cochibo road. (See p. 331.) .

18.2 Fork. Keep to right; road to left goes to temporal.

18.5 Temporal on left.

19.3 Temporal on left.

20.1 Charcos on right of road.

22.3 Faint road on left. 
24.3 Numerous crossroads and forks for next mile. Head toward right-hand notch in hills ahead and then turn to left toward left-hand notch.

26.7 Marin's represo. (See p. 332.)

27.2 Menegers Dam. (See p. 332.)

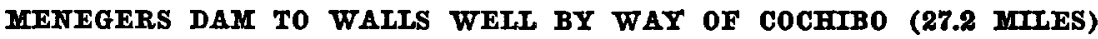

[See pp. 331-332 for log in opposite direction]

0.0 Menegers Dam. Go northwest along base of hills.

0.5 Marin's represo.

1.2 Numerous crossroads and forks in next mile.

2.2 Fork. Turn to left to temporal; right-hand road goes by way of Charco Colorado.

2.8 La Quituni. Summer ranchería; two houses; usually no water here except immediately after rains. Numerous forks and crossroads.. Go north toward gap between Ajo Mountains and Cubo Hills.

6.2 Enter gap; keep along western side.

10.0 Reverse fork. Turn left up narrow canyon.

10.1 Corral and Papago houses on right.

10.4 Cochibo. Winter rancheria with two wells; good water but should be boiled. Return down canyon.

10.8 Fork. Same as mile 10. Turn to left over gravel benches.

12.7 Turn north along adobe flat.

12.9 Charco on left.

13.1 Fork. Keep to left; road on right goes through gap to Charco Colorado (2.9 miles).

13.3 Reverse fork of same road.

16.8 Corral on left and just south of it represo. (See p. 331.) Charcos on right of road common for next mile.

16.9 Faint road comes in on left.

18.7 Fork. Keep straight on. Road on right goes to Barajita (6 miles). (See p. 331.)

19.7 Crossroad. This is one of numerous roads from Cubo to Barajita, not shown on map.

20.2 Fork. Geological Survey sign. Avoid turn to right, which goes to Cubo (see p. 280), and go northwest toward north end of Ajo Mountains.

25.6 Faint road comes in on left; this road comes from Barajita (6 miles).

26.0 Cross rocky gap.

26.2 Fork. Geological Survey sign. Take left-hand roads; right-hand road goes to Gunsight ranch. (See p. 280.)

27.2 Walls Well. Winter ranchería; well and about 10 houses. Miller's ranch, a quarter of a mile west, has better water.

\section{MENEGERS DAM TO WAILS WELL BY WAY OF CHARCO COLORADO}

(27.2 MILES)

[See pp. 332-333 for log in opposite direction]

0.0 Menegers Dam. Go northwest along base of hills.

0.5 Marin's represo.

1.2 Numerous crossroads and forks in next mile.

2.2 Fork. Turn to right toward gap between Mesquite Mountains and Cubo Hills. Left fork goes to temporal and summer ranchería of La Quituni.

4.9 Faint road on right.

7.1 Charcos on left of road. 
7.9 Temporal on right.

8.7 Temporal on. right.

9.0 Reverse fork. Road on right comes from temporal.

9.3 Charco Colorado. Summer ranchería; two houses on little hillock. No permanent water. Pass to right of houses and go between Mesquite Mountains and Cubo Hills. Road from this point to mile 17.3 was not run, and distance is given as measured on map. From Charco Colorado, just south of houses, a road goes northwest through a gap in Cubo Hills 2.9 miles to road from Cochibo to Walls Well. It is probably the best route from this point to Walls Well.

17.3 Double reverse fork. Geological Survey sign. Turn to left around point of hill into gap at Cubo. Comovo route (see p. 281) joins Cubo route (see p. 348) at this point, and the road described in this $\log$ is identical with them.

17.8 Cubo, charco on left; water for only a short period after rains. Houses and corral on right. Go west through gap, with field on left, and then between fields. Road to Charco en Medio goes north on east side of corral. (See p. 331.)

20.2 Reverse fork. Geological Survey sign at west end of gap. The remainder of $\log$ is identical with that of road from Menegers Dam to Walls Well by way of Cochibo. (See p. 333.)

\section{ROUTES FROM AND NEAR AJO}

\section{ATO TO YUMA BY THE CAMTNO DEL DTABLO (152.7 MILES)}

[See pp. 338-340 for $\log$ in opposite direstion]

This road goes from Ajo to Bates Well and then follows in a general way the route of the Camino del Diablo, the old route from Altar and Caborca in Sonora by way of Sonoita to California. The difficulties and dangers of this route are much less than in the early days, owing to the drilling of Papago Well and the digging of Tule Well. Travelers, however, should make careful inquiry as to the condition of the road, the presence of adequate equipment at Papago Well, and of water at Tinajas Altas. Travelers by automobile must be prepared to camp and make road repairs and should carry a liberal allowance of gasoline and oil. A shortage of either will entail a long walk, for neither can be procured between Ajo and Wellton, a distance of 115 miles.

0.0 Ajo. Go west from rallroad station and turn southwest and then south.

1.0 Go under railroad trestle. Fork. Take left-hand road, as righthand road is likely to be bombarded with rocks when blasting is done in the open cuts of the New Cornelia mine, which lies to the right.

1.2 Old Ajo. Most of the buildings of the old settlement were burned sereral years ago.

1.6 Reverse fork. Alternate road comes in on right, also fork. Keep to right (south). Road on left goes over Reservoir Hill.

2.3 Double fork. Keep straight on. Right-hand road goes to Cardigan (2.1 miles). Left-hand road to Darby Well (1.1 miles).

2.4 Fork. Keep to right (south). Road goes left to Darby Well.

2.6 Cement Tank. A rock tank lies 100 feet to right in the arroyo. It is improved with a concrete dam and holds water for several months after rain. The water is usually filthy and not fit to drink. Cross arroyo and go south, 
3.7 Reverse fork. Road comes in on left from Darby Well (1.4 miles). Go south with Black Mountain on left.

5.3 Wood road on left.

5.8 Wood road on left.

7.1 Fork. Geological Survey sign. Keep to right toward pass in Growler Mountains. Road on left goes to Sonoita, Sonora, Mexico. (See p. 342.)

16.6 Bates Well. Geological Survey sign. This is the east well; the newer west well is three-tenths of a mile west and has better water. It is 21 miles to next watering place and 52 miles to absolutely dependable water. From the Geological Survey sign go slightly north of west, keeping north of west well and wire fence over sandy road to rocky pass. (For other roads out of Bates Well see pp. 344-345.)

17.7 Top of pass; Yellow Jacket mine on left.

17.9 Growler mine on left and house on right. Go west across Growler Valley toward north end of Agua Dulce Mountains over fair but littletraveled desert road.

30.6 Forix at foot of ragged granite hills. Geological Survey sign. Keep to right. The left-hand road goes to Papago mine and Papago Well by way of Steel Tanks. It is about the same length as the right-hand road and some travelers prefer it.

31.6 Go between granite hills.

33.2 Go around point of hill.

39.3 Papago Well. Geological Survey sign. Drilled well on north side of large arroyo, black hill just south. There was in 1920 a tripod and pulley erected over the well. Water was obtained by means of a steel cable drawn through a pulley and attached to a sand pump, the sand pump being lowered to water at a depth of 235 feet, filled through a valve at the bottom, and pulled out by attaching the cable to an automobile. (See Pl. XXV, B.) A single horse or two men could pull out the sand pump when full, but it is doubtful if a man alone could obtain water. From the well a road goes east 1.5 miles to Papago mine, easily visible against the side of a small mountain, thence by way of Steel Tanks to the fork at mile 30.2. A road also goes north on the west side of Mohawk Mountains 52.5 miles to Mohawk. (See pp. 271, 272.) No dependable water on this route. To follow the old Camino del Diablo go west.

40.0 Cross arroyo which passes Papago Well; very deep sand. (See Pl. XXVII.)

Go west just north of spur of mountains toward gap in O'Neills Hills.

43.3 O'Neills Pass. Arroyo on right. Grave of Dave O'Neill on right of road, marked by pile of stones and wooden cross. Go west out of pass down alluvial slope toward Las Playas. Pinta Mountains north and scattered hills south.

45.4 Fork. Go west. Left-hand road goes to Batamote and Las Positas, watering places on Sonoita River in Mexico.

48.0 Las Playas. Hard-baked clay surface, with small mesquite bushes around border. During and after rains there is a shallow lake here. If it drains at all it drains to Mexico. Water will be found for several weeks after rains in charcos along the southwestern border. All variations of the Camino del Diablo route passed through Las Plavas and from this place the modern route is practically identical with the old one.

$104211-25-23$ 
49.4 End of playa. Start up sandy slope toward low mesa on west. This sandy slope is the most difficult part of the road for low-powered automobiles. From this point there is an old trail and road to Feart Tank in the Pinta Mountains. This distance is about $14 \mathrm{miles}$, and the road is impassable for automobiles because of heavy drifted sand.

49.7 Palo Verde Tree. A tree on left side of road with shelves fitted in the branches and with advertising signs tacked on it. It is a well-known landmark. From this point to the top of the mesa the sand is very deep.

50.6 Edge of Pinacate plain. Good mesa road for next 5.6 miles.

56.2 Go down mesa over heavy drifted sand.

57.0 End of sand. Go west toward gap in mountains ahead. Plains road soft and badly washed.

59.3 Automobile tracks on right (north). These tracks were made by Tremaine in 1916 when he succeeded in getting within 1.5 miles of Heart Tank by automobile. He went northeast 4.5 miles, passing threequarters of a mile west of small volcanic cone, and then turned and followed center of valley for about 4 miles more. Thus he avoided the drifted sand along the southern end of Pinta Mountains. Heart Tank is located 4.5 miles north of very prominent geologic contact, plainly visible from the Camino del Diablo, which divides the blackish gneisses and schists of the south end of the mountains from the pinkish-white granite of the north end. Heart Tank consists of a pothole in a stream channel high up on the side of the mountain. At certain water levels the water surface has the conventional heart shape, hence the Spanish name Tinaja de Corazon. It is probably never dry, but mountain sheep sometimes drown in it and thus pollute the water. There is said to be another tank on the east side of Pinta Mountains, but its location is uncertain.

64.3 Entrance to pass.

66.5 Turn to right over hills; very rough and rocky road.

66.8 Turn to left downhill into open valley and then turn north. County signboard near this last turn.

69.9 Tule Well, located just north of large arroyo among small rocky hills. There is a new well with a plank curb just south of old well, from which no water can be obtained. The ruins of an adobe house lie 100 feet north. There is usually a bucket and rope at the new well, but travelers should carry their own, to provide against contingencies. The water is salty but not dangerous to the health. A road goes east from Tule Well about 3.5 miles to a prospect and there turns northeast and goes on the east side of the Cabeza Prieta Mountains. About half a mile from the prospect is a very deep arroyo which is extremeily difficult for automobiles to cross. By this road it is 12 miles from Tule Well to a wooden county sign which says, " 9 miles to Tule Well." From this sign it is 9 miles to Cabeza Prieta Tanks, where water will be found except in very dry seasons. It is also about 14 miles from this sign to Heart Tank. (See p. 348.) The Camino del Diablo goes west from Tule Well over some low hills into an open valley.

71.7 Avoid tracks on left which lead to prospect.

72.1 County sign: "Tule Well 2 miles." 
72.6 Tracks on left.

72.9 Tule Tank. Geological Survey sign at entrance to small cove in steep mountain on right of road. Tule Tank is 1,600 feet on left up narrow canyon. It consists of a rock basin about 6 feet in diameter at base of dry falls and is usually full of sand. Water is found in the sand for some time after rains. Not permanent.

73.5 Reverse fork. Faint roads come in on left from narrow pass south of valley between lava-capped hills and very high peak. It is said that this road can be followed by automobile for 20 miles.

74.3 Fork. Turn to left (west) out of narrow pass into small open valley and strike northwest toward pinkish-white conical peak and black-capped mountain. Road on right goes north in narrow pass. It is said to go to Cabeza Prieta Tanks.

77.9 Turn west in pass betwen pinkish-white conical peak and lava plateaus on the south. Go down valley and then turn to right onto gravel bench.

78.9 Gravel bench. Very large black boulders; road rough but hard.

79.4 Go down off bench and strike west across Lechuguilla Desert. Road soft and in places badly washed.

83.2 Fork. County signs. Talke left-hand road; right-hand road goes to Coyote Water (4.5 miles). Water can be obtained at this locality by digging in the sand of the arroyo about 4 feet. The water has an unpleasant taste, probably because of decaying roots.

88.7 Reverse fork. Road comes in on left. It leads from points in Mexico near Papago Tanks. In about 2 miles it becomes very difficult for automobile travel.

88.9 Reverse fork. County sign. Road comes in from Coyote Water (3.4 miles). Travelers by automobile from Tinajas Altas to Coyote Water should stop on west side of axial arroyo of valley unless compelled to cross, as arroyo is 100 feet wide and has very deep sand. Water is found about 100 feet north of crossing.

89.6 Tinajas Altas. Geological Survey sign. Water will be found in a series of tanks in a very steep stream channel or dry falls 500 feet west of sign. The lowest tank is commonly full of sand, and water will be found by digging in sand. The second and third tanks are best reached by turning to left (south), where a steel cable will be found, up which it is easy to climb the smooth rock face. The upper tanks are difficult to reach, and it can perhaps best be done by taking trail to right and climbing to "window" and then going down to canyon above the falls. The water lasts all year, but the lower tanks are sometimes exhausted by travelers. If so, climb to upper tanks and pour water down channel to fill lower ones. The water is palatable but there are usually dead bees in it. Occasionally mountain sheep slip and fall into the tanks and contaminate the water. Travelers will find road from Geological Survey sign up arroyo to tanks very difficult for automobiles, and are advised to camp on gravel bench west of sign. To go to Yuma proceed north from sign.

90.2 Fork. Keep to right along west side of Lechuguilla Desert. Road to left goes through pass in mountains and follows west side of Gila Range to Fortuna mine and thence by way of Blaisdell to Yuma. It is about 25 miles to Fortuna mine. The road is very difficult for automobiles.

96.2 Reverse fork. County signs, Road comes in on right from Coyote Water (7 miles). 
96.7 Crossroad. Continue north. This road runs from Copper Mountain to Raven Butte Tank, a small tank with uncertain water in a canyon southwest of Raven Butte, about 3 miles from this crossroad.

97.5 Fork. Take right-hand road toward gap in Wellton Hills. Left-hand road is an old road largely abandoned, which strikes railroad near Ligurta.

100.2 Enter hills; various faint roads go off to prospects in these hills. Keep on main traveled road.

104.0 Out of hills. Wellton visible to north. Follow main traveled road by way of small house.

115.7 Cross railroad track.

115.8 Wellton. Geological Survey sign. Post office, water, hotel, garage, gasoline. From Wellton take Tucson-Yuma road to Yuma. (See p. 271.)

133.0 Dome.

153.0 Yuma.

\section{YUMA TO AJO BY THE CAMINO DEL DIABLO.}

[See pp. 334-338 for log in opposite direction]

0.0 Yuma. Follow Yuma-Tucson road. (See p. 272.)

13.3 Blaisdell. From this station a road crosses railroad to Fortuna mine (see p. 348) and thence to Tinajas Altas. Road from Fortuna mine to Tinajas Altas is very difficult for automobiles. Turn north and follow macadam road.

37.2 Wellton. Geological Survey sign. (See p. 334 for preparations necessary for this trip.) Go south from post office.

37.3 Cross railroad tracks and bear to right up slope with very deep drifted sand toward small house.

48.0 Enter Wellton Hills; various faint roads go off to prospects in these hills. Keep south on main traveled road.

53.1 Out of hills ; go south along west side of Lechuguilla Desert.

55.5 Reverse fork. Old road, largely abandoned, comes in on right from Gila Valley near railroad station of Ligurta.

56.3 Crossroads. Continue south. Raven Butte Tank 3 miles west. (See above.)

56.8 Fork. County signs. Road to left goes to Coyote Water (7 miles).

62.8 Reverse fork. Road from Blaisdell and Fortuna mine comes in on right.

63.4 Tinajas Altas. Geological Survey sign. Permanent water in rock tanks. (See p. 337.) From Geological Survey sign go south to point of cove and then southeast.

64.1. Fork. Take right-hand road across Lechuguilla Desert toward pass between conical pinkish-white mountain and low dark plateaus. This conical mountain is just south of black-capped mountain. Left-hand road goes to Coyote Water (3.4 miles). (See p. 337.)

66.0 Fork. Keep to left. Road on right goes south toward Papago Tanks in Mexico. It becomes very difficult for automobiles 2 miles south.

69.8 Reverse fork. Road comes in from Coyote Water (4.5 miles). (See p. 337.)

73.6 Go up gravel bench; very large boulders; road rough but hard.

74.1 Go down off bench and turn to left (east) to pass.

75.1 Turn to right (southeast) in pass into little valley and go toward very narrow opening in granite hills.

78.7 Reverse fork. Turn to right (south) in pass. Road on left is said to lead from Cabeza Prieta Tanks. 
79.5 Fork, at turn out of narrow pass into open valley. Keep to left (east) along northern border of valley. Road on right goes south across valley to narrow pass between lava-capped hills and high peak. It is said that this road can be followed by automobiles for 20 miles.

80.1 Tule Tank. Geological Survey sign. Water not permanent. (See p. 337.)

80.4 Tracks on right.

80.9 County sign, "Tule Well 2 miles."

81.3 Avoid tracks on right going to prospect and go through small hills to another open valley.

83.1 Tule Well. Permanent water. (For other roads from this well see p. 336.) Go south from well across arroyo.

86.2 Turn to left near county signboard uphill and then to right over very rough and rocky road.

87.5 Turn to left (east) in narrow pass.

88.7 Out of pass. Go east across plain over soft plains road badly washed.

93.7 Automobile tracks on left (north). (See p. 336.)

96.0 Deep drifted sand to top of mesa.

96.8 Edge of Pinacate plain. Good mesa road for next 5.6 miles.

102.4 Go down from mesa through very deep drifted sand.

103.3 Palo Verde Tree. A tree on right side of road with shelves fitted in the branches and with advertising signs tacked on it. Sandy road to playa.

103.6 Las Playas. Beginning of playa. (See p. 335.)

105.0 End of playa. Go east up alluvial slope toward gap in O'Neills Hills, Pinta Mountains to north. scattered hills on right.

107.6 Reverse fork. (See p. 335.)

109.7 O'Neills Pass. Arroyo on left. Grave of Dave O'Neill on left of road, marked by pile of stones and wooden cross. Go east toward scattered hills at north end of Agua Dulce Mountains.

113.0 Cross to north side of arroyo; very deep sand.

113.7 Papago Well. Geological Survey sign. Water permanent, but apparatus to obtain it may be missing. (See p. 335 and $\mathrm{PI}$. XXV, $B$, for information. For alternate road and road to Mohawk see same page.) Go northeast.

119.8 Turn to right around point of hill and go southeast.

121.4 Between granite hills.

122.4 Reverse fork. Geological Survey sign. Alternate road comes in on right. (See p. 335.) Go east across plain over fair but little-traveled desert road to gap in Growler Mountains.

135.1 Growler mine on right, house on left. Go over hill.

135.3 Top of little pass; Yellow Jacket mine on right. Go southeast into valley.

136.4 Bates Well. Geological Survey sign. This is east well; the newer well is three-tenths of a mile west and has the better water. From the sign go northeast through pass.

145.9 Reverse fork. Geological Survey sign.

147.2 Wood road comes in on right.

147.7 Wood road comes in on right.

149.3 Work. Keep to left. Right-hand road goes to Darby Well (1.4 miles).

150.4 Cement Tank. (See p. 334.)

150.6 Reverse fork. Road on right leads from Darby Well (1.1 miles). 
150.7 Double reverse fork. Road on right comes from Darby Well; road on left comes from Cardigan (2.1 miles).

151.4 Fork. Keep to right, as alternate road on left is likely to be bombarded by rocks when blasting is done in open cuts of New Cornelia mine on left. Also reverse fork; road from left goes over Reservoir Hill. Keep north toward railroad trestle.

151.8 Old Ajo.

152.0 Go under railroad trestle and follow main traveled road into town. 153.0 Ajo.

\section{AJO TO POZO REDONDO AND PERIGUA (33.8 MILES)}

[See p. 341 for logs in opposite direction]

The roads from Ajo to Pozo Redondo go through the gap between the Bata- mote and Pozo Redondo mountains. The plateaus of these ranges are separated by a small circular mesa easily seen from Ajo. The roads join and go between this mesa and the Pozo Redondo Mountains-that is, through the southern passageway of what appears at a distance to be a double gap. The $\log$ is given by way of Childs ranch. The other road is of practically the same length and somewhat easier to travel. It starts near the rear of Sam Clark's house, just north of the main street at Clarkstown.

0.0 Ajo. Follow Tucson road. (See p. 272.)

0.3 Geological Survey sign. Turn to right.

1.0 Clarkstown.

2.1 Fork. Keep to left.

2.4 Fork. Keep to left; right-hand road goes to Gunsight ranch and Tucson.

5.1 Childs ranch and slaughterhouse. Deep well and pumping plant; good water. Turn to left and go north along arroyo. A road, little used, goes from this ranch directly south 2 miles to Gunsight road, and another southeast 7 miles to the same road.

5.7 Fork. Turn sharply to right across arroyo with steep clay banks. Road straight ahead on west side of arroyo is seldom used and connects with abandoned Gaskill road. On crossing arroyo come into a maze of roads made by wood haulers. Head toward gap.

8.4 Reverse fork. Well-marked road comes in on left. This road is direct route into $\mathbf{A j o}$.

10.1 Drift fence in gap; go through gate. Keep to right; left-hand road goes 3.4 miles to new well of Tom Childs.

11.4 Rocky hill on right. Arroyo on left.

12.8 Turn to right around rocky point and cross wash. Go south in Pozo Redondo Valley.

15.6 Small rocky hill on right.

16.4 Fork. Turn sharply right across large arroyo.

16.6 Pozo Redondo. Winter ranchería. Old well; good water, which should be boiled. Niew well being dug a quarter of a mile north. From Pozo Redondo a little traveled but good road leads south 8 miles to Gunsight ranch. Road to Perigua goes east: from Pozo Redondo; recross the arroyo to fork (mile 16.4).

16.8 Fork. Go south between houses and turn southeast. Follow east border of Pozo Redondo Valley. 
22.1 Charco de la Piedra. Road passes among some small outliers of mesa and loose boulders. In these is the charco, which does not hold water for more than a few weeks after rain. Turn northeast to cross rocky ridge. Other roads lead from Charco de la Piedra to Gunsight ranch ( 6 miles), to Charco en Medio (9 miles), and to Charco de la Lomita ( 5 miles). These roads are little used but are easily passable except in wet weather. From Charco de la Lomita a road strikes across Quijotoa Valley, crosses tip of Sierra Blanca, and goes down east side of mountain to Covered Wells, a distance of 27 miles. By way of Charco de la Piedra it is then 37 miles from Pozo Redondo to Covered Wells.

23.3 Crest of ridge. Go down and cross little valley to gap.

25.8 Crest of gap is an open adobe flat with mesquite trees. Small charco on the eastward-flowing drainage.

29.4 Fork. Take right-hand road toward isolated hill in plain, avoiding many crossroads and forks.

33.8 Perigua. Summer ranchería. Two houses and some shelters on east side of isolated hill; no permanent water. Small charcos and fields on fiat to east. (For roads through Perigua see pp. 309-312, 320-321.)

\section{PERIGUA TO POZO REDONDO AND AJO (33.8 MCHES)}

[See pp. 340-341 for log in opposite direction]

0.0 Perigua. Summer rancheria. No permanent water. Go south from houses on hillside with fences on left.

0.7 Turn to right through maze of crossroads. Take best traveled road toward gap in mountains southwest.

4.4 Reverse fork.

8.0 Crest of gap in open adobe flat with mesquite trees. Small charco east of crest. Turn southwest into little valley and cross rocky ridge.

10.5 Crest of ridge. Go downhill and turn northwest.

11.7 Charco de la Piedra. Road passes among some small ontliers of the mesa and loose boulders. In these is the charco, which does not hold water for more than a few weeks after rain. Turn northeast and go along border of Pozo Redondo Valley. (For other roads see above.)

17.0 Reverse fork on far side of houses. Turn sharply to left and cross arroyo.

17.2 Pozo Redondo. Permanent water in well. Return to fork and go north. (For road to Gunsight ranch see p. 340.)

18.0 Small rocky hill on left.

21.0 Cross wash and turn to right a round rocky point into gap.

22.4 Rocky hill on left, arroyo on right.

22.0 Out of gap. Ajo visible across Valley of the Ajo.

25.4 Fork. Take left-hand road; right-hand road goes direct to Ajo; about the same distance; generally in better condition, but no water.

28.1 Cross arroyo; steep clay banks.

28.2 Fork. Turn sharply to left toward Childs ranch. Well tower visible. Right-hand road goes north and connects with abandoned Gaskill road.

28.8 Childs ranch. Turn to right at well.

31.4 Reverse fork. Road from Tucson and Gunsight ranch comes in on left. (See pp. 266-270 for detailed log.)

31.7 Reverse fork.

32.8 Clarkstown.

33.5 Geological Survey sign. Turn to left across railroad.

33.8 Ajo. 


\section{AJO TO SONOITA (42 MLLES)}

[See p. 343 for $\log$ in opposite direction]

The common route to Sonoita at the present time branches from Ajo-Bates Well road 7 miles out of Ajo and goes south on west side of Black Mountain. An old road branches from the Ajo-Gunsight ranch road east of Black Mountain. but this road is now practically abandoned.

0.0 Ajo. Go west from railroad station and turn southwest and then south.

1.0 Go under railroad trestle. Fork. Take left-hand road, as right-hand road is likely to be bombarded with rocks when blasting is done in open cuts of New Cornelia mine, which lies on right.

1.2 Old Ajo. Most buildings of old settlement were burned several years ago.

1.6 Reverse fork. Alternate road comes in on right. Also fork. Keep to right (south). Road on left goes over Reservoir Hill.

2.3 Double fork. Keep straight on. Right-hand road goes to Cardigan (2.1 miles), left-hand road to Darby Well (1.1 miles).

2.4 Fork. Keep to right. Road on left goes to Darby Well.

2.6 Cement tank. A rock tank 100 feet to right, in arroyo. It is improved with concrete dam and holds water for several months after rain. The water is usually filthy and not fit to drink. Cross arroyo and go south.

3.7 Reverse fork. Road comes in from Darby Well (1.4 miles). Go south with Black Mountains on left. Locomotive Peaks on right.

5.3 Wood road on left.

5.8 Wood road on left.

7.1 Fork. Geological Survey sign. Keep to left. Road on right goes to Bates Well and Yuma. (See p. 334.)

16.2 Crossroads. Geological Survey sign. Continue south; east-west road goes from Bates Well to Walls Well. (See p. 344.) Nearest water is Bates Well (5 miles).

18.4 Cherioni Well on right, about 50 yards on south side of arroyo. This well is usually dry.

21.0 Fork. Geological Survey sign. Keep to left. Right-hand road goes 1.7 miles to second fork, whence left-hand road goes to Dripping Spring, a permanent spring under a white gap called Puerto Blanco. This spring is $\mathbf{5 . 5}$ miles from mile 21.0. The right-hand road is a rough and little-used route to Cipriano Well. (See p. 345.)

25.1 Fork. Keep to left. Road to right crosses arroyo and goes to Milton, Levy, and Martinez camp (8 miles).

27.3 Reverse fork. Enter pass in low hills. Road comes in on left which goes through Copper Mountain mine to Bates Well-Walls Well road, approximately 11 miles.

29.5 Go through gate in drift fence.

29.8 Top of pass. Go down alluvial slope into Sonoita Valley.

33.1 Out of pass.

36.7 Fork. Keep to left. Faint road on right.

37.7 Blankenship Well at international boundary. Well on right with good water, house on left; boundary monument 167 west of well. There is also a well on the Mexican side of the line. From Blankenship Well it is 2 miles in an air line to Sonoita, Sonora, Mexico. The distance by road is probably greater and is usually called 5 miles. This distance is used on the signboards. From Blankenship Well there is an old road practically abandoned to the ruined smelter at 
Dowling and thence to Quitobaquito. A trail also goes northwest by way of Bullpasture, a small but permanent spring, across the Ajo Mountains to Cochibo.

42.0 Sonoita. Wells, springs, and water in Sonoita River. At this town there is usually a commissioner and customs officer of the Mexican Government. During the recent civil war the town has been continually occupied by troops of one or the other faction.

\section{SONOITA TO AJO (42 MILES)}

[See pp. 342-343 for log in opposite direction]

0.0 Sonoita. It is 2 miles in an air line from Sonoita to Blankenship Well. The road is somewhat longer and is usually called 5 miles. This distance is used on the signboards.

4.3 Blankenship Well, on north side of gate at international boundary. Well on left with good water; house on right. Boundary monument 167 west of well. There is also a well on the Mexican side of the line.

5.3 Reverse fork. Go up alluvial slope to gap in hills. Faint road comes in on left.

8.9 Beginning of pass in low hills.

12.2 Top of pass.

12.5 Go through gate in drift fence and down narrow valley between low mesas.

14.7 Fork at north end of pass. Keep to left; right-hand road goes through Copper Mountain mine to Bates Well-Walls Well road (11 miles).

16.9 Reverse fork. Road comes in on left across arroyo from Milton, Levy, and Martinez Camp ( 8 miles).

21.0 Reverse fork. Geological Survey sign. Road comes in on left from Dripping Spring ( 5.5 miles). This road forks 1.7 miles out, and the right fork is a rough and little-used road to Cipriano Well. (See p. 345.)

23.6 Cherioni Well on left abont 50 yards, on south side of arroyo. This well is usually dry.

25.8 Crossroads. Geological Survey sign. Continue north. East and west road goes from Bates Well to Walls Well. (See p. 344.) Nearest water Bates Well (5 miles).

34.9 Reverse fork, Geological Survey sign. Road comes in on left from Bates Well and Yuma.

36.2 Wood road on right.

36.7 Wood road on right.

38.3 Fork. Keep to left toward gap in hills. Road on right goes to Darby Well (1.4 miles).

39.4 Cement Tank. (See p. 334.)

39.6 Reverse fork. Road on right comes from Darby Well.

39.7 Double reverse fork. Right-hand road comes from Darby Well (1.1 miles) ; left-hand road comes from Cardigan (2.1 miles).

40.4 Fork. Keep to right, as left-hand road is likely to be bombarded with rocks when blasting is done in open cuts of New Cornelia mine, which lies to left (west). A road goes east from this point over Reservoir Hill.

40.8 old Ajo.

41.0 Reverse fork. Go under railroad trestle and follow main traveled road into Ajo. Alternate road comes in here.

42.0 Ajo. 


\section{WAIIS WEII TO BATES WELI (17.4 MILES)}

[See below for log in opposite direction]

0.0 Walls Well. Winter rancheria of about nine houses. Dug well near corrals. Watér 19 feet from surface; no bucket. Travelers will obtain more and better water at Miller's ranch. Drilled wells near by supplied part of water for Gunsight mine. One mile east is TucsonYuma road. (See p. 280.) Go west through gate.

0.1 Miller's ranch. Two dug wells and windmill. From this ranch a road and trail go to Alamo Well, which has water most of the year and thence there is a trail to Horse Tanks; uncertain water. Go west.

1.1 From this point an old and almost obliterated road goes north to join the road from Jaques ranch to Lewis Well.

5.0 Faint road on south goes to Copper Mountain mine and thence to Sonoita road. (See p. 342.)

9.7 Crossroads. Continue west. This is old Sonoita road, which leaves the Gunsight road east of Black Mountain. (See p. 342.)

12.4 Crossroads. Geological Survey sign. This is Ajo-Sonoita road, mile 16.2. Continue west into mesquite thicket. Road sometimes obliterated by cattle tracks.

15.6 Faint road comes in on left near entrance to pass. By this road it is 3.3 miles to Cherioni Well.

17.4 Bates Well. Geological Survey sign. This is the east well. Better water will be obtained at the west well, 0.3 mile west. (For other roads from Bates Well see pp. 335, 339, and below.)

\section{BATES WELL TO WAILS WELL (17.4 MIIES)}

[See above for log in opposite direction]

0.0 Bates Well. Geological Survey sign. The best water is at the west well, three-tenths of a mile west. Roads often obliterated by cattle tracks. Go southeast along north bank of arroyo into gap southeast of Bates Well.

1.8 End of gap. Go east in mesquite thicket. Near this point a faint road goes off to Cherioni Well (3.3 miles).

5.0 Crossroads. Geological survey sign. Continue east. This is Ajo-Sonoita rroad, mile 16.2.

7.7 Crossroads. Continue east. This is old Sonoita road, which leaves the Gunsight road east of Black Mountain. (See p. 342.)

12.4 Faint road comes in on right (south) from Sonoita road through Copper Mountain mine. (See p. 342.)

16.3 From this point an old and almost obliterated road goes north to join the road from Jaques ranch to Lewis Well.

17.3 Miller's ranch. Two dug wells and windmill. Travelers will find more and better water here than at Walls Well. Go east through gate.

17.4 Walls Well. Winter ranchería of about nine houses. Dug well near corrals, water 19 feet from surface; no bucket. It is 1 mile frorn this well to the Tucson-Yuma road. (See p. 280.)

\section{BATES WEIT TO QUITOBAQUITO (19.8 MILES)}

[See p. 345 for $\log$ in opposite direction]

0.0 Bates Well. Geological Survey sign. This is the east well. More and better water will be found at the west well. (For other roads from Bates Well, see pp. 335, 339, and above.) 
0.3 West well. Turn south across sandy arroyo and then southwest.

0.4 Go through gate.

0.8 Go through gate.

2.4 Faint road on left (south).

6.5 Powers Well on right; dry, no water. Go south into succession of narrow valleys between low mesas.

14.5 Reverse fork. Keep to left. Right-hand road goes out into Growler Valley toward Agua Dulce Mountains.

14.6 Cipriano Well. Dug well; slightly brackish water. In very dry seasons this well has little water.

14.8 Uncompleted well on right. Go southeast to gap.

15.5 Divide.

15.9 End of gap. Go south along western border of Ia Abra Plain. Faint road on northeast comes in from Ajo-Sonoita road. (See p. 342.)

19.0 Road on right goes over hill into Quitobaquito. It avoids going into Mexico but is badly washed.

19.1 Aguajita. Water will usually be found in the arroyo here.

19.3 Turn west around hills. Faint road goes southeast along boundary line.

19.4 Boundary monument 172 on little hill to right.

20.0 Quitobaquito. Several springs in little basin in granite hills at south end of Quitobaquito Hills. The springs, which have permanent flow of good water, are in the United States; the pond, field, and most of the houses are in Mexico. Since the revolution in Mexico the Papagos who formerly lived at Quitobaquito have moved away.

\section{QUITOBAQUTTO TO BATES WELL (19.8 MILES)}

[See p. 344 for log in opposite direction]

0.0 Quitobaquito. Go southeast from houses on Mexican side of line. A road northeast through gap is wholly in American territory but is badly washed.

0.4 Boundary monument 172 on little hill to left.

0.5 Turn north. Faint road goes southeast along boundary line.

0.7 Aguajita. Water will usually be found in the arroyo here.

0.8 Road on left comes in from Quitobaquito. It is badly washed.

3.9 Enter gap. Faint road on northeast comes in from Ajo-Sonoita road. (See p. 342.)

4.3 Divide. Go down into open small valley.

5.0 Uncompleted well on left.

5.2 Cipriano Well. Dug well; slightly brackish water. In very dry seasons this well has little water.

5.3 Fork. Keep to right through succession of narrow valleys between low mesas. Road on left goes to Growler Valley and toward the Agua Dulce Mountains.

13.3 Powers Well on left; dry. Go northeast toward gap in hills.

17.4 Faint road comes in on right.

19.0 Go through gate.

19.4 Go through gate.

19.5 West well at Bates Well. Turn to right.

19.8 Bates Well. Geological Survey sign. Well on right is the old well. More and better water will be obtained from the west well. (For roads from Bates Well see pp. 335, 339, 344.) 


\section{ROADS NEAR THE LITTLE AJO MOUNTAINS}

Roads near the Little Ajo Mountains are shown on the map in some detail. The region has, however, been the site of almost continuous prospecting for many years. Consequently there are many old and abandoned roads, as prospecting develops a well-traveled road within a week, which in turn may be abandoned as quickly. An almost continuous road encircles the mountains, and many of the other roads may be considered as branches of it. Reverse log is not given.

0.0 Ajo. Go north and west.

0.6 Gibson. A suburb of Ajo. Several dug wells, hotel, and stores.

0.7 Fork, outskirts of Gibson. Take left-hand road west and then northwest. Right-hand road joins Ajo-Gila Bend road at mile 2.9. It is a very rough road.

2.5 Fork. Small wooden signboard. Left-hand road goes half a mile to fork. There is a small wooden signboard here also. Right-hand road goes half a mile to Cook \& Landro Well, a dug well on west side of an arroyo in a little valley. This well has water throughout the year. Left-hand road goes 1 mile to Steele Well, a dug well said to have water throughout the year. Right-hand road at the fork (mile 2.5) goes northwest around north base of small hill at mile 3.6 and then west to gap at south end of Childs Mountain.

5.7 Well. A dug well, 16 feet to water, permanent throughout the year. No equipment. Turn left across arroyo and go southwest and then southeast on road skirting mountains.

8.9 Reverse fork. Road comes in on right from Tule Well. A dug well, with a windmill and near-by small rock tank. The water is permanent. Tule Well is seven-tenths of a mile distant. From this fork go east up arroyo into pass north of Ajo Peaks. This part of the road is practically impassable for automobiles.

12.2 Double reverse fork. Left-hand road comes in from Cardigan, a mine and well 0.3 mile distant. There is usually at least a caretaker and sometimes a few miners on the property. Formerly a few Papago families lived here. Right-hand road comes in from McNeils Well, half a mile distant. This well was dug as a prospect hole and is not a very reliable water supply. The same road is used to get to a number of prospects in' the vicinity of Ajo Peaks. There is a sand tank in the arroyo about four-tenths of a mile southwest of this fork. The tank holds water for several months after rain. Go east.

13.3 Wood road comes in on right. A horse trail to Bates Well also leaves at this place.

13.7 Double reverse fork. Road on left from Cement Tank (see p. 334) and road on right from a prospect.

14.0 Reverse fork on road from Bates Well and Sonoita into Ajo. (See 16.3 Ajo. pp. $334,342$.

\section{MINOR ROADS WEST OF AJO}

\section{ROADS IN AND ADJACENT TO SAN CRISTOBAL VALLEY}

The San Cristobal Valley lies between the Mohawk Mountains on the west and the Aztec Hills and Aguila Mountains on the east. In the valley and adjacent to it are a number of roads, and such information as is available concerning them is given in the following paragraphs. 
From Stoval, a section house on the railroad 206.4 miles from Tucson and 66.5 miles from Yuma on the Tucson-Yuma road, a road goes south 3.8 miles to Pimeria Well, a deep well, from which, however, travelers can not obtain water, becanse there is no apparatus. Then the road goes to Garcia Well, 8 miles from Stoval, a dug well which has a windmill and a depth to water of 46.3 feet. The well had only 8 inches of water in 1917 but was being deepened. The water is brackish but potable.

From Garcia Well the road continues straight south up the valley for $\mathbf{8 . 5}$ miles, where it forks and a road on right leads to Whites Well-a dug well. From the fork the road continues south to Papago Well, going between the Granite and Mohawk mountains. The total distance from Stoval to Papago Well by this road is not less than 41 miles, but nothing is known as to the exact location or characteristics of this road, except that it is very little used and that water is found only at the places mentioned above.

The ordinary route from the railroad to Papago Well goes south from Mohawk on the west side of the Mohawk Mountains. Mohawk is a station of the Southern Pacific Railroad 213.9 miles from Tueson and 59 miles from Yuma, on the Tucson-Yuma road. The road goes through a great deal of drifted sand south of Mohawk and is a difficult journey 52.5 miles long. There is no permanent water, but water is found at times in rock tanks in a cove on the west side of the Mohawk Mountains, 15 miles from Mohawk, at Glynns Falls. East of the Mohawk Mountains a road goes south through the Red Cross mine, 5 miles from the railroad. This road connects with the Mohawl-Papago Well road through a pass in the mountains marked by three hills. North of this pass on the east side of the mountains is a rock tank in which water lasts for only a short time. On the south side of the pass is an old mine.

The old Yager road from Ajo to Yuma was used in freighting ore from the copper mines of Ajo to tidewater at $\mathrm{Y}$ uma in the years following the Civil War. There were probably several variations in route, but the principal road crossed San Cristobal Valley. From Garcia Well a dim track goes southeast toward the Aguila Mountains. As seen from this point the mountains consist of a northern part which is blackish in color, flat-topped, and slopes to the northeast, a central part which consists of a series of high jagged reddish peaks, and three isolated hills stringing off to the southwest. The road goes between the largest and most northerly of these hills and the jagged peaks and thence strikes across the plain for the north end of the Growler Mountains. From the pass in the Aguila Mountains roads lead on either side of the mountains to two sets of tanks, Eagle Tanks on the east side and Don Diego Tanks on the west side. Eagle Tanks is considered a reliable watering place. The Yager road has been traveled by at least two parties in automobiles in recent years. Both parties were composed of very experienced travelers and they report that the old road is virtually obliterated and marked only by a somewhat taller and greener growth of creosote bushes. By way of Stoval and Garcia Well the route presents no difficulties which could not be overcome by a small amount of work and more traffic. This route may eventually supplant the Ajo-Yuma road by way of Sentinel.

Eagle Tanks are commonly reached from Aztec, a station on the Southern Pacific Railroad. The road crosses the railroad track and goes southeast. About 1 mile from Aztec there is a fork and a road goes southwest through the Aztec Hills and then diagonally across San Crisctobal Valley to join the road from Stoval to Papago Well, about 18 miles south of Stoval. This road has been used within the last two or three years and is a fair desert road. 
The left-hand road continues southwest, to join the Yager road near the sonthern end of the Aguila Mountains. At 16 miles from Aztec a trail leads off to the right to Eagle Tanks, which are about hali a mile west of the road. These tanks are usually considered a reliable watering place, but they have been visited so seldom in the last few years that little information is qvailable. E. L. Jones, jr., states that the tanks consist of seven potholes 5 to 6 feet deep and 4 to 5 feet wide in a deep and narrow stream channel. ${ }^{69}$

\section{WELITON TO BAKER TANKS AND POINTS SOUTH}

0.0 Wellton. Go east from post office and cross railroad east of station, then go south along west side of wire fence. Barand's house and well on left.

0.4 Turn to left (east) at fence corner; sandy road

0.7 Turn to right (south).

1.2 Turn to left (east).

1.4 Fork. Keep to left in a generally easterly direction over very poor road toward Baker Peaks. Road on right goes on west side of the Copper Mountains to various prospects. No permanent water. Travelers should consult local people in Wellton before using this road.

8.0 Fork. Turn left to windmill. Road on right goes south on east side of Copper Mountains to various prospects and continues to Cabeza Prieta Tanks. Travelers should consult local people in Wellton before using this road.

8.2 Baker Tanks. A number of tanks distributed in the bed of a deep and rocky arroyo for 1,000 feet northwest from the windmill. Water will be found here throughout the year. If much is used by stock, it may be necessary to dig in the sand near the windmill; usually the potholes 70 feet west of the windmill have the best drinking water.

\section{BAKER TANKS TO WELITON}

0.0 Baker Tanks. Go west from windmill.

0.2 Take right-hand road. (For road on left (south) see above.)

6.8 Reverse fork. (For road on left (south) see above.)

7.0 Turn to right (north).

7.5 Turn to left (west).

7.8 Turn to right (north) at fence corner, sandy road, Barand's house and well on right. Cross railroad and turn west on north side to Wellton post office.

\section{8,2 Wellton.}

\section{BLAISDELI TO FORTUNA MTNE (13.8 MILES)}

From Blaisdell, a station on the Southern Pacific Railroad, a road runs south along the west side of the Gila Mountains to Fortuna mine. This road is kept in condition for automobile travel by the caretaker at Fortuna mine.

0.0 Blaisdell. This place is $\mathbf{1 3 . 3}$ miles from Yuma on the Tueson-Yuma road. The nearest water is Imperial Well, three-quarters of a mile northwest over a sandy road. Go south through gate and cross railroad. Follow well-marked road over coarse gravelly benches.

62 Personal communication. 
13.8 Fortuna mine, in canyon on west front of mountains. The mine hoist and mill still stand; most of the town is in ruins. Water is obtained from the mine shaft and from prospect holes which are used as cisterns. Two are east up the canyon; the third is four-tenths of a mile southwest.

From Fortuna mine a road goes on the west side of the mountains and crosses through a pass to Tinajas Altas. The distance is about 26 miles, but the road is very difficult for automobile travel. A road also goes northwest to Araby and thence to Yuma. It is so sandy that it is abandoned for the somewhat longer route by way of Blaisdell.

\section{DETAILED DESCRIPTIONS}

In the following pages a cross reference to the log is given at the head of each description, and as a means of tying the descriptions more closely to the logs the log distance is stated in parentheses for many of the points described. If the log is given in both directions, two distances are stated. The first figure indicates the distance from the point named first in the heading and the second figure the distance from the point at the other end of the route. For example, "Dobbs Butte (34, 238.9)," under the heading "Tucson to Yuma," means that Dobbs Butte is 34 miles from Tucson and 238.9 miles from . Yuma; and this point will be found at mile 34.0 in the log from Tucson to Yuma and at mile 238.9 in the reverse log from Yuma to Tucson.

\section{TUCSON TO YUMA}

\section{OLD MAIN ROUTE}

[For log see pp. 266-276]

Tucson to Indian Oasis.-Tucson (too-sown'), once the site of a Spanish presidio, is the second city of Arizona and in $1920 \mathrm{had}$ a population of 20,292. Tucson was first mentioned in 1699 by. Kino under the name San Cosme del Tucson as a ranchería with "splendid fields" In 1763 it was a visita of the mission at San Xavier del Bac. The name comes from the Papago or Pima "tjuik," black, and "son," at the foot of, and signifies the place or village at the foot of the black hill. Variants of the word are Tugson, Tuison, Tuguison. The patron saint is also given as San Agustín and San José by early Spanish explorers.

The modern Tucson is a bright and cheerful commercial city. It is a center of railroad traffic and the main supply point for the stock and mining industries of southeastern Arizona and northern Sonora. The University of Arizona, with about 1,200 students, and a large Indian school are located here. The Carnegie Desert Botanical Laboratory for the study of the vegetation of arid regions is built on the northern slopes of Tumamoc Mountain, just west of the city. From this laboratory have come a series of important scientific papers on desert plants. Pumping of water for irrigation has reached a high stage of development in the neighborhood of Tucson.

The road goes west through the city across the bed of Santa Cruz River and turns south around the foot of Sentinel Hill, the most easteriy portion 
of Tumamoe Mountain, which gave the name to the town of Tucson. At the crossroads $(3.8,269.1)$ an excellent new road goes west to Robles Pass. The road to the south goes to San Xavier del Bac and Twin Buttes (p. 285). The new road to the west rises by a series of easy curves through a pass in relatively low hills that form this part of the Tucson Mountains. On the left of the road going up the pass is an old quarry of gray-white volcanic tuff, of which many houses and some of the university buildings in Tucson have been built. At the top of Robles Pass the view opens to a great plain, which extends to the south between the Sierrita, Cerro Colorado, and Tumacacori mountains on the east and the Baboquivari and Coyote mountains on the west. This plain is called Altar Valley and drains north into the plains on the right of the road. The high square tower of Baboquivari Peak, 7,741 feet in altitude, dominates the landscape. The northern part of the plain to the right of the road is called the Abra Valley and lies between the Tucson Mountains on the east and a series of low, more or less detached mountains on the west.

The road goes west, passing to the right of Snyders Hill and toward the gap at the north end of the bold light-gray slopes of the Coyote Mountains. Snyders Hill, about 2 miles west of the pass, is a low knob of blue and gray limestone, from which was quarried a large part of the road metal for the road. There is a well at the right of the road, but no water can be obtained.

Midway of the plains is the Robles ranch $(23.3,249.6)$, a spot of green and a pleasant halting place. A deep well and gasoline engine furnish water for the cattle that support the ranch. From the Robles ranch a road turns south into Altar Valley, but the Tucson-Yuma road continues west. The road passes through low hills and swings to the south of Dobbs Butte, a high rocky hill of dark-brown lava. In the early days travelers through this pass obtained water at Agua la Vara, a small spring now improved by a well, which lies on the north side of the Coyote Mountains. A few trees make a green patch easily visible from the road. At the present time roads lead off at the crossroads east of Dobbs Butte $(34,238.9)$ to winter rancherias at San Pedro, 4 miles north, where there is a well, and Alamo, half a mile south. Alamo is a new village at a well dug by American prospectors (p. 268). From Alamo a road leads south along the eastern base of the Coyote Mountains to La Alina, a Papago ranch and well. Two miles beyond this crossroads $(36,236.9)$ is the Roadside mine, a small mine at which, when it is in operation, water may be obtained. At such times there is also a small store. Just west of the mine in a small gully is Dobbs Well, dug many years ago by a man named Dobbs, but for a long time part of the Maish ranch and on that account shown on many old maps as Maish or Maish Well. This well is maintained in serviceable condition by the county but often lacks a bucket and rope.

In 1920 the graded highway stopped at this point, but a good natural road follows for the next 10 miles the northern border of the Baboquivari Mountains, here called the Quinlan Mountains, over a dissected pediment or plain cut in rock. The roadbed is rough, and there are many short grades and pitches, but occasional work by the United States Indian Service keeps the road passable. The vegetation adjacent to this stretch of road shows the full variety of the desert flora. The sahuaros are large and handsome; chollas and other cacti are numerous. The palo fierro, or ironwood, grows in clumps or as isolated trees on the rocky red hills north of the road. Coyote, in Papago Panták, a winter ranchería, of about 10 houses, lies half a mile south of the road in the reentrant between the Coyote and Baboquivari mountains. The town and well may be reached by $a$ branch road 3 miles west of Dobbs Well. 
North of the main road lies an open plain, with a few small isolated hills, which lies between the Roskruge, Waterman, and Silver Bell mountains on the east and the Comobabi Mountains, Vaca Hills, and Santa Rosa Mountains on the west. The road from Coronel, a stock-watering place, to the Santa Rosa ranch crosses the Tucson-Yuma road $(43.6,229.3)$, and from this ranch, where there is a deep well and pumping plant, a road goes northeast through the center of the plain to Silver Bell. Near the fork to Coronel $(44,228.9)$ is San Vicente, a well and windmill at a small store.

A mile farther along the Tucson-Yuma road is a fork and a United States Geological Survey sign (45.1, 227.8). Here the traveler must make his choice of routes to Ajo. The right-hand road goes by way of Comobabi, Cobabi, Covered Wells, and Pozo Blanco, four Papago villages with wells, and is called in this guide the Pozo Blanco route. The left-hand route goes through Indian Oasis, the center of Government activities in the Papago Reservation, and is called the old main route. The distance is approximately the same. The watering places are closer together and more permanent on the Pozo Blanco route, but there are steeper grades. The newly constructed highway from the Gunsight ranch east for 15 miles makes this the preferable route. The main route is probably muddier in wet weather, but Indian Oasis has a post office (Sells) and is a good supply point, where information concerning roads can be obtained. After the completion of the highway the old main route and its variants will be used only for local traffic.

The traveler by the old main route turns to the left at the United States Geological Survey sign $(45.1,227.8)$ and goes through a gate in a fence into the Indian reservation. Within 4 miles the road rounds the northwestern point of the Baboquivari Mountains and comes into the north end of the Baboquivari Valley. In a deep cove in the mountains about 2 miles sonth of the road lies Babokuk, a small Papago village with a well and represo. Eabokuk is given as Vavkux by Lumholtz ${ }^{63}$ and means " standing rock," from vav, mountain or rock, and kux, standing or prominent. The people of this village cultivate fields about 3 miles north of the road.

The abandoned Fresnal ranch lies on the right of the road $(52.6,220.3)$. Crumbling adobe walls and a rusty boilex in a grove of mesquite trees ( $P$. XXIII, B) mark the site of the abandoned ranch of Maish \& Driscoll. The well has recently been reopened by the United States Indian Service.

A mile and a half beyond the Fresnal ranch the road turns south up a small hill to a fork. On the right a faint road goes west through the fields of the summer rancheria of Jeowic ("where the plow was lying"). At the fork the right-hand road goes west into the broad valley that leads to Indian Oasis. On the south are the Iow ragged red hills and small plateaus of lava that make up the Artesa Mountains, and on the right the bare brown slopes of the South Comobabi Mountains. The left-hand road at this fork goes south to Magdalena, Tucsoncito, and other Papago villages in the broad Baboquivari Valley, on the west flank of the Baboquivari Mountains (pp. 406-408).

Turning west from the fork with the small hills on the right, around which lie the fields of Tucsoncito, the road goes west to Artesa Pond. This pond is formed by a dam built many years ago by a Mexican and now used by the Indians. From the top of the rocky hill west of the pond a wide view is obtained. To the north the Comobabi Mountains, flanked on the west by sharp hills of red lava, are separated by the south end of Santa Rosa Valley from the bold terminal peaks of the Quijotoa Mountains, and far on the western

6a Lumholtz, Carl, op. cit., p. 386. 
horizon are the vague outlines of the Copeka and Mesquite mountains, rising like ships out of the broad ocean of plains. Straight ahead to the west, across a small flat valley, the village of Artesa nestles in a notch in low hills, and beyond lies Indian Oasis, of which the visible part is the brown mass of the store on a hilltop. On the hill itself the great variety of cacti, particularly of the candle or candelabra types, is worth noting.

Artesa is a new town of 12 houses established about 1907 and is more substantially built than most Papago villages. The Indian name is Komokteturávosit ("where the turtle was caught"). The water supply comes from two shallow wells dug in alluvium and rock along the arroyo.

A mile beyond Artesa is Indian Oasis (Sells post office), one of the localities of principal interest in the Papago country. The Government schoolhouses stand in a pleasant plain at the foot of the steep slopes of the foothills of the Artesa Mountains. Just west of them, in a cove of hills, are the Presbyterian Church and the missionary's house, with its well and windmill. At this house good meals and accommodations for a small number of travelers could be obtained in 1917. Opposite the mission is the United States Indian Service well and pumping plant (p. 186), and on the hill to the west the store, originally built by Joseph Meneger, is reached by a spiral road of easy grade. Here gasoline, oil, and all ordinary supplies may be obtained. From the front of the store also there is a fine view to the west and north. A narrow belt of fields beginning at the foot of the hill stretches out to the west along the line of drainage marked by a belt of mesquite trees, toward the locality called Big Fields, a translation of the Papago name Ku-6rta or Ku- 6 itak. There are two roads, one north and the other sonth of the line of fields (p. 268). Beyond Big Fields and almost hidden by trees is a small sand-covered hill which marks the site of Copeka. North of Copeka is South Mountain, a majestic mass which forms the southern end of the Quijotoa Mountains and towers high above the plain, and around the base of this mountain the road goes northwest from Copeka to Gunsight ranch. North of South Mountain, but separated from it by a deep notch, is Ben Nevis Mountain, whose sheer sides rise on four sides in cliffs about 1,500 feet high. Because of its resemblance to the pack basket used by women, the Papagos called this mountain Kfhotóak ("burden basket mountain"), a name which, in its Spanish form Quijotoa, is now applied to the whole range. In the notch between South Mountain and Ben Nevis lies San Antone, a small Papago village which is the successor to the once prosperous mining town of Welden.

To the north of Indian Oasis sharp red hills and ragged little plateaus culminate about 10 miles away in the small reddish Cobabi Mountains, separated by a narrow belt of broken plains from South Comobabi Mountains. Here is located one of the oldest mining localities in the region, a place visited by Pumpelly ${ }^{\text {of }}$ in 1864, when it was being actively prospected. Near the principal prospect, which is called the Cobabi or Picacho mine, are the Papago villages of Nolic, Santa Cruz, and Wickchoupai. Nolic is a Papago corruption of the Spanish name Noria, which means a spring or well. There are three dug wells here62, 45, and 100 feet deep. Santa Cruz also has three wells, and Wickchoupai has one. (For roads to these winter rancherias see p. 325.)

Indian Oasis to Copeka.-The trip between Indian Oasis and the Gunsight ranch is the most difficult part of the journey, not because the road is so bad but because of the lack of permanent water. By the main route it is 58 miles from the permanent water of Indian Oasis to that of the Gunsight ranch. During a large part of the year there is no water in the represos or charcos and no

es Pumpelly, Raphael, Reminiscences, vol. 1, p. 230, 1918. 
Indians will be found in the villages. Careful preparation and provision is therefore necessary for this part of the journey.

The traveler starting from the United States Geological Survey sign at Indian Oasis may take either the northern or the southern road to Big Fields. Both roads are shown on the maps (Pls. III, IV), and local advice should be sought as to which is preferable. Just beyond the fences and scattered houses of this summer rancheria is a Geological Survey sign (73.9, 199.0). The northern and southern rcads unite here, and for 7 miles the road runs over open plains with scattered patches of wind-blown sand to Copeka $(80.7,192.2)$.

At Copeka is a large pond formed by a represo (see Pl. XX, A) just west of a low hill of pink gneiss. Wind-blown sand covers the hill and the area between it and the brush fence that incloses the pond. The road, usually obliterated by cattle tracks, passes between the fence and the hill. Froin the top of the hill can be seen the three houses of the rancheria, which lie along an indistinct drainage line that carries the flood waters passing Indian Oasis, also water from Valshni Wash, northwestward into Quijotoa Valley. At 21/2 miles to the south lies Tonukvo ("ridge pond"), named from the long ridge west of the pond, which is called Chjweton ("long ridge"). Tonukvo is also called Papatjuik and is perhaps the place called by Lumholtz "Tshíovo ("long pond"). The road to Tonukvo and Kavolik is described on page 410. Beyond Tonukvo the eye ranges over the wide plains of the Tecolote Valley and is arrested by the Sierra de Cobota and La Lesna Mountains, in Mexico.

To the west of Copeka a short and rather steep alluvial slope leads up to the Copeka Mountains, a high conical granite mass which trails off to the south in low and somewhat disconnected hills, some of granite and gneiss and some of lava. Through a pass in these hills lies an old road to Serventi Well, 8.9 miles away. It is rough but passable.

But it is to the north and northeast of Copeka that the finest view is obtained. South Mountain, whose base is scarcely 5 miles away, rises 2,500 feet above Copeka with sheer cliffs of purple-brown volcanic rock (Pl. XX, A). The somewhat flat, grass-covered top of the mountain, green in spring and late summer and brown the rest of the year, is in odd contrast to the precipitous sides. Beyond and to the left rises the spire of Ben Neris Mountain, and beyond this the dull-brown, rather smooth but canyoned slope of the main part of the range. Still farther north and west lies the Sierra Blanca, whose gray-white slopes justify its commonplace name. Two blackish buttes on the western flank of the Quijotoa Mountains mark the location of Papago villages. The southern butte lies opposite the notch between South and Ben Nevis mountains and shelters the rancheria of Black Butte; the northern butte lies west of the break between the main mass of the Quijotoa Mountains and the Sierra Blanca.

- East of this butte lies Pozo Blanco, a rancheria and watering place on the Pozo Blanco route (p. 365).

Copeka to Pisinemo.-From Copeka the road runs northwestward, parallei to the line of drainage that is marked by the adobe flats and mesquite trees on the left. Small fields and houses are passed at intervals. Two miles out is a Geological Survey sign $(82.9,190.0)$, which marks the fork of the Comovo route. The main route keeps to the right and reaches Hardimui in 7 miles. Hardimui ("burnt pumpkin") is a summer rancheria with extensive fields, mostly inclosed in brush fences. There are a few scattered houses and brush arbors occupied by the Indians when sowing and harvesting their crops.

The primitive but efficient farming of the Papagos can be seen to best advantage at Hardimui and the near-by settlement of Pisinemo. At neither

Lumboltz, Carl, op. cit., p. 385 . 
place is there permanent water, the Indians depending on rain-water pools and water stored in represos during the period of cultivation. In both localities the fields or temporales lie on streams that head in the Quijotoa Mountains and when in flood spread out in broad sheets on the lower parts of the plains. With the rains and floods of July and August the people move to the temporales and plant corn, beans, melons, pumpkins, squashes, and sorghum. In general, the fields are so placed that each flood will give them a good irrigation but the larger floods will not wash out the crop. Low embankments and shallow ditches are also used to control the water. These obstacles, together with the fences, tend to cause erosion of the fields, which must in later years be shifted in position. A locality such as Hardimui may be fairly permanent, but the area cultivated each year is slightly different. The most successful crops are corn and beans, of which the Papagos have interesting drought-resistant varieties. The beans known as tepari, of which there are several subvarieties; are said to be so resistant to drought that the plants may wither three successive times and then, if enough rain comes, mature a crop.

From the first Geological Survey sign at Hardimui $(89.6,183.3)$ the road goes between fields and then swings to the right betweenothe houses and the fields to the second sign $(90,182.9)$. Pisinemo is then 3 miles to the northwest. From Hardimui roads go northeast to Black Butte, 8 miles, and southwest to Comovo, 5 miles.

The summer rancheria of Pisinemo ("bear's head") is a larger place than Hardimui. The road enters the town by the west side of a very large represo (Pl. XXI, $B$ ). There are about 11 houses, some of them substantially built of adobe and one boasting a bright galvanized-iron roof. A large field, surrounded by a brush fence north of the houses, has a small represo at its southeast corner and a Geological Survey sign at the southwest corner. From this sign $(93.6,179.3)$ the old main route goes northwest to Charco en Medio and the Cubo route turns due west across the Quijotoa Valley.

From Pisinemo the full size of the Quijotoa Valley may be appreciated. To the east the sweep of the Quijoton Mountains and Sierra Blanca is in view. To the south the bare granite slopes of the Copeka Mountains lie close at hand, and off to the southwest lie the picturesque Mesquite Mountains. Behind them and extending to the north are the high and rugged Ajo Mountains. From this point of view the Gunsight Hills are insignificant, but the position of the Gunsight ranch is marked by a conical mountain to the northwest, which is the south tip of the Pozo Redondo Mountains. To the north the horizon is formed by numerous volcanic plateaus-the southern projections of the great group of mountains and plateaus of which the Sauceda and Sand Tank mountains form the northern part.

Pisinemo to Gunsight ranch.-From the Geological Survey sign (93.6, 179.3) the road goes northwest across the valley through a succession of adobe flats and groves of mesquite trees toward a group of four low buttes of lava. In these flats lies the main drainage line of the valley, but it is so faintly marked that it is difficult to distinguish. Beyond the buttes the road turns sharply into a narrow valley between rocky hills to Charco en Medio. This "water hole in the middle [of the hills] " has a small represo, two small houses, and a corral and is occupied at intervals by Indians from Pozo Redondo under their principal man, "One-Eyed" Joaquin. The represo lies in a little basin in the hills, surrounded by the sahuaro, cholla, and palo verde association of plants, which is in pleasant contrast to the monotony of creosote bush and mesquite of the Quijotoa Valley. 
Active prospecting and the needs of the Indians have made numerous roads through these hills. One goes south through the gap to Cubo, 7.5 miles. Another, usually very faint, goes north to Charco de la Piedra, a charco and temporal at the base of the plateaus to the north, where the Indians of Pozo Redondo occasionally cultivate fields. It is also possible to strike west from Charco en Medio and reach a prospect and well about 2 miles away, and thence by a fair road through rocky hills come out on the road between Walls Well and the Gunsight ranch.

From Charco en Medio the road swings northwestward down the slope to the valley that lies north of the Gunsight Hills. The traveler should follow the best-marked road into the valley and on reaching the new highway turn west. The old roads shown on the map will doubtless be passable for some years, and by them Gunsight ranch is approached from the south instead of from the east.

The Gunsight ranch, which has the first permanent water west of Indian Oasis, is a small cattle ranch. A well and windmill supply water that never fails, though in very dry weather its use must be restricted. The well was dug many years ago by a Mr. Haynes, whose name is perpetuated in Haynes Well (now caved), north of the Baboquivari Mountains. For many years goats were kept here, but Mr. Blair, the present owner, runs cattle and cultivates about 10 acres in corn, sorghum, and millo maize.

A mile south of the ranch and visible against the side of a prominent granite hill is the Gunsight mine. The name of the mine is accounted for by the tradition that a prospector noticed a hammered-silver sight on an Indian's rifle, learned that the Indian had dug the silver from the ground, and induced the Indian to guide him to this locality. The mine, patented in 1874, is said to have yielded a total of $\$ 80,000$ in silver. Near by are the Burro-Burro and other prospects. Recently there has been some excitement over the discovery of tungsten ore in the district.

Gunsight ranch to Ajo.-From the Gunsight ranch the road goes west and northwest over gently rolling rocky ground around the southern point of the Pozo Redondo Mountains. A road goes off to the left at the Geological Survey sign to Lewis Well and returns to the main road. Dim roads go from the Gunsight ranch to the Gunsight mine and prospects in the rolling hills to the south. Just beyond the point of the mountains the Valley of the Ajo, named for the little wild onion common in the region, comes into view. Walled in on the east and north by the cliffs that border the Pozo Redondo, Batamote, and Childs mountains, this part of the valley slopes to the gap between the last two of these ranges. The ephemeral streams are marked by lines of palo verde, mesquite, and catclaw, and the axial stream and its tributaries look from this high position something like the skeleton of a fish. To the west the Little Ajo Mountains stand isolated and quite dwarfed by their neighbors. The sharp conical Ajo Peaks and the somber Black Mountain are succeeded on the north by a sierra of granite and gneiss composing the main mass of the group. Just north of Black Mountain and at the base of the sierra lies Ajo, where the most conspicuous object is the huge smokestack of the New Cornelia mill, which looks like a thin white pencil mark against the brownish gray of the mountains. Beginning north of Ajo, the high ridge of the Growler Mountains shuts in the horizon on the west, broken only where to the southwest Growler Pass interrupts its continuity. The southern part of the Valley of the Ajo is occupied by the Dripping Spring Mountains and smaller hills that shut out the view toward Sonoita, 40 miles away. To the south, over the rolling country 
of the Gunsight Hills, the western facade of the Ajo Mountains, often called the Big Ajos to distinguish them from the much smaller mountains around the town of the same name, rises in great cliffs and picturesque pinnacles. The most notable of these is Montezuma's Head, a great mass of reddish rock which looks not at all like Montezuma.

From this point of vantage the road descends into the valley, passing many turnouts, forks, and crossroads, which have been much changed since the construction of the new highway but need give the traveler no concern, for he follows the highway northwest to the northern point of Black Mountain. Childs Well, marked by a wooden well derrick, is passed on the right at the center of the valley, and soon the road is in rougher ground, the dissected pediment of the Little Ajo Mountains, and swings into the main street of Clarkstown (Rowood post office) and thence, turning at the mill fence on into Ajo, reaches modern American civilization.

The mining district of Ajo has long been famous as a center for prospectors, who were early attracted to it by rich showings of native copper and copper oxides. In the sixties a high-grade ore was mined here and was hauled by teams at first to San Diego and later to Yuma. From both terminals it was shipped by sailboat to Swansea, Wales. The numerous small veins with native copper, cuprite, bornite, and chalcocite were a constant incitement to prospectors, but the lack of water and the long haul- $\mathbf{4 3}$ miles to Gila Bend, even after the building of the Southern Pacific Railroad-prevented the development of paying mines. Numerous companies were organized, did a little work, were reorganized, and failed again.

In an effort to avoid the cost of freighting ore one of the companies fell a prey to the promoters of patent processes. The McGann vacuum smelter and a complicated hydrofluoric leaching plant still stand as monuments to the hopes of disappointed stockholders. ${ }^{20}$

In 1897 the New Cornelia Copper Co. and the Rendall Ore Reduction Co. closed down, and the camp was dead until 1909, when the Lewisohn interests obtained an option on the New Cornelia property and Seeley W. Mudd and his associates made the same arrangement on the Rendall property. Much drilling and exploration was done by both parties. The attempts at this time were directed toward the great bodies of low-grade ore centering in Copper Mountain. As the results of drilling were not satisfactory, both options were abandoned.

In the fall of 1911, however, the Calumet \& Arizona Mining Co. took an option on the New Cornelia Copper Co. and later bought it. About the same time a group of claims were brought together under the name Ajo Consolidated, among them being claims of Sam Clark on which he had operated a small mill. The only other considerable groups of claims were those of Thomas Childs, later bought by the New Cornelia Copper Co. The Ajo Consolidated was transferred to the same company in August, 1917, for $\$ 500,000$ and 200,000 shares of New Cornelia stock.

The Calumet \& Arizona Mining Co., under the capable leadership of Col. John C. Greenway and the technical supervision of Dr. L. D. Ricketts, began extensive exploration by diamond drilling, test pits, and drifts. By these methods an extensive ore body in which the copper minerals impregnate

ea Joralemon, I. B., The Ajo copper-mining district, Arizona : Am. Inst. Min. Eng. Bull. 92, pp. 2011, 2028, 1914. 
monzonite was outlined. The estimate of ore available, as set forth by Joralemon, ${ }^{67}$ is given in the following table:

Ore available in New Cornelia mine, 1914

\begin{tabular}{|c|c|c|}
\hline Class of material & Quantity & $\begin{array}{l}\text { Average } \\
\text { content } \\
\text { of copper }\end{array}$ \\
\hline \multirow[t]{2}{*}{$\begin{array}{l}\text { Ore developed: } \\
\text { Carbonate ore. } \\
\text { Sulphide ore }\end{array}$} & $\begin{array}{c}\text { Tons } \\
11,954,000 \\
28,303,600\end{array}$ & $\begin{array}{r}\text { Per cent } \\
\text { 1. } 54 \\
\text { 1. } 50\end{array}$ \\
\hline & $40,258,000$ & 1.51 \\
\hline \multirow[t]{3}{*}{$\begin{array}{l}\text { Minable by steam shovel: } \\
\text { Carbonate ore. } \\
\text { Sulphide ore }\end{array}$} & $\begin{array}{l}11,954,400 \\
20,526,800\end{array}$ & $\begin{array}{l}1.54 \\
1.54\end{array}$ \\
\hline & $32,481,200$ & 1.54 \\
\hline & $7,776,800$ & 1.40 \\
\hline \multirow[t]{2}{*}{$\begin{array}{l}\text { Rock to be removed to make ore available to steam shovel: } \\
\text { Rock in carbonate zone. } \\
\text { Rock in sulphide zone }\end{array}$} & $\begin{array}{r}708,400 \\
2,600,000\end{array}$ & $\begin{array}{l}.65 \\
.63\end{array}$ \\
\hline & $3,308,400$ & .63 \\
\hline
\end{tabular}

The gold and silver content of the ore is less than 15 cents to the ton, and material that averaged less than 1 per cent of copper was not estimated as ore, as profitable extraction of the metal below this grade was not considered feasible. The ore body will supply a 6,000-ton mill for 18 years, and with the development of the deeper ores below the level of steam-shovel mining and because of the later discovery of good ore on the Ajo Consolidated the life of the mine is likely to be much longer.

Extensive experiments were made to determine the best treatment of the ores. In 1914 a test plant was installed in Ajo to treat the ores by leaching the crushed rock in tanks with sulphuric acid and to extract the copper from the resulting copper sulphate solution with metallic iron and the electrolytic process. The development of the $m$ ine, the leaching process, and the necessary workers required an adequate water supply. This need was met by energetic action, as related on page 174. In the meantime extensive surveys of the whole region had been made for the purpose of locating a railroad. In February, 1916, the Tucson, Cornelia \& Gila Bend Railroad was completed from Gila Bend to Ajo, and immediately thereafter the construction of the reduction plant of the New Cornelia Copper Co. was started.

What manner of place was Ajo during this period? There were a few houses scattered about the flat between Arkansas Mountain and Reservoir Hill at the locality now called old Ajo. One of these was a substantial stone structure in which for many years Thomas Childs and later his son conducted a store. In the near-by corral was a shallow well, and from this well and adjacent rock tanks the scanty population obtained water. With every influx of people the demand for water exceeded the supply. Some of the methods used for obtaining water are discussed on page 136. The permanent inhabitants consisted of 12 or 15 Americans and a larger number of Mexicans and Indians. The census of 1910 gives a population of 50. The periodic influx of new people

ør Joralemon, I. B., ap. cit., pp. 20-25. 
scarcely disturbed the old settlers, except that their hopes of greater prosperity were temporarily encouraged. They carried on, as Tom Childs expressed it, "just living in hopes." ${ }^{8}$ The old settlers contracted to do assessment work, raised a few cattle, hunted and trapped, and hung on, waiting for the real development of the camp to begin. This life of poverty, verging at times almost on want, 40 miles from the railroad in a nearly waterless country, framed men of peculiarly vivid personality. Jeff Milton, customs officer and prospector; Thomas Childs, called Tomasito to distinguish him from his father, Don Tomas; Mix, killed in the performance of his duty as deputy sheriff; Reub Daniels, miner, cowman, and deputy sheriff; M. L. Levy, a merchant with scholarly tastes; Sam Clark, miner and founder of Clarkstown; Cameron, who ran wild horses on a motor cycle; W. A. Knox, of the Cardigan; Charley Puffer, ex-justice of the peace at Ajo, now immigration inspector at Sasabewhat a group of men! ${ }^{30}$ The advent of Colonel Greenway and his associates brought great activity to Ajo, and the period of construction of the reduction plant in 1916 found it a roaring mining camp of 4,000 to 5,000 people. In this hurly-burly the old settlers played their parts. Some with money derived from the sale of claims went into business or cattle raising; others made stakes out of high wages; still others were the principal factors in the maintenance of law and order.

The old town of Ajo unfortunately lay on or closely adjacent to the great body of low-grade ore which the New Cornelia Co. intended to develop. About this time the greater part of the town burned down. The New Cornelia Co. located a new town about a mile north, which was to be called Cornelia, but fortunately the historic name of Ajo has been preserved. The buildings are substantial, and the streets are well graded and artistically laid out. As intended by the company, it is a model town, with stores, hotels, banks, a hospital, and substantial residences. However, opposition to a company town arose, and a town site was laid out by Sam Clark on a group of mining claims just east of the proposed site of the reduction plant, which was called Clarkstown, or Clarkston. The company refused to sell water to Clarkstown, but an independent water supply was obtained by deepening a prospect shaft. During the interval water was hauled from the Darby Well and other places and sold at 1 to 3 cents a gallon (Pl. XIX, A). Even in 1917 and 1918 drinking water was sold by vendors because of the mineralized character of the Clarkstown supply (p. 171). About the same time M. E. Gibson laid out a town site on a group of claims north of the company town, and a number of successful wells were dug. In both of these town sites lots were rented, not sold, and the mining rights were reserved. During 1916 and 1917 Clarkstown was the principal settlement and had a population estimated between 800 and 1,200. The main street was lined with frame stores, restaurants, pool rooms, and other business buildings, and the back streets were filled with small frame shacks. Lots rented at $\$ 10$ and $\$ 20$ a month for business purposes and at somewhat lower rates for residences. The improvements had to be made by the tenants but reverted to Mr. Clark at the end of the lease. Water rates ranged from 50 cents a month for single persons to $\$ 3$ for families.

A strike in October, 1916, caused a shutdown of all construction work, and the camp was nearly depopulated.

As a result of the victory by Carranza forces early in 1915, 450 Villistas crossed the boundary near Ajo. Charles Puffer, as justice of the peace, with

es Testimony of Thomas Childs, Hearing held at Ajo, Ariz., June 21-24, 1918, United States v. Sam Clark et al., reporter's transcript (Phoenix 032910), p. 425.

Hornaday, W. H., Camp fires in Sonora, New York, 1907. A vivid account is given of Jeff Milton, and a somewhat overdrawn impression of Reub Daniels. 
the help of Messrs. Daniels and Cameron, arrested the whole 450 as disturbers. of the peace and a menace to the peace and safety of the town of Ajo. They were held until, on the arrival of immigration inspectors, they could be duly admitted into the United States.

On February 12, 1917, the Judge of the superior court of Pima County, as trustee, filed an application to enter for town-site purposes the lands claimed by Mr. Clark and known as Clarkstown. This application was the result of a movement among the residents of Clarkstown, who desired to reduce the cost of their land and obtain title in fee under a "Government" town site, which they desired to name Woodrow. A bitter legal fight ensued. On appeal, after conflicting decisions by lower officials, the Secretary of the Interior held, in a decision promulgated December 29, 1919, that one of Mr. Clark's claims, the C. \& A. No. 2, on which the water shaft and pumping plant are located (p. 169), is on land mineral in character, and that a valid discovery within the meaning of the law has been made. The area of the remaining claims he held has not been proved to be nonmineral land, although a valid discovery of mineral has not been made. As a result of this decision Mr. Clark is confirmed in possession of the principal part of the town and retains the other claims pending discovery of mineral. In the meantime a post office has been established in Clarkstown with the name "Rowood." The population has decreased until in December, 1919, only 119 inhabitants remained.

During the same time a similar controversy arose in Gibson, and a town-site application based on similar grounds is pending for Ajo Heights, a third suburb of the same character.

Ajo to Sentinel.-From Ajo the main route to Yuma goes to Sentinel and thence parallels the Southern Pacific Railroad to Yuma. In the early days of mining at Ajo (p. 356), when ore was hauled to Yuma, the general route was north of the Growler Mountains to Gila River at Mohawk and thence down the river. This route, known as Yager's road, is now abandoned but is described on page 347. The route to Yuma by way of the Camino del Diablo is discussed on page 413.

Leaving Ajo, the road to Sentinel goes north in the Valley of the Ajo. Just north of the Geological Survey sign $(136.5,136.4)$ the northern part of the valley can be seen to good advantage. Childs Well, with its wooden derrick, is 5 miles east. No. 1 Well, from which the water supply of Ajo is obtained, is 8 miles north. The conical mass of the old volcano of Batamote rises on the northeast above the sloping plateaus and mesas that make up most of the mountains. The smooth back slope of Childs Mountain rises to the northwest. The road crosses the railroad and on the west side of it goes over a smooth plain covered with creosote bush and palo verde.

On crossing the railroad again the road reaches Batamote Well. The two shallow wells (p. 181), with their windmills, are on the east bank of the arroyo that drains this part of the Valley of the Ajo. The original well, named from the batamote, a local plant said to indicate water, has long been a welcome watering place on the otherwise dry journey from Gila River to the mines at Ajo. For many years Thomas Childs and his father have maintained cattle at this place.

From Batamote Well the road goes northwest between the talus slopes of lava mesas that inclose the narrow mesquite-covered pass. At the Geological Survey sign on the west side of the railroad $(145.4,127.5)$ the road has emerged from the pass into Childs Valley. The Sauceda Mountains, surmounted by the circular-topped Hat Mountain, lie off to the right; the Crater Mountains straight ahead to the north. The road to Sentinel goes west down Childs 
Valley, and the Gila Bend road forks to the right and goes north through a gap in the Crater Mountains.

After a hard pull through soft ground No. 3 Well is reached (138.5, 144.4). This deep well, drilled by the New Cornelia Copper Co. in search for a water supply for Ajo, was used as a watering place for cattle by Thomas Childs in 1917, but the machinery was dismantled in 1920. Flanked on the north and south by 'somber plateaus of lava, and opening on the west into great waterless plains, in which the vague outlines of the Aguila Mountains can just be seen, this locality breathes the spirit of the desert in no uncertain terms.

The road to Sentinel turns north at No. 3 Well to a gap in the Crater Mountafns, and after passing through two narrow grassy valleys comes out on the plain north of the mountains. The Crater Mountains are wider west than east of the road, and along this northward extension of the mountains the road goes northwest for nearly 5 miles. The flat-topped red mesas of the mountains break off suddenly in cliffs and talus slopes, which form a crenulated escarpment of dismal aspect. At the north end of the escarpment the road turns sharply to the west into a narrow gap between the main mass of the mountains and some outlying hills. Beyond the gap is a Geological Survey sign (158.2, 114.7) which replaces the arrow outlined in boulders that formerly directed travelers to Black Tanks. These tanks lie south of the road, well within the mountains. A fair road can be followed by automobile for about a mile and then there is a trail about seven-tenths of a mile farther to the tanks. The tanks, which consist of plunge pools in the falls section of an ephemeral stream, are described on page 130 . Though rather uncertain as a water supply, they are interesting to travelers, because they give an idea of the type of water supply on which the Indians and the early explorers were once wholly dependent.

From the Black Tanks fork the road runs west down the gap for 2 miles, with the dull plateaus of the Crater Mountains on the left, and then turns northwest to the Sentinel Plain. This plain is formed of a great sheet of basalt, which was poured out over the alluvial plains from numerous small volcanoes that now stand as low mounds and gently conical hills on its surface. The plain is roughly circular, about 20 miles in diameter, and is the largest body of igneous rock extruded in Pleistocene time in this part of Arizona. The lava occurs on both sides of Gila River, which, since the molten lava flowed over the country, has cut a channel through the plain.

The southern border of the Sentinel Plain merges so gradually with the alluvium that the traveler does not notice the change until he discovers that the road is on rock. The plain is monotonous, and the vegetation is scanty, mostly creosote bush and ocotillo, but unless traffic has been very heavy the road is good, and soon the traveler is in Sentinel.

Sentinel derives importance from the presence of deep wells drilled and maintained by the Southern Pacific Railroad. The warm but only slightly mineralized water of these wells has been hauled by the railroad for use as far west as Dome, a distance of 71 miles. The whole line from Yuma to Maricopa had for many years only the three watering stations of Gila Bend, Sentinel, and Wellton. At these stations, situated about 40 miles apart, are maintained large tanks and pumping plants for the use of trains. Commonly an extra water car is attached to each train directly behind the engine. The section houses at intervals of about 10 miles have cisterus that are filled periodically from the tank of the local freight train. At Sentinel there is a small store and hotel. Agua Caliente, a famous hot spring and resort, lies 14 miles to the northwest, on the other side of Gila River. 
A road runs northeast also to Jordon's ranch, 8 miles, and to mining prospects in the Painted Rock Mountains.

Sentinel to Wellton.-From Sentinel the road parallels the railroad to Wellton, where it joins the Phoenix-Yuma road, which from Agua Caliente west follows the north bank of Gila River. For 8.5 miles west of Sentinel the road lies on the Sentinel Plain. The roadbed, even with little travel, is hard, and, though it is rocky in places, fast time can be made. Then the road descends the western escarpment, about 50 feet high, which borders the plain. From the top of the Sentinel Plain a wide expanse of country can be seen to the west. The Aztec Fills lie to the west, south of the railroad, and much farther away and towering above them is the long line of the Mohawb Mountains, closing in the horizon to the west. Off to the south are the Aguila Mountains, of which the conspicuous portion is a high platean of lava that slopes to the north. At the south end of these mountains lies Eagle Tank (p. 347). To the southeast the north end of the Growler Mountains and the western part of the Crater and Childs mountains form an indistinct group of blue plateaus.

Aztec $(194.4,78.5)$, the next section house on the railroad is slightly more important than others because it has a telegraph station and a well. From Aztec a road goes southwest to Eagle Tank. It is at best a rough trail, seldom traveled. A similar road goes through the Aztec Hills into the San Cristobal Valley near Garcia Well. A rough road also goes north across Gila River to Palomas, a village on the Phoenix-Yuma road.

West of Aztec the road rises slightly and north of the bare and rocky granite knobs of the Aztec Hills comes into a region of low sand dunes. Each hummock of sand is capped by low bushes of mesquite, which hold the sand in place. Between the dunes are little flats of hard ground, which after rains become niniature lakes. The road winds around the dunes and avoids most of the sand, but beyond the dunes, on the eastern slope of the San Cristobal Valley, drifted sand does not lie in dunes and is an almost continuous blanket over the ground. This stretch of road is heavy and hard to travel.

Stoval is a section house on the railroad and stands about 20 feet above the flat that forms the center of the San Cristobal Valley. Out in the center of this valley is the derrick of Pimeria Well, a deep well drilled by the Pimeria Land Co. in an ambitious attempt to irrigate this valley. With increasing value of farm products, especially Egyptian cotton, there seems to be an opportunity to develop a small irrigated area here. It is, however, likely to wait on the development of the shallow-water areas along Gila River. Beyond Pimería Well and 8 miles from Stoval is Garcia Well, a shallow dug well used as a stock-watering place. (See p. 184 for analysis.) Whites Well, 6 miles farther southeast, is a similar watering place. The roads in the San Cristobal Valley are described on page 346 .

West of Stoval the road crosses the axial stream of the San Cristobal Valley and begins to ascend the alluvial slope of the Mohawk Mountains, which close in the valley on the west. At the top of this slope covered with normal desert vegetation, in which creosote bush predominates in the interstream areas and palo verde, catclaw, mesquite. and ironwood mark the stream channels, a road goes south along the mountain border to the Red Cross mine, 5 miles, and to other prospects farther south (p. 193). Off to the north Texas Hill lies in the band of vegetation that covers the flood plain of Gila River. Near this hill was the old settlement of San Cristobal, which gave its name to the San Cristobal Valley and the station of Stoval.

The road follows the railroad through a pass in the Mohawk Mountains to Mohawk (213.9, 59.0), sometimes called Mohawk Summit, at the west side of 
the pass. This station has the usual section house, a telegraph office, a small store, and a few frame houses. About 8 miles to the north lies Norton, a small village on the north bank of Gila River, once called Mohawk. A difficult and almost waterless road runs south along the west side of the Mohawk Mountains 52.5 miles to Papago Well (p. 419).

From Mohawk the road goes down a long alluvial slope covered with drifted sand. Pembroke, 3.5 miles west of Mohawk, is a siding with the usual section house. A well was drilled here by the railroad company in 1919 , but it was unused in 1920. Heavy sand continues to Colfred, a siding about the center of the Mohawk Valley, but from Colfred, as the road rises up the alluvial slope on the west side of the valley, the sand decreases in amount until a low hill on the north of the railroad is reached $(231.4,41.5)$. From this hill there is a sandy slope into Wellton, situated just south of the belt of green in the valley. This hill is one of three between the railroad and Gila River, of which the most northerly is called Antelope Hill and is the site of Antelope Bridge on the Phoenix-Yuma road. The coarse red arkosic sandstone of these hills is described on page 62 and has at rarious times been quarried for building. South of the railroad are the sharp granite spires of the Baker Peaks, and farther south the mountains that border the Lechuguilla Desert. To the west the wooded flood plain of Gila River swings north around the end of the Gila Mountains, and across the river lie the low rounded knobs of the Muggins Mountains, surrounded by the castellated red spires of Klotho's Temple. Far off to the north is a high blue mountain-the "castle dome" which gives the name to the Castle Dome Mountains.

Wellton $(235.7,37.2)$ is a little village clustered around the pumping station of the railroad and consists of a store, hotel, garage, and one or two houses. The adjacent valley of Gila River has a number of enterprising settlers who are sinking wells and preparing to irrigate. Their success will add to the town, which now derives its chief importance from its assured water supply and its position at the junction of the Phoenix-Yuma and Tucson-Yuma roads, which from this point on are the same into Yuma. The Ajo-Yuma road by way of the Camino del Diablo is described on page 413, and that description treats fully of the country to the south, which is probably the largest uninhabited tract in the Cnited States.

Wellton to Yuma.-From Wellton the road goes west on the soft flood plain of Gila River. Unless surfaced with gravel or crushed rock, the road is dusty and full of chuck holes in dry weather and very muddy in wet weather. For the first 7 miles it is a typical valley road that follows land lines for about 2 miles and then turns off to the left in groves of mesquite.

Fraser's farm and pumping plant lie west of the turn in the road. A pit 16 feet in diameter and 9 feet deep incloses a 4-inch horizontal centrifugal pump, which is belted to a 20 -horsepower oil engine. The well consists of a dug portion 6 feet square and 25 feet deep, below which is a bored well that reaches to 91 feet. The total lift of the plant is about 20 feet. About 28 acres of alfalfa was successfully and profitably irrigated with this plant in the five years ending in 1917.

Another pumping plant near Wellton is that of Robert Gael, in the SW. $1 / 4$ sec. 5, T. 9 S., R. 18 W., on the sandy slope south of the Wellton railroad station. The well is 12 inches in diameter and 115 feet deep and is cased with screw casing, the lower 25 feet of which is perforated. The water stands at 55 feet from the surface, and there is a pit 4 by 5 feet to this level. The pump is a 4-inch Byron Jackson vertical centrifugal pump belted to a 20-horsepower Witte gasoline engine and has a discharge of 500 gallons a minute, with $a$ 
drawdown of 4 feet 7 inches. About 5 acres had been irrigated with this plant in 1917. In 1919 an unsuccessful attempt was made to irrigate cotton with this plant.

Louis Berand has a well in a somewhat similar position east of the station, in the SE. $1 / 4$ sec. 4 , T. 9 S., R. 18 W., which is 10 inches in diameter, with stovepipe casing, and 94 feet deep, and in which water stands at 84 feet from the surface.

About 7 miles west of Wellton the road leaves the flood plains and follows the edge of the terrace that borders the valley. Over this stretch the road is well graded and provided with culverts and bridges.

Dome $(252.9,20.0)$ is a station on the railroad and a small village with a store and hotel. Part of the population depends on water hauled by the railroad; others on shallow wells in the flood plain of the river just north of the gravelly terrace on which the town is built. Dome was once a center of placer mining and later a supply point for mines to the north and east. This is still true in part, and the ford across the river connects with numerous roads in the desert country to the north."

From Dome the graded road rounds the point of the Gila Mountains. From one of these rocky knobs the enthusiastic Father Kino first saw the junction of Gila and Colorado rivers and looked toward California, whose subjugation and conversion seemed so much more important to him than his own work in the Pimería Alta (p. 7).

Blaisdell $(259.6,13.3)$, a section house on the railroad. was the end of the graded road in 1917. From this place numerous tracks and roads, all equally dusty and full of chuck holes, lead due west to Yuma. In wet weather this flat is very muddy and at times is flooded by Gila River. To avoid this flood plain a road is planned over the high plain south of Blaisdell into Yuma, and it was reported in 1920 that construction had been started.

Yuma, at the junction of Gila and Colorado rivers, is an enterprising little city which has a population of less than 5,000, according to the census of 1920 . Once simply a collection of adobe hovels, the typical frontier community dependent on the trade of near-by mines and ranches, it has been completely transformed by the building of the Yuma project of the United States Bureau of Reclamation.

A substantial bridge crosses Colorado River at Yuma. Here connection is made with roads to the Imperial Valley and to San Diego and Los Angeles, which have been described by Brown. ${ }^{71}$

Yuma project. ${ }^{72}$-The irrigation plan of the Yuma project provides for the diversion of water of Colorado River at the Laguna dam, 10 miles northeast of Yuma, into a canal that heads on the California side of the river and after conveying water for lands on that side crosses the river at Yuma through an inverted siphon and irrigates the rich valley lands on the Arizona side south of Yuma. From power developed along this canal electric current will be generated for use in pumping water from the canal system to irrigate lands on the bench lands south of Yuma. The land of the flrst of these units, consisting of about 500 farms comprising 6,400 acres, was offered for public sale in December, 1919. When complete the project will irrigate 110,000 acres, of which, in 1918 , it was prepared to furnish water to 73,000 acres, and actually irrigated 45,670 acres. The total number of farms on the com-

\footnotetext{
${ }^{70}$ Ross, C. P., The lower Gila region, Arizona: U. S. Geol. Survey Water-Supply Paper 498, pp. 146-150, 1923.

${ }^{71}$ Brown, J. S., The Salton Sea region, California : U. S. Geol. Survey Water-Supply Paper 497, 1923.

22 U. S. Recl. Service Eightecnth Ann. Rept., pp. 84-96, 1919.
} 
pleted project will be 4,000 . The net cost of construction up to June 30 , 1919 , was the large sum of $\$ 9,095,806.19$, which will be eventually restored to the United States by the owners of the lands in small annual payments. The proportion of the construction cost charged to lands has ranged from $\$ 55$ to $\$ 90$ an acre, according to the technical difficulties involved, but when it is considered that in 1918 the average value of crops per acre irrigated was $\$ 113.32$ and the annual maintenance, charge about $\$ 3.30$ an acre, it is. obvious that the land will easily hear the construction charges. The principal crops in 1918 were cotton, 64 per cent of the area; alfalfa, 20 per cent; and corn, 10 per cent. The total value of the irrigated crops in 1918 was $\$ 5,105,132$, or an average of $\$ 113.32$ an acre. The following table shows the development of the project:

Irrigation and settlement of Yuma project, 1914-1919

\begin{tabular}{|c|c|c|c|c|c|c|}
\hline & 1914 & 1915 & 1916 & 1917 & 1918 & $1919 a$ \\
\hline \multirow{2}{*}{\multicolumn{7}{|c|}{$\begin{array}{l}\text { Area for which project was preparegd to } \\
\text { supply water }\end{array}$}} \\
\hline & 60,000 & 71,200 & 72,440 & 73,000 & 73,000 & $b 70,000$ \\
\hline & 25,207 & 27,857 & 29,483 & 36,956 & 45,670 & 55,000 \\
\hline Canals operated & 272 & 307 & 316 & 335 & 338 & 355 \\
\hline Water diverted & 154,670 & 246,786 & 249,700 & 337,597 & 314,900 & 350,000 \\
\hline \multicolumn{7}{|l|}{ Water delivered to land: } \\
\hline & & 92,891 & 83,895 & 130,541 & 100,228 & 181,000 \\
\hline Per acre lor area under cumvalion & $\begin{array}{r}3.69 \\
698\end{array}$ & $\begin{array}{r}3.34 \\
737\end{array}$ & $\begin{array}{r}3.20 \\
790\end{array}$ & $\begin{array}{l}3.7 \\
900\end{array}$ & $\begin{array}{r}3.3 \\
1,185\end{array}$ & $\begin{array}{r}3.3 \\
1,200\end{array}$ \\
\hline Population of farms. & 1,815 & 2,036 & 2,002 & 2,700 & 4,300 & 4,500 \\
\hline $\begin{array}{l}\text { Number of towns } \\
\text { Population of towns }\end{array}$ & 4,200 & 4,385 & 5,345 & 6,735 & 7,590 & 8,000 \\
\hline Total population of towns and farms & 6,015 & 6,421 & 7,347 & 9,435 & 11,890 & 12,500 \\
\hline Number of public schools.... & 14 & 15 & 17 & 20 & 20 & 20 \\
\hline Number of churches. & 7 & 7 & 9 & 9 & 10 & 11 \\
\hline Number of banks & 3 & 4 & 4 & 4 & 4 & 5 \\
\hline ipital stock of ba & & & & & $\begin{array}{r}\$ 175,000 \\
\$ 1,321,468\end{array}$ & $\begin{array}{r}\$ 205,000 \\
\$ 1,923,287\end{array}$ \\
\hline Number of depositors.- & & & & & $\begin{array}{r}4,572 \\
4,572\end{array}$ & 5,288 \\
\hline
\end{tabular}

a Estimated.

b Exclusive of land north of Gila River.

INDIAN OASIS TO BIG FIELDS (NORTYERN ROAD)

[For log see p. 276]

Except for the magnificent views of the surrounding mountains either road to Big Fields is monotonous enough. The northern route has only one feature of interest, and that is the vegetation. The plain is an alluvial slope built up by the stream which, heading in the plains north of the Fresnal ranch and receiving tributaries from the northern part of the Baboquivari Mountains, flows past Artesa Pond and Indian Oasis. West of Indian Oasis the stream occupies the highest part of a broad fan. This highest part is a broad, low ridge, but there are other low ridges which mark former channels. Between the ridges are faintly marked swales that in high floods receive the bulk of the fiood water and because of this water and a denser soil support a very luxuriant vegetation. Such a swale lies to the north of the road, and in it are meadow-like expanses of grass-corered plain surrounded and dotted by very large and luxuriant trees (Pl. VI, A). Mesquite, ironwood, palo verde, and catclaw grow vigorously. There is also a deep-green bush which is probably the smaller hackherry (p. 46). Creosote bush grows to a height of 15 feet, and the annual grasses to 2 and 3 feet. 


\section{POZO BLANCO ROUTE}

[For Iog see pp. 277-279. Mileage from Tucson and Yuma]

On the Pozo Blanco route the watering places are wells and thus more. reliable in very dry weather. For this reason largely the route was more commonly traveled in the early days. The development of Indian Dasis as a center of life on the Papago Reservation tended to draw traffic away from this route, but the construction of the new highway for 15 miles east of the Gunsight ranch has made the Pozo Blanco route the main artery of travel from Tucson into Ajo.

The route begins at the Geological Survey sign west of Coyote $(45.1,81.5)$ and goes due west across a wide valley toward Woods Hill, which stands as an outlier on the flank of the South Comobabi Mountains. The smooth, somewhat subdued brown slopes of this range and its northern counterpart are in marked contrast to those of the Baboquivari Mountains.

At the next fork $(50.5,76.1)$ a road goes to the right to Compartidero, a typical represo for watering stock (see Pl. XXV,B), and to the Santa Rosa ranch (p. 277). Beyond this fork the road crosses to the south side of the fence, climbs the alluvial slope of the mountains to the pass between the North and South Comobabi mountains, and goes west on the south side of a barbed-wire fence. This fence, built in 1917, incloses the extensive Santa Rosa ranch of the West Coast Cattle Co. This American company, driven out of Mexico by Carranza in 1916 and 1917, purchased these watering places and leased land from the State to take care of its herds.

Comobabi $(54.4,72.2)$ lies in rolling country along an arroyo cut into the rocky plain on the left of the road. It is one of the oldest of the winter rancherias of the Papagos and has two dug wells and a dozen or more houses. The wells are relatively modern, but when first visited there were tanks or seeps which furnished water. Juan Mateo Mange, lieutenant of the Compañia Volante which protected the Sonoran border in Father Kino's time, was probably the first white visitor, in the year 1694, when he called the town Gubo. Tupo and Tups were the names commonly applied by Kino. The modern name Comobabi is a Spanish spelling of the Papago Komvaxia ("well where the cumaro [hackberry tree] grows").

Passing the village the road goes west through the rolling country of the pass. Cobabi, another old winter rancheria, lies south of the road and is reached by numerous branch roads. This village is somewhat smaller than Comobabi and has a single dug well. Mange called the village Cups, and its modern name Cobabi is a Spanish spelling of its Papago name Kavaviak ("badger's well "), for which various maps and writers have given the versions Cahuabia, Cahuabi, Cahuavi, Cusbabi, and Cababi. Off to the west of the town, at the base of the sharp red peaks of the Cobabi Mountains, is the Cobabi mine, which Pumpelly ${ }^{73}$ visited in 1861, spending the night in the village and being much impressed with the way in which the Papagos with their inadequate tools dug for water in the sand.

The road avoids the town, keeping it on the left, and goes northwest and then west down a wash into the Santa Rosa Valley. This great valley, about 10 miles wide and 4 miles long, lies between the Quijotoa, Brownell, Sheridan, and Vekol mountains on the west and the North and South Comobabi, Santa Rosa, and Slate mountains on the east. Here the Indians seem to have been almost continuously successful in flood-water farming. Certainly many of

7a Pumpelly, Raphael, Reminiscences, vol. 1, p. 230, 1918. 
the present summer rancherias, if not in the same place, at least have the same names as in Father Kino's time, 220 years ago.

The traveler will find more roads than are shown on the map, but by follow- ing the main traveled road and heading toward the broad gap between the Quijotoa and Brownell mountains he will cross the Santa Rosa Valley on the divide, where the valley is the least muddy in wet weather, This divide is a broad alluvial flat, and from it the flood waters flow north past Santa Rosa and Cocklebur to Santa Cruz River and southwest to Copeka and thence to Sonoita River. A temporal, abandoned in 1920, a represo inside a brush fence, and a few huts mark this divide $(70.3,56.3)$, which is called by the Papagos Sikulhimatk ("water going around," though doubtless they mean "water dividing"). From Sikulhimatk the road goes up the slope and turns northwest.

Covered Wells $(76.3,50.3)$ is a group of houses scattered along an arroyo that flows east from the pass between the Quijotoa and Brownell mountains (Pl. $V, A)$. The houses are in two main clusters. The eastern group, near two dug wells, is the village called by the Papagos Tjiuvak ("where something rotted"). The village at the west wells $(78.6,47.3)$ is called Maishpovaxia (" covered wells"). Here there are two dug wells, the north one 35.5 feet deep and the south one 28 feet deep. Near by are three small corrals and the 13 houses of the village. Between the two villages is Spear's store, where the traveler will flnd supplies and the most sanitary water.

West of Covered Wells the road comes into open rolling country, a dissected mountain pediment between the Brownell Mountains and the Sierra Blanca. There are numerous forks and crossroads. Some of these roads go to small mines and prospects and should be avoided. The main fork lies west of the village; the right-hand road, going northwest to the north end of the Sierra Blanca, is described on page 397 ; the other is the Pozo Blanco road and goes west to the south end of the Sierra Blanca.

The hard, flrm road over the rolling plain gives a fine view of the three surrounding ranges. The low ragged knobs of the south end of the Brownell Mountains are composed mostly of tilted lavas; the lighter-brown, rather smooth slopes of the Quijotoa Mountains are made up mostly of gneiss and schist; the Sierra Blanca has steeper slopes and bolder topography, due largely to the hard white gneiss that is the principal rock. In the intervening rolling country the rocky soil supports a flne growth of sahuaro, cholla, and other cactus, which with palo verde, ocotillo, and the ubiquitous creosote bush give a deceiving appearance of verdure. (See Pl. XV, O.)

Pozo Blanco $(83.5,43.7$ ), whose Papago name is Komvaxia, the same as that of Comobabi, is a winter rancheria of 11 houses scattered over a little flat bordered by streams that flow in miniature canyons about 20 feet deep. The corral and well lie on the right side of the road, near the main arroyo. The well, which is 49 feet deep, is dug through about 20 feet of alluvium into granite and has water at about 30 feet from the surface.

From Pozo Blanco a road runs southwest through the group of scattered houses to the south end of the black hill west of the town and thence to Pisinemo (p. 354). West of the town and beyond the arroyo a road comes in from the left from the Black Prince mine (p. 171). Proceeding west from this reverse fork the traveler goes through a pass petween the Sierra Blanca and the black hill of bedded lava flows already mentioned, guarded by forests of sahuaros which stand rank on rank on either side of the pass. The great plains of the Quijotoa Valley are spread out in a wide panorama. Off to the south are the Copeka and Mesquite mountains, and in the intervening flats, more or less hidden by the groves of mesquite, lie Pisinemo, Hardimui, and 
Comovo. The great mass of the Ajo Mountains on the west breaks off abruptly at Walls Well, and almost due west the Pozo Redondo Mountains begin with a sharp conical peak and merge to the north and east into the great volcanic plateaus around Perigua. A lower but sharp and conspicuous butte is called Ninemile Peak, and toward this the road runs almost directly.

The Geological Survey sign 21/2 miles west of Pozo Blanco (85.1, 42.2) marks a fork. The right-hand road goes to Perigua (p. 405). Continuing on the left-hand road, the traveler goes down the alluvial slope and soon reaches flatter ground and heavier soil, marked by the appearance of scattered forests of mesquite. On the left are two abandoned temporales. The first of these is badly eroded by stream action and illustrates one of the chief reasons for the constant shifting of areas of cultivation. About 3 miles farther on the second temporal lies on the main drain or axial stream of the valley, which is here almost without a channel and is simply a broad adobe flat covered with mesquite trees. In wet weather this part of the road used to be very muddy and almost impassable for automobiles, but the new highway now reaches the center of the valley, and the traveler will leave the old road and swing slightly to the south to pick up the new road.

Ninemile Peak $(101.2,25.2)$, a small butte of lava, is the most northerly of the Gunsight Hills, which consist largely of granite and gneiss. In these hills is the summer rancheria of Charco en Medio. Several dim roads cross the Pozo Blanco route in the next 5 miles going from this ranchería across the narrow valley between the Gunsight Hills and the mountains to the north. Directly north of Ninemile Peak is a sharp ridge trending northwest, and at the south end of this ridge is Charco de la Lomita, an abandoned temporal. The Perigua Valley lies to the east and is reached by a road through the pass between the ridge and the main plateau (p. 423). The Pozo Redondo Valley lies between this plateau and the Pozo Redondo Mountains, which form the sky line to the west.

At the Geological Survey sign the main route by way of Charco en Medio comes in from the south, and 4 miles farther on, at the Gunsight ranch, which lies on the left of the new highway, the Pozo Blanco route merges with the Cubo route. The road from the Gunsight ranch has already been described (p. 355).

\section{CUBO ROUTE}

[For log see pp. 280-281. Mileage from Tucson and Yuma]

The Cubo route is a variation on the old main route of the Tucson-Yuma road. It branches from the old main route (see p. 354) at Pisinemo and returns near the Gunsight ranch. For the first 2 miles west of the Geological Survey sign at the corner of the brush fence in Pisinemo (93.6, 181.8) the road is rather sandy. Then it comes to the axial stream of Quijotoa Valley, which at this point has a channel about 10 feet deep and 20 feet wide in the extensive adobe flat. The sharp pitch into and out of this channel is difficult enough in dry weather but in wet weather is almost impassable. Beyond this channel the road rises gradually up a treeless alluvial slope toward low hills. These are the Cubo Hills, a group of small plateaus and mesas that parallel the Ajo Mountains and are separated from them by the Barajita Valley. The road goes into a gap through which part of the drainage from the Barajita Valley flows east onto the alluvial slope.

At the next Geological Survey sign $(106.7,168.7)$ the Comovo route comes in on the left, also a road that comes north up the valley between the Mesquite 
Mountains and the Cubo Hills (p. 411). Half a mile farther west is the charco of Cubo (Kuvo), the "great water" or "large pond" for which the place is named. The charco is simply the channel of the stream that drains the pass. At this place the channel is overdeepened and holds water after floods. The formation of charcos is discussed on pages 121-123, and this is one of the best examples of the large charcos in the Papago country. It is a curving basin more than 1,500 feet long and, at most, about 30 feet wide. After floors it holds water for a short time. Beyond the charco the road runs beside and between temporales. Houses are scattered about, and the road is usually sandy and bad, because fields occupy the smooth ground and only the sandy places are left for a road.

About $21 / 2$ miles beyond the charco, at the head of the gap, is a Geological Survey sign $(109.6,165.8)$. From this sign the road tarns sharply to the right and follows the eastern border of the Barajita Valley toward a conical mountain, separated from the rest of the Ajo Mountains by a narrow gap through which the northern part of the Barajita Valley drains. The valley is about 3 miles wide and 14 miles long. The Ajo Mountains, a great range of lava flows that dip to the east, bound it on the west. In these mountains are two watering places. Barajita is a winter rancheria about 4 miles almost due west of the gap at Cubo and is clustered around two dug wells about a mile apart. The Indian name is Tonoka ("knee"). The fields of Cubo are cultivated largely by the people of Barajita, and there are numerous roads and tracks between the two places. There is also a road down the east side of the valley to Cochibo, the second watering place, described on page 412 .

For 4 miles from the Geological Survey sign $(109.6,165.8)$ the road skirts the most northerly of the Cubo Hills, a low mesa of lava, and then crosses a low rocky gap into the Gunsight Hills and swings west around the conical mountain already mentioned.

The next Geological Survey sign $(115.6,159.8)$ marks a fork. The lefthand road goes to Walls Well, 1 mile distant, on the west side of the conical mountain. This well was dug about the time of the discovery of the Gunsight mine, by Frederick Wall, who lived here for many years, and on this account the Mexicans call the place Pozo de Federico. A deep well was also drilled to supply a small smelter. Both the well and the smelter are now in ruins. When Wall moved away Papagos from Barajita took possession of the place, and there is now a corral, a small church, and about ten houses. Just beyond the rillage and west of a wire fence is the Miller ranch, an American cattle ranch, where two dug wells furnish a cleaner water supply than that at Walls Well. From the Miller ranch a road goes west to Bates Well (p. 344).

Travelers who do not turn into Walls Well for water will follow the righthand road at the fork previously mentioned on a hard and good road that winds in a general northerly direction toward the Gunsight ranch. Within half a mile a road from Walls Well to mining claims in the hills to the east is crossed, and within another half mile another road from Walls Well comes in at the Geological Survey sign $(116.5,158.9)$. From a slight rise the traveler may look back on the Ajo Mountains and see the picturesque western façade, dominated in this part by Montezuma's Head.

At the next Geological Survey sign $(121.4,154.0)$ the old main route by way of Charco en Medio and a now abandoned portion of the Pozo Blanco route come in on the right. Half a mile farther on the road comes to the Gunsight ranch, described on page 355 , and, passing the ranch, it reaches the new highway at a point 15.5 miles from Ajo (p. 356). 


\section{COMOVO ROUTE}

[For $\log$ see pp. 281-282. Mileage from Tucson and Yuma]

The Comovo route begins $21 / 2$ miles northwest of Copeka, at the Geological Survey sign (82.9. 190.5: see p. 353), and turns to the west across the adobe flat that, with its groves of mesquite trees, forms the bed of the axial stream of the valley. With a fleld on the right the road goes northwest to the point of a low hill which is one of the outliers of the Copeka Mountains. On the way it crosses a cleared space that was used by the Papagos for the foot races: they formerly held from time to time (p. 25). On rounding the hill the traveler sees the white church and pond of Conovo. A view of the pond from a point inside the fence is given in Plate XXII. $A$. The ground is covered with a thin mantle of wind-blown sand, which makes travel slow into Comovo. Just east of the village is a sands area cleared of creosote bushes, and on the right of the road a wooden cross on an adobe platform. The roads are usually obliterated by cattle tracks. The road to Hardimui, about 5 miles away, goes off to the right (east) of the cross. The road to Pisinemo goes to the left (west) of the cross and passing by a field reaches Pisinemo in 5.7 miles.

Comovo $(90.8,182.6)$ consists of a represo that retains a considerable quantity of water, a white adobe church, two or three houses, and a corral. Comoro (Komró) is, like ('omobabi, the "water where a cumaro [hackberry] tree grows." The represo is a horseshoe-shaped embankment about 500 feet across the base, 10 feet high, and in places more than 50 feet wide. Most of the water is held in the borrow pit. The Indians have taken advantage of the irregularities in drainage produced by low sand dunes, and this dam is somewhat more efficient than most of their structures.

The road goes west from the church with the corral on the left and soon passes out of the sandy ground into the smooth flats that carry the drainage of the Quijotoa Valley south toward The Great Plain. The temporal of Comovo lies in this valley on the road to Camote, which is described on page 410.

The road westward from Comovo soon begins to climb the alluvial slope of the Mesquite Mountains. These mountains consist of three parts. The southern part is made up of lava beds tilted to the northeast and forming relatively low ridges at the extreme tip, and a great flat-topped mountain, called by the Papago Mamatotk. which is the highest part of the range. North of Mamatottk is a belt of irregular hills and more or less conical peaks of granitic rocks. The most northerly of these peaks is called Chupan Mountain. The extreme northern part of the mountains consists of two ridges like a fish tail. These ridges. made up of flat-lying lava beds, form low mesas. Toward the easterly ridge the road goes directly and then $(95.2,173.1$ y swings northwest to the gap in the Cubo Hills.

At the Geological Survey sign $(104.7,168.7)$ the Comovo route joins the Cubo route and is coincident with it to the Gunsight ranch. (See pp. 367-368.)

\section{TUCSON TO NOGALES}

\section{MAIN ROUTE}

!

[For log see pp. 283-284]

The Santa Cruz Valley has been, since the time of the early Spanish explorers, the main artery of travel from Sonora and the west coast of Mexico to Arizona and the north. The probability that this route was flrst used br Fray Marcos in 1539 and by Coronado's expedition in 1540 has already been 
referred to (p. 4). Later, between 1694 and 1701, Father Kino made nine trips either north or south in this valley. He beliered that this part of the country would support prosperous missions in which would be collected the widely scattered Indians who made so precarious a living in the surrounding more desert areas. In the time of Kino's exploring successor, Father Garces, the Santa Cruz-Gila route to California was opened, and this route was used during the periods of Spanish and Mexican control with such success as the constant raids of the Apaches permitted. The route is now occupied by the Tucson \& Nogales Railroad, a subsidiary of the Southern Pacific, which connects at Nogales with the Ferrocarril Sud Pacifico de México, a railroad that continues south through Sonora to Hermosillo and Guaymas.

The highway for the first 20 miles south of Tucson follows the east side of the valley, paralleling the railroad. It thus lies in general on the low bluffs that terminate the alluvial slope and border the flood plain. In the flood plain lie numerous farms, most of them irrigated by pumping from wells. The fields are green for a large part of the year, and this prosperous and pleasant country is in marked contrast to the region east of the road. The barren plain slopes up to the foot of the Santa Catalina Mountains on grades that increase from about 100 to 200 feet to the mile. Numerous ephemeral streams or washes dissect the plain in narrow valleys and are crossed by small bridges and concrete dips. Between the streams the plain is gravelly and the soil sterile, with much caliche. "Caliche" is a general term for the white calcareous deposit found at or just below the surface in many desert regions. This material is particularly well developed along this road, and when mixed with the local gravel forms the satisfactory road metal used throughout this section of the highway.

Sahuarito $(20.3,48.9)$ is a railroad station and village near a small butte that projects from the flood plain of Santa Cruz River. As explained on page 285, it is possible to ford the river here and go to Mineral Hill and Twin Buttes, or take the west side of the valley to Nogales. The highway, however, continues south for 5 miles to the Canoa ranch, where it crosses the river to the west side. The Canoa ranch is one of the early Mexican ranches, confirmed as a private land claim under the name San Ignacio de la Canoa. It comprises a strip of the flood plain of the river about 10 miles long. The property is now the site of extensive experiments by the Continental Rubber Co. in the growing of guayule, a Mexican plant, in the hope of developing an American source of rubber. Numerous wells, pumping plants, and a complete system of concrete distributing pipes have been installed." ${ }^{\text {i4 }}$ Whatever the outcome of the experiment in growing guayule, the irrigation equipment is permanent, and the traveler of the future will find the Canoa ranch the site of a prosperous agricultural community.

Where the road crosses Santa Cruz River $(29.4,39.8)$ the stream has a sandy bed which lies in a trench from 10 to 20 feet below the flood plain. The recent origin of this trench is discussed on page 114. After crossing the river the road hugs the foot of the bluffs that border the flood plain on the west. Just as the bluffs are reached $(30.4,38.8)$ the road from Tucson by way of San Xavier comes in from the north. (See p. 372.) Travel on the west side is monotonous, save for the magnificent views of the Santa Rita Mountains on the east and the Sierrita, Cerro Colorado, and Tumacacori mountains on the west. The flood plain of the Santa Cruz, with its groves of mesquite and

74 Smith, G. F. P., Machine-made cement pipe for irrigation systems and other purposes : Arjzona Univ. Agr. Exper, Sta. Bull 86, numerous references and fig. 33, 1918. 
lines of cottonwood and leather-leaf ash, makes a pleasant band of color east of the road.

The Reventon ranch house $(39.7,29.5)$ is an adove building concealed from the road by a mesquite thicket. This ranch was the scene of one of the most stirring episodes in Arizona at the beginning of the Civil War. ${ }^{35}$ In 1861 the withdrawal of Federal troops left local ranchers and miners at the mercy of the Apaches. William Rhodes and a Mexican herdsman left Tubac one morning to hunt horses and found all safe at the Canoa ranch, then used as an fnn.On returning at noon they found that three Americans and a Papago had been murdered. Rhodes and his companion were attacked by more than 100 . mounted Apaches and fled toward Reventon. The Mexican escaped to Tubac by the fleetness of his horse, but Rhodes, finding his horse failing and with an: arrow through his arm, turned off the road. Throwing himself from his horse he ran to a thicket and concealed himself in a dry charco. He spread out his revolver cartridges and caps, broke off the arrow, and buried his arm in earth to stop the flow of blood. Cool and precise, Rhodes killed one after another of the Indians, reloading his revolver after each shot. When he had fired six times the Indians thought that his weapon was empty and charged, only to lose two more men. A second charge and the Apaches left this obstinate fighter to plunder the Sopori ranch, while Rhodes escaped on foot to Reventon.

Beyond Reventon is Sopori Junction, where Sopori Creek joins Santa Cruz River. Here the Arivaca road, described on page 378 , turns off to the west.

Tubac $(46.9,22.3)$, a tiny Mexican village with a post office, church, and store, is probably the oldest white settlement in Arizona. San Xavier and Guevavi had resident priests at earlier dates, but a presidio or military garrison was established at Tubac in 1752, and in the period 1754-55 it had, including soldiers, 411 inhabitants. In 1776 the presidio was transferred to Tueson, and Tubac declined in importance, its flelds and herds suffering from raids of the Apaches. In 1824 it had a small garrison, but the troubles incident to the Mexican revolution depopulated the town, and in 1842-43 it was resettled with friendly Apaches. The population was 249 in 1848 and 100 in 1852. In 1858 to 1860 the town was restored and had a mixed population of Americans and Mexicans and about 100 Papago Indians. During this time there was published here the first newspaper of Arizona, called the Weekly Arizonian. Tubac was the refuge of the whites during the Apache troubles of the Civil War but has never developed into a modern town. One of the principal obstacles to the development of this part of the Santa Cruz Valley has been uncertainty in land titles. Tubac lies just at the northern border of a tract of land approximately 12 miles square, known as the Luis María Baca land grant No. 3, or more commonly the Baca float lands. Luis Maria C. de Baca was one of the lineal descendants of that Âlvar Nañez Cabeza de Vaca whose journey from the Gulf to the Pacific has already been noted (p. 4). To Cabeza de Vaca the King of Spain granted a large tract of land in New Mexico. Part of the same land was settled by persons holding later deeds from the Spanish and Mexican governments. When the United States undertook, through the Court of Private Land Claims, to confirm the titles of lands held under such deeds according to the provisions of the treaty of Guadalupe Hidalgo, a compromise was effected with Baca by which he was allowed to select five tracts of 100,000 acres each out of the public domain in lieu of the original grant. His title in southern Arizona to the "Baca land grant No. 3 " has been bitterly contested by settlers but has finally been decided in favor of the grant, the ownership of which has long since passed out of

${ }^{75}$ Pumpelly, Raphael, Across America and Asia, 3d ed., pp. 45-47, New York. 1870. 
the hands of the Baca family. With sound titles procurable, rapid development of this part of Santa Cruz Valley is assured, for the bottom land is fertile and there is a small low-water flow in the river. Wells obtain water at shallow depths and will doubtless be used for irrigation.

Tumacacori $(50.0,19.2)$ is an old Spanish mission now in ruins which stands just east of the road. It is now under the protection of the United States National fark Service as a national monument, so that its crumpling adobe walls and fine brick façade will be preserved from vandals. San Cayetano, also called San Josê de Tumacácori, was first visited by Kino in 1691 and mentioned as a rancheria and visita of his proposed mission at San Gabriel de Guevavi, where he started a church in 1701. In 1764-1767 Tumacacori had 199 Indians; in 1772, with only 39 inhabitants, it was almost in ruins. Before 1791 a new roof had been put on the church, and it was a mission while Guevavi was abandoned. It seems likely that the present brick and plaster facade was built about this time, because of its close resemblance in material and architecture to the church at San Xavier del Bac. supposed to have been completed in 1796. Just beyond the mission is the north end of the highway as completed in 1917 .

Calabasas Store $(60.4,8.8)$ is a single building on the left of the road about a mile west of Calabasas, a small village of Mexicans at the junction of Nogales Wash and Santa Cruz River. The road goes south up Nogales Wash, also called Potrero Creek, in the narrow valley of that stream, which is separated from Santa Cruz River by the low hills that have as their summit Mount Benedict.

The Nogales-Arivaca road (pp. $380-382$ ) comes in on the left $(61.9,7.3)$ and Nogales Wash is crossed by a bridge. The road then runs along the narrow strip of farming land that constitutes the flood plain of the stream. The steep bluffs that border the valley have a light covering of perennial grass, and there is a decrease in the number of creosote bushes and other characteristic desert shrubs. Nogales and its environs are from 2,000 to 3,000 feet higher than Tucson, with consequent increase in rainfall and change in vegetation.

In 1857, when the first survey of the international boundary was made, Nogales was merely a pleasant camping place in a grove of walnut trees, hence the name Los Nogales. It is now a picturesque towi crowded into the narrow valley between the hills and divided into an American and Mexican part by a broad cross street, which marks the international boundary. Through an error in surveying, International Street lies south of the boundary, and the traveler will do well to keep his automobile off the street until he has complied with local regulations concerning entry into Mexico. The water supply of Nogales is obtained from a dug well 36 feet deep and a gallery 60 feet long under Nogales Wash, 5 miles north of the town. There are two 90-horsepower oil engines and two 19 by 16 inch triplex pumps which force the water through a 10 -inch main to an 840,000 -gallon reservoir. In the city there are about 7 miles of mains to supply 764 customers.

\section{ROUTE BY WAY OF SAN XAVIER AND TWIN BUTTES}

[For log see pp. 285-286]

The traveler to San Xavier and thence south takes the road locally called the Mission road. After crossing Santa Cruz River and turning south under the slopes of Sentinel Hill, as in following the Tucson-Yuma road (pp. 349-350), he continues south from the crossroads $(3.8,72.5)$ on a well-graded hard road. The road leading west is the Tucson-Yuma road. 
The Mission road skirts the bluffs, and below and on the left are the cultivated fields of the flood plain of Santa Cruz River. A few miles farther on (9.2, 66.1) the graded road turns sharply to the left to the Mission of San Xavier del Bac. This handsome church is in a fine state of preservation and is the best monument to the Spanish missionaries in Arizona. Bac was a rancherfa of the Sobaipuris, a Piman tribe who have disappeared or have been merged into the Pimas and Papagos. According to Lumholtz, ${ }^{76}$ the name comes from the Papago vak ("where the river reappears in the sand"). However, he states also that Quitovac, a town in Sonora, is from the Papago vapk or vaketa (" reeds" or " reedy place," and hence a spring). According to Hodge," bac means an adobe house or ruined house, but as Kino distinctly implies that he taught the Indians to make adobe houses, this derivation seems unlikely, while Kino speaks of the water at Bac which can be led into a ditch. As "bac" in some form recurs continually in place names, as in Tubac, Quitobaquito, and Arivaca, it seems more likely that the word refers to water than to a hou'se. Kino first visited Bac in 1692, when, impressed by the possibilities of the place, he gave it the name of his patron, San Francisco Xavier, the missionary of the Indies. Kino was in San Xavier also in May and again in November of 1694, in 1696, 1697, 1698, in February and again in October of 1699 , in 1700 , when he laid the foundations of a large church, and in 1701 and 1702. During Kino's time there was no resident missionary, but from 1720 to 1767 it appears that the mission was continually in charge of a succession of Jesuit priests, 22 in all. In 1768 the Franciscan Father Garcés arrived, and except for his five missionary journeys he was there continuously for 10 years. San Xavier flourished until 1827 and was under 16 Franciscan priests, including Garcés. The original large church started by Kino in 1700 was replaced by the present structure in the years 1783 to 1797 . With the expulsion of the Franciscans in 1827 the mission fell into decay, and though nominally under the parish priest of Magdalena, it was practically abandoned until 1857, when it was put in charge of the Jesuits under the diocese of Santa Fe, and the zealous and beloved Bishop Lamy sent the Very Rev. J. P. Machebeuf to take charge of the mission.

The small reservation set aside for the Papagos of San Xavier is administered from the agency situated just southeast of the church. Both a mission and a Government school have been in operation for some years. The Indians, to the number of about 500 , live a care-free life, cultivating their fields, working for their white neighbors, and very gradually acquiring the arts of modern civilization.

-From the turn at San Xavier the road to Nogales is unimproved, a simple track across the plains, which swings southwest to the base of high, black mesas. At these mesas there is a fork $(12.1,63.2)$. The left-hand road goes south across the plains toward a whitish hill about 8 miles distant, at the base of which lies the town of Mineral Hill. The road to the right goes to mining prospects and to small watering places in the Sierrita Mountains. These mountains, composed largely of granite and gneiss, have a number of watering places, of which the most important is Stevens, which lies in a little open valley on the west side between the main mass of the mountains and outlying hills in sec. 34, T. 17 S., R. 10 E. The water at Stevens comes from an artificial tunnel 50 feet long in a hillside and is piped half a mile to the ranch house. The flow is about 5 gallons a minute.

${ }^{76}$ Lumholtz, Carl, op. cit., p. 384.

7 Coues, Elliot, On the trail of a Spanish pioneer, vol, 1, p. 75, note 9, New York, 1900. 
The road between San Xavier and Mineral Hill has a good deal of traffic when the mines are active, and then the worst places, particularly where washes are crossed, are repaired and made passable by freighters. There are a number of cut-offs and alternate roads which are used or abandoned, according to their condition, from time to time. A few miles of graded road has been constructed since 1917 in the vicinity of the town.

Mineral Hill is a small mining camp with a store and post office. From the town a road goes east to Sahuarito, 9 miles. The road to Nogales goes southwest through the town and between the hills into a rolling, rocky country to a fork $(21.9,53.4)$. Here the left-hand road goes southeast to Twin Buttes, visible near some sharp rocky hills, and the right-land road goes southwest to mining prospects at the east base of the Sierrita Mountains. The whole area between the two towns and in the vicinity of the Sierrita Mountains has been actively prospected for a number of years, and there are in consequence many roads to and between the various claims.

At Twin Buttes $(27.0,48.3)$ is a small but active mine, connected with the Southern Pacific Railroad at Sahuarito by a branch railroad. From a fork east of the town a road goes northeast to Sahuarito, 7 miles. The Nogales road crosses the railroad and goes east down the alluvial slope. It is a fair plains road.

At $4 \frac{1}{2}$ miles from Twin Buttes $(31.5,43.8)$ the road comes into a north-south road, and the traveler to Nogales turns south and follows a poor and ungraded road under and east of the bluffs for 5 miles to the well-graded Tucson-Nogales Highway, which he follows into Nogales (pp. 370-372). The north-south road just mentioned goes 5 miles north of Sahuarito. Thus it is possible to go south from Tucson on the Tucson-Nogales Highway to Sahuarito, 20.8 miles, and then reach Mineral Hill in 9 miles and Twin Buttes in 7 miles, or cross to the west side of Santa Cruz Valley and reach this fork in 5 miles.

\section{ROUTES IN AND TO THE ALTAR VALIEY}

\section{TUCSON TO SASABE}

[For log see pp. 287-289]

The Tucson-Sasabe road is the same as the Tucson-Yuma road (pp. 349-350) for the first 23.4 miles, or to the fork at the Robles ranch. A small amount of road work has been done by the county from the Robles ranch south for about 14 miles. From this point on the road was shifted in position in 1917, owing to the building of fences, and most of the improvements have been made by the local cattlemen. As most of the ranches in Altar Valley have one or more automobiles, the traveler will find that the roads, however rough, are always kept in passable condition by the local travelers. The nature of the soil, particularly in the southern part of the valley, lends itself to good roads, as explained more fully on page 375 . The new road reported as under construction in 1920 will follow in a general way the road described below.

Altar Valley.-The Altar Valley, which lies between the more or less discontinuous Tumacacori, Cerro Colorado, and Sierrita mountains on the east and the Baboquivari and Coyote mountains on the west, is about 40 miles long and 10 miles wide. As previously pointed out (p. 109), it differs from the valleys west of the Baboquivari Mountains and resembles Santa Cruz Valley in having a central inner valley. This inner valley begins about 8 miles south of the Robles ranch. 
The southern part of the valley has a very light covering of alluvium, and over large areas the plains are formed of rock. From this area of coalescing pediments (see p. 109), which is called on old maps the Sasabe Flat, the flood waters drain north to the Robles ranch and south into Mexico by way of Sasabe. The main stream north of Buenos Aires and most of its tributaries lie in valleys and are dissecting the plains. Because the plains are thus subject to erosion and not sedimentation, soft ground is removed, and in most places the soil is firm and has more than the usual percentage of gravel at the surface. On this account the roads are good, and the traveler will find that he can leave the road and cut across country with more ease than in other parts of the Papago country. The small valleys, however, have soft ground in their flat bottoms, and usually the streams have steep cut banks, so it is ordinarily impossible to cross a stream except at a place already prepared.

The southern part of the valley has also a higher altitude than is usual in the Papago country, and though detailed surveys are available only along the international boundary, the average altitude is probably over 3,000 feet. Consequently upon the higher altitude is a change in vegetation, which not only gives a different and unusual aspect to the region but has important economic results. The woody vegetation characteristic of the alluvial valleys of the Papago country, consisting of creosote bush, palo verde, catclaw, mesquite, and palo fierro, is sensitive to cold and also can not resist fire. The most resistant of these plants seems to be the mesquite, which is present in the southern part of the valley but is restricted to the stream channels and to broken conntry. The bushes are, however, low and stunted. The predominant plants are grasses, mostly of annual types, which spring up rapidly after rains, seed quickly, and then cure while standing. The view of Altar Valley in Plate $\mathrm{XV}, B$, taken in December, shows the grassy, almost treeless plains covered with dry grass. The photograph can, however, give only an inadequate conception of the bright yellow-brown of the dry grass or the magnificence of the plains when green. The cattlemen call this the six-weeks grass, though botanists confine the name to one of the several species that make up the association. Occasionally on the plains and usually at the borders of the mountains are clumps and areas of perennial grasses. The bisnaga, or barrel cactus, which is rare or overshadowed by the sahuaro in other parts of the Papago country, grows as solitary individuals on the grassy plains. It seems evident that the increased rainfall due to higher altitude is the main cause of the growth of the grass, and that the burning of the dry grass has eliminated most of the woody plants. In this subtropical desert there are, then, two timber lines, one determined by an increase in rainfall sufficient to permit the growth of grass, which by periodic burning limits the growth of trees to lower altitudes, and a second determined by a sufficient further increase in rainfall either to make fres less frequent or to permit the growth of fire-resistant trees. The latter type of timber line which Russell ${ }^{\text {to }}$ has called the dry timber line, is well displayed in the Tumacacori Mountains (p. 251). The cold timber line, at which the growth of trees is prohibited by low temperature, is not found in this part of Arizona even on the highest summits.

The grassy plains of the Altar Valley are much more suitable for cattle raising than other valleys of the Papago country. Success was assured for the stock business when it was found possible to develop water either in the edge of the mountains or by deep wells in the center of the valley. The chief watering places have been in existence for more than 30 years, and the cattle

${ }^{78}$ Ruissell, I. C., Timber lines [abstract] : Geol. Soc. America Bull., vol. 14, pp. 556-557, 1903.

$104211-25-26$ 
business has long been on a relatively stable basis. According to the custom of the so-called "free range," the owner of a watering place controlled the range halfway to the next watering place. All cattle that came voluntarily to water, however, were allowed to drink, and only herds on the move and controlled by their owners were charged for water. The cattle were separated only at the amnual round-up. Under the condition that occupation was the sole claim to the range, it was impossible to save any area from grazing either to allow the forage to reach maturity or to provide a reserve for times of

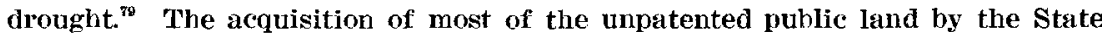
of Arizona and the development of the present grazing policy in the national forest has brought about a complete change in the previous system. The grazing policies of the Cnited States Forest Service are set forth in the description of the Nogales-Arivaca road (p.: 381). The State lands, however, are leased in large blocks for a period of years at a fixed charge per acre. The State land commissioner assigns to owners of existing watering places the areas naturally tributary to the water and in effect legalizes the partition of the range actually in force. The details of boundaries were adjusted in conference with the several interests. The advantages to the stockman are obvious; he can now fence and cross fence his range, thereby reducing the expense involved in the annual round-up, the constant search for strays, and the incursions of the petty cow thief. Also, he may divide his cattle according to grade, sex. or condition and shift from one pasture to another to allow the range to recover from overgrazing. Much greater efficiency is bound to result, and the interests of the public appear to be protected in that the rent is sufficiently high to prohibit the leasing of land except for beneficial use.

The building of fences was going on actively in 1917 and brought about a considerable shift in the roads. The cattlemen obviously desire as few gates as possible and these so located as to be easily watched. The traveler should observe the rule of a cow country, which is to shut all gates found shut and leave open all gates found open. Occasionally signs are posted asking the traveler to disregard the rule and shut the gate, even if he finds it open. Fortunately for the automobile tourist most of the ranches have one or more machines, and many fences are provided with an ingenious automobile bypass near each gate. This consists of a trench at a gap in the fence, crossed by two narrow timber bridges so spaced as to carry the wheels of an automobile. The trench is provided with stakes or slats like those of a railway cattle guard to prevent stock from going through the gap. Through one of these by-passes the motorist may drive without stopping to open or close the gate.

Robles ranch to Palo Alto.-The road goes south from the Robles ranch and passing the abandoned ranch called Bawley on the right reaches the King Well in 5 miles. South from this deep well and stock-watering place the road keeps to the east of the fences and occasional hay fields of the flood plain of the axial stream. The Anvil ranch is 3 miles farther south. This is the headquarters of the King properties, which include the two watering places King Well and Anvil ranch, in the center of the valley, with about 4,000 acres of patented land. In addition there is Redondo, a well 100 feet deep near the mountains 12 miles southwest, and perhaps other watering places along the mountain front. The King interests had in 1917 about 34,000 acres of leased land.

${ }^{79}$ Wooton, w. O., Factors affecting range management in New Mexico: U. S. Dept. Agr. Bull. 211, pp. 15-20, 1915. 
Near the Anvil ranch begin the bluffs which, gradually increasing in height, bound the inner valley of the axial stream as far as Buenos Aires. About 3 miles south of the Anvil ranch the properties of the La Osa Land \& Ioan Co., the big cattle outft of the valley, begin. Palo Alto, Pozo Nuevo, Secundino, and Buenos Aires all belong to this outfit, which has about 14,000 acres of patented land in the center of the valley, extending almost without interruption from Palo Alto to La Osa. Along the border of the Bahoquivari: Mountains this company has about 2,700 acres and controls Browns Well, Thomas Well, Peak Water Tunnel, Schaefer Well, Las Moras, and La Osa. On the east side of the valley it owns 520 acres and controls Stevens, Punta de Agua, Tully Well, Aguajita, and E. Garcia Well. Its leased lands, completely fenced, amounted in 1917 to about 94,000 acres.

Palo Alto has a deep well and pumping plant, the usual corrals, and a small store. The homes of the ranch employees make a small village.

Palo Alto to Ronstadt gate.-From Palo Alto south the traveler is aided by neat wooden signs, giving directions to the several ranches and watering places, erected by the La Osa Co. The road crosses the main arroyo of the valley 3 miles south of Palo Alto. Almost immediately the road forks; the left-hand branch follows the fiood plain on soft ground, and the right-hand branch follows the top of the bluffs over harder ground. It is the better road, and branches turn off at each of the watering places. Espinosa Well is visible $2 \frac{1}{2}$ miles away across the fiat. Pozo Nuevo is 4 miles distant. From both of these stock-watering places poor roads, not shown on the maps, lead off east to the Cerro Colorado Mountains.

At a crossroads $(48.6,22.3)$ the Sasabe road goes straight ahead; the lefthand road goes back to Pozo Nuevo, and the right-hand road goes west to localities along the mountain front. On this right-hand road the first right-hand turn goes to Browns Well, a watering place 4 miles distant. The left-hand turn crosses two valleys to a fork in a third valley. At this fork the right-hand turn reaches Schaefer Well and the Baboquivari mine, at distances of 9 and 10 miles, respectively. These places are in a canyon that heads at the foot of Baboquivari Peak. Browns Well, Peak Water Tunnel, Thomas Well, and Schaefer Well are mere stock-watering places. The Baboquivari mine is a small gold mine in a gulch just north of Mount Mildred, a prominent peak near the edge of the mountains. From this point of view the gulch lies just south of the high square tower of Baboquivari Peak (p. 380). At the mine are wells, a few houses, and a small mill. The mine is inactive most of the time. The left-hand turn at the fork last mentioned leads to the Ronstadt ranch, described below.

At a fork and crossroads $(54.0,16.9)$ the main road goes south. The lefthand road goes 0.9 mile to the Ronstadt gate, from which a road goes northeast to Secundino, woutheast to Arivaca (p. 379), and west to the Ronstadt ranch and Las Moras.

The Ronstadt ranch with its wells, corrals, and house lies in a pretty location at the foot of the mountains. The property includes about 1,100 acres of patented land and in 1917 about 20,000 acres of leased land. Las Moras (" the mulberries") is one of the oldest ranches in the valley, and the low adobe house with its big verandas is typical of the southwestern cattle ranch at its best. Las Moras is now headquarters for the La Osa Co., though the largest group of employees is located at La Osa.

Ronstadt gate to Sasabe-Going south from the fork east of the Ronstadt gate and passing through two gates and avoiding forks and crossroads, the road comes to a crossroads by a fence corner $(61.5,9.4)$, from which the Sasabe road continues south. The east-west road goes from Buenos Ajres, 
the watering place and deep well in the valley on the left, to Las Moras and incidentally to the Hart \& Miller and Aros ranches, though roads to these places are not shown on the map. Hart \& Miller have a small cattle ranch consisting of 960 acres of patented land and in 1917 about 9,000 acres of leased land. The Aros ranches belong to the family of that name and consist of about 2,000 acres of patented land and in 19177,500 acres of leased land. No information is available regarding the water supply of these ranches. North of Buenos Aires and visible from the Sasabe road is Aguirre Lake, a reservoir for storing flood water, more than $11 / 2$ miles long when full. This lake is used for watering cattle and also for irrigating hay and beans in the valley to - the north. From Buenos Aires roads go to Arivaca and the eastern part of the valley. (See pp. 292-293.)

From Buenos Aires the old road formerly went directly south to Sasabe, but on account of the fences the present road goes southwest over the open rolling plains to a fork $(66,4.9)$. The right-hand road goes to La Osa, where the employees of the La Osa Co. form a small village with a post office and store. There are good wells, and the plaza of this village is cool and green with the shade of trees. The left-hand road goes south to a gate $(68.5,2.4)$, beyond which is San Fernando, a new village on the Reveil ranch, with a post office, store, and custom house. This is now the usual port of entry from Mexico, replacing in large measure the older Sasabe. At the gate at San Fernando a road from the west comes from La Osa, and the Sasabe road goes east and southeast down the slope to Sasabe.

Sasabe appears to have been originally a Papago rancherła, called Shashovuk, ("echo"), but for many years the name has been applied to both the Mexican and American customhouses. The Mexican customhouse was for many years about 5 miles south of the boundary; the American establishment has been in varions localities. The present Sasabe is a lone store on the boundary line, with a well and windmill near the arroyo on the west. From Sasabe a road goes north and east to the Garcia ranch, sometimes called San Felicita, and thence to the Lopez ranch and Buenos Aires (p. 292).

\section{AMADO TO RONSTADT GATE}

[For log see pp. 289-291]

The Arivaca road up Sopori Creek is the oldest and most natural route from the Santa Cruz Valley to Arivaca and thence into the Altar Valley. It is now used by the stockmen of the region and for the supply of the military camp at Arivaca. The traffic is probably not so heavy as when the Cerro Colorado and other mines were in operation.

This road starts from Santa Cruz Valley at its junction with Sopori Creek. Two roads lead up Sopori Creek, one on the north bank and the other on the south bank. The distance is virtually the same by either, but the south road was usually traveled in 1917. The junction of the north road with the TucsonNogales road is 39.5 miles from Tucson and 29.7 miles from Nogales. The junction of the south road is 40.1 miles from Tucson and 29.1 miles from Nogales.

About 3 miles up the creek is the site of Sopori, once an Indian village and later a Spanish ranch. In 1855 there was, according to Lieutenant Michler, ${ }^{80}$ only a single peach tree at "Ojo del Agua de Sopori." In 1861 the ranch, which

${ }^{80}$ Emory, W. H., Report of the United States and Mexican Boundary Survey, vol. 1, p. 1]9, 1857 . 
had been occupied by an American, was raided by the Apaches, the owner being killed near Canoa the same day. ${ }^{81}$ In 1863 it was still abandoned. ${ }^{82}$ The exact location of this old ranch is not known, though it may be the same as one of the watering places shown on the map.

At Moyza, a stock-watering place $(11,22.6)$, the road forks. The left-hand road continues up Sopori Creek to the Papalote ("windmill") ranch and thence to the Arivaca ranch and Arivaca. The right-hand road, which is the preferable route, leaves the valley of Sopori Creek and strikes west across the rolling country.

To the north are the picturesque red peaks and pinnacles of the Cerro Colorado Mountains; to the west the low bare sierra called the Guijas Mountains; to the east a long ridge begins in Diablito Mountain and trends south with Sardina and Atascosa mountains as summits and joins a great and complicated mass of mountains which close in all the southern horizon and bound the basin in which the town of Arivaca lies. This basin consists of a great plain cut into rolling country by numerous streams, some of which are tributary to Sopori Creek and others to Arivaca Creek. It is a typical dissected pediment developed as a headwater basin, as described on page 289 . (See also Pl. XV, A.)

The road skirts the western edge of this basin, passing south of the old Cerro Colorado mine, also called the Heintzelman mine. Near the Tajo mine there is a fork $(14,19.6)$, and the Arivaca road is the left-hand road. The right-hand road goes northwest through a broad pass to the headwaters of Arroyo Seco, a tributary of the Altar Valley. Here are located the Moreno ranch and Liberty mine. From this locality, as shown on Plate IV, a road goes north on the west side of the Cerro Colorado Mountains to Stevens (p. 373).

At 3 miles beyond the Tajo fork $(17,16.6)$ a road comes in from the pass between the Guijas Mountains and a small unnamed range north of it. Guijas Wash, a tributary of the Altar Valley, heads in this pass. Gold placers were worked in this locality by both Mexicans and Americans in the sixties and seventies, and it is presumed that the wash and mountain gained their names at this time, for guijas means in Spanish the "rubble" or "conglomerate" in which placer gold is usually found. The road through this gulch passes a number of ranches at which water can probably be obtained and reaches Secundino Well, in the Altar Valley, in 10.5 miles.

Arivaca $(21,12.6)$ is a small town with houses strung along a wide street, on a bench about 20 feet above the flood plain of Arivaca Creek. There is a post office, store, and hotel. A well and small pumping plant east of the town supplies water to most of the inhabitants and to the military camp that has been maintained here since the beginning of Madera's Mexican revolution.

East of the town the Arivaca ranch is visible along the creek that rises in the slopes of the main part of the Tumacacori Mountains and flows through the basin in a narrow ralley and northwest past the town to the AItar Valley. The stream now runs in a trench about 10 feet below the flood plain, though formerly there were extensive swamps. "Arivaca" is a Papago word whose meaning is "little spring" or "little house," dependent on the meaning of the root "vac" or "bac" (p. 373). The locality was carly occupied by the Spanish. According to Coues 83 Arivaca, before the Papago rebellion

81 Pumpelly, Raphael, Across America and Asia, 1870.

${ }^{82}$ Ferguson, Maj. D., 37th Cong., spec. sess., S. Ex. Doc. 1, 1863. 
of 1751, was a large pueblo and visitu of Guevari, but it was deserted in $1855{ }^{\text {s4 }}$ though there were remains of a ranch and old reduction works. In 1861 the reduction works of the Heintzelman mine were located here, ${ }^{\mathrm{B} \bar{p}}$ but in 1863 it was again deserted.86 The principal cattle company is the Arivaca Land \& Cattle Co., which controls the range over a large part of the basin east of Arivaca. The McVer interests, known as the Las Jarillas ranch, have large holdings southwest of the town. Both of these companies and many smaller owners range cattle on the national forest that covers the mountains south of the town (p. 381).

From Arivaca the road goes northwest along the right bank of Arivaca Creek. Part of the distance it is on the bluff and overlooks the flood plain with fields and bands of cottonwood and leather-leaf ash. The hackberry (Celtis occidentalis) grows in this flood plain to a height of 50 or 60 feet and is a most graceful tree. For part of the distance the road is in the flood plain and for a short distance even in the bed of the stream.

The Figueroa ranch house is an adobe building on a bare knoll on the right of the road. From this house the junction of Arivaca Creek with San Luis Canyon can be seen. This "canyon" is a bluff-bordered valley in the plains about half a mile wide. West of the granite hills that bound the valley of Arivaca Creek on the south San Luis Wash and Arivaca Creek join in a larger trench, which runs north 4 miles to Secundino Well and there becomes a part of the central trench of the Altar Valley.

From the Figueroa ranch the grassy plains of the Altar Valley are spread out to view, and all the western horizon is bounded by the bare rocky slopes of the Baboquivari Mountains, dominated by Baboquivari Peak, 7,440 feet high. ${ }^{87}$ The Papago name is Vavkívolik (" mountain [vav] narrow about the middle [kivolik]"). ${ }^{88}$ There is a small rock tank on the top which holds water for a few hours after a rain, according to Prof. R. H. Forbes, who climbed the monntain in July, 1898, and perhaps this fact accounts for Lieutenant Michler's translation of the name, "water on the mountain."

The Arivaca road goes west from the Figueroa ranch to the bluff across the arroyo and thence through a lane between fences to the Ronstadt gate. From this point all parts of the Altar Valley may be reached. (See pp. 287-291.)

\section{NOGALES TO ARIVACA}

[For log see pp. 291-292]

Nogales to Bear Vatley.-The Nogales-Arivaca road has been built largely to serve the mining interests in the Tumacacori Mountains. It was reported that owing to the closing of the Montana mine this road was impassable for through travel in 1920. From Diablito Mountain, on the north, southward into Mexico these mountains were a barrier to travel, and the early explorers either went south of the mountains to the headwaters of the Altar near Saric and then west or followed the Arivaca road up Sopori Creek from the vicinity of Tubac (p. 378). Trails, however, crossed the first ridge at Puerto Torunos and Apache Pass and at the gap near Thumb Butte through which the present road goes.

\footnotetext{
89 Coues, Elliot, op. cit., p. 527.

84 Emory, W. H., op. cit., p. 119.

so Pumpelly, Raphael, op. cit., p. 243.

s6 Ferguson, Maj. D., op. cit., p. 14.

87 U. S. Indian Service Nomadic Papago surveys, detail maps, 1915.

ss Lumholtz, Carl, op. cit., p. 31.

${ }^{89}$ Emory, W. H., op. cit., p. 119.
} 
The Nogales-Arivaca road leaves the valley of Nogales Wash 6.4 miles north of Nogales on the Tucson-Nogales Highway (p. 369). It immediately climbs the bluffs and gains the flat-topped interstream area of the dissected alluvial slope and mountain pediment that slopes from the Tumacacori Mountains to Nogales Wash and Santa Cruz River. From the top of the bluff there is a fine view of the dissected pediment on both sides of the strip of verdure which marks Nogales Wash, of Mount Benedict, and to the northeast of the San Cayetano Mountains, standing as an outlier of the $h$ :gher timbered slopes of the Santa Rita Mountains. To the north the Santa Cruz Valley sweeps off to an unlimited distance, and the cottonwoods of its fiood plain make a narrow ribbon of green which runs between the dull-gray slopes of the flanking plains. To the west the plain rises steeply, scored by narrow parallel gulches about a mile apart, to the continuous timber-covered front of the mountains. About 3 miles up this slope the road descends into the gulch to the right and follows the gulch along a dry stream bordered by a narrow flood plain. The regetation increases in amount and size. Beyond the Clark Wen $(12.9,30.6)$ the walls of the gulch are so high and steep that it becomes a small canyon, and the vegetation is so dense that it is hard to believe that the ordinary desert flora exists at the top of the bluffs.

The road turns to the left $(13.8,29.7)$ over a ridge into another canyon that is still more verdant, and follows this to the south side of Thumb Butte and thence with constantly increasing gradient around the end of Atascosa Mountain. At the crest of the pass $(20.2,23.3)$ the road overlooks a mountain landscape of singular beauty. The rounded ridge tops of the lower mountains are grass-covered and dotted with live oaks; the higher summits, such as Montana Peak and Atascosa Monntain, are encircled by cliffs and stand as mesas above the lower ridges. Between the ridges are deep canyons. forming an intricate maze.

Bear Valley, into which the road descends, is an area of lower ridges, not an open valley, and drains to the southwest through Sycamore Canyon and to the northeast around the north end of Atascosa Mountain.

The national forest.-The major part of the Tumacacori Mountains is included in the Tumacacori division of the Coronado National Forest. The supervisor in charge is stationed at Tueson, and the ranger at the station on the Tueson-Nogales Highway north of Nogales (p. 283). The timber of the forest consists largely of three species of live oaks, indistinguishable to the ordinary traveler (p. 45), which grow in a thin forest of orchard-like type at altitudes above 4,500 feet. On the lower parts of the mountains the trees are rigidly restricted to the north slopes, but at higher altitudes they grow on all slopes. The oaks have little commercial value, though the acorns, under the name bellota, are eaten by the Indians and Mexicans. The principal value of the trees lies in the protection they give to the soil, which supports a luxuriant growth of grass. The grass, which is green after rains, cures on the stalk with little loss in nutritive value. The grazing conditions of the forest have been studied intensively; the number of cows which each 40 acres will support has been determined, and the whole area has been divided into natural grazing units, which depend on topography and water supply. To each unit are assigned a certain number of cattle, and the owners of the cattle have been allowed to erect fences on the boundaries. The number of cattle and their distribution is thus determined by the estimated safe capacity of the range and is subject to modification as experience may suggest. Permits to graze cattle are issued to the owners of lands adjacent to the forest, subject to goon behavior and conformity to the regulations. 
The Forest Service also provides fire guards, cuts fire lines, and builds roads: and trails through the forest. Development of new water supplies is the next logical step, and a certain amount of development work each year is required of permittees.

Montana mine to Arivaca.-The Montana mine $(31.2,12.3)$, largely a producer of zinc, supports a considerable village. The water supply comes from three dug wells and two large reservoirs. When the mine is in operation a store and restaurant are maintained. The mining company keeps the road to Nogales in good condition, for over this road supplies for the mine and concentrates shipped to the distant smelter must be hauled. This mine was not in operation in 1920.

Austerlitz $(33.8,9.7)$ is an old mining locality. The mine is said to have produced $\$ 80,000$ in gold. From this place a rough road leads to the old camp of Warsaw, 4 miles to the south, where there usually are one or two prospectors. Austerlitz is near the edge of the mountains that border the great basin near the western edge of which lies the town of Arivaca. Passing the ranch called Partridge, the road reaches Oro Blanco $(36,6.5)$, an old, partly deserted mining town. Oro Blanco was the principal center of mining activities that began in the eighties and nineties and had a revival about 1911. Many prospects were opened in the surrounding hills, but the Montana is the only mine which has been more than a prospect. Just beyond Oro Blanco the road leaves the stream valley which it has followed out of the mountains and runs on the adjacent bluff. Here there is a fine view of the mountains which encircle the basin, as shown in Plate $\mathrm{XV}, A$.

At Arivaca this road joins the Arivaca road, and the traveler may go west into the Altar Valley or northeast to the Santa Cruz (pp. 378-380).

\section{TUCSON TO PHOENIX}

[For log see pp. 293-297]

Tucson to Florence-From Tucson (p. 349) the Tucson-Phoenix Highway goes north through the unimproved outskirts of the city over an open gravelly plain, which is in part the alluvial slope built up by streams in past time between the Santa Catalina Mountains and Santa Cruz River and in part a pediment cut by these streams. This slope is now dissected by streams, each of which occupies a narrow gulch or a broad valley, such as that of Rillito. Creek, which is crossed on a concrete bridge $(5.5,125.8)$. There are prosperous farms along this valley irrigated by the low-water flow and by pumping from ground water. According to Smith, ${ }^{80}$ the drainage area of Rillito Creek is 327 square miles, of which 56 per cent is mountainous. Pantano Wash, a tributary, adds 600 square miles to this total. In the valley of Rillito Creek, which has a bottom land of sandy loam soils about half a mile wide and including altogether about 45 square miles susceptible of irrigation if sufficient water were available, about 2,300 acres was cultivated in 1909 .

The first settlement in the valley was made in 1858. The flood plain of the valley was then an unbroken forest of mesquite with a heavy grass cover between the trees. The course of the river was an indefinite channel marked by cottonwood, ash, willow, and walnut trees, with numerous beaver dams, and thus was quite different from the present channel, which is intrenched in the flood plain and has sharp vertical banks. Fort Lowell, at the junction of Rillito

${ }^{0}$ Smith, G. D. P., Ground-water supply and irrigation in the Rillito Valley: Arizona Univ. Agr. Exper. Sta. Bull. 64, pp. 85, 98, 100, 1910. 
Creek and Pantano Wash, was occupied in 1872, and the cavalry horses were supplied with hay cut in the flood plain. Cattle were introduced about this time. A new deep channel was cut by great floods, and the low-water flow of the creek decreased. The first big flood on Pantano Wash that reached Rillito Creek occurred in 1881, but the present deep channel of Pantano Wash was not cut until after 1890. The grazing of cattle destroyed the grass cover and increased the violence of floods, but these changes in the Rillito Valley were coincident with other changes in the region. ${ }^{91}$ The area irrigated has been much increased in recent years.

Beyond Rillito Creek the road goes north across the alluvial slope toward the north end of the Santa Catalina Mountains. The high, rugged slopes of these mountains are forested. Live oaks in a scattered forest cover the slopes between 4,500 and 6,000 feet, the western yellow pine grows between 6,000 and 8,000 feet, and there is a small area of fir and spruce above 8,000 feet.

Descending into the narrow valley of the Cañada del Oro the road returns to the northeast up the valley, passes a store $(13.3,118)$, climbs out of the valley, and, going north over rolling country between the Tortolita Mountains on the left and the Santa Catalina Mountains on the right, reaches Walnut Well (24.7, 106.6). Here there is a well and pumping plant, and the road to Oracle goes off to the right. The Tucson-Phoenix Highway goes northwestward over rolling country, in which there are stretches of excellent graded road, and fast time can be made.

The Simmons Well $(39.1,92.2)$ is usually considered the last water before crossing the great plains to Florence. It is the most convenient watering place, but 5 miles farther on the Meneger ranch lies a quarter of a mile to the west of the road, and water can be taken on there. From Simmons Well the road follows a straight line northwest to Florence. The Foreman ranch, which lies 8 miles east of the road, is incorrectly located on the map (Pl. IV). It lies in Suffering Gulch, about 2 miles south of the location given.

The crossing of an irrigation ditch $(66.7,64.6)$ marks the valley of Gila River. From the ditch the road goes due north between fences to Florence, receiving on the left the roads from Casa Grande (p. 390) and Casa Grande Ruins (pp. 385-388).

Florence, with a population in 1920 of 1,161 , is the county seat of Pinal County and the center of trade for the irrigated area along Gila River and a large contiguous cattle country. The State penitentiary is on the outskirts of the town. Passing through the shady main street with its stores, hotels, and garages, the Tucson-Phoenix road turns to the right and then crosses Gila River on a long concrete bridge to Florence station on the Southern Pacific Railroad.

Florence to Phoenix.-From Florence it is possible to go north by a desert road to the Phoenix-Globe Highway; the road described below leaves the Florence railroad station and turns to the west along the bluffs and passes to the south of a small rocky hill of black basalt, known as Poston Butte (incorrectly spelled Posten on PI. IV). The flood plain of Gila River, with its thickets of cottonwood trees, irrigated lands, and pastures, lies below on the left. About 2 miles west of Florence station $(72.6,58.7)$ the road turns to the northwest and, paralleling the railroad, skirts the base of the Santan Mountains, a group of more or less detached barren and rocky hills. In 1917 this part of the road had been cleared of brush and graded with a scraper. It was rather worse than an ungraded plains road and was provided with milestones

91 Bryan, Kirk, Erosion and sedimentation in the Papago country : U. S. Geol. Survey Bull. 730, pp. 77-80, 1922. 
set at somewhat irregular intervals. About 20 miles farther on (92.7, 38.6) the road turns due west and because close to the hills goes through a magnificent park of sahuaro, cholla, ironwood, palo verde, and other desert vegetation. 'To the north and east lie the Queen Creek flats, which are annually flooded. Numerous schemes have been proposed for the reclamation of this fine body of agricultural land. At the base of a steep rocky hill $(94,37.3)$ the road turns due north, and in 6.8 miles it reaches Higley. This crossroads village is on the Phoenix-Globe road, not described in this report. From this point the road turns west and within 2.5 miles crosses a ditch into the irrigated lands of the Salt River project. The roads are laid out on the public-land lines, and there are crossroads at each mile or half mile from this point on. Chandler. a small town, is 7 miles west of Higley, and here the road turns north and follows an electric power line for 7.7 miles to a well-traveled east-west road. The important agricultural town of Mesa is just east of this crossroads, but unless the traveler wishes to see the town he turns west and, following a paved road, reaches the village of Tempe in 6.5 miles. Then, crossing Salt River on a long concrete bridge, he passes through the Papago Saguaro National Monument and goes west to Phoenix, following the paved road.

Salt River project. ${ }^{23}$-Irrigation on Salt River had been practiced in a small way by the Pima Indians. In 1867 a small colony of Mormons began irrigation, which was developed under numerous difficulties until the United States Reclamation Service undertook the construction of the Salt River project in 1903 and acquired all the existing canals. The conditions in 1887 are summar. ized by Bancroft. ${ }^{23}$ There were eight main canals with a total length of 160 miles, built at a cost of $\$ 1,000,000$. About 50,000 acres was under cultivation in wheat, barley, alfalfa, and fruits. Most of the farm crops were used in feeding livestock and in making dairy products. Construction on the Government project began in 1906 and was completed in 1919 at a total cost of $\$ 10,548,253.63$, or approximately $\$ 50$ per acre irrigated. The irrigation plan provides for storage of water in a reservoir created by the Roosevelt dam, at the junction of Salt River and Tonto Creek, 70 miles northeast of Phoenix. This dam is an arch of rubble masonry 1,125 feet in length and 280 feet high. The reservoir has a capacity of $1,365,000$ acre-feet. The stored water is carried in the channel of Salt River to the Granite Reef dam, 4 miles below the junction of Verde River, where with the ordinary flow of the Verde it is diverted into canals on both sides of the river. The canals and laterals have a total length of 836.5 miles and are prepared to serve 212,960 acres, of which 184,432 acres was in crop in 1918. The project was turned over to the Salt River Valley Water Users' Association as representatives of the settlers in the valley in 1917, just 14 years after the initiation of the project and 11 years after construction was begun. The construction costs are a lien on the land, to be paid to the United States over a term of years.

In 1918 the total value of the crops raised was $\$ 18,188,800$, or $\$ 98.70$ an acre, nearly twice the cost of construction. The introduction of Egyptian longstaple cotton increased the returns tremendously, and the years 1917 to 1920 witnessed a great boom in farm values. In 1920 a cash rent of $\$ 90$ an acre a year was paid and farm land was quoted at more than $\$ 500$ an acre. The general fall in prices that occurred in that year bore heavily on this valley. Egypt:an cotton from an expected price of $\$ 1$ to $\$ 1.25$ a pound fell to 50 cents and even at this price was unsalable. In 1921 a large number of speculators were forced

- out of business and many persons were supported by charity.

92 Largely condensed from U. S. Recl. Service Eighteenth Ann. Rept., pp. 75-83, 1919.

${ }^{\circ}$ Bancroft. H. H., History, vol. 18, p. 535. 
Papago Saguaro National Momument.-A national monument, popularly called Papago Park, lies just north of Tempe, across the river. It was set aside by presidential proclamation in 1914 and comprises 2,050 acres. The. State rifie range of 320 acres is immediately adjacent on the north, and across the river Tempe Butte is preserved as a park by the town of Tempe.

Papago Park is an area of rough topography set in the midst of the flat and verdant fields of the Salt River valley. The higher hills are composed of conglomerate of Tertiary age, faulted and tilted. The erosion of these rocks produces fantastic and picturesque forms (p. 91), of which the best known is a natural window called Hole in the Rock. The gravel-covered plains surrounding the hills are typical of a large part of southwestern Arizona.

About half a mile from the concrete bridge, on the right of the road to Phoenix, is a typical rock tank, consisting of a plunge pool excavated by an ephemeral stream (p. 123). The reservation of this area preserves the desert vegetation of creosote bush, palo verde, sahuaro, and cholla in the midst of the cultivated and really alien luxuriance of the Salt River project.

Phoenix.-Phoenix, the capital of Arizona, lies in the flood plain of Salt River surrounded $b y$ and merging into the farming lands of the Salt River project. In 1920 it harl a population of 29,053 . The town is laid out on a rectangular pattern with very broad streets, most of which in the business part of the city are paved. The hotels and business houses, particularly those built since 1906, are of the most substantial character. The residence sections are attractive, the more recent houses following the California bungalow style.

Phoenix was founded in 1870 and incorporated in 1881. The Southern Pacific Co.'s branch line from Maricopa was built in 1887, and the Santa Fe, Prescott \& Phoenix Railroad, connecting Phoenix with the main line of the Santa Fe at Ash Fork, was built about 1886 .

Prescott was the capital of Arizona from the beginning of Territorial goverument in 1864 to 1867. Tucson from 1868 to 1877, Prescott again from 1878 to 1911, and Phoenix from 1912 to the present time. The State capitol, west of the business district, is a handsome structure surrounded by beautiful grounds.

Routes from Phoenix to California are described by Ross. ${ }^{24}$ Routes from Phoenix to Gila Bend are described on pages $397-400$ of this report; to Maricopa, on page 397 ; and to Casa Grande, on pages 388-389.

I

\section{FLORENCE TO CASA GRANDE RUINS}

[For log see p. 297]

The following description of the road from Florence to the Casa Grande Ruins is taken with slight alterations from that of Fewkes, ${ }^{95}$ who restored the ruins in the years 1906 to 1908.

After leaving Florence the road to Casa Grande follows the left bank of the Gila westward, crossing a level stretch and skirting for a few miles the base of a low gravelly mesa. The first aboriginal object of interest met with is a group of Indian huts situated on the left of this road. ${ }^{96}$ This settlement is of recent origin; the rectangular houses composing it are built in the old style and inhabited by Papago. Near it looms a low white mound indicating an ancient ruin, which will well repay a brief visit. Following the road farther westward, the traveler passes through a cluster of houses known as

\footnotetext{
94 Ross, C. P., The lower Gila region, Arizona : U. S. Geol. Suwey Water-Supply Paper 498, pp. 123-194, 1923 .

${ }^{85}$ Fewkes, J. W., Casa Grande, Ariz. : Bur. Am. Wthnology Twenty-eighth Ann. Rept., pp. 34-37, 1912. See also Smithsonian Misc. Coll., vol. 50, pp. 259-329, 1907.

Deserted in 1917. - K. B.
} 
Adamsville, ${ }^{97}$ formerly called Sanford's Mill, an old Mexican settlement; this consists of a double row of rambling roofless houses built of adobe. Although Adamsville is one of the "dead" towns of Arizona and for the most part is deserted, a Mexican family still lives in a fairly well preserved room at the west end of the village. The walls of an old gristmill are still pointed out, and those of the former hotel can still be traced. This settement was once an important station on the stage-coach route between Tucson and Phoenix, and many stories are current regarding the stirring events which took place in these now tenantless rooms when Apache roamed unrestricted the plains of Arizona. The foundations of the adobe walls have been much weakened: by rains, and in a few years the buildings now standing will fall to the ground.

Somewhat off the main road to Casa Grande, about half a mile south of Adamsville, on a plateau or mesa, rises a cluster of mounds indicating the site of a settlement called by the Pima Tcurikvaaki (tcurik, "bisnaga cactus"; váaki, "old house"), which is well worth visiting. This ruin is approached from the Casa Grande highway by a rarely traveled road, not much more than a wagon track, branching from the main thoroughfare a short distance west of the town. The standing walls of a house that rise considerably above the surface of one of the mounds resemble in structure and general appearance those of Casa Grande. Among the mounds in this cluster is one oval in shape with a central depression indicating a former tank or reservoir. Near by the surrounding wall of a large compound, including a high mound, suggests that Tcurikvalaki was formerly a place of cons derable importance. From this ruin there is a road to Casa Grande which passes a large, conspicuous mound, the site of another ancient Indian settlement. This mound is instructive because it shows sections of a wall formerly inclosing a rectangular area, suggesting the surrounding wall at Casa Grande.

If the visitor follows the direct route from Adamsville to Casa Grande without making a detour to the Indian mounds above mentioned, he can discern the roof, of corrugated iron, painted red, for some distance before hearrives at his destination. On each side of the road the traveler passes: several small mounds belonging to the Casa Grande group, which are situated not far from the large pyramidal elevations marking compound $B$.

The high range on the north side of the Gila in full sight of the traveler the whole way from Florence to Casa Grande is called the Superstition Mountains. This range separates part of the Gila Valley from the valley of the Salt River; it is a very wild and broken area, ending precipitously on the south and the west. Concerning this region many Pima legends are extant, the best known of which recounts how a flood once covered the whole earth. To this place an antediluvian chief, named White Feather, followed by his band, once retreated, climbing to the top of these mountains for safety. The water is said to have risen in the valley to a level halfway up the mountain side, where there is now a stratum of white rock which is clearly visible from Casa Grande. White Feather is said to have taken his stand on top of one of the pinnacles, whence he addressed his followers, reminding them that he had exhausted his magic power in vain efforts to stay the flood. But one supreme resource to control the rising water still remained. As he spoke he held aloft in the palm of one hand a medicine stone, invoking the aid of the sky god, who in reply sent a bolt of lightning that shattered the stone. But as the chief turned to his followers they were found to be petrified where they stood, and there they still stand as rocky pinnacles.

Another less conspicuous hill, called Walkers Butte, on the north side of the Gila not far from the river bank, is constantly in sight for a long distance from the road from Florence to Casa Grande. Near its base ruined house walls were discovered; and other remains of aboriginal life, as pictographs, can be found on lava rocks in the neighborhood.

The traveler along this road catches glimpses also of the lofty Santa Catalina Mountains, far to the southeast, while to the south rises the distant Casa Grande Range. A solitary peak, called Picacho Mountain, is a spur of a range of the same name that lies to the southeast, marking the position of a pass through which the early travelers entered this region from Mexico. Near this peak was situated in old times a Pima settlement called Akutchin ${ }^{\text {Be }}$ (" mouth of the creek"), inhabited from early Spanish times down to a com-

or Now known as Clemens ranch, after the present owner, W. R. Clemens.-K. B.

98 Akchin, Aquitun, and other spellings; see p. $388 .-\mathrm{K}$. B. 
paratively late date. The mountain itself, known as Tcacca by the Pima, is also associated with Pima legends of the country. The area about the ruin of Casa Grande is broken by but few elevations.

The vegetation in the vicinity of Casa Grande consists mainly of desert growth-mesquite trees, sagebrush, and giant cacti. After the spring rains begin many herbs appear, some bearing small flowers which carpet the earth with variegated colors. Long before one comes to the largest mounds at Casa Grande fragments of pottery and other indisputable evidences of former human accupancy may be detected on the surface of the ground. At a Mexican adobe house a few miles from the ruins, near Gila River, can be traced a long ditch, filled in here and there, marking the site of the prehistoric irrigation canal, resembling a modern ditch in approximately the same place.

The Casa Grande Ruins were first heard of by white men by Mange in June, 1694. and were visited by Kino in November of the same year. Nearly all later travelers visited them, and many made surveys and sketches. Of modern investigators Fewkes wrote a short description in $1892 .^{\circ}$ Mindeleff $^{3}$ wrote a comprehensive description; and Fewkes, after his excavation and repair of the ruin, wrote the report already quoted.

The or:gin of the Casa Grande ruins is shrouded in the mystery of prehistoric time. The Pimas have under questioning of travelers told some pretty stories, of which the most veracious is perhaps that which they told Emory" in 1846: "We know, in truth, nothing of their origin. It is all enveloped in mystery." The ruins of Casa Grande extend over a large area and are of several types. The principal ruin consists of a great ceremonial building of at least three stories, situated in the northwest corner of a walled inclosure or compound. Within the compound were many one-room wattled houses, in which presumably the people lived. This type of architecture is distinctive of the Salt and Gila valleys. The following quotation summarizes Fewkes's conclusions concerning the origin of the ruins.

In ancient times the whole drainage of the Gila and its tributaries from the points where they leave the mountains as far at least as Gila Bend was inhabited by an agricultural people in a homogeneous stage of culture. Throughout this region existed m'nor divisions of a common stock. The Pima name Hohokam may be adopted to designate this ancestral stock, to whom may be ascribed the erection of the casas grandes on the Gila. These "great houses" were places of refuge, ceremony, and trade. They were inhabited and ruled by the chiefs whose names they bear among the present Pima. The people dwelt in small huts of perishable character, not unlike Pima jacales of historic times, a few of which still survive. In the course of time a hostile faction bent on pillage came into this region from east or west and drove the agriculturists out of their casas grandes, or at least broke up the custom of building such structures. But although dispersed, the ancient house builders were not exterminated. Some of them became refugees and migrated south into Mexico, some followed the course of the Verde and the Tonto into the northern mountains, but others, perhaps the majority, gradually lost their former culture but still remained in the Gila Valley, becoming ancestors of the present Pima, I'apago, and Kwahadt (Quahatika) [called Kohakt Pimas in this report]. Those who went northward later built pueblos (now ruins) in the Little Colorado Valley. Their descendants ultimately joined the Zuñi and the Hopi, with whom, according to legends, they still live.

Historians have paid little attention to these migrations, for they occurred in prehistoric times, but vague legends still survive among both Zuñi and Hopi bearing on the life of some of their clans in the south. These migration

\footnotetext{
Fewkes, J. W., Jour. Am. Ethnology and Archaeology, vol. 2, Boston and New York, 1892.

1 Mindeleff, Cosmos, Repair of Casa Grande ruins, 1891 : Bur. Am. Ethnology Fifteenth Ann. Rept, 1897.

amory, W. H., Notes of a military reconnaissance from Fort Leavenworth, in Missouri, to San Diego, in Califnrnia: 30th Cong., 1st sess., S. Ex. Doc. 7, p. 83, 1848.

3 Fewkes, J. W., op. cit. (1912), p. 153.
} 
legends are supported by archeologic evidence and are supplemented by Pima traditions.

One objection that has been repeatedly urged rgainst acceptance of the trad.tions of the modern Pima that they are descendants of the inhabitants of Casa Grande is that the former do not now construct great massive-walled houses like the buildings here described but live in thin-walled houses supported by posts. The Pima have not constructed habitations of the former type. in histor $c$ times. The excavations in Componnd $\mathbf{B}$ show that many fragilewalled houses of rectangular form once stood within this inclosure, and there is good evidence that they existed in the other compounds also. The people of Casa Grande, or at least some of them, inhabited the same kind of houses as the modern Pima. These great bu ldings are not habitations; they are sacred edifices or communal citadels.

In the light of the various objects found at Casa Grande the inhabitants of the prehistoric settlement may be considered as people of the Stone Age, notwithstanding their acquaintance $w$ th copper. There is no evidence that they were familiar with any other metals, as iron, bronze. silver, or gold. But even in this stage they must have developed a comparatively high social organization. Every student of the "great houses" of the Gila-Salado basin must marvel at their relatively enormous size and the evidences of cooperation and intell gent direction of labor that they show. The erection of snch structures requires many workmen and an able director, a sociologic condition not found elsewhere in North America ontside of Mexico. In another place the writerascribes the orig $n$ of this cooperation to the necessity of union of labor in the construction of the irrigation ditches essential for successful agriculture in this region, one of many examples that might be cited of the influence of climate on enlture history in the Southwest.

\section{TUCSON TO CASA GRANDE}

[F.or log see pp. 298-299]

The road from Tucson (p. 349) to Casa Grande parallels the railroad, which follows Santa Oruz River as far as Maricopa, some distance beyond Casa: Grande. This stream occupies a channel cut about 10 feet below its flood plain as far as Rillito station, near the north end of the Tucson Mountains. From this point to Maricopa the channel is very indefinite, and during floods the river spreads widely over extensive adobe flats. The railroad runs northeast of the channel, but only in the vicinity of the Picacho Peaks is it much above the level of the flats. During wet weather the flats are almost impassable, but on drying the adobe is usually smooth and hard, and fast time can be made. In 1917 strong efiorts were being made to have a permanent highway constructed on this route, and in 1920 it was reported that enough grading had been done to make the road passable in all kinds of weather. In combination with a bridge at Sacaton, this wonld make the most direct route between Tucson and Phoenix.

From Tucson the road runs over sandy wastes or through irrigated fields to Jaynes, at the mouth of Rillito Greek (p. 382). Fields from this point on are few in number. At Rillito the traveler is near San Asustin Oiour or Oitapais, which was an Indian rancheria in Padre Kino's time. At present this part of the valley is deserted except for a few stockmen.

The Picacho Peaks, a great red mass of lava that rises abruptly from the plain, have been a landmark from the earliest time. To the Pimas they were Mount Tacca, also spelled Ttacca and Taceo. In the vicinity was a watering place, probably the Bluewater Tanks, at the north end of the peaks. Near by was an Indian ranchería which Padre Kino called Santa Catalina de Cuitiobagum and other explorers called Quitoac and Bajio Aquituno. (See p. 386.) This village has disappeared, though doubtless the locality was occupied as a temporal by the Papagos to very recent times. 
Beyond the Picacho Peaks the road comes into the area now generally referred to as the Casa Grande Vallev. Numerous enterprises have been initiated to irrigate this valley. The Green reservoir (Pl. IV) was built in 1908 to store flood water to irrigate this region, and similar long canals, heading on Gila River above Florence, bring water to the Picacho reservoir and thence into the Casa Grande Valley. In 1917 land was being irrigated from this ditch as far west as Arizola. The larger development of the valley, however, depends on the building of the San Carlos dam on Gila River and the pumping of ground water. With a pumping lift of only 40 to 60 feet over large areas and wells of large yield, the future of the valley seems to be assured, provided a highpriced crop can be developed and put on a commercial basis.

Casa Grande had a population of 948 in 1920 . It is the center of traffic for the mines to the south (p. 390), the nearest railroad point to the Gila River Indian Reservation (p. 389), and the nearest point on the main line of the Southern Pacific Railroad to Casa Grande Ruins (p. 385). With the development of the Casa Grande Valley it bids fair to become a prosperous agricultural town.

\section{PHOENIX TO CASA GRANDE}

[For log see pp. 300-301]

The traveler from Phoenix (p. 385) to Casa Grande follows the PhoenixTucson Highway for 25 miles. At a point 2 miles east of Chandler he turns south over open alluvial plains along the electric transmission line which carries power generated on the Salt River irrigation project to operate pumping plants on the Indian reservation. On the left of the road are the ragged hills that make up the Santan Mountains.

On the edge of the low bluffs that bound the flood plain of Gila River 9.6 miles from the turn mentioned above are the canals which serve the Indian lands. North of these canals the road becomes indefinite, but the traveler should turn to the left and through a maze of crossroads he will reach Santan, a small Pima village at the foot of a rocky butte. Here the road turns south across the ford of the Gila River to Sacaton $(44.3,13.7)$. This ford, like others on the Gila, can not be crossed in flood time, but when the river is low or practically dry the constant wagon trafic of the Pimas keeps the ford passable.

Sacaton is the site of the Indian agency that controls the Gila River Reservation, on which live the Pima Indians, with small groups of Maricopa and Papago. The same agency controls the Kohakt Pimas, to the south, and the Indians of the Gila Bend Reservation."

The Gila River Reservation consists of 371,422 acres. Of this area 2,500 acres is irrigated by a canal system consisting of 23 miles of main canals and 65 miles of lateral ditches, which draw water from Gila River and from wells. The old Indian ditches have been largely reconstructed by the Indian Service, and the serious shortage of water due to the diversion of Gila River upstream by white settlers, which once threatened these Indians with extinction. has been overcome by the installation of plants pumping from wells. The lands cultivated by the Indians in 1919 amounted to 10,610 acres, and crops to the value of $\$ 242,516$ were raised. The total area susceptible of irrigation if storage is provided is between 90,000 and $\mathbf{1 0 0 , 0 0 0}$ acres, but this area far exceeds the needs of the present Indian population.

The statistics in the following paragraphs are taken from the report of the Commissioner for Indian Affairs for 1919, pp. 84, 94, 140, 160. 
Statistics are not available for the Gila River Reservation alone, but the Pima Agency controls 6,260 Indians, including those at Gila Bend and the Kohakt Pimas. Of these Indians 792 are engaged in stock raising, part of them farming also, using 219,469 acres of land; the remainder are farmers. Day schools are maintained at 13 places, with a enrollment of 892 and an average attendance of 650 . About 1,500 Indians speak English. There are 9 resident missionaries and 15 churches, with a membership of 3,760 Catholics and 1,810 Protestants, the latter figure including most of the Pimas proper, who were converted by the Rev. Doctor Cook, a missionary among them for more than 40 years.

From Sacaton the road goes south to the group of rocky hills called the Sacaton Mountains. There is a gradual rise up an alluvial slope that fades into a plain underlain by rock, which projects through the venecr of gravel in small knobs and hills. The road is maintained by the Indian Service and is usually in good condition. The pass through the mountains consists of a number of intercommunicating small rocky plains, which separate the steepsided hills. The road probably affords the best opportunity in the Papago country for studying the formation of mountain pediments. (See pp. 93-101 and fig. 11, which shows in detail the mountains west of the road.)

From the pass the road goes south down a somewhat steeper slope into Casa Grande Valley, which, with its groves of mesquite trees, is spread out to view to the south. Casa Grande, at the foot of Casa Grande Mountain, is plainly visible. The only road difficulty is the crossing of the main channel of Santa Cruz River, north of the town. After floods this crossing is likely to be difficult. The town of Casa Grande is described on page 389.

\section{ROADS OUT OF CASA GRANDE}

\section{CASA GRANDE TO FLORENOE}

[For log see pp. 301-303]

To anyone familiar with Arizona, the road from the small town of Casa Grande (p. 389) to Florence, a somewhat larger place (p. 383), is altogether uninteresting, but the stranger who goes from the comfort of his Pullman car and uses this road to visit the Casa Grande Ruins will find many things to make an impression on him. The dusty and bumpy road, which he will cover at 20 to 30 miles an hour, will remind him of the hardships of the early explorers who crossed this desert when there was no road and no reliable water between Tucson and Gila River. He will see American pioneers, with the same enterprise and fortitude that distinguished those who cleared the forests of the East, reclaiming the desert. The strange plants, the vast alluvial plains, and the picturesque mountains on the horizon are described in the general chapers of this report. The Casa Grande Ruins are described on pages $387-388$.

CASA GRANDE TO POZO DE LUIS, SONORA

[For $\log$ see pp. 303-306]

The road from Casa Grande to Pozo de Luis runs almost south. It is doubtful if the full journey is ever made, but as far as the Quijotoa Mountains it is a well-known route used by mining men and also as a mail route From the Santa Rosa Valley to Mexico it is largely used by the Papagos. 
The route from the Pima villages on Gila River sunth through the Santa Iiosa Valley seems to have been first used by Kino and Carrasco in $\mathbf{1 6 9 8}$ (p. 9), and the names of some of the localities as given by Kino are still preserved. The road goes south from Casa Grande over a smooth plain and then up a gentle alluvial slope to the foot of the Silver Reef Mountains and has been partly graded for 20 miles. Chiu Chuschu, a village of the Kohatk Pimas, lies 8.5 miles from Casa Grande, at the northern base of these mountains. Here the Indian Service has a pumping plant and a school. The name is often carelessly pronounced Chu-Chu, but the Pima form appears to be Tshrihutsho or Tjuitjo ("caves"). Cocklebur, in Papago Vaívavo ("cocklebur pond"), 9 miles to the west, is a similar rancheria with a well to which there is a road from Chiu Chuschu with several alternatives. There is also a road direct from Casa Grande to Cocklebur and a road from Maricopa to Cocklebur (p. 312). The principal complications in roads are due to prospects in the Silver Reef Mountains, of which the most important is the Silver Reef mine. The lowest grades are on the road to the east of the mountains which goes through Ko-opke (11, 91), where there is a well and large fields.

The road then swings around the mountains to the pass at the north end of the Slate Mountains. The Jack Rabbit mine $(23,79)$, in this pass, once had a period of intense development but is now inactive. The Orizaba mine, 2 miles to the northwest, and numerous prospects in the Slate Moutains are still exciting the hopes of prospectors, and there is a good deal of travel on this account, particularly, in winter. Fast of the Jack Rabbit mine is the old scmmer ranchería of the Kohatk Pimas, called Taht-Mahmeli or Tata-Mumerikut ("where the foot had run"). Foot racing is said to have started at this village." The new well of the Indian Service is the site of a new village, which usually goes by the name of Jackrabbit.

Quajote, 6 miles west of the Jack Rabbit mine, is the principal village of the Kohatk Pimas. The Pima name is Kohatk ("depression," or "where a hollow has been made"). ${ }^{8}$ From this word has come the name of the subtribe, though it is spelled in many different ways by various travelers and writersas, for instance, Quahatika, Kwohatk, Qahatika, Quarities, and Cojeta." Father Kino called it San Bonifacio del Coati. The various roads to and from Quajote are described on page 307.

From Jackrabbit the road turns south into the Santa Rosa Valley, where the Papago retains to the fullest extent his primitive characteristics. Kukomalik ("big mountain crest") $(32,70)$ is the first Papago village. The village was founded at a well left by an American stockman. It is largely a winter residence for people who cultivate fields at a distance.

Anegam ("where the an tree [desert willow?] grows") $(44.5,57.5)$ is a very old summer rancheria and was visited by Kino, though he seems to have thought that San Francisco del Adid or Ati, possibly the modern Santa Rosa, near by, was more important. The Indian Service well will make possible a permanent population at this locality.

Santa Rosa, 2 miles south of Anegam, is probably the largest of the summer rancherías. The Papago name is Kuatshi ("big peak") and hence Kino's name Ati or Adid. The fields, which are not shown on the map, extend for more than 2 miles and merge with those of Akchin (" arroyo mouth"), which

- Lumholtz, Carl, op. cit., p. 387.

Idem, p. 386.

7 Hodge, F. W., Handbook of the American Indians: Bur. Am. Ethnology Bull. 30. pt. 2, p. $332,1910$. 
Kino refers to as Actum el Chico (p. 412). The Indian Service well at Santa Rosa will make possible a permaneut population at this ranchería also.

Half a mile south of Santa Rosa $(47,55)$ a road forks to the east and goes through Akchin to Cobabi. Other roads, not shown on the map, go to Brownell (p. 397) and other localities. The main road continues south in the axis of the valley and is joined by a road that comes in from Covered Wells on the west $(60,42)$, and another that goes east to Cobabi. These are parts of the Pozo Blanco route of the Tucson-Yuma road (pp. 365-367). The locality is marked by a temporal and a represo inside a brush fence, known as Sikulhimatk ("water going around"), a name which refers to the fact that this is the divide between the waters going north through Anegam and Cocklebur to Santa Cruz River and those going southwest to Copeka and thence into the Quijoton Valley and Sonoita River. From this locality roads go west to Horseshoe (Quijotoa post office), in a cove at the base of Quijotoa Mountains on the west. At Horseshoe, also called Day's camp, is a store, and this may be considered the headquarters of those who go to prospects and mines in the Quijotoa Mountains. There are gold placers near Horseshoe and in other parts of the Quijotoa Mountains, which the Papagos still work by dry washing.

Crossing the alluvial divide and going south parallel to the main stream of the valley the road comes to the summer rancherias of Kvitatk and Iron Pipe. Kvitatk ("mesquite root") is the easterly of the two, and Iron Pipe, called also Vainomkux ("iron prominence"), is the westerly. The deep well and pumping plant that supplied the Weldon mine was at Iron Pipe. The machinery has long since fallen into decay, and no water can now be obtained from the well. The Weldon mine lies behind Ben Nevis Mountain, about 6 miles distant in an air line. It is reached by a road that goes west through Iron Pipe to San Antone, a small Papago village with dug wells in the canyon south of the mountain. Similarly roads go east from Kvitatk to Nolic, 5.5 miles, Santa Cruz, and Cobabi (p. 325).

The road to Pozo de Luis, Sonora, goes south from Kritatk and crosses the Tucson-Yuma road about three-quarters of a mile west of the Geological Survey sign west of Big Fields. It was a very faint road in 1917 and may be missed. Travelers are likely to land at Big Fields. In that event they should go south of Big Fields and take the Indian Oasis-Menegers Dam road (see p. 408) until they come into this road again $(78.5,23.5)$. South of this point the road crosses vague drainage lines called Valshni Wash and Big Wash and comes into the Tecolote Valley, an open plain between the Alvarez Mountains on the east and the red ridges that make up La Lesna Mountains on the west.

The principal ranchería is Tecolote, a locality which seems to have been settled for a long time, as the name appears on early maps. It had 140 families in 1865. The Mexican name Tecolote comes from the Nahuatl tecolotl and means owl, specifically the small ground owl. ${ }^{\circ}$ The Papago. name is Tjukutko ("owl's cry"). From the large represo roads run to surrounding temporales and rancherias. The more important are Kavolik, to the northeast (p. 410) ; San Rafael, on the west side of the Alvarez Mountains; and Rocky Point, where there is now a well at the south end of the same mountains (p. 325). West of Tecolote are Onion Fields, Coyote Fields (abandoned), and in the borders of La Lesna Mountains two wells. At one of these wells is the ranchería called by Lumholtz ${ }^{10}$ La Lesna or Shuunakia (" hanging wolf").

\footnotetext{
- Hodge, F. W., op. cit., p. 713.

${ }^{10}$ Lumholtz, Carl, op. cit., p. 381.
} 
From Tecolote the road goes south through the plain, crossing the international boundary near monument No. 151, and then goes into the pass between the Sierra de Cobota and La Lesna Mountains. Cobota, in Papago Kovortk ("hollow in the ground"), is a ranchería inhabited part of the year. In 1855 the Indians maintained a well there." Southwest of Cobota and at a higher altitude in the same pass is Pozo de Luis, a Mexican ranch with a well. In 1902 the owner was J. Celaya and the place was known as Banori ("curve"), probably because it is close to a Papago ranchería of that name. The boundary survey parties of 1894 camped at this well, which seems to have been dug after $1855 .{ }^{22}$

\section{PHOENIX TO MARICOPA BY WAY OF GILA CROSSING}

[For log see pp. 308-309]

The Phoenix-Maricopa road branches from the Phoenix-Gila Bend road (see p. 397) at the Geological Survey sign $(23.9,12.1)$. This sign stands on the alluvial slope below the steep and corrugated eastern front of the Sierra Fstrella. The smooth, treeless plain stretches south toward the Table Top Mountains, which are visible in the distance as a blue shadow on the horizon. On the east and separated by a bluff is the Santa Cruz Cienaga and the sandy flood plain of Gila River with its groves of mesquite trees. Numerous roads go across this flood plain, and many of them lead to Maricopa. They are, however, sandy and difficult for a stranger to follow and should be avoided. The best road goes south and, crossing the Southern Pacific Railroad at Heaton $(29.1,6.9)$, turns southeast to Maricopa, plainly marked by the high black water tank.

Peblo Well $(32,4)$, which belongs to a progressive Indian stockman, is a dug well 98 feet deep with water about 93 feet below the surface. In very dry seasons the well is said to go dry. Water is raised by a pump run by a 11/2-horsepower gasoline engine.

Maricopa consists of the railroad station and hotel, a store, and a few houses. The place is important only because of the railroad, wells, and pumping plant and because it is the junction for the branch line to Phoenix. The pumping of water for irrigation has just begun in the neighborhood, and as the lift is less than 60 feet for large areas of the surrounding plain, time may see a prosperous farming community in this vicinity.

\section{MARICOPA TO COVERED WELLS}

[For log see pp. 309-312]

Travelers going south from Maricopa comprise Papagos visiting or trading and American prospectors. Many of the Americans reach Vekol and Covered Wells from Casa Grande (p. 390), but the road described below is the shortest route from the railroad to Vekol, although it is practically waterless for 35 miles.

From Maricopa the road goes southwest to Akchin. This village is marked by the derricks of the new Indian Service wells, which is fortunate for the traveler, as there are many tracks and roads that may confuse him. The adobe soil of the plain is covered with extensive areas of drifted sand. In dry weather travelers avoid the sand and travel as much as possible on the adobe. In

${ }^{11}$ Emory, W. H., Rept. U. S. and Mexico Boundary Survey, Lieut. Michler's narrative, vol. 1, p. $122,1857$.

12 Mearns, E. A., op. cit., p. 18. 
wet weather the adobe forms a deep and sticky mud, so that the sand is preferable. In the absence of fences there is a maze of roads, and mesquite thickets obstruct the view. The rapid settlement of the valley will soon confine the road between fences. The approach to Akchin is through a lane, half a mile long, between north-south fences.

Akchin is a small village of Papago Indians which seens to have been established on the border of the Pima country within the last 100 years. The name means "arroyo mouth" and refers to the fact that the arroyo or wash that comes through the gap south of the Palo Verde Mountains spreads out at this place into the flats of Santa Cruz River. Such localities are excellent places for temporales or flood-water flelds, and this fact accounts for the frequent useof the name for Papago villages. There is another Akchin in Santa Rosa Valley (p. 391); La Quituni is a corruption of this name (p. 412); and in Father Kino's time there existed a village called by some Aquituni or Equituni, a similar corruption, on Santa Cruz River near the Picacho Peaks (p. 388).

At Akchin the Indian Service maintains three pumping plants. The road. comes into the $B$ plant; $C$ plant is half a mile west, and $D$ plant is half a mile south. These plants assure a permanent supply of water for the village and provide for the intensive cultivation of crops in holdings of $2 \frac{1 / 2}{2}$ to 5 acres. The old village, which lies north of the pumping plants, was supplied by shallow wells that often went dry, and the Indians are building new houses near the Government wells.

From Akchin a road goes southeast to Cocklebur (p. 312), and the road to Vekol goes southwest toward a confused jumble of granite peaks. At $21 / 2$ miles beyond Akchin is a fork, where the right-hand road goes to Drake's ranch, and a short distance beyond is a crossroads $(5.7,73)$ that goes east from Drake's ranch to another ranch about 1 mile east. Drake's ranch has a well 102 feet deep, with water about 97 feet from the surface. West of the ranch is a pass between the south end of the Palo Verde Mountains and the scattered hills that lie to the south. A dim road goes west through this pass, and about 16 . miles out there is said to be a spring in a canyon below a cliff.

Beyond Drake's ranch the road runs over an alluvial slope and turns gradually to the south, passing along the foot of a small sierra of granite and gneiss and a number of low buttes. On the east lies a clump of sharp and irregular red peaks. The road turns into a narrow pass between granite hills (16.6, 62.1) and goes west over a low, rocky divide. On this divide is obtained a fine view, to the south, of an open basin and the Table Top Mountains. Table Top, with its flat summit of black lava, dominates this group. Antelope Peak, a sharp lava-capped butte on the northwestern edge of the mountains, stands alone on a conical base and is a conspicuous landmark in the Vekol Valley. The road goes west along an arroyo into a narrow pass between flat-topped hills of dark lava. At the east end of this pass the lava may be seen resting on the granite, and it is easy even for the layman to imagine the time when a continuous plate of lava extended over the whole region. The uplift of the mountains raised and tilted the lava, as in these plateaus and Antelope Peak. Only patches of the original extensive plate of lava now remain.

In the pass $(18.8,59.9)$ the remains of numerous camps indicate the presence of water. The water is found in hollows in the bed of the arroyo south of the road by digging in the sand. The water lasts for only a short time after rains.

At the west end of the pass $(19.7,59)$ the road turns south into the Vekol Valley toward a low hill in the middle of the plain. To the northwest is the great valley between the Maricopa Mountains on the west and the Sierra 
Estrella and Palo Verde Mountains on the east. The southern part of this valley is dotted with small hills and sierras, but the northern part, called the Jornada de las Estrellas, is more open.

Almost due west of the pass lies Double Butte, near which is Mesquite Tank (p. 406), and south of this butte begin the northwestern plateaus of the Sand Tank Mountains. The road crosses the rough alluvial slope built by streams from Antelope Peak and reaches the middle of the Vekol Valley at the lone hill previously mentioned $(24.4,54.3)$. Just beyond the hill the main stream is crossed. It is about 100 feet wide, and the crossing is very bad. This stream, which carries all the drainage of Vekol Valley, goes north into the Jornada de las Estrellas, crossing the railroad at Mobile, and empties into Waterman Wash, which reaches Gila River at Liberty (p. 401). Where first crossed by this road and for 5 miles farther up the valley, the stream runs in a narrow flood plain about 5 feet below the alluvial plains on either side. In this plain the channel of the stream is intrenched about 10 feet and has steep clay banks. The flood plain is covered with a thicket of large mesquite trees and thus is in marked contrast to the alluvial plains with their thin vegetation of creosote bush and palo verde.

At 4 miles beyond the lone hill there is a water hole in the arroyo (28.5, 50.2), which is described at length on page 126. Two miles farther on, at a brush corral, there is another watering place, which consists of a charco in the flat. The charco has been cut by the main stream but is dammed and made into a basin by the material brought in by a tributary. Beyond the brush corral begin the grassy flats which make the Vekol Valley unique among the valleys of the Papago country. The flats are from a few hundred yards to 4 miles wide and extend up the axis of the valley for nearly 10 miles. They are very smooth and slope gently to the north, and through them the main stream and its tributaries have no channels but in flood spread out into a broad sheet of water. Grass, locally called "galleta," in clumps about 1 foot in diameter, covers the flats, and around the margins are a few scraggy mesquites and luxuriant creosote bushes. Near the brush corral the channel of the main stream has begun to work headward, and it seems likely that unless some change sets in these grassy flats may be cut by gullies and destroyed within a few years. Across the flats to the east is a magnificent view of the Table Top Mountains, composed of black plateaus and peaks of lava, while to the west, beyond the narrow alluvial plain and rolling pediment with its outlying hills, rise the spectacular and heterogeneous Sand Tank Mountains, dominated on this side by Squawtit Peak, with its characteristic form.

The Geological Survey sign $(32.9,45.8)$ marks the fork of the Gila Bend road. Stouts Well (p. 403), the nearest permanent water, lies 9 miles west, near the gap between the most northerly of the dark lava plateaus and a sierra of light-colored gneiss. Two miles farther south the best of several roads crosses the flats to the Vekol mine, plainly visible against the mountain side. This mine, long inactive, usually has a caretaker, to whom the traveler may turn for local advice on roads. The Vekol Mountains consist of a northern part, which is a monocline of limestone dipping to the south, and a southern, more disorderly mass of mountains, mostly made up of intrusive rocks. Certain old maps show a road running east through the mountains, but at present the best road to the east seems to be the one that swings around the point of the mountains to Bitter Well, 2.5 miles away.

Bitter Well, whose name is a translation of the Papago Sivvaxia, is a small ranchería with a dug well 12 feet deep in an open valley between the north end of the Vekol Mountains and a few detached buttes that are sometimes called the Little Table Top Mountains. From Bitter Well a road goes east 
4 miles to the Reward mine, where there is a drilled well 800 feet deep and a shallow dug well. From this mine, which is inactive most of the time, it is 4 miles to the Kohatk Pima village of Quajote, where there is an Indian Service well. On the south side of the Vekol Mountains is the Copperosity mine and a Papago village with two dug wells, also called Copperosity. There may be a road directly from Vekol to these localities. The only road shown on the map (PI. III), however, is that from Quajote to Brownell.

The Maricopa-Covered Wells road continues up the Vekol Valley, crossing a number of arms of the grassy flats. A very dim road $(35.5,43.2)$ goes to a spring and abandoned ranchería in the canyon north of Squawtit Peak (p. 164). After passing some small gravel hills the road crosses the axial stream of the valley $(40.4,38.3)$ at a place where it is constricted by low hills. Just north of the road are Totobit Tanks, a series of plunge pools and potholes in the stream channel. There are three main pools, of which the lowest and largest is 40 feet long, 4 to 10 feet wide, and 5 to 6 feet deep. The pools have been excarated by a fall, which is due to the presence of beds of basalt and lava conglomerate that dip about $10^{\circ} \mathrm{N}$.

East of the tanks and dependent on them for water lies the summer ranchería of Totobit (" crooked"), a collection of three or four houses. South of the gravelly hill on which the village stands is a broad adobe flat without definite stream channels, and here are the temporales of Totobit. The Murray \& Lopez Well, which is said to be 155 feet deep and to have water 145 feet from the surface, is about 1 mile to the north.

South of Totobit the Sand Tank Mountains consist of relatively low mesas, in contrast to the high peaks and ragged plateaus in the vicinity of Squawtit Peak. The road goes south in the valley and within 4 miles turns southwestward into a rather narrow valley between the mesas and passes through a succession of these small valleys. They are similar in character-bounded by the steep and somber talus slopes of the mesas, flat floored, and after rains covered with luxuriant vegetation. The streams are almost without any channels and in floods spread from wall to wall of the valleys and make them suitable for flood-water farming. Charcos are numerous, and on them thepeople depend for water during the period of cultivation.

The road passes over a gravel hill $(47.8,30.9)$ with a house, and on the left a sign neatly made by small boulders laid on the side of the hill, "San Jose, April 18, 1906." At the foot of the hill is a long earth embankment broken through by water, which marks an unsuccessful attempt to store flood water.

A mile and a half farther west is Kaka, the principal summer rancheria of this part of the Papago country. Kaka ("clearing") is also given as Cacate and is in the same position as the locality Cazlon, which appears on many maps. It seems likely that Kaka is the locality visited by Father Kino in September, 1699, and called by him San Geronimo (p. 11). The fields of Kaka cover a considerable area, and when they are green it is hard to believe that this verdant valley has no permanent water and that the people depend on rainwater pools. Kino found 280 people at San Geronimo. and Kaka usually has about the same number each summer. Most of these people come from Sauceda and Moivavi, where there is permanent water. These rancherias are reached by a road through the narrow pass west of the fields. Beyond this pass is an open valley and the road forks. The right-hand road goes to the northwest through a tributary valley, separated by low hills from the high plateaus of the southern part of the Sand Tank Mountains. About 5 miles from the fork the road is in a rocky, rolling country or dissected pediment which leads up to a low pass. The road is impassable for automobiles but reaches Moivavi in: 
about 12 miles from Kaka. Moivavi ("many wells") is a small winter rancheria of 8 or 10 families. There is probably a road to Sauceda (p. 401) from this village, but its location is not known. The left-hand road goes west through an open valley and then through a low pass into a small valley, which is inclosed by cliffs and in which there is a charco. From this valley the road goes over a divide into the Perigua Valley. From the divide a fine view of the great dome-shaped mountain to the southeast is obtained. This mountain, almost unscored by canyons, is probably the center of the eruptions from which came most of the lava that makes up the surrounding plateaus. The Perigua Valley, an open mesquite-covered plain encircled by plateaus, is described on page 404. The summer ranchería of Emita in this plain is 12.5 miles from Kaka: Kaka is 49.3 miles from Gila Bend by the Gila Bend-Pozo Blanco road and 42.6 miles by way of Stouts Well (p. 403). The distance to Maricopa is 49.2 miles.

From the gap south of Kaka at least two roads go into the broad plain, sprinkled with hills, which lies between the Sheridan Mountains and the un= named mountains east of Perigua. The left-hand road goes southeast and east 7 miles to Whites Well and at 1.5 miles farther on connects with the road from Quajote to Brownell near the Isabella mine (p. 403). The other road pursues a more southerly course along the western border of the plain and forks 8 miles south of Kaka $(57.2,21.5)$. Here the right-hand road goes 13 miles west through a pass in the plateaus to Perigua. The left-hand road crosses the plain on a southeasterly course, passing south of a lone hill and across the south end of a small sierra, which is notable because it has two natural windows in the rock, to a temporal $(65.2,13.5)$. This temporal seems to be the rancheria called Mowepa on an old manuscript map. ${ }^{13}$ From Mowepa the road goes south into the open but rocky country that lies between the Sierra Blanca and Brownell Mountains and reaches Covered Wells in 11 miles. Covered Wells. is described on page 366 .

\section{PHOENIX TO GILA BEND BY WAY OF GILA CROSSING}

[For log see pp. 313-315]

The road from Phoenix to Gila Bend by way of Gila Crossing goes south on Main Street through the city, crossing the tracks of the Arizona Eastern Railroad to the concrete bridge across Salt River $(1.7,62.2)$. From the bridge a good view is obtained of the sandy river channel with its lenses of gravel. Most of the sand and gravel used for building in the city is taken from pits near this bridge. It is from coarse gravels similar to these but deposited in former channels of Salt River that the wells of the ralley draw water. Ta the north the Phoenix Mountains and the fantastic Camelback Mountains rise above the trees of the valley. To the south are the canyoned slopes of the Salt River Mountains and behind and west of them the steep and precipitous slopes of the Sierra Estrella.

Five miles south of Phoenix the road comes to a large canal, beyond which is a narrow alluvial slope that leads up to the Salt River Mountains. The lower part of this slope, about half a mile wide, is irrigated by the north branch of the High Line canal. A rough road leads south to a pass in the mountains, in which there is a small mine. It is possible to go through this pass and southwest to Komatke, but the road is very rough. The main route turns sonthwest along the north bank of the Western canal. Farther on $(6.4,57.5)$ the canal forks, and both the main canal and the lateral go west for half a mile; The traveler can cross both canals and follow the south bank on the main canal.

18 ribrary of U. S. Geol. Survey 
or he can cross only the lateral and follow its south bank for 1.3 miles and then turn southwest and cross the main canal. By either route he reaches a Geological Survey sign $(8.4,55.5)$ set on the south bank of the Western canal. From this sign a road runs southwest through a pass between an outlying ridge and the main part of the Salt River Mountains. The pass is floored with alluvium, and the road is smooth. Beyond the pass, at the edge of the sandy brush-covered plain and at what is also the boundary of the Gila River Indian Reservation, is Williamson's Store. The store is now discontinued, but there is a dug well 67 feet deep with water about 60 feet from the surface. From Williamson's Store the road turns south in the sandy flood pain. There are numerous roads, but the best traveled reaches Komatke.

Komatke $(14.3,49.6)$ is the post office of a Pima village that has for a long time been known as St. Johns, on account of the mission called St. John's Chapel, which stands about half a mile west of the post office. According to Russell ${ }^{14}$ the Pima name of the village is Kamatuk Wutca, meaning " below or at the foot of Kamatuk" (the Pima name of the Sierra Estrella). From the Geological Survey sign at Komatke the road goes to another Geological Survey sign (16.5, 47.4) at the beginning of a lane leading southwest to the river. Numerous roads go east to other villages in the reservation. One road, as shown on the map (Pl. VI), goes to the Gold Coin mine and other prospects on the south side of the Salt River Mountains, and another goes to Jackson Butte and thence around the east end of the mountains.

The river at Gila Crossing is about a quarter of a mile wide. In flood it is impassable for automobiles and for most other vehicles. The ford is in constant use, and the wheel ruts are usually well packed, so that machines have no difficulty in crossing at ordinary times.

Beyond the ford the road goes through a village between flelds and crosses Santa Cruz River. This is probably the worst part of the road, and the difficulties are noted in the $\log$ (p. 313). At the foot of a low bluff a road goes off to the left through the swampy land called Santa Cruz Ciénaga. The scanty salt grass of this swamp and shallow holes called Maricopa Wells, east of it, were the principal dependence of early travelers in this region. The road along the cienaga reaches Maricopa in 10 miles. The main road goes up the bluff and south across the alluvial plain at the foot of the Sierra Estrella. This range rises precipitously above the plain to altitudes of 3,500 to 4,000 feet.

At a Geological Survey sign $(23.9,40)$ the road to Gila Bend turns sharply toward the mountains and then goes southwest around the high rugged point at the end of the mountain, called Montezuma's Head, 4,337 feet above sea level. The road to the south at this sign goes to Maricopa and is described on page 393.

After rounding Montezuma's Head the road crosses a wide reentrant or pass between the Sierra Fstrella and an outlying and parallel sierra sometimes called the Enid Mountains. Numerous washes make the road heavy and sandy, but the vegetation, which is typical of localities at the foot of mountains and consists of sahuaro, cholla, palo verde, and catclaw, makes this part of the road interesting to the traveler. Beyond the point of the so-called Fnid Mountains the road passes to the north of an isolated hill and crosses from Pinal County into Maricopa. South of the hill is the railroad section house called Enid.

A Geological Survey sign $(31.3,32.6)$ marks the beginning of the long road across the valley between the Sierra Estrella and Finid Mountains and the

14 Russell, Frank, The Plma Indlans: Bur. Am. Ethnology Twenty-sixth Ann. Rept., p. 23,1908 . 
Maricopa Mountains, whose ragged crests form a blue curtain across the horizon. This plain was crossed by all the early explorers and came to be known as Jornada de las Estrellas (" the day's journey of the stars"). Later the military telegraph and the Butterfield stage crossed from Maricopa Wells to Gila Bend by this route. The road used by them begins at the Geological Survey sign and goes due west to the base of some small granite hills, 6 miles west. which appear black in the distance, and thence goes through a pass in the Maricopa Mountains about 4 miles north of the pass occupied by the railroad. This old road is passable for about 6 miles but farther on is so badly washed that it would be difficult even for a lightly loaded wagon. The insulators and some of the mesquite posts of the old telegraph line are still to be found. Many travelers take this road and then are compelled to turn back; consequently the road often looks better traveled than the main road, which at the sign turns to the southwest and crosses an adobe flat to the railroad.

At the railroad there is a Geological Survey sign $(33.9,30)$, and from this point the road follows the rails into Gila Bend. The section house of Enid is 2 miles east, and a road runs to it and thence into Maricopa (pp. 307-308). The road across the plains is monotonous and rather difficult. The valley is in a state of aggradation, and the main or axial stream, which comes from the Vekol Valley (p. 395), has a very indefinite channel or rather several channels. The tributaries are similar in type. These channels or washes have sandy beds that lie from 6 inches to 2 feet below the general level. The intervening areas are very soft. A road over such ground is bad enough, but the works put in by the railroad, which runs almost directly across the stream channels, have made matters worse. The railroad company has attempted to collect the flood waters and compel them to run in a few channels so as to reduce the number of culverts. The result is that these semiartificial channels are deeper and much more difficult to cross than normal washes.

The Jornada de las Estrellas was for the early travelers a waterless journey. There are said to be small rock tanks in the pass through the Maricopa Mountains, but otherwise there was no water. At the present time there are several wells belonging to the Beloat ranch, north of the railroad, and in 1919 the Southern Pacific Co. put in a well at Mobile (36.1, 27.8). It is presumed that water can be obtained from this well. At the other stations there are cisterns that are filled from the tank cars, and travelers are usually allowed to obtain water.

Estrella $(45.7,18.2)$, a section house and telegraph station, lies at the east side of the pass through the Maricopa Mountains. A short distance east of Estrella there is a divide from which water flows west through the pass and the down grade is continuous to Gila Bend. West of Estrella the road crosses the railroad to the south side and then crosses it again. The pass is a flat-floored alluvium-filled valley about 1 mile wide. The sides of the valley rise steeply from 500 to 1,000 feet and display in spectacular fashion the details of erosion in granite and other crystalline rock. The valley was once much deeper than now and has been filled with the alluvium that now forms its floors, for a well near Ocapos $(50.2,13.7)$ was sunk 541 feet without striking rock. Water stood 527 feet from the surface and was insufficient in quantity, so that the well was abandoned. Another well near Estrella is said to have been dug 200 feet without striking water.

At the west end of the pass the road crosses a low divide on a plain underlain by rock or mountain pediment, and at the section house of Bosque $(54.9,9)$ it turns west along the railroad on the Gila Bend Plains. These plains 
consist of an extensive alluvial slope lying west of the Maricopa Mountains, north of the Sand Tank and Sauceda mountains, and south of Gila Fiver. They are higher than the flood plain of Gila River and are separated from it by discontinuous bluffs. Along their northern margin the plains are dissected by the streams that have cut down to the base-level of Gila River. The traveler will notice the difference, for whereas the alluvium of the pass, which is being built up by the streams, is soft and the road is heavy, from Bosque west the alluvium is hard, the washes are in little sags or swales, and the road is firm and easy to travel.

South of the railroad the plains are dotted with hills of two types-small light-colored hills of granite and gneiss that form miniature sierras and seem to be outliers of the Maricopa Mountains, which they resemble in topography, and dark-colored buttes of lava that are outliers of the northwestern plateaus of the Sand Tank Mountains. The most conspicuous of these is Double Butte, near which is Mesquite Tank (p. 406).

Gila Bend, visible the whole distance from Bosque, is a small town of 745 inhabitants in 1920. It is a division point on the Southern Pacific Railroad and the junction with the Tucson, Cornelia \& Gila Bend Railroad to Ajo and also has wells and a pumping station. There is consequently a considerable railroad population. Three stores, a hotel, and the railroad eating house provide for the needs of travelers and for the scanty local trade, which, outside of that of the railroad employees, is derived from occasional prospectors, a few ranches near Gila River, and the Indians of the villages north of the town and their relatives in the Papago Reservation to the south.

According to Lumholtz, ${ }^{15}$ the Papago rancherias in the flood plain of the river at Gila Bend are, beginning on the west, Pelon, or Lower Village, called Kvivo ("below") by the Papagos; Tesota, or Second Village, called by the Papagos Unpatóitak ("catclaw field") ; and Upper Village, called by the Papagos Siflimok ("burnt saddle"). In 1910 the three villages had about 300 people. Tésota is settled by people from Moivavi and sinlimok by people who came from Sauceda after 1890. In 1699 Padre Kino found a village, or perhaps two villages, in this vicinity, which he called San Felipe $y$ Santiago del Oyadoibuise, and in $\mathbf{1 7 0 0}$ he visited El Tutto, a rancheria apparently west of San Felipe $y$ Santiago. At this time the area was inhabited by Coco-Maricopa Indians; though there were Pimas among them. In 1775 Padre Garces made the journey from the Santa Cruz Cienaga, which he called Las Lagunas del Hospital, and arrived at the Pueblo de los Santos Ápostoles San Simon y Judas, inhabited by the Opa Nation. Opa is another name for Maricopa; the Maricopa (?) name is Upasoitac, according to Hodge. ${ }^{16}$ The Papago settlements at this locality are therefore recent. They irrigate their lands with small ditches."

\title{
PHOFNIX TO GILA BEND BY WAY OF BUCKEYE
}

\author{
By C. P. Ross
}

[For log see pp. 315-817]

The road goes west from Phoenix in the fertile valley of Salt and Gila rivers, and the part as far as Buckeye is described in Water-Supply Paper 498.

15 Lumholtz, Carl, op. cit., pp. 382, 384, 385.

16 Coues, Ellfot, On the trail of a Spanish pioneer, vol. 1, note on p. 115, New York, 1900.

${ }^{17}$ Ross, C. P., The lower Gila region, Arizona : U. S. Geol. Survey Water-Supply Paper 498 , p. 105,1923 . 
For the first 1.7 miles out of Buckeye $(34.2,35.3)$ this route is a fairly good section-line road, becoming more sandy as the river is approached. Then the sandy bed of Gila River, here about a mile wide, must be crossed. When the river is high it can not be forded in an automobile here or elsewhere, but periods of high water are usually only a few days long. At all times, however, some difficulty in crossing at this place is to be expected, and very frequently it will be necessary to have the car towed across by horses.

On the north side of the river is the Buckeye canal, which is over 20 miles long. Its headgate is on the north bank of the Gila near the mouth of Agua Fria River. It is reported to irrigate more than 19,000 acres. Among the crops grown are cotton, alfalfa, millo maize, and corn.

South of Gila River, opposite Buckeje, a new project has recently been started by the Gila Water \& Land Co. Water is obtained by pumping from Gila River. The plant was installed in 1916 but was damaged by floods. For this and other reasons irrigation on a commercial basis did not begin until March, 1917. At the time of visit (October, 1917), cotton, wheat, millo maize, corn, and some alfalfa were being raised successfully.

The Buckeye Hills are south of and partly encircle the irrigated farms south of the river. They are composed largely of granite but appear also to contain a small amount of schist. Powers Butte, an outlier of these hills, near Arlington, is formed of much younger rock, mostly flat-lying beds of lava, of probable Tertiary age (p. 220). Tertiary rocks are also found at the Gillespie (formerly Enterprise) dam, at the west end of the Buckeye Hills. This dam was completed in 1922, and a large area on the south side of Gila River is now under irrigation. The traveler will find a new set of roads along the route here described.

Near Buckeye the river apparently does not flow over alluvinm several hundred feet deep, as in most other places. Outcrops of granitic bedrock project through the alluvium at numerous places close to the river in the district irrigated by the Gila Water \& Land Co. At Liberty such outcrops are said to occur on both sides of the river. On the other hand, the records of wells drilled north of the river in the Buckeye Valley show that the alluvium there is more than 250 feet deep. It is probable, therefore, that the course of the river has shifted to the south in recent geologic time and thus become superimposed on a bedrock shelf that extends north from the Buckeye Hills.

The road through the irrigated land is rough and dusty but presents no difficulties, though because of changes and additions to the roads by farmers it may be necessary to seek local advice as to the best route to follow.

The Buckeye Hills are passed on a rough road with easy grades. Between the hills and the mountains to the south lies the region locally known as "the desert." The soil here is a rather coarse arkosic sand derived from the granitic mountains and hills on both sides. It makes a good natural road surface but does not appear to be very favorable for agriculture. The vegetation is mostly creosote bush, with a smaller number of salt bushes. There is no mesquite. Cactus grows in the more elevated portions and palo verde and ironwood along the washes and drainage channels.

Farther southwest the road lies in what is locally spoken of as "the valley." The boundary between "the desert" and "the valley" may be placed at the old irrigation canal $(53.2,16.3)$. The soil and vegetation differ markedly on the two sides of this canal. The vegetation of the south side is salt brush and mesquite. The mesquite grows in small groves and also as scattered individuals. The trees in the groves are on the whole larger than the solitary specimens. In the early days the mesquite trees were very large, but 
many have been cut for firewood, so that the present growth is not of maximum size. Creosate is scarce, and what little of it was seen has a blackened and unhealthy appearance. The soil is a fine yellow compact loam. Between the old canal mentioned above and Frandsen \& Knudson's ranch some alkaline areas were noted, but these are few and small. Nearly all this valley land extending 18 miles north of Gila Bend was once occupied by farms under the now abandoned Peoria dam. Fences, old shacks, and washed-out irrigation ditches are all that remain of the departed prosperity of this area. Recent attempts to resume farming by pumping from wells have apparently met with poor success. In October, 1917, Frandsen \& Knudson were making a new attempt to irrigate by pumping from the river at their ranch $(62.2,7.3)$.

\section{ROADS OUT OF GILA BEND}

\section{GLLA BEND TO SENTINEL}

[For $\log$ see pp. 317-318]

The road west from Gila Bend (p. 400) to Sentinel (p. 360) is used by local people and is also a link in the direct but rather bad road from Tucson to Yuma along the Southem Pacific Railroad, the logs of the successive portions of which are given on pages 298-299, 300, 307-308, 317-318, 271, and 272.

The road is a monotonous desert road for 15 miles. To the north the Gila Bend Mountains are in view across the valley of Gila River, to the south lie the Sauceda and Crater mountains, and directly ahead are the bold and irregular Painted Rock Mountains. At the north end of these mountains Gila River is confined to a narrow gap, and in this gap are many pictographs or hieroglyphics marked on the rocks by some prehistoric people. They were seen by Garcess and by nearly every traveler since his time and, while exciting much curiosity, have not been satisfactorily interpreted. Near the south end of the mountains the road runs onto the Sentinel Plain, and from this point on the roadbed is firm. The aspect of this basalt plain is described on page 360 .

\section{GHLA BEND TO VEKOL}

[For log see pp. 318-319]

The road from Gila Bend to Vekol is difficult and little used by white men for the through trip, the usual approach to Vekol being from Maricopa (pp. 393397) or Casa Grande (p. 390). Indians, however, use the road in travel from Bitter Well, Totobit, and other rancherías to the Papago villages at Gila Bend.

The road goes southwest from Gila Bend over the smooth alluvial slopes of the Gila Bend Plains toward Jack in the Pulpit and the sharp peak south of it, which are, from the west, the most conspicuous summits of the Sand Tank Mountains. To the east the two pinnacles of Double Butte dominate the neighboring plateaus and mark the transition into the granite hills and small sierras that form the northern border of the Sand Tank Mountains.

At 13 miles from Gila Bend the road turns east in a narrow pass between plateaus of lava. The road lies on the narrow strip of alluvium which floors the pass. On either side rise the plateaus, some high and others low, but all rough sided and somber colored. On passing the small wire inclosure called the Halfway Corral $(16.6,29.7)$ the road comes out into a great basin encircled with mountains except on the north side. The floor of the basin slopes 
gently but irregularly to the west and north and is cut by innumerable sharp little canyons from 10 to 25 feet deep. Perhaps nowhere in the Papago country can a dissected pediment (see p. 99) be seen to better advantage. The pediment is developed largely on schist, gneiss, and coarse-grained rocks that are very different in color and texture from the lava of the plateaus. Off to the southwest, at the base of Jack in the Pulpit, the lava can be seen resting on the schist and gneiss, and similar contacts are visible at the base of many of the plateaus. The structure of the mountains is plain; the lava lies like a plate on schist and gneiss covering original plains and hills. Uplifted and faulted remnants of this plate of lava form the plateaus, but most of the lava and a considerable thickness of the underlying crystalline rock has been removed by erosion over most of the basin. The road through the basin is firm and hard but rough and rocky. It parallels the drainage eastward toward a gap between a granite sierra and a lava plateau.

Sand Tanks $(22.8,23.5)$, the first water, lie in one of the little canyons on the left of the road. The canyon is about 30 feet deep and 50 feet wide. The tanks are plunge pools (p. 125), which occur at falls due to the headward cutting of the canyon. The falls are localized, however, by beds of coarse tuffaceous conglomerate (p. 61). The tanks consist of an upper pool largely filled with sand, which is 20 feet wide and perhaps 40 feet long, and a lower pool about 4 feet wide and 6 feet long. The upper pool is now enlarged by a small masonry dam. In addition to the water left by fioods there is probably a good deal of seepage into the tanks from the conglomerate, which is very porous. The tanks are seldom dry except when the water has been used by cattle. In 1920 it was reported that a well had been dug just west of the tanks. Beyond Sand Tanks the road divides, and eastbound travelers take the hillside road, which avoids the heavy sand of the arroyo, but the westbound traveler can not use the hillside road because of its heavy grades. With either alternative this is a bad stretch of road, and it is profitable to walk ahead and get acquainted with the difficulties before attempting them.

At the top of the gap is a drift fence. On the north rises a sierra of gneiss and schist, and on the south a high and irregular plateau. The basin stretches out to the west, and the traveler can overlook most of his previous journey and trace the gap through the plateaus. There are three similar gaps parallel to and south of the one occupied by the road. Through these gaps the southern part of the Gila Bend Plains and the complex plateaus of the Sauceda Mountains can be seen, and far off to the west rise the mountains west of Black Gap and to the northwest the Gila Bend Mountains, north of-Gila River.

The road descends the eastern slope of the gap by following the arroyo, and it is a rough and anxious journey for the next mile and a half. At 5.4 miles beyond Sand Tanks the road forks $(28.2,18.1)$. The left-hand road ayoids Stouts Well ; the right-hand road goes to the well. Stouts Well $(29.3,17.0)$ was owned in 1917 by James Gatlin, who was starting a small ranch. The house had burned down, and there was only a small shack with a windmill, tank, troughs, and corrals. The traveler can get water at Stouts Well but should not expect to get supplies.

The only watering place near Stouts Well is a small spring in a deep canyon 4 miles to the south. A trail leads to the spring, which lies just under Squawtit Peak. A small rancheria west of the spring has been abandoned by the Papagos.

From a point near Stouts Well a fine view is obtained of the Vekol Valley with its grassy flats and of the Table Top and Vekol mountains. A dissected 
pediment, similar to the basin in the interior of the Sand Tank Mountains, stretches down to the Vekol Valley. Down this plain the road goes southeastward, crossing a number of steep gullies and passing by low buttes that project from the plain.

At the edge of a grassy flat a Geological Survey sign (38.3, 8') marks a north-south road through the valley-the Maricopa-Covered Wells road, in the description of which (pp. 393-397) the Vekol Valley is treated at some length. Turning south on this road the traveler may take any one of a number of dim trails across the grassy flat. The one 2 miles south of the sign $(40.4,5.9)$ is perhaps the best. It leads to the base of an isolated dark-brown hill which stands as an outlier of the Vekol Mountains. The buildings and dumps of the Vekol mine are visible against the mountains to the north of this hill. Vekol and the localities near by are described on pages $395-396$.

\section{GILA BEND TO POZO BLANCO}

[For log see pp. 320-321]

The Papagos that inhabit the three villages of Pelon, Tésotid, and Sílimok on the Gila north of Gila Bend have relatives in Sauceda and Moivavi. Visits between the people of these villages and journeys by the southern Indians to trade in Gila Bend furnish the principal traffic on the northern part of the road from Gila Bend to Pozo Blanco. The southern part of the road is largely kept open by travel between the winter rancherias and temporales.

The road goes southwest from the Geological Survey sign south of Gila Bend $(0.3,63.4)$ and for 2.8 miles is the same as the Gila Bend-Vekol road. From the road fork the Pozo Blanco road goes south toward a low place in the Sauceda Mountains, which bound the southern horizon, and enters a deep cove in the mountain front.

At 24 miles from Gila Bend the road lies under the point of a plateau on the right and crosses a tributary of the stream that it follows into a mountain valley. Sauceda is a large winter ranchería which extends along this valley for more than a mile. There are some small springs and a dug well. Sauceda is Spanish for willow, and the Papago name is Tshiulikami " where willow grows"). Pozo Colorado or Vokivaxia (" red well"), shown on many maps, appears to be the same place, though the two names may be applied to different parts of this rather large village.

From Sauceda there is probably a road to Moivavi, which lies over the ridge about 3 miles east, and to Kaka, but the location of these roads is not known. A description of the road to Moivavi from Kaka is given on page 396.

From Sauceda the road goes southeast over a pass into the Perigua Valley. This valley is about 5 miles wide and 17 miles long. The northern boundary is made up of ragged hills and sharp peaks. High plateaus of lava bound it on the east and west, and it opens on the south into the plains of the Quijotoa Valley. The floor of the valley is a continuous succession of adobe flats, which are suitable places for flood-water farming. There are many temporales, which doubtless shift in position somewhat from year to year. The summer rancherias begin with Toapit ("white clay"), which lies about $11 / 2$ miles west of the road. Emita $(36.8,26.9)$ consists of a few houses near some fields. From this place a road, very indistinct in the center of the valley, goes east to a pass north of the high rounded mountain on the east. In this pass the road is well marked. The distance from Fmita to Kaka (p. 396) by this road is 12 miles. 
About 4 miles south of Emita the road goes through the flelds of the rancherá of Road Runner, and 2 miles farther on it reaches Perigun-half a dozen houses on the east side of a lone hill in the middle of the valley. The fields lie mostly east of this hill and are very extensive. Perigua seems to be a mame of Mexican origin. The Papago name is Hikibon "where there is a rough mountain"), and this name also has a Spanish spelling, Jaquibo. The fields at Perigua are cultivated in part by people who live at Pozo Redondo. The road to Pozo Redondo is described on page 423. The road to Pozo Blanco goes east through the fields in a lane bounded on the north and south by wire and brush fences. It goes south of a prominent conical mountain, which is one of two such mountains that stand as outliers of the extensive plateaus east of the Perigua Valley. Near the base of this mountain is a fork $(43.8,19.9)$. The left-hand road goes east 4 miles through a pass to a junction with the Maricopa-Covered Wells road (p. 397). The Pozo Blanco road turns south in a little valley separated from Perigua by four small lava hills. Through groves of mesquite and small adobe flats it climbs a low alluvial divide and then goes southeast down a soft alluvial slope between low mesas into the Quijotoa Valley. This great plain with its groves of mesquite and encircling mountains has been described on page 354 .

The road goes southeast toward the south end of the Sierra Blanca, whose canyoned slopes of white gneiss are an unmistakable landmark. The road crosses a dim track $(51.2,12.5)$, which is the road from Charco de la Piedra to Covered Wells, and passes through a rancheria $(56.7,7)$ with temporales, houses, and a small represo. It is not known whether this village is occupied every summer. At $51 / 2$ miles beyond this village the road comes into the Pozo Blanco route of the Tucson-Yuma road at a Geological Survey sign $(62.2,1.5)$. Thence the road goes directly east into the pass between the Sierra Blanca and the large black hill on the south to Pozo Blanco, described on page 366 .

\section{GILA BEND TO AJO}

[For log see pp. 321-323]

A road from Gila Bend, one of the principal localities on the main route to California, was a necessity for the prospecting of the mines at Ajo, particularly after Americans were attracted to these mines in the fifties. The Butterfield stage line down the Gila and the building of the Southern Pacific Railroad intensified this necessity.

Traffic on the present road, both freight and passenger, was very heavy between 1913 and 1916 but is now light because of the presence of the rallroad and especially since the institution of motor-driven passenger cars on the railroad.

For the first 15 miles the road lies across the Gila Bend Plains. The journey is relieved by the gradual disclosure of the details of the Sauceda Mountains, which with each mile grow more distinct, and by passing Stout's ranch, where there is a new well with flood-water fields, 2 miles from Gila Bend. Black Gap is a passage through the northern prong of the Sauceda Mountains. Guarded by several small hills of lava, the gap itself is a narrow passage be tween round buttes of lava covered with unbroken black talus. West of the pass are two of these buttes, and north of them a small sierra of granite. East of the pass is a single butte separated from the complex plateaus of the main range by a narrow gap occupied by the Gaskill road. At 4 miles south of Black Gap is Deadman Gap $(19.3,23)$, a narrow passageway between some outlying hills and the southern prong of the Sauceda Mountains. On one of 
these hills a prospector is said to have died of thirst, and to this circumstance the name is due. Deadman Gap is occupied by the road, the railroad, and the old Gaskill road. Beyond the gap lies Midway Well (23.4, 18.9), a drilled well without equipment, where no water is to be obtained. East of Midway Well is a deep reentrant in the mountains. The complicated and highly colored plateaus of the Sauceda Mountains north of the gap are dominated by Hat Mountain, a round hill with a flat top, which is a prominent landmark in this region. In one of the canyons near the foot of the mountains west of Hat Mountain there are said to be some rock tanks. To the south of this reentrant lie the dark plateaus of the Batamote Mountains, surmounted by the conical peak of the old volcano.

To the west and south of the road are the plateaus of the Crater Mountains, and the road swings to the west away from the railroad to go through a gap in these plateaus. This gap $(28.1,14.2)$, which continues for 2 miles, is formed by two canyons that have worked into the plateaus from the north and south. The north canyon is the longer, because it drains to a lower valley. Near the head of this canyon is a more or less circular basin rimmed with cliffs carved out of the horizontal lavas and showing many curious and spectacular details. This strictly erosional valley, cut by water and weather, so much resembles the crater of a volcano that this locality has for many years been called The Crater, and the name is applied to the whole range.

South of The Crater the road curves into the Childs Valley, continues south across the alluvial plain, and comes into the Tucson-Yuma road at the Geological Survey sign $(32.4,9.9)$, from which it is 1.2 milea to Batamote Well, the first watering place. White Tanks, the only other watering place in this vicinity, consists of rock tanks situated north of the little gap occupied by the railroad at the end of the Crater Mountains. about 3 miles northeast of Batamote Well.

The road from Batamote Well to Ajo is described on page 359.

\section{GILA BEND TO MESQUITE TANK}

[For log see pp. 323-324]

Mesquite Tank is a watering place at the north end of the Sand Tank Mountains. In 1920 it was the site of a small cattle ranch. The original tank was a plunge pool at the foot of a low fall in lava that dips gently to the south. The tank had been deepened into a well.

The road forks from the Gila Bend-Phoenix road (p. 397) 1 mile east of Gila Bend, at the railroad crossing. It then goes east for 6.7 miles, to the north end of a small grainite mountain. Here the road turns south into an open valley with unusually luxurious desert vegetation and many palo fierro trees. At 11 miles from this turn, after passing east of Double Butte, a prominent landmark, the road turns sharply southwest and then south. About 2 miles of rough road brings the traveler to Mesquite Tank. The shaft of the Zona or Jitney mine, 4 miles southwest, is now used for a stockwatering place, but there is no road to it.

\section{ROUTES IN THE BABOQUIVARI VALLEY}

The following notes may be added to those given in the road logs (pp. 324-325) with reference to routes in the Baboquivari Valley:

Some of the settlements in the Baboquivari Mountains are very ancient and depend on springs or rock tanks; others have been made within the last 30 
years. The art of well digging, especially wells in the rock, was unknown to the Papagos and has been learned largely from American and Mexican miners. Some of the new wells around which villages have sprung up are probably the work of prospectors, but many have doubtless been dug by the Indians. The digging of new wells has been very common in the last 20 years.

San Juan, a small village, depends on a spring a mile to the north. Chuapo, in Papago Kutjuupo ("big water hole in the rock"), has a well 30 feet deep but, as the name implies, probably once depended on a large rock tank. There is also a dug well a mile southeast of Chuapo.

The next village south is Fresnal, probably one of the oldest settlements of the Papagos. In 1863 it had 250 inhabitants, in 1864 385, and in 1912 about 500. There are three parts of this community in Fresnal Canyon. The western village is Pitoikam ("where there are ash trees"), and from this comes the Spanish name Fresnal ("grove of ash trees"). The middle village is Tshíliseik ("willow forest"), and the upper village Koxikux ("where the mulberry tree stands"), now known as Ventana. It seems likely that Fresnal was visited by Father Kino and Mange, for Mange ${ }^{13}$ speaks of a flowing stream near a high square "peñasco" visible for 18 leagues, which they visited in 1699. The distances and directions given in Mange's account of this journey are confusing, but this description seems to apply to no other locality. They are now 18 dug wells in the canyon at Fresnal, and 3 more at Ventana.

East of Fresnal is the Allison reservoir, with a masonry dam. This reservoir was built for the water supply of the now inactive Allison mine, and the water is used by the Indians. At 1 $1 \frac{1}{2}$ miles northeast of the reservoir is a dug well. South of Fresnal and directly west of Baboquivari Peak are two dug wells about 2 miles apart.

Bears Well, 7 miles south of Fresnal, has two dug wells, 20 and 29 feet deep. The Papago name is Tjotomvaxiaka (" bear's well"). Three miles south of Bears Well is a ranchería with a spring, several dug wells, and a represo. This village is probably called Rincon." Two miles south of this locality is a spring and well, which is probably the old rancheria Sepanovak (" the smell of the coyote").

San Miguel Wells are east of the summer rancheria of the same name and about 13 miles south of Fresnal and comprise four dug wells. A mile south but in another canyon is a ranchería with four dug wells, known as Hendricks Wells.

Lopez Well and store lie on the international boundary at monument 142. Pozo Verde, 4 miles southeast of this monument in Mexico, is one of the principal Papago rancherias. The Papago name is Tjuitakavaxia ("green well "). There is a spring or, as some say, a rock tank at this ranchería.

Magdalena and Tucsoncito form an almost continuous village. The fields are irrigated with fiood water that comes from canyons near San Juan and Chuapo and goes north of the Artesa Mountains. Tuesoncito is the Spanish form of the original Papago Alitjaikson ("at the foot of the small black hill"), a name derived from the small lava hill at the foot of which are the cultivated fields. There is a substantial stone church at Tucsoncito. The represos of both villages are small, and the domestic water supply scanty.

18 Mange, J. M., Luz de tierra incógnita, book 2, p. 67, quoted by Bolton, H. E., op. cit., vol. 1, p. 193, 1919 .

10 Lumholtz, Carl, op. cit., p. 383 and map showing Papago rancherfas. 
Topahua has very. large fields and is an important rancheria. The Papago name is Koksumok ("burnt dog"). A well drilled by the Indian Service at this rancheria had no equipment in 1017.

Komalik, just east of the Las Animas Hills, probably derives its name, which means "mountain crest," from these hills. Chulik, just north of San Miguel, is called in Papago Tjuulik ("corner"). San Miguel, a comparatively modern rancheria, has fields that extend from the represo and well more than 4 miles south to the international boundary. With the possible exception of Topahua it has larger fields than any of the other summer rancherias. There is a Catholic and a Protestant church here, and an Indian Serrice well (p. 179).

The old Ventana ranch is 4 miles northwest of San Miguel, on the road to Vamori. This American cattle ranch, dependent on a drilled well, was occupied as late as 1893 but has since been abandoned.

At Burro Pond, 3 miles from Vamori, Hendricks, a well-to-do and enterprising Papago, had a well 700 feet deep drilled in 1917. This well is understood to furnish a reliable water supply. The Papago name of Vamori is Vámuli ("basin"); of Burro Pond, Vopelohavooka ("burro pond"); of Rocky Point, Grikivok ("where the plow was lying").

\section{MISCELLANEOUS ROUTES BETWEEN QUIJOTOA MOUNTAINS AND GUNSIGHT PASS}

\section{INDIAN OASIS TO MENEGERS DAM}

[For $\log$ see pp. 326-327]

The road from Indian Oasis to Menegers Dam was in 1917 used largely by Joseph Meneger and his employees in traveling to his reclamation project, generally known as Menegers Dam. However, it forms part of a convenient ronte from Indian Oasis to Sonoita, the distance being approximately 63 miles.

The road goes west from Indian Oasis on the Tucson-Yuma road described on page 352 to the represo on the south side of Big Fields $(10.4,32.5)$. This represo is a small one and is usually dry. From the represo the road turns southwest across the plain and after passing several forks and crossroads reaches the Tonukvo-Kavolik road $(14.8,28.1)$. The road is probably well marked and should be easily traveled. From this crossroads it goes southwest to The Great Plain through an extensive adobe flat covered in flood by the waters of Valshni Wash and Big Wash. The mesquite trees grow in dense groves and give a deceiving appearance of verdure to the waterless plain.

The road passes to the south of a small rocky hill $(23.4,19.5)$, where a vague track, the road from Copeka (p. 353), comes in from the northeast. This hill is one of four that stand in the plain and are eastern outliers of the nameless lava hills east of the southern point of the Mesquite Mountains. From the hill a wide view is obtained. The Great Plain spreads out to the south with its lines of mesquite along stream channels and its groves on sandy patches. La Lesna Mountains, on the southeast, and the Nariz Mountains, on the southwest, bound this plain, which seems to stretch southward indefinitely into Mexico.

Two miles farther on the road passes to the north of a much smaller hill. Just south of the hill is a charco, and 1.3 miles south of it Serventi Well. This well, the exact depth of which is not known, was drilled by Serventi Brothers, cattlemen operating in both the United States and Mexico. The water is reported to have a temperature of $135^{\circ}$. The Serventis were unable to 
perfect title to the land, and the well is now included in the Papago Reservation. In 1917 the well had no equipment by which water could be obtained. A reliable well at this locality would open a large area of range for cattle and also provide water for temporales that might be established in the adobe flats.

Beyond Serventi Well the road becomes more sandy, and Camote $(33.8,9.1)$ lies in an almost treeless sandy flat having a slight slope to the south. Camote consists of a pond in a brush corral, two houses, and a corral of mesquite logs. The water collects in the borrow pits and also in a charco, around which the represo has been built. This charco is from 30 to 50 feet wide and 300 feet long. It is evidently due to concentration of flood waters by low sand dunes, and the represo has been built to increase the supply. The water is now principally used for supplying stock, and one or two Papago families live here for part of the year. The Papago name of this locality is Shatikum ("an edible root"), which has been translated into the Spanish Camote ("sweet potato").

From Camote a road goes southeast across the sandy plain to Susuta, in Papago Shósetak ("where water gathers"), a pond in Mexico, described on page 121. Another road goes north to Comovo (p. 410). The road to Menegers Dam goes north of the corral, past the houses, and north of the represo. It is usually obliterated by cattle tracks, but on going northwest from the represo a well-marked road will be found. The plain is sandy and treeless and rises gently to a low alluvial divide. On this divide mesquite trees grow in open parklike fashion with a good deal of grass on the intervening sandy soil. These open groves extend on the west side of the divide into La Quituni Valley.

The Mesquite Mountains bound La Quituni Valley on the northeast; the Ajo Mountains and Cubo Hills lie on the north; and the southern part of the Ajo Mountains, sometimes called the Santa Rosa Mountains, and the Nariz Mountains form the southwestern border. The Nariz Mountains consist of a double ridge extending across the international boundary in a northeasterly direction. The northwesterly tip of these mountains is connected with the south end of the Ajo Mountains by a low, narrow ridge of lava called Los Cerritos de Angostura, nowhere more than 200 feet above the plain. There are two gaps in this ridge called Garambulla and Angostura. Through the Angostura ("narrows") La Quituni Valley drains into a similar plain lying partly in Mexico, called Bahía de Santa Rosa. Menegers Dam is an attempt to hold the flood waters in La Quituni Valley by an earth dam at the Angostura for the irrigation of lands in the Bahía de Santa Rosa. It is the plan also to plant late crops each season on the moist land of the reservoir bottom, which will be exposed as the water is drawn off. The topographic location of this reservoir is excellent. An earth dam about 100 feet long will, according to the figures of Mr. Meneger's engineer, cover an area of about 2,000 acres with water to a maximum depth of 30 feet and create a reservoir of about 20,000 acre-feet. A spillway on rock can easily be provided on one side of the dam, so that there is little danger of the dam being overtopped. The streams that are to supply the water drain a considerable area, but they are wholly ephemeral, and their flow is not known and impassible to measure. Whether there will be enough water to fill the dam each year can be determined only by trial. Large deposits of silt in the reservoir may also be expected. In 1917 a large amount of work had been done on the dam, but it was proceeding slowly, chiefly because lack of water prevents continuous work by considerable numbers of men. The borrow pits are, however, large and deep, and in these pits the water that collects after rains lasts for several months and supplies water to travelers and to the Papagos who cultivate the flelds of La Quituni. 


\section{COPEKA TO KAVOLIK BY WAY OF TONUKVO}

[For log see pp. 328-329]

The road from Copeka to Karolik is the ordinary track across smooth alluvial plains and is withont incident. Copeka has been described on page 268 . Tonukvo consists of a pond in a brush corral and two or three houses. There are no large fields near by, and the water is largely used for cattle. Tonukvo means "ridge pond," a name given because of the long ridge on the west, which is called Chiweton ("long ridge"). The road goes southeast 12.7 miles, crossing numerous other roads, to Kavolik (" hill"), so named because of a small hill south of it. Kavolik is a summer ranchería with good-sized fields and a large represo but no permanent water. It belongs to the group of rancherias on the borders of the Alvarez Mountains that includes Burro Pond, Vamori, Rocky Point, and San Rafael. The maze of roads that connect these villages is described on page 325 .

\section{POZO BLANCO TO PISINEMO}

\section{[For log see p. 329]}

The road from Pozo Blanco to Pisinemo is largely used by the Papagos. Doubtless some of the people of Pozo Blanco plant fields at Pisinemo or at any rate visit the summer rancherías there. The road forms a connecting link between the Pozo Blanco route and the old main route of the TucsonYuma road, and the two terminals are described in connection with these routes (pp. 354, 366). The road traverses an alluvial slope and can be readily followed from the map without detailed description.

\section{COMOVO TO CAMOTE}

[For log see pp. 329-330]

The road from Comovo south into Comovo Valley and thence into The Great Plain or La Quituni Valley is a common route of travel for the Papagos in Santa Rosa Valley or Quijotoa Valley on the way to Sonoita. It seems to have been first used by white men when Padre Kino and Carrasco in 1698 and again Kino, Leal, and Mange in $\mathbf{1 6 9 9}$ went from San Serafín del Actum, the modern Akchin, near Santa Rosa, south through four unnamed rancherias to Nuestra Señora de la Merced del Batqui. This locality seems to be Mesquite Charcos, which extends along the axial stream of Comovo Valley (4.1, 10.5). The Mexicans call the place El Mesquite, and the Papagos Kuichituak (" mesquite") or Vatjeki ("small water hole"). Under the last name Lumholtz ${ }^{20}$ records it as an ancient but abandoned ranchería. The charcos, of which the principal one is 6 to 15 feet wide and 1,000 feet long, remain or have re-formed since Kino's time, but there are no evidences of fields. The motern temporal of Comovo shows what can be accomplished in the way of flood-water farming in this valley.

Beyond the southern point of the Mesquite Mountains, which border the valley on the southwest, the road goes south over the sandy plain to Camote (p. 409). A trail on the southwest side of the mountains leads 6 miles to Mesquite Tank, probably a spring, where the water is permanent. The tank is 3 by 3 by 7 feet and is in a cave in the face of a white cliff, near a very green mesquite tree easily visible from Camote. A horse can drink from the

${ }^{20}$ Lumholtz, Carl, op. cit., p. 379. 
tank but must back out of the cave. Charcos are said to exist along the trail $1 \frac{1}{2}$ miles from the point of the mountains. There is also said to be a road direct to Menegers Dam. Doubtless it is this route which Padre Kino followed to La Quituni and thence to Sonoita .

The road to Camote is sandy but passable, and there junction is made with the road from Indian Oasis to Menegers Dam (p. 408).

\section{CHARCO EN MEDIO TO CUBO}

(For $\log$ see pp. 330-331]

The road between the summer rancherías of Charco en Medio and Cubo affords a convenient connecting link between the Cubo route and main route of the Tucson-Yuma road. Two miles south of Charco en Medio the road crosses a rocky divide, and the near-by hill affords a good place from which to get a view of the Gunsight Hills and the adjacent mountains. The rest of the route to Cubo lies over an alluvial plain on the east side of the Cubo Hills and is a fair plains road without incident.

Charco en Medio is described on page 354 and Cubo on page 368. The nearest permanent water is a well near a prospect hole 2 miles west of Charco en Medio. A little-traveled but passable road leads from the represo past this well to Walls Well, 7 miles distant.

\section{WALLS WELC TO MENEGERS DAM}

1

[For log see pp. 331-334]

From Walls Well roads lead through the pass into the Barajita Valley and thence south along the east side of the Ajo Mountains to the Mexican border in the vicinity of Menegers Dam. Two routes are described below, one by way of Cochibo and the other by way of Cubo and Charco Colorado.

Walls Well is a well-known watering place at the north end of the Ajo Mountains, described on page 368. The best water is at the Miller ranch, where there are two dug wells. These wells are dug in the same body of alluvium from which Walls Well derives its supply, but, being deeper and maintained in better condition, furnish a larger and cleaner water supply.

The first 7 miles is the same for both routes. The road goes east from Walls Well, joining the Cubo route of the Tucson-Yuma road (p. 367) at the Geological Survey sign 1 mile east, and then swings to the east of the great conical hill that lies directly east of Walls Well and crosses over a divide into the Barajita Valley. This alluvium-floored valley is 4 miles wide and 13 miles long and lies east of the Ajo Mountains, between this precipitous mountain barrier and the Cubo Hills. The Cubo Hills are low lava mesas divided into four groups by gaps. The Barajita Valley is drained by a stream that goes through the gap between the main range and the high conical hill east of Walls Well, by two streams that go through gaps in the Cubo Hills, and by a stream that goes through a gap between the southerly group of hills and the Ajo Mountains. Thus the valley, ringed around by hills and mountains, has four water gaps and three other gaps that are practical for roads. The somewhat complicated road system is the result.

The road avoids the water gap east of Walls Well and comes into the valley east of the conical hill and follows down the east side. The gap north of the first group of the Cubo Hills is not occupied by a road, though doubtless a wagon could be easily driven through it to the Charco en Medio-Cubo road. 
A Geological Survey sign $(7,20.2)$ stands at the second gap in the Cubo Hills. The Tucson road turns through this gap, and the traveler to Menegers Dam may turn east here, go through the fields and past the charco of Cubo (p. 368) to another Geological Survey sign $(9.9,17.3)$, and then turn south in the valley between the Mesquite Mountains and Cubo Hills to Charco Colorado $(17.9,9.3)$. At this locality there is a charco that is of little value for water supply, two houses on a small hill, and some temporales. From the houses it is 9.3 miles almost due south to Menegers Dam. The road is fair but is somewhat sandy. There are many forks and crossroads which the traveler must avoid. Some fair-sized charcos may be seen west of the road $(20.1,7.3)$, and the upper part of one of them is shown in Plate XVI, $B$. The hills in the background of the view are part of the Cubo Hills.

On the other hand, the traveler may continue south from the gap west of Cubo $(7,20.2)$ along the east side of Barajita Valley. Numerous tracks and roads lead west from this gap 6 miles to the winter rancheria of Barajita, which in Papago is Tonoka ("knee"). This village lies in two adjacent canyons. In the southern canyon are two dug wells, and in the northern canyon one well. The people of Barajita plant fields at Cubo, so that the traffic is often heavy and there are numerous roads and tracks.

About 3 miles south of the Cubo gap is the third gap in the Cubo Hills. Flood waters from a wide area collect in adobe flats and go east through this gap. In the adobe flats are numerous small charcos, and a represo has recently been built to improve one of the largest of them $(10.4,16.8)$. The embankment is low and not well designed, so that the represo does noit store much water. A road reported to be practical for wagons is said to go east through this gap to join the road from Cubo to Charco Colorado.

The fourth gap $(13.9,13.3)$ is a low col between the lava mesas and affords an easy and practical route for wagons and automobiles through the hills. It reaches Charco Colorado in 2.8 miles, and the traveler who does not need to obtain water at Cochibo will save 1.2 miles by taking this road.

The road by way of Cochibo continues southwestward toward a canyon in the Ajo Mountains just north of a high black plateau. The road crosses low gravel benches and a number of arroyos that drain south through the narrow gap between the most southerly part of the Cubo Hills and the Ajo Mountains. Along this part of the road are a number of small brush corrals and arbors, which are used when the Papagos gather at this locality to make cheese.

Cochibo ("pig well") is a stock-watering place belonging to a Papago named "Slim Joe" or José Manuel, who cultivates fields at Charco Colorado and La Quituni. The two wells (see p. 175), are four-tenths of a mile up the rather narrow canyon from the road fork $(16.4,10)$, and between the mouth of the canyon and the wells are a small corral and some small huts. There is said to be a horse trail west through the mountains from this locality to Sonoita. The wells seem to have been dug at a place where there was originally a wet-weather spring, and this locality may be the place shown on old maps as Coon-can.

From the mouth of the canyon $(16.4,10)$ the road goes south through a narrow gap into La Quituni Valley. An ephemeral stream that runs in a well-defined channel in Barajita Valley occupies this gap and then on emerging into La Quituni Valley spreads out into an adobe flat. Such a locality is called Akchin ("arroyo's mouth") by the Papagos and is favorable for floodwater farming. Here Padre Kino in 1698 found the rancheria which he called San Rafael del Actum el Grande (" the great Akchin "), to distinguish it from the smaller Akchin of the Santa Rosa Valley. Kino visited the place again in 
1699, 1701, and 1702. In 1912 Lumholtz ${ }^{21}$ learned that, while it had formerly been inhabited during the summer by one or two families from Sonoita, it had been deserted over 10 years. In 1917 there were two houses and some small fields $(24.4,2.8)$. These were occupied by Slim Joe, who it is understood had been planting here since about 1914. This farming has been made easier by the work on Menegers Dam, from which these Indians obtain water when the charcos go dry. Such shifts in people and abandonment of the summer rancherias account for much of the confusion in regard to names and for many of the inaccuracies of maps in the Papago country.

From La Quituni the low ridge that joins the southern and lower part of the Ajo Mountains to the Nariz Mountains is visible. Menegers Dam, described on page 409 , is located at the Angostura, the eastern one of the two gaps in this ridge. In the western gap, the Garambulla, is the road to Sonoita, 20 miles to the southwest, and it is doubtless over this road that Padre Kino traveled from La Quituni to Sonoita. Half a mile from Menegers Dam is an abandoned represo built by a Mexican stockman named Marín.

\section{ROUTES FROM AND NEAR AJO}

\section{AJO TO YUMA BY THE CAMINO DEL DIABLO}

[For log see pp. 334-340]

The road from Ajo to Xuma by the Camino del Diablo ("devil's road") is probably the most difficult and dangerous route in the Papago country. The region west of the Growler Mountains, east of the bluffs of Colorado River. and south of the Southern Pacific Railroad, an area 60 miles wide on the east and 20 miles wide on the west and nearly 100 miles long, has only one permanent inhabitant, who is the caretaker at the Fortuna mine. The same absolute lack of settlement extends below the international boundary to the Gulf of California. The absence of population and the rarity of travelers make accidents, which in other places are mere incidents of travel, serious disasters. The difficulties and dangers of this route are, however, much less than in the early days, as explained in the log.

History of the route. - The Camino del Diablo is the route from Altar and Caborca, in Mexico, through Sonoita to California. It gained an unenviable name during the rush to California in the fifties because of the large numbers who perished along it. The road went west from Sonoita (p. 425) along the valley of Sonoita River to Agua Salada and then turned northwest, passing by a represo near the south end of the O'Neill Hills to Las Playas, thence west by way of Tule Well and Tule Tank to Tinajas Altas. From Tinajas Altas one branch went north to Gila River, on the east side of the Gila Mountains, and the other went on the west side; both followed the river down to Yuma, which was the beginning of the route in California. This was the usual: course of travel, to which there were exceptions. The route described herewith joins the old road at Las Playas and depends for its existence on Bates Well and Papago Well. But for these wells travel west from Ajo would go south to Sonoita and then over the old road.

The adventurous Padre Kino made the first recorded trip over this route in 1699. In the previous year a trip through the Papago country to Sonoita had given him much information, and he doubtless learned of this route to Colorado River. His predecessor, Melchior Diaz, of whose explorations Kino had no knowledge, went west from the Valley of Sonora in 1540 to the sea and

stumholtz, Carl, op. cit., v. 381. 
thence northwest to ànd beyond Colorado River, but whether he used the Camino del Diablo or not is unknown because of insufficient records. On February 16, 1699, Kino, Padre Adamo Gilg, and Juan Mateo Mange arrived at Sonoita and began a new ranch with 36 head of cattle. Leaving Sonoita on the 17th, they went down the river past the Carrizal (Agua Salada), then 20 leagues [about 60 miles] to Aguaje de la Luna ("watering place of the moon"), 15 leagues to another good watering place (Aguaje), 15 leagues to Las Tinajas, and 6 leagues to Gila River in the vicinity of Wellton. This journey was made in five days.

On October 10,1700, Kino with 10 servants and 60 pack animals, having arrived at Yuma by a trip down the river from Casa Grande, turned south from the river by way of La Tinaja to El Agua Escondido ("hidden water"), 12 leagues from La Tinaja, and this is the "good watering place" of the trip of the year before. From Agua Escondido on October 11 he went to the tank of La Luna and two hours' journey beyond, 12 leagues in all. On October 12 he went to Carrizal, 13 leagues, and thence to Sonoita, 8 leagues more. It is plain from this journey that the Carrizal is Agua Salada, 8 leagues or about 24 miles from Sonoita, and that the Aguaje de la Luna is not more than 15 leagues from Carrizal.

On his next journey, in 1701, Kino left Sonoita on November 13 and went to the tank of La Luna by way of Carrizal, 20 leagues; on the 15th he went to good pasturage near Agua Escondido, and then some distance beyond the tank; on the 16th to a good stopping place with water and pasturage, 5 leagues; and thence by way of La Tinaja to San Pedro on the Gila-that is, to the vicinity of Wellton. On his return he left San Pedro on November 25 and reached Agua Escondido; on the 26th he reached La Luna, where he opened a road through very sharp stones and rocks so that the animals could drink, and went 5 leagues farther to good pasturage; on November 27 he went to Carrizal, 13 leagues, and then to Sonoita, 8 leagues.

In February, 1702. Kino and Padre Manuel Gonzales left Sonoita on the 19th and went to Carrizal; on February 20 they went 15 leagues to a point near La Luna; on the 21st they went 20 leagues to plains and pastures near Agua Escondido, passing near La Lnna; on February 22 directly to La Tinaja, which they renamed Aguaje de los Algives ("watering place of the cisterns"); thence on February 256 leagues to San Pedro (Wellton). On the return they left San Pedro on March 18 and reached Algives; on March 19 the plains of Agua Escondido; March 20, La Luna; March 21, Carrizal; March 22, Sonoita.

It is obvious from a consideration of these itineraries that Kino went down Sonoita River to Agua Dulce, or more probably Agua Salada, which corresponds to his Carrizal. From this point he went north 13 leagues to Aguaje de la Luna, a tank that was inaccessible to animals until he built a trail in 1701. This description would apply to Heart Tank, which is not accessible to animals at the present time, or to Cabeza Prieta Tanks, which lie in a mountain canyon. Cabeza Prieta Tanks are northwest, not north of Agua Salada. Also Las Playas lies 5 leagues (15 miles) south of Heart. Tank, and this may be the "good pasturage" which he reached on his return journey in 1701. The Agua Escondido seems quite certainly to be the Tinajas Altas of present nomenclature. In the journey of 1689 Kino gives the distance from Agua Escondido to La Luna as 15 leagues. By the most direct route it is about 30 miles (10 leagues), but as the way leads through a complicated pass the distance might easily be exaggerated. From Agua Escondido the road leads north " 15 leagues" to La Tinaja, also called Aguaje de los Algives. This distance is grossly exaggerated, for it is only 
27 miles, not over 10 leagues, to the Gila from Tinajas Altas. La Tinaja seems to be either one of the small tanks on the east side of the Gila Mountains near the north end or Baker Tanks. Thence Kino gives a distance of 6 leagues to San Pedro. There are thus a number of uncertainties in Kino's routes.

Padre Garcess in October, 1771, being in the vicinity of Yuma, returned to Sonoita over this route, but we have no record of his stopping places. In January, 1774, however, with Juan Bautista de Anza, he left Sonoita on the 29th and went 9 leagues west to Carrizal; January 30, north-northwest 6 . leagues; February 1, northwest 3 leagues to Purificacion; February 4, 5 leagues to Springs; February 5, 7 leagues to Agua Escondido; February 6, southwest (?) 61/4 leagues; February, 101/2 leagues to Palmas ranchería, called by the Jesuits San Dionisio, at the confluence of Gila and Colorado rivers.

In 1775 Garces with Anza, Font, and Eixarch made the trip to Yuma down the Gila from the Pima villages, and on the return from California the expedition, except Garces, returned by way of Sonoita. According to the itineraries of Anza and Font, who disagree as to distances, they were on May 14 at the ford of the Colorado below the Gila; May 15, they went up the Gila to the Cerros: del Cajon (Dome), 5 leagues (or 7); May 16, 7 leagues (or 4) to Laguna Salada (near Wellton); May 17 they turned from the river southwest 8 leagues (or 11) to Pozos de en Medio, or Zacate Duro; May 18, 9 leagues (or 18) east-southeast past Tinajas de Candelaria to Puerto Blanco or Llana del Fuzal; May 19, 8 leagues (or 10) to Arroyo del Sonoitac or Carrizal; May 20, 12 leagues past the ruined mission of San Marcelo de Sonoitac. On Garcés's trip of 1771 he seems to have gone from Agua Salada to Heart Tank, which hecalls Purificacion, and thence west to springs in the Cabeza Prieta Mountains. No such springs are now known, and Cabeza Prieta Tanks may be meant. From the springs he went to Agua Escondido or Tinajas Altas, and thence southwest (possibly an error) and then north to the Gila. The account is confusing but is not explained by the itinerary of Anza and Font in 1775 . These explorers left the Laguna Salada west of Wellton on Gila River and went southeast 8 leagues to Pozos de en Medio (" the wells of the middle [of the hills] "), or Zacatal Duro ("the place where there is hard or tough hay" or "the hard place where there is hay"). Either of these descriptions would fit Baker Tanks, which are shown on many recent maps as Los Pozos. Thence they went east-southeast past Tinajas de Candelaria to the Puerto Blanco ("white pass") or Llano de Fuzal ("plain of Fuzal"). It seems that the Tinajas de Candelaria was a new watering place which they did not see in 1774, and it may be the Cabeza Prieta Tanks, which may be reached by going " on the east side of Copper Mountain from Baker Tanks. However, the direction in south-southeast, not east-southeast. The tanks lie in a canyon off the road, and it is therefore natural that the travelers should have passed them and proceeded toward the south. There is, however, no "white pass" within the proper distance, 8 leagues from Agua Salada, or rather there are so many possible small gaps that might deserve this name that a satisfactory solution of these itineraries seems impossible.

The rush to Califormia brought about a large amount of traffic on this route. It was the shortest route for Mexicans from Sonora and also much safer from Indian attacks than the journey down Gila River. In 1861 Pumpelly ${ }^{2}$ and Charles D. Poston left Arivaca and traveling through Altar and Caborca reached

22 Pumpelly, Raphael, Across America and Asia, 3d ed., pp. 53-61, New York, 1870. 
Santo Domingo, on Sonoita River, and from this point followed the trail through Las Playas, where they encountered a storm that covered the playa with water. They crossed the Pinacate Plain where it is only a mile wide-that is, south of the present road-and made the next camp at Tinajas Altas. In 1915 Pumpelly with his family and four Ford cars left Tucson and followed the TucsonYuma road to Ajo and thence by way of Bates Well and Papago Well repeated his former trip to Tinajas Altas. From Tinajas Altas he went through the pass and reached Gila River by way of the Fortuna mine, although one car broke down on this route. He gives a lively account of this second journey. ${ }^{23}$ All portions of the trail were traveled by the boundary survey party of $1857^{24}$ but it met great difficulties on account of water, as Tule Well was not in existence at that time. The trail was in active use by emigrants to California, and the account speaks of recent deaths.

On the resurvey of the international boundary in 1893 Tule Well, ${ }^{25}$ which had been dug in the meantime, was cleaned out and furnished 500 gallons water daily. McGee ${ }^{20}$ who spent some time camping at Tinajas Altas, quotes Captain Gaillard, of that survey, in estimating that more than 400 people had died on the trail. Gaillard considered this a fair estimate after counting 68 graves in a single day's ride of a little more than 30 miles. More than 65 graves can be counted at Tinajas Altas at the present time, and many graves must now be undiscoverable, as is that of Johnson, which his murderer, Williams, showed Pumpelly in 1861."

Reasons for travel on this route.-At the present time there is little travel over this route. The Geological Survey automobile, in October, 1917, broke the trail from Papago Well to Tinajas Altas. No machines had been over the route since the last rain, which occurred some six months before. In September, 1920, the Survey automobile also broke the trail from Bates Well to Tule Well and from Tinajas Altas to Wellton. Heavy rains in the early part of September had washed the road badly, but there was abundant water at Las Playas, Tule Tank, and Tinajas Altas.

Several exploring expeditions have used the road, in part at least, in recent years. The Carnegie Expedition in 1907, Lumholtz in 1912, Pumpelly in 1915, and McGee some years before have been referred to in other parts of this report. Between 1912 and 1916 the engineers of the New Cornelia Copper Co. made numerous trips through the region, two of which were well-organized expeditions to the coast in the vicinity of Adair Bay. The loss of an Army airplane in $\mathbf{1 9 1 6}$ on the coast near Adair Bay led to a number of rescue expeditions. The aviators walked north, and one of them reached the camp of a rescue party from Wellton under the leadership of Winn Prebstel, south of Tinajas Altas; the other aviator was found that night. W. D. Tremaine, after two unsuccessful expeditions, found the airplane, and on a fourth trip towed the machine out of Mexico behind his automobile. In 1918 a detachment of engineers and aviators made an airplane survey of the area. In 1920 the road as far as Las Playas was being used by engineers in the survey of a railroad route from Ajo to the Gulf of California.

\footnotetext{
23 Pumpelly, Raphael, My reminiscences, vol. 2, pp. 761-776, New York, 1918.

${ }^{24}$ Emory, W. H., Report on the U. S. and Mexican Boundary Survey, 1857, vol. 1, pp. 114-116, 122.

${ }_{25}$ Report of International Boundary Commission upon the survey and remarking of the boundary between the United States and Mexico west of the Rio Grande, 1891-1896 55th Cong., $2 d$ sess., S. Doc. 247, p. 24, 1898. See also Mearns, b. A., op. cit., p. 19. ${ }^{26}$ McGee, W J, The old Yuma trail : Nat. Geog. Mag., vol. 7, pp. 103-105, 1901.

27 Pumpelly, Raphael, Across America and Asia, p. 55, 1918.
} 
The greater part of the travel is, however, that of prospectors who comb the mountains of this waterless region in the search for mineral deposits. The Fortuna mine (p. 348) and the Papago mine have been the principal fruits ofthis search. In addition to legitimate prospecting, which may yield eventually greater results than now seems possible, there is the lure of the legends that spring up continually about any uninhabited region.

One of the legends has to do with the lost mission. The following quotation ${ }^{28}$ gives it in substantially the current form :

Among Mexicans there is a persistent rumor of an abandoned mission somewhere in the sand-dune country east of the Colorado River, showing foundations of walls, near a spring with running water among the sand dunes, and an old smelter connected with it. Its location usually is placed near the coast south of Tinajas Altas. A man from that camp, who was looking for his horses, is said to have come across these ruins near Cabeza Prieta Range, but the lower part of the Sonoita River is assumed to be the locality by others.

According to a variation of the tale the mission was started to convert the Areneños, or Sand Papagos. Another phase of the story, that coarse placer gold exists near the mission, is tempting to cupidity, and each year treasure seekers, having some new and supposed valuable clue, hunt for the mission. They frequently combine this with the hunt for the $\$ 60,000$ worth of gold ore which, according to tradition, a prospector dug from the fabulously rich veins of the Sierra Pinta southwest of Quitovac, in Sonora. He packed the ore on burros and started for Yuma, Losing his burros one night, he buried the treasure under a large palo verde and with incredible suffering made his way to Yurı, where, after relating his experiences, he died. Doubtless much more than $\$ 60,000$ and much labor has been expended in searching for this treasure, and the traveler will have difficulty in finding along the Camino del Diablo a large palo verde under which some treasure seeker has not dug.

Another tale adds interest to the Pinacate region of Sonora. The Areneños or Sand Papagos (see p. 26) are said to have made a practice of attacking emigrant trains and travelers on the Camino del Diablo during the gold rush. Of the loot from these massacies they used the food and tobacco but stored the goods and gold, for which they had no use, in a cave in the Pinacate Mountains. This cave, therefore, is supposed to contain a treasure rivaling that of Captain Kidd. . There is no record that the Papagos ever robbed caravans, though the Mexicans make that assertion, and if they took any gold they undoubtedly used it, for all the Papagos have known the value of gold since early Spanish times, and many of them are miners.

One of the peculiar industries of the region has been the search for guano. This manure is found in considerable quantities in caves inhabited by bats, the dry climate being favorable for its accumulation. The loneliest and most forsaken parts of the region have been prospected by the guano hunter. Most of the large caves have now been explored and the guano removed.

The usual illegal activities of a border region are favored by the lack of population, but the lack of water and the perils of travel have been a deterrent factor. A certain amount of smuggling and numerous attempts to evade the immigration laws have been noted in recent years. During one of the Mexican revolutions gun running was for a time a lucrative business.

Ajo to Bates Well. - The road goes southwest through the model town of Ajo, newly built by the New Cornelia Copper Co. (p. 356), and turns south into the open valley between Arkansas Mountain and the neighboring peaks of the main mass of the Little Ajo Mountains and Reservoir Hill. This is the min-

${ }^{28}$ Lumboltz, Carl, op. clt., pp. 197-198. 
eralized area, and the large open cuts of the New Cornelia mine lie on the right of the road. Old Ajo $(1.2,151.5)$ is now mostly in ruins but has a certain sentimental interest owing to the fact that this outpost in the desert has never been wholly abandoned since it was first settled by white men in the fifties.

Beyond Old Ajo the road comes into an extensive dissected pediment south of the main mass of the Little Ajo Mountains. The Ajo Peaks rise from the plain about 3 miles west (Pl. $X, A$ ), and a road goes north of them to Cardigan and Tule Well (p. 346). , On the southeast the purplish-brown slopes of Black Mountain rise above the plain. Darby Well lies in the valley just north of this mountain.

The rolling country of the dissected pediment is covered by the typical foothill vegetation-sahuaro, palo verde, and ocotillo-and above the plains rise scattered knobs. One of these is the Locomotive Peaks, a hill with fantastic pinnacles and boulders said to look like a locomotive. The road, passing numerous forks, goes between these "peaks" and Black Mountain.

At the fork marked by a Geological Survey sign (7.1, 165.6) the road is on an alluvial plain, and at this fork the traveler turns slightly southwest, parallel to the low ridges about 2 miles off the road on the right. Back of these ridges are some charcos, and a trail runs from a point near the Cardigan mine past these charcos to Bates Well. The Sonoita road goes due south from the sign mentioned.

The Growler Pass l'es just north of a high round plateau of lava mantled hy black talus slopes. The road skirts a low mesa north of the plateau, which encircles a high jagged peak. It crosses a low divide and goes into an open valley. To the north is a sharp conical mountain, and between this mountain and the main range of the Growler Mountains lies the horse trail to Ajo. In the pass are two wells, of which the more easterly is the original Bates Well (16.6, 136.1), named from the man who dug it some 40 years ago. To the Miexicans it is El Veit because they can not twist their tongues to say "Bates," and the Papagos call it Tjuni Katk ("where there is sahuaro fruit"). It was occupied for a number of years by some of the remnants of the Sand Papagos and was then acquired by Reub Daniels (p. 358), who, with Charlie Puffer, dug the west well and installed corrals and a windmill. (See analysis, p. 184.) As many as 2,000 head of cattle have been kept at Bates Well, but that number is more than the range can support. In 1920 the McDaniels Brothers, who occupied the ranch, had removed most of their cattle because of drought. There is usually some one either at the well or at the Growler mine, but here the traveler takes leave of civilization and plunges into the most desolate part of the Papago country.

Bates Well to Tule Well.-The Growler mine $(17.9,135.1)$ lies northwest of Bates Well over a little rocky divide. It was discovered by Frederick Wall and has been an active prospect for many years. West of the mine lie the broad plains of the Growler Valley. To the northwest, in the center of the valley, are the Granite Mountains, a small and, so far as known, waterless range, visited by only one or two men in the last 10 years. The picturesque western façade of the northern part of the Growler Mountains stretches like a red wall toward the northwest; the southern part of the same mountains is a confused jumble of dark plateaus that extend south toward the border. A long and apparently continuous sierra, the Agua Dulce Mountains, oceupies the southern horizon. The road goes southwest toward the west end of this mountain range. On closer approach what seemed to be a continuous range is found to consist, in its western part, of detached hills and small mountains. 
At the foot of the first of athese hills $(30.6,122.4)$, there is a fork, marked by a Geological Survey sign. The right-hand road, which winds through the little plain between the hills, is usually followed to Papago Well $(39.7,113.7)$. This road avoids the hill and the crossing of a large wash. The left-hand road goes southwest $31 / 2$ miles to a fork, from which the road on the left continues to Steel Tanks, 5.7 miles from the Geological Survey sign. This watering place consists of two metal tanks set in small streamways in a rocky area on the south side of the road. They were installed by W. D. Tremaine to supply water on his prospecting trips, and, unless the water is used, they hold water for a month or more after rains. The right-hand road goes north about threequarters of a mile to a prospector's camp, turns over a low rocky divide, and then goes down into a valley, passing the Papago mine, which is visible against a hill on the right. The road crosses the broad wash that passes Papago Well by a long and difficult crossing and comes into the road described above threetenths of a mile east of Papago Well.

Papago Well (39.7, 113.7) was drilled as a water supply for the Papago gold mine, 1.5 miles to the east. (See Pl. XXV, B.) The water is 235 feet below the surface and is not easily obtained. (For analysis see p. 172.)

From Papago Well a road goes north on the west side of the Mohawk Mountains to Mohawk station on the Southern Pacific Railroad. The distance is 52.5 miles, and there is no water except at Glynns Falls. 15 miles south of Mohawk. The rock tanks at this locality are said to hold water for a short time after rains.

From Papago Well the road to Yuma crosses the wash and goes west down an alluvial slope and south of an arroyo to a pass in sharp granite hills. In this pass, which now bears his name, Dave O'Neill, an old prospector, died of exposure and overexertion. His burros wandered away from camp in a storm, and after searching for them at least a day he died with his head in a mud hole and lies buried along the road $(43.3,109.7)$.

A few miles beyond the pass $(45.4,107.6)$ a road turns off to the left which in 1920 was very well marked. It was used in that year by the engineers of the Tucson, Cornelia \& Gila Bend Railroad during the survey of their proposed line from Ajo to the Gulf, to reach Las Positas and Batamote, watering places on Sonoita River in Mexico.

West of O'Neill Pass the road runs down an alluvial slope to Las Playas, which is a typical playa-that is, a broad pan of clay without vegetation which holds a shallow sheet of water after a rain. Flood water from the south end of the Tule Desert and a considerable adjacent area collects here. This is the only inclosed basin in the Papago country, and it is not certain that the lake does not overflow into Mexico. A few small mesquites are found around the border of the clay flat, but the center is without vegetation and is broken by deep cracks, so that it makes a rough roadbed. The western and southwestern borders of the playa have numerous charcos excavated by the tributary streams, and water remains in them for considerable periods after a rain. There is also said to be a small rock tank near a red volcanic crater ahout a mile southwest of Las Playas, but its exact location is not known. There is a represo which does not hold, water about 5 miles to the southeast, just south of the international boundary, and near this represo is an adobe flat in which there are charcos that have water for some days after a rain. All the ancient routes from Sonoita to Yuma came through Las Playas, because there was a good possibility of finding water there and because of the presence of horse feed. 
From the west end of the playa a road goes north to the Pinta Mountains, a narrow and very precipitous range with a northwesterly trend. Drifted sand covers the plain, and sand dunes are invading the western canyons along the south end of the range. It is $\mathbf{1 4}$ miles by this road to Heart Tank, but for automobiles and wagons there is an easier route west of the Pinacate Plains (p. 336).

West of Las Playas is a long sandy slope that leads up to a low mesa. Just in the edge of the sand there is a large palo verde tree south of the road. Some one camped here for a long time and made a number of shelves in the branches, the trunk is covered with advertising signs, and the roots have been exposed by treasure hunters. This tree is a well-known landmark. From the tree to the top of the mesa the sand is deep and shifts with each wind, filling the ruts made by the previous traveler. Low-powered automobiles are likely to be stalled, and the traveler may be compelled to build a roadway of brush several times before reaching the top of the slope (p. 264).

The Pinacate Plain, an extension of the much larger volcanic region of the Pinacate Mountains of Sonora (p. 70), is crossed by a level road with a hard roadbed. "Pinacate" is the Mexican name of a black beetle, Eleodes, which lives in sandy places and has a curious habit of standing on its head when disturbed. Small cones and craters, which were the centers of eruption of the basalt that formed the mesa, are scattered about. The signs of recent volcanic activity are so plain that a short detour to one of these cones is well repaid. To the north the southwestern front of the Pinta Mountains can be seen. Here the remarkable change from the dark schist and gneiss of the southern part of the range to the light ivory-pink granite of the northern part is a conspicuous feature of the landscape.

The western edge of the basalt plain $(50.6,96.8)$ is an escarpment about 50 feet high, from which the traveler may overlook a wide expanse of alluvial plain and see the Tule and Cabeza Prieta mountains, which occupy all the western horizon. The road goes west across this plain, and the first half mile is covered with drifted sand, though not as deeply as on the east side. The plain, however, has numerous washes and very soft ground, so that the road is heavy for the next 8 miles.

The Camino del Diablo enters the pass between the Tule and Cabeza Prieta mountains between granite sierras and goes west in a narrow, flat-floored valley for 2 miles. It then turns to the right over a hill, where the roadbed is rough and covered by loose boulders weathered out of conglomerate (p. 72). An open valley, dotted with sharp hills, lies to the north. The road, after passing a wooden signboard bearing an inscription " 2 miles to Tule Well," goes north between small hills and crosses an arroyo to Tule Well $(69.9,83.1)$.

The present Tule Well is dug 31 feet deep and has a plank curb 4 feet high. It was constructed by prospectors under the authority of Yuma County about 1907. Water stands about 30 feet from the top of the curb. The old well near by was a considerable excavation, with steps leading down to the water. This well was not in existence in 1861, when Pumpelly made his first journey, but was dug before the boundary survey of 1893 , which cleaned out the well and obtained 500 gallons of water daily. Lumholtz, in 1912, did not visit the well but was told that it was dry. The water of the new well is brackish and not pleasant to the taste, though there is no reason to think it is harmful to the health. (See analysis, p. 172.)

The Cabeza Prieta Tanks, 21 miles from Tule Well by a roundabout road that leads off to the northeast, consist of eight pools one below another in a stream channel in a deep gorge that extends from the highest part of the 
mountains toward the northeast. There are six heaps of stone in a row at the entrance to this gorge. The tanks are not considered to be as reliable a water supply as Tinajas Altas. There is said to be a road passable for wagons which goes southwest from these tanks and joins the Camino del Diablo west of Tule Tank. A road also goes along the east side of the Cabeza Prieta and Copper mountains to Baker Tanks (p. 348). These roads are represented on the map but were not traveled.

Tule Well to Tinajas Altas.-From Tule Well the road goes west over some low hills into an open plain encircled with mountains. Through a gap in the mountains on the north can be seen a great white mountain with a cap of black lava. This is the Cabeza Prieta ("black head") which gives the name to the mountains and the tanks. About a mile beyond Tule Well tracks go 2 miles south to a prospect that lies on the north slope of the sierras to the south. Just west of this point is a clump of small but very steep-sided mountains of a notably white color. Tule Tank $(72.9,80.1)$ is marked by a Geological Survey sign at the entrance to a small canyon in the southern edge of these mountains. The tank was one of the camping places of the Sand Papagos, who called it Otoxakam ("where there is bulrush or tule"). The water is found in a plunge pool at the foot of a fall 1,600 feet west of the sign and is ordinarily obtained by digging in the sand that fills the pool. In November, 1917, the tank was completely dry, but in September, 1920, it was full of clear water and there was a trickle of running water both above and below the tank. (See Pl. XVII, B.) Mortars excavated in the rock by the Papagos, called by the Mexican name béchete or péchita holes, are common around the tank. (See Pl. V, B.) They were used to pound up mesquite beans, one of the principal foods of the Indians.

Half a mile west of Tule Tank the road turns north in a narrow pass, and tracks go south across the plain to a gap between the brown lava-capped hills in the west and a high, light-colored peak. It is said that this road can be followed by automobile for 20 miles. A trail continues south through another pass called Paso de Juana, 25 miles in all, to Papago Tanks.

The road turns west through a narrow gap $(74.3,78.7)$, buc a dim road keeps on northward, and this road is said to reach Cabeza Prieta Tanks (p. 337). On going through the gap, a view of which from: the west is shown in Plate XIV, $A$, the road turns northwest in a flat-floored valley bounded on the west by a dark reddish-brown lava plateau. The road goes through a gap north of this plateau and between it and a high pinkish-white conical peak. Turning west in this gap $(77.9,75.1)$, the road goes down a little valley between gravel benches and then turns north onto the bench. This is one of the few roads in the region on dissected alluvium. The grade up the bench is soft and difficult, but the top is hard, though there are many large boulders. The otherwise commonplace slopes of the Cabeza Prieta Mountains are interrupted by a lavacapped mountain ( $P 1$, XII. $B$ ). In the light of a setting sun this mountain is one of the most beautiful sights in the Papago country. To the southwest the Sierra de Lechuguilla ("lettuce mountains") project northward in a great wedge, and beyond them are the Tinajas Altas Mountains. The intervening valley is the Lechuguilla Desert, which drains northward to Gila River.

From the edge of the gravel bench $(79.4,73.6)$ the road goes west across soft ground covered with a sparse vegetation of creosote bush, and the traveler is likely to wonder where the "pasturage near the Agua Escondido" may be at which Kino camped. It is well known that there is little forage near 'Tinajas Altas and very little firewood, so that experienced travelers pick up wood at a distance and bring it with them. 
At two wooden signboards $(83.2,69.8)$ a road turns north to Coyote Water, 4.5 miles. This watering place lies in the axial stream of the valley, which is a channel filled with coarse sand about $\mathbf{1 0 0}$ feet wide and with soft banks about 3 feet high. The sand lies in great waves, which indicates the way in which the sand moves downstream during floods. The water remains in a cavity or scour depression (p. 125) in the hardpan that underlies the sand of the channel and is obtained by digging about 4 feet. A wooden signbourd and the marks of coyote or human digging will guide the traveler in finding the exact spot. The water is small in amount and not very permanent and has a bad taste. The taste seems to be due to decaying plant roots. The other roads to this locality are noted in their proper places.

Just before reaching Tinajas Altas a road goes south into the pass between the Sierra de Lechuguilla and the Tinajas Altas Mountains, to Surveyors Tanks, in the Tinajas Altas Mountains just north of the international boundary. The exact location of these small tanks is not known. A branch trail goes around the Sierra de Iechuguilla 32 miles to the Papago Tanks, the most reliahle watering place in the Sierra Pinacate.

Tinajas Altas lies in a cove in the border of the mountains, and the road comes in around the southern rocky ridge and down a bank into the bed of the arroyo that heads in the canyon above the cove. The local geography is shown by a sketch map (fig. 28, p. 132), and the characteristics and origin of the tanks are described on pages 131-132. Views in the vicinity are shown in Plate XVIII. The best camping ground lies west of the Geological Survey sign, but there is practically no horse feed and no firewond in the vicinity. A few palo fierro or ironwood trees are still standing and may furnish horse feed, but the traveler should bring his own firewood.

An analysis of water taken from the lower tank is given on page 135 . The yossibility of human contamination of the water should be borne in mind, and the traveler is advised to boil the water before drinking. The number of people who are supposed to have perished at this watering place is doubtless exaggerated, but at least 65 graves can now be counted. There are a number of inscriptions by travelers, one of which is noted on page 91 , A band of mountain sheep make these tanks their headquarters and may be seen coming to water any day. Their breeding grounds, trails, and even the odor of their bodies will be found all over the cliffs surrounding the tanks. That these animals are able to survive on the scanty vegetation and uncertain water supply seems remarkable, and it is to be hoped that existing heavy legal penalties and public sentiment will protect them from destruction.

Tinajas Altris to Wellton.-From Tinajas Altas a road goes east 3.5 miles to Coyote Water. There are two routes to Gila River. One turns through $a$ pass in the mountains half a mile north of Tinajas Altas (90.2, 62.8) and then goes northwest to the Fortuna mine and Blaisdell. It is about 25. miles to the Fortuna mine and 27 miles farther to Yuma. The part of the journey beyond the mine is easy enough, and a description of the road is given on pages 348-349. From Tinajas Altas to the Fortuna mine the road is difficult. Pumpelly in 1903 had a breakdown on this stretch of road, and it is doubtful if more than one or two machines have made the trip since that time. From this pass a trail goes due west toward a group of hills in Mexico called El Capitan, crossing the international boundary at monument 194. From El Capitan the trail goes across the " mèdanos," or sand dunes, to Laguna Prieta, a pond of slightly salty water 28 miles from Tinajas Altas. Thence it is 30 miles to Colonia Lerdo, a Mexican town on the east bank of Colorado River. 
This is part of the so-called all-Mexican route to Lower California from Sonoita.

The second road from Tinajas Altas goes north in the Lechuguilla Desert to Wellton. This is a fair plains road 26 miles long, which will be traveled without incident. At $61 / 2$ miles from Tinajas Altas a wooden signboard marks another road to Coyote Water, and half a mile farther on there is a crossroads (96.7, 56.3), from which a dim track leads 3 miles to Raven Butte Tank, a small tank in the southeast side of the Black Raven Butte. (See also Pls. XII, $A$, and XIII, A.)

The Wellton Hills, a disconnected group of small mountains, occupy the center of the Lechuguilla Desert at its north end. The road goes through thesehills to Wellton (115.8, 37.2), a watering place and railroad station on the Tucson-Yuma road. The town is described on page 362 , and the road into Yuma on pages $362-363$.

\section{AJO TO PERTGUA}

[For log see pp. 340-341]

The road from Ajo to Pozo Redondo that is easiest for a traveler to find (see P1. III) crosses the axial stream of the Valley of the Ajo north of the Childs ranch (5.1, 28.8), 5 miles east of Ajo, from which the well derrick and substantial houses are easily visible. The water supply is a deep well with a gasoline engine (p. 187). A small represo has been built to store flood water, and some attempt has been made at flood-water farming, but the principal activity of the place is the slaughtering of cattle for the meat supply of Ajo. These cattle are gathered from the neighboring watering places or are imported from Mexico.

The climb up the alluvial slope east of Childs ranch affords an excellent view of the Valley of the Ajo, which differs from the valleys to the east in having a coarser soil and smaller areas of mesquite in the center. The pass is bordered by the talus slopes of the mesas that make up the mountains and is about 2 miles long. At the entrance is a drift fence, and just beyond the gate a road turns to the left to a new well drilled by Tom Childs, 3.5 miles distant. At the end of the pass the road turns sharply south into the Pozo Redondo Valley. The soil of this valley is loamy and covered with large mesquite trees. On either side of the flat valley floor rise the talus slopes that border the mountains. To the north the battered cone of the Batamote Mountains looms up, and east of it are the red, white, and variegated peaks of the southern part of the Sauceda Mountains.

Pozo Redondo $(16.6,17.2)$ is a winter rancheria with about 12 houses on both sides of the arroyo, which drains north and through the gap. The well was dug by a man named Redondo, whose descendants now live in Yuma. He unfortunately overstocked the range, and his cattle had to be removed. The Papagos settled at the well, which is now included in the Papago Reservation. Their name for the village is Sikorttjuupo (" round tank"), doubtless a reference to Redondo. The people of this village plant crops at Perigua and in some years at Charco de la Lomita, Charco en Medio, and Cubo.

From Pozo Redondo a road goes south on the west side of the arroyo, passing a charco, of which a photograph is given in Plate XVI, $A$, to the Gunsight ranch, a distance of 8 miles. In 1920 this road was abandoned and travelers to the Gunsight ranch went on the east side of the arroyo. This road comes into the new highway about 2 miles east of the ranch.

The road on the east side of the arroyo goes southeast and on the left-hand fork runs along the low bluffs that border the mountains to Charco de la 
Piedra (22.1, 11.7). This locality is called in Papago Hotashonero ("pond at the base of the rock"), of which the Spanish name is a free translation. There is a charco among the rocks at the edge of the hills, and there are said to be fields. Numerous roads lead through the broad valley between this locality and the Gunsight Hills. They are trareled at such irregular intervals that they are not well marked, and only two are shown on the map. One of these goes east around the southern point of the hill to Charco de la Lomita, 5 miles. At this locality there are fields, sometimes cultivated, and a house on a gravelly knoll, hence the name Lomita (Spanish for "little hill"). From this place a road goes east across the upper part of the Quijotoa Valley, crosses the north end of the Sierra Blanca, and then turns south in the rolling country between these mountaius and the Brownell Mountains to join the MaricopaCovered Wells road, a distance of 27 miles. By this road it is 37 miles to Covered Wells from Pozo Redondo and 38 miles from the Gunsight ranch. The road from Charco de la Piedra to Charco en Medio, 9 miles, is poorly marked but easily traveled. The same may be said of the road to the Gunsight ranch, 6 miles, which is not shown on the map (PI. III) because it could not be definitely located.

The road to Perigua crosses the ridge east of Charco de la Piedra by a rough but practical road and then goes down into a little valley between this ridge and another spur of the mountains. Turning to the northeast the road goes through a gap $(25.8,8)$ between the main mass of the mountains, made up of horizontal lavas, and the spur, made up of similar beds that dip sharply to the northeast. Near the top of this gap is a small charco. On the far side of the gap the road comes into the extensive plains of the Perigua Valley. These plains are crossed by a maze of roads and wagon trails, and as mesquite trees are large and numerous it is difficult to see ahead. The traveler should, as he descends the gap, mark well the small hill in the center of the valley and drive toward it. The summer rancheria of Perigua, described on page 405. lies on the east slope of this hill, 33.8 miles from Ajo and 17.2 miles from Pozo Redondo.

\section{AJO TO SONOITA}

[For log see pp. 342-343]

The first 7 miles of the common route from Ajo to Sonoita is described on pages $417-418$. From the Geological Survey sign $(7.1,34.9)$ the road goes almost due south over the alluvial plains of the Valley of the Ajo to a crossroads with another Geological Survey sign $(16.2,25.8)$. Here the east-west road runs from Walls Well to Bates Well (p. 418). Walls Well lies 12 miles to the east, at the north end of the Ajo Mountains, a large range with conspicuous reddish cliffs and pinnacles, and is described on page 368. Bates Well is 5 miles to the west, and the road to it goes south of the conspicuous round plateau with black basaltic talus. Some years ago a man on a bicycle became confused at this crossroads but was fortunately found by cowboys who were going from Walls Well to Bates Well in time to save him from dying of thirst.

The Sonoita road continues south and 2 miles farther on $(18.4,23.6)$ passes Cherioni Well. This well is a monument to the enthusiasm of Reub Daniels (p. 181), but though corrals were constructed it never yielded enough water to be used and is now usually dry.

Beyond Cherioni Well the road runs southeast toward a gap between the Dripping Spring Mountains and the outlying subsidiary range of the Ajo Moun- 
tains. At the Geological Survey sign $(21,21)$ a road goes to the southwest toward the gap between the Dripping Spring and Growler mountains. There is a fork at this road 1.7 miles from the sign. The right-hand road at this fork is a rough and little used route, about 15 miles long, to Cipriano Well (p. 426). The left-hand road goes south to Dripping Spring, which is described at considerable length on pages 161-163. (See also Pl. XXIV, A.) The scenery is charming with a sort of wild beauty, and this is an admirable place for picnic parties from Ajo for whom it is an easy automobile trip of 26.5 miles. Southwest of the spring over a divide, known as the Puerto Blanco, is the Dripping :Spring mine. It is reached by a detour, as shown on the map (Pl. III).

From the fork mentioned above the road continues southeast, following the northeast bank of an arroyo that drains toward the mesquite thicket near Cherioni Well. A road to the right $(25.1,16.9)$ crosses the arroyo and thence goes south across a low part of the Dripping Spring Mountains, 8 miles, to the camp of Milton, Levy \& Martínez. There is no permanent water at this camp.

Two miles farther on the road enters a pass between low mesas which are outliers of the Dripping Spring and Ajo mountains. A road comes in from the left from a prospect called the Copper Mountain mine. This prospect is on a low hill in the valley between the main part of the Ajo Mountains and the lower western outlier. In this valley is Alamo Well, a dug well 2.5 miles south of the prospect, and Horse Tanks, a group of rock tanks 6 miles south of the rrospect. A trail runs from the Miller ranch to Alamo Well and thence south by way of Horse Tanks to Bullpasture Spring, a small seep high on the soxthwest face of the Ajo Mountains.

The Sonoita road continues through the pass and emerges on an alluvial slope $(33.1,8.9)$ that leads south to the valley of Sonoita River. Blankenship's Well is a dug well just east of boundary monument 167. In 1917 Lon Blankenship expected to water cattle from this well, and the boundary line had been fenced for several miles in either direction. The road goes through the fence by a gate between the well and an adobe house.

Sonoita, about 5 miles south of the international boundary, is a small town, once a Papago rancheria, and is called by the Papagos Kavortkson ("at the foot of the rounded hill"). As the name is sometimes abbreviated to Son or Shon ("at the foot of"), it is possible that the Spanish name was derived from this word." MacDougal ${ }^{30}$ thinks that Sonoita means "place where corn (sonot) will grow." The town was first visited by Kino in 1698, who named it San Marcelo del Sonoidag. In 1699 he brought in 36 head of cattle and started a ranch. He visited Sonoita later in 1699, in 1700, twice in 1701, in 1702, and in 1706. During the first of the visits in $\mathbf{1 7 0 1}$ he built a small church. In 1751 the name was changed to San Miguel, and on November 21 of the same year the resident priest, Padre Heinrich Ruen, was killed during the Papago revolt.s1 In 1776 the church was still in ruins. In 1865 there were 50 Papago families which then, as now, lived west of the Mexican village in a collection of huts called Akimuri ("the river"). In 1912 the Indian population was estimated at 70 or 80 persons.

During the Mexican revolution of 1915 to 1918 Sonoita was occupied by the military forces of one or another faction. The almost continual fighting and the constant exactions of the soldiery nearly depopulated the town and the adjacent countryside.

\footnotetext{
Lumholtz, Carl, op. cit., p. 393.

${ }^{30}$ MacDougal, D. T., Am. Geog. Soc. Bull., vol. 40, p. 709,-1908.

${ }^{3 x}$ Coues, Elliot, op. cit., vol. 1, p. 88.
} 


\section{BATES WELL TO QUITOBAQUITO}

[For log see pp. 344-345]

The road from Bates Well to Quitobaquito goes sonth on the west side of the Growler Mountains and gives the traveler an opportunity to see this picturesque range at rather close view. It is a fair plains road without serious obstacles.

From the west well at Bates Well (p. 418) the road crosses the arroyo, turns southwest, and goes over a small divide in low rocky hills to a valley that opens to the west. A faint road goes south to mining prospects from a fork $(2.4,17.4)$. The main road goes west and then south through a series of valleys more or less shut in on the west from the main Growler Valley by low lava mesas.

Powers Well $(6.5,13.3)$ is an unsuccessful attempt to obtain water in a place where there is sufficient grass to keep a few cattle. Eight miles farther south the road comes to Cipriano Well, so named from Cipriano Ortega, a Mexican originally from Sonoita, who with his Papago family lived here for many years. From this well a road goes west into the Growler Valley, and there is a trail to a small spring that lies on the southeast side of the Agua Dulce Mountains, a granite range visible across the plains. In 1916 three adventurous Americans camped at this well and daily crossed into Mexico, dodging the Carranzistas, who occupied Sonoita, and the Villistas, who camped in the desert to the west. In the hills south of Quitobaquito they killed many of the burros that range there in large numbers and brought back their hides. The high price of hides made this a profitable venture for a period of six weeks.

South of Cipriano Well is a low gap between the Growler Mountains, made up of somber plateaus of lava, and the Quitobaquito Hills, consisting of granite, gneiss, and schist. 'The road turns southeast through this pass, and where the pass opens into the broad alluvial plain called La Abra ("the open place") a faint road goes off to the east. This road goes north of the Dripping Spring Mountains for 14 miles to the Ajo-Sonoita road (p. 425). The road to Quitobaquito turns south and follows the eastern border of the Quitobaquito Hills. On the right a road goes over the hill direct to Quitobaquito and thus enables the traveler to avoid going into Mexican territory. It is, however, badly washed. The main road continues south past Aguajita, where a small seep of water will usually be found in the arroyo, and turns west around a low hill passing south of boundary monument 172 to Quitobaquito.

The origin of the name Quitobaquito has excited much interest. It is evidently related to that of Quitovac, a town in Mexico' and to others in the Pimeria having the root vac or bac. McGee says that the first ring of thatch In a round Papago house is ki-to and that bac is the word for water or watering place, hence in Spanish spelling Quitobac is " unfinished house water," but because the Quitobac or Quitovac of Sonora was larger this place is given the Spanish diminutive ending ito. Lumholtz ${ }^{22}$ gives the Papago name of Quitobaquito as Alivaipia ("little springs") and of Quitovac as Vapk or Váketa (" reeds" or "tule"), and therefore a spring, vaipia being the plural of vapk. Hodge's belief that bac means an adobe house has already been mentioned (p. 373). With bac derived from either vaipia or vapk, Quitovac must stand for the Spanish chiquito vac ("little spring"), and then to this must be added the

32 McGee, W J, The old Yuma trail : Nat. Geog. Mag., vol. 12, p. 105, 1901.

sumholtz, Carl, op. cit., pp. 383, 392. 
diminutive ending ito to obtain Quitobaquito. This etymological puzzle will probably never be solved satisfactorily.

The springs are described on page 164, and an analysis of the water is given on page 167. (See also Pl. XXIV, B.) Quitobaquito has been occupied by the Papagos and Mexicans and has also been used by Americans. The springs are in the United States, but the pond, which with its fringing cottonwoods makes a refreshing green spot in the desert, and most of the houses are in Mexico. This unfortunate division of the water and the cultivable land has hitherto prevented permanent settlement except by the Papagos, who are privileged characters on both sides of the line and to whom land titles mean nothing. In 1917, however, the vicissitudes of the Mexican revolution had driven these people away.

Rough roads connect Quitobaquito with Sonoita and with Agua Dulce, but the main traffic on the Camino del Diablo in past time apparently followed the river bed on the south, and most of the early travelers passed Quitobaquito without stopping. 


\section{INDEX}

A

Abra Valley, features of

well sites in

Acknowledgments for aid

Adobe flats, travel on.

Agur Caliente.

Agua Dulce Mountains, features affecting ground water in

Agua la Vara, description of

Aguajita_...................................... 292, 345

Aguila Mountains, features affecting ground water in. ............... 193-194

Aguirre Lake.

Ajo__._._._._._._._._._._. 270, 273, 355, 356, 357-359

conglomerate near.................... 62

copper deposits at ......................... 58-59

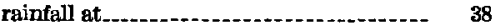

to Gila Bend. ..................... 323

to Perigua_._._. $340-341$

description of route

to Sonoita....-... 342-343

description of route

to Tucson .................. 278-279, 280-281, 282

to Yuma . . . . _ _ _

description of route.........-....... 413-423

well No. 1 of New Cornelia Copper Co.$$
\text { at. }
$$

Ajo, Valley of the, features affecting ground water in

217,219

Ajo mine, water catch at-

Ajo Mountains, features affecting ground water in

215-216

Ajo Peaks, description of

plate showing ..................... 84

Akchin........-..-309, 312, 391-392, 393-394, 412-413

Alamo-.................................... 267, 276

Alamo Well................................. 344

Alligator juniper, distribution of ........... $\quad 45$

Alluvium, depth of depth to water in...................... 180

nature of

older, nature and occurrence of . ......... 65-67

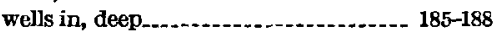

shallow

younger, nature and occurrence of . $65-66,67-69$

Altar Valley, features of...........- 253-254, 374-376 terraces in ............................. 109-110

Alvarez Mountains, features of .............. 240

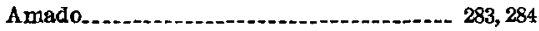

to Ronstadt gate ...................... $289-290$

description of route.................. 378-380

Analyses of waters.......... 135, 163, 167, 172, 184, 188

Anegam

log of well at................................ 178

pumping plant in well at ................. 186

Animals of the region....................... $48-51$

Antelope Peak.

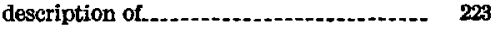

well site north of . ...................... 241

Anvil ranch. .................. 287, 289

Apaches, encounter of William Rhodes with_ 371 hostility of.
Page

Arid region of the United States, map of.-.-- $\quad \mathrm{xVY}$ Aridity, influence of, on geologic processes... 79-80

Arivaca....................... 288, 290, 291, 370-380

road................................... 289-201

to Nogales........... 292

Arroyos, crossing of crossing of, plate showing track laid for _- 264

Artesa Mountains, features of . ............... 246

Artesa Pond._.......... 268, 275, 351 plate showing........................... 264

supply of water to................... 144

Atascosa Mountains, location of

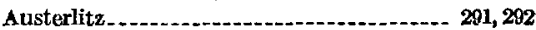

Authorization of survey . ................ XV

Automobile, choice of....................... 262 equipment to be carried for $\ldots . . . . . . . . . .261-262$

Aztec............................... 271, 272, 347, 361 rainfall at ........................... 33.

Aztec Hills, features affecting ground water in $\quad 197$

\section{B}

Babokuk

Baboquivari mine...................... 287

Baboquivari Mountains, features affecting ground water in...- 247-248, 250

valley north of, features of ............ 249

Baboquivari Peak...................... 350, 380,

Baboquivari Valley

features of

Baca land grants. . ...................... 371-372

Baker Peaks, features affecting ground water in.................. 197, 205-206

Baker Tanks, falls at........... 127-129

to Wellton

Barajita........................ 331, 332, 333, 368, 412

Barajita Valley - ................................ 411 features affecting ground water in......... 238 well sites in .............................. 241

Basalt, Quaternary flows of Tertiary flows of........................ 64-65

Basins, headwater, plate showing example of. $\quad 84$ headwater, formation of .............. 89-90:

Batamote Mountains, features affecting ground water in ................. 212-213.

Batamote Well ................ 270, 273, 322, 323, 350 analysis of water from ................... 184 features of............................... 180, 181

Bates Well _...................... 335, 339, 342, 343, 418 analysis of water from................... 184 features of

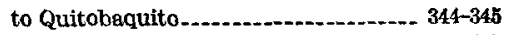
description of road.................. 426-427

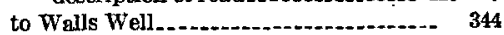

Bear Valley ranch........................... 291, 292

Beloat, W. P., wells of............... 240:

Ben Nevis Mountain, description of......-. 230 .

Benedict.................................... 283, 284

Berand's well .................. 348, 308

Big Fields.............................. 326, 327, 352 reservoir at_............................... 145-146.

to Indian Oasis............. 277 
Page

Bitter Wells

303

Black Butte $269,274,304$ description of

231

Black Gap, mountains adjoining ......... 211-212

Black Mountain, description of .............. 209

Black Prince mine..................... 278, 279 water from well at_.................. 171, 172

Black Tanks. ..................... 270, 272, 360 talls at..................... 130-131 plate showing - ...-... 126

Black willow, distribution of . . .

Blaisdell_.......................... 271, 272, 338, 363 Tertiary rocks north of . to Fortuna mine.............. 348-349

Blankenship Well.......................... 342, 343 analysis of water from . ................ 167,184 features of -

Blue Plateau, description of . ............... 224-225

Blue Water tanks . . .......................... 298

Border lawlessness.

Bosque............... 314

Boulders, disintegration of ............. 84-85

Brown Well............................... 287

Brownell . . .............. 278, 279 rolling country north of.-.-...-...-..-_ 231-232

Brownell Mountains, features affecting ground water ìn.

Buckeye..................... 315, 401 Hills, features affecting ground water in. 220

Buenos Aires well. .......................... 288, 293 analysis of water from................. 188 features of .............. 185

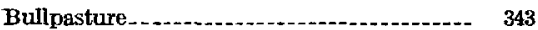

\section{C}

Cabeza Prieta Mountains, features affecting ground water in .............. 190-191

. Cabeza Prieta Tanks........... 336, 338. 348, 420-421

Cacti, descriptions of

Calabasas store_............................ 283, 284

Caliche, oecurrence of ....... . .

Camino del Diablo.................. 334-340,413-423

Camote ....................... 326, 327, 409 to Comovo ............... 330

Canoa ranch .. .......... 283, 293

Canyons, cutting of .

Cardigan ..................... 334, 340, 342, 343, 346

Casa Grande.............................. 389 rainfall at

to Florence description of route................. 390

to Maricopa........ $\quad 300$

to Phoenix _........ 301

to Pozo de Luis, Sonora. . . ....... 303-305

description of route............... 390-393

to Quajote....... 307

to Tueson_............. 298-299

Casa Grande Mountain, features of.......... $\quad 243$

Casa Grande Ruins to Florence.........- 297

Cattle raising, practices of _............ 375-376, 381

Catsclaw, habit of

Central portion of the region, features affecting ground water in............ 220-239

geography of...................... 220

ground-water resources of............... 239-242

Century plent, habit of..................... 48
Page

Cerro Colorado Mountains, features of...... $\quad 252$

Cessions by Mexieo...................... 18

Chambers, A. A., and Kidwell, C. H., analyses by-....... 135, 163, 167, 172, 184, 188

Chandler_........................ 294, 295, 300, 301

Charco Colorado . . . .................. 331, 332, 334

Charco de la Piedra... 341

Charco en Medio............ 269, 274, 354

to Cubo

description of road................... 411

Charcos, example of, plate showing--..-.-. $\quad 126$

features of .............................. 257

formation of ....................... 121-122, 368

miniature canyons at head of, plate showing

water supply from

Cherioni Well ........................ 181, 342, 343

Childs Mountain, features affecting ground water in

Childs ranch ............... 270, 273, 340, 341, 359, 423 well on, anaiysis of water from......... 188 features of ............. 180

Childs Valley, features affecting ground water in $\ldots$

Chiu-Chuschu... ....................... 303, 306, 391 $\log$ of well at................... 177 pumping plant in well at............... $\quad 186$

Chollas, deseription of

Cibola, Seven Cities of . . ........... 5,6,8

Cipriano Well features of .................................. 181

Cisterns, railiroad, water in .......... 257-258

Civil War, events of......................... 20-21

Clark water shaft, Clarkstown, character of water from.

171,172

Clark Well, near Nogales._._.............. 291, 292

Clarkstown (Rowood post office) ............ 270, $273,340,341,358$

Clements ranch.............................. 297

Climate of the region. ....... 29-40

Cobabi....................... 278, 279, 304, 352,365

Cobabi Mountains, features affecting ground water in

Cochibo _... 332, 333 plate showing -........................ 164 wells at............................ 175, 176

Cocklebur..................................... 303, 30 r log of well at ............... 177 pumping plant in well at ................. 186 mountains west of valley south of ............................. 248 to Maricopa _... .

Coledon

Colfred_................... 271, 272

Colorado River, discovery of . .............. 6

Comobabi_................ 278, 279, 365 conglomerate near

Comobabi Mountains, features affecting ground water in.................. 245

Comovo_..._. route................................ 281-282, 369

to Camote_... description of route................ 410-411

Comovo Valley, features affecting ground water in ...................... 238-239 well sites in 
Page

Compartidero represo, plate showing-....-.- 140

Conglomerate, Tertiary (?), occurrences of _- 60-63

Tertiary, plate showing .................... 40

Connecticut, wells in crystalline rocks of . 167-168

Conte ranch................................ 290, 291

Cook \& Landro Well................... 346

Copeka_................... 268, 275, 280, 281, 282, 353

to Kavolik...................... 328 description of roed

to Serventi Well........................ 327-328

Copeka Mountains, features affecting ground water in ......................... 235

hills southwest of, features affecting ground water in ............... 235-236

Copper, deposits of, at Ajo. . . ......... $58-59$

Copper Mountains, features affecting ground water in -

Copperosity -.

Coronado, Francisco Vásquez de, explorations under........................

Coronado National Forest................... 381-382 Coronel. . .

Cottonwood, distribution of ................... 45

indication of ground water by ......... 157

Covered Wells...................... 278, 279, 341

church and Papago houses at, plate showing -

40

to Maricopa

Coyote............... 267, 276

Coyote Mountains, features affecting ground water in

Coyote Water......................... 337, 338, 422

Crater Mountains, features affecting ground water in............................. 207

Crucifixion thorn, description of ........ 44-45

plate showing.......... 40

Crystalline complex, water in.......-..-. 167-172

Cubo_................. 282, 332, 334

Cubo Hills, features affecting ground water

in . . .

route.............................. 280-281, 367-368

to Charco en Medio ................. 331

Culiacan, founding of

D

Dams, construction of ....-......... 147-150, 151-153

Darby Well........ 270, 273, 334, 3355. 339, 340, 342, 343

analysis of water from . .

features of - 181

Davis ranch._............................. 208, 299

"Desert varnish," deposition of ............. 85

Desert willow, description of ........... 44, 156-157 plate showing ......................... 40

Dobbs Butte, features of................. 244 reservoir near.............................. 144

Dobbs Well . ..................... 267, 276, 277, 279, 350 character of water from ................ 170, 172

Dome............................ 271, 272, 338, 363

Domestic water supplies, use of reservoirs for

$142-143$

Double Butte, description of............. 225

Drake's ranch........ 309, 312

Dripping Spring........................... 342,343 description of................ 161-163, 164

Dripping Spring Mountains, features affecting ground water in..-.-.-..... 210

Dunes, occurrence of 106-107
Pago

Eagle Tanks_................. 271, 272, 347, 348

East-central portion of the region, features affecting ground water in.-...- 243-250

geography of . .................. 242-243

ground-water resources of...-........... 250-251

Eastern portion of the region, features affect-

ing ground water in.......... 251-254

geography of ..................... 251

ground-water resources of.............. 254-255

Emita - . .

Enid .

Espejo, Antonio de, silver found by ........

Espinoso Well................................ 287,289

Estevan, career of .......... 4-5

Estrella.... . .

Exploration by Amerieans............... 17-20

by Spaniards........................... 4-17

Falls, causes of . .......................... 127-134

Farming by the Indians................... 358-354

plate showing. ......................... 264

Faults, types and occurrence of

Fauna of the region

Fewkes, J. W. cited. . . . . . . . . .

Figueroa ranch............................ 288, 290

to Buenos Aires. . . .

Flats, adobe, cutting of channels in.......... 122 adobe, features of

Flood, sheet, description of .............. 10

Flora of the region................ 40-48

Florence-_-_. to Casa Grande. . ....................... 302-303

to Casa Grande ruins

description of route......-. 385-388

Fortuna mine water catches at ........................ 137-138

Franciscans, founding of missions by . ...... 14-16

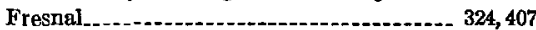

Fresnal ranch

\section{G}

Garcés, Francisco, explorations by....... 14-16, 415

Garcia Well ....................... 271, 272, 288, 347 analysis of water from................. 184

features of . ........... 160, 182

Garcia, E., well ........................... 292

Garcia, M., ranch.................................. 283

Gates and by-passes, use of

Gibson

water from Al Johns well at _._._._._. 171, 172

Gidley, J. W., fossils determined by........ 68-69

Gila Bend.............................. 270, 272, 400

rainfall at. ............................... 34

to $A$ jo $\ldots . . . . . .321-322$ description of route................ 405-406

to Maricopa.................. 308

to Mesquite Tank........ 323-324

description of route

to Phoenix.................. 314-315, 316-317

to Pozo Blanco......................... 320-321 description of route.................... $404-405$

to Sentinel.............................. 317 description of route

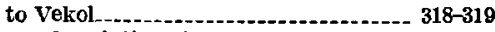
description of route...-...-.-.-.- 402-404

Gila Bend Plains, features affecting ground water in 
Page

Gila Crossing $308,309, \mathbf{3 1 3}, \mathbf{3 1 5}$

Gila Mountains, features affecting ground water in

189

Gila River, flow of

terraces bordering .................. 108-109

Gila River Reservation

Gila Water \& Land Co_._-_._._._._._._. 315,316

Girty, G. H., fossils determined by ........ 55, 56

Granite Mountains, features affecting ground water in

194

Great Plain, features of

well in............................. 242

Ground water, plants as indicators of -..-.- 156-157 potability of quality of . . . . . source and amount of ............... 153-155

Growler Mountains, faults in features affecting ground water in . . . _ 195-196 plates showing.

Growler Valley, features affecting ground water in 202,204

Guano, removal of ................ 417

Gunsight Eills, features afecting ground water in

214-215 well sites in

241

Gunsight ranch_-_ 269, 274, 278, 279, 281, 282, 340, 355 well at, analysis of water from ........... 184 features of

\section{H}

Hackberry, distribution of. $45-46$ indication of ground water by

157

Hardimui $269,274,280,281,353-354$

Hat Mountain, features of

Ileart Tank

Higley . . . .

History, of Arizona........................... 3-23 of the region, geologic and physio-

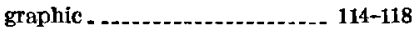

Hopis, proselyting refused by Horseshoe (Quijotoa post office) ....... 278, 279, 304 I

Igneous rocks, occurrence of .......... 58-59, 63-65 Imperial Well . $271,272,348$ Indian Oasis (Sells post office) . .......... 268 , $275,280,281,282,325-326,351,352$ analysis of water from 175,176 plains west of, features of $249-250$ pumping plant in well at rainfall at.

at.-. 186 to Big Fields regetation along the northern road 364

to Menegers Dam..................... 326-327 description of route.................. 408-409

Indians, character and habits of ............ 23-29 occupations of........-.-.-...-...- 353-354,390 prehistoric migrations of

Indigo thorn, habit and distribution of...... 44 Inhabitants of the region . . . . Inscription, painted, preservation of.....-. 91 Irrigation, storage of flood water for ........... $\quad 143$ Isabella mine
$\mathbf{J}$

Jack in the Pulpit, deseription of Page

Jackrabbit, log of well at . _._._........

pumping plant in well at............... 186

Jackrabbit mine

James Well_.................................... 268, 275

Jaques ranch . ..._._._. . well at . . . .............................. 175

Jarilla Spring

Jaynes . . 298, 299

Jenkins ranch .

Jesuits, founding of missions by

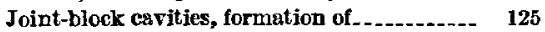

Jornada de las Estrellas, features affecting ground water in.

\section{K}

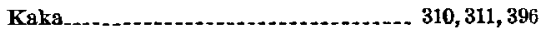
mountain southwest of ............. 229-230, 397

Kavolik to Copeka _.................. 328-329

Kidwell, C. H., with Chambers, A. A., analyses by $\ldots . . .135,163,167,172,184,188$

King Well_._._.-...................... 287, 289

Kino, Eusebio Francisco, explorations and development by ..........-. 7-13, 413-414

Kirk, Edwin, cited

Komatke

Ko-opke_..._._._. 303,306

Kukomalik ........... 303, 306

$\log$ of well at $\ldots \ldots$

pumping plant in well at............... 186

Kvitatk.... 304, 306

$\mathbf{L}$

La Abra Valley, features affecting ground water in.................. 217-218, 219

Ia Lesna Mountains, features affecting ground water in ................ 235

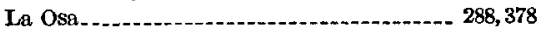

La Osa Land \& Loan Co., holdings of....... 377

La Quituni................................. 332, 333

La Quituni Valley, features affecting ground water in

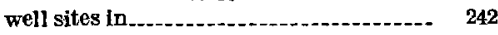

Las Animas Hills, features of . ............... $\quad 246$

Las Moras ranch. ................................. 288, 289

Las Playas......... 335, 339, 419

Lechuguilla Desert........................... 337, 338 features affecting ground water in

Levy's ranch................................ 270, 273

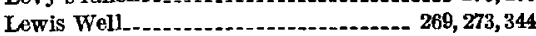

analysis of water from . .................... 184

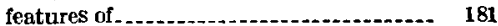

Little Ajo Mountains, features affecting ground water in................ 208-210

roads near. 346

Location of the region. .

Logs of roads, plan of ......................... 265

Loper ranch_..................... 283

Lumhọltz, Carl, cited.

$\mathbf{M}$

McGee, W J, cited.......................... 105

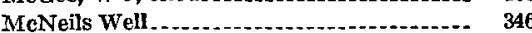


Page

Map, of the arid region of the United States_- XVI reconnaissance geologic, of the Papago country, Ariz. relief, of the central part of the Papago country, Ariz............ In pocket.

of the eastern part of the Papago country, Ariz............. In pocket. of the western part of the Papago country, Ariz............ In pocket

Maps of the region, compilation of ......... 1-3

Maricopa, rainfall at _.......... 36

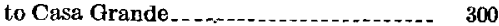

to Cocklebur.

to Covered Wells.

description of route _...... $393-397$

to Gila Bend

to Phoenix _.

Maricopa Mountains, features affecting ground water in ........... 220-221

Marin's represo 332,333

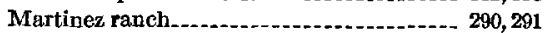

Meinzer, O. E., Preface............. XV-xvIII

Meneger ranch _...................... 293, 296

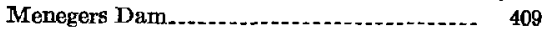

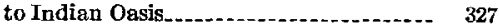

to Walls Well

Menegers Well, near Indian Oasis ....... 276, 277

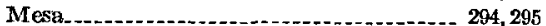

Mesozoic rocks, nature and distribution of.-- 57-58

Mesquite, dead forest of, plate showing _... $\quad 40$ habit and uses of .......... 41-42, 156 sprawling, plate showing upright, plate showing 146

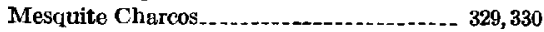

Mesquite Mountains, features affecting ground water in.............. 233-234

Mesquite Tank . to Gila Bend ....... 324

Midway Well _._._._. 322,323 $\log$ of

Miller's, W. G., ranch ranch well, analysis of water from _..... 184 features of ......... 181,182

Mineral Hill _.

Mining, before the Civil War............. 19,20 beginnings of ....... 13-14, 16, 17 since 1863.......... 21-23 use of water reservoirs for. . . . . . . . 141-142

Mission, lost_......................... 417

Mistletwe on palo verde tree, plate showing.- 40

Mobile. log of Southern Pacific Co.'s well at $\ldots$ - 185-186

Mohawk _... 271, 272, 347, 361-362 rainfall at

Mohawk Mountains, featnres affecting ground water in.............. 192-193

Mohawk Valley, features affecting ground water in

Moivavi, well at _........ 201

Montana mine................ 291, 202, 382

Monte Carlo Dairy_______._. 284

Montezuma's Head, description of _..... 215, 356

Moreno ranch . .

Mortar hole, plate showing 40

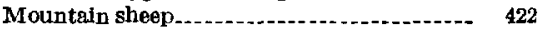

Mountains, classes of classes of, summary ............ $77-79$ composed largely of granite and schist, features of. $75-77$
Mountains, composed largely of volcanic rocks, features of

travel throngh ................. 265

Moweps

Moyza Well................................... 289, 291

Murray \& Lopez Well._....... 310,311

$\mathbf{N}$

Nariz Mountains, features affecting ground water in

New Cornelia copper mine, development of

well No. 1 at_._......................... 174-175

Niches, cutting of .................... $90-93$

in granite, plate showing _................ 84

Nogales, description of ................. 372 rainfall at. . . . .

to A rivaca.-............................ 291

description of route............... 380-382

to Tucson ........................... 284

Nogales Wash, terraces bordering

Norton

No. 3 Well, Childs Valley, analysis of water from

features of 180

0

Oak trees, descriptions of

Ocotillo, habit and uses of ................ $43-44$

Old A jo, burning of .

house in, plate showing _........... 126

O'Neill Hills, features affecting ground water in.

o'Neills Pass............................ 335, 339, 419

Oro Blanco ........................... 291, 292

analysis of well water from . ............ 180

\section{$\mathbf{P}$}

Painted Rock Mountains, features affecting ground water in ................. 207

Paleozoic rocks, nature and distribution of... 55-57 Palo Alto_................................ 287, 289

Palo Alto Well, analysis of water from-_..._- 188 features of

Palo fierro, habit and uses of

Palo verde, habit and uses of with mistletoe, plate showing............ $\quad 40$

Palo Verde Mountains, features affecting ground water in................. 221-222

Palo Verde Tree

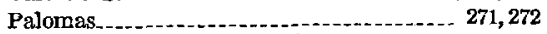

Papago country, Ariz, reconnaissance geoIogic map of................- In pocket.

relief map of central part of .......... In pocket. of eastern part of ................. In pocket. of western part of .............. In pocket.

Papago Saguaro National Monument ......- 385

Papago Well. .................. 271, 272, 335, 339, 347 character of water from

hills near, features affecting ground water in. - 198-199, 204

plate showing-.........................-. 164

Papagos, character and habits of.............. 23-26

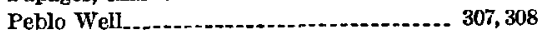

Pediments, mountrin, coalescence of..-.-..-. 97 mountain, concealed................... 97 dissection of........................ 99-101

plates showing .................. 84

nature and development of.......... 93-97 
Page

Pembroke 271, 272

Penasco Peak, description of ........... 208

Perigua . . . mountains east of, features affecting ground water in................. 229 mountains west of, features affecting ground water in ............... 228-229

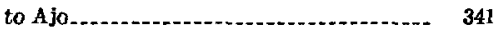

Perigua Valley, features affecting ground water in

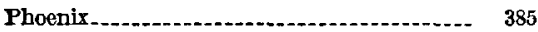
rainfall at_........................... 35

to Casa Grande . . ................. $300-301$ description of route.............. 389-390 to Gila Bend ................... 313-314, 315-316 description of routes

to Maricopa............ 308 description of route.............. 393

to Tucson.................. 295-297

Physiography of the region................ 79-114

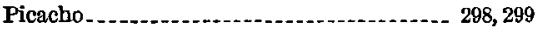

Piedra................ 317

Pimeria Well_...... 347, 361 features of

Pinacate Plain.............. 420

Piñon, Mexican, distribution of .............. 45

Pinta Mountains, features affecting ground water in......................... 192

Pisinemo................... 269, 274, 280, 281, 353-354 to Pozo Blanco:-....... 329

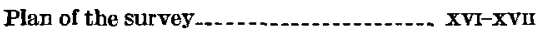

Playas, example of..................... 106

Pleistocene time, events of.................. 117-118

Plunge pools, formation of................ 126-127

Ponds, occurrence of .......................... 120-121

Poston Butte..................... 294, 296

Potholes, formation of

Powers Well.................... 345

features of

Pozo Blanco_._._..................... 278, 279, 366

route, ....................... 277-279, 365-367

to Gila Bend. ........... 321

to Pisinemo . . .

description of road............... 410

Pozo Nuevo............................... 287, 289

Pozo Nuevo Well, analysis of water from .... 188 features of .............................. 185

Pozo Redondo......................... 269, 274, 340, 341 well at . . . . . . .

Pozo Redondo Mountains, features affecting ground water in

Pozo Redondo Valley, features affecting ground water in. 237

Pozo de Luis, Sonora, to Casa Grande_.... 305-306 Pre-Cambrian basal complex, features of.-.-- 54-55

Pre-Tertiary time, episodes of............ 114-115

Prospect holes, water in

Pumpelly, Raphael, journeys by ......... 415-416

Quajote $\ldots$ $\log$ of well at ............. 178 pumping plant in well at ................. 186 to Casa Grande. Quaternary deposits, nature and distribution of - $65-70$

Quijotoa post office (Horseshoe) _....... 278, 279, 304

Quijoton Mountains....................... 352 features affecting ground water in...... 230-231 wells in pediments of
Quijoton Valley, features affecting ground water in...... 237-238

well sites in ............................... 241, 242

road through ........................ 367

Quitobaquito_......... 426-427

plate showing . . .

to Bates Well . _. .

Quitobaquito Hills, features affecting ground water in ................ 199

Quitobaquito Spring, analysis of water from. 167

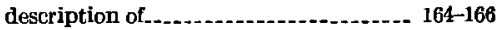

$\mathbf{R}$

Rain water, collection of, from roofs........ 136

Rainfall, action of, on mountain slopes........ 83-84 records of........... 30-40

Ransome, Frederick Leslie, cited.......... 252-253 Historical sketch . ......................... 3-23

Raven Butte, plate showing

Raven Butte Tank ........................... 338

Recent deposits, nature of

Recent time, events of

Red Rock rainfall at. .............................. 38

roads out of . .

Represos, features of plates showing

Reservoirs, construction of, designs for -.... 147-148 construction of, diversion dams and spillways .......................... 149-151

in mountains and foothills.......... 143-144

in plains and valleys ................ 144-147 protection of the dam............... 148-149

débris-filled, advantages of ............... 151 construction of . .

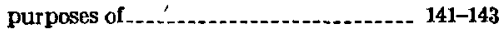

Reventon ranch ............................. 283, 284

Reward mine......................... 303

Reynolds Well ............................ 271, 272

Riffle hollows, formation of

Rillito._._.

Roads, difficulties in using. . . malpais, features of ................. 258-259 mountain, features of plains, features of quality of . . . . river-bottom, features of ............... 259-260 types of . . ..... 258 signs marking .......................... 260-261

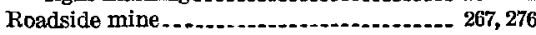

Robledo ranch........................... 290, 291

Robles Pass. . .

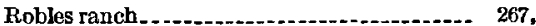
$276,277,279,285,286,287,289,350$

Rock shelters, formation of . ............. 91-93

Rock tanks, features of .

Rock tanks, names in various languages .... 123-124 occurrence of . ......................... 124-127 relation of, to water-falls

Ronstadt ranch. ................. 287, 288, 289, 290 rainfall at . . . .................. 39 gate of, to Amado........ 290-291

Roskruge Mountains, features of............. $\quad 244$

Ross, C. P., Buckeye Hills............. 220 Painted Rock Mountains ............ 207 Phoenix to Gila Bend by way of Buckeye.

Rowood post office (Clarkstown) $273,340,341,358$ 


\section{$\mathbf{s}$}

Page

Sacaton.

300,310

Sacaton Mountains, pediment around ...-... 94-95

Sahuarito................................. 283, 284

Salt grass, indication of ground water by.....- 156

Salt River project, description of............ 384

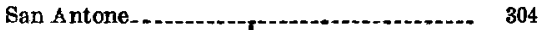

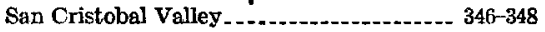
features affecting ground water in ...... 202, 205 wells in....................................... 182

San Fernando....................... 288

San Miguel............. 324, 408 Jog of well at ........................... 179 valley adjoining, features affecting ground water in

216

San Pedro_................. 267, 276

San Vicente......................... 267, 275, 277, 279

San Xavier del Bac Mission.............. 285, 286, 373

San $X$ avier and Twin Buttes route........ 372, 374

Send, crossing areas of shifting of ................................ 106-107

Sand Tank Mountains, faults in............ 71-72 features affecting ground water in...... 224-228 wells in slopes of..................... 240-241

Sand Tanks............................ 318, 319, 403 conglomerate at. ........................ 61 features of .

Santa Cruz River, flow of .................. 119 terraces bordering ....................... 110-114 wells in valley of . . ................... 255-256

Santa Cruz Valley, description of .......... 110, $248,254,369-370$

Santa Rosa, $\log$ of well at. 178 pumping plant in well at................ 186

Santa Rosa Mountains, features of

Santa Rosa ranch........... 267, 275, 277, 279, 304, 306

Santa Rosa Valley, features of............... 249

Sasabe Flat, plate showing ................ 84

Sasabe to Tueson............................... 288-289

Sauceda................................... 320, 321, 404 well at.

241

Sauceda Mountains, features affecting ground water in......................... 211-212

Sawtooih Mountains, features of ........... 243 Saxton Dairy ............................ 283, 284

Schaefer Well_........................... 287

Schrader, Frank C., cited _._............ 221

Scour depressions, formation of .......... 125-125

Screw bean, habit of .

Secundino Well.................... 287, 288, 289, 290 analysis of water from features of . Sedimentary rocks, water in_..........--_ 172-173 Sells post office (Indian Oasis) ................ 258. $275,280,281,282,325-326,351,352$

Sentinel rainfall at... to Gila Bend

317-318

Sentinel Plain features affecting ground water in . ..... 203, 205

Serventi Well. ............................ 326, 327 to Copeka._.............................. 328

Sheridan Mountains, features of ............ 228

Siprra Blanca, features affecting ground water in.

Sierra de la Lechuguilla, features affecting ground water in
Page

Sierra de Moreno, features of . ................. 246

Sierra Estrella, features affecting ground water in

221

Sierra type of mountains, development and decay of........................... 87-89

Sierrita Mountains, features affecting ground water in .......................... 252-253

Sikulhimakt_............... 278, 279, 304, 306, 366, 392

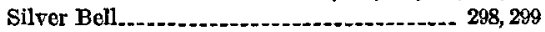

rainfall at

Silver Bell Mountains, features of ......... 243-244

Silver Bell rood ............................... 286-287

Silver Reef Mountains, features of._........... 243

Simmons Well............................ 293, 296

Sitgreaves National Forest, reservoirs at...- 146-147

Slate Mountains, features of

Slopes of mountains, boulder-controlled, development and recession of.-. 82-86

boulder-controlled, plate showing........ 84

cliffy, development of................. 82

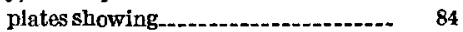

conditions governing

grades of steepness .......................... 81-82

rain-washed, development of............ 86

Snyders Hill, yield of well near ................. $\quad 172$

Sonoita, Sonora............................ 425

to Ajo

Sonoita Mountains, location and rocks of.-.- 211

Sonoita River, analysis of water from_........ 167 flow of

Sonoita Valley, foatures affecting ground water in

Sources of information................... XVII-XVIII

South Mountain, description of ........... 230-231

Spillways, protection of

Springs, flssure, descriptions of _._........ 164-167 fracture, descriptions of..-..--.-.-161-164

Squawtit Peak ......................... 310,312, 395 description of

Stanwix....... 271, 272

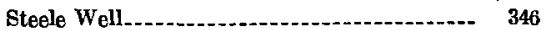

Stevens _.

Stock, use of reservoirs for watering-...-.... 142

Stouts Well_.............. 310,312, 318, 319, 322, 403 character of water from_............. 170-171, 172 elevations near.......................... 227

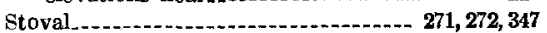

Stratigraphy of the region ............... 53-70

Streams, axial, courses of ephemeral, utility of intermittent, nature and examples of.. 119-120 interrupted, examples of.--.-.....-.-.-- 119-120 rock tanks formed in ................. 124-127 water supply from....................... 118-120 Structure of the region Superstition Mountains ..............-... 386

Susuta, Sonora _....... 326, 327 pond at_............. 121

$\mathbf{T}$

Tabaseca Tank, formation of fall at--.-----.. 129 Table Top Mountains, conglomerate north

of

features affecting ground water in...-- 222-224

Tajo mine.......................... 289

Tanks, quality of water in................... 135 
Tartron Page

Tecolote_.................. 305, 392

Tecolote Valley, features of _...........- 250, 324-325

Tempe._........................................ 295

Tertiary rocks near................... 50-60

Temperature, records of . .................. 29-30

Terraces, stream, origin and distribution of 107-114

Tertiary rocks, nature and distribution of ... 59-65

Tertiary time, events of .................. 115-117

Timber, lines limiting .......................... 375

Tinajas Altas....................... 337, 338, 349, 422

canyon above, plate showing............ 126

description of

plates showing.

120

Tinajas Altas Mountains, features affecting ground water in ................ 189-190

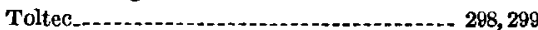

Tonukvo_.................... 268, 275, 328, 329, 353

Tools, carrying of

Topahua, $\log$ of well at ................ 178

Totobit Tanks. ............. 310, 311

conglomerate at. .

Treasures, hidden........................... $\quad 417$

Trees of the region.................... 41-46,247

Tubac_.................................... 283, 284, 371

Tucson_........................ 297, 299, 349-350

rainfall at

to Ajo

to Casa Grande

description of route........ 388-389

to Nogales_........................... 283-284, 285 description of routes. . .............. 369-374

to Phoenix. - . . description of route........-. 382-385

to Sasabe.

description of route................ 374-375

to Yuma_.............. 266-271

description of route...-.-.......... 349-369

Tucson Mountains, features affecting ground water in

Tule Desert, features affecting ground water in

Tule Mountains, faults in

features affecting ground water in ...... 191

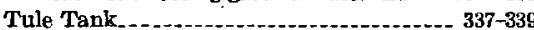

pass west of, plate showing ............ 84

plate showing . .

Tule Well _............... 336, 338, 346, 420 conglomerate near

water of .............. 160

analysis of

Tully Well _....... 291, 292

Tumacacori Mission................. 283, 284, 372

Tumacacori Mountains, features affecting ground water in............- 251-252

Twin Buttes ... . . .

$\mathrm{V}$

Vaca Hills, features of

Valleys, drainage of

245

interior, terraces in ..................... 114

processes operating in ................. 102

structural origin of

Variegated Butte, features of ................ 244

Vegetation_-.........- 40-48 ground water indicated by ............ 156-157 luxuriant, near Big Fields, plate showing.
Vekol to Gila Bend

Vekol Mountains, features offeeting ground water in

Vekol Valley, features of............. 236-237, 395 Volcanic rocks, nature and distribution of ... 63-65 Tertiary, water in 173-176

\section{W}

Wakefield ranch.............................. 298, 299

Walls Well ............................... 2830, 281, 368

features of ............... 181, 182

to Bates Well.............................. 344

to Menegers Dam -..-...- 331, 333 description of route................ $411-413$

Walnut Well ................................ 293, 296

Warren Bros. Well, analysis of water from... 188

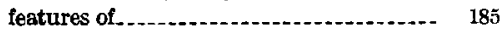

Washes, crossing of

Water, carrying of

roof gutters to catch, plate showing...... $\quad 126$

stand for selling, plate showing-_......- 126 surface, potability of .................. 159-161 sources of

Water catches, area needed for-.........-. 139-140 construction of example of, plate showing . ............ 146 sanitary arrangements desirable for...- 140-141 use of, at the Ajo and Fortuna mines .- 136-138 Waterfalls. See Falls.

Watering places, types and distribution of. 255-258

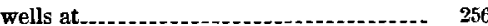

Waterman Mountains, features of ........ 244

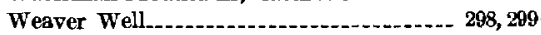

Wells, equipment of ............... 256

in crystalline rocks, characteristics of ._169-170 method of digging ............... 168,407

Wellton.......................... 271, 272, 338, 362 conglomerate east of .................... $62-63$

to Baker Tanks........... 348

Wellton Hills, features affecting ground water

in

West-central portion of the region, features affecting ground water in...... 207-218

geography of ground-water resources of

Western portion of the region, features affecting ground water in............ 189-203

geography of ground-water resources of Whites Well. features of.................................... 182 Wild china tree, description of.........- 44, 156-157 Williamson store............................ 313, 315 Wind deposits, occurrence of ............ 106-107

\section{$\mathbf{Y}$}

Yager road............ 347

Yuccas, description of ........................ 47-48

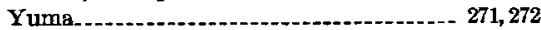

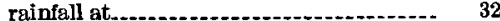

to Ajo

to Tueson .

Yums Desert, features affecting ground water in .................. 199-200, 206 project, description of .............. 363-364 